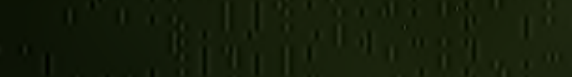

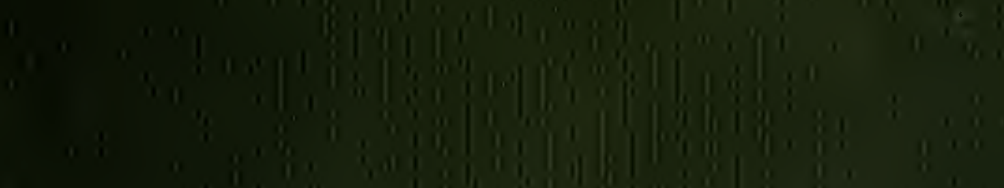

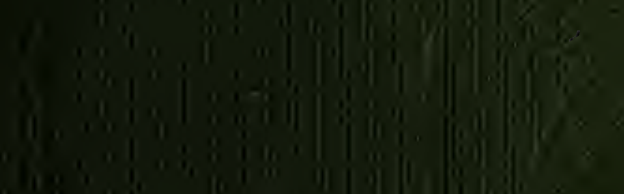

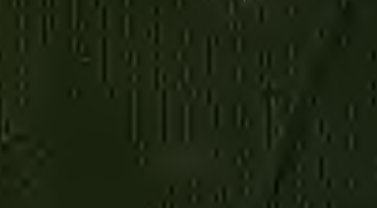

1)

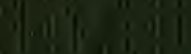

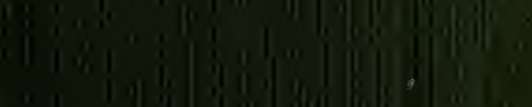

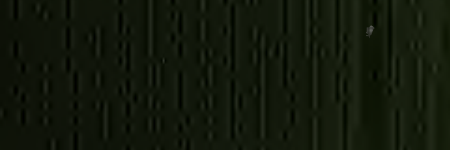

1) 1 (1)

and

v.

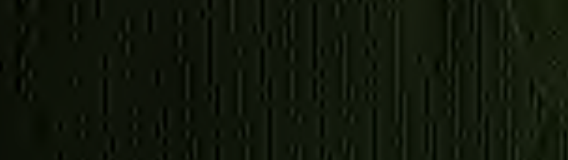

1
1

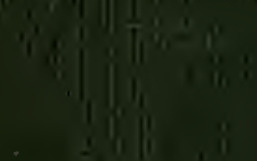

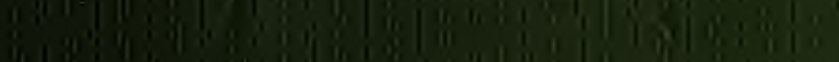

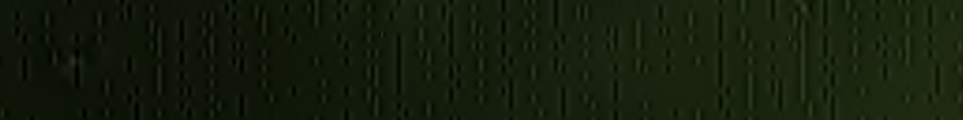


LIBRARY

THE UNIVERSITY OF CALIFORNIA SANTA BARBARA From the collection of ELSPETH HUXLEY 
Digitized by the Internet Archive in 2007 with funding from Microsoft Corporation 


\section{THE LAND OF THE LION}






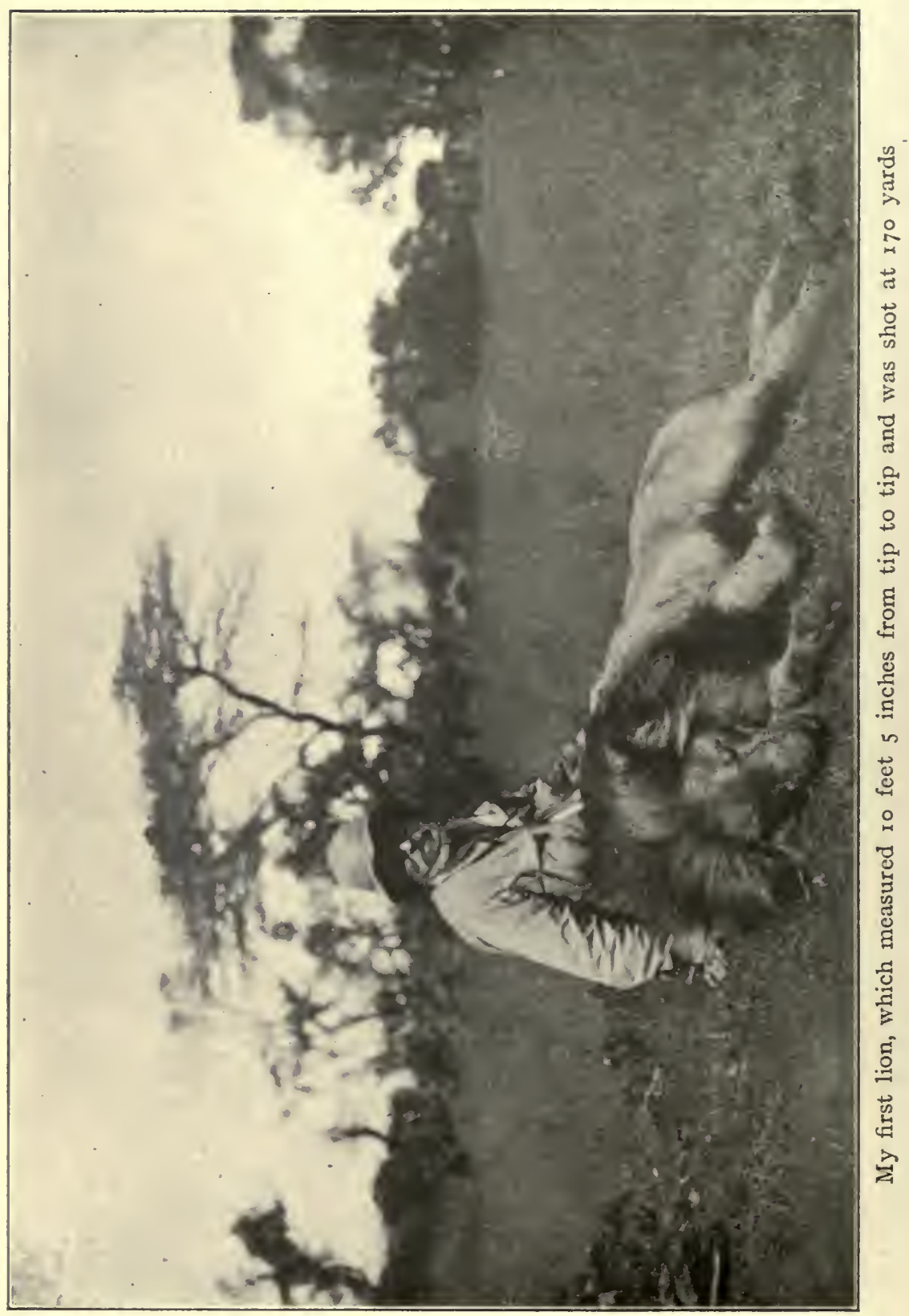




\title{
The Land of the Lion
}

\author{
B Y \\ W. S. RA I N S F O R D
}

Illustrated from Photographs

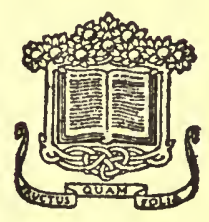

New York

Doubleday, Page \& Company

1909 
ALI RIGHTS RESERVED, INCLUDING THAT OF TRANSLATION INTO FOREIGN LANGUAGES, INCLUDING THE SCANDINAVIAN COPYRIGHT, I909, BY DOUBLEDAY, PAGE \& COMPANY PUBLISHED, OCTOBER, I9O9 


\section{DEDICATION}

TO MY THREE SONS, RALPH, LAWRENCE AND KERR, MY COMPANIONS ON MANY A HUNTING TRIP; TO MY FRIEND, J. JAY WHITE, WHO WAS WITH ME DURING THE GREATER PART OF MY LAST AFRICAN JOURNEY; AND TO ALL GOOD FELLOWS WHO, NEITHER IN BOYHOOD NOR IN AFTER LIFE, have been able to Resist the "RED god's Calling," I DEDICATE THESE NOTES OF THIRTEEN MONTHS' TRAVEL AND SPORT IN BRITISH EAST AFRICA.

NAIROBI, DECEMBER, 1908.

W. S. RAINSFORD. 



\section{CONTENTS}

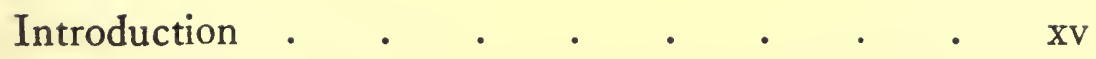

First and second trip-History of Mombassa-Portu-

CBAPTER

guese invasion.

I. Mombassa to Lion Land . • • $\quad 3$

Sunrise on Kilimanjaro-Nairobi-East African scenery - Start of the sefari.

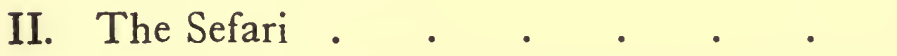

"Make-up" of the sefari-Expenses-Responsibility of employer-Headmen-Tentboys-Porters-Gunboys Cook-"Totos"-The start.

III. Across the Mau Escarpment to Lion Land .

In Mau forest-Kerio River-Mt. Elgon-Nzoia River

- Nzoia Plateau - First lion-Wild dog-Momba mauled by lion.

IV. My First Lion

First sight of lion - Cheetah - Lion hunting - Three lions killed.

\section{v. Hunting in Africa}

Early hunting days - Tracking - Rhino - Meat Gunbearers-Canadian grizzly-Hunting the grizzly in Canada-Hunting "dangerous" game-Hunting rhinoHunting buffalo - Hunting lion - Vultures - Massai guides.

\section{Sefari Life}

Early morning, "nature's truce"-Bathing-InsectsGeneral management of sefari-Native industriesAfrican meat and how to cook it-Native fruit and vegetables. 
An elephant herd-J. J. W.'s lion hunt-Following three lions-Herd of giraffe-An exciting lion chase.

VIII. Elephant

Hunting elephant - Three elephant herds - A dead elephant.

IX. Nzoia Plateau and Its Tribes

The Nzoia plateau - The tribes-Nandi-MassaiCherangang N'dorobo-Poisoned arrows-Karamojo Wanyamwazi dance-Lion hunting in the Nzoia-Malim wounded by a lion-Valley of the Kerio-Elgoan customs-Tribal treatment of a "liar"-Elgoan views of God-Native dance.

X. Good-bye Sergoit

A lion "ride"-Best gun for lion shooting-"Riding" a cheetah-A porcupine-Ostriches used as "time pieces" - The "honey bird" - Hyena traps - A python climbs into a ship-The lion's roar-Good-bye Sergoit !

XI. From Gilgil to Kenia .

Naivasha Lake-Kinan-Kop-Waterfalls-Hippo on the Embellossett-Water birds on the EmbellossettThe Guasi Narok-Malaria and its remedy-Mr. Stauffacher and the man-eating leopard-Lions on the Guasi Nyiro-The Massai spear-An aard wolf-PartridgesMassai flies-Mt. Kenia-Thorn tree-A piper-A rhino.

\section{Syce's Adventure}

A family of lions-Syce's adventure-A buffalo herdTracking a wounded buffalo-A buffalo's " charge "Reminiscences of the West in '68-Reminiscences of Ireland-Mt. Kenia.

XIII. A Morning's Ride Through Rhino Country The flora of the country-Baboon's war cry-An ostrich and his family-The giraffe's neck-The home of the rhino-Wild $\operatorname{dog}-A$ mountain stream and its fauna-The rhino and its Myocene ancestor-An " attack" by a rhino. 
Government-Land-Education-England's "policy""Forced" labour and "freedom"-The agriculturalist -The contractor-Native taxation-The law courtsThe Hindi and Boer settlers-What does British East Africa need?

$X V$. A Plea for the Native East African and His Missionary

Missions of the past-Four hundred African bishoprics in fifth century-The African explorer-What does the native believe?-Witchcraft-Can the native be taught to work ?-What the native needs-The fight at Lubwas Boma-What the missionary can do-The kind of Christianity Africa need -Why is Africa becoming Mohammedan ?-The education of the future - Hope for the African missionary.

XVI. The Last Sefar

Nairobi-Kenia-Hunting buffalo and rhino-Goodbye to Africa.

\section{Appendix I.}

Notes on Personal Outfit .

Clothing-Saddlery-Medicines-Tent-Food.

\section{Appendix II.}

Notes on Animals and Where to Find Them

Localities in which animals can be found.

Appendix III.

Lion Telcgrams

Appendix IV.

Vocabulary of African Words 



\section{ILLUSTRATIONS}

My First Lion

Frontispiece

FACING PAGE

Map Showing Locality in which Game is Found . xxiv

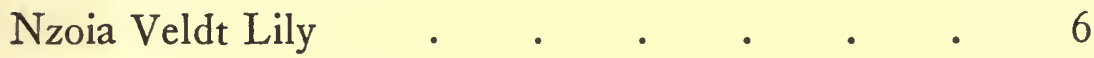

Australian Moon Flower (Datura) . . . 6

Water Gate of Old Fort, Mombassa . . . $\quad$ I2

Ruins of Old Portuguese Fort at Harbour Entrance,

Mombassa . . . . . . . . $\quad$ I2

Strong Men (Porters) Going to Bathe . . . 30

Hairdressing Extraordinary. My Dandies . . 30

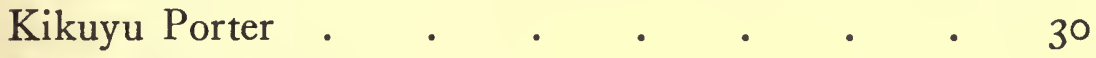

In the Mau Forest . . . . . $\quad 5^{6}$

The Grass is Long Beyond the Nzoia (October) . $\quad 5^{6}$

What a Storm on the Nzoia Can Do to a Strong Tent 70

First Lion of the Party, and Momba, the Gunbearer

He Mauled . $\quad . \quad$. $\quad$. $\quad$. 78

A Good Lion - After a Good Ride . . . 94

A Laikipia Lioness $\quad$ • $\quad$ • $\quad$ • $\quad$ • $\quad$ • $\quad$ • 94

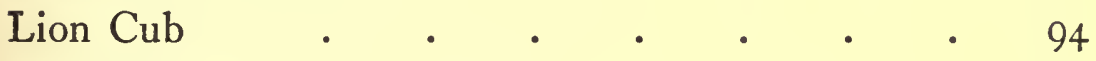

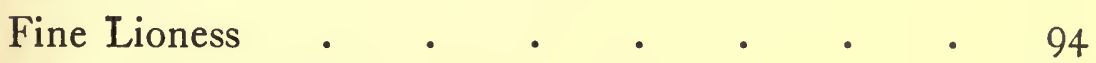

Falls of the Athi River . $\quad . \quad . \quad . \quad . \quad$ I08

Water-Buck on the Nzoia . $\quad . \quad$. $\quad$. $\quad$. 124

Wild Dog Photograph Taken at a Few Feet Distant $\quad$ I24 
Jackson's Hartebeest (Kongoni) • • • • I 24

Good Rhino Head • • • • • • • 124

Camp. Early Morning . • . . . 140

Camp at Eldama Ravine on the Edge of the Mau Forest

Head Porter (Wanyamwazi)

Little John Connop, My Tent Boy • • • ${ }_{4} 46$

Porter. Winding His Blanket into a Turban Before

Starting . . . . . . . 146

My Gunboy . . . . . . . . 146

My Gunboy on Sefari . . . . . . 150

The Toto - the Tail of the Sefari . . . I50

David Rebman, Headman on Both Trips . . I50

A Prospective Feast • . • . • • 152

Crossing Swampy Streams, Look Out for "Crocs" 162

Elephant and N'dorobo, Beyond the Nzoia . • I9o

Elephant Herd . . . . . . . 200

Elephant Ford on the Nzoia . . . . 200

Massai Warriors . . . . . . 2 I4

Massai Women and Totos Outside Miunyata . 2 I4

Massai Moran Warrior . . . . . 2 I4

Some of Our Wakamba Porters . . • • 224

Karamojo Warriors - a Ten Minutes' Halt . $\quad 224$

Karamojo War Party . . . . . . 224

Kikuyu Blacksmith Making a Sword • • . 224

Elgao Elephant Harpoon . • • • • 232

Elgao Spears, Shield and Snuff Box . • . 232 
N'dorobo Bow, Arrows, Axe-club, Quiver and Honey Bottle . . . . . . 232

Karamojo Spears (Sheathed), Shield and Pillow . 232

The Result of My Last and Hardest Ride - a

Cheetah . . . . . . . 248

Naivasha Lake . $\quad . \quad$. $\quad . \quad$. 260

Nzoia River . . . . . . . 260

Mr. Kenia from the South . . . . . 276

Mt. Kenia from the North . • . . . 276

White Ants' Nest. • . . . . . 280

Native Bee Hives . . . . . 280

Good Buffalo Head . . . . . . 290

Buffalo. An Old Bull . . . . . 290

Bean Tree on the Nzoia . . . . . 304

A Thorn Tree on the Nzoia . . . . 304

Wild Fig Tree on the Nzoia . • • . 304

Euphorbia, Laikipia Plateau . . . . 304

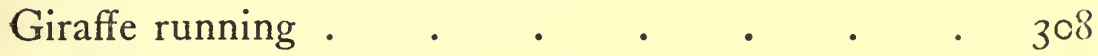

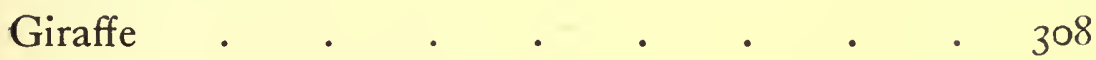

Laikipia Red Granite Kopje . . . . 316

The Terror of the Sefari . . . . . $\quad 324$

A Settler's Beginning . . . . . . 368

Interior of Mengo Cathedral . $\quad$. $\quad$. $\quad 368$

Missionary House on Mengo Hill Near Cathedral . 400

Forming a Living Chain . . . . . 430

Wanyamwazi Column Marching into Camp . . $43^{\circ}$ 



\section{INTRODUCTION}

OF воoks on African sport and travel truly there is no end. What excuse then, can I make for adding another to their number? Frankly, my first reason was the pleasure the writing of these notes afforded me.

My memory has never been a good one, and after years of somewhat hard work, I find, alas! it is less and less serviceable. If I wish to retain vivid impressions myself of what seems worth remembering, or if I wish to convey the result of my impressions to others, I find it necessary to make copious notes at the time. In this way I fell into the habit of writing down as I went along, some account of what I saw, and sometimes of what I heard.

Then you cannot travel every day and all day, in Africa. There are long hot afternoons to be passed, and occasionally long wet days to be wiled away, and since it is not always easy to carry many books, writing of some sort seems the natural thing to do.

I fear the results of such a method of writing will be only too apparent in these notes of mine. For notes they were in the first instance, made on horseback (more accurately, mule back) as my faithful burden bearer walked soberly along, or jotted down on my knee, as I called my gunboys to a halt under the shade of some rock or tree, while I did my best to put into hasty form, some word sketch of the strange or beautiful things before me. When I sat down more at my leisure, to reduce to orderly form what I had written, I did not find it always possible to do so.

I can only, then, plead for the indulgence of my reader, and add, by way of excuse, that what is here put down may claim at least the merit, such as it is, of being the 
result of an effort to state accurately what I saw, and at the time I saw it.

As to the stories told, I have made place for none except such as I heard from men who were themselves actors in them, or else were present when the things they tell occurred. "The Railroad Lion" stories are, of course, an exception, and they have been told before. But, then, few Americans have heard them. They are very well authenticated, and, I think, deserve re-telling.

Then, again, I have another reason, and one of some weight. If an Englishman wants to go to any part of Africa, he can probably find someone in the next parish who has been there for years; an American cannot so easily get reliable information. I have found it very difficult. to obtain the sort of information I required. The literature on the subject is voluminous. Africa always was supremely interesting to me, and for years I have read what I could lay my hands on, as I always hoped, some day, to take the journeys I have made within it. But read as I might, and question many sportsmen and travellers as I did, I found myself, once I was in Africa, and had started on sefari life - very poorly informed indeed.

One man says, "Go by all means in the wet season," another, "As you value your health, don't go in the wet season - go in the dry." When is the wet season? Says one: "It begins in March and is over in June." Says another: "It begins in June and goes on till September." Africa is a hard country to find the truth about before you come; and to sift out the truth from all abounding exaggeration and inaccuracy, when you are there.

Want of accurate information wrecked my first expedition. I had a pleasant time, it is true, and saw a great deal of game; but failed to go where I wanted to go, or get what I most wanted to get.

Now, after a year's constant travel, during which I have 
ridden and walked more than five thousand miles, I really think I have some knowledge that is not without its valueabout the country - the best place to go for certain sorts of game; the most beautiful and healthy parts of it; the sort of sefari to gather round you, and how to control and manage it, so that your men are contented and happy, and the days passed with your black folk are a pleasure to both yourself and them, and not what, unfortunately, they too often are when ignorant or thoughtless sportsmen hurry their men from point to point, misunderstanding and dislike increasing as they go. I have learned, too, a good deal about African hunting; how it should be done to-day, and that, I can assure my reader, even if he has hunted as I have, in a great many different places, takes care and time-African big game hunting is quite unlike any other.

These things that I have learned and seen, I have not been able, as I say, to find in any book, or gain from any sportsman. That may have been my fault or my misfortune, but the fact remains. I have therefore resolved to publish the record of them, being confident that there are others who may wish to visit this beautiful country, and who need to gain all the information they can before doing so. Much time and expense are saved to the man who knows what he wants to do, and has at least some idea of how he intends to do it.

Some may, I fear, think that I have overburdened my story with detail; items of outfit; measurements of animals; distances at which shots were made; description, or, rather, attempts at description of scenery; or notes on the habits of little known beasts and birds. All I can say is that I do as I would be done by, and to the best of a poor ability put down for others what I wish heartily someone else had put down for me.

But when I have said all this, I have not yet mentioned my strongest reason for publishing anything about Africa. 
That reason is: Africa fascinates me as she ever has those who visit her. The old Arab proverb proved true at least in my case: "He that hath drunk of Africa's fountains will drink again."

The first view of southeastern Africa is unattractive in the extreme. As I made my second visit to the coast this was again impressed on me. Three years before our "Messagerie" steamer had taken a course close in shore and day after day one gazed on those mountainous sun scorched sand dunes, where no blade of grass grew, that seemed to hiss and sizzle in the heat as the blue waves washed them. Now and then a faint curl of smoke marked where some Somali camel herder or fisherman had pitched his black tent, that through the glass might be seen clinging like a black snail to the yellow ground. One of the English civil servants on board, who had been stationed for some time on the Juba River, which divides British East Africa from Italian Somaliland, told me that a boat's party who landed on these Somali sandbanks would have their throats cut in half an hour. Sincerely he pitied the Italians for having such a dangerous and unprofitable colony, and thanked God that the Juba marked the British line.

On the second trip the barren unfriendliness of the Somali coast was illustrated afresh. Our German steamer called at Naples, and then took aboard sixteen Italian officers. The company undertook to land this party at Mogadicio, which was somewhat out of the usual course, and thus we came to make a call at a little port seldom visited.

The officers were charming gentlemen, as Italian officers usually are. Picked men, too, for their business was no sinecure. The Somali under (or supposed to be under) Italian rule had, as they love to do, made trouble, and had cut up a large party of askaris, * killing some two hundred

\footnotetext{
*Native soldier. The askari on Sefari life, is above a porter, and under the head man. He carries no load (ordinarily) but is armed, carries your messages, and guards camp at night.
} 
men and several officers. Our fellow voyagers were commissioned to take the places of the slain, and to reorganize and stiffen the native soldiers. They have no European troops on the coast, and were wholly dependent on what, I fear, was a rather poor quality of native; to beat back, in the first place, and then reduce to order, the rebellious Somali - they surely were not to be envied. The monsoon was only beginning, but already the big blue whitecapped rollers were thundering full into the unprotected mouth of what was really no harbour at all. A small coasting steamer, and some dhows, reared and tore at their anchors, as though they would wrench their bows out. And landing our friends, their scanty supply of ammunition and stores, as well as their mules, taxed evidently the resources of the place-as well as those of the crew. The leaky undecked dhow that came off for them, leaped up and down alongside. The mules had, of course, to be slung, and popped down into the hollow of the dhow just at the right moment. The hold would be full of shouting, gesticulating naked men, being shot up into the air, when down would plump among them a very bewildered mule, dropped sharply by the donkey engine. When there were a lot of mules in that narrow hold, as well as a crowd of men, it seemed nothing short of wonderful that everything and everybody was not kicked to pieces. And the rotten boat itself was so leaky that it looked as though the turmoil within it would make it founder. Charming men, and, no doubt, good officers, those Italians were. But who could help feeling sorry for them, dropped down in a little open port, into which no steamer could enter till the monsoon blew on, that is, in three or four months' time. Thy could not receive mails or reinforcements by sea, and on land the Somali had so infested and harassed the place, that no mail runner had got through from Juba for months. 
Italian Somaliland is a country surely not worth fighting for, not worth the blood of one honest patient Italian soldier or officer, and yet since her flag has been raised over its barren waterless wilderness, Italy seems unwilling to haul it down. But if she will not take this course, then most surely she will shortly have to send from her shores expeditions of another sort, than that one which the Gertrude landed. Our friends were so hastily dispatched that they had not even sun helmets, but had to search Port Said, after midnight too (for the steamer made a late landing), for such poor substitutes for headgear as its shoddy shop could supply.

Mogadicio was under the Muskat Arabs an important town; but it has sunk into insignificance. The squalid little place, with its apology for a port, is a mere huddle of whitewashed mud houses, crowding close down to the sea. It has no safe anchorage, soon as the monsoon begins to blow, and no good water.

A high sand-dune back of the town is crowned by a small lighthouse. Here some earthworks have been thrown up, and the Italians have placed small shell guns, taken from one of their gunboats on the coast, in position.

The thorn scrub which covers the country at a short distance from the sea, has been cleared away for a couple of thousand yards from the muzzles of the guns; and for just that distance, and no more, life is pretty safe round the place. Beyond it patrols were cut up.

We drank to our friends' health and success at dinner, and bade them good-bye with sincere regret. Far away from home and friends and support, they took up the thankless work assigned them, with that light-hearted courage that has so well served their fatherland during the long dark days, now we hope forever over.

But as I saw the last of them go down the ship's side, I couldn't but feel that someone had blundered. That 
they should have come with far greater reserves of men and supplies, or not come at all.

After days of slow coasting close to the sun-baked dunes, where the sparse brushwood, when it did show in their hollows, seemed burned black, the somewhat shabby greenery of the coast line near Mombassa is a relief to the eye. But the cocoanut palms are short and bedraggled - and the tangle, that descends to the very surf, looks decayed and unhealthy.

As the big rollers came in before the monsoons, and broke in creamy spray on the dark rocks, I seemed to see another coast line far away. There little headlands of red rock are covered with pines twisted and bent by many a winter storm. Between them lie curving sandy bays, to whose smooth yellow edges delicious meadows come sweeping down, purple and white with clover and marguerites. Surely Swinburne must have dreamed of a Maine or New England shore in springtime when he wrote those matchlessly beautiful lines:

"Where waves of grass break into foam of flowers

Where the wind's white feet shine along the sea."

Africa's coast line seems sad and dark to me.

Mombassa has probably been besieged, stormed, sacked, and burnt, oftener in a short time, than any other place on the globe. Look where you will, you see signs of ancient warfare. Rusty Portuguese guns thrust their muzzles forth from the jungle, and close down to the water, the ruins of strongly built batteries still hold their own against the destruction of climate and creeper.

The citadel, finely placed, overlooks the port.

How did they manage to build such a place, those few ill-supported white men of the sixteenth and seventeenth centuries? How much one would give to know something more about them! They were few. They were far 
far from all sources of succour and supply - surrounded by utter barbarism and in a land where the deadly fever daily sapped the strength of the strongest. Yet they made a bold bid for Empire.

It would sometimes be well, if the Anglo-Saxon remembered, that others than he and his, have paid heavily for the rule of the sea - paid and lost.

"If blood is the price of admiralty" - as Kipling says - the Portuguese "have paid it well."

Look at the main fort. It is larger and incomparably stronger than the original citadel Montcalm held for France. Built so solidly that even to-day its bastions would for a time withstand artillery.

An old tradition has it, its mortar was mixed with human blood, and, indeed, the loss of life in building such a place must have been enormous. Forced labour was employed, for, from Pharaoh's time onward, none has taken any account of the labourer in Africa.

They were cruel men, those Portuguese adventurers, as were most of the men of their time. Perhaps even more heedless of human life than their fellows. But surely they were strongest of the strong. They had their short day, and though its sun soon set, they accomplished much in it. Their King Henry, the navigator, half an Englishman, be it remembered - for his mother was daughter of "Old John of Gaunt, time honoured Lancaster," led them in the very van of discovery. But Africa proved fatal to Portugal. In the northern part of that continent - in Morocco-she strove hard to found an empire; and there, far inland, worn down by thirst and lost in sand drift, the adventurous young King Sebastian, aged but twenty-three, fell on one disastrous day, with the youth of his little kingdom round him, and from that overwhelming calamity Portugal never quite recovered. Then in the southeast, for many a long year after her 
disaster in the north, Portugal continued to pour out blood and treasure. Here, in briefest outline, is the story of the town. Vasco de Gama anchored off Mombassa, April 7, 1498, and Camoen, writing of the town as it then was, says, on "it's sea-board-frontage" were to be seen "noble edifices fairly planned." In I 505 the Portuguese fleet attacked the place and the town was stormed. The Arabs retook it, and in I 528 Mombassa was stormed and burned for the second time.

In 1585 Turkish Corsairs drove out the Portuguese again, carrying off plunder to the value of $£ 600,000$ (a great sum for those days) and fifty Portuguese prisoners. Portugal retook it in 1586 and lost it again to the Corsairs in 1588 .

In 1592 Portugal returned in overwhelming force, conquered all the neighbouring towns, stormed Mombassa, and made it the capital of East Africa.

The great citadel was commenced in 1593. See inscription inside the porch.

In I63I all the Portuguese in Mombassa were murdered in an Arab rising, led by an Arab whom they had sent to Goa to be educated and baptized, and who had married a Portuguese lady.

A punitive expedition drove him out - but not till he had dismantled the fort and burned the town.

1635. The fort was repaired. (See inscription over sally port.)

1660. An Arab fleet sailed from Muscat to aid the inhabitants to throw off the intolerable yoke of Portugal's tyranny. The town was now constantly attacked by the Arabs till 1696, when the great siege began. An Arab fleet entered the harbour March I 5 th, and the population of the island, black and European, which had been much reduced by constant warfare, took refuge in the citadel. There were, in all, 2,500.

A relieving fleet was driven off. 
January, I697, the plague broke out in the garrison and by July 23d there remained but the Commandant, nine Swahili, fifty native women, and the king of a neighbouring tribe - Faza.

The Commandant died August 24th - yet the desperate remnant somehow managed to keep the Arabs out for three weeks.

A relieving fleet came in September, and I 50 Portuguese soldiers and 300 Indian mercenaries were thrown into the place - then the grip of the besiegers closed on it again.

For fifteen months longer this almost unparalleled struggle went on, till December I2, 1698, when the Arabs at last stormed. The garrison, reduced to eleven men and two women, was too feeble to offer serious resistance, and all were slaughtered.

I699, I703, I710. Portuguese expeditions tried to retake Mombassa and failed. What a story of tenacity, cruelty, and courage it is! - and scarcely one memorial of it save the yellow crumbling citadel, and its deep moat hewn with infinite labour from the coral rock, remains.

Dense tropic tangle and the carelessness of the East have combined to wipe out almost entirely the scanty memorials of the great past - even the graves of the brave dead of those old days are now lost and forgotten. Arab and Portuguese alike, no one knows where they lie.

One of the most intelligent Arabs in Mombassa - one too, who claims descent from the conquering Sultans who, drove the Portuguese out - and for so long reigned in their stead - gravely assured me that there never were any Portuguese graves - as they always buried their dead at sea. He was equally ignorant as to where his own conquering ancestors, who fell before the place, lay. 


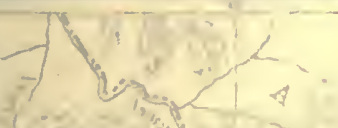

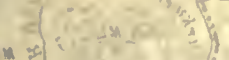

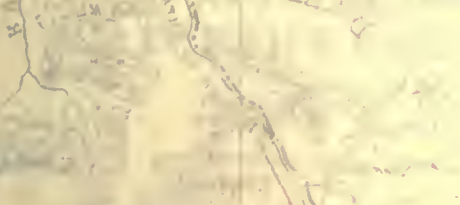

$$
\text { - } 2+10
$$

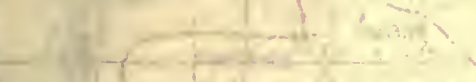

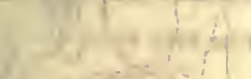

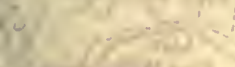

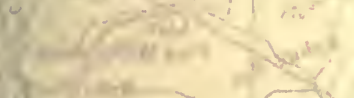
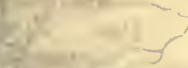

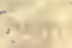

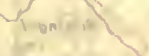

(4)

yoperito

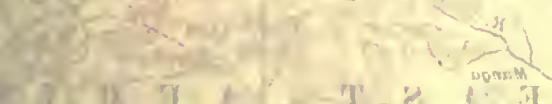

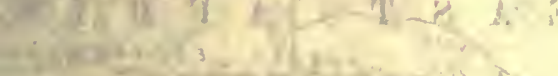

2.

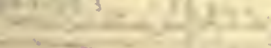




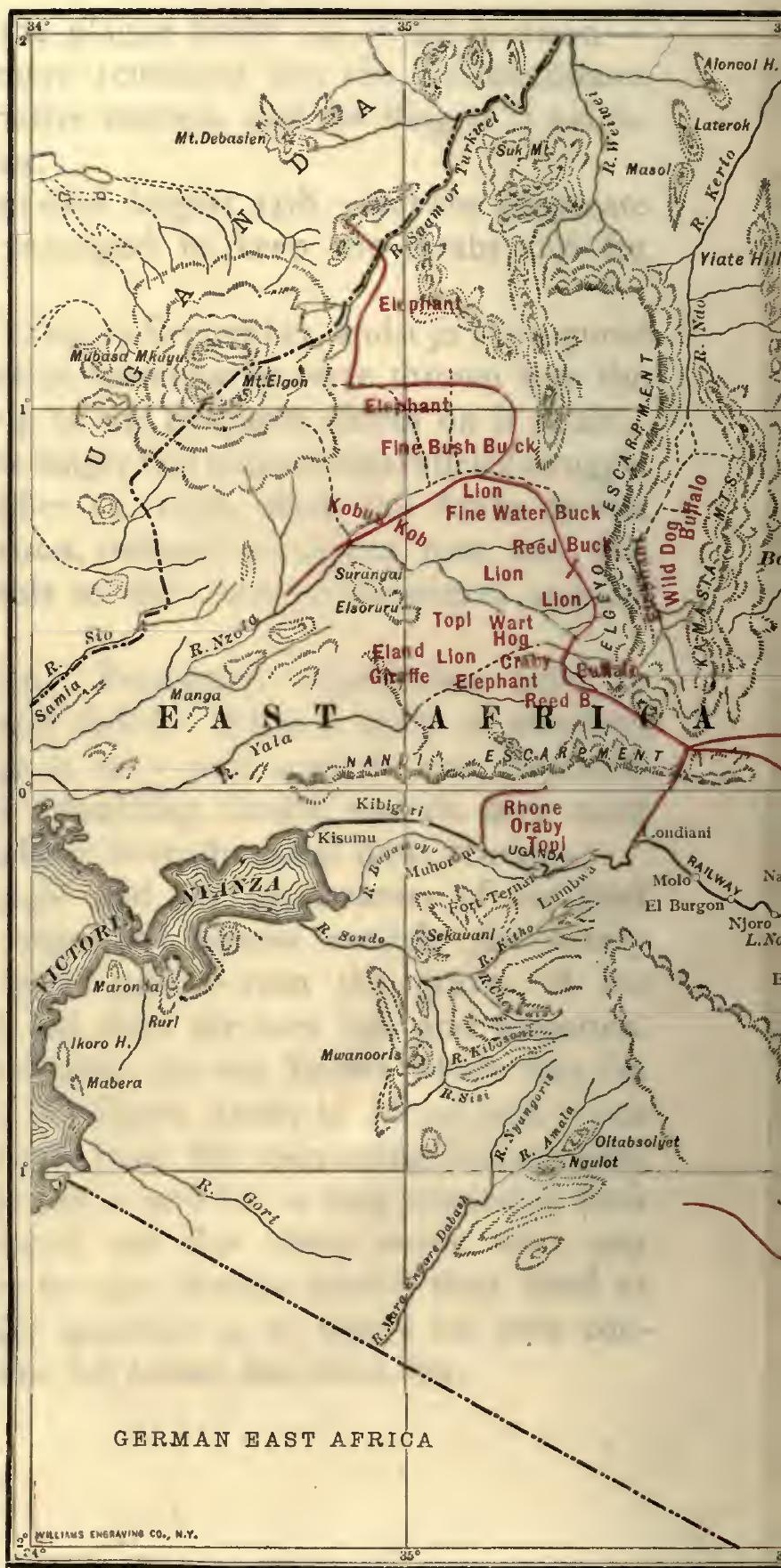




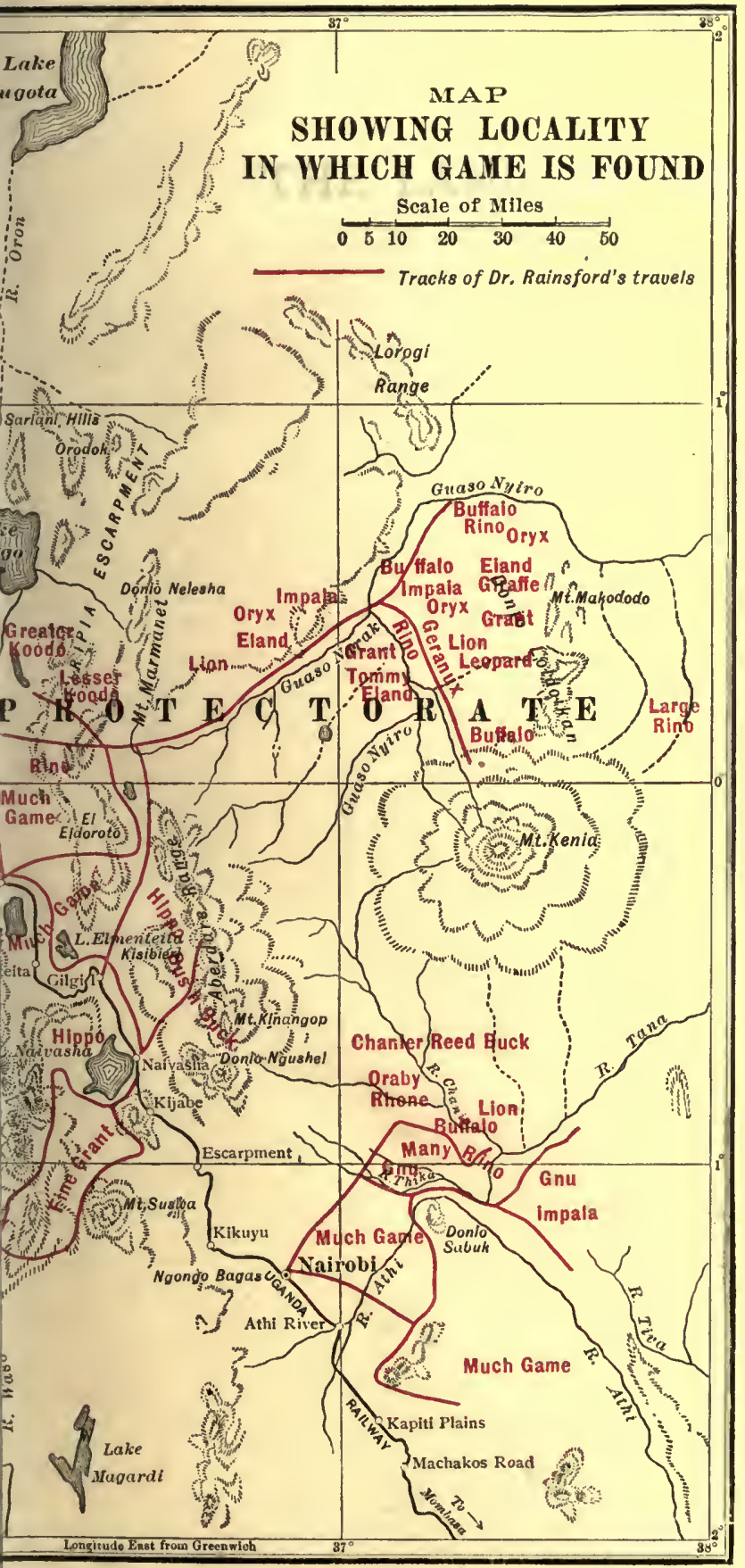


er. A If

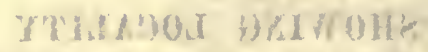

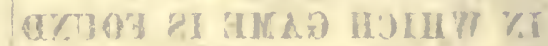

13

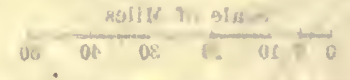

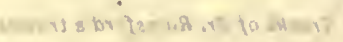

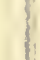

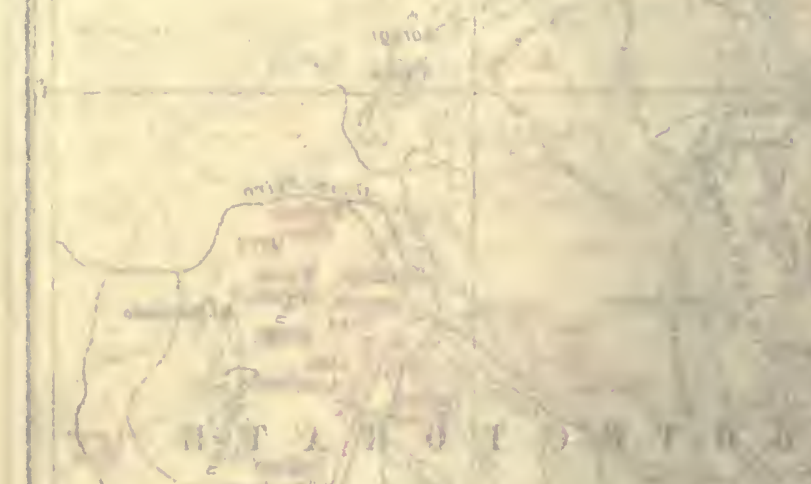

.
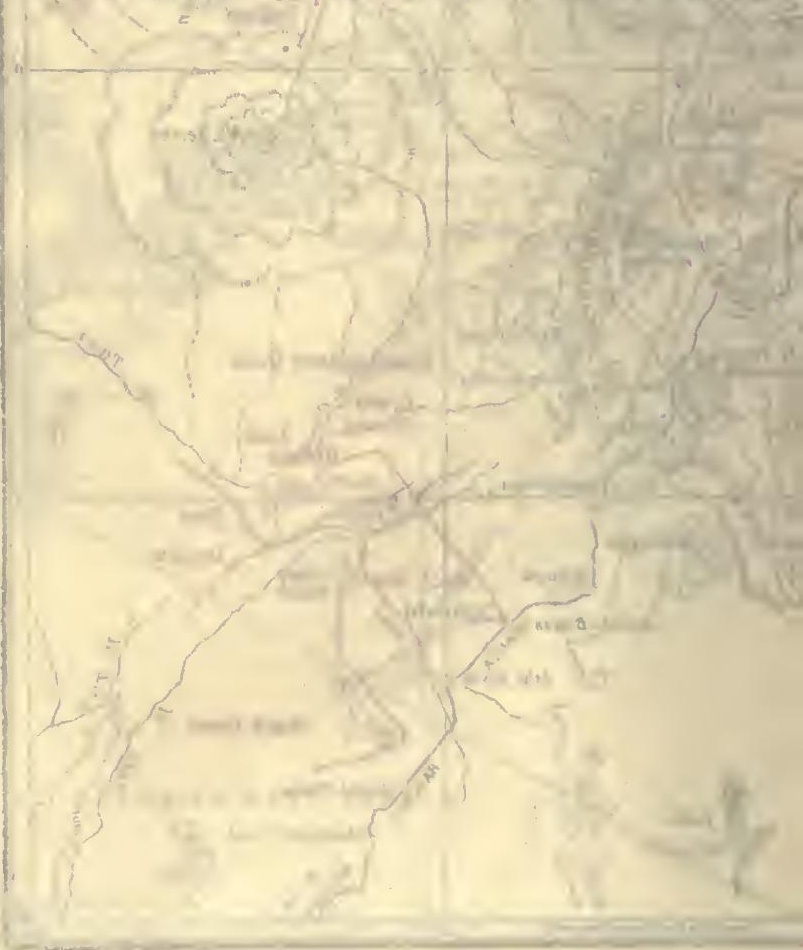
THE LAND OF THE LION 



\section{The Land of the Lion}

CHAPTER I

\section{MOMBASSA TO LION LAND}

7 HE scenery on the Uganda railroad, between the sea and Nairobi, is often picturesque and interesting. I shall not, however, dwell on its features, as these have been described time without number. But one view there is of Mount Kilimanjaro which with good fortune may be seen, and of it I want to speak.

The through express train from Mombassa to the lake, if it is on time, passes near enough to the mountain to afford that view. Just before sunrise I had been told to look out of the left hand carriage window, at about five o'clock in the morning, and see what I could see and what I saw that clear morning three years ago, I shall never forget.

All around was the dark plain illumined only by the stars, for there was no moon. It was about quarter-past five, when to southward I saw a vast pink column, flattened on the top, that rose distinctly against the dusky purple sky. Redder and redder it grew, as the first sunbeam touched its snows, and then at its base, the fringe of wooded mountains showed in the earliest light of the coming dawn. Kilimanjaro is more than nineteen thousand feet high, and that morning it seemed to have all the wonderful sunrise glory to itself for quite a long time, while still the veldt at its feet lay in the darkness. Just that column of pink, changing to scarlet - and nothing else to tell 
of the sun, not yet risen, on a far lower, and more commonplace world. Great mountains are usually so surrounded by gradually rising country that they are robbed somewhat of their height. Kilimanjaro, however, rises sheer from a plain only two thousand feet above the sea - and over these levels it towers superbly. Like all African mountains it is broadly belted by forest. Above this it lifts itself in this one mighty cone, whose steep sides and flattened summit, no less than fourteen miles across, are covered with perpetual snow.

Half an hour after sunrise the rising mists of the woodlands have closely woven their swathing veils around it. The mountain has vanished, and you can scarcely persuade yourself, as you jolt over the dazzling plain, that the vision of an hour ago was more than a dream.

I have often seen Kilimanjaro since then, but never as I saw it first, during that half hour before the sunrising. In full daylight its height and bulk are imposing. though few, I think, would hold it remarkable for its beauty, But the mystery and magic of that crimsoning column, rising out of utter darkness against the morning sky, was alone worth a long journey - and I shall never forget it.

Nairobi, the capital of the Protectorate, is more than three hundred miles from the sea, and stands at an altitude of nearly six thousand feet. The site was mistakenly chosen without doubt, and the native town, as well as the shop and bazaar lie too low, and are not easy to drain. But Nairobi has one charm that should not be denied it. That is the fine broad well metalled main street that runs for more than a mile straight from the railroad depot to the Norfolk Hotel.

I cannot fancy any other mile of roadway in semicivilized Africa so interesting. Farmers, Boers, civil officers, and soldiers very smartly dressed, in well-fitting canvas or khaki, and last, but by no means least, the 
rare Englishwoman, far more admired and petted here than she ever is at home, in every sort of dress and undress (a renowned English politician on his recent visit, made mortal enemies of many of them, in that playful, if not always kindly way he seems to have, by admitting their good looks, but describing their dressing as "dowdy") and on every sort of "mount"- pony, mule, donkey, bicycle, in 'rickshaw or wagon, motor-car or camel cart - pass ceaselessly up and down.

But you come to see the brown and the black man and nowhere will you find him in greater variety - many tribes and races here throng together.

Arab and Somali traders are here, some of them knowing more of inmost Africa than any white man alive. Hindu merchants and shopkeepers, among the least honest of the earth. Wanyamwazi porters - whose homes are in far-away German East Africa; many of them would fain change from a German to an English overlordship if they could; but the German hand reaches far and grips tightly, and they love their distant cattle - and, let us hope, their wives, and these the Germans take great care of in their absence - and so German natives they are fated to remain.

Then you come across hundreds and hundreds of Kikuyus, for this is their country, and all the rich shambas* of the neighbourhood, European or native, are tilled by them. Most of the natives in the motley throng are on pleasure bent. These Kikuyus are not like the rest, a casual glance at them is enough to convince you they are no idlers. Up and down the streets they trudge with their burdens, quite as many women as men. They are the moneymakers of this part of the Protectorate.

There is movement and colour everywhere. Smart black women, often with very fine figures, in their most

*Name for farm. 
picturesque cotton togas, stand in groups at many a corner, laughing and chaffing the idle native porter as he saunters by, while hundreds of their more virtuous (let us hope) and much more naked sisters, stand in companies or squat on the ground outside some Indian's store or contractor's office, a black baby in an unspeakably oily bag at their breast, and sixty pounds of mealy meal, tightly bagged, slung by a headstrap, and carried low down behind their shoulders. Yes, I never can get tired of sauntering in Nairobi main street.

The Europeans whose bungalows dot the wooded hills that on two sides surround the town, have a fine view over the Athi plains. With Zeiss glass it is still possible to see immense herds of game - harte beste, zebra, gnu, Grant's and Thompson's gazelles - feeding. Thirty miles away stands Donyea Sabuk - a partly wooded precipitous hill; rising some three thousand feet, and round its base within a circle of a few miles, I suppose it is no exaggeration to say, that twenty white men have been killed or mauled by lions.

The flowers in Nairobi are a delightful surprise and wonder. Even in the dusty streets of the town they are plentiful. In poky little ill-kept gardens, or on unsightly corrugated iron roofs they climb and twine. When some pains are taken with them, and they are tended and watered in drought, they bloom and flourish as Italian roses do, only instead of blooming as these, for a few weeks only, at Nairobi roses bloom nine months in the year. Roses, passion flowers, pomegranates, orange trees, Bougainvillea, and many more, make scores of cheap little houses seem bowers of delight.

Even along the unsightly paths that always struggle into a frontier town, rare and beautiful flowers sometimes surprise you, growing luxuriantly in front of many a mere hut. 


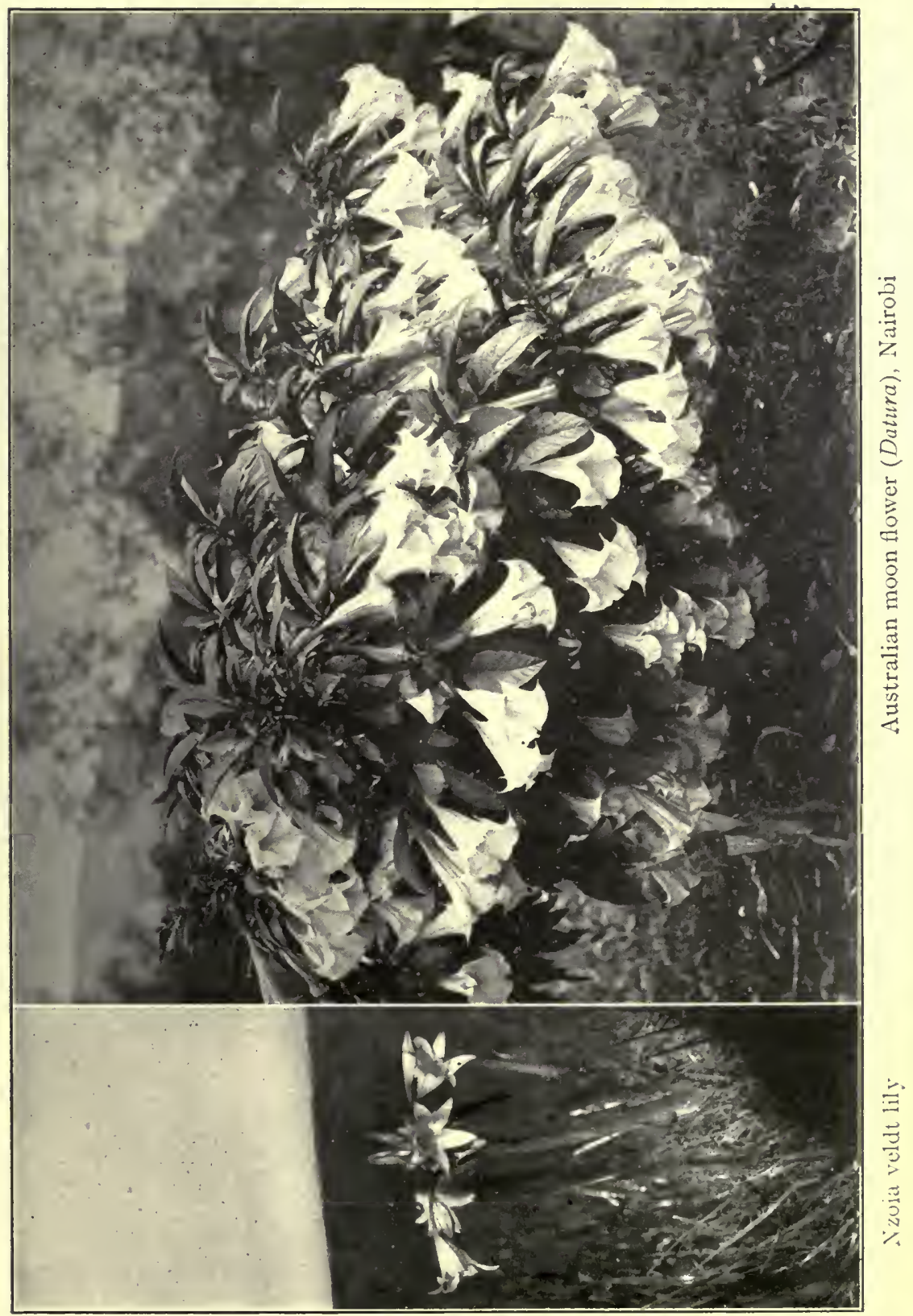



Having now reached Nairobi, the usual starting point for sefaris, I may as well try in a few words, to give some general idea of the country, and especially of that part of it, where the best scenery and best hunting are to be found.

A volcanic upheaval has raised a wide plateau in East Africa far above the level of the continent. Roughly speaking, that plateau runs three hundred miles east and west. It begins about two hundred miles from the sea, and slopes down on the west to Lake Victoria. North it falls away toward Abyssinia and Italian Somaliland.

In the middle it is divided by a huge cleft, the great Rift Valley (the eastern end of this valley is called the Kedong) and in this valley lie a string of lakes - Naivasha, the most easterly; Rudolph, the most westerly; Nukurn and Baringo lying between. The Rift Valley is well named. It is a mighty crack in the world crust, running, as geologists have traced it, all the way from Lake Rudolph to the Jordan Valley and the Dead Sea. On either side of this valley rise two lofty chains of mountains. On the western side these are called the Mau Escarpment; on the east the Kikuyu Escarpment and the Aberdare Range. Mountainous branches and spurs from these ranges run back into the plains to west and east - and two fine mountains standing far out from the tumult of tumbled and crossing ridges, dominate all other mountain peaks. These are Elgon on the west, looking down on Lake Victoria, and beautiful, lonely snowy Kenia, rising above the wide Laikipia plateau on the east. I shall speak of Kenia later. Now our faces are set toward the high table lands lying beyond the forest of the Mau. Here but three years ago entrance to the traveller and sportsman was forbidden. The Nandi, a numerous and warlike tribe, were in process of being chastened. Several hundreds of them were killed, their crops burned and many of their cattle taken 
from them and sold. The discipline was severe, but it seems to have been most necessary. So far as the natives are concerned these plateaus are now as safe as Central Park, and there are probably more lions there than in any other part of Africa.

One hundred and forty miles from Kilimanjaro, and some thirty from Nairobi, another view of surpassing interest suddenly bursts on you. It is the first peep into the very heart of a bit of primeval African forest - and it, too, to be had, from the cushioned seat of the railway carriage.

Shortly before reaching Escarpment station (Escarpment in British East Africa means a steep line of sharply defined mountainous country) the road begins to plunge downward. The zigzags are very sharp, and the torrent beds are far below. Here a dense belt of forest country, stretching many miles to north and west, has to be traversed, and, as I said, you can have your first glance into the impenetrable, inextricably interwoven masses of all kinds of greenery that, matted and twisted together, make up the living wall of the African wood.

In such cover man's progress is only to be achieved by the hardest sort of work. The ponderous elephant alone moves there at will, breaking and bending as he pleases everything in his way. And when the wild man passes he passes only by the paths the elephant has made.

You may travel or hunt for a long time in the country and yet never really get such a good idea of the quality of the forest as you can from the train. On foot or on horseback such jungle is always avoidable. It is most dangerous to hunt in, and the noise that even a naked N'dorobo (wild man) must make is enough to disturb the game. Look, now, right down into its labyrinth of tree stems and creeper. Into its cool damp glades, into chasms cloven by yearly torrents whose rocky sides are clothed many yards deep with densest hangings of tropic tangle. 
Here and there streams tinkle far below, as a viaduct lifts you above the tree-tops standing massed together in some dark ravine. From a high embankment you see right in among the straight forest stems, and can mark the massy green herbage that mounts up and up them, throwing stout climbing ladders over the wide spreading lower boughs.

Were you on foot, the upper world of the land that lies now all open to you would be completely or almost completely hidden, and your path would twist amid dark and damp herbage, that, arching far overhead, left you in deep shade. Now, in a quarter of an hour you make above the forest a progress that on foot would have taken you days of heartbreaking struggle.

You are, indeed, seeing what you may not see again. On sefari you will avoid such difficulties - no band of stout Wanyamwazi porters you may command could hope successfully to struggle with them. Your trail will go when need be, many a long mile round, rather than attempt the passage of so much as one-half mile of it, unless, for some reason, there is no way round, or a road has been already cut through.

For a little while the train now winds in and out amid these sombre haunts of the elephant, then, suddenly, as you rush round a corner, the glowing, sunlit Rift Valley opens right underneath you. The contrast is dazzling. Here, indeed, is Africa. Shade so dense that the tropic sun never gains an entrance, and sunlight so intense you soon want to rest your eyes, and so turn them on the long strips of woodland that come tumbling down almost two thousand feet to meet the plain.

The Kedong Valley (it forms the nearer end of the great Rift Valley) must be, I think, quite unlike any other in the world. To attempt to describe it is beyond any modest powers of mine. The cañon of the Yellowstone 
River - where the sun shines full into it - is a marvellous bit of colour. But here the colours are as brilliant, and yet have the softness that the chasm of our mountain river lacks. One of Turner's magic sunsets, transferred from sea to land, would alone give an idea of its iridescent splendour. I fancy the clouds formed by the steep escarpments that shut the valley in on either side are partly the cause.

During the night African forests breed clouds all their own. The dense moisture floats off slowly in the morning sun, clinging to the tree-tops as it rises, and forming clouds heavy enough to hold together till almost midday. On both sides of this glowing valley these cloud-forming forest ridges rise for more than two thousand feet, and from them, let the wind blow where it will, during the morning hours at least, the drifting vapours will partly shade the plain. Through these breaks, the sun, lighting up broad stretches of corn yellow grass land, shining on purple woods pushing down the steep incline, and on all the tossed and broken masses of ridge and valley, heaved up ages ago, when this vast chasm yawned open in a cooling crust.

Colour everywhere. Colour changing, shifting. Colour on the red-brown cones of two long extinct volcanoes, that must have bubbled forth lava thousands of years after the valley's floor had grown firm. Colour on the great volcanic rocks that seam their sides, and over which the greenery of the tropics has not yet had time to weave its mantle and colour at last far away down the glowing valley, caught up and flashed upward from Naivasha Lake.

Up and down the Kedong Valley in pre-railroad days - that is to say, not ten years ago - passed much of such commerce as there then was between the great lakes and the sea. Here tribe clashed with tribe. The 
Massai who claimed the country having usually the better of it. And rival caravans struggled for slaves and ivory. Here, too, only a few years ago, an English adventurer, named Dick, was with all his men wiped out by the Massai. So far as is known, the tragedy came about in this way. A Swahili sefari, coming back from a trading expedition, and "feeling good" as they neared the end of the journey, celebrated the homeward march by blowing their horns and beating their drums. This unusual noise raised pandemonium among the Massai herds, which were gathered in great numbers in the neighbourhood. The Massai say they sent messengers to tell the Swahili to stop the racket, and to go quietly through the land. Whether the Swahili received the order or whether they understood it will never be known. In any case, they went noisily on, and the Massai attacked and speared them to a man. Dick, with a small sefari, happened to be close behind the Swahili caravan, and for some reason or other, soon as he heard of the slaughter, at once attacked the Massai. The Massai seemed to have tried to avoid fighting; but Dick, a man of desperate courage and a good shot, opened a deadly fire on them, and in a few minutes had killed twenty. Then his rifle jammed, or some accident happened, and he fell, speared in the back. The Massai declare he killed several with his clubbed rifle. His grave is on the hill close by, and still the Massai call the place, "The grave of the English lion" (simba ulya). Skulls still thickly strew the kopje where he made his last stand.

At 4.30 A. M. of a bitterly cold September morning, we came to a stop at the little railroad station of Londiani - more than one hundred miles west of Nairobi. It was pitch dark, and the hundred and ten men that composed our motley array huddled miserably under their blankets on the platform. A very unreliable railroad lamp here 
and there, served only to reveal the confused piles of tents, boxes, guns, fodder, and all the innumerable odds and ends that are essential if you would make a prolonged stay in a country far from supplies. Londiani is one of the higher points on the line, and the glass must have been almost at the freezing point. David Rebman's* energy even, was not proof against that bitter fog laden cold, and when I crawled out of my carriage I found him, too, crouching among his blanket-covered men.

Well, the welcome sun came out at last. And the glorious African morning broke, cloudless, opalescent steamy vapour rises from grass as yellow and tall as ripe upstanding English wheat-that fills the hollows, clothes the sides of the steep hills, and pushes right up against the railway platform.

Two long swaying, struggling ox teams crawl slowly away, half hidden in the golden morning haze. The numbed sefari shakes itself into order, and, breakfastless, we take the road on our last stage of the way to the Nzoia or Guash'ngishu country whither we are bound. The Sergoit rock, which may be said to mark it, lies some seventy miles away.

Here I will say a word, as, indeed, I shall have occasion to do again and again, for the often well-abused sefari porter. I say we all started breakfastless, but in my friend's case and my own, we had dined fairly well at Nakuru the night before. Our porters were not so fortunate - railway travelling is slow in British East Africa. The single line is of narrow gauge, and there is of necessity much shunting and many. stops. Nairobi was only a little more than one hundred miles away, but we had entrained there early the morning before. Headman, Somali gunboys, tentboys, cooks, Swahili, many

\footnotetext{
*David Rebman was my headman, on my previous hunting trip to the country. I give something of his quite eventful history in another article. He is a quite first class headman.
} 


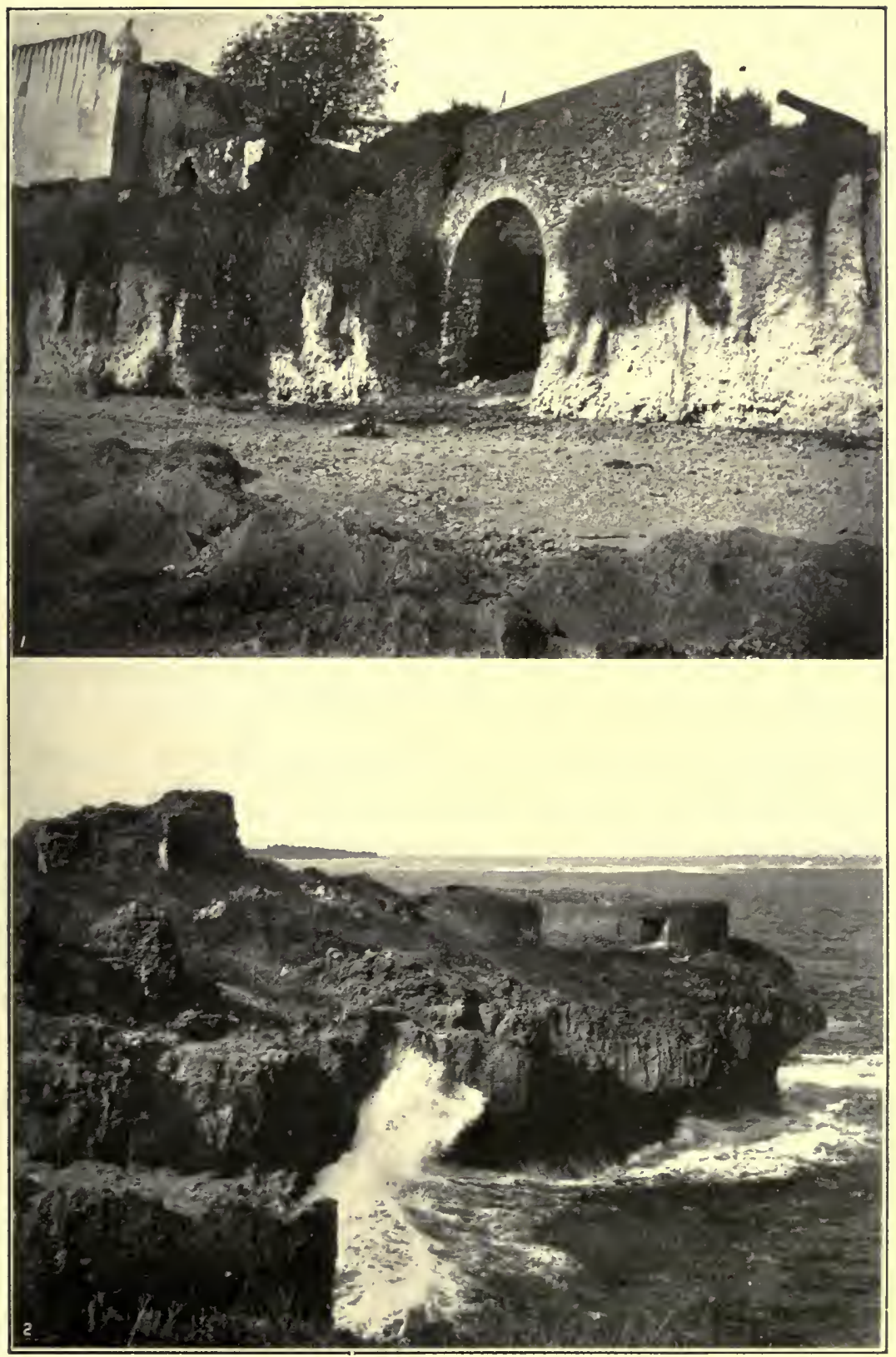

I. Watergate of old fort, Mombassa

2. Ruins of old Portuguese fort at harbor entrance, Mombassa 

Amwazi porters, Wakamba trackers, Waganda, Massai guides and totos*-all breakfastless - had then scrambled into the cars, and, according to the benighted custom of the country, had been at once locked into iron trucks assigned them.

Potio $\dagger$ they had, of course, each man carrying six kabalas, i. e., six days' rations - about nine pounds. But meal or rice cannot be eaten raw, and on a railroad journey cooking was out of the question. So these breakfastless men had had nothing to eat since the afternoon of two days before, yet cheerfully they shouldered their unusually heavy burdens, and marched more than five hours up hill and down dale to the first convenient camping place.

Now, few porters anywhere would cheerfully, as these did, undertake such a job. The eminent politician I lately referred to, has just published in the Strand Magazine some account of his brief experience of sefari life in Uganda. He describes his sefari's start on the march between the lakes - his strongest porters scrambled for the lightest loads, while the heaviest remained to be carried by the weaker ones, who wept over their jobs. And he goes on to say that though there was one headman to every twenty porters, such a state of things was permitted.

I have had no experience of sefarying in Uganda, but I can confidently say that in an ordinarily well arranged sefari nothing of the sort could possibly happen in British East Africa. Travelling with such men, and under such circumstances would be intolerable. There never should be any scrambling for loads. All of these should be weighed carefully before any start is made. The loads are

\footnotetext{
*Totos are boys learning to be porters. They are not reckoned on the "strength" of a sefari nor do they receive potio. They are engaged as a private matter by men in the sefari to help carry their belongings. Hence often arises difficulty.
}

†Potio-the meal allowance of about $\mathbf{I} \frac{1}{2}$ lbs. which each porter has a right to daily. 
then laid out in a long line on the ground. At the headman's bidding all the porters line up behind them, and each has his own special burden assigned (which he carries unless other arrangements are made, till the end of the trip). $\mathrm{He}$ is then allowed to take his load aside, and fasten to it his own little belongings, sleeping mat, clothes, potio, etc., etc.

Our sefari numbered one hundred and ten men. There were six different tribes of Africans represented on it, and instead of one headman to twenty porters, there was just one - David Rebman. Though all our things were dumped on the platform, and there lay in an immense heap, each package had been previously weighed and tied up, so there was no confusion and no inequality certainly no weeping porters. (It is well to take the time, and see the loads weighed yourself, before the sefari starts from Nairobi.) There was far more food to be carried to Sergoit, than there were men to carry it. I had, therefore, arranged for the main supply of potio to be hauled in two wagons with ox teams from Londiani to the next government boma at Eldama Ravine, where donkeys were waiting for us. Four different kinds of food had to be provided for the men. Somalis bargain for an allowance of Halwa (rice). This is the most expensive portion. Headmen, tentboys, syces, and gun bearers take Monza rice (i.e., rice from the German lands round the lake). The porters try to get Monza if you can be persuaded to give it, but they do just as well on well ground mealee meal, which is usually half the price. The Kikuyus want beans, and crushed mealies must be taken along for ponies and mules. Of all these various grains we had more than three tons to carry.

I give these details of food needed for a sefari, just to convey some idea of how much planning and forethought is necessary if a sportsman elects to cut loose from the 
railroad, and push far afield.* One rule it is always well to observe in planning a sefari - be sure and engage many more porters than you have loads; men fall sick, occasionally, a few desert, and at the last something is sure to happen which calls for extra porterage. My observance of this rule stood me in good stead on this occasion. When the ox wagons were piled high with all the teams could draw, we found that there were seven loads left over. These must have been left behind, if my men could not shoulder them. Next, as I stood on the platform, a note was handed to me from M. A. C. Hoey, a professional hunter I had engaged for this trip, as I wished to ride lions, saying, that as he knew I had plenty of porters, and he had not been able to hire any at the station, he hoped I could bring his personal belongings along. That meant nine loads more. Here, then, were sixteen extra loads unexpectedly cast on me. Things seemed to go wrong this morning, for two of my men had sickened in the night, as natives often do (small blame to them, poor fellows, shut up in iron trucks for so many hours), and for a time it looked as if some necessary things must, after all, remain behind till I could send for them. But I called the men together and laid the case before them, asking them to help me out, and so they did right manfully.

I am not a little proud of a that first breakfastless march in bitter cold out of Londiani, with men who had had no food for thirty-eight hours, and who cheerfully, in spite of that, carried, some of them, almost one hundred pounds, to please me, and save delaying the sefari. Would any other men but these good natured, willing, black folk do it? Certainly neither English nor American soldiers would or could.

*I make no mention here of personal supplies-tents, clothes, ammunition, food delicacies, wines, whiskey (we carried no alcohol whatever for ourselves) and selected provisions for the whole tripshould be bought and boxed in London. The boxes must not weigh more than fifty-five pounds. The Army and Navy Co-operative Company do this work admirably. Full details of such provisioning I give elsewhere. 
The road, or more properly, track, for as yet there are no roads in the country (if a few miles of gravelled roadway near Nairobi be excepted) winds between rolling hills and dense spurs of encroaching forest, twenty-two miles to Eldama Ravine Boma. There is a government station, and a district commissioner holds his court, ruling the neighbouring tribes. The country you pass through for all these twenty-two miles, is exceedingly rich and capable of raising almost any crop and of supporting great herds of cattle. Yet not one single settler's shamba * is visible for all the long way. You ask why? And the answer is of a sort one hears far too frequently in the Protectorate: "Oh, all this is So-and-So's concession."

Twenty-two miles of splendid land, near the railroad, too, locked up and refused to settlers, just because someone with a "pull at home" asked, and someone in authority gave, what he did not know anything about. Real settlers are naturally discouraged by such a policy. As I have mentioned this concession, near the railroad, I may as well, since it is a flagrant case of governmental unwisdom and lack of foresight, state what I learned about it later on.

Not only is this rich district between Londiani and Eldama Ravine held back from settlers, but you may ride more than forty miles after leaving Eldama Ravine, through a country perhaps the very finest and certainly the healthiest in East Africa, and look as far as you can on either side of your way without seeing a head of cattle, or one sod turned for purposes of agriculture. All has been "concessed" to a group of individuals as a forest concession. Now, it is true you are passing through the great Mau forest region. Hundreds of square miles of the finest timber borders your pathway. Let Government give away the mighty Mau forest if it must, or does not know any

*African word for farm. 
better use to put it to. But why in the name of all that is reasonable give away the splendid reaches of rich down and blossoming prairie, watered by clear mountain streams, that by thousands of acres lies between the ridges and horns of this many branching forest.

It seems, too, to be adding insult to injury, when the tired would-be settler is obliged to trudge behind his oxen or his laden donkey, these seventy long miles, through just the sort of land he has heard about, and has come so far to seek, while he is forbidden to take up one acre. $\mathrm{He}$ would be well contented to leave the forest alone. It is much too big a job for him. If all the settlers in East Africa cut their fence poles within its great borders, no one would miss an acre of it. But the rich lands, watered by the many streams born in its depths, and husbanded by its shade, are just the lands he wants. They lie open to the temperate sun of that upland region. There is never any severe heat by day, and the nights are cool. Frost is not known.

Here is surely one of the garden spots of East Africa, and if I mistake not one of its most valuable sanatoria.

But I must bottle up my wrath, and go on my way, for I am on sefari. The hot day is over, it is warmer down near the line than on the higher uplands of the Mau; and the deliciously cool evening time has come, a tender light falls softly on everything. It is impossible to exaggerate the exquisite quality of that last glow, before the brief twilight falls. Golden shadows pass slowly over the yellow slopes, and softly outlined against the distant horizon, the wooded hills are a dreamy blue. The sunsetting is often splendid. The last glow light seems to fall across the world in bars of actual colour. In these the waving grass heads seem living gold. The trees are bathed afresh in a greenery so vivid, that it is as though their leafage had burst from the bud but a few hours 
before. All the world is glorified for a few minutes. It is a new and wonderful world, "without spot or wrinkle or any such thing." All things beneath, as all things above, catch the last parting sunset colour, as only cloudland sometimes catches it in our northern climes. One great last wave of pure pink light sweeps softly, slowly, over prairie and woodland, then for an instant hovers on the hill tops, changes to dark, rich purple, and then fades to gray, for night comes apace in Africa. 


\section{CHAPTER II}

\section{THE SEFARI}

QEFARI is the name used all over East Africa for what in the West we call "outfit" - the men you take along to enable you to prosecute your journey, or procure your sport. The pleasure and success of an East African trip, depend more on a well-chosen and well-managed sefari, than on anything else, more, even, than on the perseverance and skill of the sportsman or traveller.

If a hunting trip of three or four months is all that the visitor to East Africa feels inclined to undertake, the sort of life I try to describe in this article cannot be fully enjoyed. It takes time to see this strange and beautiful country, and it takes time, and even considerable trouble, to come into any real touch with its tribes.

But a most enjoyable trip can be had, and very good shooting as well, in even three or four months; and the best arrangement to make is to put yourself in the hands of either Messrs. Newland, Tarlton \& Company, or the Boma Outfitting Company, both of Nairobi. Write some months, if possible, before, saying how much time you can afford, what you want to shoot, where you want to go, and how much you are prepared to spend. On arriving at Nairobi you will find things ready for you, and in a few days you can take the field.

If you only intend taking short trips of a few days' duration along the railroad line, you will not need a sefari of more than twenty men all told. If you want good shooting, and wish to try for elephant, lion, etc., you must 
'go farther afield. Each sportsman will then need thirty porters, one headman, two askari (native soldiers), one cook, one tentboy, and one or two gun bearers.

These your agents will provide. Your expenses will run from $\$ 350$ to $\$ 500$ a month. This will not include your own food, which should be brought boxed from the Army and Navy Stores in London. It will not, of course, include your battery or ammunition, nor yet the cost of a professional hunter - if you engage one. It will not include your railroad fares or passage out or home.

Your licence will cost you $\$ 250$. Customs dues on entering the country are Io per cent. on what you bring in. If you elect to ride a mule or pony this cost will be extra. But the shorter your stay is to be, the more advisable is it for you to "do yourself well," and not to go in for too hard walking. On the march I strongly advise your riding.

If two friends are together, $\$ 500$ a month ought to cover everything.

In olden days of sefari travelling, when ivory or game were sought, the process of collecting a sefari on the East Coast was simplicity itself. Zanzibar was usually the starting point, and the Zanzibar authorities were the intermediaries between the white men and the unfortunate natives. These were compelled to go on any journey, with any adventurer their masters gave them orders to accompany. Some little part of wages due to them, they might or might not receive. They were mere slaves, and had no choice in the matter. They were landed on the mainland, men, women, and children, at so much the head, and started with their loads into the dangerous unknown. If they fell down by the way they were kobokoed* till they rose again. If they could not rise, they were left where they lay. If they deserted, they were shot by their

\footnotetext{
* Koboko - the hippo or rhino whip of the country. It is about three feet long, made from one strip of raw hide.
} 
masters or, if they escaped from them, were murdered by unfriendly tribes, who naturally strove in every way they could to prevent the inroads of caravans whose object was generally to steal their ivory or capture them.

East Africa till very lately was in an awful plight. The curse of age-long slavery and perpetual wars and cattle raiding among the tribes turned what should have been a prosperous country into the darkest and most hopeless of lands, where every man distrusted and feared his fellow. There was no rule, no central authority. The strong consumed the weak. A region where rapine, cruelty, and bloodshed perpetually reigned. The distance from one inhabited oasis to another was often great. Vast tracts had been depopulated by native wars, pestilence or the slave trade. Sefaris, therefore, whether they were made up - as were Somalis or Swahili expeditions for purposes of trade, or for discovery or sport, had to be large - a march through much of the country meant a little war, and every porter carried a gun in addition to his pack.

So it came to pass often, that, willingly or unwillingly, almost every sefari's progress tended but to increase the native distrust and discontent, and to add to the misery of the country it passed through.

The food question was ever the burning one, for men carrying trading goods into the interior could not carry a sufficient supply of food as well. The limit of human endurance is reached at sixty pounds the man. It takes a stout porter to carry that, day after day in the sun. Now that same porter eats in one month forty-five pounds of his load, so it is at once evident he cannot carry food and other things as well. (I will here mention a fact that illustrates the difficulties of African travel far better than pages of explanation. Till the Uganda railroad was built, the regular cost per ton to carry goods from Mombassa to Lake Victoria, almost six hundred miles, was 
$£ 200$, or $\$ 1,000$. This speaks for itself.) Sefaris had, therefore, to get food by the way, or perish.

It is but fair to try to put ourselves in the place of the stranger, travelling in those, not so far away days, before we judge him too harshly. He was, in part at least, the victim of circumstances, the reaper of other men's sowing. $\mathrm{He}$ is in dire need, his two or three hundred men must be fed. He offers barter, wants to buy. The owners still refuse. Nothing is left to him, then, but to arm his men and take the precious meal by force. So he goes on his way, relieved for a time, but discontent and anger dog his footsteps, and he leaves his bills unpaid behind him, to be met by the unfortunate next comer.

The result of such a state of things was misery unspeakable to the inhabitants, and danger and demoralization to the traveller. Yes, demoralization, I say. Africa has demoralized many a man, not a weakling either. She seems to do so still. But in these days I speak of, less than fifteen years ago, men fell under her evil spell of prevalent lawlessness all too readily. If the truth were known about the many expeditions undertaken for sport or even for exploration (except certain world-famous ones undertaken for rescue and relief), it would make gruesome reading. All higher honour, then, to that small band of truly great and brotherly men, who, like Livingston, and Bishop Harrington, would sooner starve than take one pound of food by force from ignorant savagery.

Sefaris left Zanzibar several hundred strong, and crawled back in one, two, three, years, less by one-third, two-thirds, sometimes smaller still. What wonder! The porters on whose perseverance every one's life depended were poor beasts of burden merely. They had no shelter from the cold rains of the higher plateaux so fatal to the coast natives; no provision for the wounded, no medicine for the sick. The koboko was their one counsellor and 
friend. None marked it if they failed to return. Some one grabbed their pittance due, at the coast. The hyenas had the rest. The sefari struggled on!

I am drawing no fanciful picture. I am simply stating what I have been myself told by men who took part white men be it understood - in many such old time sefaris from Zanzibar and Mombassa.

It is needless to say that with the abolition of slavery, and far more still, with the introduction of Protectorate rule by England, rule that does most really attempt at least to protect the native, all this has ceased. You are obliged to do a good deal for your sefari - often much more than local opinion deems necessary.

The porters' wages are fixed. You cannot pay less, and for this country they are high. The quality and quantity of food you must give him are fixed. He must have a blanket, tent, and water bottle from you, even if he is engaged for but a few weeks. He is supposed to be examined and passed as fit to work by the medical officer. He "signs on" for so long a time with you, and at the end of that time, if he demands them, you must pay him his wages. You are supposed not to punish him, but hand him over in case he misbehaves to the civil authorities. But as you are likely to be often more than a hundred miles from any court, a reasonable enforcement of discipline, when necessary, is expected from you, and not resented by him.

So much about present sefari life. Every would-be traveller soon learns. He knows his own amount of baggage. He knows it to the pound, and to his cost, if he pays his steamer bills at Mombassa before coming up country, and a further interview with the railroad authorities on the question of baggage is likely to impress him still more. He reads in books, or hears from friends that he will need so many men, and that he had better engage 
them at Nairobi rather than at Mombassa, and so save the $£ \mathrm{I}$ railroad fare per man. That is about all he knows. He chooses his agent at Nairobi and seeks advice, says how long he intends to be out and what he wants to get; whether he will ride or walk; live simply, and content himself with a Swahili cook at 30 rupees a month, or luxuriate in a Goanese, and pay him 6o rupees; whether he is determined to go far afield and stay away from the railroad for several months at a time, or make shorter trips moving his sefari by rail from place to place.

These matters settled, his agents undertake to do the rest, and promise in so many days to have everything ready for a start. There are competent agents at Nairobi and other places, and unless there is a great crush of departing sefaris, they keep their word, and supply good or fairly good men. And so, before he knows it, our traveller has embarked on one of the most interesting undertakings any sane man can engage in, viz., travelling in a country he knows little about, with men about whom he knows nothing whatever - men on whom he is absolutely dependent, as no traveller is dependent on any one in civilized lands.

I have sketched without exaggeration the growth and starting of nine sefaris out of ten, and nearly all of them go out and come back without serious friction or disaster. Things are not stolen, lives are not often lost, and this fact alone is an unimpeachable testimony to the faithfulness, endurance, and worth of the despised East African native.

A man may, and often does, hurry off in this way. He knew nothing when he started of his fellow travellers, and except a name here and there, he knows as much and no more, when the hurry and scurry of collecting indifferent "heads" of as many different varieties of game is over. But I protest this sort of thing is, first, not hunting; second, 
is not seeing one of the most beautiful and interesting countries anywhere; and, third, is not real sefari life at all.

Now it is of sefari life I want to write, and it is to enable even an inexperienced sportsman to enjoy something better than what usually passes for it, that I beg some patience for my seeming prolixity when I try to describe a little of its interest and charm. Before I put foot in East Africa, I did what I could to gain reliable information as to what my sefari should consist of. How could I manage it? How far march it? etc., etc. One said leave all to your "headman"; he will do everything. Well, the first headman I had, though more than highly recommended, and though armed with chits (testimonials) that if true made him out too good for the job, had among a multitude of other shortcomings one insuperable one - be couldn't walk - and arrived at camping ground from one to four hours after the sefari.

Another said, "Hire a professional hunter and leave everything in his hands." Elsewhere I speak strongly of the value of a good professional hunter. If you want to spend some time in a really interesting country, and kill interesting and dangerous beasts, unless you have reasonably complete command both of your nerves and of your weapon, you will be foolish not to secure such a man. But I like doing things myself. I like to try to understand the men by whose aid I alone can do them.

So much for the general view of the case. And, next, I don't like, as a rule, the Afrikander's views on natives and native questions in this land, any more than I liked the views of trappers and miners and settlers, on Indians and Indian questions in our own land, when first I became well acquainted with them many years ago.

To feel the interest and charm of a new country, you want to feel it not through the eye or ear alone but surely through touch and knowledge (however necessarily 
slight) of its most real thing - its people. We are far, too far, away from our fellowmen as it is, and we do not want, when it can be avoided, any widening of the distance between us and them, by unnecessary employment of intermediaries. Then, of course, your chosen agent has his ideas of how things should be managed, how the men should be treated, how fed, how led, how camped; and if you leave these matters to him, in all justice, you are bound to give him your support. Even if you find after a time that things are going on around you that you disapprove of, it is difficult to make a change on sefari - like swapping. horses while crossing a stream - it is a hazardous undertaking. You had best leave matters alone till you make a fresh start. From the beginning, the men know that some one man is really responsible. Chopping and changing about they don't understand. A harsh leader is much better than no leader at all.

But why not face the business yourself? You are really responsible for every man who marches with you. You are their guide, protector, doctor, magistrate, and friend. You cannot hire anyone to discharge these duties for you. You are more than all these - you are a visible embodiment and illustration of the great unknown outside world to these poor black folk - a world that has given them so far few of its good men, and many of its bad, a world that has harried, tormented, enslaved, dispossessed, and slaughtered them as it seemed best to its most ungodly wisdom. As you treat them, as you hold yourself before them, they will judge of it and you. English rule has already done them good in many ways, and they know it. But then it has also taken from them much that they value, and insists on still taking. Their lands are being steadily taken away. I don't say for a moment that this shouldn't be. I hold it most reasonable that good land, lying untilled or half tilled, should be put to the best use; 
and that savage cultivators should be induced or forced to make use of what remains to them. There is plenty of land still for every one, but it is the speculator who makes here as everywhere else the loudest outcry. But these poor folk cannot understand such philosophy in a day. There is no one yet to teach them, to prepare them for acceptance of the cruelly inevitable, but a scattered band of devoted men and women missionaries. They cannot be expected to welcome a cutting down by half of their grazing lands, if they are herdsmen like the Massai; or a ruthless removal of their shambas to equally rich lands as those they till, but many miles back from the railroad, if they are Kikuyus, because the iron rail means little to them, tho' everything to the incoming settler.

Why, too, they ask, should they be obliged to pay two rupees tax on each of their huts. They never paid such a sum to any one before, and the huts and gardens are just the same that their forefathers builded and tilled. It matters not to them that the hut tax can be paid out of the increased money they earn, and that when fully rendered it does not pay the cost of their protection against enemies and cattle plagues.

In time they will understand, but fifteen short years of partial occupation is not nearly time enough to reach the intelligence of a dozen different tribes, speaking a dozen entirely different languages, with no means of intercommunication except tribal gossip. No schools as yet, often no chiefs who wield any real authority. (One of the mistakes made by the administration, as it seems to me, is the too common lessening of the native chief's authority.) But they will watch you, the white man, wonder at you, study you. Your stay among them will surely help them up, or tend as surely to pull them down.

I don't judge harshly the local Afrikander influence, when I say it rarely indeed troubles itself about any such 
things. The Afrikander is but an uncertain bird of passage. $\mathrm{He}$ does not care for the land or for anything in it. He wants money. As soon as he has that, his one idea is to go home to the old land that he does love. The Boer alone wants to make a home. But his home must be one after his own mind and plan. The best land and immense tracts of it he wants, and with all his silent, obstinate nature, he determines to have it. The native and his rights are nothing whatever to him. He will not crush him out of existence, for he needs his labour to cultivate his farm and tend his cattle. But without one particle of scruple he will kick him out of his way. And the Boer as England knows by now, can kick very hard indeed. So when six weeks from London you may find yourself in a country where till two years ago, in some parts of it at least, white man's feet had never come, among people strange and new, yet so friendly that you are safe, so far as they are concerned from danger, as you would be in London, and far less likely to be robbed than you would be in New York. Then look kindly on them. Study them, as well as Ward's valuable book on record "heads," and make up your mind for good or for bad to run your own sefari. If this is your decision, then tell your agent at Nairobi that above all other things they must give you a really honest, reliable "headman." They can do this; there are several such on their books. They procured David Rebman for me, and a better headman - capable, experienced, kind, and thoughtful with his porters - there is not in the country. Your headman will make you or mar you. The problem of potio is quite beyond even the most painstaking investigator at first. You will have to do as you are told, and get the hang of it as soon as you can. At the beginning of sefari life, you will have to be guided by your headman. Show him your baggage. Tell him roughly what you wish to do and whence you go. 
He on his part will tell you where he has been with other bwanas (masters) and what luck they have had, how long they were out, what number of porters were necessary, and if the sefari was able to employ donkeys to save porterage - a very important point.

After one or two quiet talks with your men, you will have some idea of the size of your expedition, but not yet, I am sorry to say, even a glimmering notion of the size of your bill. It seems so hopeful at first, to find out that you can hire a quite first-class porter for three dollars a month and feed him on two. I remember well how golden were the dreams I indulged in when I took out my first sefari. Here at last was a delightful form of sport that cost less than ordinary hotel living. The disillusionment when it came was complete. No, you cannot "do" Africa cheaply, and of all countries under the sun, this is the very worst, I should fancy, in which to try to practise economy.

You will need porters -

To carry your

Tent (a green waterproof one, $8 \times 8$, made by Edgerton,

2 Duke Street, London Bridge) . . . 3 porters

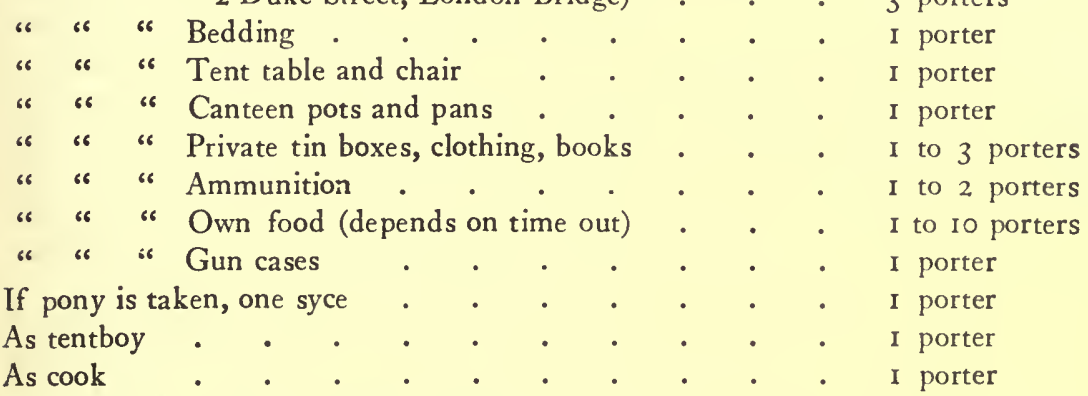

It is a safe rule to allow twenty porters for your personal belongings, not, of course, including men's food or anything else. Now I admit that these numbers sound excessive and some of the items I have named may seem - specially to those who have only been accustomed to 
hunting in our woods and mountains - mere encumbrances. I cannot enter here fully into this side of the question, and can only say if you cut these figures down much, you will surely be sorry for it. You had better be guided by the experience of those who have lived sefari life for years. Here in Africa you cannot take the happy chance that every one gladly accepts in northern climates. Three men to a tent means a big heavy tent, it is true, but to travel with any other is to endanger your health. Your tent is your home for months. Often you must eat as well as sleep in it. And in all weather, even under equatorial torrents, it must be dry. You may have long days of sickness in it - then it must be cool. And so on. I only name the African tent as an illustration of the absolute need of "doing yourself well" in everything. If you cannot do this, go somewhere else than to British East Africa Protectorate.

You can count on your men costing you from I 5 rupees to 18 rupees a month each (I 5 rupees equals $£$ I or $\$ 5$, the difference depending on the price you must pay for their potio. If you wish to travel more rapidly, you will take your sefari perhaps the first stage of the way by the railroad, and since you thus cover in one day what it would take you several days to do marching, you will find the expense comes to about the same. You will find that a month away from all base of supplies is about your practical limit. For remark - and if you remember this it will save you many tedious efforts after calculation - each man carries sixty pounds of potio, and each eats forty-five pounds each month. A porter is, therefore, able to carry fifteen pounds only for you in addition to his food. A sefari of one hundred porters, not including, remember, gunboys, headman, tentboys, cook or syce - can carry for a month I,500 pounds over and above their food and no more. Of course, this is all very con- 


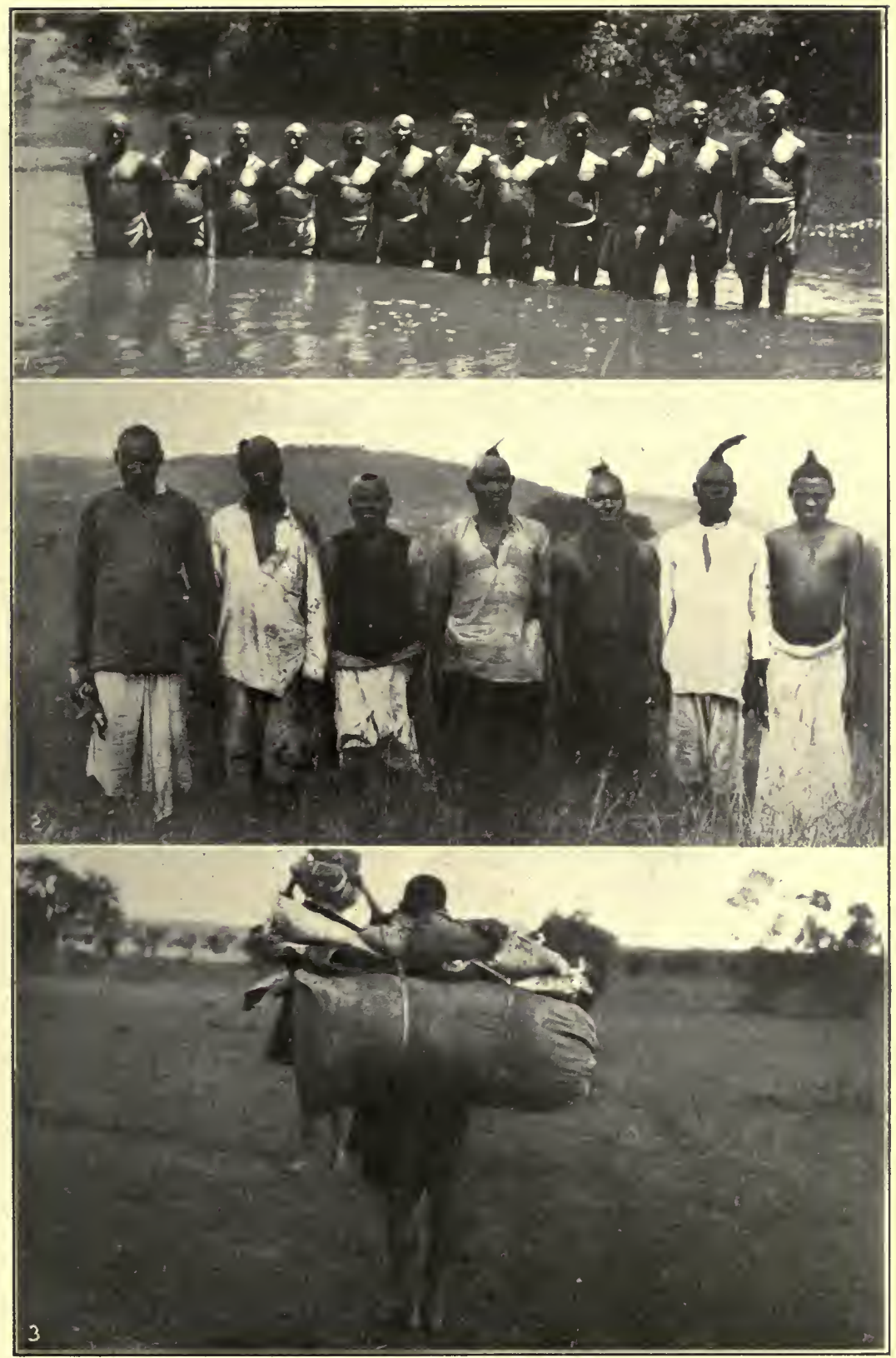

r. Strong men (porters) going to bathe

2. Hairdressing extraordinary. My dandies

3. Kikuyu porter - see the way all Kikuyus carry load 

fusing at first. You can only trust your headman and keep perpetually noticing things.* Gradually it will dawn on you that to be a successful headman implies a most unusual combination of qualities. In addition to those I have already named, he must be absolutely fair minded as between man and man. He must be strictly just in giving out potio. The little cup of meal must not be heaped or shaken for one, and just dipped into the sack for another. That the sefari will not endure. He apportions each man's daily burden. The loads should be weighed before starting from Nairobi. After that there can be no daily weighing. At a glance, therefore, he must know what each must have. He can have no favourites, and no enemies. His eye it is that notes the sick man - the really sick - and detects the lazy and incompetent man. He it is who must decide who shall be relieved of his burden on the march, and among what other reluctant fellows that burden must be shared till No. I can take it again. The multitudinous employments of the camp, as well as of the march, he can alone apportion. So many men are chosen, during the first few days marching, to pitch the tents, the moment the sefari comes in. So many to go at once for the wood, sometimes these men must go more than a mile for it, so many to fetch water. One has to trench each tent. There are from ten to twenty other tents to be pitched. The men whose duty it is to do this are all told off, and, let me say here, that no one can, I believe, pitch a tent so fast or so well as these people can. I have camped with smart regiments in my early days, but neither in England nor in America could any of them compare with sefari folk in tent pitching. Smartness at the job is of vital importance. For instance, only yesterday we had to reach a certain water spring, and as

* The question of food supply is the question above all others, and of the best ways to meet it I speak elsewhere. 
we neared it, over us drew one of those dark, gray lipped clouds that here mean a torrent. Many of the men were sick and suffering from the severe cold and rain, for a month "African fountains" had not been "sunny," and in the evening and at night you needed a suit of fur-lined underclothes, some one said. To get these men dry to bed was all important, for we would be out of potio, if we delayed, and there was no game just there. It was a race against time and storm. The pipers piped up manfully, the sefari came in after a long march at its best pace, and I counted fourteen tents and our three big ones, pitched perfectly and trenched completely so that they could stand any weather, in eight minutes from the time the first bundle was thrown down by the first porter marching on the ground. That such a feat could be accomplished many will not be prepared to believe, but I timed the men watch in hand. I shall have other stories to tell of what the native can accomplish when he likes his job.

The headman practically decides, till you get to know the men yourself, who needs punishment when (it is to be hoped very rarely) punishment has to be meted out. Disobedience to definite orders and theft must be punished at once. But if the influences of the sefari are good, there are scarcely such things as either disobedience or theft. In thirteen months of sefari life I was obliged to koboko three or four men for disobedience, and had one case of theft.

I cannot for myself see how any one can travel with his sefari for even a few weeks and not be interested in all these things, and numberless others besides.

Your next ally in the managing of the sefari, and your hourly instructor in the way in which you should go, is your tentboy. If you have friends in the country, write beforehand and beg them to choose for you the man you want. He can be found. There are many excellent 
tentboys, wonderful to say. A good one will valet you, as well as you have ever been valeted in your life. Indeed, I have yet to discover what a good tentboy will not do. But I wrote hastily. My boy John, the best tentboy man every had, will not do one thing - he will not under any inducement whatever, make one of a party to beat a swamp or bit of brush for a lion. I have asked him to do for me pretty nearly everything else that an inexperienced learned could ask, and he has never once failed to do it well. When I am away he looks after the sefari. When we camp he always chooses the best place for the tents - something that is not easy to do. When I am off on a small personal sefari away from main camp, he is my excellent cook. If I want to be called any hour before sunrise, I am never, never, awakened five minutes late. He keeps the accounts of the sefari and writes a far better hand than I do. The comparison does John injustice, for he writes a singularly good hand. $\mathrm{He}$ is cleanliness itself, and it is a pleasure to be waited on by him. I never was able anywhere to get my Jaeger shirt washed without shrinking. I get them a foot too long and a foot too wide, and still periodically give them away to some small poor man, good as new, nay, better, for they are three times as thick, and so much warmer than when I bought them. Well, John, can, in some niraculous. way, wash "Jaeger" without shrinking it. Our tablecloth is white oilcloth, but our daily dinner napkins are as clean as at home. He knows where my money is, where my letters are, and always carries all my keys, thank heaven, and never loses them.

But I am only one of the departments John has to regulate and care for. Every pound of flour, pound of oatmeal, ounce of tea, piece of precious bacon; every dried prune or fig - all the ingredients and accessories of our food - John dispenses them all. There is not a 
native cook I verily believe, in all Africa who would not make a hotch-potch of the best packed and assorted "chop box" * in one hour. But John saves me, for every chop box is locked, and kept locked, and he carries the keys. Simple, faithful little soul, never out of temper, never bringing tales of anyone however badly he may be served, you come by your fine, capable nature right honestly, for your father before you, John Connop, was one of the two or three indomitable black boys that no suffering or danger could drive from the side of the lonely, great man, Livingstone. All over unknown Africa they tramped with him, tended by them only he died. And down to the distant sea coast they brought his body. Needless to say, John, too, is a Christian and a mission boy.

I am not drawing a fanciful picture or writing a novel; I am only stating facts, a few of many that might be stated. John, among a considerable variety of employments, served as a nurse for a year in a hospital. When we had one of our men mauled by a lion, and when for six weeks twice daily, the wounds had to be treated with boiled water and antiseptic, John could and did for days together undertake the man's treatment. He can march all day with the best porters, and as he does so carries an extra gun for me. He lives on one meal a day, boiled rice if he can get it. If not that, any potio going, and he doesn't have that one meal till he has seen the tents up, the beds made, the mosquito nets hung, our dinner cooked and eaten. Then he has his meal, and I know - though I can never catch him at it - one cigarette afterward.

Porters are to the sefari what the Macedonian phalanx was to Alexander's armies. There can be no safari without them. Successful sportsmen there have been who depended for transport almost entirely on donkeys or ox wagon, but as between the donkey and the porter, many

* Box containing personal foods and delicacies. 
a solid advantage rests with the latter. You can never tell where you want to go in East Africa. Plan your trip never so carefully, a hundred things may arise which will deflect, if they do not alter, your route. You set out for a six weeks' journey. You do not return for four or five months. Freedom of movement is an essential in this land where the unexpected is forever happening. Now, donkeys pin you down in two ways: They cannot make more than ten or at most, twelve miles a day, even where the trails are good; and when there are none, or when there is much swamp, cannot be got along at all. Donkeys are excellent to keep your base of supplies full. It is often necessary to have a number of them regularly travelling with potio, between the railroad and some selected spot near the country to be explored or hunted. In this way, you can keep the field for as long as you please, for it is easy to send ten or twenty porters from your hunting camp to this supply base, while, if you had to send the men a hundred miles or more for potio, ten or twenty could not carry any sufficient quantity, and would consume a large part of their loads on the way; and to send more than a small number of men is to cripple your travelling machine, and to force you to remain camped till they return. Never so denude yourself of men that you cannot march. This is a rule every sefari leader should remember.

Let me go back, then, to the phalanx of the safari the porter. He may be a Kikuyu or Wakamba, a Swahili or a Kavorondo, a few of these tribes you will probably find on your official list, but Wanyamwazi make far and away the best. They are particular about their food, and demand rice if it can be got for them; but they are willing, good tempered, and very strong. They seldom steal, seldom fight among themselves, and practically never desert. (Kikuyus are always apt to do so, and you can seldom find out the reason why.) They carry their loads 
cleverly and well, and (for porters) are cleanly in their personal habits. They always hang together on the road, and in the bivouac, and you can tell them at once by the regularity of their line. They take pride in keeping time and distance as they tramp along, and they start from camp in the morning and tramp home when the day's work is done, to weird pipings and flutings of their own, on little reed pipes and oryx or water buck horns, carefully guarded for such time-honoured usage.

The Wanyamwazi want meat, and will eat any amount you give them. On the other hand, if meal gives out, many of the Kikuyus will starve; they are confirmed vegetarians, whereas when meat is plentiful, and the difficulties of providing potio is great, you can put your Wanyamwazi on half meal ration, and let him fill up on meat. On all these accounts they are admittedly the best porters in East Africa. I should add that they are easily disciplined, and in tent pitching, helping with cooking, and making themselves generally useful around camp, they are unequalled. Like all the rest of us, they have, of course, their weak points. On no account be induced to let one of them carry your extra gun. If you come across a rhino or lion they would be sure to let it off, possibly into your back. They are, one and all, arrant cowards, and a gun in their hands is a dangerous weapon to anything and everything but the thing aimed at. They can seldom be induced to beat a swamp or donga for a lion. I mean, of course, unwounded lion, for after a wounded lion no porter should on any account be taken. If you want him, go yourself alone with your gunboys. To take porters in to cover after wounded lion, buffalo, or rhino is sheer and criminal folly. If some one is not mauled or tossed, two or three are likely to be shot. But I need not enlarge on this part of the subject, for, though the Wanyamwazi is a coward, he is not a fool, and he will most probably 
relieve you of a responsibility you should not think of incurring, by refusing to go.

Sixty pounds of your belongings, carefully boxed so that he can keep the box on his head, the porter will carry. A humane man will see to it himself, that this amount shall not be exceeded unless circumstances arise - as they sometimes will - in spite of the best care and foresight when heavier loads must be carried somehow for a few days. Remember the sixty pound box or bag of potio is far from being all that your black companion has to carry - under the burning sun. His own sleeping mat, his sufurea (cooking pot), an extra pair of giraffe or eland sandals he has carefully made by the way, the fly of his little tent or the tent itself, his water bottle, knife, probably some pounds of dried or fresh meat; from one to eight days' potio (that is, from one and a half to twelve pounds), a tent pole, some tent pegs, and how many dearly prized odds and ends, I have never been able to discover. With all these cumbersome things stowed somewhere around him he uncomplainingly does his twelve to twenty miles a day, often over ground thickly strewn with poisonous thorns, up and down water-courses, over every conceivable sort of obstruction, Surely he earns, if any man does, his pound and a half of meal.

Look at him as he tramps along. How he carries the load he does, I confess I don't know. Except for a comparatively short time in the year he lives on his potio alone. While working on a shamba or government contract he gets nothing else. He loves meat, and that is one of the chief reasons he will often leave wife and child and a good steady job, to go with you, an unknown bwana, on sefari. When he does get meat he seems to take special pains not only to cram himself with an inordinate quantity, but to do so in such a way as to cause himself the greatest possible bodily harm. His custom is to cut the raw rhino 
meat or venison, in long strips of about a square inch in thickness. These he warms over the fire, no more, and then, cramming as much of one of them into his mouth as it will hold, places the knife as close as he dares to his lips, and cuts the chunk off, which, without further chewing, so far as I could see, he swallows down in one monstrous gulp. The meat is nearly raw, and he scarcely uses his magnificent teeth on it at all. It is hard, too, to induce him to cook anything thoroughly - sweet potatoes, beans, rice, maize-none are half done when he consumes them.

Poor fellow, he pays his score. He seldom lives to be over forty. The cause of this unnecessary shortlivedness is uncertain, for in this new land where there is so much to do, and alas! so few capable of doing it, few scientific observers have as yet troubled their heads about him. But the presumption is he dies of worn-out bowels. His life is short, but till the sad, swift breakdown comes and he slips away, as he himself laughingly will tell you, to the seci (hyenas), it is merry. In a good sefari where porters are carefully chosen, and fairly treated, you hear the men singing and piping all the time. They start at daybreak to the tune of the piper and the whistle and pipe play them into camp.

As he tramps along, a more miscellaneous bundle of rags no one ever saw, yet, as you look closely, you will see remnants of coats once "built" in Bond Street, shreds of breeches long ago faultlessly cut by Tautz or Hammond, and, somehow, held together round his waist. Where the clergy part with their cast-off clothes I do not know, but unmistakably clerical collar coats are quite common. Through all these curious rags, patched in a hundred places with every imaginable stuff, from cheap, American cotton to kongoni hide, his finely moulded limbs, magnificent back muscles, and soft, silky, brown black skin shows freely. Look at him, for he is well worth your study! 
He is doing a job that Africa, his native land calls on him to do, and he is proud of it, and does it extraordinarily well. Anyone who has marched with him as I have, for more than five thousand miles, cannot readily accept much of the cheap current talk about the worthlessness of native labour. In more than a year's sefari work I only had one man steal from me, and I have, on the other hand, to remember countless deeds of unselfish kindliness.

Before leaving my Wanyamwazi porters, I must find space to tell of his day of modest triumph. As the sefari prolongs its journey, he reaches a pitch of raggedness that I will not venture to attempt to describe, much less photograph, but this perambulating bundle of rags, that reminds you of a caddis worm, is capable of a veritable transformation. Grub turning into butterfly never worked it more deftly. On the morning of the day when, proudly led by the chief porter, who carries the heaviest load, or the biggest tusk, the phalanx at last marches in from its long journey, then open your eyes wide, for if you do not you will not recognize your own men. From some mysterious hiding place a new suit of some sort is forthcoming. His duty loin cloth has given place to a snowy pair of drawers. He has a new coat. He has invented somehow a new hat, or, if that is beyond even his resources, he has an ostrich feather, or a zebra tail, or a fluffy head covering of white marabou down, which he cunningly and with much rakish taste, fixes on his black pate. He feels bound to do honour to himself, the sefari and his bwana.

I generally made it a point while on the march, to keep near the sefari. I found in many ways the habit paid well. I got to know the men, and they came to know me, and to get good work from any man, he must be sympathized with and known. The East African can, I am convinced, be led far, but the man that would lead him must take some trouble to know him. In such a little 
thing as a sefari's marching, sympathy counts for much. When a hard march had to be made, I took care to be behind or alongside the men. The common custom on hunting expeditions is for the bwana to ride miles ahead and wait for the porters to come up. I never could see any possible advantage to anyone in this custom. In difficult country, master and men lose each other to their mutual exasperation; mutual, I say, for though the bwana alone is permitted to relieve his feelings, by swearing at innocent and guilty alike, you may depend the tired porters "feel damn" (as the boy did whose father licked him for swearing), and in the rainy season, which is also the best hunting season, master and men of ten get needlessly wet, for though on the approach of a storm, camp should be pitched, an African law of Mede and Persian forbids the most undisciplined sefari to camp till it has found its bwana.

When you hunt, hunt; when you march, march, I have always found to be as good an axiom as in the Rockies. We had out there a cook once who not content with his own job, believed himself to have a heaven-born eye "for country." One day there was a difference of opinion as to the trail to take to next water - a long way off. The cook was sure. So he went one way and the wagon another. We camped tired, baked with August heat, in "bad land" country. Sunset came. No cook. Eight o'clock, none. Nine! At ten a miserable wreck of a footsore man stumbled in and sat down to think. $\mathrm{He}$ asked for a drink of whiskey, and then quietly said, "If God gives me strength, I'll never again leave the cook wagon." We all roared with laughter and he joined in.

The sefari should however be prepared to do more than mere porterage, and camp making. It is your moving household and army. The Wanyamwazi stand for the housekeeping part of it and for nothing more. They are, taken by themselves, like lost children in a new country. 
Their eye for country is poor. They are superstitiously afraid of strange people, and rhino have a terror for them. Let but one of these beasts come within fifty yards of the marching line, and no well drilled battalion of infantry ever grounded their musket butts with more simultaneous ring, than will they throw down their loads, and take to the nearest tree. You cannot make assistant gunbearers out of these. If your syce is useless, or runs away, the chances are you cannot replace him from among fifty of them. They cannot often be taught to skin well or to take care of heads and trophies, which here, in the changing weather, require the greatest watchfulness, and some skill, too. It will be seen, then, that there are many important items of sefari life they are in no wise fitted to fill. Now, one of the important things to remember in making up a working sefari is to so organize it, that within its ranks are to be found men who can fill gaps unexpectedly made in those ranks. Sickness may disable many of your dependable men for a time, or your own change of plans, or change of country, may result in some of your fellows taking their wages, as they have a right to, and leaving you. Others will misbehave or prove too incompetent to be of further use, and to retain such is but to weaken your discipline. Their places must somehow be filled and for this you must fall back on the body of your sefari. My first sefari were all Wanyamwazi. I had them, because I was told, and told truly, they were the best porters in Africa. The consequences were, I found myself with a body of men who could march anywhere and could do little else. They could pitch my tent admirably, but could not save my skins or heads. As gunbearers, they knew nothing of game, where to look for it, or how to kill it.

In a tight place they always ran away. Not one of them could track, only one of them could skin. That sefari 
was not a success. Not to be too prolix, I will state what a sefari should further consist of.

There should be interpreters, men who can speak to the Massai, Kiuyuk, Sambowru or N'dorobo or any tribes occupying the country you intend to explore or hunt in. As I say in another place, the services of the local native are often of utmost importance, and unless you can communicate freely with him, not only in a few jumbled half understood words, you will often fail, though your perseverance in travelling has brought you to the verge of a most gratifying success.

Quite as important is the tracker, I have written of him also elsewhere. Look long and patiently for him! When he is found, hold him fast. Let his burden be light day by day, or let him have no burden at all. Then, if you are bent on lion, you must furnish yourself with someone else besides your specially chosen and highly paid gunbearer. Lion hunting must have, as it deserves, a chapter to itself. I shall content myself for the present by saying that there are many parts of the country where more lions can be brought to bag by the use of ponies than the most persevering and expert sportsman can get by foot. Lion riding needs one, better two, mounted Somali. Somali cost money, and often cost besides that an immense amount of annoyance. They are everything that is bad, but cowards, and lion riding needs a plucky man. They are fair horsemen, though they seldom take good care of a horse, and they ride light.

For a long time I scorned the advice of one or two knowing friends who urged Somali on me. But circumstances in the end proved too much for me. I found myself in a country full of swamps and full of lions, where the ground was made for fast riding, and where, work hard as I might, I could get no nearer to my lordly game than half a mile or so. To see one, two, nay, as I have, ten, 
tawny heads led by a veritable black maned king, go safely loping off in a level country, while you gaze helplessly at them through your glasses, that dark mane falling, as it seems to your longing eyes, almost to the ground - almost sure, too, to fall a prize to some lucky fellow who brings ponies along, and has only been weeks in the country to your months. Well, I fear green jealousy is a mortal sin, but if ever it be mercifully counted a venal, it is under such circumstances. I have been tempted, and have, I fear, sadly fallen. Next trip to save my soul, I will sacrifice my pocket, and get me two ponies and a Somali rider.

One of the most delightful things about sefari life is that there should be no hurry in it, and I fear I shall be accused of wasting much time, as I seem to dally with my black family. But all I can say is, there shall be purpose in my digressions, and if I take a zigzag path to reach my camping ground, I only do what every sefari does.

No tribe, native to this part of Africa, except the unapproachable N'dorobo, of whom more anon, compare as hunters with the Wakamba. Two or three at least of these should find places in your little company. They will turn out willingly in the evening, even after a hard day's march, and search for fresh "sign" for you. They will assist your gunbearer in skinning out heads, or preparing hides and bird skins, and from among them you can most probably secure a second gunboy if you have not already engaged one. They are very clannish, and it is better to have a small group of them, than only one or two.

And this leads me to say a few words about that friend, companion, guide, and mentor, the gunboy. As in Ireland so in East Africa, everyone young and old, as soon as he can talk and as long as he can totter, is a "boy."

Your gunboy should have many qualities - he must have one. He must stand. Now that is the one thing it is generally hard to get him to do, and considering how 
often and needlessly his life is risked by stupid or reckless, to say nothing of cowardly, sportsmen, and for some unaccountable reason men who are utterly lacking in nerve (I will put it as charitably as I can) do sometimes elect to hunt big game, it is small wonder that, having been mauled or tossed once, he is shy of undergoing that experience again. All the same, if he will not stand, he is worse than useless. The Wanyamwazi generally won't. The Kikuyu do not pretend to. The Swahili will if they are sure of their bwana's shooting powers. The Somali almost always do, but then they set a monstrously high price on their services, often demanding 75 rupees or more a month. They are careless gun cleaners, break everything and place the blame on someone else. They are lazy around camp, get others to do the work they are paid for doing. They are exclusive, fastidious, quarrelsome. But they are keen hunters and brave men, and unless a good Wakamba can be secured, one must, for dangerous shooting, be taken along. They are absurdly confident of their own powers of straight shooting, which are usually of the poorest, and it is often necessary to teach them a sharp lesson on the very first opportunity.

When the sefari has settled a little into its "stride," have your gunboys up and let them understand that you know your own business and theirs as well. That you will brook no disobedience, no departure from settled orders. Such a gun must be carried, always. Such cartridges must be placed always in such a pouch. Your rifle must be handed you in a certain way, etc. Then enforce these commands by constant drill, till automatically, these men, on whom your life and limb will depend some day, know instinctively what is expected from them. It is strange how many sportsmen, not without experience in big game shooting, neglect such necessary precautions as these, and then loudly denounce the stupidity or cowardice of 
the gunboy who has, they imagine, failed them. They themselves only are to blame. Far more natives are mauled, tossed or killed than the white men they serve. It may require some nerve to follow dangerous game, when wounded, into thick cover, even when you have a powerful rifle in your hands, and are confident of your power to instantaneously use it. But it surely requires far greater courage to do so, where you carry another man's rifle, which under no circumstances are you permitted to fire. Yet is this the gunboy's fate. 'He depends entirely on his bwana, and many a bwana proves but a broken reed to trust to. All the same, no gunboy should be permitted to fire the rifle he carries. There can be no two opinions on this point. Yet a sharp lesson, enforcing immediate obedience to such fire discipline, is often needed.

When my first long-waited-for lion charged and charged very quickly, I saw out of the corner of my eye that Dooda, my Somali who squatted beside me, was on the point of firing my heavy double .450 cordite rifle (my reserve gun) at the great beast whose head and tail could alone be seen as he bounded toward us. I had to give him a sharp jog with my right elbow under the jaw which put both him and the rifle out of action for several minutes. When the affair was over and the fine beast turned "paws up," Dooda, to do him justice, forgot for the moment his rude reminder, and cheered lustily, but as soon as the first congratulations were over, he ruefully pointed to his jaw and groaned. "You do kill me!" It was not quite as bad as that. And though, on another occasion, he fell back on me so rapidly that he almost knocked me down, he never fired one of my guns, unless I told him to. On the whole, Dooda was a good gunbearer, and though he had a genius for making other men do his work, he made no trouble in our sefari.

My Wakamba "Kongoni," however, was a man after 
my heart: A good tracker, a splendid hunter, a self-sacrificing guardian, a heathen and a gentleman, all this and more, and I believe we shall remember each other so long as we live. I never knew him to confess to being tired. $\mathrm{He}$ always did his own job well, and what was wonderful in a native, he seemed to take genuine pleasure in helping less efficient workers to do theirs. He would, without any request being made, aid John in the tent, arrange my bed, help with cooking or track a lost mule. I would find him fastening with a firm knot the shaky bundle of some tired or inefficient porter. The totos loved him (I tell the totos story later). He would have a handful of ground nuts or a bit of sugar cane for them. As we marched along, some porter behind us was sure to find on a rock or stump Kongoni's cigarette, not burned to a stump. Don't smile! That meant a real bit of selfdenial, and met with appreciation. If a man broke down Kongoni was the first to take up his load, a thing no selfrespecting gunboy was supposed to do. "Brownie" I christened him, for, as his photograph shows, he was the very picture of one of the "Brownies." He was very strong, though he had no more flesh on him than has a Daddy Longlegs, and he couldn't hit a barn door, if his life depended on it. Clear grit all through, devoted to his little wife, a true friend, a real man, is "Brownie." I greatly fear I shall be accused of inventing an impossible black paragon, but after eight months of camp life and danger shared together, I may reasonably, I think, claim to know something whereof I speak, and I am only describing a man as I found him and proved him.

The sefari cook is an important personage. He literally makes you or mars you, and a good, cleanly and honest cook is not found every day. Still, the East African has a natural bent for cooking. He cooks his own rice when he is not in too great a hurry, as none but the man 
of the East can cook it, and since you eat rice twice a day, that is something to begin on.

My cook Peter was a friend of three years ago. I had suffered at his hands and in consequence he had, on at least one occasion, suffered at mine, or, rather, at the hands of my official representative, the askari.* Peter knew he deserved it, and so bore no grudge. Indeed, had I defrauded him of his just dues, I should have fallen greatly in his estimation. When he heard, therefore, that I had returned to the country, he at once sought me out and begged for his old job. His weak point, I well remembered, had been his bread, and good, well baked, well raised, yeast bread (not baking-flour abominations), is one of the few things absolutely necessary to health. Many who do not know Africa, nor realize that they are under the equator, eat little rice, or fruit, or vegetables, and do eat large quantities of the very stringy game meat which is the only flesh usually obtainable. They are very likely to take trouble home with them. I made immediate inquiries as to whether Peter had been to a baking school. He assured me he had, and that by now his productions were unrivalled. His poverty-stricken appearance certainly belied his optimism, and I pointed this out to him. But he was prodigal of excuses, said he had lost my "chits," and had been out of a job for a long time. I sent him off under John's charge to bake a loaf. While his guardian looked on to make sure that he had no unfair assistance, and as the result proved fairly satisfactory, I reëngaged him.

Little Peter was really not a bad cook, and he was quite willing to learn, which is more than you can say about all cooks, out of Africa as well as in it. His things, if he was constantly looked after, improved. He made admirable soup. His curries were excellent. With the aid of a mincing machine (make a note of this and always

* When men have to be punished, the sefari askaris, superintended by the headman, inflict it. 
carry one) he reduced the toughest kongoni to something edible, and before the trip was over he was equal to roasting quite appetizingly a partridge or duck.

$\mathrm{He}$ had to be outfitted, of course, $i$. e., provided with khaki coat, trousers and boots, for the rags he stood up in were not decent. Amid all the dire misfortunes that had overtaken him since he was with me, he had managed, he told me with evident pride, to retain three hats, and he produced them. Two were like his trousers, and were hats only by courtesy. But the third was a brand-new blazing scarlet tarbushe. His belongings he said had been stolen the same time as his chits, and he saved his hats from the fate of his clothes by wearing them night and day. Peter with two black hats, and the tarbushe, of course, on top, was a sight not easily forgotten. As he marched along, a kettle usually in each hand, the flaming red top hamper would tip rakishly first to one side then to the other. When we got among game, I suppose to make assurance doubly sure, and to save its loved colour from the drenching rains of the wet season, which we were then encountering, he actually extemporized a fourth and most serviceable head covering of raw kongoni skin, which he drew down over all his precious headgear. The last was all you saw on his head till the end of the trip, when oily, but otherwise good as new, the temporary eclipsed tarboushe shone forth in tarnished splendour, to celebrate his return to Nairobi and civilization.

I began with the headman, the director and guide of my little company. I have come now to its tail - the toto - its apprentice boy, not entered on your list of men. You have no knowledge of his existence till some day, from somewhere, he bobs up before you, just a toto. It may be you see him first, though this is unlikely, wedged in among the legs of a dozen or fifteen men, in one of the already dreadfully crowded third class compartments 
of the train, that is carrying all your party to some wayside station. It may be he has so far escaped you entirely, as he surely has the ticket collector, and your first sight of him, is as fagged out, he totters along, carrying a much too heavy load for his little boy's body, far behind the rearmost askari, on some long, hot, marching day. Thus it was I first came to know him.

"Is he a little fellow following his father?" I asked. "Oh, no, he is just a toto." To my ignorance on that my first sefari, this meant nothing at all. I was soon to learn. The boy on that occasion was on the point of collapse, and, fortunately, I had determined to walk myself at the rear of the column, as the way was long, water distant, and the lava rock we were traversing terribly hard for all our feet. The boy was not more than fourteen years old at most, but had been ill or underfed, for he lacked the robustness of totos generally. I halted the men, and asked who claimed him, and how he came to be carrying, as he was, a man's load, not less. Five or six big porters came up. Still I was mystified, and only after some time did I learn that I was supposed to have no responsbility for him at all. He was not on the "strength" of the sefari. He was just a toto, hired by the aforesaid five or six to do their little jobs around camp, carry water, cook food, and carry at least a part of their potio. Had he a father? No. A mother? Doubtful. Generally these little black mites are orphans. Many such there are, alas! They hang around government stations claiming no one, recognized by none. In some sore strait some helpless woman laid him at a stranger's hut door, to live or die as it might be. Many of the totos show too plainly traces of that early disaster. Rickety, consumptive, half-starved atoms of humanity, who yet face with an African's quite wonderful cheeriness, the chances of sefari life, because it offers them plentiful food and some sort of a home. 
Others there are of them, of course, who are in a far better condition, whose mothers have died and who come along with their fathers. The worst used toto I ever knew was such an one. I found him one dreadfully hot day when we were marching without water for eight hours, struggling along two miles behind his useless father, who since he was an askari, carried not one ounce himself, but his short Schneider carbine. That half-starved child was struggling under four men's potio for eight days, i. e., 48 pounds of meal beside a large sufuria and his father's sleeping mat, quite 60 pounds in all. I was very ignorant, as I say, of African matters then, but that day taught me a lesson, and ever after I make a point of turning up unexpectedly at the tail of the column and staying there sometimes for hours, when long marches have to be made. No totos should be admitted to any sefari till they have passed the bwana's inspection, and the men who engage them should be obliged to come forward and show themselves. Nor should these men be paid their wages (this is very important) when the sefari is paid off, till you are sure the toto has received his modest and well-earned dole.*

In this poor child's case I was able to see rough justice done. We had fully two hundred miles steady marching ahead of us, and for every mile of it, his father carried that load, while he marched free. I got him to hospital on my return, and after long sickness he at last recovered from that awful day's march.

It is five o'clock in the morning, scarcely any sign of coming day yet, but every one in the sefari except perhaps yourself, from headman to toto is stirring. The little tents into which from five to seven men pack themselves, like sardines, are being taken down, and sleeping mats and personal whatnots are rolled tightly together. The

\footnotetext{
* From one rupee to three rupees a month.
} 
great pile of baggage in front of the bwana's tent has its green ground sheet covering removed, and the men's loads are placed in a long line. The men like starting early, and camp should, if possible, be reached by midday. You hurry through your breakfast. But even if you are up as soon as your men, and you should be, for you take a much longer time to get ready than they do, you are aware of watchful eyes and waiting figures, ready to pounce on and carry away any and everything you are using. The table goes to one porter's load, your chair to another, your second cup of coffee makes the man who carries the canteen shift uneasily from leg to leg. He is mentally calculating how long behind the others he will be, before that closed and locked canteen is handed over to his tender mercies for the day.

Lay away in its chosen place the night before, every thing you want in the morning. If you do not, you will find the world locked up against you, and it is a hard-hearted bwana indeed who will make an anxious porter take off the many windings of his porter's kamba (tying string), and stand over him while most unwillingly he pulls the whole wonderful conglomeration to pieces. To rearrange a load once it has been fastened up, is something the best porters thoroughly dislike to do; and now, each man taking up the box or bag assigned him, goes back to his own camp fire and fastens his day's burden together with much coiling and twisting and tying of "granny knots." Next, he deftly twists his scarlet cotton blanket round his head, in a compact turban, so that on it rests the weight of his load, and stands waiting the order bendika (load up). When this is shouted, up go a hundred bundles, and the porter, balancing the weight carefully, stretches out his foot for his porter's stick (something none of them will travel without) which he grasps, yes, grasps, between his big toe and the next, and bending his knee, while he holds 
his body erect, places it thus monkeywise, in his hand. Now, with whistling of reed pipes and blowing of horns we are off, the head porter carrying the heaviest load, probably the bwana's tent, leads the way, and the headman with an askari or two, and some spare men bringing up the rear. The tail of laden men has scarcely left the circle of camp fires, before down swoop the brown kites, and expectant vultures flap from farther to nearer trees.

Six hours is a sufficiently good march, and a well ordered sefari will make in that time from twelve to fifteen miles, with ten minutes rest every two and a half or three hours.

Even if they are strangers to the country the men instinctively know when they are nearing camp. The column closes up. The weird music rises shrilly, and lead by the Wanyamwazi who grunt one of their marching songs as each man taps the water bottle of the man in front of him, the long, twisting line comes marching in.

Not seldom the afternoon storm, black and angry, is rolling up, and then it is that you reap the advantages of having well drilled your men. There is no confusion, each knows his work and deftly does it. The heavy tents have, from the first day out, allotted to them their team of men. These teams race against each other with a will, and there is a good deal of emulation among the men as to which tent shall first stand pitched true and taut. When the bwana's tent is in place, the pile of camp baggage, horns, hides, provision, boxes, potio, saddles, ammunition, etc., is laid on brushwood or logs, a trench dug around it, and the whole covered with a waterproof ground sheet. Then, like magic, the pretty low tents of the porters spring up in horseshoe curve round the large tents, a thorn boma is built for the donkeys or riding mules, if it is a lion country. Wood is cut, water brought, and in front of fifteen or twenty little habitations cheerful tongues of fire rise fragrantly in the evening air. When they have cooked and eaten 
their porridge the men gather in groups round the fires of the most popular. Songs begin to rise first from one quarter, then from several. The Somalis produce from somewhere a snowy white cotton robe and kneeling on their mats, chant loudly their evening prayer. Within ten feet of these stoical Mohammedans, a Wakamba dance is most probably in full swing, or Kikuyus are chatting loudly one of their endless minor songs, with leader and chorus. The clatter of laughing and story telling in four or five languages rattles on ceaselessly till eight or nine o'clock, when the askari on guard shouts Kalale! (shut up), and obedient silence falls on the sefari.

As you lie awake, you wonder at the stillness of the African night. Often there are no sounds but the soft treading of the watch as he replenishes the fire before your tent, and, perhaps, the tinkling* of innumerable frogs refreshed by copious dew. You may hear the rasping cry of the leopard, such a sound as a saw, badly set, makes when drawn through green wood. Or the quite indescribable howl of the ubiquitous hyena uttered in any and all cadences, and, perhaps, a distant lion roaring a signal to his mate.

\footnotetext{
*When the rainy season begins, quite a number of different frogs join in the night's chorus, and never cease their croaking till day breaks. But one tiny little fellow does not wait for the rains, and seems to need no other encouragement than that afforded him by a plentiful dew. Soon as it begins to fall, he takes up his chanting and it is as though a thousand elfin silver triangles were touched by minute bars of steel. A silvery tinkling sound.
} 


\section{CHAPTER III}

\section{ACROSS THE MAU ESCARPMENT TO LION LAND}

A LDAMA RAVINE BOMA* stands on a high, flat A topped hill commanding an immensely extensive and very beautiful view. To the east rises the fine Aberdare range, not yet accurately surveyed, but probably some of its summits are 14,000 feet high. To the north, surrounded by a very tumult of gorges and precipices, lies Lake Baringo. On the west and northwest the wall of the forest clad Mau lifts its fine purple masses.

Evening is the best time to climb to the neat native village on the very summit of the hill. Here the askaris's families live. The red earth is swept twice a day, no trace of rubbish anywhere, and the red thatched circular cottages stand in orderly rows. As the sun sinks behind the great woodland, a flood of such evening light as is only to be seen in Africa, pours all over the varied country you are looking down on from a height of almost eight thousand feet. At your feet are some of the richest shambas in the whole Protectorate. In them two heavy crops are raised yearly, and I measured a peach tree in the government shamba fifteen inches in diameter, only seven years old.

For forty miles the land slopes eastward and northward, The country toward Baringo is very dry and sandy. The mountains on either side seem to catch and hold the rain clouds, for the rainfall at the boma and on the Aberdare is excessive; in the valley it is light and precarious, and

* Boma means many things, a fenced enclosure to guard against lions, bence any fenced place. Government posts in earlier and unsettled days were always rudely fortified. 
near Baringo, were it not for clever native irrigation, the people would often starve. Three years ago I tramped down the valley from Nakuru and found large quantities of game, but most of it now has gone elsewhere. But one sportsman's prize may still be gathered amid those stony and sunbaked ridges - the greater koodo. On the precipitous slopes near Baringo, and in the broken, almost waterless country on the southern side of that lake, he is to be had for the diligent seeking.

North of this, beyond Baringo, koodo are fairly abundant, but, alas, the tantalizing game reserve line is there drawn across your path, and, into this " northern reserve," common mortal may not, at present, enter. Later, I hope to have something to say about the game reserve policy which now obtains. Game should be preserved. But in my humble judgment, the best way to do so, is not the present way. Now, great areas are permanently closed against sportsmen, while within them, native hunters and some unprincipled poachers, work their will. If a man is willing to lie, it is impossible for any official to say where he got his trophies. There are no fences, only one or two game wardens for several hundreds of thousands of square miles. Once launched, a sefari can go anywhere and no man be the wiser. A far better plan surely would be to have several preserved areas, each with its own game officer, and to open one or two each year, keeping them open for a set time only, then closing them again. The old bucks carrying the finest trophies would, if this plan were adopted, be shot down, and the herds would gain, not lose thereby. Any way, you cannot get into the northern preserve at present, even to take one greater koodo unless you have a "pull." I hadn't and so did not go. There is a chance, however, as I said, of finding this finest of all the antelopes to the south of the forbidden land, and it is worth trying. 
One mile from the ravine boma the trail toward Guash'ngishu plateau, whither I am bound, plunges across the Mau forest. There its belt is about fourteen miles wide, but the sinuosities of the path make it a hard day's tramping. If there has been much rain, you slide down hill and slip up, till you feel you are working out the old problem of the snail that crawled up six feet of wall at night and slipped back five feet eleven inches during the day. The miles seem very long indeed, as you plod along in the semi darkness. Mighty trees, rising some of them a hundred feet without knot or branch, mostly junipers, tower above you, and dense green tangle, thick and high as a woody wall, shuts you in; progress, unless along the narrow well worn path, is out of the question.

The great Mau forest, which the path crosses at a narrow point, is well worth studying. Here and round Mount Kenia are the future lumber regions of the East. I fear I run the risk of wearying some by such lengthy reference to the great woodland region. But to me it seemed, not from the traveller's or hunter's point of view only, but from the point of view of one wishing that all good things may come to the dear old land where he was born, a possession so important, an asset so valuable, that every Englishman should be interested in its safeguarding.

One immense advantage the African lumber regions have, over those of Canada and the United States. They are practically fireproof. Let the high grass fire come rolling down, in as fierce a flood as it may. Let even a furious wind drive it on. It sinks, baffled and beaten down, at the very foot of those great, green walls. The dense and dank herbage, like a vast, wet, enfolding blanket, almost instantaneously smothers it.

Here, there is a great lumber region insured against fire and as yet absolutely untouched by man. No local demand for its timber could possibly exhaust even a small fraction 


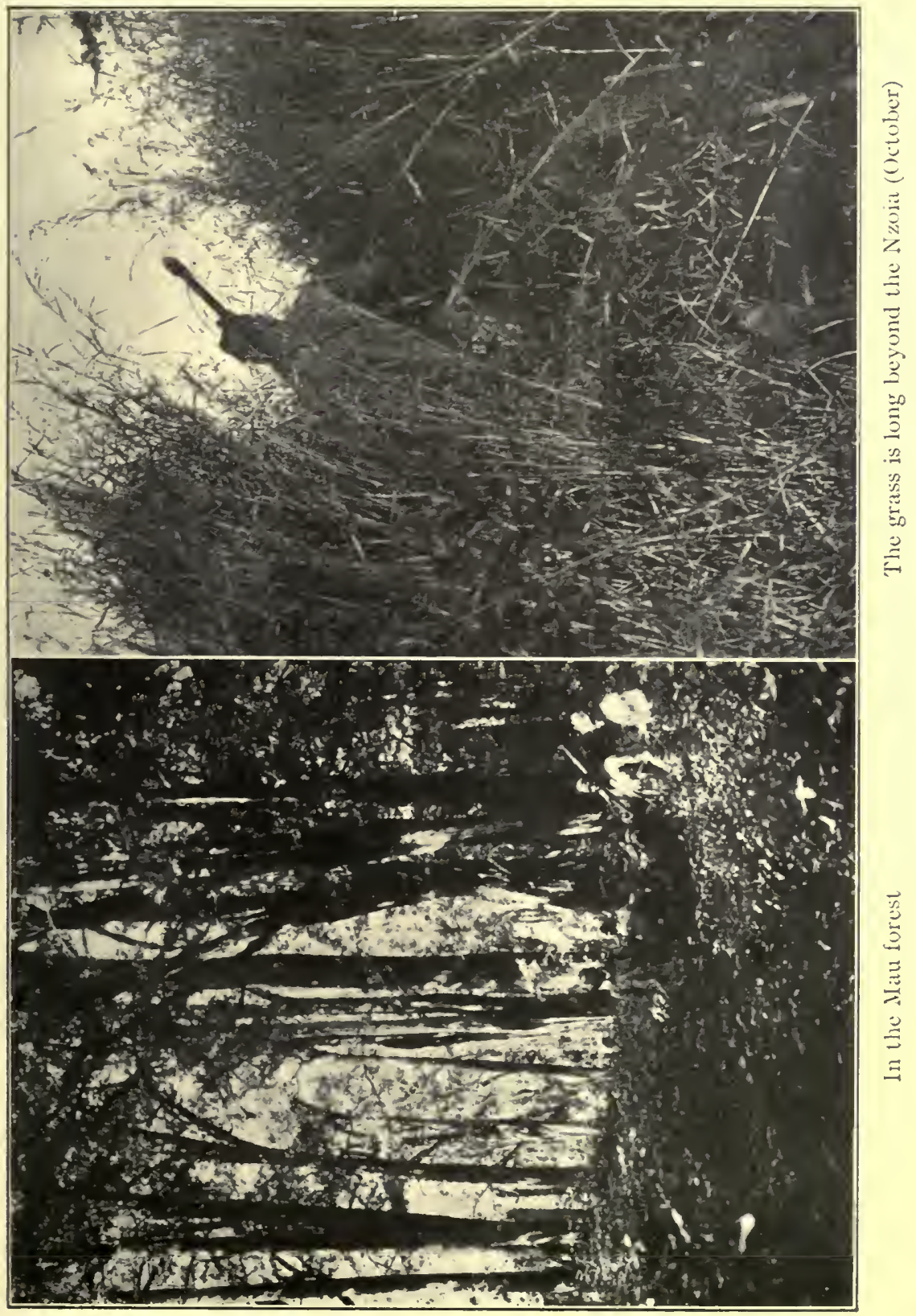


10 
of its resources. To-day, it cannot be reached. No railroad comes near it. If all the railroad facilities of the country were to be bent on handling export from it alone, they would be absurdly inadequate.

But what of the morrow? What, when other and nearer lumber regions are exhausted and Canada and the Baltic can no longer supply pine wood, red, yellow or white? What of the forest land then? Great trees, many of them measuring from six to eleven feet in diameter at the base, rise, tall and straight, knotless as reeds, forty, sixty, a hundred feet into the air, before, free of the strangling embrace of their fellows, they burst forth with their rich, heavy crowns of branch and leaf. I am no forester how many grow to the acre I cannot say. But I can say that, though I have ridden much in our own great woodlands, I seldom have seen a country that would yield a heavier return. The sugar pine groves in California are finer, and high on the Columbia River forty years ago there was an unequalled forest. But these Mau woods are well worth looking after. What has Government done? Granted at least one hundred and ninety two thousand acres of the very best of it, to two or three favourite concessionåries.

Of course, there were certain conditions entered into, and also, of course, as almost always happens in this country, those conditions proved to be beyond the power of either party to keep. That stage of the proceedings has, I believe, been reached.

It is hard to imagine any system more hurtful to a land which has been, as this has, much advertised as a white mans' country, and which is admittedly hard to populate with desirable immigrants, than this system of granting great concessions to individuals or companies with a "pull." Concessions are begged for, more with the hope of passing on the thing to someone else at a good profit, than of 
actually working them. Everything is tied up, no one is benefited or satisfied.

These forests are their own insurance agents against fire. Try as you may, you cannot burn them down. No casual farmer living on their edges, even if he take what his house and farm need from their wealth, can do them any harm. And, till a special branch line is built, and great outlay undertaken, of course no real attack can be made on the lumber. So long, therefore, as reasonable conditions. are attached to any farms granted, the timber is pretty safe. But the concession of the Mau forest or a great part of it, does serious harm in another way.

Every foot of the road from Londiani to the river that bounds this region, and is the actual dividing line between it and Sergoit plain, a distance of seventy miles - runs through the "concession" - the land has been granted as well as the wood, land fine as can be seen. And so, year after year, enviously and angrily, the would-be settler tramps behind his wagon those seventy long miles, cursing a system of favouritism, which forces him to move mile after mile farther away from the railroad and the market, while here are uncounted farms, wooded, sheltered, healthy, nearer home, occupied by no one, yet denied to him. $\mathrm{He}$, ready to work and willing to pay, reasonably enough asks: "Where are the signs of either work done, or pay made to the Government, for this splendid demesne?"

The forest is very silent. Now and then is heard the chattering call of the monkey, ensconced far above mother earth, in his own upper sunny world of the tree tops, and occasionally you notice a parrot or a pigeon. Beneath in the gloom, the rich loam bears few game signs. Now and then the rooting of the bush pig, or a very rare bush buck slot - that is all. The thing that impresses you as. you struggle through this new vegetable world for the first time, is its stubborn obstructiveness. You are not only 
held back by barriers so tough that steady cutting and chopping with axe and sharp panga can alone enable you to make any headway, but you are attacked and wounded. Woody trailers, thick as your arm, or frail, delicate, twining things, slender as a blade of grass, spread forth strong, clinging hands and fingers to hold you back. Twigs that instinctively in other lands you would easily brush aside, here may not be so dealt with. They may be fine as wire, they are surely as strong. And all are armed, armed with thorns, some of them so stout and sharp that they will rip a mule's tough hide. Or thorns so sharp and barbed that they cut and tear the toughest hunting coat. All nature here seems to cry out against your intrusion. "Why are you raiding where you have no right to come?" she seems to say. "I want no stranger here."

Nor can it be said that to her own dark children the woodlands are kindly. The hardy native hunter pays the same penalty as does the well-clothed European. And none suffers so much as the N'dorobo wild man, who is born and lives and dies among these woods. Very large numbers of these folk, you will notice, have lost an eye. Or their well-shaped legs show deep scars where ulcers, that months couldn't have completely cured, bit into the bone. You see these horrid scars, and in your mind's eye, conjure up some deadly encounter between ill-armed savage and terrible beast. You ask the cause. The answer is prosaic enough. Nine times out of ten it is: "The thorn."*

The forest ends as abruptly as it began. Suddenly you emerge from the dark tangle into sunlight, and joyfully see before you wide rolling pasture lands of freshest green. It is May, and you might fancy yourself in the Berkshires, were the soil not so rich, and the grass and trees so high.

* Thorn wounds are always painful, sometimes dangerous. Never fail to treat them antiseptically at once. They are almost as poisonous as tooth or claw wounds. 
Fifty miles of these green rolling hills and downs, with the stately forest ever bordering them, on your right, you must pass before you reach "the rock." On these fine uplands there is little to remind you, but the waving clumps of feathery bamboo, dearly loved of the elephants, that you are travelling not only in the tropics, but almost under the Equator.

- Great beds of bracken, and on the higher slopes, masses of flowering heather, grow luxuriantly at the feet of the bamboo; and in some places thickets of a thorny bush exactly like our blackberry, but bearing luscious yellow fruit (the only good wild fruit I tasted in Africa) are found.

The nights up here are bitterly cold, the altitude is over 8,000 feet, and many of the porters are sure to be suffering and ill. In the evenings there is not as much singing and dancing as usual. The men cower over their fires, and you sit in a heavy overcoat near your own. I found the air most invigourating, and if I could fancy ever making a real home in Africa, and I think very few Europeans can, here is the place.

There is but little game. An occasional hyena and, very rarely, a lion may be heard at night. African game, like African natives, seems to dislike the cold. Leopards are numerous, as their tracks tell, but you never see one. The Colobus monkey, late in the evening and very early in the morning, utters from the forest border his extraordinary cry - like a coffee-mill quickly grinding. But this land, though rich and beautiful, is as yet lonely, and still awaits, undeveloped, the coming of the white man's plough and herds.

The second day's march from the boma brought us to the head waters of the Kerio River, a sort of watery dividing line between the streams flowing east and those we are soon to camp on, all of which empty themselves into Lake Victoria. The Kerio has a long and a lonely way to go. 
It falls into far Lake Rudolph, which must be more than three hundred miles to the north, through one of the most stupendous valleys in the world. In that land of rocky steeps, where little native shambas nestle, on patches of rich soil not bigger often than a large carpet, dwell a brave and interesting tribe, almost quite unknown. I camped with them, and learned from them many strange things of which I will speak later.

When we first cross the Kerio it flows through an open country, and over a clear, gravelly bed, an ideal little trout stream - then suddenly plunges into the dark forest. One more march, and before us lies the wide Guash'ngishu plain. And eighteen miles from this nearer edge of it, where camp is pitched by beautifully clear water, and under widespreading juniper trees, can be seen the gray summit of the rocky hill of Sergoit.

Sefaris are always in a hurry to get there, so let me at once stand on its rounded summit, and point out some of the features of this finest of all hunting countries. The view is immensely extensive, and very grand - everything beneath and beyond is vivid green, for it has been raining every afternoon for three months and trees and grass are donning their summer finery. Two long lines of mountains rise on either hand and run far to northward, where, closing together somewhat, they form the two sides of a bluntheaded triangle, at whose broad base I am standing. A rough idea of the geography and local features of this region is necessary, if I am to succeed in creating an interest in those who may read this account of my wanderings, or giving aid, as I wish to do, to those who may visit the land themselves.

The purple mass of Elgon at first catches the eye. Lying to the northwest, it borders the plain on the lake side, and from it extends a whole chain of oddly shaped rocky knobs and irregular ridges that sink gradually down 
into the level country to the west and southwest. This is Nandi land, or rather, the eastern border of the Nandi, who all over the wide plain are looking down on their cruel raiders who came and went till three or four years ago. Further to the north of Elgon faint blue mountain tops can just be seen against the sky: Mount Debasien and the Suk Mountains, these last very high and as yet unsurveyed.

Now turn to eastward. Eight or ten miles off the purple line of the forest comes down to the grass land then rises over a wide plateau to the base of another steep mountain chain also running to the north, not so high as Elgon evidently, but no one has yet measured its exact altitude (almost all African altitudes, even that of Kenia, are still debatable points). On the map this chain is called Chipcharanguani; why no one knows, least of all the natives who live among these mountains. None of them were ever guilty of so monstrous a name. They all contentedly called it, and themselves, Cherangang. This range prolongs itself in a very wilderness of high mountainous country, bordering the Turkwell River, which flows into Lake Rudolph. These mountains to the east and north are the home of four small but independent peoples who, like other mountaineers, have held their own bravely against their far mightier neighbours of the plain. From some of them I learned later many interesting things.

Having looked all around it, look now at the lower country, where sefaris come to hunt, and Boers are crowding to settle. For many miles from the base of the hill, the plain is unusually flat and the grass is cropped short by game herds that continually browse it.

To the west a dull green line, eight miles away, that bends and curves gradually among the low swells of the veldt, marks a ten mile long papyrus swamp, through which, the river you camped by yesterday, flows. As you look you can scarcely believe it. But here rivers twist, in a 
way, that is destined on this very plateau, again and again, to baffle and confuse you. Within and around this reedy stronghold there are probably more lions to-day than anywhere else in Africa. On these countless herds of game they feed abundantly. At night they kill, and earliest dawn finds them where they are safe from any hunter, in their impenetrable papyrus stronghold.

Far away on the horizon to the west, north, and east, the faint patchy beginnings of a sparsely wooded country are seen, but all round the rock the grass lies green, not even a bush growing anywhere. Here on this treeless greensward lions can rarely be stalked, but they can be "ridden" gloriously.

Look carefully with your glasses over the plain, and well-defined paths show up. These the elephants have made, as they take a pleasant one-night excursion of thirty miles or so, from their two favourite forest haunts from Elgon's slopes on the west, to the far denser woods of Elgao and Cherangang. Sometimes they, unwisely for themselves, break the journey and linger by the way to eat the succulent shoots of the thorn trees that cover the lower slopes of the plain. Amid these low-growing trees the sportsman has the very best of good chances - cover, for a close approach, and some shelter, in case there is trouble. Standing on the summit, a good view is had into the basin of the little, brackish, well-hidden, Sergoit Lake. Troops of eland, herds of zebra, and Jackson's hartebeest, in hundreds, troop down in the evening, to drink around the reedy margin of the water. Reed buck are always to be found, and a fine band of waterbuck seem to make their home in the little bit of broken ground, that lies just to the west of the water. A sportsman will leave game just hereabouts alone. If meat must be had, and by now your porters will surely be pestering you with cries of $N^{\prime}$ yama, bwana (meat, master), go a mile or two out of camp and 
shoot one or two of those picturesque but most useless, and from a farmer's point of view most destructive, zebra; but spare a rifle shot near the lake, and so do what little you can to preserve for others the beautiful sight which game approaching water affords. Here, if they are undisturbed, the wild things of the veldt will still come for years, in great numbers and wonderful variety. Game is quick to discover and appreciate a sanctuary, however small. At Laikipia boma large herds may always be seen. The commissioner has requested sefaris not to shoot close by, and though a great number of hunting camps are pitched there, his wishes have been respected. At Laikipia I rode close to a herd of twenty fine eland, that were peacefully grazing with the commissioner's cows.

When in May last I came to Sergoit, five thousand head of game must have been visible at one time to the naked eye. Oraby bounded away as only oraby can, with long, springing leaps, and a fling-back of the hind legs, thrown in just for the fun of the thing. Steinbuck dashed off, without so much leaping, but quite as fast. Jackson's hartebeest (a very fine antelope, indeed, not to be confounded with Coke's hartebeest, the common kongoni of the more southern country) in vast numbers dotted the whole land, and sentinel bucks kept watch on every high ant hill. A band of stately eland trotted steadily away, the bull bringing up the rear. Waterbuck waded in the lake's margin, and dikerbuck jumped up at your feet, where the grass grew long a mong the ruins of the stone kraals of the perished Sarequa.*

A few miles farther north, where the thorn trees were filling the air with their heavy perfume, several herds of giraffe ranged slowly, remaining in the same neighbourhood for weeks together.

Among the cliffs and steep glens of Cherangang to the

\footnotetext{
* A large and prosperous tribe once inhabiting the plateau. They alone of East Africans built themselves stone kraals. They seem to have perished utterly about one hundred years ago.
} 
northward, and in the broad bottom of the valley of the Kerio-Elgao country, only ten miles to the right, buffalo are plentiful, but can only be successfully hunted when the grass is quite short. The Elgao absolutely refuse to go after them while it is long. And the Cherangang forests are so full of staked game pits, that no man, not even an N'dorobo is safe among them, unless at the same time of year (January to June).

Between the plateau you stand on and this last range, there opens the deep gorge in which the Nzoia River has one of its chief sources. Here, too, the elephant sometimes makes a halt, it is so near home, and the rocky sides of the valley shelter many a leopard. As the fine stream leaves its rough cradle, and winds among the rich lands farther north, its banks grow marshy in places, and numberless sedgy hollows drain down to it from the uplands. In these or near them is the chosen retreat of the finest water buck in East Africa (Sing Sing). My friend secured, thirty miles farther down the river, the record head for the Protectorate (33 inches long by 32 , spread, tip to tip such a spread is quite unusual in East Africa).

About twenty-five miles from the rock, the Nzoia bends back to the southwest, sweeping round the slopes of Elgon. In the flat, reedy prairies on its margin, and only there, a fine antelope is found in great abundance-kobus kob. Be merciful to him, good brother sportsman. $\mathrm{He}$ is easiest of all Nzoia's wild company to kill. Very handsome he is, and very poor meat when killed. So, though by an oversight in the game laws, you may shoot ten, hunt up zebra again, they are much larger, and the men think them better eating, and be content with one or at most two pair of the strong, gracefully curving horns.

There are hippo everywhere on this lower part of Nzoia, and a very few rhino. But, leaving these out of count, for river hippo are always small, and rhino horns in this 
country do not compare with those obtainable near the German border, what a game list I have made out for this beautiful part of East Africa! I should have said that very large reed buck and bush buck are constantly to be met. One more animal I must name, for he is well worth taking trouble to secure - the African wild dog.

There are lions from Mombassa to the Lake. They turn up often in most unexpected ways and places, and you may hunt for months in good lion country and see none. A greenhorn strolls out of his tent on the Athi, at an absurdly late hour for a sportsman to go forth, and walks on top of a lion, sunning himself, on an ant heap. The lion is looking the other way, and the lucky greenhorn gets his first lion so easily, that he tells you "there is nothing in lion hunting."

I knew an engineer who has run up and down the Uganda railroad on his inspecting Spider, thousands of miles in the year. He has been doing it for many years. His train hands, on construction trains, often see lions and shoot them. A German professor looks out of his carriage window, sees a lion feeding on a zebra. The train is courteously stopped, he bags that lion. Hundreds of lions have been seen from the railroad, but, my friend has, in all these years, never seen one.

A young friend of mine found himself in Mombassa with a few idle days on his hands. He knew little about hunting and nothing about the country, so he scraped together somehow the odds and ends of a small sefari, and hied him into the rough scrubby bush that surrounds that town. He not only saw a lioness, a thing most unusual thereaboutsno old-timer could have found even a lion's spoor in the place - but he wounded her, and crawled after her into the worst sort of thorn scrub cover. She waited patiently for him there and - charged and mauled him? - not a bit of it! But most amiably let him finish her off.

Emboldened by his luck, he did the same thing with 
a buffalo, wounded and followed it, literally on hands and knees, and the buffalo made no more trouble than the lioness. I am glad my friend has gone back to lands where savage game is not to be had, for he would end by being killed most surely. That sort of luck is dangerous.

In spite of the unfortunate engineer's experience, all along the railroad line lions are still far from uncommon, as the skins offered to passengers prove. The lions of 'Tsavo are famous. And near Voi, one hundred miles from the sea, Mr. Buxton, accompanied by his daughter, had to ring his bicycle bell at one of them, he says, to make it leave the road.

On the Athi plains near Nairobi, and round Donyea Sabuk mountain, I suppose more than two hundred lions have been shot. At Naivasha and Nakura they may be heard any night, and several are shot each year in both these localities. Here, lately, herdsmen are taking up land, and where herdsmen come lions are rightfully doomed. They are to them vermin of a dangerous order, and if rifle cannot reach them, poison can.

On the Mau escarpment some splendid dark-maned specimens are occasionally shot. The cold of that high region seems to result in a heavier and blacker mane than lions generally grow. But the farmer is there in force.

Now that the Mau is passed, all settlement is left behind. The farmer and cattle owner have not yet taken possession of this wonderfully fertile country. Game abounds, and lion till quite lately have had things all their own way. Till three years ago this country was a closed district. No sportsmen or settlers were allowed to enter the land. The Nandi* war was in progress, and sefari would have

\footnotetext{
* The Nandi, a large tribe akin to the Massai, and always at war with them, could not resist the temptation offered them by the scarcely guarded railroad that ran through the middle of their territory. Here was an opportunity to provide themselves with very superior quality of iron for their broad spear heads. Spikes were to be had for the taking. If an unfortunate Indian track walker raised a protest nothing was easier than to test the temper of the new spear head on him. So the Nandi treated the road as a convenient iron mine till, remonstrances proving useless, they had to be thrashed.
} 
been cut up. The poor Nandi had to have their lesson, and it was a hard one when it came. But the result was salutary, for finding that their cattle could easily be captured, and that once these were taken from them they must starve, or give in, they not only gave in, and so received back the larger part of their loved herds, but, being a longheaded people for Africans, they concluded they had better begin to imitate the example of the hitherto despised Kikuyu, and commenced some cultivation on their own account. The Government gave them seed and help, and these most interesting natives, possessed of some of the finest lands in East Africa, are to-day on the road to a more stable prosperity than they have ever enjoyed before. The Sergoit region borders the Nandi escarpment, and had been for a long time before this brief war broke out, a sort of debatable land. Once it was densely populated by another tribe, also allied to the Massai. This tribe, of which I speak farther on, was utterly wiped out, so far as can be learned, about one hundred years ago. Since their destruction, it has remained unoccupied, and was left to game and the lions. Some day, and I cannot think that day a distant one, tens of thousands of cattle and sheep will surely graze it, and from many thousands of its acres, rich crops will spring, to feed the native and the settler.

Just a few words more about the Nzoia plateau and the country across that river to the north of it, where I spent many pleasant hunting days, and then I will follow the sefari to the next camp. There has been quite a little raiding among the tribes that live round the borders of the plateau. Old habits are not to be at once eradicated, certainly not at the mere bidding of some distant civic officer, who has had no time to come round and look after his unruly charges. Massai from the south, Elgao from the east, clashed in the old days constantly with Nandi and Katosch from the west. Occasionally an adventurous 
Karamojo war party pushed down from the north and northwest to try their luck, or Turkana came from the northeast to steal anything they could lay hands on. In these never ceasing efforts to steal each others' goats and cattle, a number of warriors of course lost their lives. But the East African native is a born fighter, whether he carries only a stick or goes armed with the great spear of the Massai, the longer, beautifully balanced weapon of the Karamojo and Elgao, or the quite as deadly bow and poisoned arrow of the N'dorobo.

This sort of thing seems to afford these fighting tribes a pleasurable form of excitement, but, dangerous as it sounds, it in no way jeopardizes, any longer, the white man's sefari. If you come across the path of a band of raiders, as I did twice, they will, in all probability, slip quietly by your camp fire, in the night, and next day you are surprised to see the unmistakable narrow winding trail, that only a long line of bare-footed men can make, winding, snakelike, through the heavy grass.

I tested the climate of the plateau pretty thoroughly, and always found it delightful. The nights are refreshingly cool, though not nearly as cold as nights, spent on the uplands, crossed to reach it. The sun during the day is hot, but the glass never rose above $85^{\circ}$ in the shade. And where there is deep shade, as under a thick tree, it is never too warm for comfort. There are scarcely any flies, and very few mosquitoes or ticks. Twice we came across deadly snakes, one a black and the other a vividly green cobra. Each was about five feet or five feet six inches long. There is also a very beautiful green tree snake, that is extraordinarily quick in its movements, and another which, to my ignorant eyes, differed in nothing from our own common black snake. These last two are constrictors, and, of course, harmless. The men are ever in mortal terror of all and every sort of snake. When I once caught 
a small black snake and holding it in my hand ran after some of them, the way they "cleared" was a sight. One evening four of them were lighting their little fire, after an unusually hard, hot, march under a thickly growing large-leaved tree; the pungent smoke curled up among the branches and must have incommoded a fine green tree snake that had also sought the tree's shelter against the burning sun. My porters were lolling at their ease, when into the very midst of the four tumbled the snake. The yell they raised was so sudden and unearthly, that I ran up with a rifle in great alarm. And it was some minutes before I could even get an explanation from the thoroughly scared men.

In May, June, July, and August, as well as in October, I can, from personal experience, vouch for the fact that here it rains almost every afternoon. Sefari life is none the worse for such a rainfall, indeed, in many ways it makes the hunting better, as tracking can be done and camps made, when during a rainless period it would be difficult to hunt or camp. The flowers, too, are out, mushrooms grow (which, in a land where there are no vegetables, is important), and the country is green and lovely. The day's work can be done before the afternoon storm rolls up. Indeed, I much prefer the rainy season for hunting. Its one and only drawback is the difficulty that sometimes arises in saving your headskins. The rain, in East Africa, comes in a way all its own. Probably you notice a little cloud, and not a very dark one, that circles round half the horizon for an hour or more. "It may rain," you say, "but it won't be much. There is clear sky all round the cloud, and beneath it. If it does come, it will quickly rain itself out." Still, on it comes, and it seems to grow bigger as it moves, and as its fringes draw over you it begins to rain rain hard, big, heavy drops, every one of which hits, as they come, and you feel them land with a cool pat, and sink in. 


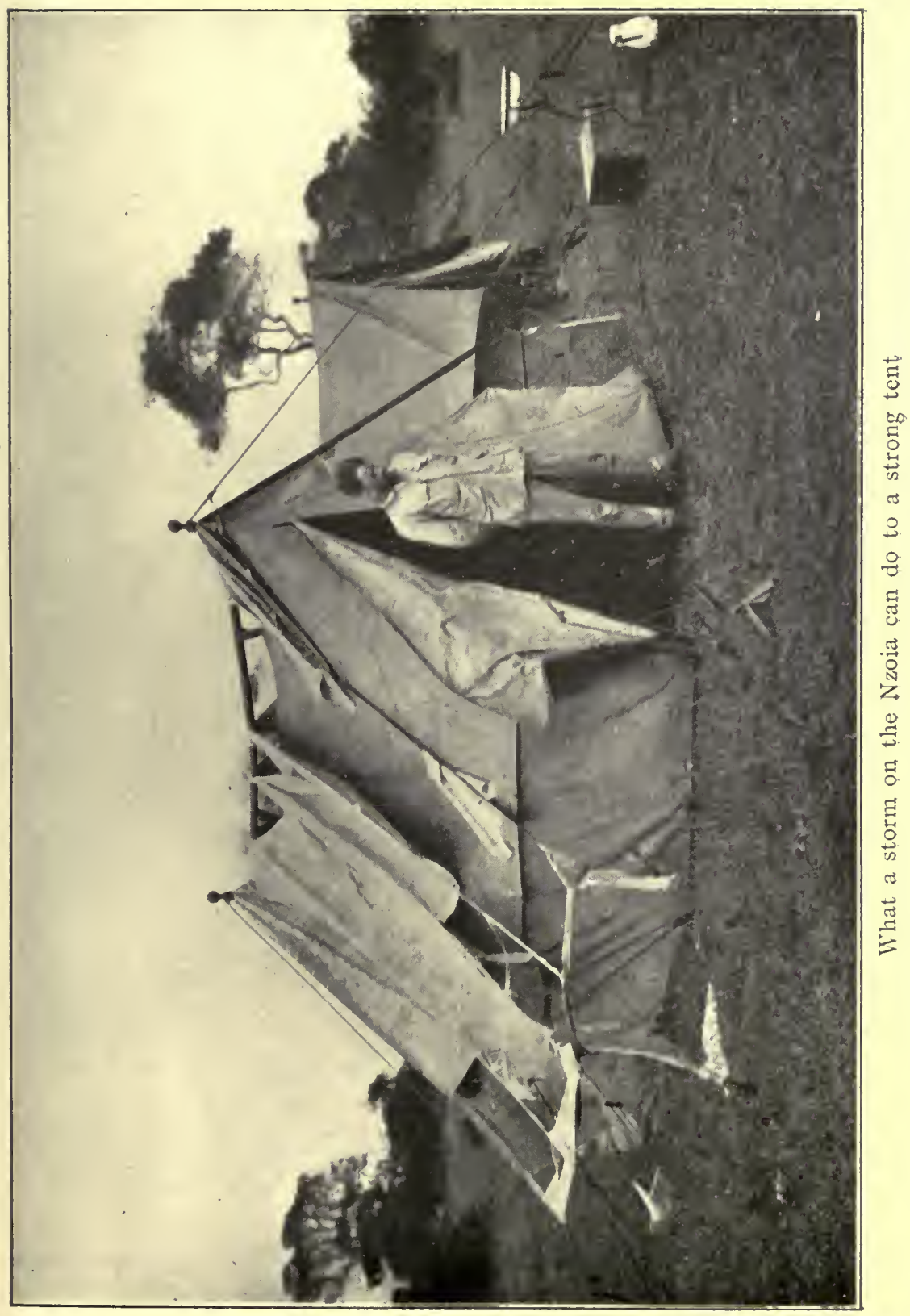



Then, in some unaccountable way that little cloud spreads itself out, and the rain now pours down in a deluge. In our land such a torrent would quickly empty any cloud. But in Africa clouds must be thicker through, than they are wide; and from some higher source, that we below them cannot see, they can spread themselves out, as though they held water in a funnel and not in a saucer, and grow thicker and darker as they pour, from somewhere, the water down. Once they come they do not seem, as ours do, to drift aside, but wait on you and over you, and pour and pour, hour after hour, till all the level ground is deep in standing water. Other clouds there are, with rough, ragged edges like short fingers sticking out of a hand, white misty rims circling up from them. Then look to your tent pegs, for wind comes before rain. (See photograph. This tent was wrecked in about three minutes.)

We did not camp long at Sergoit. There is little or no wood to be had, and over its level greenswards we soon saw that the chance of stalking the lions we now heard nightly, was but poor.

I had not been able to find out much about the country we had now entered. The maps that the department had on hand at Nairobi were not very correct. Men who had been there said it was a great game country, and that there were more lions there than anywhere else. So now nothing remained for my friend and self to do, but to explore for ourselves.

In what part of the plateau lions were most numerous, whether they kept along the Nzoia River in goodly numbers, or whether they were only plentiful in the neighbourhood of the great papyrus swamp, to west of this rock, where ponies were needed to hunt them-all these things remained to be found out.

Now lions were what I had set my heart on. I had on my first trip succeeded in securing many other species of 
game. But never a lion! I had hunted early and late, risen before the sun, morning after morning, and sat up in a machan* all the night, but never shot at a lion. I had walked all round Donyea Sabuk and never seen a lion, while two other men who had walked part of the way round, beginning at the opposite side to mine, had shot four.

You can fancy that after waiting so long a time, and just missing getting one so often, I was pretty keen set on lions.

J. J. W., naturally, like most Americans, wanted everything he could get, so he was not above trying for a lion also, and on his way to get the king, he was pretty sure in the country we were now in, to be able to secure a specimen of most of his subjects. Here then, happily, as in other things, we found ourselves of the same mind. Game herds there were everywhere, and also abundant evidence that hundreds of elephants had lately been, not only crossing the plateau, but resting and feeding on it. So it was with great expectations we moved northward from the rock.

On May 26th, J. J. W. and his hunter saw the first lions, two females. They offered no chance and made off into long grass bordering the river. Following on, the cover grew thicker, and as there was ominous growling they left them. On getting back to the mule, J. J. W found his syce and the porter who was with him, in a great state of perturbation. They declared that soon as he had entered the cover, four lions, one a large male, had broken back and crossed the open glade behind the guns. There were, therefore, either four or six lions in all in that bunch. But unarmed black men may be pardoned if they exaggerate. During the next two nights we heard lions constantly and once on the march I had a glimpse of two great darkmaned fellows who heard the sefaris rattle, and made off before we came within shot. Had I known then, what I learned afterward, that the very best country to follow

* Platform built in a tree. 
them in is long-grass country, for the wide grass trail of the big, low body is easiest of all tracks to follow, I would have gone after them as long as my knee held out. Still, at that time, I could walk but little, and most probably they would not have given me a chance. As it was, I had to content myself with a good view of the splendid beasts as they mounted a stony hill bare of grass at some four hundred yards distance; and with my Zeiss the manes looked dark and long. One was a specially fine beast.

I am pretty well satisfied that the colder the country the darker and longer the mane. In India the lion is maneless. On the Athi plain a really dark lion is seldom seen; in Somaliland is never seen, my Somali tell me. The nights on this great plateau at an altitude of almost seven thousand feet are often bitterly cold. In the Eldama Ravine country, which we passed through, they are even colder. It was there Mr. Aikly, for the Field Museum, succeeded in securing as fine a black-maned lion as has been taken out of the country.

I met some Boers just come from the Transvaal. They were looking at land to take as homesteads, and were enthusiastic over the country they had just seen. They had killed two lions, one of them carrying a fairly black mane though the hair was not very long or the lion exceptionally large. They told me they had never seen a lion in South Africa to match it, though they had shot many. All of which goes to prove, I think, that the colder the country the darker and heavier the hair. I might add that no wild lion has a mane to match some I have seen in the Zoological Gardens in London and Dublin.

On the night of May 29th we heard two or three lions calling some distance down river, and fancied they might be feasting on a water buck J. J. W. had shot that afternoon down there, and he, with his usual unselfishness, insisted that I should go down river and take the chance. 
But as I had said I would go up river the evening before, when we tossed for country, I didn't think it fair to change, and, moreover, if they were at the carcass, the bait was his not mine. So I stuck to my plans, and went up stream. I saw nothing of lion, though I secured what I had wanted a long time to get, viz., a good specimen of the African hunting dog, a fine animal, though very destructive on game. The dogs are the size of large, powerfully built setters, great muscle in leg, back and jaw, with fine brain lobes and broad forehead. The colour is black with brownish stripe down the back, and tan-coloured patches. on the side, the tail bushy and ending in a white tuft of hair. I had seen them before, but had never been able to get near. In the Nzoia country I think they are not rare. They hunt in packs, and will run anything on the plain down. If they could be caught young and crossed with either a greyhound, bulldog or setter, something useful ought to be produced. The eyes are fine and intelligent, though fierce and wild in the extreme. I made a lucky shot at the leader of a troop of a dozen. They were feeding on a kongoni they had pulled down. He mounted an ant heap to look round and I killed him with one shot at 318 yards, using, of course, my telescope. The pack then got confused and several of them ran on me, when I shot three more. One of them, very badly wounded, was so fierce, and showed such fight, when we approached I had to shoot him again.

When I got back to camp rather late in the day, I found every one in the bluest of blues. J. J. W. and his hunter had gone down river to the water buck carcass, or what was left of it, and had come on three fine lions taking their ease close to where they had dined. They were sprawling on and round an ant hill and saw nothing of the hunters. It was J. J. W.'s first shot, and most naturally he was nervous. He used his .450 , a rifle which he didn't know, and missed, 
as he thought then. We found afterward that one of his bullets had passed through the foreleg low down, not breaking the bone. His hunter, waiting for him to shoot, missed his first shot, too, but as one of the lions made off toward the river, wounded him twice, the first time shooting him through the body but too far back, the second time in his rump. The lion first stopped in the long grass that borders the river jungle, and somewhat recklessly they went after him, into it, but he kept lying low and growled ominously; then, finding they couldn't see him, they left for home There was plenty of blood, and the hunter felt sure he would die in a few hours.

In the evening we talked the matter over and coming to the conclusion from what J. J. W.'s hunter said that by morning the beast must be dead, we determined to take our gunboys and twenty porters to beat up the whole place, if necessary, and save the skin from the vultures. Looking back on the whole affair now, I blame myself for allowing the porters to go into such a place, as I blamed the hunter at the time, for taking my friend into long grass after a wounded lion. It is an exceedingly dangerous thing for even an experienced shot to do, one who has command both of his nerves and of his weapon. J. J. W. had had no previous experience of really dangerous game, and his hunter, who afterward proved to be a very nervous shot himself, failed his man badly in acting as he did.

I also placed too much reliance on what this man told me, of where the wounds he had given the lion lay. Had the first bullet from his $.35^{\circ}$ Rigby taken the beast anywhere near the shoulder, it would indeed have been safe work to look for him next day. No lion could live twelve hours shot, in that place, with such a gun. Unfortunately, instead of the shoulder, the bullet had taken effect far back in the guts, a wound that must prove fatal in time, but one which might not cause death for some days. 
When I got to the place in the morning, I found it far more formidable even than I should have fancied from the account given me. The long grass in which they had left the lion was bad enough, but it could be searched. It was safety and simplicity itself, however, when compared with the riverside jungle into which the lion had crawled afterward. This was almost impenetrable. On the right hand side, the deep river ran with steep-cut banks so high that no wounded lion could cross it anywhere. From the bank there extended a belt of cover, shaded by large trees, where vines, reeds, and a hundred thorny leafy plants were matted together. Here were pools of water and deep black hollows, and over all was spread even at midday the dark shade of the trees. Sometimes the sunlight broke in. Usually it was so dark that it was impossible to see anything at even a few yards' distance.

Nothing would have induced me to allow, so long as I could prevent it, any one to enter such a place, had I not had the most positive assurances from J. J. W.'s hunter that he knew where his bullets were placed, and that without any doubt whatever the lion was dead by now. $\mathrm{He}$ had emptied his repeating $\cdot 35^{\circ}$ Mauser at the lion, and had at least one steady standing shot (the distance measured afterward was only I 20 yards), so presumably he should have known what he was talking about. Vultures now rose from the darkest of the thicket, and sat expectant on the tree limbs overhead. Everything looked like a dead lion. So we went in. We formed the beaters up in line, only a few feet apart, with a gunbearer or askari carrying rifle or double barrel gun here and there to give the men heart, and slowly, foot by foot, began our advance into the semi-darkness. (There were twelve rifles and double barrels in all.)

My knee made it impossible for me to enter the thickest of the jungle, so I had to content myself with the left of 
the line. Hobbling along with my stick, my gunbearer behind me with the rifle, nerves were, naturally, a bit strung up, and when some bush buck or reed buck would crash through the bushes a few feet away, the line so far as I could see it would bend and sway, sticks would go up in the air; soon as the porters saw it was nothing, they would steady again.

Presently I could hear from the sound of beating sticks. and voices that the line had beat backward in the middle, and was no longer straight but bowed, with either wing so pressing forward, that if anything happened the men would shoot into each other. If I had had any experience of beating out such a place, I might have known that it would prove impossible to keep even well-drilled men in a straight line. But this was my first and my last attempt at such a job.

A moment later there came a quite appalling grunting roar right in the middle of the line, where J. J. W. and his Somali gunbearer and his hunter were. It seemed only a few feet off, it so pervaded the whole dark place, and my heart stood still. I knew the lion was not dead by a long way, and that we were all embarked on a foolish business. Then a wild fusillade from all sides. The men shot in every direction, some into the air, some into the ground. Poor Momba, the hunter's Kikuyu gunbearer, said afterward, that the askari next him "shot at the birds." Nobody seemed to know where he shot, and nobody, of course, hit the lion. I only knew that one of them nearly shot me, for a bullet buried itself in the bank at my side. I counted eighteen shots, and there may have been more. Then roar on roar and shot on shot. Four or five from heavy guns coming in quick succession. It seemed an age to me, who. could see nothing, but it was really all over in two minutes. Then silence for a moment! Then a loud cheer. And. then another loud call for water, and my heart sank, for I knew someone must have been either shot or mauled. I sent my gunbearer back to where my mule was tied, for 
my saddle bags, and hobbled in, getting through the few yards that separated me from the centre as quickly as I could. Mombo the Kikuyu gunbearer had been pulled down - a good fellow, brave to recklessness, very unlike Kikuyu generally, but who had had no experience of lions in cover

Momba had come on the lion near the river bank. He was on the extreme right of our line of beaters. The wounded beast was nearly done. When Mombo stumbled on him he could scarcely raise himself out of his lair one shot would have finished him. But Momba, like almost all black men, could hit nothing with the rifle, and at a few feet's distance missed him two or three times. The men near him who had guns did the same. One good shot would have been enough, but none came, and slowly it seemed the great beast closed on him. All he could do was to throw himself backward into the brush, and that was so thick it doubtless saved his life. The lion grabbed him by the left arm, and somehow took at the same time the stock of his rifle in his mouth. The lower teeth bit into the tough wood and this somewhat saved the arm. The lion tried to draw the man toward and under him, but the stout brush held the poor fellow, and saved him also from the deadly claw, worse than tooth wounds, for they soon bring gangrene. The lion let his first hold go, taking a second to draw him down, but he was wounded to death and the brush was thick and tough. Then he let the man go, and turning back struck the line in the middle, where the hunter and J. J. W.'s gunbearer stood. Both these shot at him with .350 rifles two or three times each, and he sank down dead with two bullets in the chest. The bullets were in all likelihood fired by the hunter, for, though Noor, J. J. W.'s Somali, is a steady man, and never for a moment flinched, he is, like most Somalis, a very indifferent shot.

When the great beast was down everyone cheered, for 


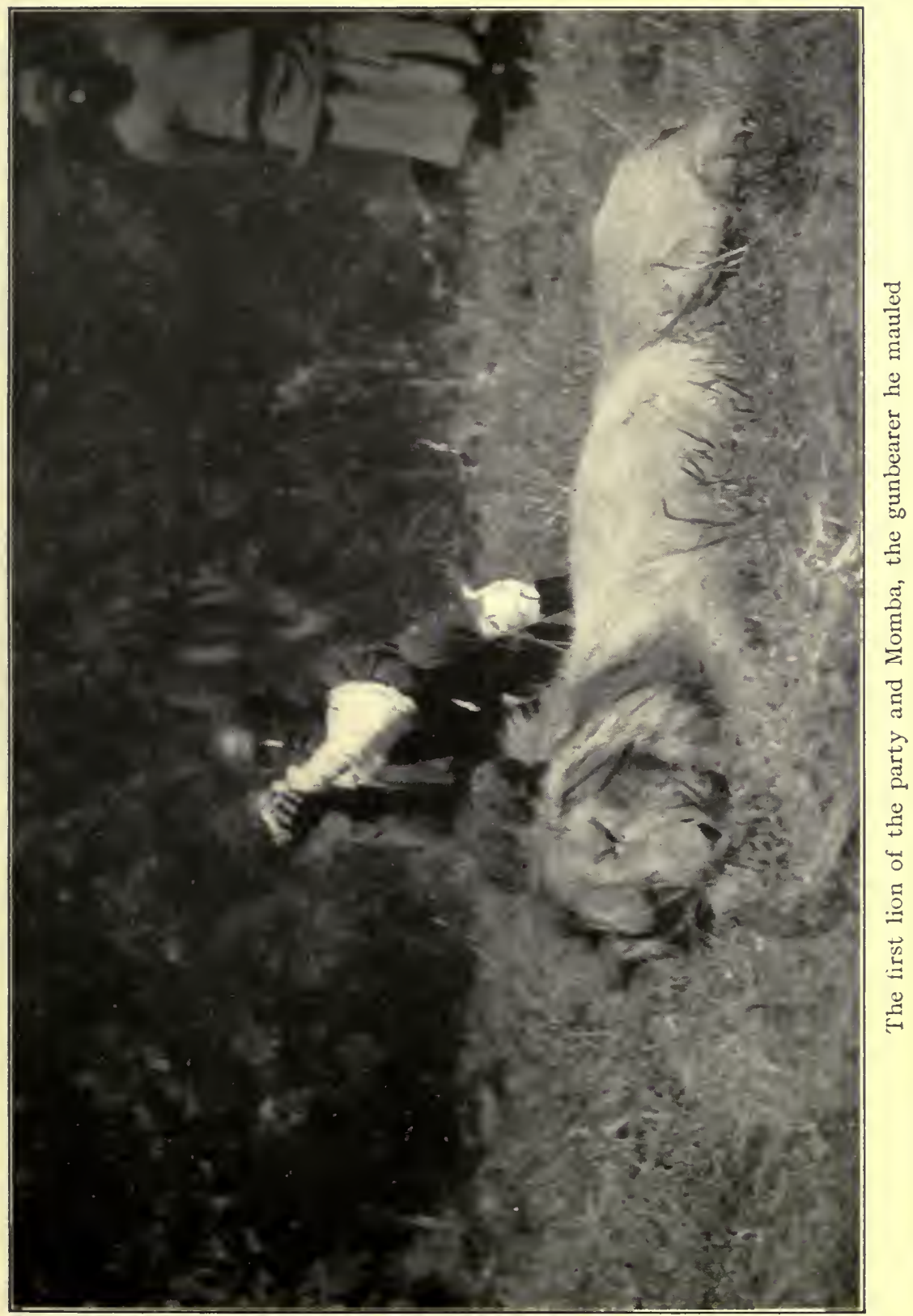



few knew Momba had been mauled, but presently two or three brought in the poor fellow, all limp and faint. It was then he said that the fellow next him had shot at the birds, but he, Momba, had put two bullets in him. We comforted him by assuring him that he had.

It was fortunate that I always carried in my saddle bags permanganate of potash, lint, bandages, and a strong syringe; also, that my syce carried my water bottle full of boiled water. These were to hand in a few moments, and I did with them, for poor Momba, what I could. He had made no outcry when the beast gripped him, though the wounds of the great teeth, almost through the forearm, showed plainly the sideways tug he had received - and flesh and sinew was forced outward by the straining. But he cried pitifully when the fierce burning current of disinfectant was forced into all the wounds. He said afterwards that he had "awful pain up his arm and into the back of his head, and then things were very dark." His description, I fear, was accurate enough. But the one thing that must be done, let it pain as it may, let it even be necessary to hold a half-distracted man down in order to do it thoroughly, is at once and with a strong solution to syringe and syringe thoroughly. The claw wounds in his legs were slight scratches, and gave no after trouble, healing up at once. But hand and arm were terribly torn and lacerated. Seventeen wounds in all he had.

We tended and fed him as well as we could, dressing the wounds twice daily. The crushing his arm had received caused most trouble, pus gathering near the bone, under the larger muscles. The wounds could easily be washed out, but deeper in, the poisonous matter lay, and I was afraid to lance it as I did not know what harm I might do. Momba had a temperature for almost seven weeks. His whole left arm remained dreadfully swollen, but gradually improvement set in. After a time he could eat well and 
sleep well, and when we reached Laikipia we were fortunate indeed in securing the help of a medical missionary, who probed and lanced the arm, leaving in drainage tubes, so that in a week all swelling had gone.

Nine weeks after his mauling, Momba marched off joyously on an eighty mile tramp to greet his four expectant Kikuyu wives, dropping sundry hints that as he was now possessed of seventy-five rupees he might add to their number! 


\section{CHAPTER IV}

\section{MY FIRST LION}

YEAR after year it grows harder to get lions to stand. 1 Even three years ago it was more common than it is now to have a lion you come on suddenly, "wait a little on his departing," taking stock, first of all, of the intruder on his demesne before slinking away. That first questioning pause was of course the hunter's golden opportunity, and the man who was always ready, and the initiated know well not one sportsman in ten belongs to that category, gathered his roses while he might - or rather - promptly got his lion.

Now if you see a lion in the open, and he sees you, which nine out of ten times he does, before even good native eyes see him, he is sure to beat a retreat, even though you may be a thousand yards away. He will retreat, too, at a pace that makes pursuit on foot out of the question.* And he will make off in a careless cunning way, as though he was going off anyway on business of his own, with which your coming on the scene had nothing whatever to do. That is his game. Again and again I have seen lions follow it so long as they had the enemy in sight. You, of course, encouraged by so slow and leisurely a departure, as soon as some slope of the ground or other welcome shelter affords you the chance run for all you are worth to make up distance, and full of hope, if you are out of wind, panting, you raise your head cautiously about the cover almost sure of a shot. Alas, no! The moment you were out of sight, could you but have seen him, you would have been surprised to see your quarry,

* I mention, later, circumstances under which, even when lions see the hunter and get aw ay - they can be followed up on foot, and probably one at least shot. 
throw to the winds his feigned indifference, and "clear" like a frightened cat.

Surely like all wild animals, the lion is learning and learning quickly the lesson the modern rifle so effectually teaches. Tigers, Indian Shekaris tell us, do not charge as they did. Our own grizzly bear, of whose fierce savagery, we feel ourselves (in honour to the country of big things) bound to make the most - may have in Lewis and Clark's days charged in quite orthodox fashion. I have proved, to my own satisfaction at any rate, that he is not half as likely to charge as a wounded water buck to-day.

Anyway lions won't stand. If they do stand for you, count yourself lucky. If you come on one at a few yards off, his surprise will chain him to where he is, for - well-long enough for a ready man to shoot him. Then under these circumstances the surprise sometimes is mutual. A friend of mine was hunting with another man on the Athi three years ago. They divided, each walking on the edge of a narrow water course - an excellent place to chance on a lion. My friend's companion had come all the way to the Protectorate to get a lion, so he kept saying. He cared to shoot nothing else. Presently out of the yellow nulla grass a fine male lion stepped right in front of him, and, not seeing him stood at thirty yards distance stock still. The wouldbe lion slayer stood stock still too, and the lion walked back into the cover, and he back to camp, a disconcerted man. Of course he never had another chance like that and went home wiser if lion-less.

My own chance seemed as though it would never come. J. J. W. saw ten or eleven different lions. He longed to give me his luck but could not. Morning after morning I left camp at dawn and carefully searched the country where I had marked their nightly roaring. I could only comfort myself by repeating my own old fisherman's motto, "If you want salmon keep your fly in the water." Some- 
times when I had had an unusually long and useless tramp of it, that unlucky railroad engineer, running up and down the best lion country, in his spider with his rifle in front of him, yet never seeing a lion, would dismally recur to me. My friend was sympathy itself and even offered to lend me an Indian charm of potency immense, a notable chief had given him long ago. But he kept seeing lions and I didn't. It was almost three weeks since we had so bunglingly rounded up J. J. W.'s first lion that I shot mine.

We had made permanent camp near a fine spring of water, and in a most excellent game country, some twenty miles north of Sergoit. Five miles to the westward ran the deep valley of the Nzoia and across it rose the Elgao ridges. The grass on this bushy part of the country was by now beginning to grow long. The herds do much to keep it down, but especially among the thorn trees, in patches of a few acres, it would partly hide the smaller antelope, and it seemed to me that my chances of success lessened daily. One morning, after almost four hours' hunting, about ten o'clock, I was riding near the edge of the great Nzoia valley, when suddenly I heard, or thought I heard, a low purring grunt. I stopped my gunbearers and questioned them. The Somali, Dooda, said it was only the mule, but Kongoni said simba, and I felt myself that it was simba (lion).

Now the lion makes a good many different noises (of that much debated question more anon). But this little social family circle grunt, is a most difficult sound to locate. In this respect and in this alone, it is like the very, what shall I say? "trying" grunt angry lions and lionesses give when they are near you in the grass. This may come from thirty yards away, and it may be at your very feet. And I say again, and advisedly, a cool man often cannot locate it at all. Then if anything can beat him, the repetition of that growling snarl coming from everywhere and nowhere surely will.

After a good night's hunting, lions like to dry off a bit in 
the sun. And when, as now, the grass is growing, and the dew lies heavy after the night, they will choose some high dry ant heap for a morning conclave, and a needed sunbath. All through this lower Nzoia country, the ant hills some of them of great size, stand thickly, and the game has a habit of mounting them and looking around. You see a level unobstructed stretch of green grass for a hundred yards or so before you. Then a group of ant hills, with thorny bushes in clumps of ten or fifteen yards in diameter, standing between them. Then an acre or two of higher ripening grass, the whole forming an ideal stalking country, also a sort of place where wounded game may require some reaching for. It was through this sort of thing we had advanced very silently for a quarter of a mile or more, when another purring grunt sounded, not a bit nearer than the first. but as we were all expectancy, and the mule was away behind us, we heard it clearly this time and knew it was made by a lion. Almost immediately afterward my Brownie whispered "simba" pointing at a clump of bushes two hundred yards away, and I knew that after long waiting I was at least within shooting distance of a lion at last. To many a man such a moment may have come as an ordinary one, but not so to me. Day after day for five long months, I had never gone out hunting in the early morning without hoping and longing to find myself face to face with the finest beast in the world; the lion of British East Africa - and though I cannot say that hope deferred made the heart sick in my case it certainly did make the hunter keen.

One hundred and seventy yards in front of the bush we crouched under, a bushy screen of thorn stretched for twenty or thirty yards. Beyond that rose a wide low red ant hill, and round the warm sunny bare base of it, there seemed to be a buff coloured yellowish mass. The intervening thorns hid the crown of the ant hill, and anything there might be on it was invisible to me, but the fawn coloured mass at the 
base just showed movement to the naked eye, and through the glass I saw legs, tails, yellow flanks, and heads all pressed together, as that great cat family - the lord, his harem and their offspring - took their pleasure in the sun. The bushy screen that hid them from me was far too dense to permit of my shooting through it, even if the light were sufficient to enable me to draw a sight on any one lion in that huddled mass, which it was not, so my position was a tantalizing, and an also uncertain one. I was fully 200 yards from my game. The wind was very light, and, as it is apt to be in the early morning, very treacherous. The little silvery spiral wreaths of dew smoke rose gently twisting in the air as the sun searched out the shaded grass under an overhanging bough, and as they rose they drifted every way. I noticed them anxiously as I sat there, my heart I admit, beating fast. My gunbearers Dooda and Brownie, were greatly excited, and I at once made up my mind to pay no attention to their tugs and beseeching whisperings to right and left of me - tugs I say, for they were pulling me first one way then the other - but to do as I thought best myself. A choice had to be made and that right quickly. Here was the situation: the patch of thorn that shielded the lions from me, and through the thinning lower stems of which I could just make out their colour, but not their form, was about twenty yards across, and, as I said, two hundred yards away. From where we crouched, two narrow green aisles of open grass, only a few yards wide, passed on either side of it. As I sat I could command the one to my right, but not possibly the one to my left. I could from no point command both at the same time. Beyond these little bush lined avenues of grass there was more cover; and though it was quite open enough in many places to shoot through or shoot over, there would be little chance of a steady sitting shot, and that above everything was what I wanted to get at my first lion. Which way would the pack take? I thought hard and concluded to 
chance it to my left. It instantaneously occurred to me that in that direction lay the steep river valley on whose edge we had been hunting, and there was more probability of the lions denning up for the heat of the day among its rocks, than in the opener country to the right. The lions couldn't see me, the danger was that they would smell, and that increased moment by moment. I might crawl fifty yards nearer, and chance a shot through the tough intervening thorn stems, but I knew that would be foolishness. The band would scatter, the surrounding cover was long and I might get nothing at all. If I got a shot, on the other hand, at the leader, lion or lioness, I was likely to hit a fine animal.

These thoughts and hopes, and far more unnerving desperate fears, that after all I could not get one, that they would escape me, whirled through my brain, as I sat still, before I made up my mind what I would do. I knew of course that if the wind did give me away, the lions might just retire behind the ant heap they were lying on, and then it was "good-bye" and all my trouble to begin over again. But I was not without hope that when they got the wind, they would come forth just for one moment to make sure, and I staked my all on that. If hard luck had been mine in my long waiting, surely fortune would smile on me at last. I crawled away from my men, ignoring a last agonized whisper from Dooda, and sat up in the grass, here two feet high, where I could command the side toward the river, I rested my elbows on my knees and waited.

Was there a big lion among them? Would they clear at once? or would they wait and make sure? Would they stand? Would they charge? I had my tense, glorious moment surely. I could hear the panting breath of the two men who had crawled out after me, and were now crouching beside me. And then at the long last fortune smiled on me indeed. I saw a movement among the fawny mass. And 
slowly, casually, out of the bosom of his family he came. And the lion of my dreams he seemed. Big and black with no common blackness, surely the true king of that wild and beautiful place. Slowly on and on, till in the middle of the green grassy aisle he stood, the sun shining full on his magnificent coat, and the dark rich low hanging mane that covered his shoulders. Then slowly, carelessly, he turned, his broad black head toward me and sniffed the tainted air that drifted down to him over the dewy grass. I had kept my "fly in the water" and my chance had come at last. Who shall attempt to describe the feelings of the man who after long waiting, when the golden chance comes to him, knows as he steadily presses the yielding trigger home, that he is "on!" That triumphant instant may be the result of some dark survival of barbarism within him: all the same it is "living!" It is glorious! It was mine, and is part of me forever.

A deep grunting roar answered the shot, and quickly he swung round his body toward where it came from. As he did so I fired very quickly again, just as fast as I could move my Mauser's bolt.

Then he saw me, and with another deep grunt came straight for where I sat with great long bounds. When I say he roared to the shot, I do not mean that he made any sound at all comparable to that first terrible roar that the lion that mauled Momba made when he charged in on the men. None of our party ever heard any lion deliver so loud and awe-inspiring a signal of onset. Several other lions that I shot later on just growled angrily as they came forward, a nasty enough sound for any one. But that first dying beast made more noise than all of them put together. The distance from where I sat to where the lion stood I measured carefully afterward. It was one hundred and seventy yards; and now he came one hundred and twenty of them, faster than I could have believed it possible for any 
badly wounded beast to come. The grass was just long enough to hide his body from me, except when he was actually bounding in his stride. If I had risen to my feet of course I could have seen him more clearly, but I had thought the whole thing out beforehand and had determined to remain seated With elbow on your knee you have an absolutely steady rest, and are not nearly as apt to throw away a shot as you may be standing up. So I sat fast, determined not to fire again until I could kill him dead, even if I had to let him come to within a very few yards of me. I knew, besides, that I had hit him and hit him hard the first shot, and I hoped I had landed the second, but could not be sure. I did not believe he could last the distance, certainly not at the pace he started at. One more reason pinned me to the ground. It was my first lion. It was all-important to give my gunbearers confidence. If I stood up they might be dancing round me, and in spite of the awful threatenings I had fulminated against anyone who should ever under any circumstances fire one of my guns, the guns might have gone off of themselves, as gunbearers' guns have a way of doing; whereas, if I sat, they must sit, too; and sitting sobered them. I glanced at my men quickly as he made that grand rush over the first hundred yards, and it was well I did. My Wakamba, Brownie, was sitting still as a stone. But the Somali, Dooda, his eyes and teeth gleaming, raised my double .450 to his shoulder, and was on the point of firing, when I hit him with my right elbow under the chin a smart rap, which had the effect of putting him and the gun out of commission for a few minutes. It had to be done; a gunbearer firing off your spare gun may cost you your life. How long it takes to tell of these few intense seconds! How quickly they are over!

At about fifty yards he raised his head high above the grass and slowed down to a trot, and as I saw his breast I shot full into it, and the great dark head and yellow eyes 
sank slowly from sight again. There was just one instant's pause, and out of the grass came the big forefeet and the tip of the tail. He was dead without a groan. I turned as quickly as I could to see what had become of the rest. I was only in time to fire at a large lioness as she made off in the grass. I missed her, and I did not care, to tell the truth. I had drunk deep just then, and was quite contented to let the whole family of them go. Had I not seen the great paws of the king himself stretched upward to the sky! My men ran to the ant hill and could count the troop as they crossed the distant rise of land. I went over and stood by my first lion. When they returned they told me that they had counted eight lionesses and half grown or three-quarter grown pups. He was a magnificent fellow indeed, very large and in fine condition with a quite first-class mane. As he lay dead, the tape passed from the tip of the nose to the tip of the tail gave him ten feet five inches; the stretched skin was twelve feet six inches. When our rejoicings were abated a little, Dooda remembered his jaw, and coming up to me with a rueful countenance said, "But you do kill me." I told him that next time he attempted to fire my rifle while he was my gunbearer I should hit him not with my elbow but with the stock of my rifle, as he would endanger all our lives. He never as it happened required another lesson, and really was a good hunter and brave man, but like most Somalis very excitable. Once afterward when he saw a lion in thick scrub suddenly he gripped my arm with so tense a grip that I could not use it for a moment, so later I said to him, "Dooda, I will show you the way to touch your man's arm when you think you see something that he does not." And I gripped as fiercely as I could the inside of his arm where he had held mine. He danced, of course, with the pain, but admitted after that he deserved it. So the lion was skinned and brought to camp, and I heard for the first time that weird Somali chant which the Wakamba and 
Wanyamwazi have already learned from the Somali, and which they call the "Lion Song." Fully a mile from our camp my gunboys raised the song, and when we were still. so far away, that the men's figures seemed but little moving dots the porters heard it and came streaming out to meet us. My men had put green sprigs in their hats; the porters who ran to meet us stuck greenery in their woolly hair and danced round us, as bearing the great skin, my little party marched proudly as they camp into came. If I had had bad luck finding the lion until now, fortune did what she could, during the next few days to make up to me for past disfavour. The day after I had shot my first lion I was up betimes as. usual in the morning, but saw nothing. But the day after that I came on a band of nine. My gunbearers and I had reached a place about six miles from camp when, as we were crossing a hard red earth ridge, Brownie noticed a faint sign and took it up. When we came to a dewy patch of short grass, it showed quite fresh, and was joined by a second. A little later a third came to company, and the men concluded we had come on the sign of a band of lions that were gathering to a point, a rendezvous - they have made after they have been hunting in a long and extended line. I have never been able to see lions doing this, but I think that when they hunt in packs there can be no doubt as to the method they usually follow. Perhaps one or two keep uttering at intervals the deep resonant grunt or roar. This alarms the game, and makes it run hither and thither, if it cannot get the lion's wind and these, hunting up wind, take good care that this is impossible. The rest of the band hunt silently and the stampeded zebra, or kongoni, rush near enough to some of them come within the range of the lion's short but terribly swift charge. When rain has fallen, it is often possible to read in the morning quite plainly, the story of the oft-repeated tragedy of the night. There closely clumped lay the zebra, some lying down, others on the watch, and in 
the tell-tale earth you see where one, two, sometimes many lions, lionesses, and cubs, drew the fatal circle round them. The little knot of zebra burst forth in all directions, scattering like an exploded shell, and here one of them racing for dear life, has been stricken down; here the soft paws of the lion bite into the ground, and the deep indentations tell their own story of his rush and spring. A few yards away lie the remains of his prey, killed with scarcely a struggle by one bite back of the ears, or, if as is sometimes the case, the lion has missed his spring, the zebra hoofs cut deep into the soil as he rushes away, and the lion's stride shortens at once, and the tracks swing back to those of the band. Zebra are his favourite game. They are fat, and seemingly easier to stampede and pull down than waterbuck, Kongoni or eland. But strange things happen in the to us so little understood animal world. Even in places where game is very abundant, and the lions fat and flourishing, I have found a lion "kill," where, disdaining zebra or kongoni, his majesty deigned to eat up a cheetah (A cheetah, is first cousin to the leopard, more lightly built and much faster, claws non-retractile, spots solid black not like those of the leopard black but circular, skin much lighter). I have known a lion that had well feasted on an elephant, finish off his repast by eating almost an entire hyena, the last sort of a dish you would think he would choose. This hyena was not eaten by his own kith and kin, but by a lion, and while unlimited elephant meat, of which lions are very fond was lying within a few feet. There often seems to be as little sense displayed by lions hunting, as there is poor discernment shown by them in their gastronomy. H. of whom I speak later, who has killed many lions and is what very few professional hunters are, observant, saw four lions tryto stalk a band of waterbuck in broad daylight. It was after nine o'clock. The great antelope simply played with their enemies, would let the crouching hunters come as near as 
they (the antelope) saw fit and then gallop away. This evidently hopeless performance was repeated several times, and the curious thing about it was, that the hungry beasts were so intent on their hunting, that they didn't observe the men hunting them, and so came on and on until three of them were shot.

Usually all attempt at hunting seems to be abandoned by the lions are soon as the sun is up. I have see more than once lions quietly trotting off like big dogs going to kennel, bound for their reedbed haunt; and the game herds would just look at them a moment, and moving a little way out of their path, let them pass. Indeed they scarcely stopped feeding. But let me get back to my own lion band. The spoor on the dewy grass was fresh as could be as we crept along. In a few hundred yards we were off our grassy ridge, where the herbage had been cropped quite short, and on the edge of a large patch of unburned grass, grass that had somehow escaped the autumn fires (which sweep all over the country). It was the old story. When lions lie up for the day, they choose their retreat wisely. We were in a nasty bit of ground, the bushes grew very thick, and the tangle mounted in many places above our waists. Brownie to my left suddenly sank down, and I heard again the soft purring noise, but could not for my life say whether it was behind my back or in front. I saw that he saw them; but as I came to his side there was a soft swishing sound in the grass some fifty yards away, and for an instant the strangest conglomeration imaginable of sticking up and sticking out tails whisked off before me, and yet one single lioness or lion I could not see.

They had been sunning themselves, as had my first band, on the other side of an ant heap, drying the heavy dew off their coats, and of course one or two had lain down with their noses just on the edge of the ant hill looking down their 
back track. These had warned their fellows in time, and into the grass the whole lot plunged.

One advantage the hunter has in such cover. It is the easiest cover possible to track lions in. I had never been told this, never indeed had read it or heard it, but anyone could follow the trail that the band left, and at a half run we went after them. This sounds far more dangerous than it really was. A lioness will sometimes charge when she has cubs with her. A young Englishman went home seriously crippled, I fear, from Nairobi a few days ago, who was mauled by an unwounded lioness.

$\mathrm{He}$ and some others had been looking for her. None of them knew of the cubs, and having hunted long in vain, gave her up and turned home. On the way he almost stepped on her, and she had him down in an instant. But usually there is very little danger in following lions into grass or swamp unless one is wounded, and I am inclined to think, though I have only my own limited experience to fall back on for proof of my theory, that large bands of lions are not as dangerous as lions in two or threes. Anyway we followed them in, and presently got somehow right among them. I did my best to see something to shoot at, but waving grass or a quickly moving bit of fawny fur, offered no mark in such cover. I made up my mind at the beginning of my sefari life that I never, never, would shoot at dangerous game until I knew exactly where I was shooting. I am very sure the rule is a good one, and much trouble would be avoided if every man going after dangerous game, and having his men's lives on his conscience, to say nothing of his own, strictly adhered to it. There were lions on each side of us, and the grass waving in front showed that there were more ahead. They growled now and then all around, but not one of us could locate the sound. Try as I would I could get no shot. I think I made a mistake here, moved thereto by the entreaties of Dooda who was rather nervous. Both 
of my men by the way had been mauled before, and changed my .350 for my .450 , a good gun, but one I never learned to shoot as well with as the former. We kept on after the lions in front, for most of the pack seemed there, and I had to slow up again and again to wipe off my glasses, as the sweat blinded me. All the time the lions seemed to know that I could not hunt them in their own chosen cover, and they took matters leisurely, sometimes passing rapidly ahead of me, and then allowing me to come up till I could guess their proximity by the low growling that would rise from two sides at once, and that seemed almost under my feet, but yet could not be exactly placed. It was jumpy work enough, and the tangled, unburned grass, made the rapid walking very hard. It was easy to keep their trail, for the low, heavy bodies left unmistakable tracks in the still wet grass, and we pushed on without pause or check. At last a head was raised clean above the grass some eighty yards away, and I steadied myself to fire. As I was on the point of pressing the trigger Dooda pulled my arm down, and pointed to a large lioness that was standing quite close at my left, some twenty yards away. She was in a tall bit of grass, and none of us had seen her. As I turned she vanished. The lion in front during the instant's delay, had sat up on his hind legs and gave me a fair shot at his chest, which I hit full, though I was shaking a bit from exercise, and my glasses were terribly foggy. He jumped high in the air, came down on all four feet, and, of course, vanished. The shot seemed to scatter the band. The grass tracks separated in every direction. We came cautiously to where I had hit him, and found a heavy blood trail easy to follow. Then I set Brownie to track him, and made Dooda look ahead, for my eyes are not much good at any time, and my glasses all foggy from perspiration were of little use in detecting such a difficult thing to see as a wounded lion always is. 


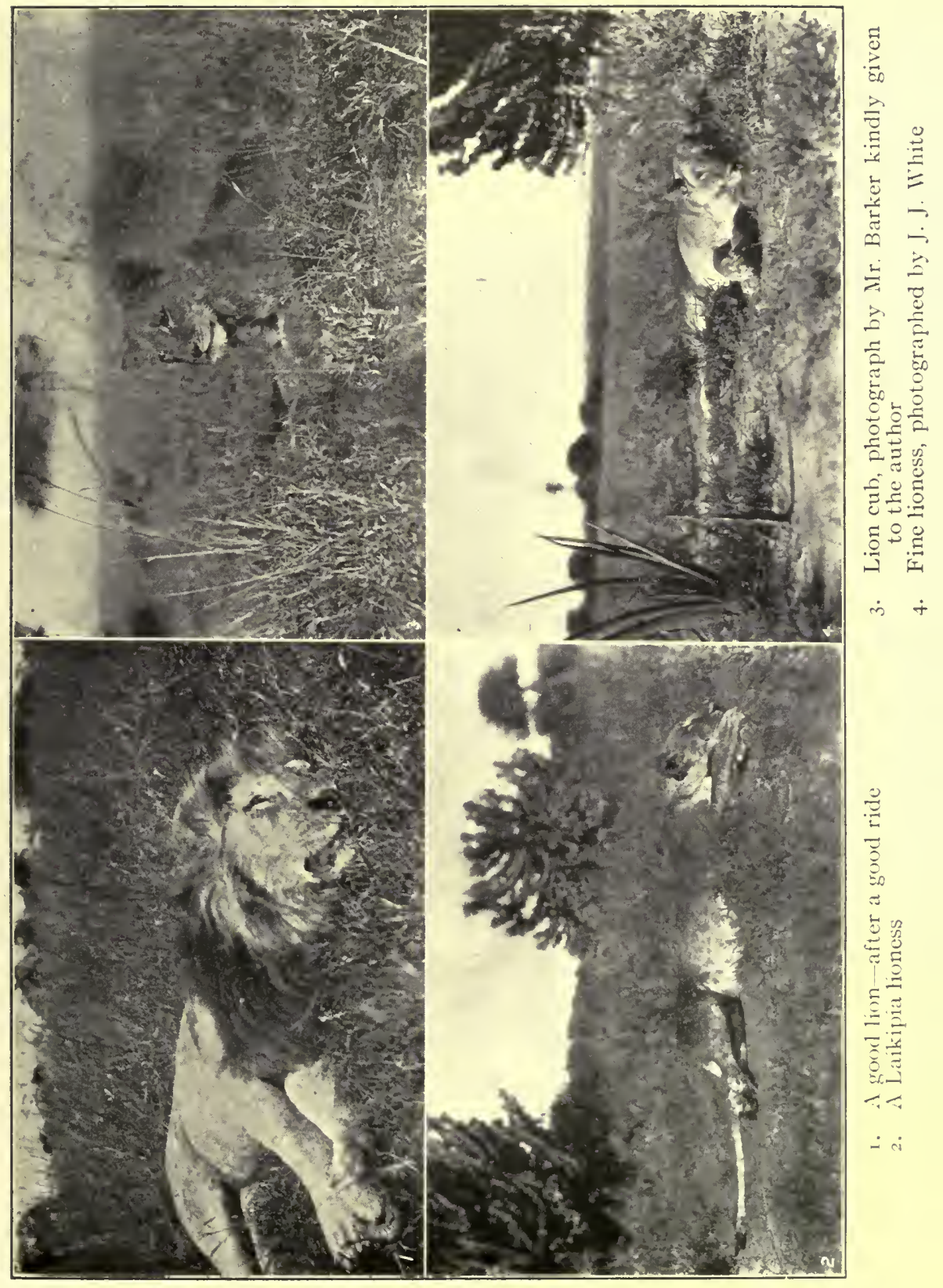



We had not gone over a hundred yards, when Dooda touched my arm and pointed out the lion, a three-quarters grown male, lying not quite facing me, under a bush, looking sick, but with head still up. He growled, and I, so close was he, shot for his neck. To my amazement he got up and instead of collapsing, walked away, when I killed him immediately. That shot was a lesson to me. I found I had cut a groove in his mane and just drawn blood. I measured the distance. It was a scanty fourteen yards. How I missed I am sure I don't know. We never came up again with the band. They ran out of the cover, where I had been among them, over a ridge into an open bit of country, and we gave them up. There were nine in this lot, and we never saw a big male among them, though, of course, there may have been one of these in front of the band.

The very next day at about the same distance from camp, in another direction, Brownie and I, who were at this time alone, came on a fresh lion sign beside a puddle of rain water. The tracking was most difficult, the ground rocky, and hard. We took more than an hour going a mile. Things then improved. The ground was grassier, and softer, and another lion came to company; then another and another. Once more we were after a band. It was a glorious fresh morning in June, not nearly as hot as the day before, and I could see how keen my boy was to show me that I needed no other guide than he. We hadn't gone more than a mile farther, when I saw with my Zeiss an old gray-headed lioness's nose just sticking out over an anthill about 500 yards in our front. As I looked she drew her head down, and slipped quietly into the grass. When we came to the place four or five different grass tracks ran away from the mound, the chiefest and broadest made by several of them travelling together. So it was evident there was another large gang on the move. I fear one lion 
hunt sounds very much like another, to those condemned to read the poor account of it; but to the man following up the lion or a band of lions, there is sure to be interest and variety enough. The wisest and most experienced can never tell what a lion will do. Lion hunting, to my mind, has a charm all its own. Nothing compares with it, and no driving of ravines or swamps, or catching the great cat at his kill, is comparable to the joy and steady excitement of tracking him down. He chooses the ground. You follow him into it. You pit yourself against him. Crouching flat against the yellow earth, covered only, perhaps, by a few inches of grass, he is almost unbelievably hard to see. His rush and spring from a few yards distance, is the fastest thing in the world. No animal can escape it, much less clumsy, slow-footed man. He has a chance to pay off the universal lord and master, the wrongs of the animal world, and here in East Africa the lion's revengeful toll taken on human life and limb mounts high. In the thirteen months I have been on sefari, two white men have been killed by lions and fifteen mauled badly, to my own knowledge, and these may not include all that have suffered from his claws and fangs. The band we were now following would not permit a close approach. Every half mile or so I could see the rear guard slipping off an ant hill or with ears just raised above the grass watching our approach. They did not seem to fear us, but kept just out of farthest rifle shot. At last, as I mounted a stiffish ridge, I had just a glimpse down below me, of a regular bunch of lions all trying at the same instant to clear off an ant hill on which they must have been packed together as close as they could be. Innumerable tails and hind legs seemed wrapped and twisted together as the pack tumbled again into the long grass. (This may seem a ludicrous way to speak of the aspect of lions in a pack when disturbed. I searched at the time for words to describe what I saw, and neither then or since can find 
any better.) I was keyed up for a shot as I mounted the ridge, and had my Mauser's 300 yard sight already raised.

I did not think I should get nearer, and the morning was by now well advanced. I shot twice, as quickly as I could, aiming for the head of the lot, and to my delight and surprise heard each bullet tell, and two loud answering grunts. The grass was here quite long. Perhaps that was the reason our friends had let us nearer than before. We came, Brownie and I, down into it cautiously enough. for two were hit, and there must have been at least six or eight others unwounded.

When, shoulder to shoulder, we came to the edge of this heavier cover, there was ominous growling from our front. Until it stopped we stood still. Then a farther advance of ten or fifteen yards would be met by more low gruntings. And we would stand again. It took some little time to reach the place where the running band was when I fired into the brown of them. (It was much too far away, and there was not time to single out a lion.) Here we saw that one lion was shot low down in the leg and another high up and too far back in the shoulder, the height of the blood marks on the grass and bushes marking quite accurately the nature of the wounds. Two wounded lions: in front of us, the grass growing longer as the plain sloped to the river, bushes thickening around us, and several deep. brushy dongas cutting our path - this was, as they would say in the West, rather a poor "layout." I will not weary those who have followed my day's story so far by detailing the hunting of the next four hours, for during all that long time did we two steadily press that growling, protesting band, till at last it took cover in the impenetrable jungle of the river border, not so far from the place where, almost a month before, Momba had been mauled. I never put in before such a four hours, and I don't think I shall again. The sun grew very hot, my poor fog-dimmed eyes failed 
me once, when I might have finished the big wounded lioness (for the one shot high up and far back was an old lioness). But having only now one gunbearer, Brownie had to keep his eyes on the ground, and thus it was we came on the old lioness, her head very gray, and didn't see her till what I had taken for a weather-worn tree stump vanished with a loud, angry grunt from before me, and the chase was all on again. The band numbered nine, and, strangely enough, we never were sure that we saw a big lion in it. They never let us come among them as did the other band the day before. But persistently they kept from one hundred to three hundred yards in front. When we first drew up to the spot where the two had been hit, we might, of course, have walked in among them then, but grass and thick bushes made it impossible. To do so would have led to our instantly being charged, by how many I don't know (but several were growling very close), and in such cover you could not see a crouching lion at gun-barrel's length. After that the band would not let us near till we came to some heavily wooded cover. On its edge they would make another stand and growl again. Our waiting tactics were then repeated, and when the grunting sounded farther on, we moved in on the track. I should here say that the noise the lions made when they were, as it were, standing us off, was a different, quite different, sound from that they made among themselves as they trotted avay together. This last, though not like their common night-call, could be heard at some distance, while the low snarl they gave when crouching in the grass, though not at all a loud noise, was always to me a horrid, blood-curdling sort of thing, but did not seem to carry any distance. Every ant hill we came to, rising out of the long grass, every hard ridge we had to cross, I hoped would give me a chance but the afternoon wore on, and try as we might there seemed no way of coming up to them. Once we counted the lot, 
nine, and could see the two wounded ones lagging behind. But these kept after the others, and though the blood signs never ceased, they kept their strength.

Just as I was thinking of giving it up, for my troublesome knee was hanging out signs of distress, and I had been going as hard as I could, my nerves pretty well strung up, for more than four hours since I had wounded the two, we came to a heavy bit of cover that bordered a small stream running between steep rocky banks, and strangely enough, before entering this stronghold (where they would have been quite safe from me), the whole band stopped and looked back. The halt was so very brief that I had no time even to take a hasty shot. Before I could struggle out of the long grass I was in, and find a place from which I could see to shoot, they were gone, or rather eight lions had passed into the shade. Brownie had counted them. They were too far off for me to do so. What of the two wounded? He said they had not come in sight yet. As I waited one of them came slowly out of the grass and stood, looking very tired, just for an instant. I fortunately shot it dead. The big lioness, as we saw by following her spoor, crawled cunningly down a little depression into the dark thicket by the stream, and so was lost to us. It seems poor sort of work, when you try to tell accurately what happened, to follow ten lions from early morning to late afternoon, and only get one. All I can say is that, taking it all and all, I had the best hunting day I ever had in my life. I might have fired almost at random on lions moving in concealing grass, as I might even more frequently have done during the hour or so on the day before when the band was scattered all round me, and when at times several were within a few yards, but, both for the sake of the lions and for our own, I am sure, to do so would have been a grave mistake. I have no conscience about killing lions. They are magnificent cats, but dangerous and cruel above all others 
excepting the leopard. As game decreases they will become in East Africa, indeed, they are already becoming, more destructive to domestic beasts and to man; for the lion that jumps a boma to stampede a herd is on the road to be a manslayer; but even lions should not be recklessly wounded. Then, for our own sake I never fired until I knew I had a fair chance to kill. My own unaccountably bad shot, at only fourteen yards distance, at a lion lying down, had taught me how easy it was, even when I shot steadily, to overshoot one of these dangerous beasts in the grass. If that lion had come at me instead of turning away, I should have had to kill him at a few feet distance, or, failing that, go down, and no living man can be sure of killing a charging lion dead, at a few feet distance.

Our return to camp, if it was delayed, was triumphant. Three lions killed and twenty-seven seen in five consecutive days, made up for the long spell of bad luck that went before. The curious thing was, however, that though I hunted much harder than J. J. W., even after this his fortune in sighting lions remained remarkable. He saw them again many times before I had another chance to see, much less to kill, one.

I fear it may seem like boastfulness or exaggeration when I write as confidently as I have done about the size and quality of the lions to be met with in the neighbourhood of Sergoit Rock and on the Nzoia Plateau. I can only assure those who read my story that there are good and sound reasons for my statement. The bulk of a lion depends on the regularity and abundance of his food. The mane of a lion depends, in my humble judgment, on three things; first, on the cold weather, that is favourable to long hair; second, on the nature of the covert in which he hunts if this is open and free from thorns the mane will probably be abundant; and third, on an abundance of food. If, on the other hand, there is much cactus scrub and thorn, 
it will be shorter and more torn. But no lions foraging for themselves in any country grow finer or indeed as fine manes, as do the old fellows who grow fat and are well looked after in the cold air of the London Zoological Gardens. Black-maned lions are quite common up here on this high and cold region, and are extremely rare anywhere else in the Protectorate. A few are shot in the Mau "highlands" clothed like these. But the Mau valleys are settled, and lions are already hunted down. In Somaliland lions are often half-starved and never seem to attain the size they commonly reach here. There, too, they hunt in extremely thorny cover, and as a consequence are almost without mane. I should say, speaking from memory only, the measurements of Somali lions and lionesses are almost a foot shorter.* The time of year in which the lionesses withdraw from the male is of importance to the hunter. During May, June, and July the sexes seem to keep company. It was in June and July I came on three bands of lions, nine, ten, and eight respectively, in five days, hunting. Lions and lionesses were all running together. In two cases I, as I know now, recklessly followed them up, after wounding one one day, and two another, for hours and hours, mile after mile, on foot, in the long grass, pressing on to finish the animals I had wounded. Had I been following one or two lionesses with cubs instead of large, mixed bands, I must have been charged and charged home. As it was, though, they growled a good deal just ahead of me, and on either side, and sometimes came within a few yards, I was never charged. When lionesses are alone they are exceedingly dangerous. Indeed, a lioness is, I think I am safe in saying, roo per cent. more dangerous than a lion. She has a way of crouching so flat on the yellow ground that even in grass no more than two feet high it is hard to see her. Such a lioness caused the first accident

* Since returning to Europe I have verified this statement. 
that I had personal knowledge of. When hunting near the Athi River, on my first visit to the country, Mr. L. and Mr. G., who is now one of the game rangers, had been hunting lion on one side of a mountain which rises from the plain thirty miles from Nairobi, and which every visitor to the country knows well - Donyea Sabuk. I had been doing all I could on the other side to find one to hunt. They killed three in ten days. During three weeks' hard work I never saw one. Such is luck in lion hunting. Well, one day the two men saw a lioness, and rode her hard. They lost her in some shortish grass, and incautiously came nearer than they should have done to look for her. In an instant she was on them, carrying Mr. G. from his pony, and biting him through and through the thigh. Then, like a flash, turning on Mr. L., whom she dashed down with a claw wound across the face which destroyed one eye and cut through the nose. As she stood on unfortunate L., mauling his shoulder, G. crawled up, wounded as he was, and blew her brains out. Mr. L. died a few days afterward.

Lions will sometimes, though very rarely, charge from a distance. When they do, they are apt to come fast. A friend of mine, a first-rate hunter, with another man who had neither much nerve nor experience, came on two lionesses lying on a bare hillside about two hundred and fifty yards away. My friend took a steady shot at one of them, and disabled it at once. His man missed the second. This second, without a moment's hesitation, came at them fast. It was evident at a glance that the lioness meant business; so — ran quickly to an ant hill, a few yards to one side, crying out to the other as he did so, "Don't fire; let her come." But that onward rush was more than untried nerves could stand, and while she was still more than one hundred yards away, fire was opened on her first by _ and then by his frightened and demoralized Somali gunbearer. 
Maddened, but not even scratched by the bullets, the lioness covered the remaining distance at an awful pace. Ten yards off, not another inch, when a shot from the man seated on the antheap, full between the eyes, averted a tragedy. It is madness to shoot at a really charging lion, at any such distance as that at which this man and his gunbearer shot; for be it always remembered, shooting and missing demoralizes all hands. Nineteen times out of twenty, however, a lion comes slowly when he charges. As you watch him at a distance, it seems very slowly at first. The man in his front may not be able so accurately to gauge his pace. Gradually he quickens, and crouching may make the last few yards very fast indeed. He sometimes stands for a moment before finally closing. The Masai who still spear many lions, in the old days killed many more than they do now. They told me positively that when their warriors were charged by a lion they always stood stock still. To move meant death, to stand quite immovable meant that before closing, the lion, if unwounded would stand, too. Then came the spearman's one chance. The stories you hear of lions charging when unwounded, and from a distance, are generally like the same sort of story told about rhino or elephant, gross exaggerations. Confused by the shooting, the beast rushes away and may come your way; or again, he will run up to have a nearer look. A missionary I knew was in this way "charged," as many would call it, by three lions, a male and two females. $\mathrm{He}$ had two cartridges only, and an unreliable .303 carbine. The lion ran up to within twelve yards, he estimated it, and on his standing firm, growled, and ran back to the lionesses. Then a lioness would go through the same most trying performance. He standing still, she, too, retired. This happened no less than four times. Last the lion came so close that the missionary, feeling that this time he was coming in, fired and shot away one of his large 
front teeth. The shock knocked him down. He got up slowly, and growling his displeasure at such treatment, they all three went off slowly together. The good man thought himself very fortunate, as he was, and took another road. A few days later the Kikuyu killed the lion and brought in the skull. Strange to say, though the great tooth was shattered, the jawbone was not broken. 


\section{CHAPTER V}

\section{HUNTING IN AFRICA}

\section{THINK I can truthfully say I have always enjoyed}

1 hunting apart from mere killing - the distinction is important. I learned to enjoy and value it for the knowledge it gave me of a thousand useful and beautiful things, and for the opportunties it afforded of studying them.

I was an overgrown, lanky boy of thirteen when my father who was himself a good shot and an accomplished horseman, gave me my first gun. It was a I4-bore doublebarrel shot gun. I remember it cost $£$ ro, a large sum for him in those days.

We lived in Ireland, and in Ireland the grammar schools keep early hours. I had to be at school at seven in the morning, but that gun drew me from my bed at four; and two and a half precious hours I had all to myself while the day was young. I was only allowed to kill for food, and rabbits brought me sixpence each, wild pigeon, threepence. So I paid for my ammunition at the same time that I increased my chest measurement. Every stream, every bog, every mountain, within a radius of ten miles (Irish) I got to know, and I learned to love dearly the open air. Since then I have hunted in many places, Scotland, Austria, Sardinia (one of the best places, by the way, in the world to hunt in, and no one goes there), in almost all parts of the Canadian Rockies, and in our own splendid Alpine land, from California to the Canadian line. On the great Western plains I spent many months as far back as I868, when no white man came, and the whole country swarmed with game. I have hunted in the forests and on the barrens 
of Nova Scotia, New Brunswick, and Quebec. So I have had some experience in hunting. But African hunting is a thing apart. It differs from all other forms of sport. You may, with good reason, believe yourself capable of holding your own in the Rockies or the Alps, and yet you may find yourself unsuccessful or only moderately successful here. My first trip to the country was unsatisfactory to me. Though I was a fair shot, and capable of standing pretty well the fatigue of a long day in the sun, I didn't get what I hoped to get. I was confused with the great variety of game, and couldn't tell a good head from a poor one. I did not understand the make-up of a sefari, and had no idea at all of how much one's comfort depends on getting together before leaving the starting place such men as shall make the expedition successful. I could see my trophies well attended to while in America, but African trophies and African climate are so utterly different that experience gained in other lands is here of slight value. I had not one single man that could hunt, or knew anything about the habits of the game. One of my gunboys' feet gave out, owing to his insisting on a foolish habit they have of wearing a wretched sham ammunition boot, served out to sefaris at Nairobi, which, by the way, an immutable custom obliges you to give to your tentboys and gunbearers. The other was an utter coward. I tried, too, to march all day, and hunt in the afternoon and evening, a great mistake always. And last, but not least, I knew really nothing of the country.

These ignorances I have enumerated are, as anyone can see, sufficiently serious, but I am sure that very few ever coming for the first time to Africa, know even as much about the country of their hope, as I did.

How then, you may say, do any first trips succeed even measurably?

In the first place, a great majority do not succeed. 
I remember a friend of mine, who had spent three months in Rhodesia, showing me the result of his trip with pride. I was ignorant then of African game, and so was duly impressed. I know, now, there was scarcely one head in the lot worth keeping.

$\mathrm{He}$, however, only brought back what he had shot himself, for he was a good sportsman; but the truth is, very many of the bags reported are not made by the men returning them. The professional hunter does much of the shooting, and not seldom skins, tusks, and horns, are bought. It is not hard to forget (at least, some seem to find it easy) what you yourself have or have not shot.

But is that sort of thing sport? I am not speaking from haphazard hearsay, but from things that I know.

I have often seen a would-be salmon fisher on our own rivers, sit reading a novel hour after hour, day after day, in his canoe, while his expert Indian threw a good fly over his shoulder. When the fish was hooked then the sportsman played it, and landed or lost it as the case might be. It takes more than money to make a sportsman. Enough said perhaps on an unpleasant subject.

In the second place, game is not at all as plentiful as it was even in Africa. You cannot expect to stroll out of camp about eight o'clock, after a late and heavy breakfast and run across what you came out to get. A few years ago the Athi Plains were almost a sure find for lions. I do not believe that to-day one sefari in five gets a lion at all on them. There were a dozen places where with reasonable industry you at least had a chance to get a fifty pound elephant tusk. Now you may visit them one after the other and never see a reasonable tusker. It is the same story with rhino. Five years ago anyone could within a radius of thirty miles of Nairobi, make sure of securing his two heads, with horns measuring over twenty inches. Now rhino scarcely exists in that vicinity at all, and you may 
hunt perseveringly for months all over the country, see scores of rhino, and yet never come across a horn over sixteen inches. In short, Mr. Ward's measurements are a delusion, an alluring but impossible dream, so far as East Africa is concerned. I fancy the same thing holds good for the whole country.

But though the great trophies are gone or nearly so, if a man takes the trouble to study the game of the country, and rigorously refrains from blazing at the first thing he can see, if he rises early in the morning, and does not mind an occasional crawl in the sun, he can still secure beautiful trophies, and, what is more, can do so without indiscriminate slaughter, and without measurably diminishing what remains of this wonderful fauna; for an old buck killed, scarcely ever hurts the herd, and it carries almost always the best head.

Nor can game be approached any longer in the haphazard fashion of yore. Now and then, of course, you stumble by good fortune on a desirable beast, but consistent stalking is usually necessary to secure anything worth the having. The sportsman, too, will find that he must take many shots, at a much farther distance, than he would be obliged to do in America, Scotland, or Europe.

The common animals such at kongoni, zebra, Tommy, and rhino, usually permit a close shot. Waterbuck and oryx will now and then let you near. On some days you can quickly walk up to Grant, and pick your head from a herd at one hundred and fifty yards, but you will not get such chances every day. Far the larger number of shots made are over one hundred and fifty yards, and often over two hundred, sometimes over three hundred, which is a long shot. It follows, then, that old-fashioned rifles (and the fashion in rifles changes almost as rapidly as that of our clothes), form a poor battery. Black powder guns of all sorts are, of course, to be left at home; .500 


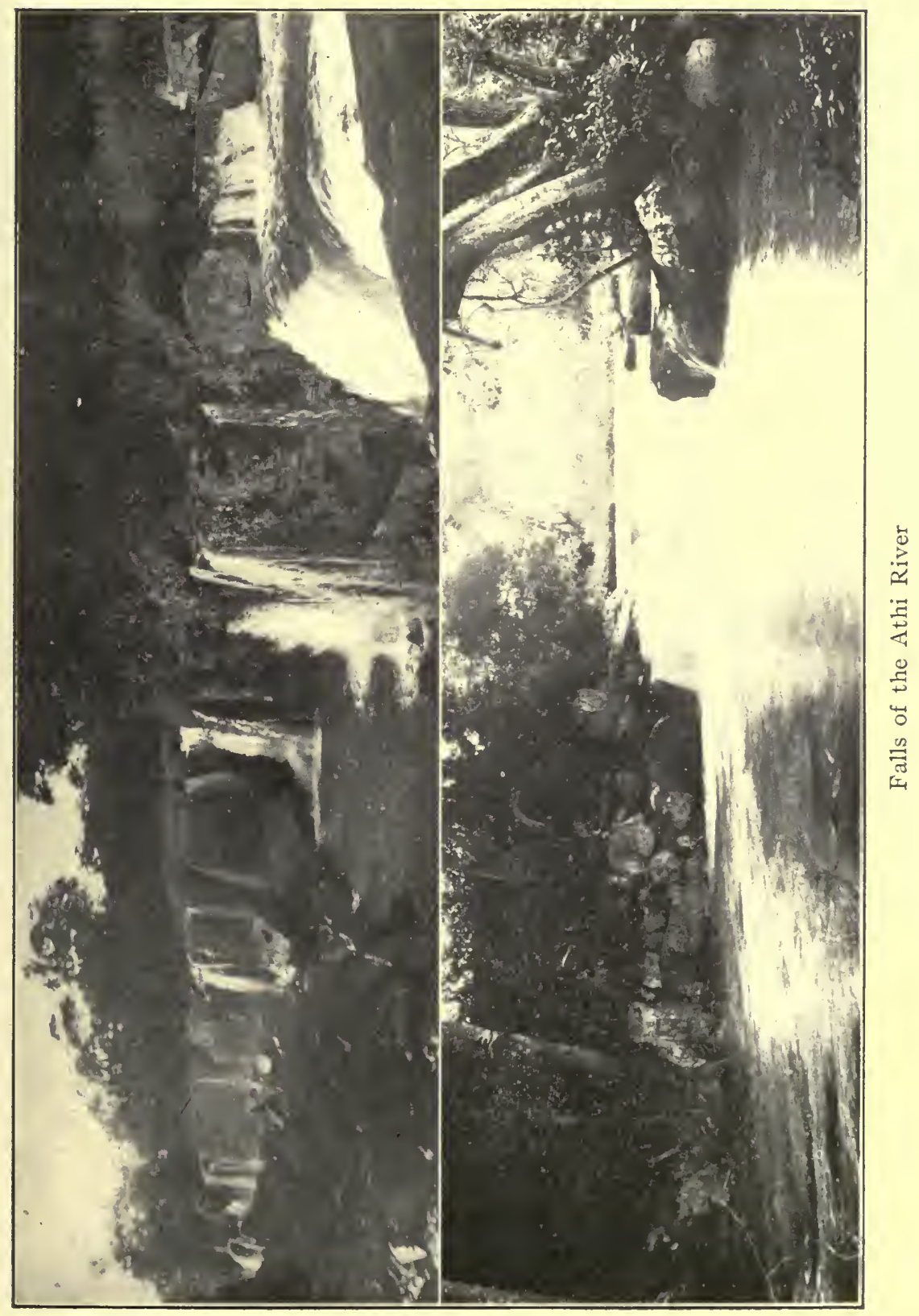



and .600 bore expresses are cumbersome and very unsatisfactory weapons. A $.45^{\circ}$ double Cordite express will kill anything in the country, but you will be wise to use constantly a much lighter gun, and one with ammunition easier to carry. The rifle question needs a page or two to itself.

One of the most important matters, as I have found it, and one never insisted on in any books, seldom mentioned by any hunter, is to so regulate the marching of your sefari, when you are changing ground, that there will be time for a quiet inspection of the country, the evening you make camp.

A sefari is at best a noisy affair. Forty to a hundred men. will make a noise when they reach their resting-place. Tent-pitching, wood-gathering, very often from a distance of a mile or more, cooking and water-hunting and carrying, all mean noise. Game may be found that same evening of arrival, within half a mile or more of your tent, which next morning you may seek in vain at five miles distance. The rule is a good one, start at daybreak, and camp before noon. The early hours are the coolest, six hours of hard, stony or thorny ground with sixty pounds, often more, to carry, is all a humane man should ask of his porters. To rush from place to place does no good, tires your sefari out, and if there are many other hunting parties in the country, is apt to make you deservedly disliked.

Never under any circumstances give up an animal you have wounded, unless night is falling, or you are utterly done and can go no farther. In that case give your rifle to your head gunboy and promise him "bakshish" if he brings in head and meat.

Perhaps even mentioning such a matter seems useless to many, I wish it were so. But to see, as I have often seen, poor wounded zebra, kongoni, or many another, limping painfully after the herd, with month-old wounds. 
is a sight that should give pause to the careless shot. No man has a right to kill things carelessly, or to waste life; least of all to inflict pain, and continuous pain, just because he is lazy. If he is a good shot, nine times out of ten his chosen beast dies with far less suffering, than if it died by disease, driven forth from the herd, or by the lion's grip. It moves but a few paces from the place it received its death shot. If he is a poor shot, he will only fire at game within his killing distance, which distance is soon learned by all. But no man, surely, should leave the thing he has chosen to kill, to slowly die. The people of the country are often peculiarly careless in this respect. Game has been and is so plentiful, "Let it go, there are many more."

The natives and Somali have no feeling whatever about inflicting pain. It never occurs, seemingly, even to the most intelligent of them, that an animal should be considered at all. You must act for your servants, and insist that they obey your orders, punish any breach of them immediately. So far as they are concerned nothing more can be done.

And this leads me to say something of "tracking." Every sefari should number among its porters men who can track, who know at a glance the meaning of a footmark that may baffle you or escape you altogether. Some experienced hunters advise the engaging of $\mathrm{N}$ 'dorobo trackers and say there are none so good. I have found the Wakamba to be about the best trackers in the country. The Wakamba are a hunting tribe and all the little but important matters, such as skinning, cleaning heads, making kobokos, they are adepts at.

Your gunboy is, of course, a good tracker. All his "chits" say so. Alas, chits are usually as reliable as cooks' references at home. Men who continually do nothing but abuse their gunbearers while they employ them, in some mis- 
guided fit of compunction, I must suppose, salve their consciences, at the same time that they inflict a real wrong on the man himself and on his future employer, by giving him, shall I call it, an "inaccurate" chit.

Hast thou found a gunbearer who is staunch and a tracker, raise his wages, and hold on to him while you are in the country.

I believe Indian Shakeris are often wonderful trackers. I have met and employed one master of the craft, in Nova Scotia. I have heard of another. I name them, for one of my objects in publishing these travel and hunting notes of mine, is, not merely to tantalize a reader by telling him what I have discovered after long search and many failures, but, if it is possible, to help him to. succeed where I failed. If you have got a good thing, hand it on, share it as far as you can, your own share will never be denied you. But I must not fall into sermonizing. The two, the only two whom I have ever met, who were the sort of trackers you read of in novels (written by men themselves who never followed a tracker probably), are the brothers Malay of Moser River, Halifax County, Nova Scotia.

Fortunate indeed is the sportsman who secures either of these men for a moose hunt. For three long September days I have seen Will Malay follow one bull moose, over eighty miles of rocky bog, fallen timber, alder swamp, and fern-clothed lands, pick out that one hoof mark, when again and again it merged, and to any other eye was hopelessly lost, in not less than fifty other tracks, and three times bringing up his man to within forty yards of the watchful beast, hidden in darkest, noisiest, black spruce swamp, till at least that head was ours. Go to Nova Scotia, it is well worth the trip to see such work.

Your Wakambas cannot approach your Irish-Scotch Nova Scotian. But encourage them, make them see you 
expect good work from them, make them look out their best man for you, keep them to it when they think they are beaten, and you will have always an interesting and sometimes, as you deserve, a successful time.

Even if your gunboy can track, as mine can, you need a man at your hand whose eyes are not on the ground but above it, and in the surrounding grass or bush. See a lot of men unaccustomed to African hunting, and probably they all of them will have their eyes on the ground at the same time. The first thing you know there is a crash or a growl and the beast is away. Insist, and keep on insisting, that the man who carries your rifle, look not on the ground, but ahead of him and around.

Rhino, in spite of their great weight, are difficult to track once they are travelling on the inconceivably hard, sunbaked ground. They seem most aimless of all beasts, there is no purpose in their wanderings. They will move quite rapidly, too, in all directions. No one can predict safely their course.

Lions, generally move in a large curve or half-circle. It pays, therefore, to follow them and follow them for hours. One track is apt to lead you at last to quite a family conclave.

Impala, spring off on a seemingly steady course, but never keep it. No wounded beast is more artful than this beautiful antelope.

Bush buck, crouch and hide, like a fox. Water buck, will cunningly find a patch of thorn, so exactly corresponding with their own coats, that nothing but the closest hunting will find the wounded or dead game.

Oryx, generally go pretty straight, and the sharp hoof beneath the heavy body, make them perhaps easiest of all to follow.

Always see your head skins, if you want them, taken off yourself. See them packed with grass or green twigs, 
to prevent the bloody edges soiling the skin. All blood harbours flies, and flies too of ten blow and ruin a good skin or pelt.

See to it yourself, too, that all the meat is brought to camp. You are not legally obliged to give your porters meat. Potio is supposed to be ample provision for them. But you will find that most of the men require meat more than occasionally. The Wanyamwazi, who are likely to be the mainstay of your sefari, are good marchers, and if they like you, and have arrived at the conclusion that you mean to act fairly by them, will, in their turn, act fairly by you. I have always been open and above board with them. Sometimes for many days together I have had to put them on half rations of potio, sometimes to give them beans, the despised Kikuyu's diet, instead of meal or rice. But when I can get meat they know they will have it, and so they are willing to strain a point to please me. I have told them I badly wanted to take in such and such heavy trophies, for instance, If these were to be carried many of the loads would be nearer eighty than sixty pounds. They have taken them up cheerfully, and in one instance $I$ well remember made fifteen miles. without water, on a very hot day indeed.

So, as I say, see all your meat is brought in and neither on the veldt, nor yet in camp, wasted. But here you may find an unexpected difficulty. Half or more of your sefari are professed Mohammedans and these do not eat meat that has not been "hallaled," i. e., throat cut before the animal is dead. If the porters who happen to accompany you on a certain day, are Mohammedans, and you want to save a head skin, of course, refuse to have the throat cut, or, if the shot has killed the animal instantly, and so there is no possible excuse for throat cutting, they will need a sharp eye on them, if the unclean meat is to be carried in. It is a good plan judiciously to keep away from any 
fallen beast you kill for meat. Give orders as soon as you see it down, that it be "hallaled," and some good Mohammedan will not hesitate to cut its throat even though the poor thing has been dead as a doornail for several minutes. In any case insist that all meat killed be brought in, and if, as is rare, there is more than the men can eat, let the headman see that it is dried. The natives do this very well, and are much less likely to make themselves ill on dried, than on fresh game.

Nothing is more interesting than hunting with a camera. I said before that a close approach to game is now very difficult. The large herds, I have never been able to get near. Of course, you cannot crawl through wet grass with a kodak. Still, occasionally perseverance is rewarded, and at least you get interesting views of the animal world. Scores of times I have managed to reach fifty or sixty yards, but that is too long a shot for anything but a "telephoto. (A telephoto that would not shake in the breeze as all I have seen do, should certainly give excellent results.)

Every man has his own ideas about the way he wishes his rifle carried, but there are a few points as to which I fancy all sportsmen who have shot much in Africa are agreed. One is to have the gun, you are most accustomed to, so near you that you can use it instantly. Often the chance of the trip will come, when least expected, not when you are equipped for a day's hunting, maybe, but when you are moving slowly along, in front of a noisy sefari. There stands a lion, waiting to be shot! Or, the one head in a thousand, calmly gazes at you, over a bush. To pause then, to drag at a gun cover, to fumble for cartridges, to give up one gun, in order to grasp at another, is most surely to be undone.

I have known a man who was dying to shoot a lion, come suddenly on one not fifty yards away in a little open 
glade. The obliging beast waited to let him get off his riding animal, but when he stopped to take out "the solids" (bullets covered with nickel used usually for rhino, elephant, and wrongly for buffalo) and substitute "softnose" (the ordinary expanding bullet for soft-skinned game) he lost an easy lion, and it served him right.

If you can carry your own gun do so. No matter how quick your gunbearer is or how well trained, and there is much in training him, no matter how steady, no matter how well he knows you or obeys your orders, appreciable time is lost and many a chance thrown away in taking your rifle from his hands. If you have a professional hunter, do not let him march in front, as they all like to do. When there is no trail, or the country is unusually difficult it may be necessary. But usually it is not necessary at all, specially if you have had any previous experience in hunting. Use his eyes, they are apt to be better than yours, use his judgment of the relative size of heads, it is sure to be better. But do not let him go in front. It is the front rank man who gets the chance. In the pause and the movement of passing, fatal notice is given to wary game. If the beast is looking at you, don't crawl for an ant hill or dodge behind a bush. Take your shot at once, miss or kill.

A lion or leopard seldom will let you change your position once he sees you, without rapidly changing his. Of course, if you are still unseen you can be, and ought to be, as deliberate as you choose. The duffer hurries when there is no occasion to hurry, and fumbles and hesitates when the chance is an instantaneous one or no chance at all.

With the young beast, even if you have missed, reload quickly and look out for another shot, lion will often give it you, but be careful once he is wounded. A young threequarters grown lion has mauled many a man. 
And this leads me to speak of dangerous animals, when they are dangerous, and how, so far as I know, that danger can be met and minimized.

How a man should hunt in Africa, whether alone, accompanied by his gunbearer, or if he finds it too hard work to carry a rifle all day long, by his two gunbearers; or whether he should engage a professional hunter to go with him, a steady shot in an emergency, depends, of course, on the man himself.

If he can depend on his nerves, and has a reasonable command of his weapon, it is far pleasanter to hunt alone. Hunting, even with a tried friend, is a doubtful experiment. One man is certain, at times, to spoil the other's shot. The moment to fire cannot possibly be arranged by the "one, two, three" method, or by any other. To get a wary animal you want, nine times out of ten, to make the final part of the stalk alone. If it is a dangerous beast, such as lion, rhino, buffalo, or elephant, you must have a second gun to your hand. This is absolutely necessary. But if two sportsmen are making the final crawl, then there must accompany them, at least two gunbearers, that makes four, to get up unnoticed to killing range, something not always to be accomplished.

On the other hand, very few comparatively, who visit Africa for the first time, have had much opportuntiy to test their nerves, under such circumstances, as are likely to arise here. If a visitor intends to make but a short trip, to confine his wanderings to those parts of the country easily reached from the railroad (even then I think he will find the trip interesting and well worth the journey), in such a case he need not, I think, fear a test of his nerves too severe. But to enjoy sefari life, and to see the beautiful and wonderful things that are to be seen, then he must go farther afield to-day. To pick up twenty different kinds of heads and bag a specimen of each of the large beasts as well, is 
not to be done, any more, in a few weeks. Even to get good specimens of such beautiful antelope as the common Grant, Thompson's gazelle, Impala bushbuck, Gnu, or oryx, will, in all likelihood require many weeks of conscientious work. Lion go by luck, you may hear them nightly and rarely see them by day. Nine times out of ten you may take every precaution, mount the ridges slowly, use intelligently your gunboy's splendid eyes, as well as your own inferior ones, they will see you first. In that case you have no chance, unless you are on fairly good riding ground and have a sufficiently good pony to bring them to bay. This is all true of rhino with presentable horns. He takes much trouble to find. Good men have spoored buffalo for a month without getting a shot, and elephant no man can count on.

So I cannot advise anyone to attempt to get a good collection of heads, or to hope to see African wild game at all thoroughly, unless he can spare six months at least for the trip. For a serious trip then, how should you go? I have no hesitation in saying that there is little danger likely to attend it, if you secure the backing of an experienced hunter, on whose shooting and nerve you can depend in a tight place. I also have no less hesitation in saying that a man who is not reasonably a master of his nerve and weapon, is foolish to attempt dangerous game, alone. Then, it must be remembered, that sometimes, especially in the case of the plentiful and unaccountable rhino, vicious game may attack him, and is sure to do so when he least expects it. Reliable hunters knowing the country, who will not take the tyro when he ought not to go, are to be had. Mr. Hoey, of Eldama Ravine, is one of the best. Mr. Cunningham is another, Newland, Carlton Company, can supply several more.

I am far from wishing to exaggerate the danger of the wild beast. I believe that, from a variety of causes, this 
has been in the past, and still in the future, is likely to be much overstated.

When we tell our tales of adventure by flood and field, if one has any gift of speech at all, the story is not likely to lose in the telling. No one can question facts or measure distances on the smoking-room floor. The length of shots is apt to increase with the years. The aspect of the charging heads to grow more, not less, formidable. To say as much is but to confess to one of the limitations of our common humanity.

But apart from such perhaps excusable licence, multitudes of stories told in good faith by the actors in them are actually unreliable to the last degree, because these gentlemen have not known, or cared to know, the habits of the beasts in whose slaying they have won renown.

Take our American grizzly bear, for instance. It seems a point of honour, with everyone who has shot a grizzly, be he Western ranchman or sportsman who spends his occasional holiday in the Rockies, to help our one savage (so-called) animal to live up to, or rather, die up to, such a reputation that shall not lose by comparison with the king of beasts himself.

This is ridiculous. When Lewis and Clark first saw and named our great gray bear, he had the country pretty much to himself. His only opponent was the illarmed Indian, whose flint arrows could scarcely pierce the bear's thick hide. The bear was no use to the Indian, who naturally kept clear of him. Lewis and Clark, therefore, found him a formidable animal enough, especially when compared with his smaller black cousin, who could be killed with a well-wielded axe. The men accompanying Lewis and Clark's expedition were armed with the musket, a very inferior weapon, or the small bore rifle. These were not likely to kill, at one shot, the fine beasts which weighed eight hundred pounds or even more. 
He seemed to them, as, indeed, he was, immensely strong, and tenacious of life. The early trappers for the same reason dreaded him, and trappers' yarns largely helped to retain for him his reputation. I saw myself a great skin which two trappers tried to sell me in I868. They told a blood-curdling story of his slaying. He had hurt neither of them, but the skin certainly had thirteen Henry rifle bullets through it. The rifle with which they were armed was an admirable gun for standing off Indians, but a poor weapon to kill a grizzly with. But with the advent of the powerful modern rifle things changed. It was found by those who tried to tell the truth (and I am not in any unkindly way maligning the memory of those interesting old fellows who lived hermits' lives amid the mountains, when I say they very seldom did try to do this) that a grizzly fell to a well-placed shot just as quickly as any other heavy animal. Moreover, it came to be known that that bear has an almost invariable custom of falling right down to any shot that hits him anywhere, even though it inflict but a small wound. This accounts, by the way, for stories so common of this unusual tenacity of life. Then at length men who had hunted him regularly for years and killed him in his chosen haunt of rocky canyon and steepest darkest mountain woodland, began to confess to each other the simple truth; and it was this: that no animal capable of killing a man, took more pains to run away or ran faster or farther than Ursus Horribilis.

I can speak with some first-hand knowledge, because for ten consecutive years but one I hunted him perseveringly. I never was charged by a grizzly except once, and that was when creeping up to his kill, which he had buried under a great heap of stones, earth and stumps, and behind which he lay half asleep, after a heavy meal. He mistook my footfall for that of some cousin of his, coming without an invitation to sup off his elk, and in incontinent hurry 
threw himself up and over the mound to drive off the intruder. That was, of course, not a premeditated charge. I had to shoot quick, because he was very near and could not well stop the impetus of his rush, I do not think he had time even to try; but I am confident all the same, that that bear's last mental impressions were those of dismay and not fury.

The largest bear I ever had the good fortune to kill, and he was a very large one, I came on suddenly in the dark, as I felt my way along a narrow mountain trail toward the cheering spot of camp fire that burned far below, lit by my hunter to guide me to our solitary bivouac. I did not see him till he loomed up before me, Very high he looked in the darkness, and very near. He did not charge nor did he get out of the way. But then all savage beasts know their advantage at night, and are not ready to forego it.

I know many of my readers may not be convinced by these statements of mine, yet I am confident there is weight in them. Remember, too, that seven times out of ten when a grizzly bear was first seen, he was grubbing under stones on the higher mountain slope along which he would move almost as fast as a good man could walk. He had to be followed, perhaps for hours at a fast walk. When at last the hunter drew near, he was pretty well spent with climbing, and was inclined, unless he was an old hand, to save himself the trouble of mounting some hundred feet higher than his game, so took his shot from below. The grizzly's haunts would be down the steep, not up, some woody canyon, from which he had started, he would be sure to make for, at the first alarm, His sight is poor. $\mathrm{He}$ cannot distinguish, among the boulders strewn about, the spot of brown that is shooting at him. He simply plunges downward and homeward, and if the man is on his way, he will run into him or over him. 
I have seen, myself, a bear, shot at from that foolish position, almost run over two good men, who in their hurry to get out of his way, missed him clean, and were themselves in danger for a moment.

I have also known of a soldier of the Fifth Infantry, an excellent shot, killed by a small bear in a plum thicket, into which he had the temerity to follow the beast, after wounding him with his Springfield rifle.

I have seen a three-quarters grown grizzly charge savagely after being shot through the body, when he had been followed into a corner of the rocks, from which he could in no way retreat.

But none of these instances, nor yet hundreds more like them, which anyone who had hunted successfully in our mountains for years could supply, invalidates my contentions; that whatever sort of an opponent the great gray bear may have been a hundred years ago, he is to-day, and he has been for many years, an exceedingly timid animal.

$\mathrm{He}$ falls to the slightest wound. I have seen one fall, making a terrible outcry, and roll fully fifty yards down hill, to a shot that only slightly wounded one of his fore paws. When, still roaring, he rolled almost up against me, his sudden dismay was ludicrous. He gathered himself up from the ground in an instant, and went off at a great pace till shot. My hunter, Frank Chatfield, who was with me in my annual hunt for many years, a splendid shot, had killed before his death, more than a hundred grizzlies. He told me he never knew a grizzly to charge home. Very rarely he would rush forward on receiving his wound (he did not probably see his enemy) and also very occasionally before "clearing," he would stand up straight and growl, giving any man with ordinary nerve, all the chance he wanted, to shoot him dead. But charge in, he never did. I have shot, in the old days, twenty-five, I never saw one charge. 
I will add one short story, as a further illustration of my contention. A friend of mine, now dead, told me he wanted above all things to kill a grizzly. So I wrote to Frank C - and my friend went out to the Shoshone Mountains. In a couple of months he came to see me in New York, and told a blood-curdling tale, of how he and Frank had been charged by three bears, and how, at a few feet distance, they had killed them. I was surprised, but, of course, said nothing. Next year I said to my man, "What about those three grizzlies that charged you and —_ ?" He laughed. "We were hidden," said he, "in the scrub, at the foot of a nut pine. The bait we had for them was fifty yards away. An old sow and two yearling cubs came all right in the evening. - wounded the sow he first shot, and she and her cubs came rushing by our tree, they never saw us, they had no idea where the shot came from. We killed them as they ran by and passed us."

I hope these dissertations on our only dangerous game animals may not seem without interest or out of place here. I dwell on them, for I am convinced, that the danger of charging beasts, which is I admit, considerable in Africa, has been very needlessly and grossly exaggerated.

It is serious, and must be prepared for, but there is no need to make it out worse than it is. Many men have killed all sorts of animals here, and will tell you honestly they have never seen the determined charge of lion, rhino, elephant, buffalo, or leopard. Yet, of course, the fact remains that many are killed or mauled by these animals. And though you may shoot several of them, and never stand on the stern defensive, when it is your life or theirs, the very first lion or rhino you wound, may come straight at you, and may not swerve or pass to either side.

The little burial ground at Nairobi has several headstones marked "killed by lions." All elephant hunters tell 
the same story; and men are yearly run down and gored or trampled to death by rhino. Buffalo are scarce, but no wounded animal in Africa is perhaps quite as dangerous or so cunning or determined. These facts are well known, and do not need confirmation by anyone.

Therefore I say again, it is for the man himself to decide whether he goes hunting alone, or whether he takes, to back him, a hunter of tried nerve and a steady shot.

Mr. Buxton in his delightful book, "Short Stalks," tells (I hope he will not be offended with me for saying) in a somewhat too flippant strain it seems to me, the story of the "boys" adventure with a buffalo on the White Nile. The lad wounded the animal, followed him up, and was promptly charged. Failed, of course, to stop him, and was thrown into the air. His escape was wonderful. Not one man so caught in five escapes with his life.

Inexperienced shots, intent on making real hunting trips, are to my mind foolish indeed to hunt in Africa alone. They may not be guilty of the folly of certain ladies who have lately told of their extraordinary experiences in another part of Africa, and who seem to have run up to bushes where they had seen two lions enter, and only shot at one. Or who took their unfortunate gunbearers into thick scrub after rhino, and as soon as they saw the big brown hide, blazed into it, anywhere, not having any idea whether they were shooting at rump or shoulder. Small wonder indeed that one of these wretched men was gored and stamped to death. Such action is criminal in its folly. The African scrub is no place for a woman anyway.

The surprises of the country are so many and so sudden, that I should advise most men, to avail themselves of experience maturer than their own. Be it remembered, too, that apart from its danger and pain, a serious accident 
spoils the trip for yourself, and most probably for your companion, if you are not alone.

What I have said refers to the highly dangerous animals every hunter wants to bag. But caution is necessary in approaching all wounded game. Even the most pacific beasts are perpetually defending themselves by guile or force from predatory beasts. The African antelopes are on the watch from late evening till daylight. Their horns and hoofs are formidable instruments, offensive and defensive. The stroke they can deliver is so lightning-like in its quickness that no one who has not seen it could realize it.

The oryx, the sturdy and keen horned bushbuck, the hartebeast or kongoni, and, above all, the splendid waterbuck, will on occasion, turn sharply on the foe. Many a careless sportsman has been wounded, one I know of killed, by wounded waterbuck. The only accident I have met with, befell me from one of these antelopes, and I had no one but myself to blame. It was my first visit to Africa. I was coming back toward Nairobi from a three weeks' unsuccessful search for a lion. I was using a little six-pound Mannlicher rifle, I am very fond of, and which I always carry for its lightness. We (I had a good professional hunter with me at that time) were in a country where the Sing Sing waterbuck was to be found, a different species from the common waterbuck, and I had not yet secured a specimen. So seeing a waterbuck's head through a bush, not more than eighty yards away, I shot at it with the little gun, and it fell to the shot like a stone. On going up, there it lay full length on the ground. The bullet had entered the forehead, just at the inner side of the eye, and did not kill instantly, though the poor beast seemed just gone. I told my gunbearer to finish it with the knife. He was a cowardly fellow (though on this occasion he showed his sense) and refused point blank 


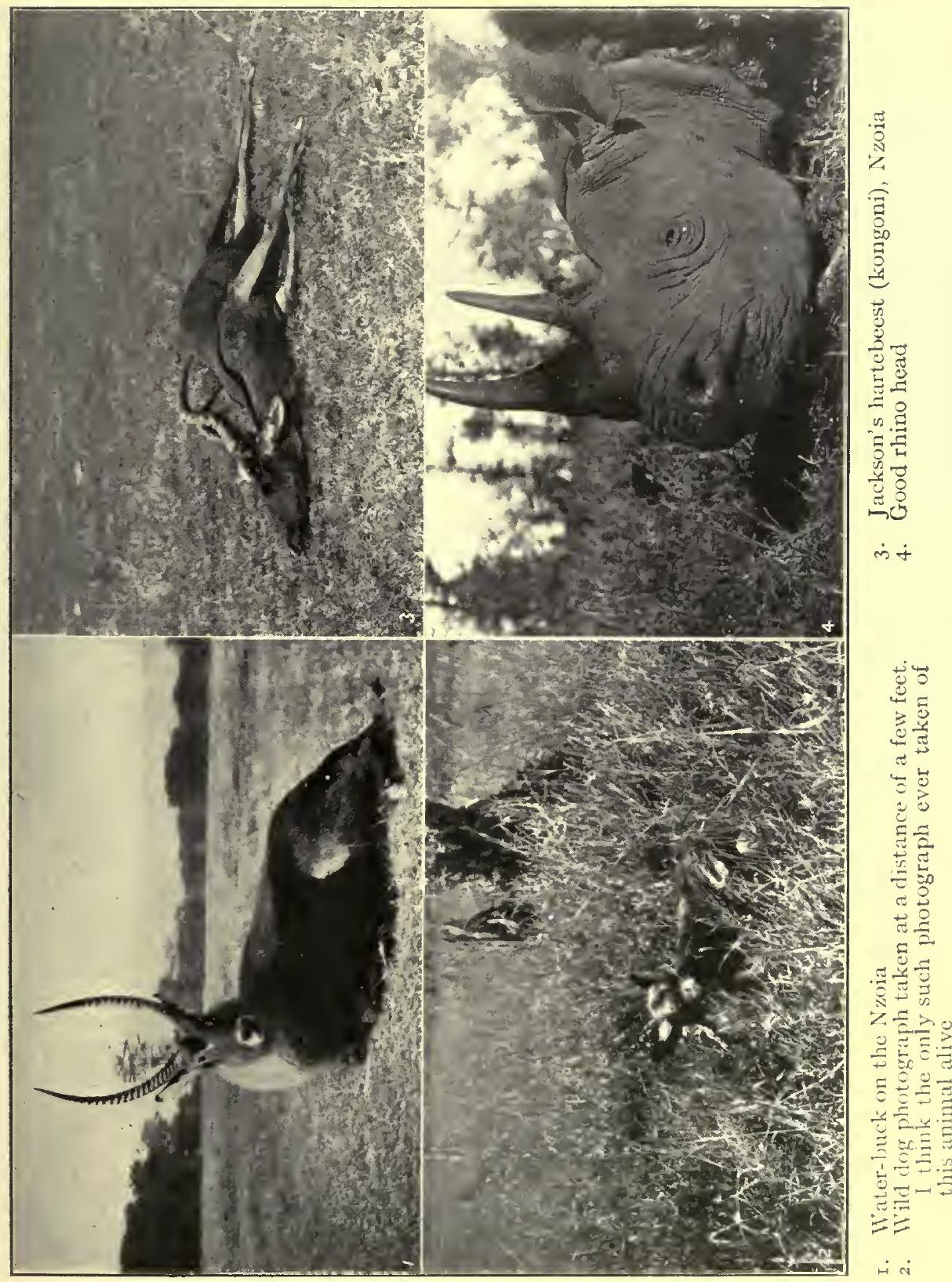



to go near. Now, I had just four cartridges left for that rifle, and I hated to use them up, so instead of following the man's example, who had at least had far more experience than I (and as once or twice already I had finished animals that he had refused to go near, instead of using another cartridge to make sure), I came behind the waterbuck, well clear of his horns, and straddling him as I had to, drove the knife in. He was on his feet with a bound, throwing me, I cannot say how many feet, over his head, and with another bound was on top of me. My hunter shot him in the neck promptly (a foolish place, by the way, to shoot, for no man can be sure of breaking the bone, and if you miss it you do little harm). He was too far gone, most fortunately, to do me damage with his horns, but his trampling hurt me dreadfully, he weighed quite six hundred pounds. I limped to camp and lay there for several days before addressing myself as best as I could, to the eighty-mile walk to Nairobi. I got there at last, hobbling along about eight or ten miles a day, my ankle and knee much swollen. The ankle hurt most and mended soonest. But that knee cost me many a weary month in bed and on sofa afterward.

After what I have said, I shall not, I hope, be accused of exaggerating the danger likely to be met with by the well-equipped sportsman in pursuit of game in East Africa. But after making due allowance for hunters' stories, specially inexperienced hunters' stories, a certain amount of risk has to be run. Lion, rhino, elephant, and buffalo, at times are very dangerous, and life is often lost. Ninetynine times out of a hundred, it is the wounded beast who does the damage, and not only so, but it is in following up wounded beasts that life or limb is lost.

Every good man will take a risk sometimes, and will be surely right in doing so. But there are risks to his own life, and be it remembered to his men's lives, that 
he is not justified in taking. I have written at length of lion hunting in another chapter, but here let me jot down a few things about the other savage beasts; and will my reader please always remember that I am not trying to instruct the experienced, but seeking to help the inexperienced sportsman. And as I attempt to do so, may happily interest some, who would like to know a little of that wild life circumstances have denied them chances to see.

Take the rhino, a great lumbering brute he seems as you look at him, with his extraordinary ill-formed, ugly head, small pig eye, and formidably armed snout. He weighs perhaps two tons, and looks as though nothing could stop or turn him. I have myself no doubt from what I have seen, and also from what I have heard, that the rhino, like our grizzly, is losing in the presence of well armed man, a good deal of his pugnacity. He very seldom charges deliberately. I have approached fifty rhinos,* and beyond the usual stamping and snorting (his method of greeting an object he cannot make out), I have never seen any of them show determination to attack. (Later I had good reason to modify this statement.) Yet if you are to believe stories you hear of men who have seen but one or two, and indeed I must add stories told by some old hands, you would expect every second rhino you meet to charge you without warning.

When a rhino receives a shot he is apt to spin around once or twice, and rush off at a great pace, leaving the direction of that rush almost to chance, though he will go up wind usually if he can. He may happen to take your direction, most probably he will not. He cannot see you at more than thirty of forty yards off. But he is certainly very sensitive to the footfall of man or horse, and sometimes, even the wind, of course, being favourable for it shows signs of alertness, at a hundred yards distance.

* And many more since this was written. 
He is not hard to kill for all his thick hide, and, most fortunate of all, he is not hard to turn, when he does come your way.

The danger with the rhino is, that in an extraordinary way, he manages to conceal himself in cover, when it would seem impossible, and getting the wind of the hunter or the sefari, as he is taking his siesta in the brush, he stumbles forth blindly and in a hurry going up into the tainted breeze. Your porters' loads go cracking down, and men and totos take to the trees. In this way damage is sometimes done. But there are many, many scares for one man really hurt.

I had once a rhino thrust his head out of a bush on to me, at not more than three or four feet distance. My useless gunboy bolted; and so did the poor beast, when I had to fire quickly in his face. I don't think I hurt him much, I am sure I hope I did not, but he might have crushed me had I not fired, and, of course, to take chances of his turning away at that distance, were not to be thought of. If his temper is up, and he comes right on, a shot from a good rifle will always make him swerve in his charge, and pass you a few yards to one side. If you want to kill him, a shot as he passes will usually do it. Small-bore rifles seem to kill rhino almost as quickly as large. Better use nickel bullets.

Buffalo are more plentiful than they were a few years ago. The cattle plague almost exterminated them in some districts where it used to be possible to get a fair head. But, at best, buffalo are hard to bag in British East Africa. They frequent the denser thicket country generally near rivers, feed early in the morning, and late in the evening, and at the slightest alarm plunge into scrub, when it is highly imprudent to follow them if wounded. Unwounded, even a cow when followed by her calf, will sometimes charge desperately. If the ground is at all open, and 
there is space between the bushy clumps to see what you shot at, a charging buffalo with lowered head, should be easy to stop. The great broad shoulders and neck offering a mark which is almost impossible to miss. Such a country is that round the upper waters of the Guasi Nyiro end of the north, and usually these animals are very plentiful here.

Thickets near the water side, or on mountain land, are a totally different matter. No one who has not tried to force a way through African cover, can have any idea of its holding qualities. Legs, arms, rifle, hat, may be tied down, dragged back, plucked over your eyes, all at the same moment. For long distances you must crawl through dark, leafy, prickly, tunnels, where you can see nothing ahead of you. So handicapped, the best shot in the world has a poor chance for his life, with the rhino or buffalo.

The rhino blunders on top of you. The buffalo lays in wait for you, cunningly chooses his position near his own retreating spoor, but to one side. He has doubled back on his course to do so. And when he sees you, and you cannot see him, charges home, nothing but death stopping his rush.

I have known of a good man killed in the evening by a buffalo he had wounded in the morning, and whose spoor he had for many hours abandoned. He was coming back to camp through the same country he hunted in the morning. As he did so he unfortunately chanced to pass close to the spot where all day long, the wounded beast had awaited his enemy. He was killed almost instantly.

I was, as I think now, foolish enough in just such a covert, to follow the first buffalo I had wounded, for four hours. There, several times, he doubled on his track, and stood waiting till I came up and passed him by. It was quite impossible to see him. His heart must have failed him at the last moment, for all the sign I had of him was 
the crashing of the bushes, a few yards away, as he charged off, and not at me!

Mr. A - of the Chicago Field Museum, a first-class shot and hunter, tracked buffalo for two months in this country before he secured what he wanted. If you have time and patience, and wait till you get a fair chance, and so can choose your head, you are reasonably sure, for years to come, to be able to secure, what I think is the best trophy that Africa can yield you.

Professional hunters have always made use of the local native for elephant hunting. These were commonly sent off to look for fresh "sign," or to locate herds, the ivory hunter staying in camp till reliable news was brought to him. This is really almost the only way to secure big ivory, and it means that for a considerable time, all other hunting and travelling must be foregone. Personally, I never cared enough for an elephant to do it. The waiting may be for long, and the wooded country you are obliged to wait in is dreary in the extreme. Of course, sefaris may, and do, happen on to elephant. I have done so three several times, and twice have been able to stalk close up to the herd. But in none of those three cases was there a big tusker in the lot. The game regulations now forbid any elephant to be shot carrying less than sixty pounds of ivory to the two tusks. Now there is no reason why a much more frequent use of local native help should not be made, when other game than elephant is sought. But very few sportsmen think of doing so. If you want lion, try and reach the neighbouring N'dorobo, or Massai or Kikuyu, tell them they are sure of "bakshish" if they show you a fresh and undisturbed "kill." The "undisturbed" part of the bargain is all important, for if they, as they are apt to do, go first up to the carcass, and cut off some of the meat, or, if you are in Kikuyu land, and they set snares for the birds (these snares are very cleverly laid, 
nooses of kongoni sinew, laid down in the grass; maraboo and vultures entangle their feet in them, as they come to feed on the carrion) whose feathers they covet, then the chances of the lion returning to the kill are but slight. Generally a lion will return next night to his kill, often staying there till quite late in the morning. Even if he goes away at daylight, he will lie up at the nearest water or in some brush hard by. You can, in this way, get some idea of his whereabouts and often get a shot.

Or, the natives may locate him in some favourite ravine, where several lions, will often for quite a long time, take up their quarters. Or, again, the Massai may have tracked the great cattle thief to some family refuge in a kopji, and you might be weeks in the neighbourhood without discovering it. There are, in short, a great variety of ways, in which you can get aid and information from the local native and be sure and use him when you can. You must be prepared, however, in the first instance, to be often denied all information. I suppose the tribes have their own reasons for this cause of action, for it is very common, but I could never discover it. The N'dorobo, for instance, who may be very meat hungry, when you first see them, and who are living meagrely on honey and meat stolen from lion "kills," are likely to assure you, when you ask if there are many lions round, that there are none within three or four marches. In a week these same $N^{\prime}$ dorobo will haunt your camp, crowd to your fire, till you have to drive them away, and bring their sick to get "dowa" (medicine).

If there are many of these hunting "wild men," as the other tribes call them, in your neighbourhood, better come to an understanding with them about this matter of "kills." Promise to give them a kongoni now and then, if they will leave all kills alone, and come to you as soon as they find one. If some such arrangement is not made with them, 
you are likely to find your meat taken from the carcass you intended for your boys, unless you have left a man to guard it (while you went to camp to order porters out), and it is not always possible to leave a man on guard.

It is wonderful to see the vultures come to a carcass. Not one can be seen with a glass, as you first sit down, near the fallen game. But in ten minutes, the broad black wings are sure to be sailing far above you. The coming of the wild man is, to me, almost as mysterious. I have walked away from my game as though I intended abandoning it, and going to a distance, have hidden behind some shelter from which I could command the country with my glass. In a wonderfully short time a black dot of a head would be cautiously lifted from the grass, or miles away I would see one, two, three, tiny black figures running along in single file, as they always travel, all making a true course for the game they somehow smelled out so strangely.

The lesson I would have drawn from this is: Have someone in your sefari who can talk to the N'dorobo. Sometimes these people can speak a little Massai or Kikuyu, oftener they cannot, and in lion country especially, it is well to be on good terms with them, they are exceedingly timid, and quite harmless. Though sefari men are generally rather nervous of meeting them, saying they fear their poisoned arrows.

In Massai land, if you happen on a country where there is little game, but where the lions still are heard, you can reckon on the hearty support of the herdsmen in hunting them down. Where game is plentiful lions seem generally to leave the herds alone, but when game is scarce then the lion becomes bold indeed and exceedingly dangerous. Then he will, by some cunning device or another, stampede the crowded occupants of the kraal, and spite of spear and firebrand, take his pick, and carry it off. In such 
cases the Massai are glad of your help, and you may reckon pretty safely on the lion's return to his toothsome "kill." The difficulty is to prevent the owners taking all the meat the lion has left. If you can by purchase or persuasion prevent this, and if the moon is shining, then have a thorn boma, built for yourself, a few yards from the kill, and you have as sure a thing as there is in lion hunting, which is not saying much. I have never been able to induce a lion to come back to his game kill, if it had been disturbed, or if a boma was put up nearby. When there was no game to speak of, and a fat cow had been killed, I have had him come back two nights running and pull a boma, we had built, to pieces, to get at his meal, and, the Massai tell me, it is always so.

If there are trees close by, there is a much easier and safer way of getting him. Have a place put up in a tree, close as you can get to the kill, and fix yourself so that you will not fall down if you should nod. This can be done near an undisturbed gamekill. One man, I know of, killed, in this way, four fine lions, on one lucky night. But I should not advise either of these methods unless there is a moon, and the weather is dry. A soaking cold rain may do you so much harm that even a lion skin will not repay you. The night, too, seems very long, and it is cramping, tedious work. If you have crouched in the bows of your "birch bark" all through a September night, while your hunter has "called" the harmless moose, you will remember well how every bone in your body ached, before the welcome sunbeams came slanting over the dark spruce tops, and the tall frost rimmed swamp grass. But you can make yourself far more comfortable in a canoe, than you can, perched on a tree limb, or crouching behind a thin screen of thorn bush. Still lions are worth trying for in every sort of way.

The most difficult trophy to get, and I think the finest 
of all, is the buffalo head. And here, at least as much as with the lion, the local native can help. One of the chief difficulties about the buffalo is, that some slight cause may make him change his quarters. $\mathrm{He}$ is here in large numbers one month, the next he is gone and trace him you cannot. His chosen haunt is often inaccessible to you, even if you are willing to take the risk of following him into the dark labyrinth of swamp and jungle through which he tunnels or crashes, or, wonderful to relate, moves if he wishes it, almost noiselessly. You cannot do so. No living man, not the naked savage himself, can force a passage without making a noise, sufficient to give warning of his approach. Nor can the breeze be depended on in these thickets. No, the only real chance you have, comes, when he leaves his fastness, to feed in the glade or on the marsh, close by. Now, unlike the elephant, which loves rain, and can never have enough of it, the buffalo dislikes it. Consequently information you collect with care, about where you should go, etc., and when, etc., is by a change of season rendered useless and misleading. You march the sefari ten days to some locality where your friend got a good head, where he left plenty of buffalo, and which you have good reason for believing has not been disturbed since he left it. Your hopes are high. Alas! nothing comes of all your trouble; when you reach the land of desire and hunt it thoroughly, you are not rewarded by so much as a fresh sign. Never then be so sure of getting buffalo anywhere, that you do not make arrangements to have one or two dependable natives gathering information for you, going out themselves to look for sign, in some other locality, on which you can fall back, in case of failure.

At most of the government stations there are such natives, kept in government employ. The district commissioner will always oblige you with their services. They cost little and may prove of great value to you. Before 
I leave the subject, let me say one thing more about these dark skinned fellow helpers of a day. Invite them to your big central fire in the evening, and as you all draw round the welcome blaze, have an interpreter up and talk to them. How many interesting things you will hear, about them, their plans, their hopes, their discontents and wrongs, and, some none less interesting things you may learn, about yourself, and your fellow countrymen. The native helper, when he is employed, is often, in sefari life, shoved to one side as soon as his bit of information has been had from him. In your camp he is almost sure to be without kith or kin, unless he has bargained for a companion of his tribe, to bear him company. Remember, you are his host. It will indeed pay any traveller well to take some time and pains to draw these casual companions out, make them feel at home, and let them see you are not visiting their country simply and solely to get something that is partly theirs, at as little cost to yourself as it may be had.

I remember three Massai, we once had, to guide us to a thickly wooded haunt of buffalo, where other sportsmen had met with success. Our start from the government boma was not very auspicious. We had with some difficulty procured a tent for them, the rains just then were very heavy, The tent did not weigh, poles and all, more than ten pounds, but they promptly refused to carry it. (Massai will seldom carry any load but a gun.) Well, we started without the tent, for all the porters were loaded. Soon after camping, some four hours out, the downpour commenced. Whereupon the three came and wanted to know where they were to go out of the rain. We arranged a shelter for them beside the loads, under a big ground sheet. Next day, close to our second camp we found a Massai munyata*

\footnotetext{
* Temporary village - wattle houses daubed with cow dung, built in a circle usually depended by a high thorn fence.
} 
breaking camp in much excitement. Two lions had jumped the high thorn boma, landed in the middle of the packed herd, and, of course, stampeded the lot. The maddened beasts burst their way through the double fence of wattle houses and thorn barriers, and were at the mercy of the lions. Two of them were quickly pulled down, one of these was carried into the long grass, some two hundred yards away, and there was devoured at leisure. From the other, the Massai with spears and fire drove the lion off. This all happened in the early morning, and when we came up, the Massai had bled the bullock, and carefully, as they do, preserved the blood for drinking.

Now we were out of meat, and so tried to buy that bullock's fat hunk.. No, they would not sell. But our three moran (warriors) brought along with them an appetizing shoulder and brisket. They had their potio, as was their due, that night, but though they ate that, they kept their beef and offered us nothing. Next day I had a most interesting talk with one of them, and learned from my "warrior" more about their customs and views on things in general, than I had been able to pick up in eight months' previous travel. When dinner time came the fat brisket was set to roast on a stick leaning over the coals. I noticed a brief consultation going on among the three, and then one of them said, "We have eaten your potio, this is good meat, take half." That evening was an interesting one. We sat and chatted and explained things all round, tried to make them say "Oryx," (natives find the $\mathrm{x}$ sound almost impossible), while they, in turn, defeated us with their gutturals. Before we turned in, they made an evidently sincere request that when buffalo had come back and the rains were over, we would give them another chance of guiding us to where we should find a big head. Very intelligent, with a certain dash of independence, that other natives lack, I always 
find them. I am sure Mr. Shauffaker* is right in saying, that if he can but secure their alliance, if he can gain the confidence of the Massai, more can be done with them, than with any East African people.

* Mr. Shauffaker and his brave and capable wife - aided by two deaconnesses, all Americans are members of the African Inland Missionary Society. Mr. Hurlbut is chief organizer and head of that society in British $E$ ast Africa of able, sensible, and devoted men. If any can succeed in mastering the immense difficulties of this situation, these people surely will. They build their own houses. Live on next to nothing - and seemed to me the most practical and level headed men and women (missionaries) I met in the country. The civil authorities of the Protectorate, enthusiastically welcome their aid and value their opinions. 


\section{CHAPTER VI}

\section{SEFARI LIFE}

HOWEVER reluctant you may be to leave your com1 fortable camp bed, it is well to force yourself to rigorously maintain the habit of early rising.

The first hours of the morning are far the best of the day, are indeed an unmixed delight.

If you are on the plain, all the world shines with a silvery glitter as the first level sunbeams fall on the dew. The tough-jointed stem of the grass carries a heavy and bushy head; when you press through, it may reach to your waist, or even to the shoulders, and every several head will seem to carry, for your special discomfiture, not less than a cup full of icy water.

Take the plunge, if you are afoot, as quickly as you may. No clothing devised by man will keep you dry for ten minutes. But there are compensations. In two hours' time you will be dry and warm again. Meanwhile, if you have eyes in your head, and will but look before you, you will see, spread for your delight, such a play of sunshine on the steamy vapours, such a wonderland of silvery crystal, with miniature, iridescent rainbows everywhere peeping in and out of it, as no man ever looked on, out of Africa.

The plunge is cold, but it is a plunge into a veritable silvery sea; and yet "silvery" fails to convey any idea of the clearness and radiance of its beauty.

If the sun is still low in the heavens at your back, the grass wears a shining halo round the long-thrown shadow of your head and shoulders as you move along. You might be a mighty Gulliver, striding, waist high, above the forests 
of Lilliput, that spread, beneath your feet, their miniature but inexhaustible beauty. You are in the elfin land of the dew, where Queen Titania still rules supreme, and Puck plays pranks on human fancy.

Look well at it, and drink in its beauty. For, like life's best things, it will have vanished, before you are aware, and you will find yourself, an ordinary mortal, pushing your way under a hot sun, through obstinately tough grass, with nothing to requite you for the lost visions of the morning, but a pair of rapidly drying legs.

The woods during those early hours are deliciously cool and fragrant. Every fern, nestling among the knees of the trees, or climbing and clinging, as they beautifully do, on to the long, mossy branches, sparkles as the dew-drops still rest on them. Early morning is a very quiet time, in the woods and on the veldt. The early twittering of the birds, which greeted the dawning, is soon over. The frogs and crickets which always make most noise, take rest, tired by the continuous chorus of the night. Watch and ward among the beasts of the wild, has been kept all night long. The barking call of the bushbuck to his mate, the strange, coughing bark by which the sentinel zebra signals danger, all have ceased now. If you sit down, glass in hand, and watch the herds, you will see them feed for a little while, and then, choosing a safe place, lie quietly down.

The tension of the long tropic night is over, in the daylight they know themselves safe. Now, and during the hour before dark, is the best time to study the wild things, great and small.

I have seen a band of lions come sauntering along in single file, on their way to the reed bed by the river, when, till nightfall, they will make their retreat in perfect security. The feeding or resting herds of zebra, kongoni or Grant, divide slowly and casually, as it were, to let them pass. Neither the lions nor their prey pay much attention one 
to the other, each recognizing the day time as the time of nature's truce. The swift have no need to flee, the fierce no wish to pursue. Each goes about his business till the evening. But when once darkness has fallen over the plain, at the first deep guttural roar of the lion, you can hear, though miles away, the tumult of retreat, into which that dreaded signal throws them.

Be sure and make good use of those first, fresh hours, there are none others like them. To start early from camp, and to get back early, is a golden rule in Africa. Arrange your personal matters the night before. Leave nothing to be done at the last moment in the morning. He who is hunting round, then, perhaps in the semi-darkness, for cartridges, compass, knife, who calls to his tentboy to see that his saddle bags are in order, is almost sure to leave something important behind. Here let me suggest a plan to others, which I, a man with the poorest of memories have found to work admirably. Have your sefari clothes made with large, and very numerous pockets, all of them covered with buttoning flaps. Let each indispensable thing have, and always keep, its own special pocketcompass, whistle, tobacco, and pipe, measuring tape, knife, matches, note-book - biscuits and chocolate, syringe and permanganate of potash, bandage, lint, and string, always carried in your saddle bags. Keep these indispensables there during the day. Leave them always there during the night. Put on your clothes in the morning, and there you are. This saves the unforgivable on sefari, keeping others waiting, till temper is lost or strained.

There are really a great many things to be seen to, before you start for the day, and the uncertain light of early morning is not a good time to see to them. There is, on the other hand, plenty of time in the evening. See to them then.

A prompt start at or before sunrise has another 
advantage; it enables you to return early, and to avoid too much of the midday or early afternoon sun.

From noon till three o'clock, many will find the heat exhausting and the fagged out man, is not usually the best of company in camp.

Now one of the things most worth sacrificing something for, when you are camping for months in the same company, and cannot get away from it, or it from you, is a cheerful atmosphere, a life of give and take, a steadfast avoidance of all friction, even of little differences on points unimportant.

There is very much to try a good temper, in sefari life, much to strain and worry even a placid disposition. If things are to move smoothly for all parties, try to get rid of your ill-humours, when you must have them, in the open. Work them off outside. Do not visit them on your men or your friend. Surely the success of a trip is not to be measured by the trophies taken, only, but, at least as much, by the memory of beautiful things seen and arduous things done, in the pleasant company of others. A witty man I know, as he stood at his country house door, and bade good luck to some of his guests packed for a day's ride in his automobile, said: "I do not think I can give you any better advice than that Joseph gave to his sons, when they were starting for Egypt. "See that ye fall not out by the way." Well, on sefari not to do so means forbearance and allowance made.

Carry a few good books. When you feel out of sorts, turn to them. There are so many things one wants to know in life, and that one never can get time to learn. And there are so many others that once we knew and remembered, but have in part or in whole forgotten, that it is a demoralizing waste of time to hang round the camp doing nothing, reading nothing, thinking nothing, often watching nothing, no recreation but killing things. Such a life does no 


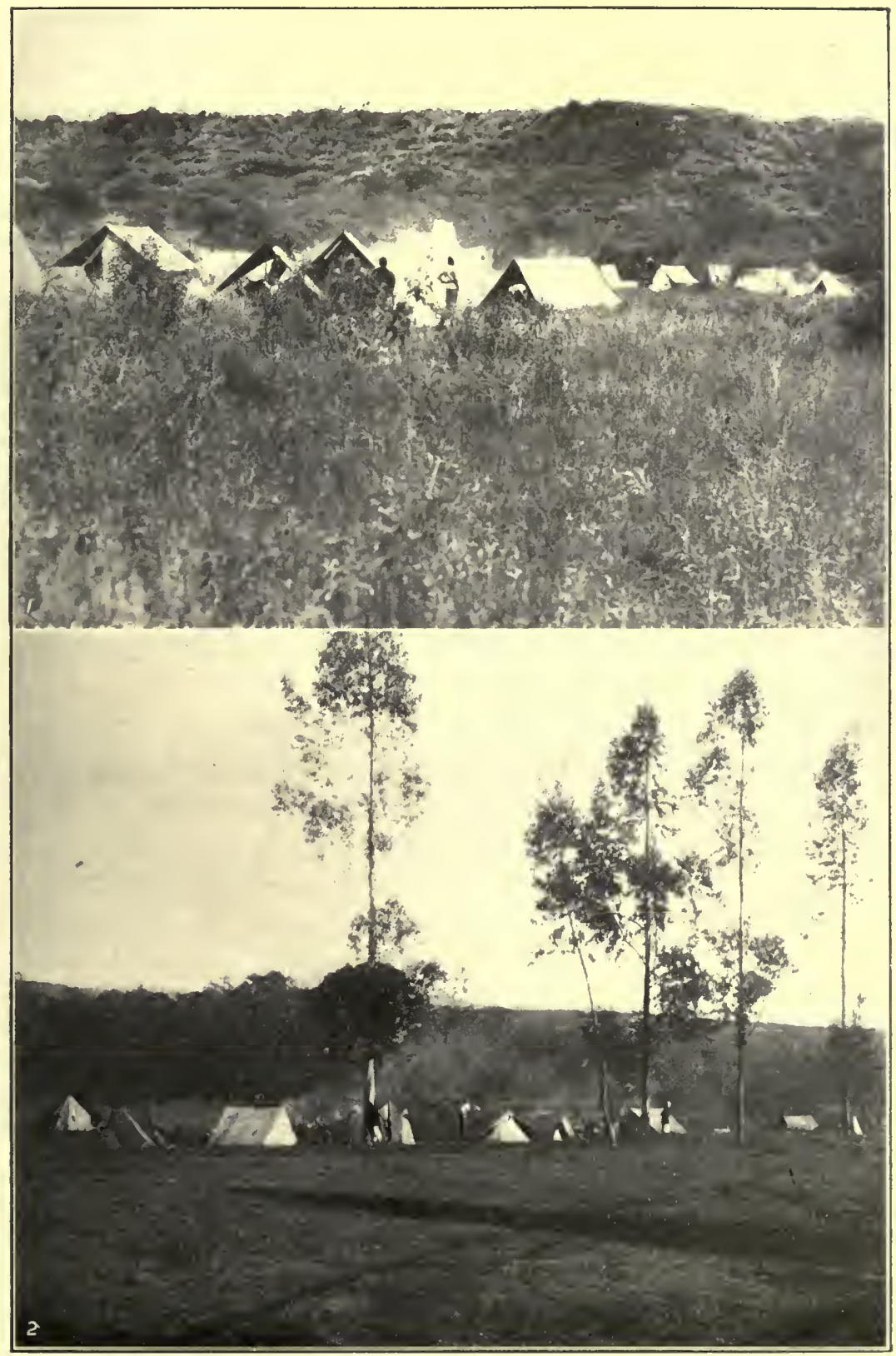

I. Camp. Early morning

2. Camp at Eldama Ravine on the edge of the Mau forest 

man much good - and yet, many live it. They are like the poor old "chaw bacon" who sat hour after hour, day after day, by his cottage fire. "What do you do sitting there for so long, saying nothing?" "Well, sometimes I sits and thinks, and sometimes I just sits." A man is. easier to live with, for having kept company for an hour or two with some of those, who, being dead, yet lead us and teach us.

There are certain things one is accustomed to, at home, which are better left off, here. Cold baths, are unfortunately among the number. I suppose a very young and strong man could enjoy his cold tub with impunity for a time, but certain it is, that no one, no matter how hardy, who has been long on the veldt, can take one. Just now we are nursing my friend's hunter, who came down three days ago with a violent chill. We had to cross our mules over a river, running in flood. There had been heavy snow falls, in Kenia, and the snow water loses most of its chill, soon as it leaves the woodland border of the mountain. Still, for African water it was cold. The mules had to swim, and in getting them over, he was, perhaps, for ten minutes, waist deep. A hundred and five degrees of temperature is a heavy price to pay for a cold bath - yet he is young and hardy. One friend of mine I persuaded to give up the luxury of his cold douche, till, after an unusually long and hot march, having had time to thoroughly cool off, he could no longer resist the clear brown water, by which our tents were pitched. He came down that night with a heat rash, that made next day's march an experience he is never likely to forget. Cold water is enticing, but avoid it, and take a very hot bath in your canvas bath tub, with a good rub-down, instead.

Be always careful to look for signs of crocodiles, even on small rivers, and warn your sefari to be careful; the 
men are as careless as children, and even a nine-foot crock can take a man down and drown him.

When I came to the country first, the cool water, when I could find it, after the hot day, was a temptation not to be resisted. One evening I went to bathe in a brown pool, overhung by a broad-limbed fig tree, on the Athi River. I sat myself down in a bend of the lower branch, arranged my clothes and towels, and dropped quietly into about five feet of water. I landed on a rough sort of rock, as it seemed, and was proceeding to duck my head, when the rock began to move away! I made the jump of my life, back to where my clothes were. I never went into a river since, unless I had to swim or ford it with mule or horse, and then was careful to see what sort of "sign" the bank showed above and below. One of the settlers living on Donyea Sabuk, near Narobi, told me a few days ago that one of his "boys" had been taken by a crocodile, while washing clothes in the stream, quite near the place where I had my own startling experience. My moving platform may, of course, have been a large river tortoise, but I did not wait to make sure. There is nothing in all Africa so repulsive to my mind as a "crock."* The Athi, I found afterward, is full of crocodiles.

It is well to wash hands and face in warm water, soon as you return to camp, especially when you have been hunting, crawling in grass, brushing through scrub, handling live or dead game, you constantly touch many kinds of poisonous plants, thorns, and insects. The juices of several common creepers are highly poisonous, and a hand soiled by them, drawn across a sweating forehead, or

\footnotetext{
* Crocodiles are often very destructive to native life. But this is so cheaply held that small account is taken of its loss. The native women themselves, who are chief sufferers, are most careless of all. One hideous maneater, made his haunt near a shallow, where the women came to do their washing. A railroad bridge spanned the little river there and under its shadow the evil monster lay in wait. A friend of mine saw a woman taken down there one day. He assured me that within half an hour all her companions were back, washing in the same place, spite of all he could say. After much difficulty he had that "crock" snared. And out of its belly he took twenty-four pounds weight of womens bangles! The beast must have eaten more than thirty persons.
} 
rubbed into the corner of your eye, may bring a severe inflammation. The men's eyes and skin are often badly inflamed from this cause, and they are much tougher, in such matters, than we are.

When you are on elevated plateaus, such as Laikipia, or Nzoia, you will find no insect life, to trouble you much; but when you descend or are hunting the country nearer Nairobi, or near the Athi, Theka, or Tana rivers, or, if you visit the fine hunting country near Megardi, and pass toward the German line, you must prepare yourself carefully, to ward off poisonous insects, of several kinds. In these lands never wear slippers in the evening or morning, and under no circumstances permit your men to place your tent, or theirs, if you can help it, on the site of old encampments.

Jigger fleas abound, and the jigger is a terror! He is so tiny, it is hard to see him, and even when he has taken up his home and established his family in your toe, his only mark is an infinitesimal speck on the skin, spite of the horrid irritation, you cannot see anything. At last a small red spot appears, and, if your tentboy is skilful, he will cut a splinter of hardwood, and root at your foot, till he shows you, beneath that red spot, a sack the size of a marrowfat pea. This he carefully removes, not on any account breaking it, or causing the opening to bleed, see it put in the fire, not thrown on the ground, and rub some disinfectant in. This is not, I fear, a pleasant description, nor is the job any pleasanter, but it must be done, and done thoroughly, or you may find yourself unable to walk for weeks. Wear long, light, mosquito canvas, boots, round camp of an evening. You can get them at any outfitters in London, or at the Citadel Stores, Cairo, where, by the way, you will find, if you are introduced, an admirable assortment of camping fixtures, more complete and quite as cheap, as anywhere in London. 
Accustom yourself to sleeping always under a net. All good tents, and there are none better in the world than Edgington's, 2 Duke Street, London Bridge, have strings so arranged that your net doesn't close down on you; take an extra net with you, they will tear and stretch, and they weigh nothing. You may not notice many mosquitoes when you camp, but round you, are lying, some scores of men, whose blood, in very many cases, is infected with the malarial microbe - one "Anopheles" will do the business; and even a slight attack of fever is a nuisance, and may seriously spoil your trip. There are, too, many sorts of flying and crawling things that seem to let themselves loose in the night. Inside a well-set net, you are free from them. The only night visitor that thoroughly defeated me was a rat. He crawled inside my net and gnawed my ear, till he awoke me. I clapped my hand to my head, when he ran down my back. I had a bad scare then, for I feared a snake, and could only shout for John, and tear my clothes off. We never caught him, after all. When you are in Massai land, and mosquitoes are rare, you will often, during the day time, take tobacco, books, writing materials - everything - into your bed, and there and there only, escape the crawling, sticking, greasy, housefly, that in thousands and thousands literally tries to eat you, during the sunny hours.

After the rains are over, in the lower country, every second blade of long, strong, green grass, supports, near its crown, a tick, some so small you can scarcely see them, some lusty and flat. They crawl into the creases of your clothes, up your legs, and down your back, and are a very serious drawback to any enjoyment, whatever. Their bite is irritating, to all, and highly poisonous, to some. Where they are bad, horses die from their persecution, unless the poor beasts are constantly and carefully freed from them. I hunted once, on the Athi River, for three weeks, in May. 
The rains were over early, that year, the grass was rich and long, and the ticks were there in strength. I had John pick me clean, three and four times a day; took hot baths, with Condy's fluid in them, used every means I knew to ward them off, and reduce the fever of the bite. But I had a most uncomfortable time, and lost much sleep.

After the grass is burned, or when the country is thoroughly dry, ticks are not so bad. But my advice is: don't go down into the Athi River country till the grass fires are over. A friend of mine came back to Nairobi and lay in hospital there for months, as the result of taking up work on the Athi during the rains.

One of the pleasures of sefari life, as I have found it, is getting to know the men. It takes time, but nothing pays better in the long run. I have never found any men, anywhere, quicker to appreciate a little personal interest, than are these black companions of our pleasures and dangers. Easily contented are they, and surely very patient, under circumstances no white man would endure. In little clubs they tent together, five to seven in number; covered, in rain and shine, by a tiny Americani* tent, of the value of seven rupees.

The tent lets the heat in, and though it is sure to be cunningly pitched, will not, for very long, withstand the torrential rain. Stretch it, trench it as you may, an African torrent shower, floods its floor. Most of these black folk have fever in their bones, and a soaking night, when the rain is cold, will often bring a large number down with it. When the white man has malaria, he stays in his warm, dry tent, wrapped in warm blankets, and carefully supplied with warm drinks he brings on perspiration, then quinine, etc., etc., while all the sefari waits anxiously on his recovery.

* The cotton cloth used everywhere in East Africa is made in the United States. Hence its name Americani. 
But these poor fellows must face their daily march, and, with sixty pounds on aching heads, keep up,as best they may.

Soon as your tent is pitched, and wood and water have come in, tell the headman to call to you all who need "dowa" (medicine) - let it be understood at once that you will doctor their ills to the best of your ability, and that you will do so at a certain time, and your clinic will soon be fairly under way. When they come, let them tell their roundabout story in their own way. They often bear, uncomplainingly, very severe pain, that they have had to grow accustomed to, while they make a fuss over a trifle. They will fearlessly and skilfully use a knife themselves often a dirty-bladed one - in cutting out a thorn; but most of them grow evidently nervous if you have to produce a small lancet. We had a gunbearer mauled by a lion. He made no outcry when the great teeth cut his arm and leg, he stoically endured, for six weeks, the pain of dressing, twice daily; but when a medical missionary produced a lancet, in order to open one of the great fang wounds, which had too soon superficially closed, though he was reduced to a skeleton, and had never been without a temperature for six weeks, he vaulted like a flash over the veranda railing where we were sitting, and distanced, over a very rough ground, too, a good runner who tried to catch him. Strained sinews and muscles, boils and blanes, fever, and above all, the natural and inevitable consequences of eating too much meat when they can get it, and eating it almost raw (indeed they never cook any food enough), these are their most common ills. Epsom salts, chlorodyne, in addition to a "Burroughs and Welcome" medicine chest, will be found useful to have at hand.

Give them time, and close attention, when they come before you, with their disputes and grievances - you owe them so much, at least - and their point of view is often very interesting, and instructive, too. They have not, 


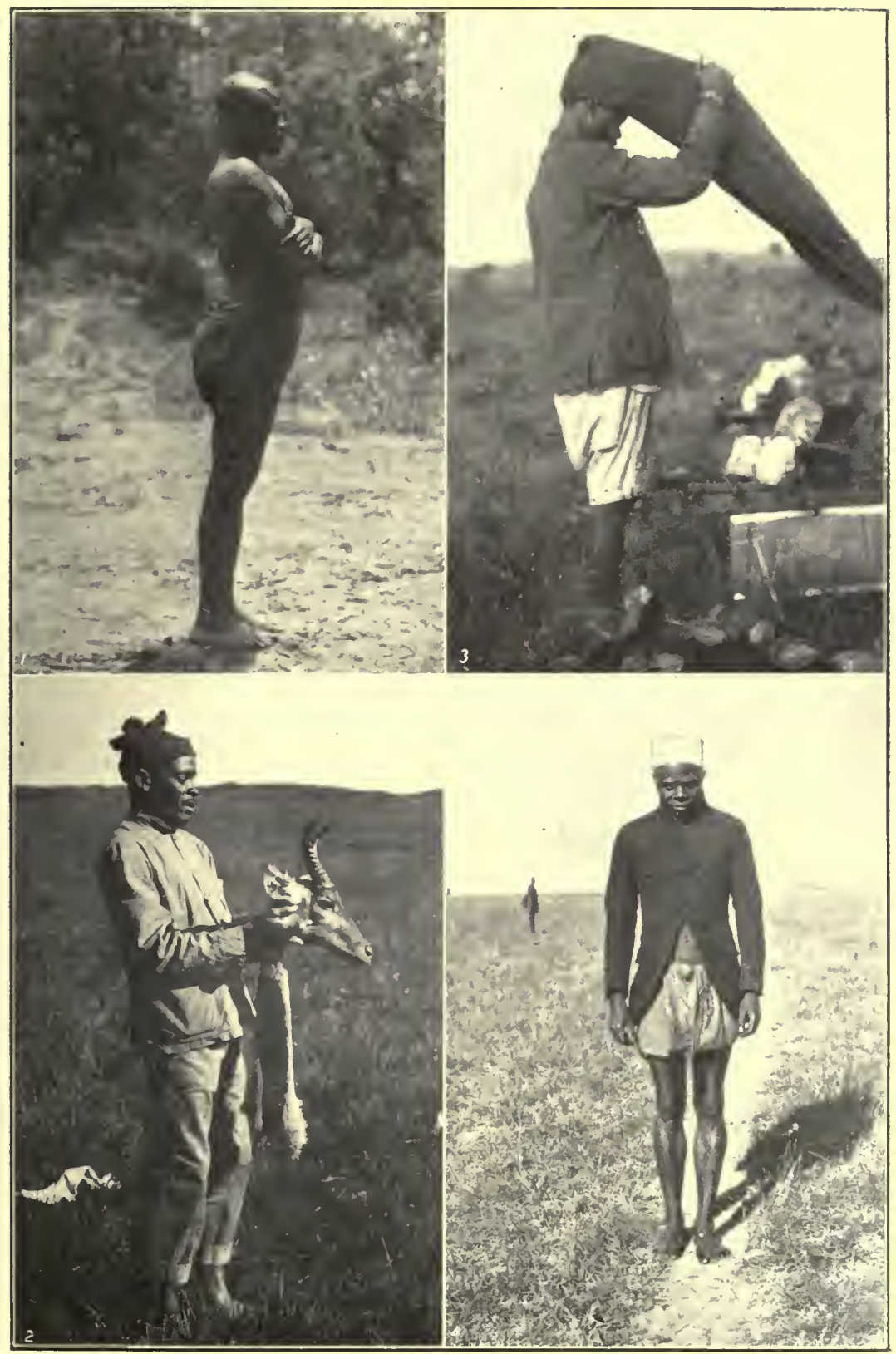

r. Head porter (Wanyamwazi). Carried from 85 to 98 pounds each day for five months

2. Little John Connop, my tentboy, holding a reed-buck's head

3. Porter. Winding his blanket into a turban before starting

4. My gunboy - going to town 

as yet - no, not even in English territory - a dawning perception of their rights, as these may exist, against a white man. Momba's saying, as he looked at a picture, gave well the native point of view: "The white man is like God - he can do what he likes." If they are unfairly deprived of potio, or unjustly kobokoed, they may run away, but, even if they do, they make no reprisals, and are sure to leave their load behind them. They seldom make a complaint against the white wrongdoer.

One thing they strenuously object to, that is a reduction in their potio, and each tribe wants - when it can be got its own sort of meal. The government, I think, has made a mistake in entering on sefari regulations an order to get rice potio. Rice is sometimes not obtainable, and is even then excessively dear. Moreover, rice can not be at present grown in the English Protectorate. Now good mealie meal, well ground, is quite as nutritious, and not nearly so costly, and can be grown everywhere. Were its cultivation encouraged, much more grain would be raised, and money now going in very large sums to German growers (for all the rice comes from German East Africa) would come to natives* living comparatively nearby, whose success in selling their crop could not fail to have an encouraging effect on those other natives who, sooner or later, must cultivate the land in order to live, but who have not yet had the courage to change their method of living, and make a beginning as cultivators.

This subject of potio is a very serious one, indeed the all-important one, and needs further explanation. All I will say here is, look ahead; don't put your sefari on halfrations, unless you have to. When you do, explain everything to the men, so that they all understand that your action is not the result of niggardliness on your part. Under such circumstances I have always found them most reasonable.

\footnotetext{
* I understand this change has been made since I wrote.
} 
But, on the other hand, many, many sportsmen are both ignorant and unreasonable. They blunder along any way, caring nothing for their men, knowing nothing of them; trusting to some intermediary, some hired hunter or servant, to look after the wants of the sefari, no provision for serious sickness, no extra porters for an emergency, no previous arrangement about base of supplies. Their own "chop boxes" are filled, their own food certain. They seem to care for little else. Most of the pain and discontent they cause is dumb; no outcry reaches them, and so they pass on their way. "The hunting was good, but as to the natives, they are a discontented, thieving set, they are glad to be rid of them."

Another thing that needs looking after, from time to time, is the loading of the porters. Carry a spring weighing machine, and now and then weigh the loads yourself. Some, otherwise good, headmen show favouritism, they are only human; you are your porters only protection against a possibly unfair discrimination. If you, yourself, see, just now and then, that the loads are fairly divided, there will be no need, whatever, for you to be constantly questioning your headman's judgment, for he, as well as every man in your company, will recognize, that you mean to allow no favouritism, and fair play will be the rule.

When several days' potio has been served to the sefari, it is always worth while to look sharply at the toto's loads. This is the time when the poor little fellows are likely to be cruelly overloaded. If you find one in such a case, take off his extra burden, and put it on the man or men who hired him. This always has an excellent effect, and saves constant "koboko," which is a mistake. See, by the way, when you are paying off your sefari, that the totos on it are paid then and there. The men disperse, in a few moments, they are soon lost in the bazaar. I have had to go to much trouble, more than once, to have a poor little 
cheated toto paid his dues, because I neglected to see his very petty cash, handed over to him, on the spot. When you buy potio, see the loads weighed yourself, before paying for them. Do this on the men's account, quite as much as your own. So many loads mean so many days food for all hands. If you are receiving a fifty pound load when you are paying for a sixty pound, and this is quite common, especially when dealing at outlying bomas, with Indian traders, your men may find themselves seriously short. And the shortage may come when the sefari can least stand it, viz., toward the end of a long trip, when all are heavily laden, and you are in a country where game is scarce.

$\mathrm{Oh}$, there are so many things I found myself longing to teach these men of mine. Things they surely needed for their well-being, but alas, it could not be. For ages they have gone on their own sad, merry, contented way; living like Æsop's cricket, and dying so young! Going, as they say themselves, to the fécé (hyenas). Missionary work has not yet influenced them (the sefari porters) at all. When they are not Mohammedan they are nothing, and their Mohammedanism is the thinnest of veneers. English rule has stopped bloodshed in their home lands, and may be trusted to accomplish, slowly, what English rule almost always has achieved, the betterment of the natives' condition. But at present, unfortunately, there is no denying the fact (though home and local authorities shut their eyes fast to it) that England's coming here has resulted in bringing among comparatively pure native stock a terrible poison that nothing whatever is being done to check or restrain. Another grave danger to the natives' wellbeing arises from the perhaps, sometimes, necessary breaking down of the tribal rule and law. These are his own and he understands them, and we take them from him, before he can possibly understand the laws we force him to obey. His 
own tribal law and penal code are often pretty good things. They work well, and if gradually the more brutal side of them were toned down, the native would understand, appreciate, and obey. But to force the Indian* penal code on Massai, Kikuyu, and Nandi, is far worse than to ram a tall hat on a Chinaman. This aspect of the native question, however, is too serious a one to be dragged in here. I will say what I have to say on it later on.

Walk round the little camp fires, as cheerily they blaze up, in the cool of the evening. It is a good way to get to know your men. Here one cries out to you, "Caréboo" (come and eat with us); but this intimate, though respectful salutation you will not hear, till the sefari has shaken itself together. I always regarded it as a high compliment, and waited by the fire to taste of the pot.

The industries of the sefari are various and interesting.

Here is the lace maker. Who would expect to find so delicate a trade, favoured by a hulking Wanyamwazi? But several men in the ranks are probably busy, making the lace caps, that all natives put a high store by. The materials are strong and expensive, a bit of good white linen, and white silk thread - yes, white, and in some wonderful way kept white, even during all the vicissitudes of swampy marching and ubiquitous grease. The instruments, so far as I could discover them, only a fine needle, and a very finely sharpened bit of hard wood. The linen was stretched on a little drum.

There sits the snuff maker. He carries his two smooth stones, somehow or other, wherever he goes, and right good, though terribly strong, snuff he makes from native tobacco. His income, though small, is steady.

Then there is the shoemaker and cobbler, hard at work reducing tough eland or giraffe (best skin of all) skin, to

* Under this code East Africa at present is ruled. It would be hard to conceive of one less well adapted to the natives' needs. 


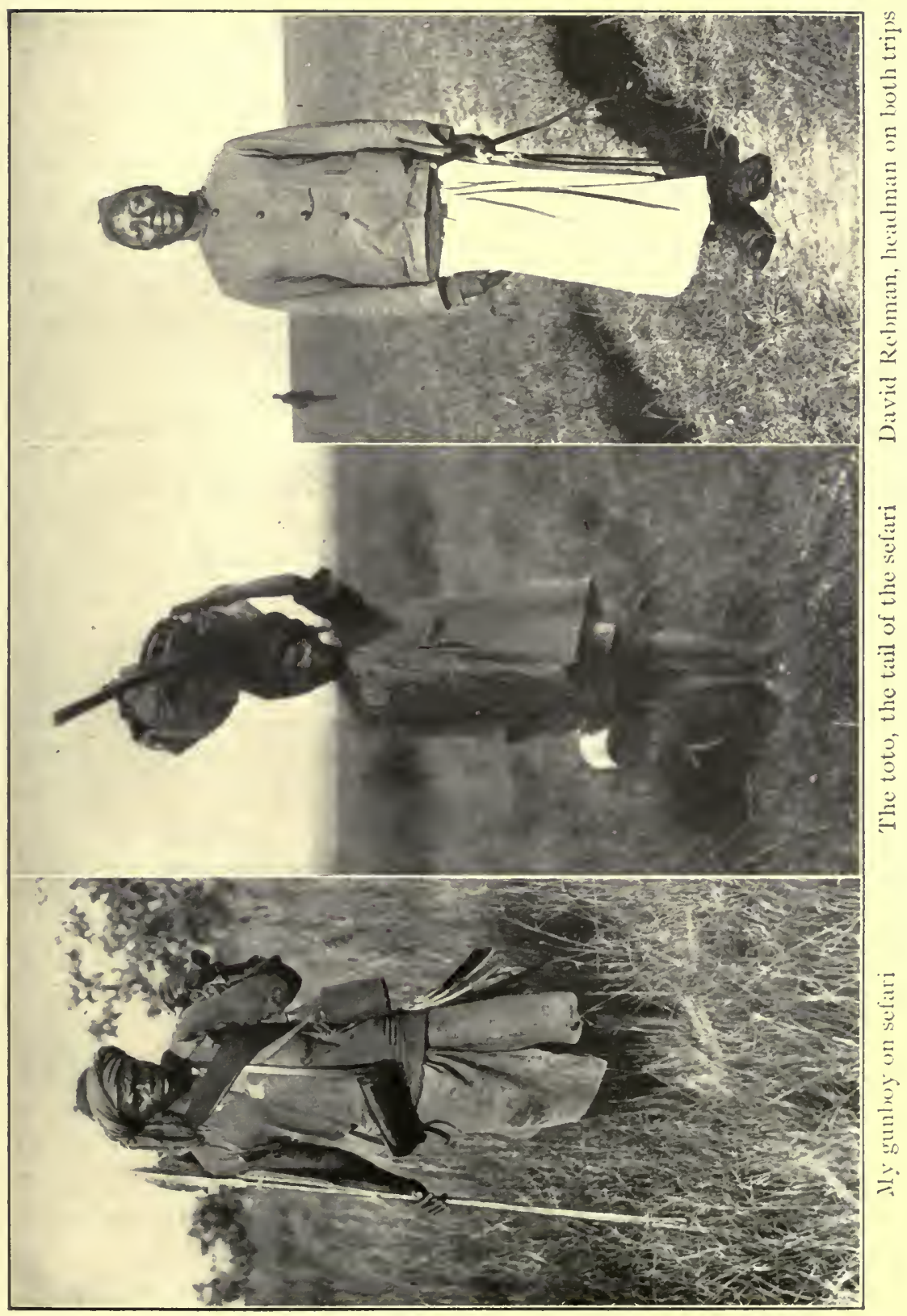



sandals. The men willingly pay half a rupee to him for a pair, and they supply the material.

The barber is in a class by himself; among all the trades he seemed to me to claim an undeserved preëminence. But the wonders he performs with a sharp hunting knife are beyond me. He will shave three to six completely accurately drawn, circles, round the patient's (sic) head these circles are half to three quarters of an inch in width and are as regularly drawn as though the great man used a compass. I have never seen him draw blood - no hedge-cutting, shrub-trimming Dutchman in Holland ever produced, on his favourite greenery, stranger or cleverer portrayals of still life, or animal life, than the sefari barber cuts off, or leaves on, or makes up, in a native's woolly hair!

The sefari doctor, however, is important, too. If you fail the men, or if your "dowa" is too strong (they hate liquid quinine - which is, of course, the best form in which to give the drug to a man in fever) they hie them to him, and pay him too. The compounding of his medicine he keeps to himself. I never could get him to tell me anything. Speaking of doctoring, I found that, occasionally, the men suffered much from toothache, and I regretted that I hadn't brought along a forceps, and had not taken a few lessons in tooth drawing.

Hoey (my professional hunter, a fine fellow, who accompanied me on my late trip, when I rode lions) always carried one, and as he was very muscular, had never been beaten by even a back grinder, but his methods seemed to me rather forceful.

I learned something about "my boys" as I strolled among their little fires of an evening. I was surprised at the natives' aptitude for industrial work; and encouraging and developing this is surely the best way to help and elevate him. Practically nothing has yet been attempted here, and all work in iron, wood, and stone is left to the 
inefficient and expensive Hindus. I learned to honour and esteem many of them for what I saw they were - faithful, kindly men, living honestly up to the light given them.

There was an immense porter I had, who carried the cook's bath - this description may be misleading, for nothing that I could do, ever succeeded in inducing little Peter to wash anything but his hands, but his bath it was called, and over it and its contents he exercised a despot's rule. All the odds and ends and left overs, the food for the next hurried meal, sugar, potatoes, bacon, and Worcestershire sauce (I may as well stay my hand), all these, and numberless others, were ever to be found in Peter's bath. All our cooking paraphernalia, from the big kettle to the iron soup ladle, frying pan, coffee pots, baking pans for bread and the like, filled high up this immense receptacle. The most awkward and unwieldy load in the sefari. My big porter carried this load always at the head of the sefari. The moment he reached camp and laid his burden down, he was off to get wood for the cook's fire - a purely voluntary act on his part. For the cook's boys, not the head porter, whose rank is high among the men, has this allotted duty to perform. He marched all day in a coat that fitted his stalwart six feet two inches well. It was a clerical coat with regulation high upstanding collar, buttoning tightly across the breast. Under this quite non-tropical and very English garment, he wore the regulation porter's sweater. This was on the march, and in exceedingly hot weather!

As the evening fell one of the askaris would take up, as usual, his place by my fire. I had four of these native soldiers, their height varying from about five feet nine inches, to five feet. Short or long, these gentlemen invariably turned up clad in that unmistakable clerical coat. Its tails dragging on the ground almost, when the little men stood up.

During the heat of the day its owner claimed it. Dur- 


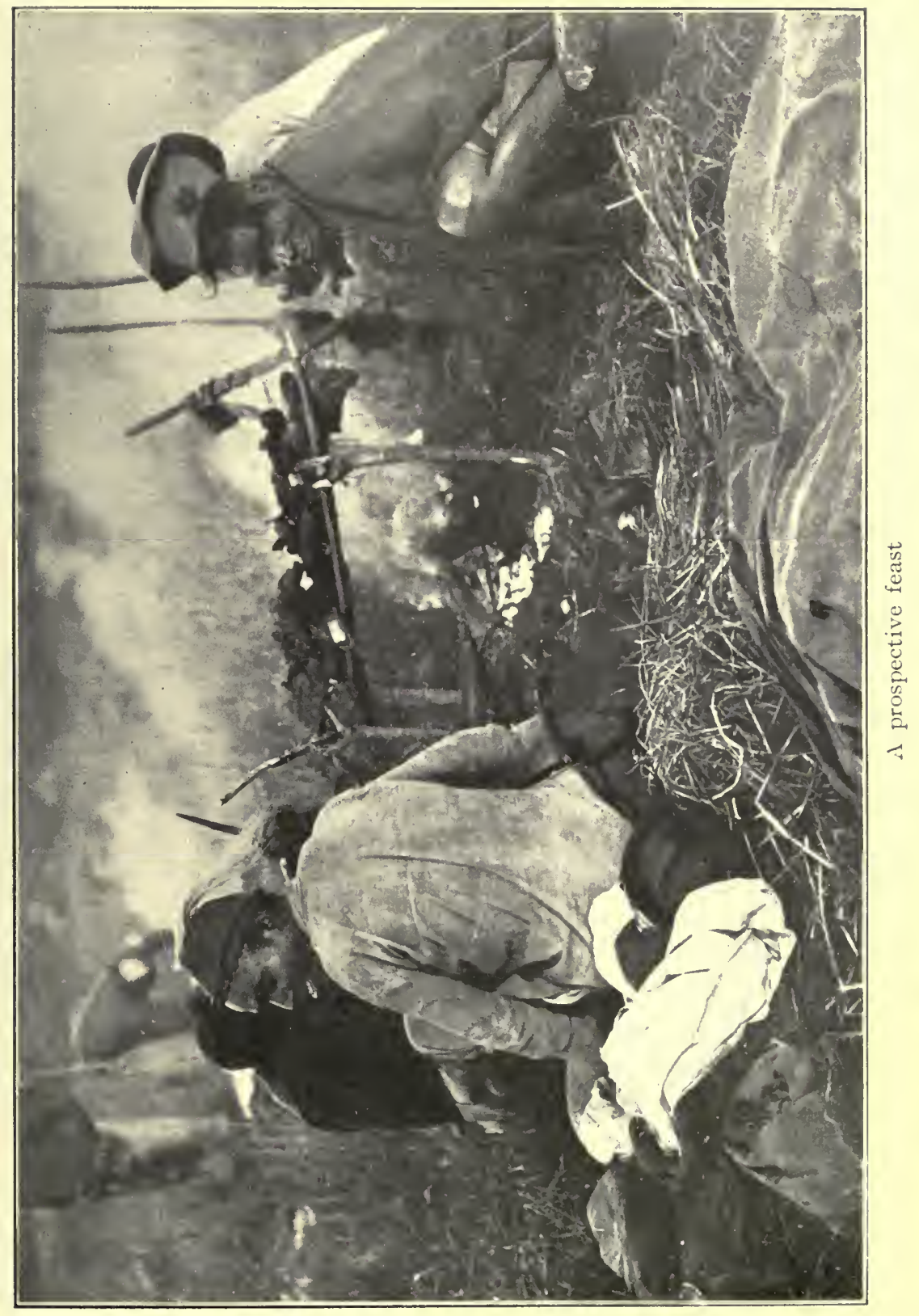



ing the night's chill he invariably loaned it to the man whose duties kept him outside. He knew nothing of the Christian doctrine of universal brotherhood, but a true giver of the cup of cold water, a true brother of his black fellow man, most surely he was.

The extraordinary way in which the men carry all sorts of odds and ends round their ragged persons without losing them, on the most difficult and upsetting marches, is interesting. Call on them to produce them, and out they come from the most unexpected places. I was well accustomed to this proceeding, when we engaged some Karamojo* hunters to accompany us, for I had been many months on sefari, but these men puzzled me. They were quite naked, a few narrow iron chains and strings of beads their only drapery, yet they produced snuff and one or two other small luxuries on the march, like the rest. They carried no wallet or bag of any sort. Watching them closely, I saw them tuck their "what nots" into a little hollow in the mud-plastered chignon, into which their hair was firmly made up at the back of their heads. This is the usual Karamojo custom. A Massai guide we had for some time, carried, as all self-respecting Massai who are not moran (warriors) do, an umbrella - among them the cotton umbrella seems the "cachet" of social importance. It is the only thing they have borrowed from the white man. They never put it up, so far as I could see. You see them running at a tremendous pace alongside a stampeding band of their excitable cattle to head them off when these are in danger of "rushing" a sefari's line. A long spear in one hand, an umbrella tucked under the other arm, neither of these, to all appearance, awkward things, interferes with the splendid bounding stride that carries them over all inequalities of the ground, in a most different and thorny country.

*An interesting tribe, as yet almost unknown. 
Our guide, of course, carried the usual umbrella. We had left the boma, and he, on the strength of two rupees' advance, treated himself to some tea. It was a tiny package only, and was wrapped in many wrappings of discarded newspaper. It was the wet season, and there was a daily downpour, so he carefully tied the precious package to the point of his umbrella, outside.

I made constant and quite useless efforts to restrain the men's gluttony. My best porters seldom or never overate themselves. But some of the biggest and strongest were not to be denied.

The Kavorondo, who live near the lake, signalized themselves in the eating line. I had two immense fellows, who, on one occasion, ate three days' potio, i. e., four and a half pounds of good mealie meal and a great mass of fresh zebra meat (I couldn't weigh it, but it was certainly several pounds), at one prolonged sitting. They began in the morning and kept up the boiling and roasting well into the night. Both, of course, were ill next day, as they said "their stomachs were boiling." They could not go out, as the headman ordered, to fetch wood. I was inclined to be merciful, when David came up and told me the extraordinary story. I promptly ordered them a strong dose of Epsom salts, and saw them drink it with many protestations. But it was all no use, they came back in the evening to say they were out of potio, and wanted more. So David took them for the next two days good naturedly into his own mess, and they kept comparatively Lenten fast with him. After my lecture, as they turned away, I asked John what they said. "The bwana does not know much about eating - any two men in our village will eat a whole sheep before they get up."

These Kavorondo were steady, frugal fellows in their own way. I discharged them at Lundiani, after they had worked well for four months. I saw them roll up their mats, take their little savings, and start on foot for their 
mother's hut by the lake, one hundred and fifty miles away. Most porters would have immediately spent a large sum (for them) in buying a ticket on the next train, and so impressing their relatives with their importance.

Before closing this chapter, which is nothing if not practical, I will add some hints about food which every traveller knows to be an important subject, and in Africa, is doubly important, since good food is not always easily obtained, while the trying climate renders it peculiarly necessary.

I was prepared to put up with poor meat. I was told "African meat is dry and tasteless, and has small nourishment in it." I must admit that much game meat is very poor stuff; that no meat compares for a moment with the flesh of our own wild animals, fed on the short bunch grass of the prairie, or mountain. You never see a bit of rich, brown fat on anything, or indeed, any fat at all, except on a hippo or a lion, which, well, smells! or a cow eland (which you cannot shoot now, though you could a few years ago). But though all game meat here is unaccountably thin, one of the chief reasons it eats so badly is that everyone in the country seems possessed with the idea that it cannot be kept but must be cooked at once, or at most in twenty-four hours.

When I first began to spend my holidays after big game in our Eastern woods or Western mountains, I encountered precisely the same prejudice - and it was not till I made my men use gunny sacks for the meat I wanted for myself, and saw it hung in the shade, safe in its rough covering from flies, but open to the air, that I succeeded in convincing my experienced companions that meat could be kept, when properly butchered, often as long as ten days, and yet remain sound and sweet. So kept and hung, there is no meat game in the world that can compare with our blacktail, wapiti, or mountain sheep. Now, though no cleanliness in preparing, or carefulness in hanging African 
meat, will make it like that, such treatment can, and does, greatly improve it.

On my first trip I had so much to learn and so short a time to learn it in, I never was able to tackle satisfactorily the larder question, though I came away convinced that it was not necessary always to eat such stuff as I had been obliged to put up with. Then, too, I was misled, as who has not been before me, by the confident assertion of those who professed to know what they spoke and wrote about, that such and such parts of such and such animals were dainties. Even in the United States my experience in that line had not been satisfactory, and I had learned to cherish the sad doubt of the disillusioned. I had heard, for instance, of the deliciousness of beaver tail, and believed till one sad, hungry day I made an experiment on a goodly beaver tail, and I found that more nauseous, uneatable stuff a hungry man never tackled. One night I could not get back to camp, but had to make my foodless fire by the side of a big grizzly I had killed. Water was good, but I had not even a biscuit, and many a long mile I had gone that day. A sudden inspiration seized me. Who had not often heard of the deliciousness of soup made from bear's paws? So one of the big skinned, humanlike paws was cut up, and part of it set to stew in my drinking cup. As it slowly, so slowly, stewed, there was a suspicious odour about it. But when it was done - well, one sip was enough, even for so keen set an appetite as mine. Then my cup needed double rinsing. One by one I sadly tried all those famous fabled dainties. Found moose moufle about the only part of a moose that was not good to eat. I make, I say one exception, and that is a good, strong one. It is in favour of buffalo hump. Buffalo hump is - alas, rather was undeniably good.

Well, here noted hunters spin the same unaccountably ridiculous yarns. Elephant trunk! Why you had better 
try and dine off your cast-off, greasy boot. I need not go on. But there are some eatable things even in unpromising beasts.

Rhinos' tails will, if boiled, for five hours, make a fair substitute for ox-tail soup. Kongoni's marrow bones are delicious and unusually welcome since you cannot anywhere get fat. Tongue of the rhino, if boiled all day, is not bad, and it is big! Giraffe marrow is the best I ever tasted in my life, and there is enough in one hind leg to furnish a little course by itself for six men.

The ordinary animals, if their meat is well butchered, will furnish fairly good food. I think the little steinbuck is the best. Then bushbuck, Tommy, and a long way down comes the useful and ubiquitous kongoni, destined, it is safe to say, to furnish you three meals out of four. Lower still in the scale come Grant and reed buck. The men always love zebra, and as you go off hunting, if they know you well and like you, will sidle up saying, "Punda, bwana"; but I have not been able to face it. It is donkey, and smells donkey.

The birds are fairly good. The great bustard, not an easy gentleman to get, weighs thirty-five pounds or more, and slices of him fry well. The lesser bustard is very good indeed. So is the little spurred partridge. Guinea fowl are plentiful and tough. We found it best to reduce them to curry. The breasts make a good curry. But African meat has usually no chance to show how it can serve you. It is almost always handled by natives, and no one takes the trouble to see that it is even kept clean and dry.

Life has been lived rudely, by the white man, everywhere in Africa. (Read Sir Henry Johnstone's book.) $\mathrm{He}$ has been and often is, an exploiter, a ruthless destroyer of its people and its game. "Go out and get a bit of meat," the saying is; and "a bit" taken, the rest is left. I have never seen (I may have been unfortunate) meat hung up, 
and protected from flies, in any sefaris but my own. "Let it go, we will get some more to-morrow," and so they live on tough, badly prepared stuff.

See your game butchered yourself. If your gunbearer does not know how to do it properly, do it for him, once or twice, after that insist on its being done exactly as you say, and if it is not so done, punish promptly.

Open the carcass, have all the paunch removed, see that the bladder and big gut are not broken in the operation, but are drawn out whole. Then make the men wipe it out with grass, and leave the skin on the whole carcass if it is a little one, or if a big, on that part which you propose using yourself. It then is clean, and can be hung up dry in camp. Keep it for three or more days, in the shade of a tree or bush, and you will have fair meat. Keep, too, your soup pot going all the time, and let the coarser bits stew, slowly, in it for hours. Then you have a foundation for a hot soup; a good thing to take when you come in fagged.

Of wild fruits and vegetables there is but poor store. A pretty, yellow-globed tomato, that hangs from a thorny plant, sometimes eighteen inches, and sometimes many feet high, is really of the nightshade variety, and is poisonous.

The enticing little ground melon, the size and colour of a lemon, you commonly see, is of no use. The palm nuts are too tough for the monkeys. The wild olive berries are so bitter that they taint the usually good flesh of purple pigeons that feed on them greedily. There are some yellow, plumlike fruits(the porters eat) but these are far too sour for a European taste. One most delicious berry I have found, but it does not seem to be common. It grows on a bush very much like a blackberry bush. The fruit is like a large, luscious raspberry, but yellow.

There is no denying, however, the excellent quality and 
flavour of the common mushroom. Here it is often as large as a breakfast plate, and sound throughout. While they last, they are a luxury indeed, especially if you have been, as is likely, for weeks without vegetables of any sort.

I should add, when you make permanent camp, direct the headman to put up a rain-proof grass hut for your own use, without delay. It is much cooler than a tent to sit in, and it is better to have the flies, that will accumulate at meal time, pay their inevitable attentions to you in the open air, than swarm in your tent, as you try to eat or read.

I find I left out one delicacy. J. J. W. declares that lion's tongue is excellent, but he had the dish to himself! 


\section{CHAPTER VII}

\section{HUNTING ELEPHANT AND RIDING LION}

NE beautiful morning in late September, with a large sefari, we moved from our camp on the stream that borders the open treeless country, and set our faces once again toward the Rock.

The plateau had already yielded specimens of all the game frequenting it excepting elephant. These, too, we followed on our first visit, but had not had the luck to come on any with sufficiently big tusks to warrant our shooting. In May, June, and July the herbage here is short, thorn trees have not put forth their new shoots, and elephant are not tempted to stay and eat. If they visited the country, the probability was they would pass rapidly across it to the better feeding grounds that Mount Elgon or Kamasea afforded them. Now, in September and October everything - grass and reed and tree - had attained their semi-annual growth, and the thorn groves were just as the elephant like to have them. So we came hoping for great things.

If elephants cross the treeless part of this land, they do so usually at night. Unless they are in a country where they are little disturbed, they very seldom venture into the open flat during the hours of broad daylight. Knowing this we had no expectation of seeing anything of them until we had reached their usual stopping places and feeding grounds, among the many square miles of thorn dotted country that extends from ten miles north of Sergoit into and beyond the wide bend that the Nzoia River makes, as it flows from Kamasea and Cherangang Mountains on the 


\section{HUNTING ELEPHANT AND RIDING LION I6I}

east of the plateau, and bends in a wide sweep round the southern base of Mount Elgon.

But this beautiful morning a genuine surprise awaited us. The sefari, a hundred and ten strong, stepped out bravely. They were as anxious as we were to reach the land of abundant n'yama (game). The long tramp across the Mau escarpment with its cold nights and high and beautiful, but gameless downs, had whetted their longing for unlimited "punda" (zebra).

We had scarcely swung out, well clear of the last vestige of forest land, when a row of strange black dots caught my attention far away on the right of the trail. The sun was only just up, and in its earliest light the ripe grass shone like gold. Against such a background these black things showed up sharply. Could it be? Yes, here, far away, from woodland or cover, here is the elephant at last. We could scarcely believe our eyes. Sixteen great beasts moving steadily along at a pace that seemed far slower than it was. No doubt they had kept to their unerring course the long night through. That dangerous open prairie had to be passed. From the Nandi woodlands on the west they were bound to the Elgao forests on the east, a march of at least thirty miles, and so well was this journey timed, that in half an hour they would surely be in their desired covert.

With curving trunk they marched along, the sun glinting now and then on the ivories. It was a beautiful and interesting sight. I need scarcely say that we examined that dark line attentively. Were they cows and bulls, or were they cows and totos only? Alas! not a bull in the lot! It was a sad disappointment, for here in the open, had there been "tuskers," there was no escape for them. It was the fourth time I had had a good view of elephant, but not once had there been a good tusk in the herd. Once we were satisfied that there was nothing there for us, 
we did what we could to photograph them, but while we waited to make sure of their "ivories," they had gained the edge of a swampy bit of valley where the bush was thick. This wouldn't have saved them from a hunter, but it was sufficient to embarrass the would-be photographer. I got within seventy yards of one big cow, but she went into dark shade and was lost to my camera. Whether any result shall reward our efforts to get a picture I cannot at present say, but even if we failed, it was a most fascinating stalk, the dark bulk of the great beasts, moving in that mysteriously silent way, through brittle and thorny bush. Here and there a vast ear would be thrown out and forward. They seemed to suspect some strange thing near (though the wind was steady and in our favour) and showed some restlessness for a time. Then, having apparently found the sort of feeding they liked, they settled down for the day in the deep shade, and so, undisturbed, we left them.

How is it possible for these animals whose sight is so bad that they cannot detect a man at fifty yards distance, to take the wonderfully straight course, they invariably do, when making their great marches? If you want to steer a good course in a difficult country to find the nearest way from point to point, avoiding rough places and deep fords or swamps, follow travelling elephant. You cannot improve on his topography. He knows where he wants to go and how to get there, by the shortest and safest road, How, without vision which would enable him to recognize locality, he does this, no one knows. He will wander up and down in the bush he feeds in, like any other browsing beast. But once travelling is the order of the day, he "stakes his line" unerringly.

This great country that stretches from Sergoit to the Turquell River is much cut up by steep and swampy streams. In the rains, and for weeks following them, these are so 


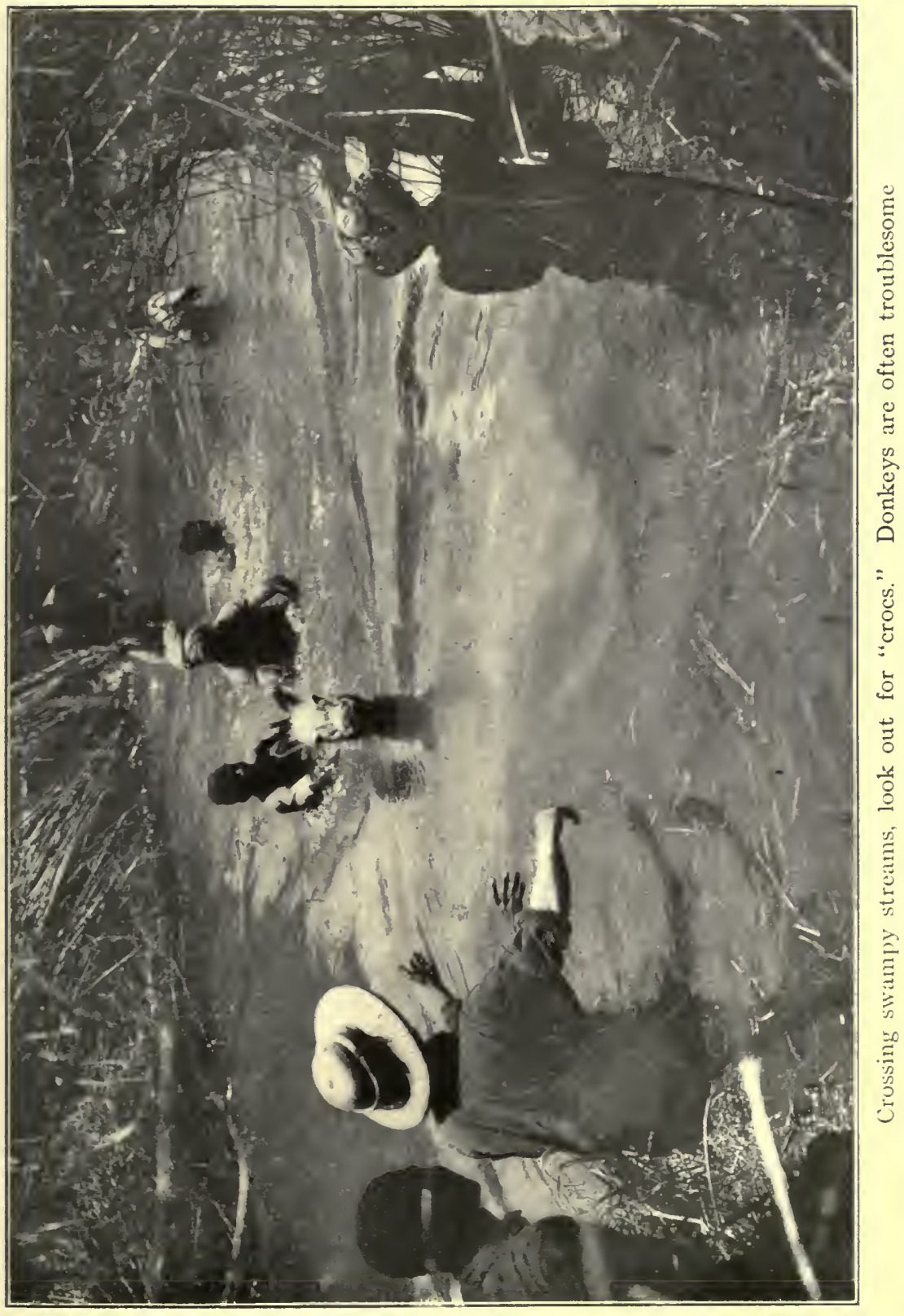



swollen that their passage is often impossible. Even in dry weather the easy crossings have to be carefully sought out. In such cases no hunter can do better than keep his sefari on the higher ridges, taking, so far as possible, the direction he wants, and attempt no crossing till he comes on an old elephant trail. Once one is found a passage can be made. Till one is found much time is apt to be lost in looking it out. Excepting the Congo country, which is closed to all hunters at present, save only to such as can, through Belgian court favour, secure a permit, no district in Africa holds probably as many elephants. The plateau lies between two great fastnesses of theirs the Elgao escarpment on the east and Elgon on the west. In either of these they are secure from all approach, unless it be the stealthy stalking of some unusually adventurous N'dorobo.* A few elephants are annually killed in this way with poisoned harpoons, but they are very few indeed. For the white hunters to attempt them in such cover is dangerous and useless. A few hours' struggle with its underbrush would quickly convince the most skeptical on this point. The great tree trunks break up the air currents, and a steady stalking breeze you never get in the deep forest, while apart from that, a silent approach is out of the question (at least in this forest). But after the rains the great beasts seem to have a craving for light and air, and the fresher fodder that has sprung up on the green veldt, and covered the innumerable thorn trees growing all over it. In little bands and great, they stream down from the high hills, out over the sunny plain. Sometimes a hundred or more may be seen together - cows, smaller bulls,

\footnotetext{
* N'dorobo literally means wild man. The term is applied to any native who, leaving the tribe for a time, or for good, takes to hunting. There are Lumbwa, Nandi, Kikuyu, Massai N'dorobo. But the Pukka N'dorobo are a people apart, with districts and language and customs of their own. Their chief home and country lies to east of the Nzoia plateau and north of Charangang Mountain. Here, amid impenetrable woods and mountains they leave their women and children when they go hunting on the plain. Here too they raise their scanty crops of whimby etc., and here are their only kraals. Other large settlements of $\mathbf{N}$ 'dorobo, Newman speaks of. These live to east and west of Kenia. They are the same people.
} 
and totos, growing and tiny, the great tuskers generally keeping to themselves.

Then is the time when the hunter may take his toll. They are far from any safe retreating place, and the nature of the country makes approach comparatively easy. In a few years at most they may be expected to learn caution, and to descend less frequently or in fewer numbers to their loved pleasure ground. But they have been hunted so little here as yet that for some time to come they are more likely to be met with near the Nzoia River, than in any other part of British East Africa.

Great tusks, too, these Elgon elephants sometimes carry, not so large, it is true, as their cousins of Uganda, where teeth of two hundred pound the pair are quite common, but still very much larger than those of elephants found in any other part of the country. My present companion and hunter, Mr. A. C. Hoey, has been at the death of several of these ancient bulls - one pair, records, I think, for the Protectorate, weighed 137 and I 28 pounds respectively.

No hunting is as uncertain as elephant hunting. They are here to-day, quite fifty miles off to-morrow. They stay for days, or even weeks in a country where almost any greenhorn can shoot them, or they slip silently, like great noiselessly moving ghosts, by your tent fires in the night, and you couldn't persuade yourself of the reality of their visit, did you not see, in the morning, the broadly beaten track.

You hastily rally your gunbearers, fill your saddle bags and rush off on the spoor. Do not be in so great a hurry that you cut short your breakfast, or fail to fill your water bottle. In all likelihood you are in for a wearying day. Put an extra saddle blanket on your mule or pony. The nights are chilly, and you may need it before you see camp again. There is no experience the hunter meets with, in Africa, no pursuit of any of its game, that tries him as 


\section{HUNTING ELEPHANT AND RIDING LION I65}

does a stern chase after a band of travelling elephants. When and where they are are likely to stop no one can tell. The only thing to do is to follow on, sleep on the trail and follow on again. Many of course will not give themselves this trouble, and let a travelling herd go, taking their chances of coming on other bands which are feeding. I should not advise anyone to take up the chase unless he is in fair condition, and a night under the stars has no terrors for him. To go six or seven hours, hard as your men can walk and run, and your mule or pony trot or canter, and then to turn back, is a very wearying business. Let them go, and trust to luck and another chance, or follow on till you get your shot, or the herd gains some covert where they are safe from pursuit.

Though we were not destined to get elephant this time, it seemed a good augury for our future to meet them so soon, and, indeed, this day auspiciously begun was to prove a red-letter day on our calendar. We had made ten or twelve miles of the eighteen that separated us from our camping ground, at the clear spring that rises two miles beyond Sergoit, when $H$. suggested to me that we might leave the sefari and explore an exceedingly likely bit of country, through which in the rains a water course trickled, one of those broad, shallow depressions in the plain that are common in East Africa, its bottom dotted with small rushy hollows where water lay occasionally, its sides sometimes rocky, often sloping smoothly up to the level - an ideal place for lion.

We followed the windings of this open donga for several miles and saw great quantities of game. The nature of the country enabled us often to get quite close before we were seen. Oraby, topy, eland, warthog, scattered before us, but we wanted lion and let them alone. It was a charming ride, and over a country that must soon pass into the settlers' hands. The soil and climate are too good, 
and water too abundant to permit of its remaining for much longer what it is to-day - a no man's land, and only the favourite feeding ground for innumerable game herds.

The sefari had made camp before we rode in. The men came running up to say that J. J. W. and his hunter had shot a great lion (simba koubwa). Another waved a zebra tail that he carried for the flies. "Mane long and black like this!" he cried. Here was news indeed. Elephant seen in the open, and a black maned lion bagged on the very first morning's ride into our old game country. Presently the hunters came in. It seemed that almost as soon as we had ridden away from the sefari, my syce, who was leading my mule, saw a fine lion going quietly along, on the opposite side of the sloping ridge they were marching on. He was about a hundred and fifty or two hundred yards away, and in full view. Both J. J. W- and his hunter shot at him twice without hitting him; a moving lion at two hundred yards, is not an easy shot. He broke into a gallop, and dashed over the crest on to the level veldt beyond. There they had him, for J. J. W.'s syce, a Somali, accustomed to lion riding and very well mounted, rounded him up, in five or six hundred yards. The great fellow must have fed too well that morning, and was not able, or did not care, to run fast or far. Anyway, he came to a stand in short grass. This part of the plateau is ideal country for "riding" - the game having kept the rich sod well cropped, there are few holes and no bushes. The lion stood grandly to bay. J. J. W.'s hunter rode a mule that was faster than his, and in his excitement, did what no professional hunter should under any circumstances be allowed to do, unless you want him to shoot the lion instead of yourself. He galloped ahead of his man, and got up within shooting distance some time before J. J. W. did. The latter who got up on his mule, soon as he could, had forgotten to take his rifle from his gunbearer. So here 


\section{HUNTING ELEPHANT AND RIDING LION I67}

he found himself within seventy yards of a bayed lion, and he and his hunter had only one rifle between them, and that, as it turned out later, was loaded with solid bullets. He did the only thing he could do under the circumstances - took his man's rifle, and aiming steadily, shot the beast, who had not yet begun to advance on them, full in the chest.

The lion sank to the shot but, rising immediately, advanced toward them, increasing his pace as he came on. J. J. W. handed the rifle, a .350 Mauser Rigby, to his hunter, thinking he could better stop the charge. Again and again the brave beast was shot, the bullets taking effect in the neck and chest. He came on, nevertheless, steadily on, till he could not have been more than twenty yards away, when the fifth bullet must have taken him in the heart, for, springing into the air to his full height, with widely extended paws, he fell dead.

I have read of lion so springing upward on receiving a death wound, and I remember in some story book of my boyhood seeing an illustration of such a lion's death. But none of us had ever seen or heard of so splendidly dramatic an ending to the king of beasts. When the skin was spread the great beauty was evident. It was a blacker lion than even my first, and that was a most unusually fine one, not so large by a good deal, but with heavy, waving masses of rich yellow mane turning to glossy black, covering the shoulders, and falling almost to the ground. Unquestionably no such skin has been shot for some time in the Protectorate. He measured nine feet five inches as he lay, and was an old fellow with teeth a good deal worn.

He died hard. But this was accounted for, as I said, when we came to examine the bullet holes. J. J. W.'s man had loaded his rifle with solid bullets when we came on the elephant, and carelessly forgot to change them to 
soft nose on as he rode on his way. It was a piece of forgetfulness that might have cost him dear. Solid bullets are not good things to stop an oncoming lion with. One, or at most two, well-placed, soft-nose 350's would, on the other hand, have taken the fight out of any lion. No man can afford to take any chances with lion. It is by taking chances, or by some act of carelessness or ignorance such as this, that so many men are mauled. But all's well that ends well. And none of us will ever see a finer lion than this one that died so gallantly.

For the next two days I had a bout of decidedly bad shooting. The great herds of game are always far harder to approach than small groups or single animals, and round the Rock a near shot is generally difficult to get, as there is little but cover. Still, with patience, you could even here get within three hundred yards of kongoni and zebra, and at that range $I$ had killed a great deal of meat. But now it was not to be. I felt all the more chagrined as I had promised the men a big feed once we reached Sergoit camp. I missed one kongoni at three hundred, wounded another at not much over two hundred, and wounded a big pig. Then I thought it was time to stop, and for the present, at least, depute to $H$. the task of getting meat for our hungry men.

Next day we moved camp to a place $\mathrm{H}$. knew well, and where, on another occasion, we had seen several lions. The water was fair, but we had to send forty men more than three miles to bring in wood. Tents were pitched in a closer circle than usual, and a large central fire kept going, as our mules, donkeys, and ponies needed hereabouts very special looking after.

Early in the afternoon we rode off for a look round but saw nothing. Next morning I determined to make a very early start, H. and I going in one direction, and J. J. W. and his hunter taking another. The season was so early 


\section{HUNTING ELEPHANT AND RIDING LION I69}

we had little fear of being interfered with by another sefari, and as lions would keep, but elephant would wander away, we determined to make a wide circle and try and cut fresh elephant spoor.

It was dawn, but not day, when I and my man rode off to the westward, toward Elgon. We had not ridden a mile, before we came on elephant signs, that could not be more than eight or nine hours old, and, turning off, followed as fast as our trackers could make it out. Much of the ground was bare, and all of it baked hard, so tracking at times, even though the N'dorobo, we had, were good at their work, was not easy. In a couple of hours we had left the level, treeless plain, and were among stunted thorn and patch, and long grass, that in some places was four or five feet high and very thick. We had scarcely ridden a mile, in this sort of cover when my Brownie and $\mathrm{H}$. at the same moment, saw three lionesses, slinking away, some five hundred yards on our right. It was a most undesirable sort of country to ride them in. You could only see ahead of you, for a little way, and the grass was long enough, even when it was shortest, to cover a crouching lioness. But it was our first chance, and anyway we took it quickly. H.'s pony was a beauty, and very fast. I had mounted my syce (a Somali, who had ridden lion) on a good strong mare, that had a turn of speed too, and for myself, I rode a quite extraordinarily good sure-footed mule. Nothing could separate that mule from H.'s pony. Where the pony went, that mule could not be prevented going, and at a pace that was quite wonderful, for a mule. H. took his .450 from the gunboy, I seized my .350 repeater. Brownie had to follow as best he could, and we were off.

No riding like it anywhere in the world. On, on, the yellow, waving grass often above my saddle, no chance to see holes, or rocks, or fallen tree stems. Amid the thickening brush I had all I could do to sit tight and keep the 
two men ahead of me in view. We started at a hard gallop but now there is a wild yell in front and the ponies are going at very topmost speed. They see the lions before them. The bushes thicken, the grass is rank and high. I must keep near those ponies at any cost, so in go the spurs and we tear along. There were three lions or lionesses - we had not a clear enough view to tell which. But now there is but one ahead. Where on earth are the other two? Where did they turn? Where do they crouch? This thickening grass hides anything, and everything! No insurance company in the world would grant you one of those delightfully comprehensive accident policies, if they but knew what might lie waiting you, all unseen, in that yellow, waving grass.

My plucky mount by now is almost spent - we have raced for more than a mile and a half. Here I am on the brow of a sudden descent, and no man or horse in sight. I saw them not two hundred yards in front, less than half a mile back, and expected to catch sight of them each moment, as I forced the mule along. The lions have swerved to right or left suddenly, and I have swept by the lot. Where are the lions now? And where are my men? I don't fancy one bit riding back through that all-hiding grass, and so dismount. Just in time, as it happens, I hear shouting far to my left, and as I do, there, through the grass, not forty yards away, are two big ears moving. I look beyond and on either side of those ears, anxiously, I confess, for a moment. The tall grass is all round me. This is not the sort of place, by any means, I should have chosen to make my accounting with three thoroughly angry lionesses. Are there one, two, three, ten? Who can tell? Those ears come steadily nearer, just those ears marking a broad head, which remains invisible. They are equi distant. The lion is squarely head on. One thing at least is sure. I must kill the beast with one shot. Now 
they are not twenty yards away. I aim, well below the ears and straight between them. There lies the brain, and at this distance anyone could hit it. I fire, a deep grunt, more than a growl, torn, twisted grass, and big paws in the air. All is still. The grass does not even tremble.

I look with all my eyes into the grass before me and around. No sign of another! And now the shouting comes nearer, and I see $H$. coming at a stretching gallop, my Somali close after him. "Are you right?" he cries. Very evidently I am. "Where are the lions ?" "The grass beat us. We have lost two." "When I heard only one shot I was very anxious. I feared you had ridden into them and missed." Of course we shook hands all round, and vowed we'd not "take on" lions, and more especially lionesses in this sort of riding country again.

It was still very early morning. One of my Wakamba, my second gunbearer, stayed to skin my prize, and we rode back to our temporarily deserted elephant spoor. We followed it all day, losing it sometimes when the ridges were bare. At other times following at a canter, the gunbearers hanging to the horses' tails. But it was all to no purpose. The band we followed separated on some rough ground to hunt for water, and though we made a long cast, in order to pick up the trail again, we failed to do so. It had been a hard day. We had started very early and gone for at least twenty-five miles, and hard as man and beast could travel, and keep the spoor. It was already late in the afternoon, and we turned campward. Our course had been in a wide circle, and fortunately "home" was not more than ten miles away. On the way back we rode almost among a large herd of giraffe. They were looking at something that alarmed them, directly away from us. The riding was good and the grass muffled the ponies' feet, so we were among them before they knew it. I longed for a camera film, but I had used up my last, or I could, without 
difficulty, have taken the splendid towering bull as he stood at less than forty yards from me, before he got his wits about him and trundled off. When at last he got his mighty legs going, $\mathrm{H}$. couldn't resist the temptation of running him for four or five hundred yards - just to try his paces. The pony was of course not at its best, after so long a day, and $\mathrm{H}$. rides as heavy as $\mathrm{I}$ do - one hundred and ninety pounds - but the plucky pony had the pace of him easily. It was most interesting to notice the great bull's tactics when horse and rider were right on him. Without altering his rolling, rocking stride, he would strike out with his rear hind leg, getting off a prodigious kick that, if it landed, would have smashed almost everything.* This he did four or five times. H.'s pony swept him against a low, stout bush, and off he went, so ending the curious race. The giraffe almost immediately pulled up. He seemed to be thoroughly winded, and calmly looked down on us as we wished him good luck and rode by. To shoot such great, harmless creatures, almost sole survivors, as they are, of races of animals long extinct, seems to me a thoughtless cruelty. I speak of the giraffe's extraordinary neck and leg action in another place.

A transparent streak of green blue colour in the east just light enough to see the stones and holes that make riding dangerous, and $\mathrm{H}$. and $\mathrm{I}$ are off again. Yesterday morning we were after elephant sign, and as the lionesses came in our way, we "fell into temptation" - and it might have been a "snare." To-day it is lion we want, and no place in all Africa could offer a fairer chance to get them. First of all, for at least three months, the country has

* I have no doubt that it is respect for that terrible kick of the giraffe which keeps the lion from attempting to pull down the young. No simpler beast lives on the veldt than a young giraffe. He is big, too, and must be toothsome. I watched one near our camp, when we were here in May. But though lions were very plentiful, he seemed to meet with no difficulty. On speaking of this race of ours after giraffe to Mr.F. J. Jackson, Lieutenant-Governor of the Protectorate, and a well known -authority on the game of Africa, he was greatly interested, assuring us that he had never seen or heard of giraffe kicking out in self-defence before. 
been quite undisturbed. No shot has alarmed the wary monarch of the plain. Here there are more lions than in the same extent of country anywhere. Far more! They abound near Laikipia where we have been hunting, but there the riding is not nearly so safe nor the going so fast. There are not only more holes, but the ground is soft, for long stretches of a mile at a time. It is black and sticky, too,. in parts when it rains, and when the rains are over, thesame black soil, baked by the sun, cakes to a bricky hardness, and as it has been much trampled by game, the surface is often exceedingly rough, making it dangerous riding. On the famous Athi plains, near Nairobi, the black soil. is a veritable gumbo, and wild pig and badger holes are so, common, that in many places fast riding is impossible.

Here the going is superb; not, of course, over the whole. plateau, but, just by good fortune, in that comparatively small part of it, round the Rock. Some eight miles to east of Sergoit is a long papyrus swamp, surrounded for many miles, on all sides, by plain. The soil is rich, the grass sweet and strong. The game herds seem, for their mutual protection, to have made an agreement to meet after the rain on this wide prairie land, and to graze it down and keep it down. I say for their mutual protection, for in the long grass that soon after the rains covers the low lands bordering the Nzoia, and also clothes all the country across that river, both lion and N'dorobo can work their will on the larger antelope and the zebra. Neither of these dire enemies of the game find much difficulty in crawling within a few yards of their prey, sheltered as they are by the dense growth of long grass. From that distance the lion makes his terrible rush, and the wild man speeds his deadly poisoned arrow. As the grass lengthens, the larger herds of game leave the lower country for the tableland on which we are hunting, seemingly knowing well, that on it, they are in comparative safety. The $\mathrm{N}$ 'dorobo kill little game on the: 
upper plateau, or anywhere else, when the grass is short. I visited scores of their little hunting lodges before the rains began, in this very country, and found little meat and very little fresh skin. What meat and skin they had was evidently robbed from the lion, as they were constantly hunting up "kills." They seemed very meat-hungry, and lived, they assured us, on honey only, and I think they spoke the truth.

As it is with the wild man, so it is with the lions. They kill, of course, on the high veldt, for a band of them can, during the night time, surround a herd, and so thoroughly stampede it that some unfortunate beast must be dragged down. But they try again and again before success comes. $\mathrm{H}$. has seen them, vainly hunting, far into the morning evidently only driven to this useless, proceeding, by dire hunger. During daylight all the antelope simply play with them, watching their stealthy approach in a half interested sort of way, and then easily distancing them. Two months ago we had a most interesting view of five lions trying to surround a zebra herd at nine in the morning. So intent were the lions that he and his man got two of them, but at no time were the zebra in any danger.

Well, let me get back to my story, and try to tell as well as I can of a ride the like of which will probably never come to me again. There is simply nothing like riding a lion in the world. There cannot be, and soon, very soon, it will be a thing of the past.

We started - H. and I and my syce, as I said - long before sun up, soon, indeed, as there was light enough to see. We had camped some six miles from the great swamp, so that no noise from our sefari might spoil our chances. Moreover, we had not fired a shot near camp the evening before. Such precautions are often thought unnecessary, but it is not so. Lion are timid in the extreme, so long as they have a chance to get away; it is when retreat is cut 


\section{HUNTING ELEPHANT AND RIDING LION I75}

off, when wounded, or when they are thoroughly angered by a hard run, that they are dangerous. Hereabouts, they have been hunted, both on foot and on horseback a great deal. They have learned that it is wise to end their hunting, soon as the sun rises. After that time, the friendly swamps' impenetrable shelter is good enough for them. Just now the grass on the wide prairie round the swamp, while nowhere long, is still at its longest. Here and there are narrow ridges, on which it grows scarcely to two feet high, and scattered among the rocks and hollows, there are patches that will, from a distance, completely conceal a lion. Thus it comes to pass that September and October, of all months in the year, are the very best for riding lion near Sergoit. There is enough cover just to tempt his majesty when the night has been, for him, fruitless, to linger a little on his way home. When the grass fires have swept all the country as they will have done by December, every lion of any experience is sure to be safe in the dry reed border of the damp swamp, half an hour after sunrise; and if anyone would cut them off from their hold, as they return from hunting, he must somehow manage to be there by that time, too.

Remember sixty lion have been shot within sight of Sergoit in three years. It is, therefore, small wonder if lion education has advanced hereabouts. I knew all this, knew that all circumstances favoured me, and hope ran high as we moved out of camp in the dim light of the delicious fresh morning. Mile after mile we rode slowly along, stopping now and then, to search carefully, with our glasses, the slopes and levels before us. Five miles had been passed, and no lion seen. Now half a mile away, the dark green papyrus wall stood out sharply against the grass yellow, of the surrounding prairie. "Let us sit down here and have a good spy," said H. "I have never been here yet at this time of year without seeing lion." The words 
were scarcely out of his mouth before a tiny yellow spot, fully one thousand yards away, caught his eye first, and then that of my gunbearer Brownie. I heard Brownie whisper "simba," and an instant after H. clapped the glass into his pocket. "A lion - and we can cut him off! The going is splendid. He is ours!"”

We started at a hard gallop. The gunbearers, of course, came along as fast as they could, but were soon far behind. But H. and I carried our rifles, he a double .450, I the gun I always use - my .350 Mauser repeater. Now to the naked eye that yellow spot, above the yellow grass, on the far-off ridge, was visible. $\mathrm{He}$ is watching us, but cannot make up his mind to run. A hundred yards more, we are within a third of a mile of him - he is off! As he clears the grass and bounds away with long, clean stride, every bit of his splendid lissome body is visible - a full grown male. Now it's sit down and ride hard as man and beast can go. A yell, and we are off! The horses need no urging. They see their game and race for dear life. He holds his own, or almost his own for about half a mile. No twining grass or weeds pull him back. And then we gain fast. I try and keep within a couple of hundred yards of the racers, and so staunch is the fine mule I am riding and so eager is he not to be left behind, that though in the first keen rush the ponies distance me, I am almost holding my own now. More than a mile and a half we have ridden. I can see the lion is done. Suddenly he halts in his stride, he drops from gallop to trot. $H$. is past him in an instant. He wheels to bay, stands looking first at one pony, then at the other, then back at me. His retreat is cut off, and he knows it. For a moment he lies down and takes his breath, then slowly rises to his feet. His tail swinging from side to side - which of the three of us shall he tackle? There is no time to lose, so I cut him down with two shots.

We had only just dismounted and were congratulating 
each other, when one of H.'s Massai comes rushing up, running as only a Massai can, and pants out, "simba." Sure enough, we had ridden by another lion, who was making his way homeward. Doubtless as the chase tore by, he crouched. Anyway, all our eyes fixed on our own lion, we never saw him. But as the running men behind us came along, he moved aside, and now, they said, he was making for the swamp over the very country we had passed. Would the ponies stand it? He had such a start, more than a mile, and the swamp was not over two and a half miles away. Try, anyway. So it's up and off again.

Fortunately for us, this time our lion didn't hurry himself, and not being pressed, proceeded with some deliberation. Still, to cut him off from that green, upstanding papyrus wall, seemed impossible. He was watching the rush of his enemies, evidently, for as the ponies were driven, not after him, but at right angles to his course, he came almost at them, as he galloped down the long slope, leading to the reedy river that flowed out of the swamp above. We were riding for all we were worth, and as near to the river edge as we dare go, he to our left on higher ground, we below him, edging minute by minute more and more between him and his one chance of escape. Now horses and lion were done. H., quite close by this time, could see his tongue hanging out like the tongue of a fagged dog. He'll race no more. He turns and comes right down the incline. H., riding finely, makes one more attempt to head him off, but his gallant pony is spent, and boggs badly in the soft ground. At a few yards distance the lion jogs by him, and $H$. throws himself from his pony, and, as the beast almost gains the outer and thinner fringe of reeds, takes a snap shot at him in hope of making him turn and stand. The bullet cut the flesh of his hind leg without breaking the bone, and the brave beast wheels to it like a flash, and growling loudly, advances on $\mathrm{H}$. I 
was coming up, the going heavy, just as fast as my tired mule could gallop, but closer up I could not get, for deeper and deeper the bog ground grew, when I saw something was the matter. $H$. was trying to go backward as fast as he could. His pony, free of his weight, was out of the scrape, but $H$. seemed about to get into it. The lion was not coming on very fast, but his wound had angered him, and unquestionably, he meant business. Why $\mathrm{H}$. was trying to get away as fast as the soft, swampy ground would let him, of course I could not tell. In any case, I had to do my thinking quickly. I was two hundred and fifty yards away (afterward we measured the ground and thought it three hundred - a long distance from which to make a diversion in my friend's behalf); but $\mathrm{H}$. and the lion were getting far too close together. I must do my best, and do it quickly, too. I threw myself off, the ground was clear of grass just there. I could see all the length of that fine, long side. I drew a deep breath to steady my shaking arms, and a quick sight, aiming well over the backbone. "Phut!" The bullet was home - a little far back, as it proved, but only a very little. Anyway, it took the fight out of him. He slowly turned round growling, and instead of going farther to the papyrus, lay quickly down a few yards away in the long grass bordering the stream we had been riding along. I left my quite beaten mule, where he stood, and made as fast time to H.'s side across the bog as I was able. When I got there, the mystery of his retreat was cleared up. He hadn't had time to grasp the bandoleer that held his cartridges in the hurry of our second start, and thus it was that he found himself, after firing that snap shot in the grass, which, fortunately, made the lion stand, facing an angry charge in a most disadvantageous position, with only one bullet in his gun. The grass was rank and high on the borders of the stream where his horse had bogged. He had a very poor chance 
to make a good shot, and the only thing to do was to get on firmer ground just as fast as he could, and keep that single cartridge till the lion was a few yards away. My lucky shot had saved the situation, which otherwise might have been serious indeed, for though he would probably have stopped the lion, no man, no matter how steady his nerves, cares to face a charging beast with one cartridge.

We walked up together to the little grass patch that now completely hid our game. We shouted and waited, no sign. The lion was lying low. To enter it was not for a moment to be thought of. The reeds and grass grew seven feet high, and he would, though mortally wounded, have pulled someone down. As I said before, he had crawled into a narrow bend of the stream, and as we looked the situation rapidly over, I noticed that on the other side of the water only a few yards away the bank rose sharply for a few feet. Could we gain that point of vantage, I thought we had him at our mercy. Would he let us go quietly by him, within a few yards, wade the stream, and look in to his lair from the other side? We formed our gunboys silently into line across this possible line of retreat, and ourselves stepped through the edge of the high cover down into the water which here was almost five feet deep and running strong. I must admit that for myself I was profoundly relieved when I found my footing at last on the other bank. free from that strangling grass that hid everything at three feet distance. Here I was my own man again. Here, indeed, all risk was over, both for ourselves and our men, and we had him, at last, under our guns not ten yards away, and in a position from which we could at least partly see him. The moment we stood on the little elevation, and had our heads at last above the grass, the lion saw us, and made his one last hopeless effort to come on. He rose, swaying from side to side, and growling deeply. I finished him at once, with a shot in the chest. 
Five miles that morning we had ridden, fast as good horses could go. Our game in full view all the time, not a bush, not a rock to hide it for a moment, no cover of any sort, till the long start the second lion had on us, enabled him to gain the swampy ground and bordering reeds that fringed the stream. $H$. said he never had had quite so ideally perfect a ride, and as we again grasped hands over our lion, safely down, we agreed that there is not, there cannot be, anything in all the world quite equal to riding lion on Sergoit plain.

As they lay, the lions measured nine feet four inches and nine feet five inches: full grown males.

It is interesting to note the way a ridden lion advances on his enemy. These two, and the others that were ridden and shot, stood or laid down for a moment to rest and get their wind, and then rose and faced us. None of them growled loudly, as did my first lions when hit, none of them attempted such a roar as the wounded beast that mauled Mombo gave utterance to, as he was roused from his painful lair, and came for his tormentors. These snarled and, thrusting the head forward and the ears down and back, just as an angry cat will, advanced rather slowly at first with stiff tail. Mr. Hoey who had killed and helped to kill many lions, tells me if they are missed or only slightly wounded, they increase steadily the pace of their advance. Generally speaking, lionesses seem to crouch lower than lions, and to come more quickly, too. This renders a really charging lioness one of the most difficult shots that can be made. None of my lions bounded in, after being wounded, except the first, and he stopped and raised his head at fifty yards distance from me. From what I can learn from those who not only shoot steadily, but observe the beast they are shooting at (and there are not a great many hunters who really do this carefully and constantly - nine times out of ten the accounts one hears are the unreliable fancy. 
sketches of excited men who, in the presence of dangerous game, let their guns off as rapidly as they can manipulate them), the advancing lion comes forward to the final attack more slowly than is generally supposed, and if he is missed, certainly quickens his pace. He seems scarcely ever to charge at once when brought to bay, but needs an instant or two to make up his mind as to which of his enemies he will select. This instant's delay is, of course, the time to shoot him. To do this I always, when it was possible, sat down. No time is lost in sitting; the motion is very much more rapid than kneeling, and the rest on both knees immensely more steady than the partial, swaying rest of one. The only disadvantage of the sitting position is that once you have taken it, you must abide by it for you cannot get up quickly. This, I hold, is its very greatest advantage. To change position, and move around in the face of imminent danger is folly. It is straight shooting that is wanted then, not active jumping. There is another argument in favour of sitting to receive a charge, that I think is worth considering. The sitting man does not attract the same amount of attention as the man who stands, jumps about or runs. A restive horse or mule near by is far more likely to draw a lioness charge when wounded, than a sitting hunter.

Only to-day a poor fellow, terribly mauled by a lioness, has been brought into Nairobi. He and another young fellow rode her. They rode too close, the old story, and like a flash she turned, his horse bucked, and bursting the girth, threw him almost into her jaws. The lioness sprang on the kicking horse, not on the semi-conscious man. She clawed the former, but it kicked free, and she was actually leaving the ground when, dazed and not understanding the folly of his act, the unarmed man staggered to his feet, when she was on him in an instant. Poor boy! Tall and strong, seven days of agony have pulled him down 
dreadfully. His fine condition will save his life, but I hear his left arm is doomed.

Two men in the last three months have lost an arm, and almost their lives, riding lions. In both cases the same mistake was made. They pressed the beast too closely. No horse can turn or stop as can a cat. I have seen a cheetah I was "riding" - an animal very much faster than any lion, and that can easily outlast one actually stop in its very stride. It was as though its claws were glued to the earth. It did not seem possible that such a sudden halt could be called, by anything that ran. Nor can any other beast show the desperate speed of a cat for a few yards' distance. Mr. Percivale, the game warden of the Protectorate, who has probably ridden more lions than any man in the country, tells me that he, though well mounted, was once almost pulled down by a lion that he had ridden into cover. $\mathrm{He}$, too, on that occasion, came too close, the lion for some reason or other, dispensed with all the usual preliminaries and rushed at him. He turned his horse as quickly as he could and rode for his life. He had quite fifty yards start, and yet he believes that, had he not fired his heavy revolver into the face of the lion when it was almost on his horse's hind quarters, both he and it would have been pulled down. Mr. Percivale was alone. There was no other horse or hunter near to divide the lion's attention - this, perhaps, may account for his very unusually rapid and deadly attack.

Hoey was attacked by three lionesses, near the Rock. The only provocation he had given them was, that he had shot two hours before, the lion of the band. He was riding back to his camp unarmed, having left his rifle with his gunbearer, who was skinning the lion he had killed. The three saw him, from a distance of quite two hundred yards, and pressed him hard, for a quarter of a mile. He was riding the same fast mule that I rode, and so distanced them. 
There are one or two things that any man riding lions would do well to remember: First, do not follow a lion or lions in to cover if you are on horseback - not even thin cover. Once you have chased a lion he is a very different beast from the beast that rapidly slinks away from you when you are hunting on foot. In this last case he instinctively knows he can get away if he cares to. In the former, he finds you have the pace of him, and, resenting that, he will attack with determination. The second lion $\mathrm{H}$. and $\mathrm{I}$ rode on that memorable morning, when we chased two and shot them in half an hour, had after H.'s bullet had only stung him, every chance to walk into the impenetrable stronghold of the river grass, if he wanted to. It grew thickly not twenty yards from where he was first hit. But he did not want to do anything of the sort, and angered by the long, hard chase, and casting all idea of further retreat behind him, he came boldly away from the covert he had striven so strenuously to gain, and advanced quickly into the open to grapple with his pursuer.

To follow a lion in such a mood into even short cover, on horseback, is to court death. You are within a few feet or yards before you know it. His terror-striking growl as he rushes in will render your mount unmanageable, and make shooting out of the question. You cannot escape, and are at his mercy. This is, of course, also the reason why it is folly to ride lion in grass or bush country. You see one to ten galloping in front of you, next moment some of these have vanished. You may not ride into them, but you may, and if so, you are done for; and then, at best, you will do no more lion riding that trip.

Second, the man who does the shooting must dismount without delay or hesitation. He must quickly choose his place, fixing it in his mind as he gallops up, if possible a spot from which he can command the lion for a few yards every way, and on which he can plump down. 
If there is no such place, of course he must stand up and shoot. All delay is dangerous. Get him before he rushes in on any man or horse. Any cool shot can knock a lion out, with one shot, at one hundred yards or less. No living man can be sure of doing this to a rushing, charging, snarling embodiment of death. He must remember that he has to depend on himself and himself alone. The man or men who are mounted can do little or nothing to help him. A plunging horse is a poor shooting platform.

Third, all, riding a lion, should ride not behind him but to one side. You may not be too near as you gallop along, but he can check his paces so much more suddenly than you can, that if you, from the position you have got yourself into, are obliged not to swerve your horse, but to turn him round in order to gallop away, you are in extreme danger of coming to grief.

Fourth, remember there are plenty more lions in the country, even if you lose the one you are after, and take no needless risks. You may hunt lions on foot for months and have no luck. Well mounted, and in a good country, you are certain to get them. So do not ride too close. Pull up at a hundred yards - that distance gives you plenty of time to take five or six steady shots, let the lion come any way he choose; but make up your mind beforehand that steady shots shall be aimed at certain spots in him, and not ploughing up the ground round him, only angering him, and demoralizing yourself.

Summing up the whole matter, no man can tell what a lion will do, how he will come, or whether he will come at all or no. He may die as tamely as a house cat, or he may make you shoot for your life. And just here is the unequalled fascination a man experiences in pitting himself against the lion in East Africa.

Let no fool persuade you to think of shooting from horseback. 


\section{CHAPTER VIII}

\section{ELEPHANT}

T HAVE been for days struggling through swamps, cor1 duroying little streams that seem easy to cross, till you try to cross them. Then they swallow the mules and donkeys, swallow them down; and donkeys must come along somehow, for donkeys mean "potio." Two fine mountain ranges looked down on our strivings from the east and the west, while far away to the northward, where the early morning air was clear, stood out the tender blue outline of an unknown, or rather, unmapped mountain chain, rising above the Turquell River that falls into far-away Lake Rudolph.

The exact whereabouts of my camping I may not, in fairness to my guide,* disclose. His patient and persevering study of the country, and of the ways and wanderings of the great elephant herds, should be as much his perquisite as are my ivories when I have shot them. "The way in" cannot long remain unknown; but I certainly shall not "give it away," and I am confident no sportsman will expect me to.

Mr. Hoey and I had worked quite conscientiously for elephants since we had arranged our partnership; had turned from no spoor that was at all promising, till all reasonable chance of coming up with our game was gone. So long as elephant are not thoroughly alarmed, or have not had your wind, or smelt the sefari, it is well worth while to follow on and keep following, even if the trail when you

* On this my last sefari to the Nzoia country, I had secured the services of A. C. Hoey (Eldama Ravine) as I wished to know the natives of the Cherangang range, and also to ride lion. I could not possibly have found a better man. 
"cut" it, is quite twenty-four hours old. They may be found dozing under some shade trees only a few miles in advance, or cooling their rugged flanks in the moist mud of one of the numerous marshes. Or they may be resolutely forging ahead at a pace just a little faster than that at which your splendidly agile natives can follow, never to pause or rest or feed, till some dearly loved haunt of theirs, known only to themsleves, is at last won.

Following up spoor, then, is of ten trying work, far harder work than the hunter is called on to engage in in the pursuit of any other animal. Of course, many men get many elephants without following up the trail at all. They camp near some favourite river crossing, or within reasonable distance of swampy feeding ground, and keep their natives scouring the country for news. This is a good and, if you persist long enough, a generally successful plan of proceeding. The natives of a district in which elephant are to be found are nearly always ready to lend a hand, as the meat is most welcome to them. But, as I have said elsewhere, the sefari should be so constituted as to make communication with the shy wild man easy. Interpreters are as important in its make-up as porters and cooks, and this the inexperienced stranger is slow to realize. Here in this very Nzoia country, only a few months ago, we missed elephant, though we hunted pretty thoroughly for them for three months all over it. It was a game of hide and seek. The elephant would cross the river while we were at the swamp, or spend the night in the swamp while we were watching the river. We never won over the N'dorobo. Had we succeeded in doing so, we could not well have failed of success. We had no one among us who knew either them or their language. When we met Nandi N'dorobo, who are no use whatever, but are only the wandering outcasts of blacklegs of the Nandi tribe (a flock owning people, having some affinities to the Massai), and, 
consequently, are but poor hunters, we could not distinguish them from the Pukka N'dorobo of the Cherangang range, who are the very best hunters in all the country, and who know every corner of it. These, however, on the other hand, are so shy of strangers that you must have secured the strongest of introductions to get near them at all. They are watching you, you may be sure of that. They keep themselves well informed of all your movements, but beyond, perhaps, the casual glimpse of a black dot of a head, seen for an instant only above the grass or over a rock, so far as you are concerned they might be non-existent.

The help of real wild men hunters, it is no exaggeration to say, at least doubles your chances of success. Promise them a blanket, or a goat or two, and they will be off at dawn, and stay away all night; and if the great game is either feeding or travelling in your vicinity, you will in all probability learn of it from them. Stay in camp till you have reliable news, but be ready for a hurried departure at the shortest notice - and once you are on fresh spoor, with capable trackers, follow on! follow on! The nights in the warm season, when the grass is long, and elephant come down from the mountains, and out from the impenetrable forests to feed, are most pleasant. It is no hardship to sleep out. You have your saddle blanket, and your men quickly put up for you a grass hut, giving complete shelter. Carry always some biscuits in your saddle bag, and a little salt, as well as a bit of dried meat. Thus prepared, a night out is a pleasure, and after it you will look forward with renewed zest to camp luxuries of coffee and steaming hot bath, when you do get in.

Of course, there are lucky men who happen on elephant that seem to know they are to be killed anyway, and help their pursuers to do it. Elephant will at times come down to a swamp and refuse, even by gun fire, to be driven from it. They will stand to be shot down, and do all sorts of 
unaccountable things, and sportsmen who have been thus favoured by them, have often been known to say that elephant hunting is a simple matter. But ask the men who know. Read such a book as poor Newman's, who was the greatest elephant hunter East Africa has ever seen, and all say the same thing. No sport is so arduous as elephant hunting, perhaps none is so dangerous, though I think there is little doubt that, for the relative numbers of elephant and lions killed, the latter take a larger roll of human life.

The denser forest country of the Protectorate holds still a very large number of elephant, but from its very nature, it is of little use trying to shoot them within it. The breeze is too uncertain, a silent approach impossible, and a resolute following up of the wounded out of the question. Hoey has spent months trying to kill some of the very large bulls that bury themselves in the dense tangles of the Elgao woods to east of our plateau. He has secured just one, and that one came out into the open one August evening.

There is another element of danger besides the elephants themselves that attends forest hunting in these regions. It is the game pit. Now game pits, even in the open veldt, are bad enough. They are so cunningly concealed that an observant man may fall into them and be quite seriously hurt - three of my men did so this trip. But when these deadly death traps are set in densest wood, concealed by creepers and heavy shade trees, armed too, let it be remembered, in many cases with sharp stakes set so as to impale any unfortunate that falls in, then commonest prudence will avoid following game where they are known to be used.

Chatting by the camp fire two nights ago, we were discussing the likelihood of securing a good buffalo head in the lower ranges of the Cherangang to the east. The old chief of the Cherangang N'dorobo, who accompanies us on our trip, listened for a time, and then said: "Yes, there 
are many buffalo, but there are many game pits also. They are nearly all armed with sharp stakes. The lower Cherangang N'dorobo will make them, and when the grass is long, they take much meat. But they are very dangerous to men as well as game. The lower Clierangang N'dorobo are paying toll still to me, for one of my young men staked in one of them last year. Some years I lose two young men, almost every year I lose one. If the N'dorobo find them dangerous, you would find them much more dangerous. Do not hunt buffalo or elephant there, not at least till the grass is burned." Wise advice, it seemed to us, on which we determined to act.

$\mathrm{H}$. had an experience two years ago - not in the forest, but in the comparatively safe ground outside it - which might easily have been fatal. He came on some elephants, and was creeping close to one that stood on the other side of some bush; as he was going to fire, his game moved slowly on and, at a few yards distance he followed, trying for a shoulder shot. There was a narrow opening before him, wide enough just to permit the bulky body of the elephant to pass. To his astonishment the great beast, instead of taking the evident path before it, without pausing or seeming to make any examination of the ground, deliberately trod, not in the open space, but full in the middle of the dense thorny bush on one side. Thought $\mathrm{H}$. to himself, "What a fool of a beast. I'll cut it off, and get a good shot." He rushed down the narrow clearing to do so, and in an instant was crashing down into a ten-foot deep pit, a cocked double .500 rifle in his hands. Had it been staked, he would never have come out alive. As it was, he was badly hurt, and had to wait till his men found him, and dragged him out. In a few years game hunting by the N'dorobo will probably be stopped by government, though it seems a little hard on these brave and independent people, that customs that have been 
theirs from time immemorial should be banned. But at present they are utterly uninfluenced by the white man's near approach. They live where their fathers have for ages lived, and they live as their fathers have lived, defending their mountain homes against the raiders of various tribes, hundreds of times more numerous than they. They dig their pits, use very deadly poison on their arrows, and elephant javelins, and procure what little iron and brass they need, in exchanging ivory and skins with the Swahili traders.

Let us leave their forest stronghold inviolate. These will shelter for many a year the breeding elephant, and though the N'dorobo do take toll of the herds, they will never wreak the destruction in years that an ivory poacher would accomplish in one season.

I need scarcely say that all cow elephant are sacred in British territory to-day. Cow ivory is contraband, and heavy fine is imposed for killing a cow. Nor can bulls that carry tusks of less than sixty pounds to the pair be shot. Of course, careless or inexperienced sportsmen do still at times mistake a cow for a bull, but a little care, and a little coolness, are all that are necessary to avoid any such mistake. The cows are smaller than the bulls, and their tusks saldom weigh anything like thirty pounds each. The one thing above all others to remember, once elephant are located, is to take time, and on no account rush in in a hurry. Make sure of the bulls. Make sure of the one you want. Estimate his tusks for yourself, and then carefully keep him in sight as he saunters in and out among the crowd of those you do not want. So long as the wind is fair, and the herd not alarmed, there is no reason whatever for hurry. If the wind is steady, keep a watchful eye out for the animals at either extremity of the herd. See that they not do edge in toward you. In scattered woodland, stalking, of course, is easier and safer, too. Trees and 


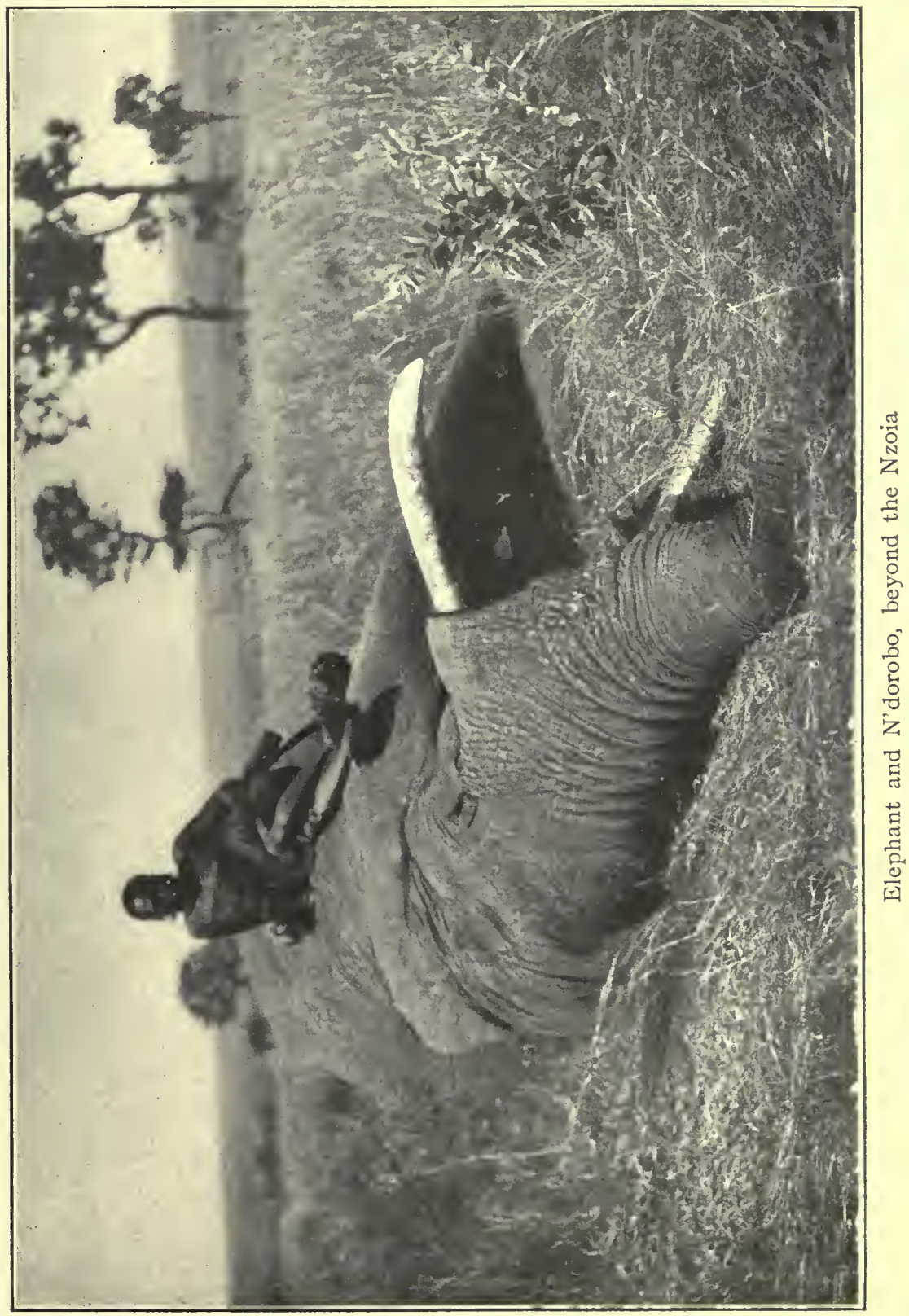



brush are a great assistance, and I do not think any man can come up close to these monsters, without wishing that somewhere, near at hand, might stand a friendly tree. Under all circumstances their sight is so poor that they do not seem able to pick a man out at forty yards. In deep shade he can stand still and remain undetected often at twenty. But let them once catch your wind, and they are off at a pace that baffles the best footman - or on you, in a charge that may be difficult or impossible to turn aside or avoid. A close shot from a good rifle in the head or chest will often make the animal receiving it swerve sufficiently aside to save the hunter, but if the herd move down in line, as they often do in the open, or if you let yourself get between two herds, your chances are not good. A friend of mine, a gallant fellow and a good shot, saved his life once when so charged by a herd of twenty in the open: he dropped his rifle, and waving his hat in the air, danced and shouted with all his might. "But never again," said he, "will I tackle an elephant herd in the open." Another good sportsman I know well, followed too closely a herd into very thick thorn scrub. The wind was puffy, which made his doing so exceedingly dangerous. One of the corvs got scent of him, and trumpeting loudly, charged. She was followed in a rush by all the rest. He fired into the onrushing mass of them, but it was no use. Tied by the thorns he could not run, even if running had been any good. Nothing remained for him but one terrible chance. He threw himself down, and the ponderous charge trampled over him. His coat was torn from his back by the foot of an elephant, but miraculously he somehow escaped without a scratch. He, too, says he has had enough of elephant shooting.

In the days when ivory hunting was permitted, two resolute men could sometimes kill a considerable part of a herd. Mr. Newman succeeded once in driving over sixty 
elephants into a morass and securing the tusks of thirty of them. It is only a very few years since such slaughter was forbidden in English territory. Many an adventurous or broken man turned to elephant hunting for a living, and to-day many an explorer or sportsman, pushing his way into the Abyssinian country, expects to pay a not inconsiderable part of his heavy travelling expenses out of the price he hopes to get for his ivory. Selous, as he tells us in his well-known book, made his living from ivory, and Newman was reputed to have laid by a large sum. These and all other ivory hunters killed everything, big and small, cow and bull, that carried tusks. If ivory averaged them ten shillings a pound, and their animals averaged them sixty pounds the pair of tusks, each elephant would mean $£ 30$ - a large sum. But when the outlay that was necessary is taken into account, the long distances food had to be carried, the great journeys made, the preparations for defence against uncertain or warlike tribes, but little profit remained to most of them. In the Protectorate, under present government regulations, no one can kill elephant unless a $£ 50$ licence is taken out. This permits the holder to shoot two. A third he can take, on his paying £I 5 extra. It seems to me that these restrictions are not sufficient. Many an idle man is now tempted, when word reaches him at Nairobi or elsewhere, that elephant are in some approachable locality, to take out a licence and enter on a small speculation to the amount of $£ 50$. He seldom covers his expenses, it is true, but surely no good is gained by encouraging his onslaught on the fast disappearing game. I should advocate the issue of a special permit costing $£$ Ioo to kill two elephants in the Protectorate, and so check the present very prevalent custom among settlers and loafers, of trying to make a little money each year from their slaughter. Many poor beasts go away wounded, and there is no doubt at all that some undersized tusks are taken and 
traded or hidden in this way. A man paying $£ 50$ for a licence to kill two elephant, and who goes after them, hoping not only to cover his expenses but to make money, cannot afford to pay the fine imposed for shooting undersized tusks, nor can he be contented with small ivory. The temptation in his case is very great therefore, to leave elephants he has killed, if they are small, and go on shooting till he has secured animals that pay him.

The elephant herds are comparatively few and small, their range comparatively restricted, and there is good reason for preserving them. In Uganda the case is very different. There elephant still are found in immense numbers, and there they do, in a cultivated country, very great damage. The natives are not permitted to shoot or trap them, but there is no penalty for trading in ivory, as there is here. Such regulations have created an anomalous condition. The honest native protests against the wholesale ruin brought on his shamba, by beasts he is not permitted to kill, while the very officers who rule the country may, if they choose, and sometimes they do choose, trade to their profit in ivory. The Swahili traders go everywhere trying to buy tusks, and carry evil and disease with them wherever they go. Surely the whole situation needs reviewing and rearranging. The two governments should act together. Here, where I have been travelling, on the Uganda border, there is no semblance of control on such a traffic. Any number of tusks killed thereabouts could with utmost ease be taken over the long, imaginary frontier line, and no man but the unscrupulous trader be the wiser for it.

Something must be done in Uganda, for the herds are on the increase and the damage they do is great. White men, if they are not professional hunters, will not, in large numbers face the risks of the climate, so long as elephants, even smaller ones, can be secured in the healthy uplands of British East Africa. Professional hunters cannot possibly 
pay their expenses if they are limited to three bulls. It would seem to be a wise thing to license certain well-known men to kill, within certain districts in Uganda, a given number, and to trade ivory of reasonable size, they depositing in the government's hands a considerable sum - say, $£ 300$ as their guarantee. A very substantial licence fee would be paid, and the gain to the government and the province would be considerable, for the ordinary ivory trader, getting his ivory as he can, whether it has been smuggled over the frontier or killed by natives who have no right to kill it, is nothing less than a cause of evil and demoralization wherever he goes.

Modern rifles are so deadly that one or two shots, if the elephant are standing, bring them down. But those shots must reach certain vital spots in the vast bulk, and many, forgetting this, confused by the very size of their mark, only wound and fail to kill. Perhaps the surest shot of all is the shot between the eye and the ear, nearer the ear, and if you are standing so close as to be obliged to shoot upward, lower than a line drawn between themfor of course, the bullet travels upward. The African elephant's brain is very small, and protected by heavy bone formations. Look at him as he faces you, and there is no palpable place to aim at, as in the Indian elephant. He can be killed, and quickly, by the frontal shot, but that shot must be aimed well below the eyes where the trunk and head join. There the cellular structure of the skull permits a solid bullet to pass through quite a lot of light packing, as it were, straight to the little brain. Full in the middle between the tusks the ball must strike, in order to kill, and there must be behind it the driving power of a good charge. As I have looked elephants full in the face at thirty yards distance (I don't care for a nearer front view) the mark seems a small one to me, and unless the animal was on top of me, I should prefer to take him low 
down in the chest. The eye and ear shot is easier, if only he holds his head steady for a moment, though that mark too, is not large. Care must be taken to shoot below the line of eye and ear as the bullet will range upward. I repeat this, as again and again good men shoot too high for this shot, and then the bullet does no permanent harm. He may stagger to the blow, but is soon going off, and going strong. As he swings straight away from you there is a good shot to be had, one of the easiest, one of the deadliest - and, strangely enough, one seldom taken. His spine makes a great curve from its highest point in the centre of the back down to the root of the tail, six or seven feet long this curve extends, and the vertebrate column is fully ten inches across. Land a bullet in it and he comes to a halt. It is a big, fair mark. High up in the hump of his mighty shoulders is another vital spot. If you are standing alongside, and grass and bushes are so high that a clear view of the shoulder cannot be had, here his backbone is at the very widest where the shoulders rise to it. Two feet six inches or three feet from the top of his back straight above his legs - put a bullet there and he falls like a $\log$.

But I have reserved for the last place my final hints, if I may modestly offer them. The shoulder, or just behind the kink of his big foreleg is the easiest mark and quite deadly enough. There lies the great heart, quite as big as a large water bucket, and any man who keeps his wits about him, and fires from broadside, can hit it. Let anyone examine the skeleton carefully, or stand by while the carcass is being cut into, or cut up, and he can satisfy himself on these points I have named. The trouble generally is, men fire wildly at the vast mass, plant bullet after bullet somewhere. They really don't know where - and then go away and insist that an elephant cannot usually be killed without great expenditure of ammunition. At thirty yards, 
not too near at all for a shot in cover, if the elephant is threequarters facing you, you can easily send your 450 through the shoulder into the heart, and he will not travel one hundred yards, and, what is important, you have no more need to fear his charge.

Most shots in the side fail for two reasons - they are too far back, and they are too high. Few hunters seem to take the trouble to stand by the bloody, high-smelling mass, and wait till they see for themselves how far forward the heart lies, and how low down. When a boy I had, of course, read Sir Samuel Baker's sometimes extraordinary stories of the impossibility of quickly killing elephant. I remember well handling with reverence in Riley's gun store, in Oxford Street, his famous elephant gun, which he nicknamed the "Baby." It took a half-pound shell, if I remember rightly, and I do not dare to say what was its powder charge. It certainly did damage at the butt end, whatever it did at the muzzle. Selous was, I think, the first man to try a small bore .450 on elephant.* He did so because one of his other rifles was not to hand when he wanted it. Thereafter he used that calibre constantly. Then came the day of real small bores, the .303 English gun. Men found that rhino and elephant came down to well-planted shots from even that inferior weapon.

To-day no one who has had experience burdens himself any longer with the old-fashioned heavy rifles that were for so long deemed indispensable. I think that shortly the use of even a .500 or .577 cordite rifle will be uncommon. They are not needed. Any good rifle with a powerful powder charge will kill an elephant stone dead if the bullet, however small, is planted in the brain. It

\footnotetext{
* This was of course a black powder gun, very different from the cordite .450 of to-day. But in Selous's time, and in the country he hunted, you could ride elephants on a trained pony, galloping up to them, and galloping away. There was no need for the stealthy approach. You easily escaped the charge. In East Africa elephant hunting is no such simple matter. The odds are much more. Even to-day many are maimed or killed and elephants that have been much hunted are very dangerous.
} 
is quite common to shoot in this way the largest bulls, even with the tiny .256 Mannlicher, or the .276 Mauser rifle. I have known an elephant to fall dead within two hundred yards to one shot from a .256 Mannlicher that penetrated the whole length of the body from behind, and at last lodged in the heart. On the other hand, it is still quite easy, even with the most powerful of modern rifles, to plaster an unfortunate beast all over with bullets, and not to bring him down. Twenty large bullets were fired into one bull by my friend's professional hunter and his gunbearers before the poor beast fell. I amused myself on several occasions after I had secured my elephants, by stalking close up to beasts I did not wish to kill, and thinking how and where I should shoot them, if I did wish to kill. I seldom found them holding their great heads steady enough for me at least to attempt the head shot. Either they were feeding, or whisking away the flies, or there were branches or cover between, whereas the shoulder, or the spine shot offer a target so large that it can easily be hit even in a moving elephant.

The great home of the elephant is in the Congo. There just now many hunters, some licensed, and most of them not, are bending their steps. The old régime is over. The king of the Belgians' authority has been superseded, and the new rulers of the country are not on the ground. I believe a case of champagne, falling into appreciative hands, has been known to remove obstacles hitherto deemed insuperable. As much as two tons of ivory have been lately taken out of the Congo by one hunter in four months. There are reports flying about of even larger kills. They say that elephant there are not so dangerous as with us in the Protectorate, and certainly there do not seem to be anything like the same number of fatalities among Congo hunters that there are among men following elephant in Uganda or the Protectorate. It may be that those who 
set out for the farther country are generally more experienced, men who have studied the dangerous game against which they pit their lives. Here accidents keep happening because anyone who can borrow a gun and take out a licence fancies himself capable of elephant hunting. Taking little notice of wind or cover as they do, the marvel is that so many escape. A man is a fool to take any liberty with an elephant.

So long as ivory fetches the price it does, and it must increase rather than diminish in value, it will prove a sore temptation to a poor man, finding himself in elephant country, not to attempt to pay off at one stroke the heavy price of his shooting licence. It is for that reason that I think sportsmen should welcome any legislation that places the elephant in a class by himself, and makes the man who wants to shoot one or two in British East Africa, where they do no damage, and are not too plentiful, pay heavily for the privilege. (Uganda elephants are another matter.) It seems rather a hardship, on the other hand, to prevent the native hunter who for ages has taken his modest toll of the herds, and certainly has not destroyed them, from doing as his fathers before him have done, just because rich sportsmen want all the fun, and the ivory too.

Allow him to trade his occasional tusk if it is sizable. Forbid him otherwise to trade at all. Employ the right sort of traders to trade with him, and grant licences for such trade. Do this and the law will enforce itself, and small ivory and cow ivory will not be killed. Instead of prohibiting all ivory trading, which can never be stopped, give an opening to honest men to do the trading. There will be no difficulty in finding them, for there is money in the business. At present the Kikuyu, N'dorobo, and other tribes have hundreds of tusks of buried ivory only waiting the coming of the unscrupulous ivory runner. 
$\mathrm{He}$ is the very last man who should be encouraged to have any dealings with the native.

So far as I could learn, the two small bands of Cherangang N'dorobo, kill about one or two elephants to each band yearly. The Elgao perhaps as many more. Some of the old men tell me they have killed forty. This is probably an outside number.

H. and I had determined to try and make our way into a new country, not a very extensive one, still a region so guarded by river and swamp that our N'dorobo declared, and we believed truly, no rifle shot had been heard within it for ages. They declared that when the herds were chased off the Nzoia plateau, they went to this place and stayed there or near by for a long time. There they would show us elephant "like the grass" - a term they always use when they speak of large numbers.

We had had two very hard and unavailing "follow up" rides. On each day we must have covered not less than thirty-five miles, and this is enough for a day's going under an equatorial sun. One day the herd separated, and on hard ground we lost them. On the second, a fine herd headed straight for where J. J. W. and his hunter were waiting for them, so once we had assured ourselves of where they were going, we turned away from a fresh spoor. We had our difficulties to overcome, of course; we expected as much, the heavy work falling on $\mathrm{H}$., my weak knee rendering it difficult for me to do more than look after myself. I could not swim, for fear of putting it out again, but we managed to flounder through somehow. Here let me say a word about what you can and cannot get natives to do for you, when you are in a difficult country. They know the country well - so much is a matter of course. But though they do, once they find themselves in the company of the "bwana" (white master) nothing seems to induce them to take the initiative. Is there a bad swamp to be 
crossed? They will wander aimlessly along its side, or gaze at its quagmire hopelessly. You must decide the line of country, you must select the crossing. Were they by themselves they can go ahead. If you are present, you must go ahead, or, if not, minutely direct them where to go. They are of course utterly ignorant of how to get a mule or an ass over. They know where they want to go; they know where the game is likely to be, and where its long, tortuous ramblings will probably end; and in these matters they are to you of inestimable value. The rest you must do for yourself. We found ourselves after a time in a country that certainly had every appearance of being the undisturbed home of many elephant bands. The broad tracks of herds, and the single ones of bulls, crossed and recrossed each other. The thorn trees had been much fed on. The high grass was trampled and eaten. Still we had come to no fresh sign for two days.

One morning in early October, surely a red letter day, we broke camp very early and had ridden about three hours through a swampy country when, suddenly, without any warning, I heard a far-off, shrill note blown. It sounded more like the clear note of a high organ stop than anything else I can think of. $H$. had said to me, not five minutes before, "This is the first morning we have had in ten days that I should call a really good morning for elephant hunting. The breeze is fine and steady."

Here at last were the elephant. Here in their own chosen home, not harried by Boer settler on the plateau or hunting sefari, but resting in their own land, under the shadow of the great mountain that had sheltered their herds for countless thousands of years. Here, safe from all harm, amid solitudes that had seldom echoed a rifle shot, it seemed like vandalism to enter. But the truth must be told - to be the first there but added to the zest of entrance, something of the barbarian charm of conquest. 


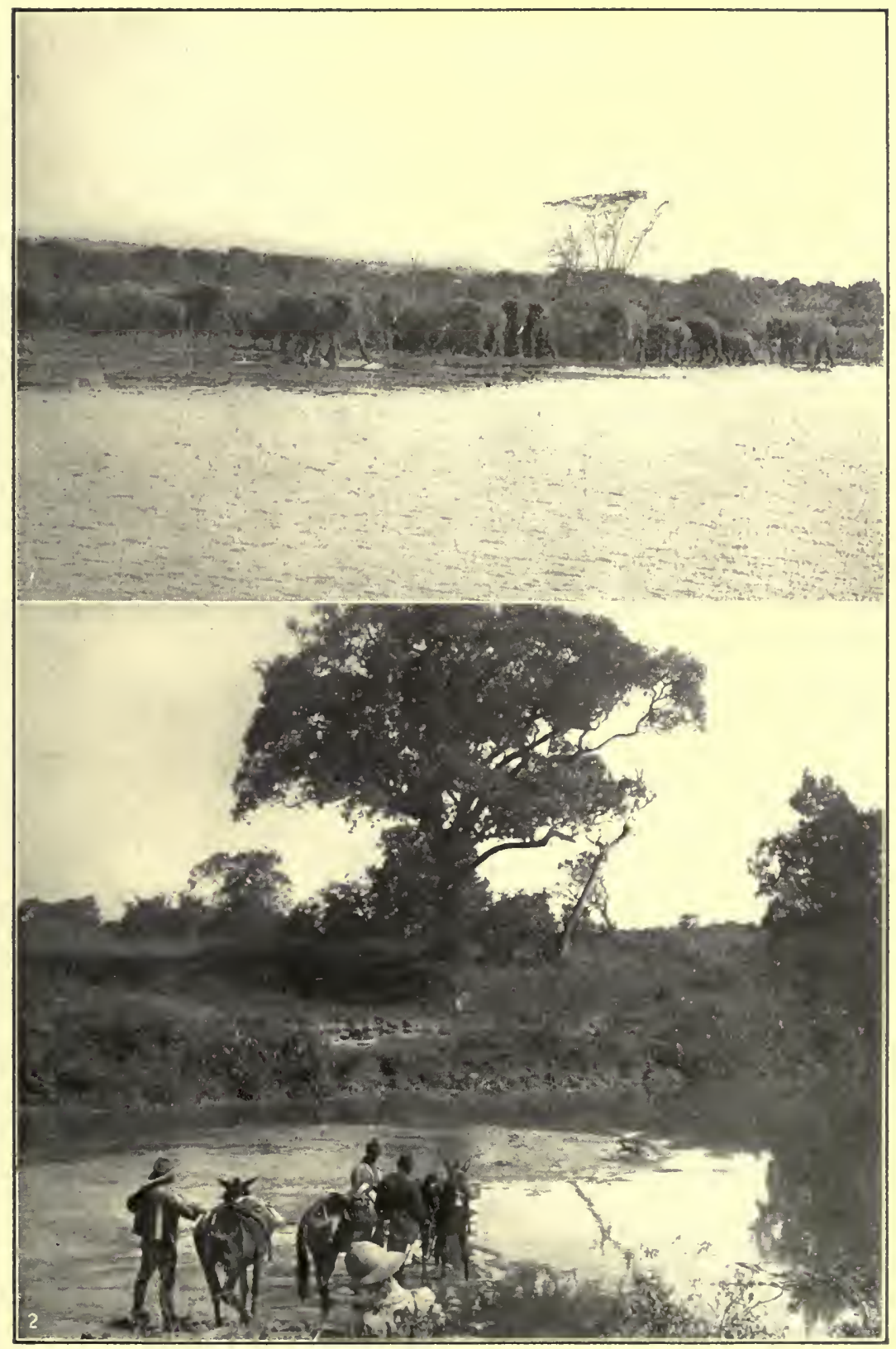

I. Elephant herd. Photographed by W. A. Bowring. Presented to the author by C. C. Bowring, C. M. G.

2. Elephant ford on the Nzoia 

The shrill, carrying, but far from unmusical sound was borne to us on the cool morning breeze from a distance of quite a mile, and, strange to say, whether it was that they recognized the note, or sniffed the wind tainted with the smell they fear, our mules resolutely refused to be led or driven one foot nearer. So we left them there, and went forward on foot.

Crowning the next swell of ridge, standing sleepily under the shady trees, we saw some twenty great black backs rising above the yellow grass, and outlined against the sky. Somehow, as they solemnly and slowly moved forward, for they didn't stand still for long, ploughing their way through the rank grass, yellow as ripe wheat, they reminded me of nothing so much as the big black whales I had rowed up to, on the lower St. Lawrence. The herd - we now saw they numbered about thirty - moved out of all cover into the wide prairie. But they were far from suspecting any danger, and had evidently no idea of travelling. They amused themselves by tearing great wisps of the grass and throwing them over their own and their friends' shoulders, and spouting red dusty showers on each other. The finely curving trunks often touched, and were slowly carried from side to side, or round the little black totos that, almost invisible, in the tall grass, moved along by their mothers' sides.

As I mounted the ridge the elephants had slowly left, a wonderful prospect opened before me. On my left hand, deep purple masses of virgin forest sloped down from mighty Elgon to the wide yellow plain, now clothed with golden waving grass six feet high. Before me for mile after mile those grass lands spread, bounded only on my right hand by the other great woodlands that fell downward from the mountain range to the east. Here at last was the home of the elephant, and as I stood on its threshold that glorious October morning, down from their inviolable 
fastnesses of the mountain, came not one, but three herds in stately march before me.

I stood a long time on the ridge's crest and tried to fix the panorama in my memory. Here was Africa indeed. The Africa of my dreams. Africa that had been hedged off, hidden away from the busy movements, the all-changing activities of restless man. The Africa that had known no change for thousands and thousands of years. Here it lay at last at my feet. It waited for me. I had come a long way to see it, and that morning's view well repaid the toil.

After carefully examining all three herds, there must have been more than one hundred elephants in them we concluded that there was not an extraordinary big tusker in the lot. And this was not to be wondered at, as very large and old bulls seldom are permitted to keep in the herd, and so are usually found alone.

The wind, as I said, was steady and fair for us. But the herds stood in such relation the one to the other, that it was impossible to pass between them. Had we attempted to do so, we should have been quickly inclosed. There were no specially large tusks in the farther groups, so I determined to take two quite good-sized bulls, who led the herd we had first seen. And now the last hundred yards of approach alone remained, and, keeping well down yard by yard, we drew near.

I had often been told by men who had shot many elephant, that everyone's knees felt a bit weak when, for the first time, he stalked close for the shot. I cannot honestly say I had any such feeling. A thought of the presumption of it all did come to me, as higher and higher the black bulks towered. What pigmies we were! And what mere popguns our rifles seemed. How could we harm creatures as mighty as these? Why did they not move forward in a body and crush us into the very earth? Had they wished 
to do it, nothing could prevent them. No tree, no shelter, no hiding place of any sort. As the black bulk of the herd rose above me, I felt as a man might feel who proposed to himself to shoot into one of our high New York Central locomotives, with about as much chance of knocking it off the line, as he had of bringing down this mountain of black life.

When we had crawled within about fifty yards, there was, for some cause or other, a movement in the long black line. It grew longer, stretched out, and for a moment or two threatened to bend inwards toward us at each end. The elephants seemed to suspect something, and the curving trunks were held high in air, and the great black ears rose upright at right angles to the heads, standing out on either side like sails of a boat running dead before the wind, and going "wing and wing."

We had, naturally, an anxious time of it for those few moments as we crouched watchfully in the grass. Any flank movement of the herd would give it our wind, and they then would come down on us, or rush away. Their suspicions died down, and they again stood still.

Now was our time. Perhaps fifteen yards nearer we pressed. I was, of course, to do the shooting, $\mathrm{H}$. to fire after me. My bull kept moving his head up and down, so I determined, rather than risk the head shot, to take him in the shoulder and well forward. I picked my spot and fired, $\mathrm{H}$. firing immediately afterward.

Then arose pandemonium! First they all seemed to rush together, then wheel outward, facing in all directions. Then such trumpeting and noise of mingled cries! My bull stood for a moment, and as he wheeled I shot him again, when, to my surprise, I admit, he crashed to earth with a rumbling noise, and never seemed to stir again. Now the herd swayed and rocked, all huddled together. At one moment it looked as if they would sweep forward, 
next they swayed backward. We reloaded fast as we could, and I fired again at the second bull, and it was, I think, well that we did so, for this seemed to decide them and they rushed off.

We ran after, fast as the high tangle allowed us, and in five hundred yards came on them again, all standing heading our way. These elephants had probably never heard a gun, and this would account for their standing as they did after our shooting. But by now they were very watchful, evidently trying hard to make us out and get our wind. But the merciful breeze kept steady. We drew up as close as we dared, not nearer than seventy or eighty yards this time, and tried to pick out the second wounded bull. But the cows covered him, and an adventurous young bull came forward by himself, evidently bent on mischief. $\mathrm{He}$ walked out of the herd, his trunk held high, and, looking very ugly indeed, sharper-eyed than the others, he must have been, for he came perfectly straight. We let him come as near as we dared, for I certainly didn't want him, as his tusks were much smaller than the other two. No sign of turning about in him. He now saw us plainly, and was coming right into us when two bullets took him full in the heart and he fell in his tracks. At his fall there was more rushing hither and thither of the bewildered and angered herd, and both $\mathrm{H}$. and I began to wish we were in sparsely wooded country, and not on a shelterless plain. Nothing could be done, absolutely nothing but to be still and let them quiet down, then follow up our wounded bull. As we anxiously waited, he came out our way slowly heading to our right - a very big fellow, with good ivory on one side, and on the other a stumpy, heavy tusk broken off. Again as crawled as near as I dared, and saw close above me his great black side, I could not help thinking what a game of bluff it was, but he offered me a fine broadside, and crashed down to the shot. 
Both leaders had fallen, and those elephant stood without moving ten yards for, I should say, a quarter of an hour, while we profoundly wished they would take their leave and let us crawl away. I tried once more to get near enough to take a good photograph, while $\mathrm{H}$. came alongside covering me with his rifle, but before I got within fifty yards the cows screamed so, and so evidently were ready to charge in a body that I had to content myself with, I fear, an unsatisfactory "snap."

At last they began to move - very slowly indeed - and as they went one way we gladly crawled the other. Three bulls down, two of them moving more than twenty yards after the shot - we had been fortunate indeed and we knew it. In an hour or two the herds had moved about two miles away. Some were feeding, others settling down into the long line formation that means travelling - were beginning what was doubtless to be a steady march across country, to the blue escarpment on the east.

We camped the sefari and had our tea. I never enjoyed it more. Some of the elephants only travelled for a few hours after our attack on them, and then headed back to an extensive patch of thorny country not more than five miles from our camp. It was easy to keep in touch with them by means of our N'dorobo. They remained feeding on the mimosa shoots for another couple of days, before leaving for the nearest forest land to the eastward.

The last evening we were camped to the northeast of Elgon, one of our wild men came in saying that a herd was making its way campward. We started off immediately, and John, my tent boy, who in all his far wanderings had never seen an elephant, begged to be allowed to come along. It was one of those evenings one loves to remember. The heat of the day was over, and a steady soft breeze, fragrant from its passage over wide stretches of blossoming mimosa thorn, on which prickly delicacies 
the great beasts love above everything to feed, made walking delightful.

We soon had them in view and the stalk was an easy one, though, since the herd stood in the open and far from cover, we had to go cautiously. We got within fifty yards and carefully looked them over, but as no good bull was there we left them in peace. I tried a photograph, but heavy clouds had gathered over the mountain, and the light was poor.

As we leisurely strolled campward, the black storm clouds burst among the cliffs and cañons of the great crater summit of Elgon. For a few moments, no longer, no mountain could be seen, and incessant lightnings alone marked where the rocky points drew down the electric currents. Then the sun beat through the storm, and all the many square miles of broken forest that clothes, and softens as it clothes, the jagged outlines of broken scarp and crag, were actually lit up by the evening glow. One great mass of snowy cloud still held together in the very crater itself, and on it the full strength of the sun seemed to fall, till it radiated over the cliffs and dense masses of woodland round it, a soft white light all its own.

I never fancied anything so strange or so lovely. The secret places of the great mountain that were quite hidden before, stood for th to view, as this lower light searched them out. Then the smoky spirals of drifting cloud still clinging to the tree tops, the leavings of the warm storm, rose at last in silvery columns, slowly freeing themselves from the earthly claims that had bound them, and you could hear the augmented roar of the river torrent, as it came down the dark cañon of the Turkwell.

The last evening light fell tenderly over the yellow plain, while slowly the mighty herd moved off into the darkening east.

Let me close my rambling chapter by saying that I 
should not greatly care to kill any more elephant. They are too big, too old and wise, to be classed as mere game. As I stood by the side of that vast fallen bulk, I realized I had extinguished a life perhaps more than three times as old as my own. What had not these great beasts seen and survived? What comings and goings of the tribes? What changes among the petty bands of men. He was probably a full-grown elephant when Livingstone first resolutely set his face toward Africa's unknown interior. I felt small, and a little guilty. 


\section{CHAPTER IX}

\section{NZOIA PLATEAU AND ITS TRIBES}

$\mathrm{F}^{\mathrm{XCEPT} \text { on our own plains bordering the Rocky Moun- }}$ invigourating than the breeze blowing over this green and beautiful land. Some day it may prove to be the health resort of the country. There are a few papyrus swamps, but I never saw a mosquito. Flies there are none, nor fleas, nor ticks (the pest of man and beast); the soil is evidently rich, the grass rank, except where the vast herds of game keep it down. And the forests on its borders furnish the finest and most abundant timber in East Africa. As I said before, Boer colonies from the Transvaal, have put in applications for the whole of it. And the value they place on possible holdings there, I saw illustrated but yesterday when one of them (a few are here already) calmly said, he had sold his concession of I0,000 acres to a newcomer Boer for $£ \mathrm{I}, 200$, and this, be it remembered, was before he had put up one fence post or turned one sod. I doubt greatly whether the Boer's proposed transfer of a farm he had done absolutely nothing on, and which had cost just the survey fees (less than $£_{40}$ ) and not another penny, will be favourably considered at Nairobi headquarters. This same Boer loses no single opportunity of openly saying he hates the government under whose too easy rules he has already acquired these 10,000 acres of fine land, at one halfpenny an acre annual rental; and yet he actually proposes to himself the raising of a sum, which to him is a fortune, on such terms as these.

It is only fair to the rest of his countrymen, who are about 
to establish homesteads here, to say, that they have been the first to see, and avail themselves of, the advantages of the Nzoia Plateau. So far as a stranger could judge of them, by talking with their leaders, they were appreciative of the country, and of the easy conditions offered them to acquire homesteads in it. The Boer certainly has a good eye for country. He will take trouble to find the land that suits him, and having found it he sits down on it, and makes a home. This is just what the Englishman out here does not do, he crowds where some of his fellow countrymen have already settled, and even then nine times out of ten only buys that he may sell at the earliest possible moment. Now the Boer may move on in this land, as he has moved on and on in other lands. But even if he does, he yet stays long enough to outstay the Englishman. And I must say it looks at present as if he was likely to hold and control ultimately much that is best in the Protectorate. He objects to the present arrangement of long lease for the land, he prefers actual ownership, but since that is denied him by the law as it now stands, he takes up his holding on the best conditions permitted him, confident in his own stubborn mind, that long before his eighty or ninety years lease is out he will have a good deal to say as to the terms of its renewal. $\mathrm{He}$ is wise in his day and generation is the Boer, he knows that the man who stays by the land, will in the end settle the terms by which the land stays by him.

Of all these things and many more I thought as I saw the sun setting beyond western Elgon. Ah, indeed, whoever holds it, this is a land beautiful as it is rich, and so far as human foreknowledge can go, likely to furnish homes of peace and plenty in the future.

For many years this green land has been tenantless, the chosen haunt of bands of lions and herds of game. But it was not always so. If the dead could come back to claim their own, if ghosts of cruelly injured peoples walked and 
could haunt the scenes of their wrongs, this would indeed be a gruesome and uncanny land to dwell in. Even the unobservant sportsmen cannot fail to notice all over this country innumerable stone circles and walls, more or less solidly put together, which stand in groups, some big, and some little; many thousands of such dwellings, or stone outlines of dwellings, still stud the veldt, and crowd on the hilly slopes of the plateau and the country nearby. Who raised them? When were they built, these habitations so unlike all other African dwellings? What evil fortune has overwhelmed those who once lived therein? No one can answer with any certitude these questions. The wandering Nandi, the N'dorobo of the neighbouring mountains, mumble something of "the spirits" that long ago were the builders. None of themselves have any idea of a stone kraal.

In other countries tradition of some sort lives for several generations, at least, and the name of the tribe, if little more, is sure to survive the tribe for long. Here it is not so. Names among these people mean little. The name Lumbwa for instance, now used by that tribe living near the lake, is not their rightful name. So lately as fifteen years ago they called themselves Sikesi. The white men who came first to this country on their way to Uganda before reaching them, passed through Massai tribes, of whom they asked naturally the name of the people they should next meet. The Massai said they were "Lumbwa," their own term of contempt for them. By it therefore the visitors called them. By it they have ever since been called, and by it they have ended in calling themselves.

The very name, then, of the unfortunate people whose kraals dot perhaps the richest plateau in East Africa is uncertain. Probably they were called Sarequa. Were they a fighting race, who held their rich home land against a league of tribes that coveted their herds and unequalled pasturage? And were they, only at last, by overwhelming 
numbers destroyed? One of those ill-fated races, to be found in all lands, who, like the Irish, "went out to battle and always fell?"'

Was their last stand made on one of these high hills, still crowned by their rude buildings? Or did some withering plague, such as still walks in the noon day of Africa, some deadly pestilence of long ago,lay its blight on a whole people? Or were they a timorous and unwarlike race, shrinking from open fight, and seeking in rude intrenchments a means of defence against neighbours stronger and more warlike than they?

Few may ever question, none may ever know. The mighty forest and rich, encroaching veldt will soon blot out their only memorials, these strange stone circular foundations of their homes. They are gone, and but one more is added to the innumerable and forgotten tragedies of this sad and. beautiful land.

Nor are tragedies here things of the long past alone. Not three years ago, a scoundrelly Goanesse trader conducted against the Turkana, a tribe, not yet placed under English rule, a private war of his own. It began with a well organized cattle raid. Then, when the unfortunate people tried to recover their own, the robbers swept them down with rifle fire; then more cattle were driven in, then another useless onslaught by the ill-armed Turkana followed. After several months of such wholesale buccaneering, the trader was actually taken by the authorities into Barengo boma, and the Turkana were told to come in and identify the cattle if they could. It was hard to get wild men like these, who had lately had such bitter cause to distrust the white man, to come. But some of them came. The murdered men naturally could not. Many cattle were identified by them, and these the trader gave up. He was then allowed to go, keeping the rest. He returned to more settled regions with his stolen gains, and actually succeeded in selling a part 
of them. One thing above all other things this country wants badly, and wants now. A strong impartial government. That is just what, alas, it has not got. A policy of "cover-up," and "hush-up" at any cost, prevails. If an official fails in his office, or if worse than that, he has been guilty of more than one failure, too often the course pursued is one of concealment. "Let us not have a scandal whatever we do." This criticism may seem harsh and uncalled for, especially coming from a visitor who has received, as I have, on all hands, nothing but kindness and courteous consideration. But I have fully convinced myself, by actual personal investigation, of its unfortunate and literal truth. The difficulties facing the executive in British East Africa are very great. Every allowance should be made for those who are set to do a task, with means utterly inadequate to the accomplishment of that task. But however inadequate those means may be, the policy of hushing up, and pretending not to know flagrant wrongdoing of public officials, must be ruinous to official discipline and efficiency.

This raid of Mr. —, known all over the land, was not punished as it should have been. It is true that there are difficulties in procuring evidence, natives would have to be brought from a long distance, expense might have to be in incurred, but if an example was once made of such unscrupulous villainy, it would strengthen the hands of every single magistrate in these far scattered posts, and help greatly to raise the prestige of the native police (askari), which by the way, needs raising badly. That hundreds of innocent men should be murdered in cold blood, for attempting to defend their poor little all of possessions, that this should be done within an English protectorate, and that the man doing it should remain not only unpunished, but untried, is surely not according to what is best in English tradition.

In a land where disorder and injustice has wrought its 
evil will for countless years, British rule should be just, wise and strong. Here, it would be but unkind flattery to describe it as being anything of the kind. The fault is not with the individual civil officers. These must impress any fair minded man as being usually most hard working and competent. But there is no sign of settled policy anywhere in the Protectorate. There is a too evident lack of system, of coöperation; no man is sure of being firmly supported if he does his job well. Men are aimlessly shifted from post to pillar. From work they have but just begun to understand and to do, to other work, for which they cannot, in the nature of the case, be as well prepared to do. Good material is wasted, good lives and much money thrown away, and everybody is grumbling.

The southern portion of the plateau is now well known. A district commissioner has taken up residence there, and stores will soon spring, up like mushrooms round the "rock." Three years ago it was a no man's land, where all who came looked for enemies and sometimes found them. There can be few places, even in Africa, where the laws of change have worked so rapidly.

The northern portion has as yet scarcely been travelled or hunted at all. South of the Nzoia, since the Nandi war that is, for the last three years - raiding by the tribes has generally ceased. And the small but continuous blood lettings, so common wherever the country is not actually policed have stopped. The Nandi whose rich lands lie to the west of the Plateau, till they were defeated and brought to reason, were responsible for most of the quarrelling.

They were far more numerous than the other tribes to east or north of them, and their young warriors found amusement and adventure in raids, big and little on their feebler neighbours. The Nandi are an intelligent and interesting people. Some of the women especially, having features that strike you at once as refined. Like the Massai they 
are not only polygamous but polyandrous, and I think in great part this moral laxity is fostered by tribal custom.

For many generations, how many no one can tell, for African tradition reaches but a little way back, the Massai tribe set the fashion (to put it briefly) in war and peace, for East African native life.

The power of this strange and strong people has been broken. Wars among themselves, carried on with ruthless determination, wars, in which for many days continuously, thousands of warriors fought from morning to night an endless series of desperate duels, man to man, while, camped closely by, their women looked on, have decimated them.

Then came the rinderpest, and carried away all their cattle. On these they were wholly dependent, and the Massai perished in thousands. If cruel fortune has in late years dogged their path, none can say it was undeserved. They had trampled bloody pathways all over East Africa. The invaders had penetrated even the Mombassa streets; and from time out of mind they had boldly lived up to their creed, one article of which was, that God had given to the original father of the Massai all the cattle on the earth, and no other tribe could lawfully hold a goat, sheep, or cow.*

The Massai were enabled to win their victories and maintain their power, because they alone were organized for war. This war organization enabled them to mass their soldiers at any given point more quickly than could other tribes.

Every male Massai between the ages of twenty and thirty was a warrior (moran). He lived in separate villages (munyatas) with his fellow soldiers. And these soldier villages were placed in such strategic positions as the chiefs thought would best assure the safety of the other villages, where lived the old and married men, and round which were pastured the innumerable and splendid herds, which the

* See "Massai Language and Folklore," p. 270, Hollis. Oxford, Clarendon Press, A most interesting book. Notice in Mr. Hollis's book the extraordinary similarity between many of the Massai folklore stories and the stories of Uncle Remus and Br'er Rabbit. 


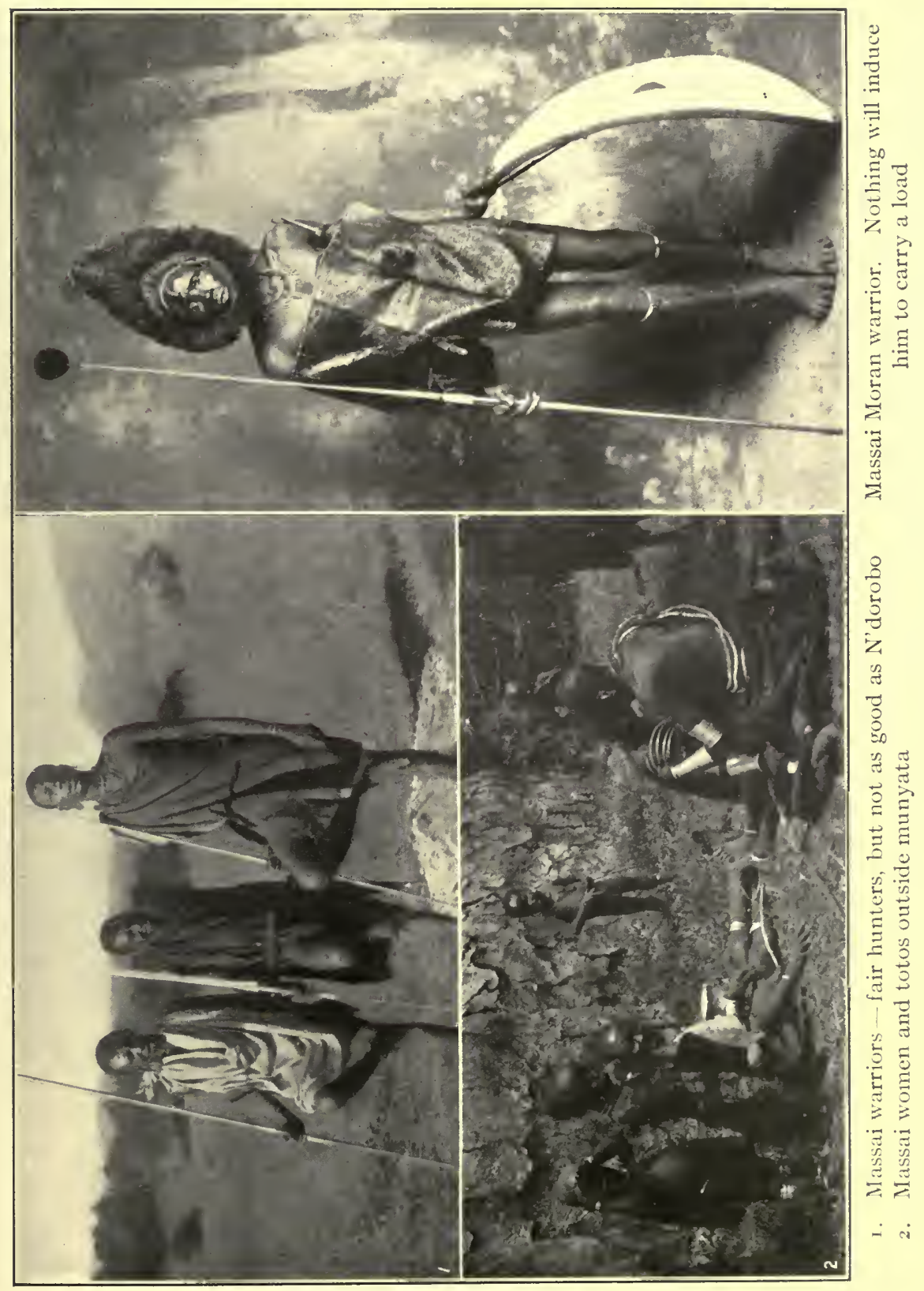



Massai owned and by which they all lived. on milk and blood.)

(They live only

North of the Nandi country the wide spreading slopes of Mt. Elgon rise. These are seamed and broken in an extraordinary way, owing to the tremendous activity of the great volcano years ago.

When first seen the fine purple masses of the mountains, seem to rise gradually and smoothly right up to the rocky cliffs that form the upper lips of the crater. But from a nearer point (and to gain it requires some hard and patient marching, fighting through swamps and crossing and re-crossing soft banked streams) the real nature of an African volcano is revealed. The mountain (I 4,200 feet) is split and torn. Groups of mighty kopjes are tossed up here and there, while there is at least one cañon cutting the broad summit almost in half, splitting it up, a vast gash into its very roots.

Through this fine gorge, rushes down the clear volume of the Turquell River. I stood on its banks after a hard day's marching and my men waded across into Uganda. The delicious water was cool, and far above us we could see where now and again it forced its way white and foaming down the rocky defiles of its mountain home. On the southeastern slopes of Elgon a little known tribe, called the Katosh, dwell. The people used in the riotous days gone by, to retreat with their cattle into a range of mountain caves of great extent. They barricaded the entrances and generally seemed to have made their defence good. These caves, which are of great extent, were hastily visited by Joseph Thompson when he made his famous journey from Mombassa through Massai land, to the Lake, in I883. $\mathrm{He}$, in the most positive way, pronounced them to be artificial, the work of a remote age. Since then several competent men have explored them (which Thompson had no time to do) and there can be no doubt that they are natural. 
I refer to the Katosh, because, though I had no time to visit them, I came very near to being spectator of a pretty little native cattle raising affair between them and a large Elgao war party.

As $\mathrm{H}$. and I made our way northward toward Turquell, looking for elephant, we crossed the quite fresh trail of a large war party. There was no mistaking that narrow beaten path which the foot of men moving in a long single line leaves on the veldt. Who were they? Where were they going? Had I come across such a trail four months before, it would have meant nothing to me. I might hunt the country over from Elgon to Cherangang, and Sergoit to the Turquell, and know really nothing at all about the people that thickly inhabited all the mountain lands that, from west, north, and east, looked down upon it. Now I had at last an introduction to them all. The land that had been so silent before, now had a voice. And evening after evening as we sat by the fragrant thornwood fire, I heard in part at least, something of its story.

My teachers were the Cherangang $N^{\prime}$ dorobo, the most interesting natives I met during my year's sojourn in the country, and men, too, who had never camped and hunted with any white man till my companion Mr. A. C. Hoey, with wonderful patience and tact, had succeeded in winning their complete confidence. Henceforth for me, if the days were interesting, the evenings round the camp fire were more interesting still, as I hear the stories of their own little tribe, or traditions somewhat loosely held among them of other tribes far larger and more powerful, that long since had been broken up or swept away.

There are, be it remembered, N'dorobo and N'dorobo. Our friends and guides of to-day are, in the language of the country, Pukka N'dorobo, a tribe guarding jealously its own language and customs and territory, living its own distinctive life. There are Nandi, Kikuyu, and Massai 
N'dorobo. I daresay others too, but these are only deserters, restless wandering fellows, or criminals driven forth from their own people, or leaving them voluntarily in order to live and hunt on the veldt. Such wanderers are very common in the little known parts of the Protectorate. Sometimes they find their way back whence they came; in a few cases they are adopted into the tribes they visit. These were the wild men we met when we first hunted the country in May, June, and July. They could be of little aid to us. They were Nandi turned N'dorobo, poor hunters, knowing little of game or its habits, living chiefly on honey (it was then the honey season) or on such meat as they could get by hanging on the skirts of sefaris, and on the leavings of the lion.

Our present friends are members of the Upper Cherangang, taking their name from the mountain range to the east of the Nzoia plateau. In its highest forests they have held their own for ages. The Lower Cherangang, a quite separate community, hold the heavily forested lower skirts of the range. Neither of these small mountain communities have ever come in touch with the white man, till $\mathrm{H}$. came among them and won their confidence. The Lower Cherangang even he has scarcely met, they still hold aloof. If you approach one of their well hidden villages you find no one there, except perhaps some crippled aged folk, who cannot escape into the woods.

I was most anxious to visit this tribe, but my friends of the Upper Cherangang dissuaded me. To go unannounced they said, "might be dangerous." Even they could not be sure of safely avoiding the numerous staked game pits which filled the lower regions of the forest, besides, some of the younger men might let off an arrow or two in panic "dangerous or not we should find no one." In short they would not guide us there.

These small independent communities came evidently of good stock. They could not possibly be ranked as pigmy, 
though they are somewhat undersized, and considering the uncertainty of their food supply, this is perhaps to be expected. The Massai legends have it (says Hollis) that "in the beginning, when God came to the world, he found three things in it, an N'dorobo, an elephant, and a snake."

Like other little mountain tribes, the value they place on their independence and freedom is marvellous. Here in remote unexplored Africa, the wide world's story is told over again. Slaughtered, harried, reduced to starvation, they have been times without number: but never conquered, dispersed, or absorbed. Their mountain freedom has often cost them dear. But the heavier the price the more they value it. They cultivate a little "whimby" (a small, very hard, round seed, something like canary seed and very nutritious; all East African natives are partial to it. It fetches a higher price than maize, and is in great demand for beer). They ferment the meal and add honey. The drink is highly intoxicating and with the aid of the honey bird they steadily pursue the bees. From time to time they visit the plateau on hunting expeditions, usually leaving wives. and children in the mountains. During these expeditions, they often, in times past, suffered from the Nandi, Katosch, and more especially the Karamojo, a more distant tribe, but one that sent its war parties very far afield.

When grass is long, they have no difficulty in procuring much kongoni, and zebra meat. They can then stalk to within thirty or forty yards of the game, and, at that distance, seem always to send a heavily poisoned arrow home. These arrows of theirs are terribly effective weapons; they are quite beautifully made, smooth on the shaft, feathered carefully with vulture wing feathers, a twist being given sometimes to the feathers (something I have never seen in any arrow feathering before), the result being to give the arrow a spinning flight, like that of a rifle bullet. The arrow heads are made from iron wire they have traded (in years gone by they 
were in touch with tribes that smelted their own iron) and which, by tempering, they render into a good, mild steel, very suitable for their purpose. Some arrow heads, generally one in a quiverful, are sharpened to a long plain keen edge, like a prolonged bay leaf. These they use as a sort of pocket knife, cutting the meat from finer skins with them, cutting out thorns from their feet, etc. They also use them against small game, easily killed, when poison is not necessary.

Others are even more carefully made, the points long and cruelly barbed. These last they use for hunting large game, when there is small chance of the shot being missed and the arrow lost in the long grass. The shaft is of fine split bamboo. Into this shaft fits exactly an ironwood head, some six inches long, and on this again, the barbed point is fastened. The steel head of the arrow, and the iron wood top piece, for two inches or more, are smeared with the much dreaded poison. The kongoni, stung by the arrow, rushes off, and the feathered shaft drops, leaving the iron wood head and barb of the weapon in the wound. If the poison is fresh, and a shoulder or a neck shot has been made, the N'dorobo say positively that no beast will run a hundred yards. I am inclined however to think that they exaggerate somewhat the action of this poison. That it is very deadly there is no doubt. Newman who lived among the Kenia N'dorobo satisfied himself of that. In a man's case its deadly action was almost instantaneous. Quite lately there happened hereabouts a small fight between ten Massai (young bloods) and some Kamasea, who used the same poison on their arrows. The Massai were cattle stealing, and had the temerity to attack a small village. The Kamasea saw them coming, and, lying in the grass, let them come. Eight out of the ten raiders fell almost at once. They had only time to cut up their shields and break their spears (no enemy at least should ever wield these) and die beside the 
broken weapons. Gallant fellows anyway! The broken war gear was taken by the Kamasea to the nearest civil officer. The bows are very strong and well strung, and, poor as these Pukka N'dorobo are they will seldom part with their really good bows and arrows; the old and inferior weapons are not hard to buy. Each poisoned arrow is very neatly wrapped with skin tape, and kept so covered till needed. The arrows they use on their enemies are not tipped with steel, but have long iron wood unbarbed points. They are heavily poisoned, and are not nearly as carefully made, nor could they pierce nearly so far, as the heavier hunting arrow. I asked them why they did this. The reply was, they wanted many arrows to shoot at their enemies, and these were easily made, and less costly. There was no need in a man's case for the heavy piercing heads. A prick was enough. I think I remember reading long ago (if I am mistaken I crave forgiveness for I am far from books of reference) that the Malay tribes who use the blow pipe and dip its tiny darts in deadly poison have strange customs which they jealously observe, when that poison has to be prepared.) These people most scrupulously continue to obey the customs their forefathers have handed down to them. A hunter must not make any poison, while with his family. For two days he must not eat meat or touch blood, and he must leave his hut and live alone in the forest. If these rules are neglected, the poison will have no power to kill. All the neighbour tribes to these Cherangang use the poison: Kamasea to the east, Maraquette to the north, and Elgao to the south. But the wild men say the poison these tribes use is not so strong, and, even when they trade it from themselves, it is apt to be old and so to lose much of its power. Certainly the Pukka N'dorobo's instruments and archery are markedly superior. The arrows and bows made by the Nandi or the Massai are weak and inferior when compared with them. I am convinced that our 
guides' contention is true, and that in the long grass and cover, the spear and shield armed warriors of the Karamojo, Elgao, or Nandi, are no match for them.

Where these people came from they have no idea. They say they were here before the Massai, before the Sarequa, and Massai tradition asserts as much. But wherever they came from, even to a casual observer it is evident that they are a highly developed race. Often the hair alone is negroid in type, the lips are thin, the nose fine, sometimes almost aquiline, the forehead well modelled. I said some way back that we came on the trail of an Elgoa war party, and that these Cherangang guides of ours seemed instinctively to know whence it came, and on what errand it was bound. Their guess we proved afterward to be accurate in every particular. It seems the Elgoa had been obliged to pay their hut tax (but lately imposed on this tribe) in goats. Said they, "The white man has taken many of our goats, and says he will take more; let us go and take some of the Katosche's goats to make up." One has heard of larger and more civilized peoples going to war on pretty much the same ground. One of our best hunters, a halfbreed, Massai Nandi, who has done a lot of "scrapping" in his day, was heard to remark, under his breath, that if "Bwana Hoey had not engaged him just then he'd dearly" have liked to join the crowd." They are born "scrappers," these people, one and all. They don't make the fuss and boastful show, that our own red men, in the days of their power and glory, so loved to indulge in. They go much more quietly about the trade of stealing and murder, and indeed are far braver men. Their contempt for life, all life including their own, is complete. Death seems to mean very little to them. They bury one of their own dead, if you insist on it. If you do not, they leave the body in the nearest clump of bushes, and no shadow of death seems to trouble, even for an hour, the living. 
No East African native seems to have the slightest idea of a future life, not even those who profess Mohammedanism. Their Mohammedanism is the shallowest of superficial things. It offers them an alliance with a "caste," which they have come to think of as a higher one than their own, and as such they accept it and rather look down on the tribes that remain heathen. But of the doctrines of Mohammed they know nothing whatever. They have never seen a Koran and they never say their prayers.

Before I leave the, to me, fascinating subject of the Cherangang, I must mention one peculiarity of theirs and of the Elgoa. It is their lack of all boastfulness or exaggeration, and their accuracy of statement. They are careful observers, these wild men, of the animal life around them, and many were the stories told by our nightly fire.

One of these supplements in a rather singular way that remarkable incident Mr. Fleischman saw on the Tana River, an account of which is published in Mr. Selous's last book, where Mr. F.'s photographs are reproduced. In that case a crocodile pulled a rhino under and ultimately devoured him.

The old chief of the Cherangang knew from his boyhood the Nzoia river. He had himself killed forty elephants in its neighbourhood. Once, he said, when he was watching at one of the fords (the river there was running rather deep and the banks were steep and slippery) a large herd of elephants came to the crossing. There were several small toto elephants with the herd, and one of these went under the surface. The old man said he saw a big bull carefully put his tusks under it and so lifted it slowly and carefully to the bank and up the bank. He was asked if he ever saw the bulls carry the totos on their tusks, as some native legends say they do during long marches. He at once said he had never seen it, nor did he believe the bulls ever did this. Then he went on to tell how on the same river he saw a toto 
attacked in midstream by a crocodile, when the mother quickly seized the loathly brute with her trunk and fairly hurled it through the air, far up on the bank. What a scene that would have been! One evening near the sources of the Turquell river, excitement was caused in our party by the arrival of a dozen slim, tall, well formed Karamojo warriors. They had heard our shots, they said, and as they were out after elephants themselves, and had failed to kill, they came to us and hoped we would give them some meat.

One spoke good Swahili and we were all soon on a friendly footing. At first our N'dorobo and Massai were evidently distrustful of the strangers: they drew $\mathrm{H}$. aside and said, "they were lying, that they were not hunting, but were a war party trying to pick up a few Nandi N'dorobo, or some of their own people." Afterward we found that our men's surmise was quite correct, and that the small parties of trackers we had sent out to look for elephant had had a very narrow escape. Had they fallen across our new acquaintances they would have been promptly speared. $H$. indeed had advised his friends to carry, when they went out, one of our guns. This would have at once marked them as belonging to a white man's sefari, and would have insured their safety. They laughed at the idea of any Karamojo raiding so far from home. The recklessness of the East African is extraordinary and on this occasion came near costing them dear. The Karamojo are a powerful tribe living chiefly on their herds, living in complete ignorance and independence of English rule. Their bitter enemies are the Turkana whose country lies on the eastern side of the Suk mountains and between these tribes the Suk, friendly to both, act as peacemakers; Suk Turkana in part pay hut tax. We travelled for several days, going hard, in order to visit the Karamojo village. Our friends evidently wanted us to come and, owing to their hospitality no doubt, declared the distance to be less than it was, and the road 
easier. But time was precious, potio short, and little or no game in the country. So regretfully we had to turn back. One could not but admire these tall young fellows, so much alike in figure that they might all have been the sons of one mother. They were as different as could be from our sturdier Wanyamwazi porters, very slimly made in the hips, with beautifully formed legs, good travellers, but poorly built for field work or burden bearing. Their narrow shields tipped with ostrich feathers were made of elephant or giraffe hide and were very tough. Their long, well-balanced and very narrow-headed spears were highly prized by them. I had difficulty in securing two. They carried on the left hand an iron hook, about two and a half inches across, and fixed to the third finger by a ring. They used this charming instrument, they told us, for gouging out their enemies' eyes. They had neither bows nor swords and did not know how to make poison. They are great game trappers, using snares, not pits, and judging by the rarity of all game in this region, they have trapped only too successfully. They say they can trap the elephant, using rope nooses which are fastened to a fallen tree as a clog. Our old N'dorobo confirmed this extraordinary piece of information by saying he had once found such an elephant's snare, all torn to pieces by an elephant which had been noosed and broken loose. I found a piece of an old kongoni snare which, for patient construction and clever adaptability, shows rare ingenuity. It must have been set in some such way as this: A rawhide noose has evidently been laid over some slight hollow on a kongoni run or under one of the shade trees the animals frequent at midday. If the kongoni stepped into the noose and sank his leg through it into the dip beneath, he might easily kick out of the noose. So this circlet of thorns has been very ingeniously made and is placed beneath the slip-knot of the snare. This clings to the animal's leg, and holds the slip-knot in place, the thorny 


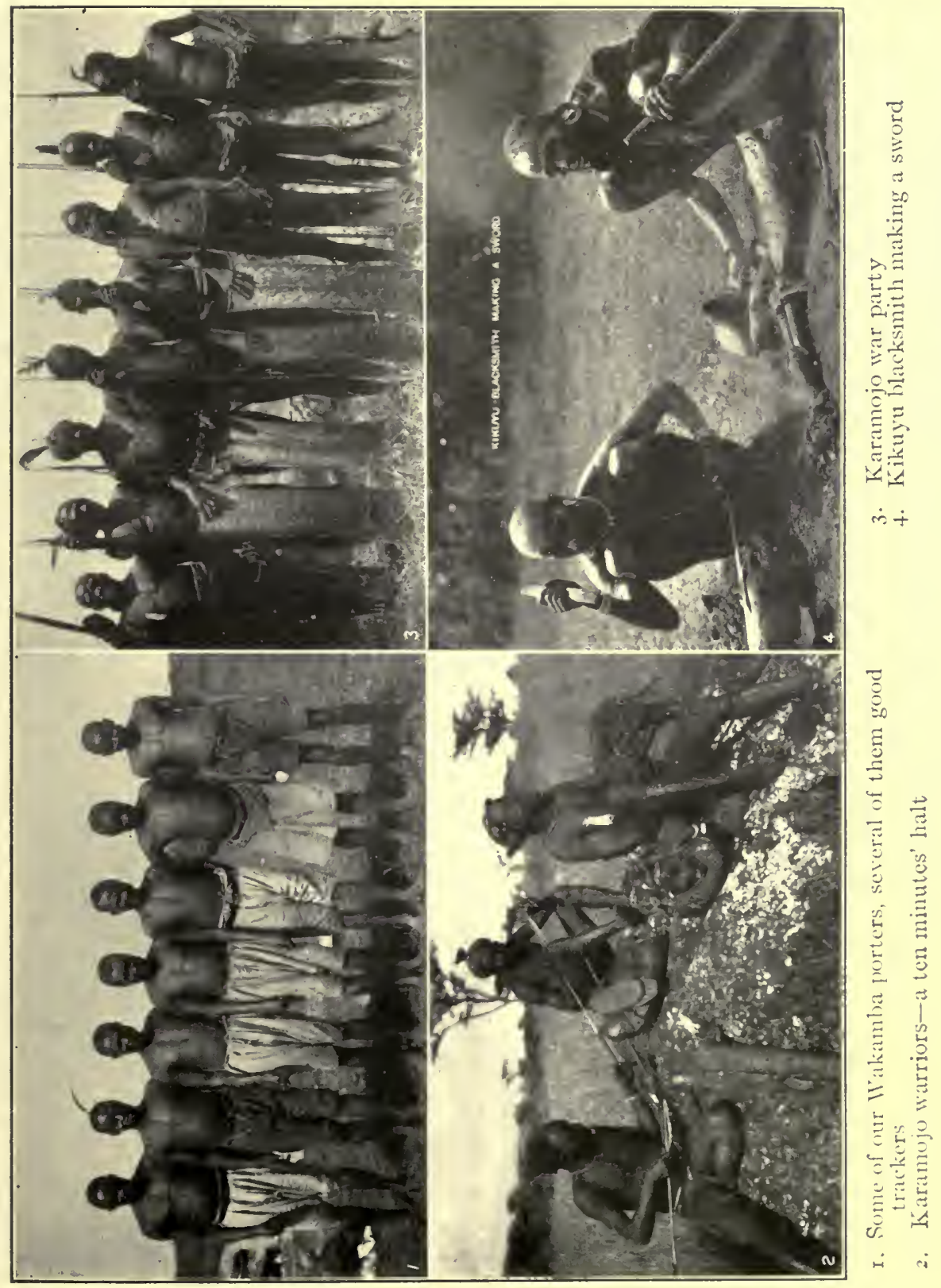



collar makes him jump, and holds in its place the noose that is drawn taut by his jumping. To the other end of the rawhide is fastened a heavy wooden clog which lies hidden in the grass or is covered by sand. We found these traps still set, and I must say they seemed to me the cleverest traps I ever saw. These Karamojo have never, so far as I could learn from them, had the visit of a white man. They knew nothing about missionaries and they said with justifiable pride, that diseases the curse of those tribes that had come in contact with the white man and the Hindi were unknown. The women wear skin aprons and short cloaks. The men are quite naked. Their skins are very glossy and smooth and black. They wear the hair tightly drawn back and worked into a chignon which affords a very real protection to the head. The clay they use in working up this elaborate head dress seems to be impervious to heavy rain. After a moderate shower you see the Massai head dressing coming sadly to grief, and all their faces and shoulders dabbled and streaked with red runnels of water. While the Karamojo's headgear is no more affected by a downpour than a duck's back. At the nape of the neck they leave a little opening into the chignon, which has a hollow somewhere within it, and in this they carry a snuff box or any small articles on which they place value.

The evening of the day on which I shot my elephants, and on which the Karamojo had come in, there were tremendous rejoicings in camp. Some of my Wanyamwazi had been with me since May; now it was October and they determined to honour the occasion by getting up a dance, one of their regular dances, the dance of the elephant. I noticed after dinner, as I sat by the fire, that the camp seemed unusually still and that the men were absent from their cooking fire. Suddenly round the back of my tent came a long rank of men dancing with measured prancing step, a green twig on each man's head and another in each hand. With admirable 
precision the line wheeled on its leader and swept round and round me and the fire as the men chanted their weird minor song. A dance seems to electrify the East African. You could see the eyes of the Karamojo and the N'dorobo flashing, their hands and bodies trembling, as the swaying line passed them. Presently they were off in a dance of their own and, not to be outdone, joined the Massai and N'dorobo; and the high flame, as it leaped from the heapedon logs, shone on a wild circle of naked leaping figures. In a few moments the whole mass seemed somehow to find and recognize its leader, a slim young Massai, who soon led and controlled the whole; still directing them he extemporized a song and every rude voice took up its chorus:

The Bwana came to hunt lions, he has got lions.

The Bwana came to hunt elephants, he has got elephants. Our fathers came here to kill each other and steal cows.

But we come no more in war but in peace, To help the Bwana to kill lions and elephants.

It was a long time before they grew tired and the singing and dancing gradually died down.

I can fancy no more interesting sefari than one pushed along the eastern skirts of Elgon, a visit then made to the Katosch, then following the mountain's eastern base, push north to the Turquell river and down its bank to the great plain through which it flows. Here we could see with our glasses surely one of the strangest formations in Africa. Scores of actual pyramids (they seem), volcano cones they were of course, dotted it for many miles. One was as regular and of almost the height of the great Pyramid. To the north of the plains rise the Suk mountains. Keep along the southern base of these and, travelling east, penetrate the extreme northern end of the Elgon escarpment and, by its ridges and forest country, work southward to the Cherangang. In all this new and interesting region there are few 
mosquitoes and very little fever. Horses and mules do well, as there is no tsetse, but one thing must be had in mind in planning such exploration. During April, May, and June there is a belt of country north of the Nzoia where sefari is impossible, owing to the numbers of the gadfly. Mules and donkeys cannot live, but actually bleed to death, and porters cannot march. These terrible pests, strangely enough, do not cross to the southern bank of the river in any considerable number, and south of the river these months and March are the very best hunting months in all the year. The grass is then short, the country a beautiful fresh green. Lions can be ridden round the rock and to the southwest of it, and can be hunted in the bushy lands bordering the river where they are very numerous; but once the grass makes head it is dangerous work following them there.

I know more about such hunting now than I did when I first followed them on foot and alone, six months ago. And to follow up bands of lions when more than one of their number has been wounded in long grass is taking a risk, a very grave risk.

If this is done two guns should work together. Only a few months ago $\mathrm{H}$. and a sportsman with him missed an accident by a hair's breadth. The grass was still short, not up to the knee. They had wounded a lioness badly and then, thinking they couldn't fail to see her in time to avoid all danger, walked side by side slowly through the little patch of sparse cover she had slunk into. They heard her growl but could not locate the sound. Do what they would, they could see nothing. There are little ant heaps all scattered through the grass hereabouts, the size and colour of a big brown overbaked loaf. H.'s man shot quickly twice, and $\mathrm{H}$. saw the dust puff up from an ant hill a few feet away. Then there was a yellow rush, and from somewhere, almost under their feet, the lioness was on them, 
mercifully to be met by an almost chance shot from H.'s heavy .450 which paralyzed her. No man cares to look back on a shave like that.

Quite near the rock another affair came off this spring, which, but for the cool courage of a native askari, would have ended fatally. Two men, Englishmen, who should never have gone after dangerous game, shot at a lion and missed it. It seems there was a lioness with the lion, which neither of them saw. The lion "cleared," but round a bush the lioness suddenly came and came fast. Captain - ran, and his gun-boy, Malim, once in my employ, a lad brave to rashness, standing his ground, was pulled down immediately. Now the most extraordinary thing about this true story is that, while serving with this same gallant officer, four months before, Malim had been slightly mauled by another lion. On this occasion (it happened near the Tana River) his bwana also ran away, and the boy's life was only saved because a man now in my employ stood by the gunbearer and shot the lion, which was standing over his body, with a double-barrel smooth-bore, which he carried. After the second affair I found poor Malim in a bad way, still suffering from a severe mauling. Several men, now in my employ, were on these gentlemen's sefari, and there is unfortunately no doubt whatever as to the accuracy of the facts. What induces some men to attempt dangerous game no one can say. That many who are constitutionally unfitted for its pursuit, do come out here and do attempt it, everyone in the country knows. But fortunately such a scandalous affair as this one is rare indeed.

Ten miles due east of Sergoit rock, an easy and wellmarked pathway worn by the Elgoa cattle climbs through the dense forest ridge to one of the gathering points of this tribe. This trail opens up to traveller or sportsman a completely different country. A country that has as yet never been hunted by the white man. And at its very head there 
is a view as extensive and as lovely as any in the land. Not even excepting that from the Kikuyu Escarpment into the Rift (Kedong) valley. As you ride along Sergoit plain to northward you see, some miles on your right, the heavy purple fringe of the great forest that borders it. You have probably ridden with that fringe on your right for almost seventy miles, if you have come from the Ravine. You have noticed the swells and dips of the great wood, that seems to cover mile after mile of almost level land. Now, to the east of the rock, you turn into the forest and climb gradually for a mile or more. Suddenly, without any warning, you pass out of the heavy gloom of the tropic wood. You find yourself on a rocky shelf that juts out over a precipitous slope, and right at your feet, 2500 feet below, lies a vast blue valley. The change from dense shade through which you cannot see twenty yards ahead, to the splendid spaciousness of the view beneath, beyond you and all around, is actually bewildering.

The valley of the "Kerio" is thirty miles wide and perhaps three hundred long. The river from which it takes its name flows into Lake Rudolph. The opposite side of the valley wall rises much more gradually than the western, on whose extreme crest you stand. On this side is Elgoa land. Twenty miles to northward begins the Maraquette country, and farther still to the north comes the Suk. In front of you to the east are the Kamasea, and beyond these again to northward the very numerous Turkana. Thousands and thousands of the people, whose flocks graze these hills and whose little shambas of whimby are dotted here and there amid the valley woodlands, have never seen a white man. And Hoey was the first ever to stand on this particular signal rock and look on this splendid panorama. Joseph Thompson crossed the valley in 1883. The old chief of the Elgoa was a friend of H.'s and him we particularly wanted to meet. The manner of his coming was 
most interesting. We had an Elgoa native with us. Soon as we stepped out of the forest path, into the dazzling sunshine, he mounted the rock and gave the tribal cry, a long falsetto call. Some hidden Elgoa warrior on the lookout, from some other vantage point which I could not see, took it up; then another and still farther away another; and far off you heard the cries echoing amid the craggy sides of the great steep. Soon armed men came panting up. They knew H. and welcomed him, spitting on their hands before they shook ours, as their custom is if they wish to show that they thoroughly approve of the stranger. The grayheaded chief came in about half an hour from somewhere. H. knew him well, he had been his guide before after elephant. A well-knit man, capable and shrewd; but for his colour he might very well have posed for a south-of-Ireland peasant, a splendid hunter in years gone by; now I fear that as he had some cattle, and shambas to grow whimby, and sons to collect honey wherewith to compound their much-loved and very strong beer, he does far more drinking than hunting.

Not one hut could we see, as we examined the valley's slopes and level floor. These people hide their houses, as do the $\mathrm{N}$ 'dorobo. They have only one village proper, some twenty miles to the south, and in the valley. The Elgoa have defended themselves with great bravery and complete success against tribes like the Nandi, far more numerous than they, from which, by the way, they are probably an offshoot. The valley beneath them, or rather their part of it, they have not always been able to hold as their own. But no one has driven them from the precipitous slope, where their little dwellings and gardens are so well hidden. The forest belt on their westward side has served them well as a defence in times long past against that interesting and almost forgotten people who held the plateau with their stone kraals; and in later days against the raiding Nandi. 
Had I had time I should have liked greatly to hunt in that great valley and travel down the Kerio River to Lake Rudolph. The tribes that live on its banks are but little known. Some of them, like the Maraquette and the Cherangang $\mathrm{N}$ 'dorobo, have never received a white man into their forest strongholds. But the time for returning had come and most unwillingly I rode away.

The numbers and power of the Massai tribe in old days can best be estimated by the wide-spread influence they still exercise on surrounding and sometimes very different peoples. Their customs suited no doubt their circumstances. Their war organization was much more perfect than that of any of their enemies, and by its means they were enabled to hold their own even in struggles in which they were heavily outnumbered. The Elgoa have been always men of the forest. Their herds were insignificant when compared with those of a great veldt tribe. Yet somehow among them Massai customs have been universal for ages.

In their method of fighting they seem to differ radically from the neighbouring tribes, some of whom, like the Karamojo, fight only with thrusting spear and shield (Karamojo do not use either sword or club stick), or like the N'dorobo who use pointed arrows alone. The Elgoa arm half the men with beautifully balanced spears, and narrow, oval shields of buffalo hide, and half with bows and poisoned arrows; the spear is however counted the more honourable weapon. Their use of the bow to support the spear would suit admirably the nature of the country they must defend.

The Elgoa and the Cherangang, their near neighbours, take the most serious view possible of homicide (of course within the tribe; no significance is attached to killing outside of it).

The old chieftain, who was much looked up to by his people and who was everywhere watched over and waited on by his two fine young warrior sons, is unquestionably 
well informed; he has travelled, hunted and fought a great deal, and was careful and slow in his statements made to us around the camp fire. In the main, he said, the Elgoa, Kamasea, and Maraquette observe the same tribal customs.

If a man among the. Elgoa murders another member of the tribe-that is, kills him in unfair fight- he is handed over by the old men to the relatives of the slain, who kill him, no fine or other punishment being accepted.- (This is most unusual in Africa.)

All his property, with the exception of certain goats and cows, dues as fees to the old men who act as judges, goes to the relatives of the man murdered.

If this murdered man has offered grand provocation to his slayer, such as stealing his cattle or forcibly taking away his wife (and the first offence is counted a much graver one than the second), or if the killing is purely accidental, though the extreme penalty of death is not imposed, still the punishment is very severe.

The old men decide how large a part of the slayer's goods goes to the victim's relatives and, when these ruinous fines are paid, certain social marks of tribal disfavour remain.

$\mathrm{He}$ cannot touch blood. (All these tribes, as do also the Massai, count milk and blood, which is taken from their bullocks at regular intervals without killing them, as the chief delicacies of their lives.) If the tribe goes to war he cannot touch spear or shield, but must fight among the boys with bow and arrow only. He can purge himself from the tribal ban and these disqualifications only in one way, and a most extraordinary way it is. I at first fancied there must be some mistake, and that imperfect knowledge of the language had led to a misunderstanding, but after debating the question for several nights, and after much cross-questioning, I came to the conclusion that there could be no possible mistake made in reference to it.

The warrior under the ban of this homicide, must kill 


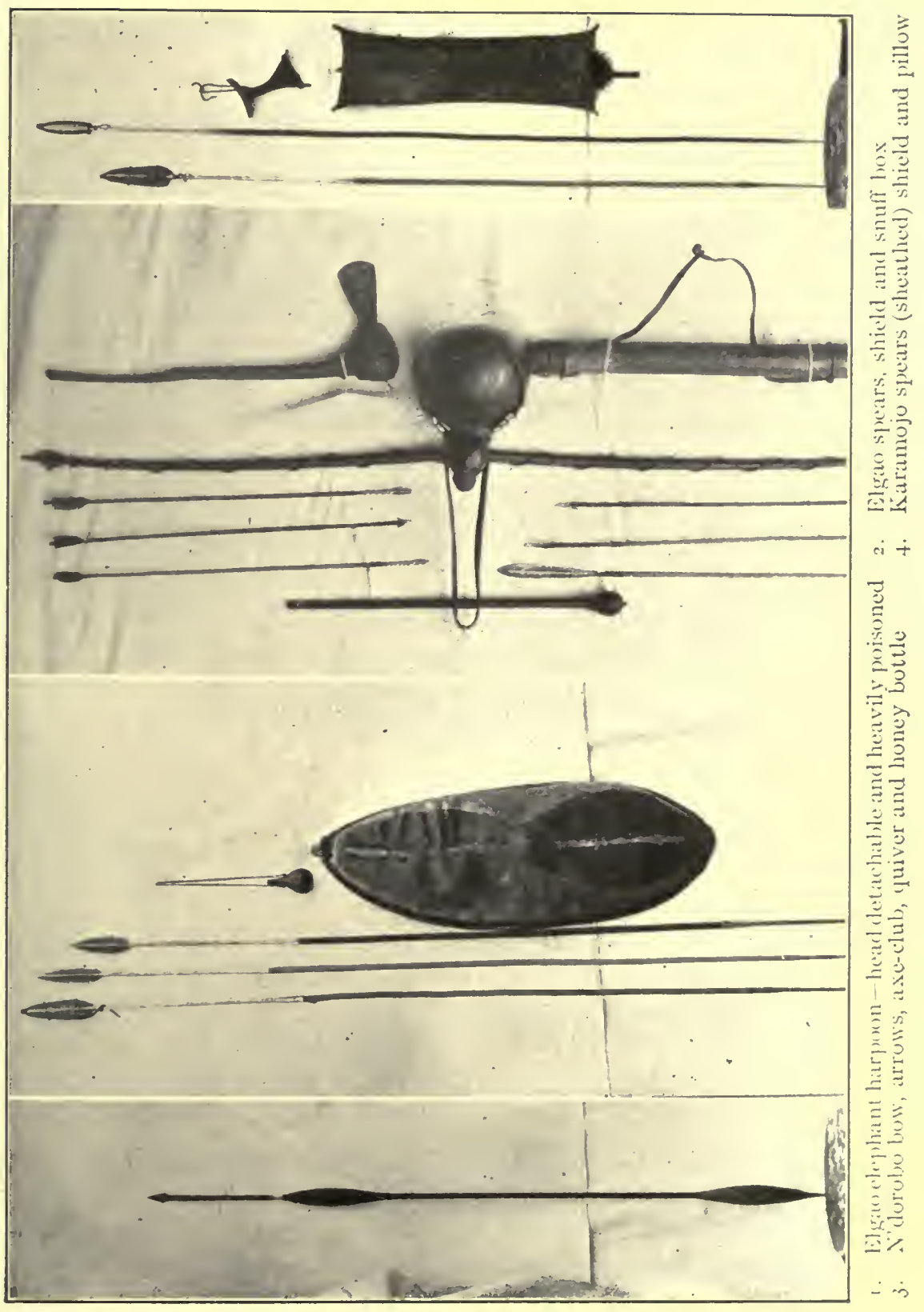



three women (of course of another tribe). The smallest child counts on the tally. When he gives proof of this, he is received formally. Spear and shield are returned to him, and he may drink milk and blood. I tried hard, but in vain, to find from the Elgoa some explanation of this method of removing the tribal ban. All they would say was, that they, the Kamasea, and the Maraquette, only obeyed the customs handed down to them by their fathers.

The Cherangang had no such custom. Tribal homicide among them seemed extremely rare. The Cherangang chief had lost three daughters and two wives, some years before, to the raiding Nandi. I asked him whether if he had the power, he would kill the man who captured them and still held them. For, Enoch Arden like, the old Cherangang had made the dangerous trip across the plain, and had one night discovered the exact whereabouts of his missing family. His answer was strangely pathetic. "No," said he, "why should I ? He took them by strength." I am glad to say steps are being taken to bring them back to him.

The Elgoa woman is allowed much greater freedom than is granted to the Massai. None can be sold by her father (inside the tribe or without) to anyone unless she approves the man. She can and often does, in the early days of her independence, seek out the youth she desires. If she would do this, she must observe the custom of her tribe. She must waylay him in the forest paths and, having met him, wait till he speaks. He says, "What are you looking for ?" She, "I am looking for my lover." He, "Well let us go." Henceforth she is his wife, and takes rank as his first wife if he marries other women.

Their burial customs differ completely from those of any other community. If a man or woman dies leaving children, these take the body and bury it deeply in the ground. 
All the community keep within doors for two days, the women crying loudly. They honour a mother in this respect, as they do a father. If anyone dies childless, the body is drawn into the bushes and left to the fécé and birds.

The one thing that impressed me above all others in meeting and questioning the Elgoa and Cherangang is their high regard for the truth. No one but an ignorant and most unobservant man could possibly speak of those tribes, who are still uninfluenced by the white man, as untruthful. Very much the reverse is the case. A man questioned by you will pause and take evident pains to be accurate. A Swahili, a man of very mixed race, or a porter who has been for years round a town or boma, may lie if you confuse him or make him afraid, though this is not nearly so common a thing as it would be among ourselves). But a native East African, even if the truth be to his manifest disadvantage, scarcely ever lies. Confuse him (he is easily confused) and he may try to say what he fancies his bwana wants him to say, but be patient with him, let him tell his story in his own roundabout way, and from beginning to end he will so tell it as to do accurate justice, so far as he knows, to his adversary as well as to himself.

I have been deeply touched often, as I watched these poor fellows witnessing truthfully to their own expected hurt (I speak of all East African natives).

In Elgoa the liar is a doubly branded man. If he is known to have lied in any important matter, he is officially driven from the community.

Take the matter of their dearly loved cattle as an illustration. If they accept the care of some cows or goats for a stranger, years may pass before that outsider can claim his own; he may, however, depend on an accurate accounting for every calf or kid born during the interval, no matter how long it be; no one, from chief to herd boy, but will tell him all the truth. Fancy what the result of 
such truthfulness would be among our own western cattle owners! Ask the owners of small herds, that try to keep their property intact in the neighbourhood of great ones, ask the men who really know what goes on before the Indians are goaded into killing some rancher's cattle, if they think western truthfulness approaches the standard of the "heathen" Elgoa.

If a case comes up, when the chief or old men doubt the truth of the story; if, for example, a homicide has gone to war, and comes home declaring he has killed three women, and so is absolved from the tribal "ban," and his fellow soldiers doubt him or think he has killed but one or two at most, the matter comes before the chief. $\mathrm{He}$ sends the homicide to the woods to kill a hare. He then takes a piece of the hare's skin and buries it in the earth at the door of the hut the suspected liar lives in. He then says, "The goats will tread over that skin day and night for ten days; if you are a liar you will die before the tenth." I could not find out from them what the significance of this "goat's treading," etc., was. They simply said it had been their custom for ages, and that it was effectual, "for the liar died." I should think he probably did die. They often used the word God, pointing to the sky. They speak of God's will, "if God is kind" to them they will get honey, kill elephant, escape death in war, or have no visitation of the cattle sickness, etc., etc. But further than that they seem to have no idea of the Divine. They have no religious ceremonies except the initiation of the young people. No idols or fetishes of any sort. There are some crags on Elgo highly metaliferous on which they believe no man can stand in a storm and live. This, so far as I could find, is the only spot to which any of the tribe ascribe a sacred (if it could be so called) significance.

I asked them what they meant by God. And how they knew there was a God and the old man said, "I fall 
asleep, and while I am asleep something speaks. It says, 'your cattle will die, you will find honey, the elephants are coming.' I wake up, there is no one there who could have spoken to me, it must be God."

Then he turned to me and said, "We black men do not know, but you white men know everything; what do you think of God?" It was a sobering and most searching question. When we were leaving them, without any request made, the Morans and Laiock formed a column and broke into a dancing song and dance. The chief's son, a fine youth of whom the old man was evidently proud, was marshall and leader. It was the finest, clearest song I have heard in Africa, and they danced well. The first song was the song to the women:

"Ob women you need not fear,

These are our friends, not enemies."

The second to the birds:

"Ab birds, you will not feed on men,

You may fly away. There is no war."

Of the upper Cherangang N'dorobo I have already said something. Their customs of circumcision, the high regard for truth, the purity of the women, so far as strangers are concerned, are identical with those of their neighbours, the Elgoa. They have, however, little regard for the bodies of their dead; and unless a man has gained great power among them, they treat the corpse as all dead are treated, leaving it to beast and bird.

Simple, truthful and most lovable peoples these untouched East Africans surely are. Where their customs are vicious, where they err grossly, they do so innocently; they but follow in the steps of those who have gone before. Perpetual war they have been for ages accustomed to, and in warfare they are ruthless, like all savage peoples, yet they are far from cruel, and, as they have told me again and again, except where a man seeks to purge himself 
from the tribal ban of manslaughter, they never kill women or children, and torture is unknown. Smallpox has occasionally decimated them, so much you can see; but it is: the white man's, or yellow man's, coming that threatens their ruin.

I can fancy no journey more fascinating than one undertaken to visit the almost unknown peoples of this beautiful and healthy part of East Africa. The tribes whose country borders the great lake, have already experienced the profoundly modifying influences of civilization. That the Waganda have on the whole gained thereby, there can be no doubt. They are a prosperous and well-organized people -but how these wild children of Africa will live under the changing circumstances that await them is not so easy to foresee. As I write six Boer wagons slowly cross the sky line. They are but the advance guards, doubtless, of large numbers soon to arrive. I cannot but see in these Dutch immigrants the visible symbols of the future of this country, and anxiously I ask myself how these simple, lovable companions of my wandering will fare at the unknown strangers' hands?

On the rich plains for long centuries the N'dorobo. has gathered his meat harvest and, drying it in the sun, has slipped away to his mountain home. Soon, very soon, there will be none to gather. Game disappears before the Boer as green grass before the grasshopper. I fear me greatly N'dorobo, and in time Elgoa too, will disappear as completely as the game.

The Waganda hold their own, on rich lands bordering the lake chiefly, because there are none to dispossess them. Their country is in time deadly to the white man. He cannot live and breed there. But here, if anywhere in East Africa, Englishman and Boer can found and maintain a real home. You have not to think of the climate, no fever threatens. you. Unless some new and evil surprise springs up, some 
unknown epidemic sweeps away the herds, as is always possible on this continent, this would seem to be the sanatorium of the Protectorate. Alas, in so highly favoured a region small place, I fear me, may be found for these children who for ages have possessed it, and who have fought bravely and often paid dearly in blood the price of its possession. 


\section{CHAPTER X \\ GOOD-BYE SERGOIT}

7 HE Nzoia Plateau and the country to north of it bounded 1 by the Suk mountains, is only a little corner in the great and very imperfectly known territory called British East Africa, but for travellers and sportsmen its interests are unsurpassed. I feel I have good grounds for urging its claims on all who, like myself, enjoy seeing the strange things and people of this old world of ours, before they are changed beyond recognition.

Under these inevitable processes we call civilizing, all things belonging to savage man suffer change. The tribes lived and only lived by struggling; failed in the fight or won. Some quality, not unworthy to survive, there always must have been.

We come suddenly, ruthlessly; and in a few years the long past is swallowed up and forgotten, as though it had never been.

We call them, nay we force them, from paths and customs and laws they knew, to ways they know nothing of; our ways, not their ways.

We take from them what they have slowly learned to approve and value; we give them in exchange, what costs us little, sometimes alas, our cheapest and our worst, both in vices and in men.

Kindly pardon my digression and let me get back to my last, involuntary, lion ride.

Our camp was pitched ten miles north of the Rock by a little sluggish stream that crawled down to the sources of the Nzoia. 
Five o'clock tea, the most pleasant of all the incidents in a pleasant day, was just over, when in rushed a "boy" to say that two great lions (simba koubwa) were feeding on a kongoni not half a mile away. He was a thoughtful fellow too, for he had left his comrade (they always go out from camp two and two) up a tree, marking them.

We had come down from the high veldt into a grassy and bushy country most unsuitable for riding. J. J. W. had that morning come on two fine lions, and had very wisely refused to let his syce or his hunter attempt to ride. And when I swung on to my faithful mule, I had no intention on earth of "riding" these lions just reported to me nor I think had $\mathrm{H}$. We simply mounted as the men brought our riding animals round, because we could see better from their backs.

It was quickly arranged that $\mathrm{J}$. J. W. should go with his man, cautiously up to the kill, and H. and I and my mounted syce, swung far off to the right, just in case the lions might slip off that way, wounded or not.

From a distance we watched our friends approach the kill, the boy in the tree signalling to them the place. They drew up to it, looked around. No shot rang out. The lions had cleared. Where? We cantered forward on a chance, the going very bad. Rocky ridges, bushes crowded together, and long grass. A mere chance if we see them at all. Right to the rear of the kill, some six hundred yards back of it, there was a narrow clear grass ridge. As we looked, there surely-yes, there were two very fine males, racing side by side across it, and almost directly athwart our front.

That sight was, I fear, too much for us. Anyway, with a yell we plunged forward and once going there was no holding back. How amid that labyrinth of bushes and grass we held them I don't know. It was indeed a hard bit of riding. But by dint of "going it blind" we did. J. J. W.'s syce had come up on my left. He was very well mounted and rode 
well. He on the last lion's flank, H. on the leader's. I was very near the white pony J. J. W.'s syce was riding, when in an instant, the second lion turned between two bushes and was literally swallowed up in the waving grass. The leading beast held gallantly on past the covert, and $\mathrm{H}$., riding a few score yards furiously, turned him to bay under a fine tree. There he stood, a noble sight indeed, advancing first toward one man then toward the other. Right behind him, not twenty yards away, was the cover that had swallowed up his companion; but he seemed to want to fight, and never even looked behind him for the support he surely deserved. They might both be on us any moment. It was a very nasty place indeed, the grass waving as high as our ponies' backs. So I shot him just as quickly as I could. We waited where we were for a quarter of an hour; no knowing in the least where the second lion might be crouching, and frankly not too anxious to go into the thick cover where the dead lion lay. After a while we went in and measured and skinned him. He was a splendid beast, with a rich, dark mane covering his shoulders. Not so fine a one as J. J. W. shot on our way to the Rock, but a very fine one and very large, nine feet eleven inches as he lay. Four lions in three days, seven shots to the four, not so bad; and this one the very, very last I will ride in long. grass or bushy country.

I thought I had had the very best of lion hunting, when on the lower part of this same plateau three months before, I got in five consecutive days three lions. I never expect to experience any sensation quite equal to that of the moment when, after five months' fruitless search, I at last saw the great black-maned fellow step grandly out of his harem, and stand alone in the morning sunlight within one hundred and seventy yards of my rifle's muzzle. It was a grand day's hunting too, when, from morning till late afternoon, I followed up in long grass two lions I had 
wounded in a band of ten, and at last got one of them. On both these occasions I was alone (saving my gun bearers).

But to my mind riding lion is the sport above all others. It is unquestionably a dangerous sport. So dangerous that, unless the country is open and the galloping good, it should not be attempted. Even then if a man persists in it, it is only a question of time till his luck turns and he comes to grief. If he allows himself to be carried away by excitement and ride blindly as he must at top speed amid high grass and bush, then let him at least know what he is doing, and what he is inducing or allowing others with him to do. He is simply courting death.

Comparatively few lions have yet been ridden in this country, and already several men have been mauled and two at least have died. I am not guilty of exaggeration in saying so much. Under reasonable conditions let a fair rider and shot do it by all means. Under other conditions than these let him determinedly set his face against it. The unwounded lion is seldom dangerous to anyone on foot. At times unwounded lions will attack, as will lions that have lain down after a hearty meal and resent being disturbed. The unwounded lioness sometimes is dangerous, especially if her cubs are young. But the lion or lioness, once ridden, is a quite different beast. He does not come to bay until he is thoroughly tired, and quite convinced that his retreat is cut off. Once he is bayed, the last thing he thinks of is getting away. He wants to get his enemy down. He runs from nothing but man, and it is as though, resenting the indignity man has placed on him, he rushes in to kill. There is no turning, no swerving about him then, unless he has received a death shot. Be it remembered too, that though, broadside on, he offers an ideal mark; head on charging, he is a most unsatisfactory target. The bones of the forehead which protect the very small brain are massive and slope sharply back. A well-aimed bullet 
glances from them easily. The frontal mark of a fullgrown lion's brain is not four inches across by three up and down. The great incisor teeth too, are apt to catch the bullet and I have known one of these shattered to the base by a nose ball, and so to take the full shock of the shot. That lion staggered but did not pause in his charge, and was fortunately killed at a distance of only a few feet. It must, too, be remembered that the man on horseback, when a lion has been ridden, can do little to help the man on foot, who has dismounted to kill. Horses are restless, and riders have themselves to look after. If there are two, or as it happened twice with me, three lions, all crouching close together, some visible, some not, any one in the party, mounted or on foot, may have to look out for himself at an instant's notice, or have to stop an enraged brute's headlong charge, at a few yards' distance, or go down under it. When everything goes as it has been planned there is no difficulty, but the one thing and the only thing that is certain about lion shooting is, that no man can say beforehand what unexpected turn matters may take. I have seen many natives, gunbearers and hunters, who have been mauled and yet who still cheerfully followed the bwana up to lion. But, so far as I have been able to learn, few white men take a mauling so stoically. Once downed by a lion, the white hunter has generally had enough of him. One indisputably brave man, who holds, I believe, the record for lions killed in East Africa (an extraordinary record it is, and was of course made some years ago - it is fifty-two) openly states that he cannot and will not face another. He was mauled at last, curiously enough, by a very young lion.

As to the best weapon to use, men of course will differ. Each man will most likely advocate the gun he can shoot best with, and there is, I think, no better rule. But generally speaking, heavy rifles are not the thing; they are awkward to handle and burdensome to carry, and once 
lions are on foot, one absolutely necessary rule for every man to follow is to take his own gun, and never give it up to anyone for an instant till he knows his lion is stone dead.

Some men have theories that the muscles on a lion's chest and shoulders are so unusually tough that ordinary good soft nose ammunition driven from modern rifles fails to penetrate properly. That this is a mistake I can confidently assert. I have always taken care to search closely the traces of bullets fired by myself and by others in the dead game. Now the rifle I used to kill hundreds of animals in Africa is a $.35^{\circ}$ Rigby Mauser, a gun with many solid advantages and of course some disadvantages. The advantages are an unusually heavy bullet and a good charge of powder. For a repeating rifle the bullet is a good deal longer than those fired from repeating rifles generally, much longer than the bullets of a new Winchester pattern. It has not the velocity claimed for several of those new rifles that are thrust on the market by their makers almost monthly. These I dare say do shoot up to the velocity claimed for them, but be it remembered, velocity can only be won by two methods: shortening the bullet, or increasing the charge of powder To increase the charge means to increase the weight of the gun. To shorten the bullet means inevitably to lessen its penetration, and so its killing powers.

Now for the disadvantages of the weapon. The heavy bullet means a comparatively high trajectory. You aim, for instance, for argument's sake let us suppose, with absolute accuracy at a kongoni's shoulder at three hundred yards' distance. But the antelope is four hundred, not three hundred yards away; well, the heavy bullet will pass beneath its brisket.

Then another thing, the bullet shoves too much lead at the point and I am sorry to say I have not yet been able to convince the Rigby firm of this most evident and palpable fault. Compare the German bullet for the $8 \mathrm{~mm}$. Mannlicher 
rifle (which is an ideal bullet) with the .350 Rigby, and the difference is apparent to a tyro. Instead of a big soft lead snout, which is forever in danger of being battered out of shape, as day after day it jogs about in the magazine of the rifle, the Mannlicher just shows the lead, neatly protected by a close rim of the nickel, and that is all.

My contention then is, that the .350 Mauser bullet, though a heavy one, still does not penetrate in any unusual way the game shot with it. I have often shot kongoni running from me, in the rump, and never found that this bullet had ranged forward into the vitals. Yet, and this is the point, that bullet invariably goes right into a lion's vitals, whether it be fired into the side or the shoulder or breast of a full-grown male. I have found it then a very serviceable weapon. Its shock is heavy. And I find I can shoot more accurately with it, than with any double-barrel rifle I possess. It does not weigh, with magazine full, quite $8 \frac{1}{2} \mathrm{lbs}$., which is not heavy for a big game rifle. And if you can approximately estimate your distances from game you desire to kill, I find it very accurate indeed. I must say, however, that several men I know who understand something about rifles (and be it remembered, many a man who is a good shot knows little or nothing of them) have not found this rifle work as satisfactorily as I have. Another advantage of the .350 Mauser is that it is not too heavy to carry in the hand, even when you are forced to ride at top speed over rough ground. A .450 for close quarters will, of course, smash things up more, and so is a better weapon, but you have to sit right down and ride close to keep a lion's company, and a heavy gun is a good deal of a handicap. As a gun to fall back on at very close quarters there can be nothing better than a good double-barrel smooth bore, to the handling of which you have grown thoroughly accustomed. The right barrel loaded with ball, the left s. s. g., a good charge of powder behind 
both of them. If I must go up to a lion that is wounded, when the cover is thick (something I sincerely hope no one who reads this account of my wanderings will ever be induced to do) I'd rather go with such a weapon in my hand than with any rifle that was ever built. You can shoot with it quicker and truer than with anything else.

Speaking of rifles and their use, I would venture to give a piece of advice to those who are buying a battery. Make sure that your trigger pulls are alike. Many men never seem to pay any attention to this most important detail. Especially is it needful to see to this if you are using guns which you change constantly in a day's sport. If one, let us say your every day gun, has a light pull (four lbs.) or a sharp pull, and your heavier rifle has a heavier or dragging pull, you are likely to be exceedingly annoyed by the bad shooting that you make on just those occasions when you would wish to do well. Yet no man could do good shooting under the circumstances. Our American Winchesters have two very strong points in their favour: their breech action is much quicker and easier than that of any "bolt gun" (all the European magazine rifles are of this make), and the pull off is to my mind perfect. The insuperable objection to them is, the action cannot stand the heavy powder charge that a heavy bullet requires, and their ammunition cannot be obtained here, when fresh ammunition is desirable.

It takes quite a time for one accustomed to the Winchester to familiarize himself with the sliding bolt of Mannlichers or Mausers. And I cannot too strongly urge on all who intend using these weapons, to constantly practise, first with empty magazine and then with full, the manipulation of the gun they are going to work with. The slightest downward jerk of the Winchester lever throws the full or empty shell over the shoulder. In the bolt rifle the latter has to be drawn right back to the full length of its slide, 
before it is reversed and driven forward. Failing in this, failing by only half an inch to pull the bolt quite back, the empty shell is at once jammed back into the chamber on top of the full one rising up from the magazine below. This causes an immediate and very bad jamming of the piece. You constantly hear complaints of bolt guns jamming when rapid fire is needed. I am convinced the fault then lies not with the gun or its action, which is quite automatic, but with the excited manipulator who, in his hurry to put another cartridge in, has not taken time or care to throw the old, used, cartridge out. I know this was so in my own case, when in America I first began to use the Mannlicher instead of the Winchester, and I cannot accuse myself of carelessness in the use of firearms. I lost a great moose in that way once, and a good mouflon too, in Sardinia.

One American rifle I could, however, strongly commend to all going on sefari. That is a .25 single-shot Stevens. The most perfect toy rifle I know, a long pistol barrel, with an adjustable skeleton stock, the whole weighing only $3 \frac{1}{2}$ lbs. Nothing can be more accurate up to 75 yards, and it is quite beautifully sighted. Have the high foresight with a small bead, under a heavy protecting steel concave protector (the usual sight for this rifle) and a peep back sight. For shooting guinea fowl, and wild fowl generally, there can be nothing better. A twelve bore makes noise and the cartridges are heavy. Guinea fowl, a quite important article of diet, are often very hard to reach with a smooth bore gun. They will keep running at about 45 yards in front of you, and on the ground at that distance take a lot of killing. Then there are many other birds shy of approach. The bustards, the lesser, and the greater, a big rifle tears, and to get within small shot range is often impossible. For monkeys and many small things that you will want to get, use the Stevens. On no account burden yourself with one of these much-advertised .22 Winchester repeaters 
for such work. In accuracy, good sighting and in weight they are very inferior to the Stevens; moreover, they are almost impossible to keep really clean, and once foul a $\mathbf{. 2 2}$ won't shoot well. A .25 is much easier to keep clean. I fear it will seem to some that I have written on lion hunting with a degree of assurance that ill becomes one who has only hunted this grandest of all game for little more than a year. I may not be able to clear myself from the charge. But I can say at least, in extenuation of my fault, if fault there is, that I have been privileged to know very well indeed one or two men whose experience of lion hunting has been very extended. I have submitted what I put down to their judgment, and have the satisfaction of knowing that I have written nothing with which they do not thoroughly agree.

I had one more rather remarkable ride before leaving this beautiful country. It was after a cheetah. Now as everyone knows there are few animals that can put up the pace that this hunting leopard can. You see them oftener than you do leopards, which, though they are quite numerous, are seldom seen. The cheetah seem to know their own powers and do not seem to mind showing their yellow-black spotted beauty even in the daytime. They run their prey down, and trotting across the open veldt you sometimes come on them. Unless well mounted you may save yourself and your pony the trouble of a race. And unless the ground is very open, no matter how fast your mount is, their pursuit is hopeless.

As $\mathrm{H}$. and I were returning southward from our elephant hunt on the Turquell, we sighted a mother and two halfgrown cubs. There was a long stretch of good galloping ground, and gallop we did for all we were worth. The cubs soon took to the grass and our men following secured one of them, getting a good scratching as they did so. The full grown mother gave us a tremendous run, fully three miles, and then stopped. I noticed a strange 


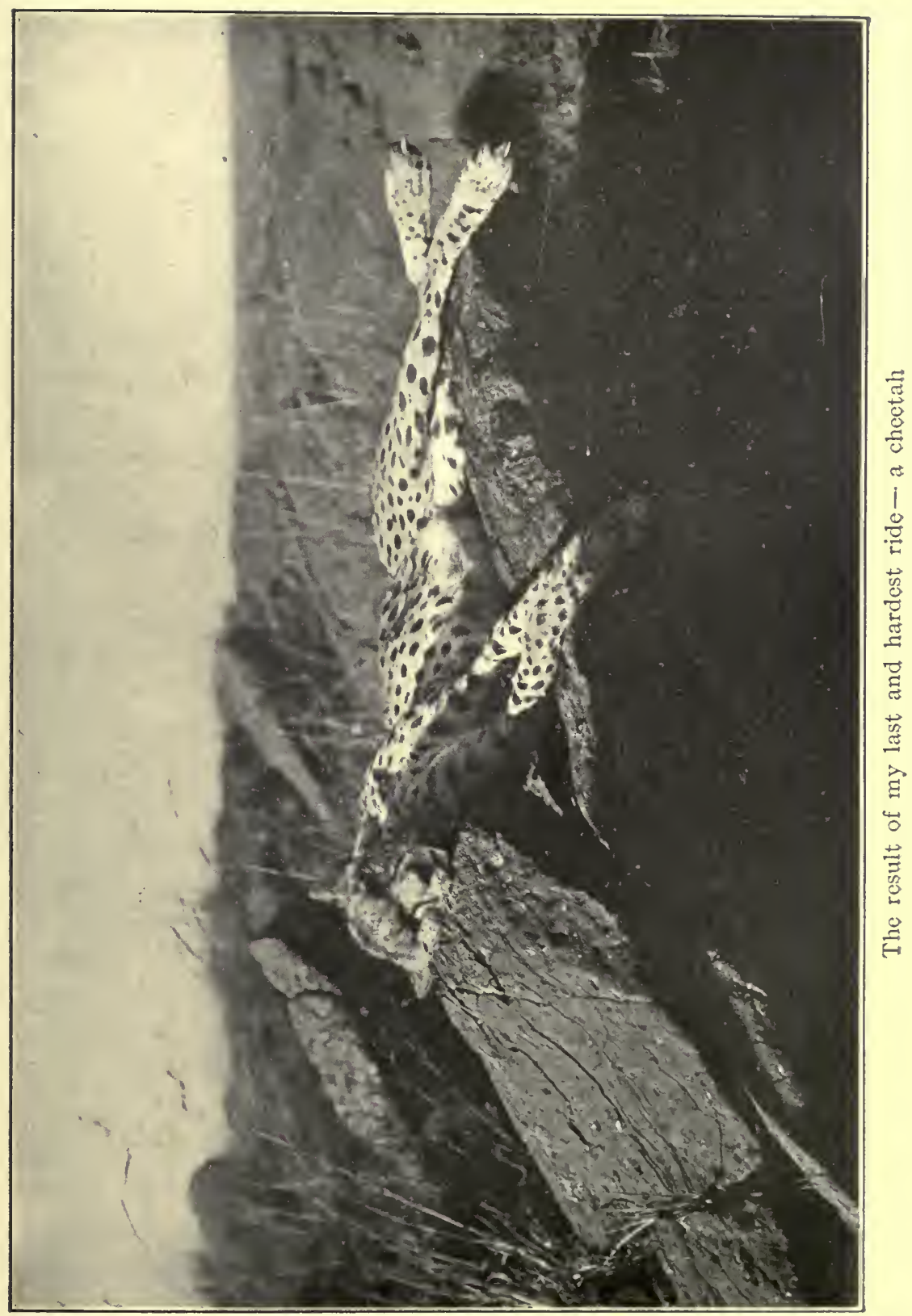



thing about the stopping. She is bounding along though much distressed, and in the very middle, as it were, of her stride, stopped with quite extraordinary quickness, and then never moved. Cheetahs are not dangerous, and I rode her as close as I could. She lay down broadside on, crouching till shot.

I have made little reference to any but the dangerous game of the Nzoia country, as in its pursuit I was chiefly interested, but its splendid water-buck, and the fine brushbuck that are still abundant along the banks of its marshy rivers, carry trophies that can seldom be equalled. Here alone the kobus kob is found; and reed-buck are larger and more plentiful than anywhere I have been.

I had no idea that buffalo were to be found amid the Cherangang mountains and in Elgoa country, till my second sefari to those parts. When I did get to know the wildmen, and had the inestimable advantage of their experience, I was limited for time; and the short grass season, during which it would have been quite easy to secure all the buffalo I wanted, was over. We made afterward a very long and unsuccessful journey especially to kill buffalo, whereas if we had been in touch with the $N$ 'dorobo at that time, we had all we needed within two days' march of our camp.

This again illustrated one of the greatest difficulties the sportsman must meet in the country. It is new; no man knows it yet. The district commissioners, who are usually capable and hard-working men, have not had time to learn their districts, or even to meet, much less know, the tribes they have been appointed to rule. Mr. A. B. Percival, the head game ranger, and his two assistant rangers are active and indefatigable in their efforts to accomplish the impossible tasks set them. But how can three men, even if they commanded the services of a perfectly equipped airship, oversee such a country of mountain, desert, swamp, Sahara, and forest as B. E. A. A country 
of probably 500,000 square miles (no one has measured it yet, but such is the estimate of Mr. Gregory, one of the ablest and best informed of those who have written on it).

These things being held in mind, I would say to all who come here, get all the information you can from officials, then get in touch with the best natives, and then go slow and take time.

New men, new beasts, new birds and insects are round you everywhere. Go out to watch and study the wild life, not merely to kill it.

Often the most interesting time in the day to me, was the quiet hour or more I tried to take before the sun set. I would choose a spot from which I could command a view and, staying quite still, would watch. In the evening I never shot unless I had to. Twice I saw at that time a cautious leopard stealing round in the grass, and each time I gave up my nature study to follow him, but in vain.

Once I saw a great porcupine come out of his secret hiding place, almost at my feet. Mr. F. J. Jackson, perhaps the best naturalist in the country, tells me he has never succeeded in seeing one, and that $I$ had rare luck. I had chosen a low rocky ridge, about two miles from camp, as my goal. The sun was setting gloriously over Lake Naivasha, and beneath me hundreds of Grant's antelope, "Tommy," and zebra were feeding quietly.

I heard a gentle sort of rattling noise in some rocks not ten yards below where I sat, and out of a big crack in them a black nose peeped. He never looked above him - animals seldom do - and when he had satisfied himself that the coast was clear, out he came. The way that porcupine unfolded his immense sheaf of quills was a wonder. First he shot them out a little, as though he were treating himself to a yawn, and then wider and wider the white and black quills were spread and flattened on 
the ground. It looked as though he had been forced to fold himself up like an umbrella, in his narrow rocky retreat, and that now he could not stretch himself sufficiently. After some minutes he gathered his prickly belongings round him, and soberly waddled off. I watched him for a long time till he turned the corner of a rock a quarter of a mile away.

A little earlier in the evening is the time to find ostrich nests. Ostriches are now strictly preserved; they are much too valuable to be treated any longer as wild game. Every settler wants to rear the young and gather the feather harvest. Three years ago stalking an ostrich meant patient work, and killing one, good shooting. Since then this unusually canny bird has quite altered his habits. Then you could not get near him; now you cannot get away from him. A few days ago an old cock, protecting his fine brood of half-grown youngsters, chased my old mule ignominiously off the Fort Hall road, a few miles out of Nairobi. And I had loudly to call on the "boy" who had charge of the brood to come to my aid. $\mathrm{He}$ kept hissing, and shoving his beak into my face. By the way - as evidence of the advancement of the country - I had scarcely got rid of the great cock, when my poor, demoralized mule for the first time in his life, found himself confronted with a motor car, with the result that we both of us nearly charged the stiff barbed wire fencing that lined the roadway.

During the nesting time permits are given to gather the eggs. Now an ostrich's nest is not an easy thing to find by any means. But the cock bird is so good a father, so regular in his hour of home-coming, that his very virtues betray his home. During the dangerous hours of the night he sits on the eggs. At nine in the morning the hen relieves him. And at four in the afternoon, punctually, he comes back and changes places with her. 
These two hours, nine and four, are kept with extraordinary exactness. Men who make a business of collecting the eggs, if they are in a country where a view can be had over an extensive country, find that they can do better, by going to such vantage points at nine and four with their field glasses, than they can by roving over the country, even when assisted by sharp-eyed natives. They have assured me they can almost set their watches by the appearance of the birds. It used to be supposed that the broken eggs found lying round a nest were broken carelessly by the birds, or by the attack of some marauding hyena or jackal. Evidence is accumulating that the hen arranges certain of her left-over eggs, when the nest is full, at such a distance from the edge of the nest that both she and her faithful lord can feed on them. Ostriches, instead of being, as the fables had it, the most careless of parents, are extraordinarily brave and intelligent in the defence of their nests and their young.

Several months have passed since I first said something in these notes about the "honey bird." When my men told me that this strange little fellow was an actually reliable guide to the bee tree, and that the natives depended on its guidance to find them honey, I did not believe it.

Since then I have made a point of following up this little feathered challenger whenever I could do so.

About the size of a small brown thrush, creamy white on the neck and upper breast, with a sharp chattering cry, it will light on a bough by the trail side and flutter from branch to branch.

If a native wants honey he whistles to it at once. The N'dorobo and Elgaos sing a song to it: "You are a pretty little bird with a white throat, but don't tell me any lies and lead me straight to the honey tree."

I think I must have followed the bird certainly more than a dozen times, and it never once failed to "lead me 
straight to the honey tree." You must be a little patient for it will flutter with seeming aimlessness before you, flying from one tree to another, as though it could not quite trust you to give it a fair share of the sweet spoil. Then it makes up its little mind that it cannot have what it wants without your aid, and flies straight to the tree it has marked. I have followed a bird for many hundred yards. It would wait for me, and while it was waiting, never cease to utter its sharp, chirping cry. Once I was up it would go on again. The whole proceeding always seemed to me very wonderful.

Mr. Jackson tells me the bird sometimes leads his. follower to a leopard or a cerval cat's lair, seemingly wishing to have his enemies killed.

Hyenas are very numerous all over the Nzoia Plateau. I had an illustration of their extraordinary cunning. We set a trap for some that would keep howling hideously near camp. The accompanying (bad) photograph gives some idea of how it was set. A branch, not seen in the photograph, stretches over the trap. Two short stakes are driven into the ground two or three inches apart. A cord hangs from the bough above and supports the Schneider carbine, which moves easily between them. A crotched stick in front supports the muzzle of the gun. This is cocked and a string passed round the trigger and fixed to the two stakes between which the butt of the rifle hangs. Fasten meat to the muzzle, and a tug at that will drag the gun forward against the string across the trigger, and anything pulling at the meat is shot in the head or chest.

The trap had not been set a couple of hours the first night before we heard the shot. We went down in the morning and found a young hyena dead.

That was the last we secured. The trap was set constantly and as constantly fired, but never again was any 
harm done. We gave it up at last as a useless expenditure of ammunition. We fixed thorn bomas round it, tried every possible device to force the visitor to pull at the meat from the front, but in vain.

These hyenas certainly knew that they must not come at the meat they wanted, and which they always carried away, no matter how securely it was tied on, from the front. It really looked as though they had placed a paw on the trigger and then proceeded to dine leisurely.

I never saw so large a python as one $\mathrm{H}$. secured on the Nzoia. He almost walked on it as he was tramping the border of a large swamp. It lay fast asleep and died immediately at a shot in the head. The skin was magnificently coloured shining with a purple iridescence, which left it soon after death. Three men could not haul the body, which measured unskinned 24 feet 6 inches, out of the soft yielding ground. And more had to come from camp before it could be handled.

Python on Victoria are not uncommon, but are not often so large as this one.

Snake stories are proverbial, and here is one actually true, yet so unbelievable that it could have happened nowhere but in Africa:

Captain - commanding one of the smart steamers that ply round the great lake, was bringing to Kasumo (the rail-head of the Uganda road) a little band of passengers from up country - civil officers, hunters and military men - some six or seven, I believe, in all. They had on the long way down to the coast been celebrating too constantly their temporary return to the homeland - their six months' leave in three years' service. It was late afternoon, and since there is no hotel at Kasumo and the train for Mombassa did not start till next morning, all the party remained on the steamer and were having five o'clock tea - shall I call it? - on deck.

Captain 
was sitting with the rest when one of his black crew came running up to say that a snake was swimming round the stern of the ship. Captain looked over the side and saw a big python that had probably been washed out of its near by swampy retreat by the prevailing heavy rains, trying to make a landing somewhere. The planking of the pier and the side of the steamer were too much for it, but making its way round the ship, it came to the ladder which was down to the water's edge on the offside, and began to crawl up the sloping steps at once. A great snake crawling on shipboard! Was such a thing - even in Africa - possible? There were plenty of guns to hand and the men standing there knew how to use them, but each looked at the other and no one cared to be the first to make a move. The Captain took in the situation and with his smooth bore shot its head off, to the immense relief of some of his companions. The python measured sixteen feet four inches.

The lion when possible conceals his kill carefully. If thick bushes are near he often succeeds in hiding it long enough for even the vulture's eye to permit of his satisfying his appetite a second time.

The roar of a lion is, as everyone knows, a much debated point. Some will have it that the historic sound is one but very seldom heard. When the Jewish poet of long ago wrote, "The lions roaring after their prey do seek their meat from God," he used a term it seems to me that suited well what he meant to describe. In many places at once, and often all night long, you can hear it in East Africa. Then again in a land full of lion, you will not hear it at all.

I saw twenty-seven lions in five days once, on the Nzoia. During those days and for several before and after them no lion called within earshot of camp. I also found two lairs in daily use quite close to that camp. 
I am inclined to think that lion usually hunt at a long distance from the place where the family lie up for the day. When the bands are divided up into twos and threes this may not be so. But whenever I came on large bands of lion I never found kills nearby. ( $\mathrm{I}$ give this for what it may be worth.) My idea is they hunt far away from their lair. When two or more lionesses and a partly grown family accompany one large male, they make a family dwelling place that there is no mistaking. I have examined several of these but never found in or near any of them so much as a scrap of bone or meat. When the lion family jogs homeward it does so very silently. There is no loud grunting indulged in; a very soft, low purring grunt now and then betrays their conclave, that is all.

When shot into and angered they will grunt as they move off, and snarl as they crouch or wait about in the grass, undecided whether to move on as you advance toward them or no. I incline to believe that these large parties are not as dangerous to follow, when one or two of them are wounded, as a single lion or a lion and lioness, one of them wounded, would be. One of the gang moves on, none of the gang likes being left behind, so, instead of attacking they keep on the move, the wounded bringing up the rear.

A lion wounded to death will, as I once heard him, roar terribly when roused from his lair and about to charge. But an unwounded lion coming on thrusts the head forward and the ears back, shows his teeth and make no sound but a low snarl.

The roaring lion is the lion calling to his mate or signalling in some way his presence, either to frighten the game not yet caught or to call a friend to, or warn an enemy from, game that has been caught.

The distances which that sonorous sound can travel are great. Ordinarily hearing it, you fancy the beast 
some hundreds of yards away, whereas he is probable miles. When a lion calls really near, say within three hundred yards of your tent, you are never likely to forget it. You will agree with your men, who by that time are likely to be looking you up, when they say, "He makes the ropes shake."

In hilly country I have heard lions quarrelling or calling over a rhino carcass at seven miles distance on a still night.

I agree with the Psalmist: "Roaring after their prey" is the best description of the sound that they can make when they so choose.

A yellow light lingers long in a lion's eye after death; much longer than I have seen light live in any other dead animal's eye. I have wondered at the reason.

Unwillingly at last I turn my face southward and leave behind me the beautiful land over which I have wandered for so long. I am back once more among the forest edges of the Mau.

When first I rode this trail it was springtime, or a season that seemed to correspond in some important respect to spring. The rains were just beginning and the whole country was one green carpet of short, freshly springing grass. We ate quantities of succulent mushrooms, immense in size, and excellent in flavour. Springing flowers made the veldt gay.

Now the land is a rich ripe yellow, where creeping grass fires have not blackened it. The vigorous growth of leaf and twig has been checked by unbroken days of dry heat. And all the flowers that cannot rear a sturdy head above all the enclosing tides of high grass, have disappeared long ago.

The change is great between May and October, but the borderland of the forest is very beautiful still, though with a different beauty.

The crowns of the trees in Africa are thicker and 
heavier in quality than in our northern woods, they are more rounded, they branch more luxuriantly.

Now in October, as though following the custom of far other lands, they have ripened into a dull burnt gold, sometimes deepening into a fine crimson.

Nor are all the flowers gone. From the abrupt edges of the wood, where it meets the yellow grass, salvias grow luxuriantly; sometimes filling spaces in the curving forest line with banks of purple flower that rise fifteen or even twenty feet to meet the spreading boughs stretched out to shade them.

I halted my mule on the highest ridge of the great sweep of down, from which first, many months before, I had seen, far away to northward, Sergoit summit stand out pink in the evening light.

Good-bye, Sergoit! What changes has not your gray head looked down on! In ages long ago that softly outlined purple Elgon that now faces you to the west was pouring forth devastating tides of lava from the rocky lips of the great crater that this evening are sharply outlined against the crimson sky. And the wide plain, almost to your base, was a sea of fire.

Then the tropic rains and scorching suns did their faithful work, till the land grew rich and green, and forests smoothed away the harsh wrinkles that Elgon had plowed on the face of the country.

Then came the wild life, man's and beast's, much of it almost the same as it is to-day. Tribes rose and perished, surged forward, fell backward.

Our poor, forgotten Sarequa built the stone kraals that lie around your feet, and no doubt many a bloody fight you beheld, before the attacking spear men forced their narrow stone entrances.

Then came the groaning slave gang, toiling along its bonestrewn way to the sea. You have looked down on it all. 
And now you are looking on another change. A new mark lies on the face of the level; like a faint strawcoloured ribbon it winds across the veldt. It is the track of the Boer's wagon. If sefari fires are lighted here and there on your plateau, the fresh grass will soon cover over the small gray circles where they burned for a night, and no trace of them remains. But that faint yellow line deepens and widens year by year. Old things for you are indeed passing away. You have looked on many strange old things, and seen them pass; things that the wisest of us know nothing of. Would you could tell me of the new!

Across the thin rising vale of grass fire smoke, I now see your rocky crown but dimly, and for the last time. And so, Sergoit, true land of the lion, Kua Hèri. Kua Hèri. Good luck! Good-bye! 


\section{CHAPTER XI}

\section{FROM GILGIL TO KENIA}

A FEW hours after the head of the sefari has turned A north from little Gilgil station you are among the pretty wooded hills that gather round the base of Gojito, I3,00o feet high.

As you press still northward the splendid Aberdare range rises abruptly to your right hand. It begins with Kinan Kop (also over I3,000 feet) and prolongs itself in fine forest ridges that slope to the plain at the northern end of Embellossett swamp.

Four or five miles after leaving the railway, the trail crosses a plateau that commands a view behind and beyond you that is worth remembering.

Blue Naivasha Lake lies twenty miles to the southward, in the heart of the great Rift Valley, that strange, long crack in the shrinking earth crust, that only ends far to northward, where the Jordan Valley falls sharply to its Dead Sea. Beyond the lake two extinct craters cut the sky line, Longanot and Suswa. To east of it are the purple crests of the Kikuyu range. To westward the tumbled masses of the Mau across which we made our way to reach Nzoia.

As we marched northward all the beautiful land before us looks as little like Africa as can be imagined. Were it not for the striped skin of a zebra showing now and then as we mount some grassy rise or descend some deep dell with running water at its foot, we might fancy ourselves among the Tennessee mountains. But leave the trail a short way, try and mount these great purple ridges 


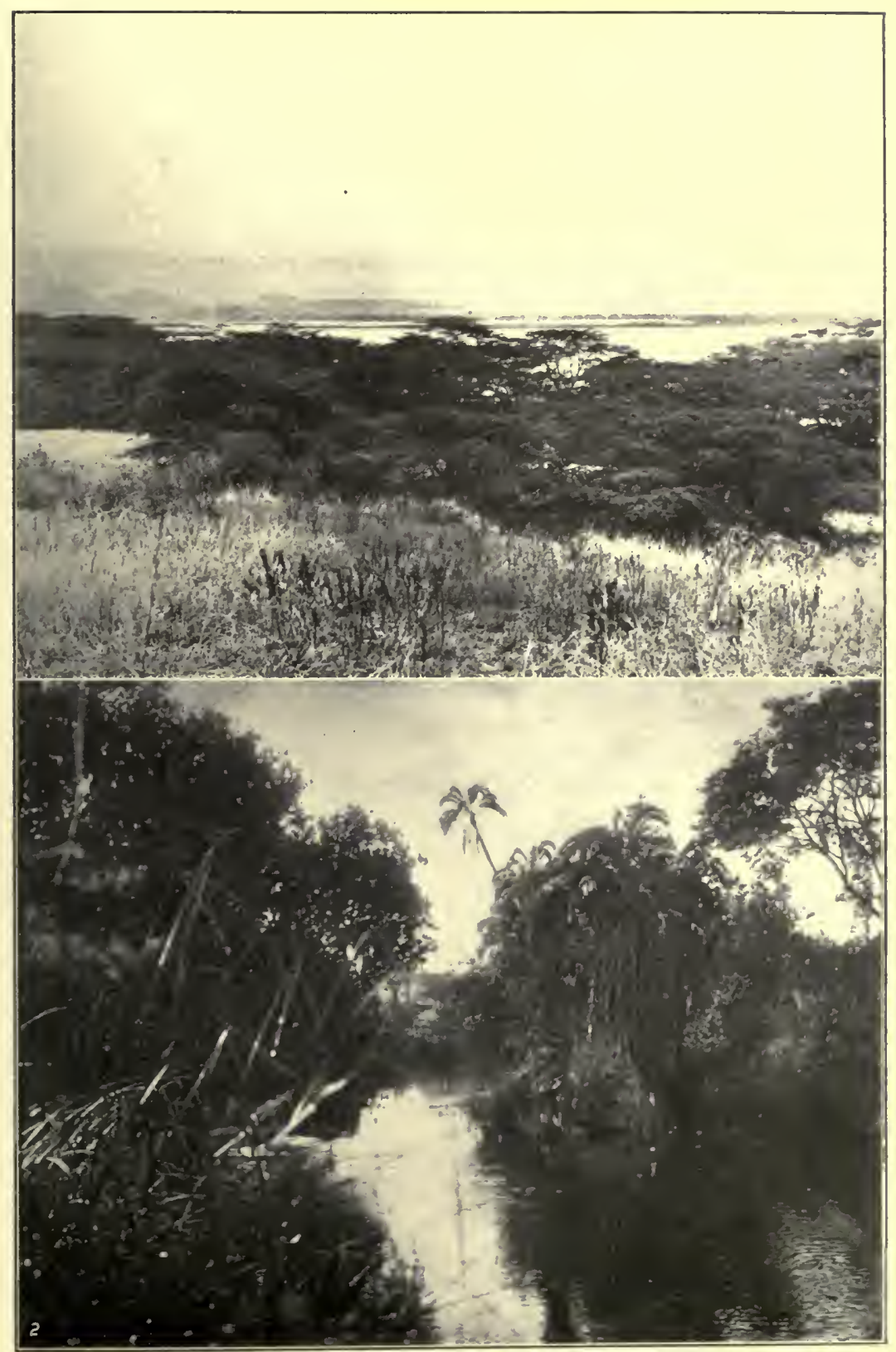

I. Naivasha Lake

2. Nzoia River. Hippo and crocodile are in the pool 

of the Aberdare, and you soon find yourself not only in Africa but in the face of obstructive Africa, the real.

These great mountain ridges, near as they are to the one highway of the country, the Uganda Railroad, are practically unknown, almost unexplored. In them still herds of elephants have their retreat and find in their impenetrable bamboo thickets food and shelter so much to their taste, that they seldom visit the plain, or the lower valleys that lead to it.

Kinan Kop is more accessible, its woodlands are less rugged and compact and shambas stud it here and there. Its elephant herds, too, have been searched for big ivory. But the almost perpendicular ridges of this great escarpment that now rise beyond and to north of you, as well as the density of its forest, have effectually barred even the ivory hunter's progress: he has turned away discouraged to seek a more penetrable country where, in shorter time, he can hope to secure two paying "tuskers."

This is surely a land to invite to leisurely sefarying, and not by any means a country to hurry through. Flowers never classified, birds not even named, find hiding in the sheltered "chines" that slope to the wide marsh land of Embellossett; and weeks might be passed in ascending the unmapped mountain solitudes from which they come. There is game enough for food, and wild fowl in thousands breed safely in the marshes. Here, four years ago, an inexperienced English subaltern saw a fine herd of kongoni and rode after them at top speed. When he and his companion got among them they found themselves riding the tail of a band of twenty-four lions.

In these Aberdare mountains the Guasi Narok, one of the chief streams that make the Guasi Nyiro of the north, has its rise. On this sefari we took it as our guide and followed it down through the Embellossett swamp 
by Laikipia Boma for eighty miles, to its junction with the main stream of that beautiful river.

Two short marches from Gilgil bring you to the foot of the Aberdare, a rocky wall fifteen miles long, on the south end 2,000 feet high, on the north, 200. Down its front tumble fifteen waterfalls, some taking the steep at one bound, others falling sheer a hundred feet and then in cascades often hidden by dense brushwood come flashing out again into the sun, to fall tumbling to the plain.

That grim rocky wall, scored with little mountain torrents tossing themselves at one bound, or tumbling all brokenly down its great steep, is one of the finest things in East Africa.

The level country beneath spreads out into swamp land, and in its long wilderness of marsh piants, mud banks and secluded lagoons, at the highest elevation in the world, are found large herds of hippo. When his haunt is near cultivated land the hippo is an unmitigated nuisance. He will devour and trample down in one night what has taken an unfortunate native months of labour. His nocturnal habits make him difficult to destroy. On the Athi and Tana rivers, where I shot them, they do great harm. The river hippo's tusk is seldom worth taking; he sinks when shot and so, unless you have the luck to find him on a sand bank, the crocodiles get him.

These Embellossett hippo, however, are very large indeed, and carry fine tusks. They are so well off in their marshes that they seldom come to shore, and a collapsible boat would be necessary in order to do anything with them.

While we camped by the marsh we saw no signs of the big beasts landing. I saw them on sunny evenings, floating lazily along, the great bulk of the shoulder making them look like upturned boats, or steadily swimming to keep some aquatic appointment, only showing above the 
water the upper rim of a broad nostril and the little round covering of the eyes; a truly mighty "submarine!" Hippo are not supposed to be dangerous though sometimes they are, as was proved by one chasing a band of men on a public road within two miles of Mengo, the capital of Uganda, while I was there. The ponderous beast actually san them down (and the Waganda are well known to be very fast runners) and bit one man completely in two. Next morning two hundred Waganda surrounded the little swamp where the furious beast lived, and from which he had charged forth in his quite unprovoked attack. Doctor Cook, with whom I was staying at the time, took me to his admirable hospital and showed me the results of that encounter. One man had his thigh shot through, another had a ball in his shoulder, a third had a great piece out of his buttock, and a fourth was trampled into and under the mud and the reeds till he was a mass of wounds and, besides, was nearly suffocated. They killed the hippo.

I am inclined to think that, during low water, the Embellossett hippo is not so hard to bring to bag as he was at the time we waited in vain for him; for during low water his supply of soft eating far out in the swamp fails him, and he has to content himself with the meadow grass that, as soon as the rains stop, begins to grow luxuriantly all along the rich margin of the marsh. On moonlight nights he will often take a long walk inland. I remember one night seeing two great fellows solemnly walking all round our circle of tents. That was to north of the Nzoia, and the swamp they had come from was a good way off.

The borders of Embellossett are extraordinarily rich and green, as they are watered by the swamp vapours as well as numberless rivulets from the hills. A deep lush growth of white clover spreads up to the very feet of the cliffs and upon this the bush-buck love dearly to feed. Very early in the morning and just again before 
dark, this fine, shy buck comes down out of the upper thickets, and ventures into the green glades that everywhere border these pretty mountain brooks. I counted no less than sixteen bush-buck during one short morning's walk. They were unharmed by me as I had already secured good heads on the Nzoia.

There is one drawback to the foot of the Aberdare as a hunting ground, it is generally bitterly cold there. The mountain winds seem to be drawn down along the sharp edges of its ramparts, and the shivering sefaris always call it "Beréta" (cold) camp. The equatorial line here crosses the swamp and it is a strange experience to wrap yourself in the heaviest overcoat you possess and seat yourself by a roaring fire, exactly under the Equator!

One of the chief charms of Embellossett is the bird life that everywhere within it breeds and lives quite undisturbed. Here above all other places can the naturalist study the aquatic birds of the continent. In vast numbers and in great variety they are here. I used to take my glasses and sit by the water's edge in the evening, while flocks innumerable, dabbling, diving, swimming, would come before me. Some parent birds were just guiding their little downy balls of fluff out of the nests, for a first swim; others led forth broods almost fledged, none seemed afraid and this I think is remarkable.

When the chase of hippo proved hopeless, I watched the water fowl a great deal. Not once in a long afternoon could I catch any sight of so much as one bird of prey, no eagle or hawk disturbed the mother birds as boldly into the open water they led their countless broods. Land life has many an enemy, water life seemed there to have none.

Beyond Embellossett we enter Massai land, where till three years ago no one might come. It says much, surely, for English influence - it is scarcely fair to call it rule (for the civil and military officials are a mere hand- 
ful) - that you can travel unarmed, if you wish, over every square mile of Massai land. From the natives you will receive nothing but courtesy and yet but a very little while ago they were accounted the most bloody and intractible savages of East Africa!

Here the rhino alone occasionally resents your intrusion. Once in a dozen times, perhaps, he puts your sefari to rout, on the other eleven times he rushes snorting away.

It is hard to realize that much of the country we were about to hunt, particularly that lying beyond the Laikipia Boma and across the Guasi Nyiro, had until two years ago only been visited by a very few white men, and to visit it then they risked their lives.

Where else in all the world within six weeks of London could a country so new, so strange, so beautiful be found?

But she offers more than strangeness and beauty to men like myself, tired and no longer young. She offers more freely, more certainly than any land I know, the untold boon of reasonable exercise with quietness and rest.

Day after day as you travel slowly from stream to stream, from valley to table land and then down to wood and stream again, always greeted and interested by some new experience, some bit of knowledge that comes as it were leisurely to welcome you; riding along five miles or twenty as the fancy takes you, watching your little army crawl like a long, brown snake across the veldt as you stand on some higher ground above them. The peace and independence of it all slowly but surely sinks into you; you are at last centuries, generations, away from that torrent life in which you lately swam and in which you have worn out your strength in swimming - Life "with its sick hurry and disappointed aim," as Matthew Arnold describes it, has faded very far away; you drink it all in and feel something within you making, if not for Shakespeare's "Sea change," yet still none the less for 
a change into something strange and new. That smoothlimbed Wanyamwazi who saunters off to get wood for your night fire knows he has done his day's stint. Once that is finished, this wood-carrying business is a leisurely matter and so with beautiful carriage of head and shoulder he strolls along, restfulness in every movement of him; to hurry him would be an outrage. Before the quickly fading twilight has vanished, he will come as gracefully, as leisurely back, poising on broad shoulder a mighty log of the very best burning wood in the world; and this should go far to convince even American restlessness that in this old new land, at least, efficiency and leisure are not incompatible. The African wilderness is very restful to the over-tired man.

At the northern end of the swamp your trail bears away from the river for a few miles, and you will most probably next camp on its banks at Laikipia Boma.

Here the Guasi Narok runs strong and clear till it enters, just below the Boma, one of the finest swamps to be seen anywhere in B. E. A. I use the word fine with a purpose, for swamps usually are in no way beautiful, in this or other countries. But the borders of this great Papyrus garden have a distinct beauty of their own. The ground in Africa is often hard, far harder than any earth I have seen. Even after rain there are large tracts, not by any means stony, where the earth itself is so compressed that a mule's hoofmark would easily escape an untrained eye. And a two-ton rhino can pass and leave only a spoor that takes pains and skill to follow at all. Well, the soil round this great fourteen-mile swamp that swallows up for that distance the Guasi Narok, has this African property. On it springs grass soft, green and level as can be seen anywhere, but as you ride over it you can with difficulty make out even the heavy four-toe footmarks of the great hippos whose nightly browsing keeps. 
the turf as smooth as a cricket crease. So the swamp's border is a beautiful thing, an almost level sweep of turf that is ever green, which with a very gradual slope goes down to meet the solid high upstanding wall of impenetrable Papyrus. Impenetrable that wall is, even to the vast bulk of the elephant, who will turn aside and make no effort to penetrate it or to do more than bathe at its borders. The hippo alone, heavy and short-legged, succeeds in forcing a path to its dark solitudes. There is his safe retreat and home.

The country around abounds in game, but water is scarce. So this green rich water meadow is cropped by the very best of nature's mowing machines which, moreover, as it passes nightly over it, except in a few soft places, leaves no mark of passing hoof to cut or roughen the level green.

Here flowers grow abundantly and seem to bloom as they do in favourable localities, the whole year round. Primrose-coloured sweet little single things, thick lowlying patches of African "for-get-me-not," bunches of purple salvia, and many another. Here, when now and again the flowing water has worn a channel round the foot of the papyri wall, and for a little space the brown stream widens out in the sunlight, beds of purple water lilies are spread, and the shy water birds swim and feed. The beautiful white egret and lesser egret are found here. Why they and all birds (excepting the wild fowl on Embellossett) are so wary I have no idea. It may be that the natives have hunted them for food or feathers long before the white man came. Whatever the reason is, the birds, excepting partridge, quail and snipe are strangely wild.

In the evening you can hear as you stroll quietly round the swamp's edges

"The river horse as he crushed the reeds

Beside some hidden stream," 
as Longfellow very accurately wrote in his New England study; and very completely here does the swamp swallow and hide the strong stream. Here too the Grant, the Tommy and the impala come down to drink, and here nightly the lion's deep hunting call sounds. About once a year elephants appear on its borders. Most probably these come from blue Mount Kinan Kop some fifty miles away, for Kinan Kop still shelters many bands of elephant among its bamboo forests and, were it not set over against Kenia, would be a mountain worth coming far to see.

I have written elsewhere of Mr. Stauffacher's mission work. His little mission house stands on a rocky knoll by the swamp border, and his garden occupies a little corner of its green fringe. He has well tested the valuable properties of this hard damp, rich soil, as its roses and vegetables prove, and here with the help, most readily given, of the civil officer, Mr. H. B. Partington, he intends to carry out a modest scheme of irrigation which should be both easy and inexpensive to accomplish, and would give some practical evidence to the wandering Massai of the productiveness of their land. One irrigation ditch, taking the water from the river, just before it enters the swamp, would irrigate hundreds of acres of as rich land as can be found anywhere. And since the Guasi Narok is fed almost entirely by mountain springs its flow can be counted on. Mr. Stauffacher also mentioned to me another scheme which this mission cherishes. That is to establish a sanatorium on the shoulder of Kinan Kop. The mountain is very accessible, and many spacious plateau and slopes are to be found situated well above the frost line. Water will sometimes freeze as much as an inch at night. The country below is (for Africa) densely inhabited and well cultivated. Food supplies are abundant and the mountain springs are clear and cold as mountan springs should be. I cannot fancy any place that would 
be likely to benefit the over-tired and fever-smitten people of the Protectorate more than this. Malarial fevers are not as deadly as they were a few years ago but even now valuable lives are of ten lost because hard-worked men have had no time to look out such a place for themselves, or because when fever has prostrated them, they have. neither means nor energy to transport themselves to such a mountain climate.

If comfortable housing, good nursing and carefully prepared food, at an altitude of say I0,000 feet, could be had quickly and at reasonable cost, the benefit to all East Africa would be immense. It is the recurring attack of fever that eats away the life and energy of men often invaluable to the country. These are the very men who stand to their job, beat down the poison with quinine, and wait and wait for the far-off home going, that will "surely set everything right." So it would if it came soon enough, but when it does come it comes often too late. Nothing, not even a sea voyage, kills African malaria like real mourtain air. Mr. S. has been all over Kinan Kop and describes it as most beautiful.

Mr. S.'s little stone mission house which he built with his own hands, stands on a knoll, a third of a mile from the water. We were camped at Boma less than two miles. away, and went over there one afternoon for tea. He had a curious story to tell us of a leopard.

Two nights before their little child, only five weeks old, had cried a good deal; and that his wife might get sleep he took it to the next room and tried to hush it. He thought he heard a noise outside and went to the window. On looking out into the darkness - there was no moon right before him, not two feet away, was a leopard's head, the eyes looking straight into his own, while the forepaws rested on the window-ledge.

$\mathrm{He}$ had actually time to go into the next room, fetch 
his rifle and shoot it dead, for the beast did not seem in the least scared and waited for him. I think this was the same leopard that had thoroughly frightened the little native bazaar a few days before. He had broken two windows, one the postmaster's, and the other the district commissioner's. In both cases if he had not been fired at he would no doubt have come in. Had Mr. S. not shot him there would soon have been a man-eating leopard at Laikipia.

Man-eating leopards are not unknown hereabouts; one of the best and bravest of the Church Missionary Society's men, Mr. McGregor, was so mauled by one of them, some years ago, that for a long time he hung between life and death.

This beast had carried off several children from one of the Kikuyu villages which it was in the habit of visiting. Emboldened by success it next broke into a hut and seized a woman. Mr. McG. happened to be there, and hearing her cries, rushed out into the darkness after the beast. $\mathrm{He}$ is a good shot, and carries a $45^{-90}$ Winchester. He came upon the leopard round the corner of a hut, and managed by a flambeau's light, to shoot it through the body; but it sprang on him and tore a large part of his scalp away, and so clawed and mauled his shoulder and left arm that they are to-day almost useless to him. He told me that he lay unattended (missionaries were few and far between then) in that village, for almost six months.

Lions in this neighbourhood have a bad reputation and are not like those on the Nzoia, which are treated, by the almost unarmed N'dorobo of that plateau, with contempt. The N'dorobo are very numerous on the Nzoia, yet they seem scarcely ever to come to an encounter with the packs of lions that hunt over the country. They sleep in twos and threes under any convenient rock or thorn tree, light their tiny fires, hang up their meat on the brush 
above their heads and go to sleep without watch or guard. So far as I could learn they are scarcely ever molested. I did hear of one boy on the Nzoia dragged from such a fire by his leg, but in that case the leopard was the aggressor. Here, however, the lions are very bold, though not nearly as numerous. Last night two of them united in an attack on a very well fenced munyata (I examined the thick thorn fence; it was seemingly impenetrable and quite eight feet high). They leaped this high strong thorn barrier, that the Massai had carefully built to protect themselves and their prized cattle, and landing in the dense pack of beasts that are always crowded for the night within the circle of wattle huts, drove the herd in wild panic against the thorn barrier that blocks the kraal entrance. Through this the cattle burst and then, in spite of spears and firebrands, the lions pulled down two fine cows. The Massai drove them from the one that lay a few yards from their kraal, but the second the lions dragged two or three hundred yards into the grass and devoured at leisure. The necks of the cows were broken.

By our camp of yesterday, the men pointed out to me the grave of one of their fellow-porters who was taken from his tent when they were on sefari here a year ago. They drove the lion off and many shots were fired at him, but in the pitchy darkness he was not hit; his victim died almost at once. Strangely enough when only three months afterward they were camped at the same spot, another boy was seized, but he somehow managed to free himself, and escaped with slight hurts. The lion also escaped.

There is little game in this part of the country (I was camped twenty miles back from the swamp when writing) and this is probably the reason of their exceeding boldness. Buffalo there are, but then these can take good care of themselves, and lion seem to leave them alone.

The Massai spear, seven feet long, looks, and indeed 
is, a formidable weapon. With it they do kill lions. To this fact the fine lion head-dresses worn by the warriors are quite sufficient proof. But since the white man has taken over the country, the Massai seem to prefer leaving lion killing to him, and the coveted head-gear is generally an old one, and not worn nearly as commonly as heretofore. One of the government officers stationed among the Nandi tells me that these natives still face the lion resolutely in defence of their flocks; and not rarely skins are brought in of spear-killed lions. Our Somali say that before the British occupation of Somali land, they had in self-defence to combine to kill a lion, when once he had tasted human flesh. That as soon as such a beast appeared in a neighbourhood, all the men were commandeered by the chiefs and that on horseback, armed with spears, they hunted it down, be the cost what it might; otherwise the villages would have been uninhabitable. They added, however, that since the white man came lions are much fewer. All over the Guasi Nyiro country lions can be found, but when the white farmer, and more especially the white herdsman, comes in they soon disappear, for he very properly poisons them. It is so in every wild land. As soon as the little mountain streams of 'our own Rockies were used for irrigation, and the mountain slopes were chosen as pasturage for small, well watched herds of valuable beef cattle, the grizzly disappeared, and with him the' gray timber wolf. By the same ignoble means the lion is doomed to pass.

Along the banks of the Guasi Narok, especially on the northern left hand bank, the going is stony. Thorny scattered scrub comes down to the river's edge, yet we found some delightful camping places where the grass was green, and where wide-spreading thorn trees threw a grateful shade. The river is full of fish and its water deliciously clear and cool. To find such a stream is so rare in Africa that no camp near it can be a poor one. 
Rough as the country is on the northern bank, it teems with game. Very fine impala are plentiful. Large flocks of Grant and Tommy feed on the more open country across the river to the south, and eland were quite plentiful, some carrying good horns.

Three miles back from the river, the bush slopes sharply up to a wide table-land. I saw oryx, eland and rhino as well as two lions and a leopard all on one morning. The oryx and rhino I did not want - and I needed a pony which I did not then have, to get near either of the other animals.

At the junction of the Guasi Narok (down which we had been marching ever since we came to the Embellossett Swamp) and the Guasi Nyiro we made permanent camp for several days. This is an excellent place to establish a hunting camp, and as you move farther north toward the mountain, a base camp from which to supply the sefari.

On the Guasi Narok, fifteen miles above the junction, I shot an aard wolf and saw two others. This is an exceedingly rare animal in the Protectorate.

Several kinds of partridges and frankolin are common along the river banks. One little brown partridge with a sharp spur, which I have seen nowhere else, is the best eating bird I found in Africa, except the snipe, quail and lesser bustard.

The morning star burns gloriously in the east as I stand at the front door. There are no signs as yet of daylight, but you can smell the day, and the earliest birds are beginning to call and twitter. Presently the blue black of the eastern horizon takes a tinge of clear gray which changes almost suddenly into a low-lying band of dull red; in a moment this becomes first crimson, then golden, and then between the two great mountains, over the dark purple plain that divides them, bursts the sun. 
On the one hand are the forest-clothed slopes of Kinan Kop, no insignificant mountain, but dwarfed by the solitary giant opposite it, whose summit rises rocky and snowcrowned to 18,600 feet. There are many beautiful things to see in this wild land, but the one thing unsurpassably beautiful is the brief pageant of the African sunrise. To tell the truth, getting up before the morning is not at first an easy or pleasant thing to do, but to make good marching or to enjoy good sport it should be done, and done regularly; and soon you find that these first and freshest hours, nay moments, of the day are well worth the effort they cost.

From Mt. Kenia's broad base there stretches to the east, north and northwest one of the most impressive plains to be seen anywhere. A large part of it is Massai Reserve but sportsmen can obtain permission to hunt on it from Lieutenant Governor Jackson, at Nairobi, who issues all hunting permits. Many visit the country, but few do more than camp at the junction of the Guasi Nyiro and Guasi Narok. The river should be followed up to its very sources, on the slopes of Kenia - for here is some of the finest hunting country in the world.

We found ourselves at this central camp on the Guasi Nyiro, in the very middle of an unusually severe wet season, but though rain in these parts has some disadvantages, there are certain solid compensations which it brings with it. Chief among these must be reckoned the fact that, though we were in the Massai country, i.e., the cattle country, the very original source and breeding place, I am certain whence must have come Pharaoh's famous plague of flies, we were only bothered, and not as I had been on other occasions, driven to desperation by them. When Massai flies are really bad you have but one place where you can enjoy any rest at all; that is under the mosquito nets. They literally blacken the table, float, 
freshly drowned, in your soup and coffee, crawl in companies into your food, nest in your hair, and will not come out until killed, crawl up your nose (and not even furious smoking will prevent them attempting to do this), and cling on the morsel of food you are raising to your mouth, while driven well-nigh frantic, you use your fork as an extemporized fly-whisk. But why attempt the impossible? Their numbers, stickiness and persistence cannot be described; mercifully the heavy rains banish most of them at last!

Our camping ground at this junction was a little oasis, in the very middle of extensive, gray cactus brush. Taking fresh life from the rain, it was as green as an English lawn, and the bordering scrub rising high all around, we had been well sheltered from the heavy storms that had drenched the land. The river ran within a few yards of our tents, and its banks were so rocky, its bars so sandy that no mosquito pest forbade our pitching within the sound of its waters: it is generally wise to camp well back from a stream. The little waterfall close by had been very pleasant to listen to both by night and day. It seemed now to have added a deeper bass to its chorus of water music, as the stream ran in spate, yellow and turbid among its enclosing rocks. There was another little green prairie just across the ford from our camp, also shut in by the dense cactus scrub; and in the evenings you would see the pretty shy gray monkeys come out to play and feed. They would chase each other round and round its circle, their tails, which were much longer than their bodies, carried in a funny stiff half hoop-like curve as they ran. Then suddenly one of them would espy something eatable, and the game would stop while he sat up and ate it. Rushing rivers and pleasant waterfalls are rather rare things in this land and they were pleasant to look on and to listen to. But the Guasi Nyiro is a real mountain river, 
rising amid hills that mount to a height of over 10,000 feet above the sea and flowing among rocky gorges and valleys for scores of miles before it brings its pure waters to the slow, muddy, fever-haunted Tana. It flows right around the great bases of Kenia and from Kenia's snows and dark, unknown forests takes many a tributary on its way.

Mt. Kenia stands all alone in the middle of a vast blue plain. On the Nairobi or southern side, the foot hills of Kikuyu, richly wooded, break somewhat the splendid upward sweep of its ascent. Looked at from the south it reminds me of Etna, as you see it from Taormina. Though Kenia's crown, even from that side, rises far more abruptly, and as its altitude is over I8,000 feet, it has a far larger snow-field.

From where I now was, I looked toward the northern face, grandly precipitous and abrupt. The final peak, an unbroken bastion of rock, ribbed and crowned with perpetual snow, looks absolutely inaccessible to the foot of man from this side. The mountain was ascended some few years ago, after a desperate struggle of three months. The party was well equipped, and had its base camp not fifty miles from the southern face. They cut their way through swampy jungle and densest forest; when these were conquered the chief difficulties of actual climbing were overcome but the porters fell ill by the score and many died. The Meru, a then unknown tribe, murdered many more, and it was a sadly wrecked sefari that struggled back to Fort Hall. The mountain looks as though when once the forest was passed there would be no great difficulty in reaching the peak and ascending it from the side on which this party made the attempt. But on the northern front, and up this absolutely sheer wall of rock, which must be higher far than the final rock precipice of the Matterhorn, no unwinged thing will ever mount. 


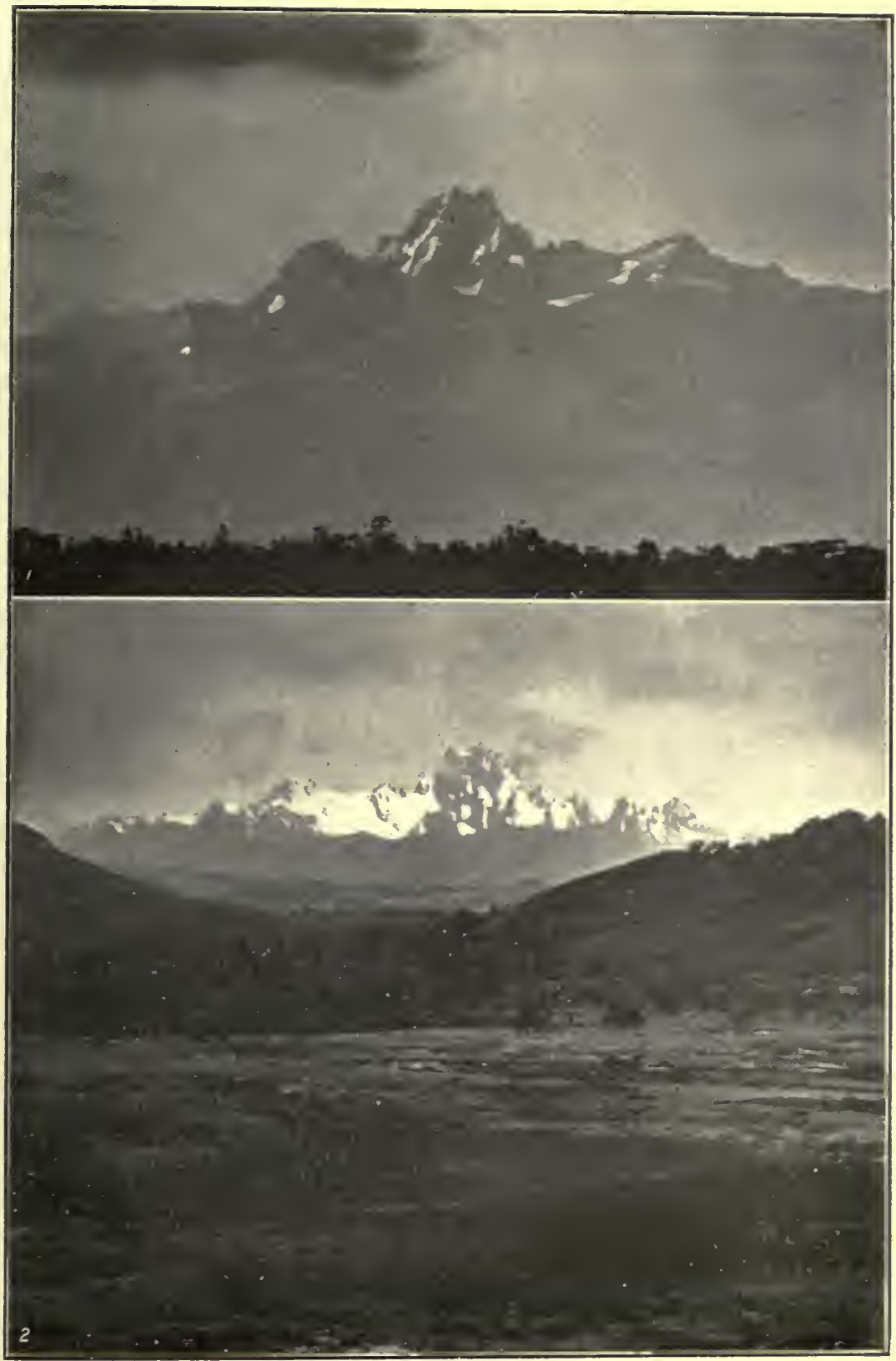

I. Mt. Kenia from the South

Altitude 19,000 feet. Telephoto taken from distance of 90 miles by H. Binks, Naircbi, B. E.A. 2. Mt. Kenia from the North

First photograph ever taken from this side. Telephoto at 20 miles range. Copyright by W. McGregor Ross 

On this brilliant morning as I looked across the level plain, the ascent of the lower part of the mountain looked easy enough and I feel sure that if from this northern side an attempt to penetrate the forest girdle were made, it would be found that the woodland and jungle belt that offer so stubborn a resistance on the other side, were much narrower and easier to pass. From this side an ascent has never been attempted for as I said before, until two years ago the country hereabout was very dangerous.*

Crevasses and bamboo thickets were here merged in soft dark blue mass. Fleecy trailing clouds were still clinging to the tree-tops, as if unwilling to obey the upward call of the sun. As the sun gained power and these fleecy veils drifted away, Kenia, in all her radiant beauty, rose majestically before me. Two years before, for a full week, evening and morning, I had studied her, but that was from the other side. This grand new mountain I had never seen. Not one summit but a group of peaks with fine snow-field and tumbling ice fall between them. Sheer from the rocky base below they rose, sheer as a wall for more than 2,000 feet, one bastion mightier than his fellows rising high above them all. There is not in all North America, neither in Canada nor the United States I speak advisedly for I know the whole Rocky Mountain chain pretty well - anything equal to the splendour of the summit of this virgin mountain of the plain.

Kilimanjaro is higher, but for beauty it is not to be

\footnotetext{
* When I returned to Nairobi some months after writing these notes I found that while I had been camped within a few miles of the forest belt on the northern slopes of Kenia, unable to move my sefari as our transport had broken down and we were quite out of food, a small government expedition, undertaken by the forest department, had actually attempted to penetrate the forest belt from this side. The estimate I had formed of its difficulties, as these notes show, proved to be quite a true one. The party penetrated the magnificent forest region with little difficulty. They then encountered very heavy bamboo thickets, but in piercing them were greatly aided by the elephant paths, and these once mastered, a comparatively easy ascent to the base of the great final peak lay open. From this northern side that crowning mass of rock, snow and ice seemed quite unscalable. The party made a complete circuit of the mountain, travelling well above the forest belt, and having gained some useful knowledge returned, all well, to Nairobi.

Mr. Wm. McGregor Ross (Director of public works, E. A. P.) took many admirable photograph8. One of these is here reproduced.
} 
named with Kenia. Such beauty thrills one and I wanted to be alone. I turned aside from my party, and rode off to a red granite kopje, climbed up it and sat down.

The soft clouds thinned out and parted, slowly, gently. The misty morning light played on rock and ice and snow. The fleecy veils of the night were drawn aside. And upper regions, too high and holy for poor man to reach and spoil, stood out against heaven's blue sky. Words fail me utterly; I cannot put down what I see, but Wordsworth's lines come to my mind, and now I think that a little better than ever in my life before, I understand what he felt when he wrote it. "The holy time is quiet as a nun, breathless with adoration."

Our path was a. plain and easy one to follow, though it passed at first through the densest and most impenetrable cactus thickets; for no herdsman takes better care of his cattle than does the Massai, and the ways by which he drives them from pasture to pasture are kept open for their use. Along one of these we rode.

I have said before that rivers in Africa are sullen and sluggish things, bordered generally by dense jungle, approachable only here and there where the wild beasts have chosen their drinking place or their ford. But this river might have come from the Wicklow Mountains or been born among the fells of Westmoreland. It rushed over its water-worn stones, and leaped down the gorge, as any old-country salmon stream might; only the smooth black polished boulders had an unEnglish look, and spelled Africa.

Then suddenly it would widen and deepen into sullen pools, and the current would creep along under the sweeping boughs of the thorn and wild fig trees. To these pools, in spite of the rapids below them, somehow or other the crocodile had made its way, and here and there you saw his marks on boulder and sandbar. 
As the sun mounted overhead, and the warmth penetrated the tangle overhanging the water, shrubs and flowers filled the air with pungent, aromatic scent, the smell of Africa's rainy season.

Down to the left bank of the river, grew an impenetrable euphorbia wood that clothed for miles the slopes on that side, and straight out of its gray-green mass rose one of those precipitous hills, too high to be called kopje yet scarcely a mountain. Up its rocky sides the all-conquering jungle had won its way, tearing at it, as it were, till the hill seemed to own nothing of itself but its crown, one splendid mass of red granite, which, clear and bold and quite bare of any shrub or greenery, looked full at the rising sun and in its early light shone a rosy red. In most of the woods of East Africa there is surprisingly little colour, as there is surprisingly little flower or fruit; everything in the vegetable world seems on the defensive, has all it can do to live, and has no time to be beautiful. But our little river seemed to have won for the gentler things some space and chance to twine and grow. White and purple convolvuli hung from the wide-spread, cedar-like arms of the thorn trees, far over the yellow water, and swept down nearly to its surface. As they swayed in the morning air more beautiful and fragrant wreathes of colour one could not wish to see.

Then the thorn tree, one of the hundred species of thorny mimosa here, was partially in flower, and when the mimosa tree flowers there is always the tireless African bee, surely one of the most cruelly used insects in the world. $\mathrm{He}$ has no winter time in which to rest and recuperate but toils all the long hot year around, and when his hardly won store is discovered by the keen-eyed native, aided by the honey bird, wood smoke does too quickly its deadly work, and grub, drone and worker all perish together.

In these thorn trees hung on all sides N'dorobo honey 
pots. These are hollow logs of wood some four feet long, and ten inches or a foot in diameter. A hole at one end admits the swarm. Bees seem to find it hard to secure a safe place to store their honey in any part of the country not heavily wooded, and so the poor things too readily accept the deceptive hospitality provided by the wild man for their undoing. In they go, and soon the rude hive is filled with rich comb. Twice a year the honey lover comes, smothers the lot, and hangs again in the same tree the hollow log. I counted seven of them in one tree that morning.

The thorn tree when it gains any size is beautiful to look upon. The sportsman and traveller, for all its prickly welcome, owe it no small debt. Its sparse shade is most welcome by day, there is often no other, and its hard tough wood makes an incomparably good fire by night; no wood that I have seen anywhere burns so warmly or so long. No deluge can put it out, and last but not least, it makes a grand cooking fire. It has another charm, viz., the beautiful soft golden green bark that covers its limbs and stem. The feathery flat spreading branches do not shut out the sunshine, and when after drenching rain the sun comes out the graceful lines of the glossy branches are most beautiful to look upon.

As we wound along the hillsides, and climbed up and down the rocky gorges that ran to the river, the weird sound of the sefari's piping came from the rear. How they manage to keep it up was always a wonder to me. Of pipers we had two; one favoured a short reed pipe from which he was never parted; he always carried it in one of the many corners of the bundle of rags that served him for a coat. The other produced a shriller tone from a water-buck's horn. I love the sound of that rude piping. Whence it comes, that sad minor tune, no one can tell. It reminded me of another sunny morning when I sat on 


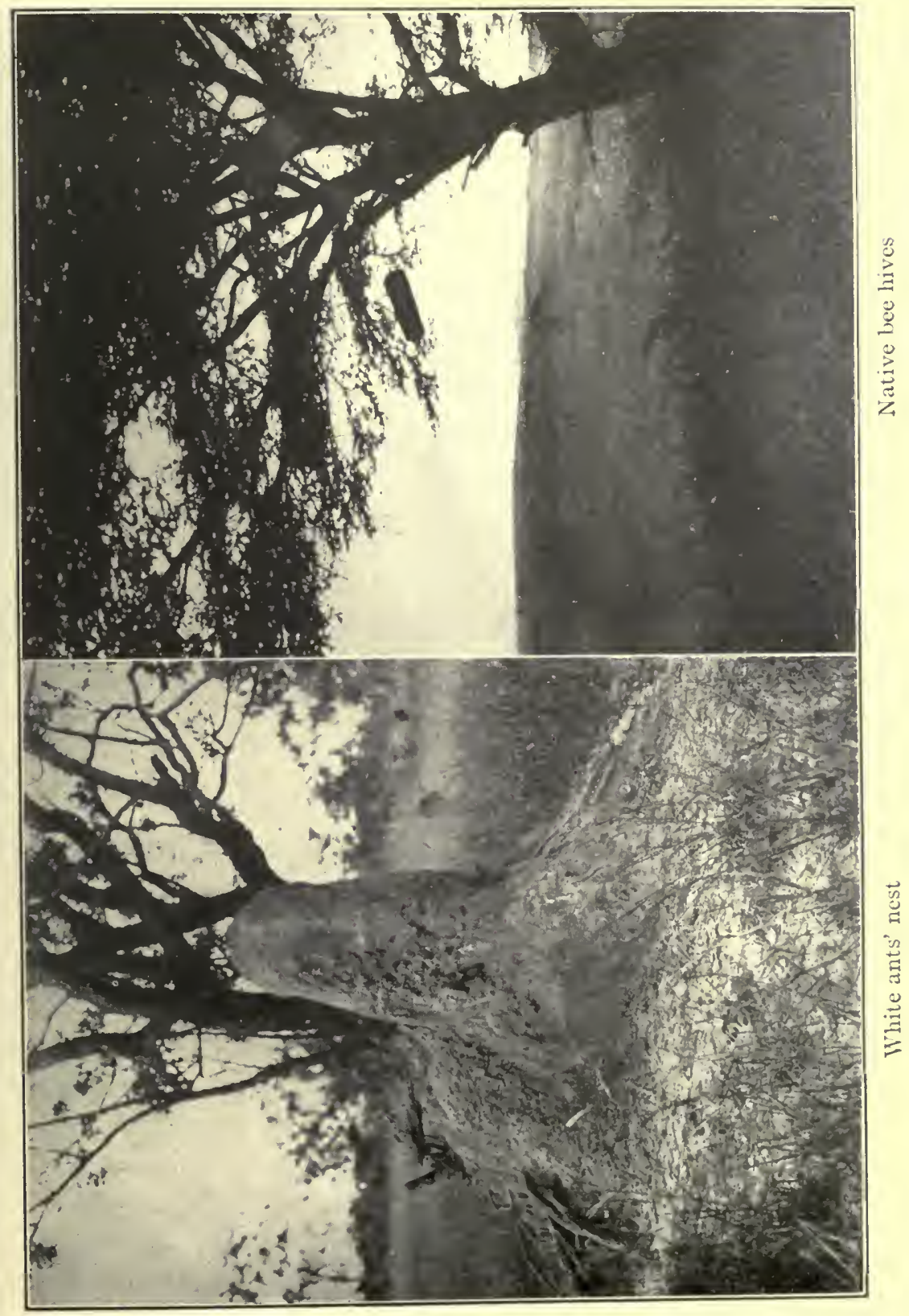



the very edge of the great cliff that overhangs the sea at Taormina. More than I,o0o feet below wound the road, and along it, a mere speck showing up against the white dust, marched the little brown piper at the head of his goats, playing the same tune no doubt that his forefathers had marched to more than two thousand years ago.

The banks of the Guasi Nyiro are far from the classic ground where Carthage and Rome strove for the world's mastery. No Gods ever dreamed of piping by an East African stream. Yet perhaps for all that the poor thin little minor tune with which my black porter cheers himself and his comrades as they trudge bravely along under the noonday sun, has, if we but knew it, a history of its own. For how many ages has its monotonous refrain cheered the monotonous life of a forgotten race? All he knows about it, anyway, is that his father played it before him, so he plays on.

\footnotetext{
"Will no one tell me what he sings?

Perhaps the mournful numbers flow.

From old forgotten far-off things,

And battles long ago."
}

I have been half dreaming as I ride, and now I notice that the sefari has closed up behind me, and is in unusually close formation. The reason is plain to see. There on the soft sand again and again appears the odd three-toed foot mark of the rhino. Every now and then the cactus scrub is tossed aside and torn, stamped and battered where he rolled, and large bushes by the trail side half uprooted, tell of his evil temper. Several have passed here since last night's rain, and we may hear his snorting squeaking cry, and know his sudden vicious rush, too, at any moment. That is the reason the sefari has closed up, and the pipers have stopped their piping.

To judge by his action the rhino is nearly always angry with something or somebody. For him two at most 
is company. He keeps to himself; all other beasts move out of his way. The native hates him and fears him more than he does any other animal, far more than the lion, and the feeling is most natural. His spear, made of wrought iron, with its keen point and four-foot blade, he can drive through and through a lion, but it is a poor weapon when matched against this monster's bulk and horny hide. He lets the lion alone and the lion avoids him, but no man can tell what an aroused rhino will do. $\mathrm{He}$ is so blind that he cannot see anything at a greater distance than fifty yards. When he sees it he seems to act as the fancy takes him. If it is the long line of a marching sefari, sometimes he rushes off and far as the eye can follow never abates his pace. Sometimes he rushes on, and then down in a trice go the loads, some pretty strong and some very breakable, while with extraordinary activity, the sefari takes to the trees, dodges behind ant hills, and undergoes in short a very complete demoralization and disbandment.

One day on a former trip such a rhino, accompanied by her calf, put my men up trees and danced on some of my loads. To-day, however, we were lucky and came through unmolested. And so the sunny morning passed away and we neared our camping ground. As we did so pleasant sights and sounds greeted us. Across the river was a munyata, Massai herds were grazing near and on a beautiful bit of level sward by the river bank a dozen or more black totos were playing one of those children's games which are the same the wide world over.

As I stood to watch them I noticed in the sand at my feet the foot marks of a large lion who came there to drink after his kill this morning, and then, for reasons best known to himself, did what lions seldom do, took to the water and swam the rapid current. There were the tracks in the 
soft mud across the stream, where he had landed. Behind and on either side of the flocks of cattle and sheep, armed with spear and bow and arrow, as were the herdsmen of 4,000 years ago, the black herdsmen stood to guard and little "totos" and at least equally loved cattle, seemed safe under their care. 


\section{CHAPTER XII}

\section{SYCE'S ADVENTURE}

THINK all who have travelled much on sefari will agree 1 that one of the least satisfactory individuals in it is the syce. To begin with, he is pretty sure to know nothing either of horses or mules, and these are of course his one cause for being.

Then he is disposed to act the part of gentleman of leisure. He has an easy time of it, for he has no burden to carry, except it may be a water bottle or a spare gun, and he may kick at carrying even these; and when the sefari is hard pressed and trophies have somehow to be brought along, he is sure to demur at carrying his own sleeping mat and "potio."

Next because he walks behind you on the march or when hunting and generally has to consort with the gunboys, he too demands "boots." Now boots are unfortunately a time-honoured perquisite of the gunboy, unfortunately, because the boots are dear and bad, and since nothing will induce the gunboy to keep his feet clean, he often seriously injures those members of his just because he insists on looking smart after his own idea. The syce, in short, copies the gunboy in everything except in the altogether necessary virtue of standing by his bwana in a tight place.

My syce, Amesi, alas, is no exception to the general rule. If he has to knee halter his mule he is apt to cut the foreleg of the unfortunate animal, so tightly does he fasten the hide rope. If he neglects to knee halter him he calmly lets him stray or take the back track.

Yesterday, however, he displayed unexpected qualities of 204 
horsemanship. The day began badly for him. He brought up my mule as usual and stood on the off side while I mounted. The saddle had a lumpy look about it, and for an instant I hesitated to mount. It was well I did so, for on looking over to his side I missed my off stirrup. Sure enough, he had actually saddled the mule and girthed him tight, with the off stirrup securely fastened down on the unfortunate beast's back, under the seat of my saddle!

I have seen a mischievous boy, in the South, put a hickory nut under the saddle of a skittish Virginian mare, and when the rider, a good one, mounted there was a circus indeed. I don't fancy my mule could have emulated that Virginian horse though he can buck reasonably well on occasions, but as we were surrounded by tent ropes and all the paraphernalia of a camp, there would have been some grief had I mounted. However the danger was averted, the syce rebuked, and I rode off from camp.

After going for an hour or so we cut the spoor of a family of lions returning from the night hunt. The head of that family was plainly a very big one, judging by his "sign." It had poured the night before, so tracking was possible even on the hard ground. I determined to follow the trail though the chance of getting a shot was small, the country being quite open when it was open; and densely, imperivously bushy when the cactus jungle skirted the Quasi Nyiro.

The lions made their usual semi-circle round and finally, as I feared they would, led me into the great belt of cactus scrub that bordered the river. Here all manner of known and unknown vegetable barriers combined to bar the way; thorns long and short, creeping trailers thin and thick and all of them unbreakable. Here the dark places in the dense thicket were tunnelled by heavy beasts forcing their way through. Yet these tunnels would be strung across by creepers innumerable, and were so low that you could not 
stand in them, but had to stoop and bend and even crawl to make any progress. Then a lighter patch of jungle would cheer you and you could rest for a few moments on an ant hill, wipe off your drenched head and hat, clean your eye glasses and begin to crawl again. I am leaving syce all this time some hundreds of yards outside such cover, feeding his mule in the open. The lion spoor turned in and out and led us suddenly on to the fresh track of a herd of buffalo. We had not got much farther, when close to us there sounded a dozen short sharp whistling snorts and then a commotion quite nerve-shaking as the herd of great beasts crashed away. I should have said that in this dense steaming tangle there was no wind; little puffs of light air came now and then, not enough to cool you but evidently quite enough to give you away. This experience was repeated twice in the next hour. We drew within a few yards of the buffalo, when the same stampede would occur. Once I almost kicked a calf that rose from the dense tangle right under my feet and then we paused and let her go her way; for a calf means a cow, and a cow with calf will charge quickly and charge home, and no charge of any beast that runs is more determined or deadly. Moreover, this cactus thicket was no place to receive a charge in.

Somehow we succeeded, by no plan of our own, to work the herd toward the outskirts of the wood, when they broke cover for the open. You could tell they had reached the open by the thunder of their hoofs, unaccompanied by the heavy crashing they made while in the underbrush. Now was our chance. We found ourselves near the edge. My two gun bearers, struggling side by side, tore a way through the few intervening yards of cover that shut us in. It was a desperate moment. Pricked and torn, I was outside, sitting panting on the ground, my .450 double rifle resting on my knees. But alas, they had had too long a start, so I had to content myself with the sight, and it was a splendid 
one, of fully fifty great black beasts charging in column across the veldt which was very uneven here, some 400 yards away. It would have been easy, but useless and cruel to fire into that plunging line. You are allowed only one buffalo and that a bull, and to select and kill at that distance would have been impossible.

Now comes in syce's adventure. He was, as I have said, standing by his grazing mule some five hundred yards off, when this living tornado burst from the wood. He and his mule took in the situation with wonderful promptness. He was on that mule's back with an ease and quickness that no one would have credited to my slow-going syce, and if he had been one of those who are born to "witch the world with deeds of noble horsemanship" he could not have ridden faster or better. The mule saw what was coming, and did his best and Amesi splendidly seconded his efforts. The mule took the road be knew, the road to camp, and needed little whipping, but whipped soundly he certainly was.

When I got back in the evening I found a somewhat anxious encampment. Syce stoutly asserted that I had been tracking ten lions when suddenly I was charged by a whole herd of buffalo. He stood his ground, he said, till all my men gun bearers had bolted and left me. Then he came to camp and if he arrived there before the others it was only because the mule was so frightened he could not stop it.

Syce had scarcely disappeared and the great dark column of jungle beasts with him, when right behind where I stood, in the dense fringe of thicket, suddenly there arose a mighty hubbub and a crashing and trampling louder and nearer than anything we had yet heard. The herd had somehow been cut in two, one-half going off on a long circular wheel, to return as it proved, to their loved cover after a round of a couple of miles. The other half had not yet emerged, but getting our wind rushed, as buffalo sometimes will, in a 
compact and overwhelming mass to investigate the enemy. It looked for a moment as though we must be crushed to pieces under that thundering, snorting, whistling charge. It required some nerve to stand one's ground, for the roar of it seemed almost on top of me, and yet I could see nothing, absolutely nothing, but swaying limbs of trees and tossing brush. When about twenty yards off, suddenly, as it arose, it came to a dead stop. Half a minute's pause, and then another smashing retreat. This time the herd seemed to scatter and from the sound I could tell that some were taking the same road toward the open as the forty or fifty had, before whose onslaught Syce had wisely and expeditiously retreated. Now came my chance at last and I knew it, for they must cross a narrow opening if they followed their leaders, and as they crossed I might get a shot. I put my best or rather my worst leg forward, and made as good time as I could. As the leader, a cow, came out I was within one hundred and fifty or one hundred and seventy yards. There were four of them, the last a fine bull, with oh! such splendid horns. He let me see their width for one instant as he half turned his black, fierce head. Had he but stopped for just one second I had had him, but as my foresight bore on his shoulder he swerved into a thicket so I could only swing the sight of my .450 a few feet ahead as I fired. The big bullet told loudly and of course I knew I had hit him, but the question was, where.

Well, my gunboys and I went cautiously up, for no beast in Africa is quite so deserving of care as a wounded buffalo. He has a well-known trick of turning off his own trail at a sharp angle, and so standing (hitherto of course by the dense brush) within a few feet of the blood-marked track which savage instinct teaches him his enemy, be he man or beast, is sure to follow. As the hunter, lion or man, comes along, his charge is swift and most deadly. You can generally turn a rhino by a bullet in the head or shoulder, no matter 
how fiercely he comes on; he will usually swerve, if it be for only a few feet, and pass on one side. So, to, generally does the elephant who seems to dread a repetition of bullet shock, and so swerves to the impact of the modern heavy charge. Were this not so many more men would be killed by elephant and rhino and the white man would dread the rhino charge more than the native, for he is not so nimble and the native has a holy horror of the ill-tempered brute. But a wounded buffalo who waits for his enemy, waits because he knows he is in a corner and cannot retreat, or if it is a cow, because she thinks her calf is in danger; nothing but death, and sudden death too, will stop that incarnation of cunning rage. A man was killed not long ago in East Africa by a wounded buffalo in this way. He had wounded it in the morning, often when the herds come out of the densest woodland to feed in the green glades that run up into the forest. The wounded beast had rushed off into cover and the hunter, following the spoor, had tracked it the best part of the day, and finally lost the trail. At length he gave it up and went on with his hunting, only turning back to camp in the evening. Tired of carrying his heavy rifle he gave it to one of the gunboys and was sauntering some few yards ahead of them, when he passed near the place where he had lost the trail in the morning. Close to that trail the buffalo had been standing immovable for hours and as he passed, for the moment unarmed, it was upon him with a rush and in a few moments all was over. Knowing well the need of caution, I therefore went carefully forward with my men. My game had been shot through and through. There was blood on each side of the spoor and from the height of the blood marks on the stained grass and scrub, it was evident that the bullet had taken him half way up.

Every one tells you on no account to follow up, in scrub, a wounded buffalo, and every one who has, after months of hoping and working, sent his bullet home into a fine bull, 
an animal that to my mind carries the finest trophy in Africa, follows it up as a matter of course. So we followed on and on. Alas, I have no triumphant ending to tell of. The day was warm and in the bush the heat was stifling. We stooped, we crawled, now and then straightening up, when overhanging cactus and clinging thorns permitted, to wipe off the sweat and go on again. Twice we roused him. Twice we found where he had lain down, and there were blood spoor. My II $\frac{1}{2}$-pound rifle grew very heavy and my nerves were on the qui vive every instant of the time. But the dense scrub and suffocating day were against us and the afternoon torrent came down and blood signs were washed out, I had unwillingly to acknowledge defeat. But it was a great day, and I would not forego having heard that terrorizing sound, that thunderous rush of the aroused and stampeded herd at a few yards' distance in the well-nigh impenetrable jungle, for a great deal. In the dark.forest of the Congo the hunter of future years may for many a day hear it. But from penetrable Africe this mightiest of the wild tribe of Bos must soon perish. In Uganda the buffalo are in some places so destructive to native shambas that their extermination is demanded. They seem, too (though all well-informed men are not as yet agreed on this point) to bring in their train the dreaded tsetse fly, one of the worst of all African scourges; and not only at the advent of the white man must they perish, but as the native learns to cultivate the land they must go, as their habit of night feeding is ruinous to the cultivator.

Some time after I had written these notes on my long hunt after a wounded buffalo in the cactus thickets of the Quasi Nyiro, a fact came to my knowledge which largely accounted for my failure to bag that fine bull.

My Somali gunbearer, Dooda, though a keen hunter and brave man, had in full measure the usual Somali's fault of overweening conceit. He had got it into his head that the 


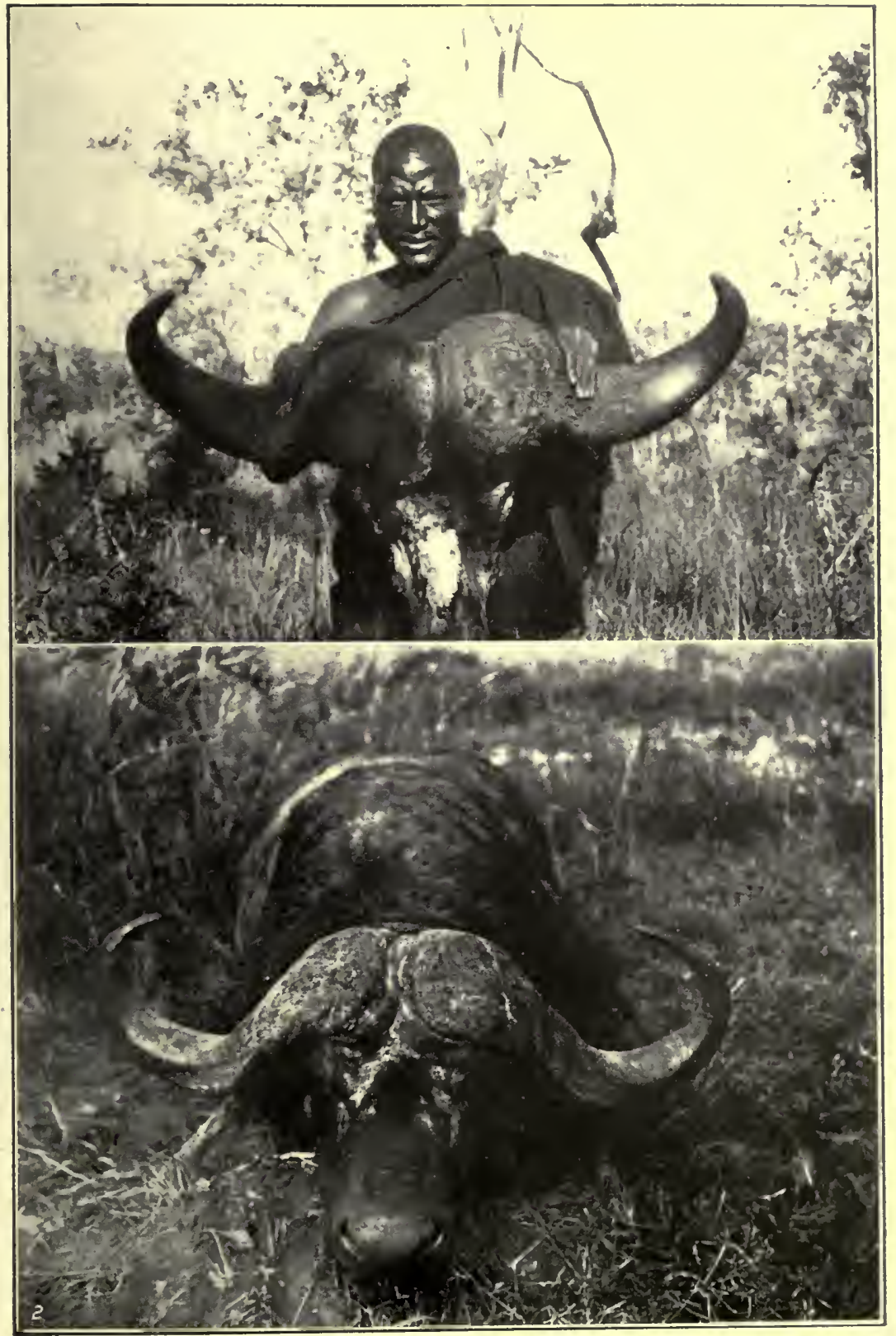

I. Good buffalo head, bones $14 \frac{1}{2}$ inches across

2. Buffalo. An old bull 
bullet to shoot buffalo with was the solid, not the soft nose. Of course he was quite wrong, the soft nose bullet being much the deadlier on such soft-skinned game. He had his orders and he knew them; Kongoni carried as second gunbearer my heavy .450 and Dooda the .350 . When I took the latter, Dooda took over the former, Kongoni handed him the rifle charged as I directed it to be and he, as soon as he received it, took out quietly the soft nose bullets that were in the chamber and substituted solids for them. Thus it came about that contrary to my intention, I fired a solid, not a soft nose bullet into my fine bull, when I had my snap chance at him.

I thought it strange at the time, when I found by the blood spoor that the bullet had gone quite through, and that there was blood on both sides of the trail that this should have happened - as a soft nose bullet should never go through a large animal. But it never occurred to me that one of my men would dare to tamper with my guns, as I had had both of them for a long time, and they knew well that if they did so they would be severely punished. When things went wrong, as they did all that long dangerous afternoon, and when hour after hour we crept and crawled in vain after the wounded bull, Dooda made up his mind to hold his tongue. It was only after he had left my employ, he at last confessed to Brownie what he had done.

That is one of the maddening faults of a Somali. His conceit is insufferable, he thinks he and he alone knows what the occasion demands. His eyes are good, but not so good as those of a Wakamba, a N'dorobo or Massai. His judgment of course is worthless and, though he will seldom desert you, he is apt to become uncontrollably nervous in a really tight place, and fire off his gun. In the old days when none of the East Africa natives were trained gunbearers, he was often the best thing to be had. To-day he is a mistake. 
I have never heard anything as nerve-shaking as the noise made by fifty or more buffalo when charging through dense scrub. The fact that they are quite invisible when within so short a distance as fifteen yards, adds to the strain, the tornado of sound, snorting, whistling, crashing, thunders on, you feel that you must be swept down. But no, the rushing column sees you a few yards off, though you can see nothing, and stops like a wall.

Long before this point in the proceedings is reached the trackers and any gunbearers that are not first rate have decamped, and I do not blame them. Dooda would have retreated if he had dared, but he knew well what he would have got had he done so. As usual, my Brownie was cool and calm, standing up to my elbow.

As with rhino charging, so with buffalo. The action of the animals is often misunderstood. The black mass rushes forward. A wild fire is opened, men take to the trees if there are any. The herd divides or sweeps back, and the sportsman by the camp fire has yet another blood-curdling yarn to tell, of gory death narrowly averted by strenuous rifle fire. Of course it is not so. Had he kept his nerve and stood his ground silently, his men (gunbearers at least) would have been quiet and he would have really learned something of the mystery of jungle life. I have three times awaited a rushing column of buffalo in densest scrub. They have come up at great speed to within a very few yards, then stood stock still for half a minute, sometimes more, and then as wildly rushed away.

A single old bull, or a cow with calf, is a far more deadly antagonist than a whole charging herd.

While I was in the Protectorate I heard of four white men who were tossed by buffalo. One was killed, another, though horned three times and trampled on, was not much hurt. The other two were rather severely wounded.

Why my wounded bull never mustered up courage to 
rush in I cannot tell. He was, certainly twice, as Kipling would say, "anxious." He turned to one side of his own spoor, went back on his track, lay by the trail we had to creep slowly and cautiously along, as we followed the blood sign, and when thus, all unconscious of his presence within a few feet of us, we came near to where he stood, he rushed off, not on to us.

I had had poor luck in finding buffalo, or I should not have pressed after this one as I did in such an exceedingly dangerous place. If my bullets had not been changed he could not have gone a mile and I should have got him, or he might, under the circumstances, have got me. But of one thing I satisfied myself of on this and on another occasion, namely, that herds of buffalo will not charge over standing men.

It had been a hard day, I was weary with continual crawling and stooping. And my easy chair by the camp fire was a real luxury. As I sat and looked long that night into the glowing embers of our thornwood fire, I seemed to see another herd in another land of very different buffalo, not at all like these fierce black denizens of the East African jungle, but a noble and useful beast that once in countless thousands roamed the broad prairies and mountain lands of our own far West. I saw again the buffalo of long ago, as I saw them on that first fresh, frosty September morning in 1868.

\section{"I speak of one, from many singled out, \\ One of those blissful days that cannot die,"}

when before me stretched the boundless yellow prairie and behind me rose the run. The sky was blue, as I think you see it only in our Autumn Indian Summer days. And the air! Well, I was only eighteen and it went to my head. Since I had been able to read anything, I had pored over Ballentine's “Dog Crusoe” and other Western story books 
for boys. They were sound, healthy books too, though no one reads them now; and I had always dreamed that some day, somehow, I with my own eyes might see those glorious plains and mountains and the painted wild men who rode over them brave and free. Here at last was the dear dream coming true. Here was real prairie. With and behind me rode two hundred and fifty naked Indians, stripped to the breech clout and armed for hunting or for war; and beyond us, shaggy and dangerous looking as the morning vapours magnified their great bulk, stood countless herds of buffalo. The most distant were quietly feeding, having as yet seen nothing of the long line of cantering ponies. Those nearer were stamping the ground as though, with mingled anger and dismay, they resented man's inroad into the rich fair land that was all their own.

We had left the teepee camp, cunningly hidden in a fold of the great plain, at earliest light, and as all the warriors streamed out a crescent line was formed. In the centre rode the war chief of the Crees, he alone carrying a spear, and wearing an eagle war bonnet; on one side of him rode my boyhood's friend (to whose kindness I owed the journey that took us for more than six months into the wild), and I was on the other. Now the swift, smooth canter quickened, the graceful swaying line of copper colour bent and bulged, as each naked rider pressed his war pony on. The chief put his hand to his mouth and gave his signal yell, and every one went at the charge.

The dust rose in clouds, here and there a rider went down as his pony stumbled and crashed to earth in a badger hole. Our hunter, one of the most skilful buffalo killers in the Hudson Bay Company, riding to my right, was hurled to the earth, rolled over and over and lay still. The following women and boys would pick up the fallen; the wave of horsemen rode over them and on. There was no stopping nowyou had to ride whether you would or no. 
In what seemed but a few minutes we were close on the mighty herd. The dust rose in blinding clouds while the thunder of the headlong rush shook the very earth.

Rider rode against rider. Horses were forced against the very sides of the maddened mass. Buffaloes fell and men and horses fell on top of them. Then the terror-stricken beasts gathered a sort of order as they ran and in a long dark line streamed away from their pursuers. It was now that most of the killing was done. Good hunters and well trained ponies getting out of the melee had at last their turn. Hanging on the flank, coming up with sharp, sudden rush when the trade gun was again loaded with a handful of powder, or a bullet spit from the Indian's capacious mouth, with a smack of the gun butt on thigh or horse's quarter to settle the powder into the priming pan of the flintlock. At a few feet distance such a charge well placed was enough. Then fall a few yards behind to load again. So on, and on, and on - !

I had a very confused idea of what I did on that first great day. I was armed with about as cumbersome and ineffective a weapon as I could have chosen if I had tried, a heavy thirteen-pound double-barrel rifle by Rigby that took a bullet almost the size of an egg, and kicked so that it nearly knocked me off my pony. I only know that I did all I knew, and at the time that was'nt much!

You may have heard of the brave citizen of a lawless little cattle town, in the early 70's, who was elected by his fellow citizens to fill the dangerous office of sheriff, and who, as was expected, in consequence of his acceptance of the post, died soon after, as the Western saying is, "With his boots on." He was popular, and the community voted him a public funeral and a headstone. The inscription on the latter ran, "To the memory of _- Sheriff of - _ _ _ "He did his damn'dest - no angel in heaven could do more." 
I found myself at last at the foot of a steep bluff, my pony ridden to a standstill, and one bullet, my last, in the left barrel of my rifle. Right before me stood a wounded and irate old bull. Whether I had wounded him or not I didn't know. Most likely I had, for he was old, tough and useless, and the Indians only killed for meat; anyway, with that last bullet I finished him and, decorated with his tail, started campward on foot, triumphant. Where camp was I had no remotest idea, but the slain buffalo dotted the plains, and women carrying in meat soon marked the long hot trail homeward.

Yes, as I looked long into my African camp fire, that great day came back to me again. My rude but hospitable hosts of long ago had vanished with the innumerable herds that fed and housed them. Towns flourish and wheat harvests wave where the buffalo streamed along in thundering flight. And I thought, will this wild land in like manner know change as momentous? May it too become a land of health and homes and plenty? It is hard to say. Prophecy is fascinating but dangerous. Certainly the black man here shows no sign of vacating his heritage, nor does the white man, as yet, often give proof that he is able or willing to be in it more than an adventurer and fortune seeker. The country must of right belong at last to the men, black or white, who find in it a home.

Since I have allowed myself to be betrayed into the reminiscent mood, I may as well tempt my readers' patience a little further. When I was quite a little fellow I looked daily for years at the blue Mourne Mountains as they sloped gradually to the Irish Sea. The sweeping line of those purple hills, with the climbing patches of yellow oats and barley, that made a brave fight to hold their own against the surrounding bog and heather, are as clearly before my eyes now as they were in the autumn days of fifty years ago. On one side the mountains rose from the sands and mud 
flats of Dundalk Bay, but on the other they tumbled down most precipitously, to as beautiful a little sea lough as even the Irish coast can boast. Carlingford Lough, with the hanging woods of Rostrevor on one side and its line of ruined robber castles on the other, battered into submission, as most Irish castles are fancifully supposed to have been, by the great Protecter's cannon, or so the local tradition had it. We boys used to be permitted sometimes, as a great treat, to take the long walk from Dundalk to the little inn at Carlingford, where no one ever seemed to stop, over the mountaintop. We chose of course the highest and most difficult point for our crossing.

Coming down those steep two thousand feet we would incontinently plunge, all heated as we were, into the cool waters of the lough. Then, a great supper of fresh herrings followed by another swim. Oh, those golden days! Fortunate is any one who can look back on such, when

\section{- "lads that thought there was no more behind \\ But such a day to-morrow as to-day, \\ And to be boy eternal."}

Those days had their sorrows and pains and disappointments, seemingly irrevocable disasters. Things you could never see right. Wrong bitterly eternal. The tears of children are very bitter tears while they flow. But some kindly alchemy in life passes a gently obliterating hand over them all. You cannot remember the dark things if you would, while the golden days still shine for you with that "light that never was on land or sea."

"Now the beauty of the thing when the children play is

The terrible wonderful length that the day is.

Up you jumps and out in the sun,

And you fancy the day will never be done."

T. E. Brown, when he wrote those lines, had the very secret of boyhood in him still! But I must come back from far away prairie and vanished Indian hunters, back from 
that dear blue slope of curving Irish mountain land and take myself and my patient reader across the Quasi Nyiro and so back to the civilization of Nairobi and the iron road to a distant coast.

I have lingered so long at the foot of Kenia that I have come to feel as though this great mountain was henceforth to be a part of me. It makes one sad to turn one's back on it, as I must, to-day. I think it is Kenia whose majesty and wonder are responsible for the dreaming in which I have again seen so clearly those dear Irish sea-girdled hills that are a real part of myself.

Arthur Hugh Clough says somewhere:

"Oh ye whose eyes with constant toil are tired,

Come rest them on the wideness of the sea."

Sea has never rested me as have the mountains. The seas to me always seems relentless, cruel, estranging, as Matthew Arnold calls it, while the mountains carry me back and make me live over again the transfigured days of boyhood.

Then, somehow, mountains seem to call forth anew the hopes and yearnings which, if we did but speak out the whole truth, if we resisted the slavery of convention, we all should confess are woefully apt to suffer abatement and decay, and yet are more precious to us than any mere earthly possession.

Brown has put what I want to say into beautiful verse. His peasant muses:

"I suppose it is God that makes when He wills

Them beautiful things, with the lift of His hills

And the waft of His winds; His calms and His storms

And His work - and the rest - "

So true men, wearied in the unending battle, have in all the ages turned, as did the Psalmist of old, "to the hills whence cometh our help." Bedford gaol wall could not shut out from John Bunyan's eyes those "delectable mountains" which he 
could fancy no place so fitting for the great Teacher as the bright hill-top:

"For with the lapse of years old fervours fail, And old beliefs and hopes and longings fade away.

$\mathrm{Oh}$ ! for an hour on the bright hill-tops with that glorious voice

If we could only believe and live out our belief, that we men, in spite of all separating differences, are in our deepest, truest things alike; that all of us lock in our hearts the same hopes and doubts that cheer us and cast us down, we would then be more frank one with the other, and would surely oftener succeed in what we really want to do; that is, lend a helping hand, say a cheering word to our fellow travellers marching, sometimes stumbling, along the high hard roadway of life. How many of us in our heart of hearts have thanked William Wordsworth no less for the honesty than the beauty of his verse. So if I have lingered too long, before the mountain I have learned to love, it must at least be admitted I have some precedent for my loitering and that I wait in good company.

For several weeks I have looked on Kenia; seen her looming near and high as the gray dawn came on. Watched for the first flush of morning to strike her ice and snow; and all unexpectedly in the late evening, have watched as, suddenly unwinding the cloudy wrappings that all day long had completely hidden her, she shone forth, baring her mighty brows, rosy, glorious in the last light of the sun, for us already set.

I have in mind the manifold beauties of our own mountain chains; Yosemite, before the winter snows have melted from the peaks and tablelands. The Shoshone crags, wild exceedingly: you can at one place I know count two hundred separate summits, all snow crowned. The lonely solitudes of the Granite range, that few have penetrated, where in midsummer great ice islands still float in but partially thawed lakes, and where snow fields of many miles' extent 
still await the explorers. And yet one more, most beautiful of all I think, that view across the blue five miles of Jackson Lake, to the three great Tetons rising sheer from the farther shore. Yes, I have these and many another lovely mountain panorama in our country and in Europe before my eyes as I write. But here surely are beauty, stateliness, charm, that surpass them all. Limitless green lawns of grass, worn smooth by nature's cropping, lie at her feet. Mountain woodlands are drawn up to her for square miles by the hundreds. Impenetrable forest belts her as a girdle; and then from the mighty girth of her base (I 50 miles) she lifts herself, up above the woodland, above the bamboo thicket, above the sparse mountain pasturages, up into dark rocky gorge and crevass, up still into the solitudes of ice and snow, till at last with one lonely majestic column she crowns herself, I 8,200 feet above the sea.

I have ridden far from camp for this last look. How near she seems in the hazy sunlit vapour of the morning! But though the glass brings even her secret places near, the distance to that group of summits, to that great ice fall pouring into the profound hollow between them, is probably quite fifteen miles. Now the last lingering mists around these summits are melting away, and virgin snow and tumultuous ice fall, all lie open to the blue, blue sky. I can see the very base of her topmost crown, and can mark the sheer perpendicular line (as seen from this side) in which, with never a waver, it mounts upward for the last two thousand feet. But Kenia's mystery and charm gathers not only round her matchless peak. Her mighty bases have their secrets, too, unsolved, unpenetrated. The forests on those great slopes are probably the densest in all Africa. The trees are of immense size, the bamboo grows to sixty feet. The sides of the mountain are broken up, carved and ploughed, more deeply even than the sides of Elgon, by the volcanic forces that tore their way to the light. 
These purple hollows, these mighty undulations of the mountain woodland are not distinguishable during the day, even when a strong glass is used. But there is some quality in the morning light, some reflective play of mist and shadow, some illumination of deep spaces between the rocky walls that, at that hour, help you to get some idea of the quite wonderful tumult of heaved-up mountain side, which makes up the whole forest-covered mass.

Woodland wave crests, hiding profound hollows, show up momentarily in this tender light of the morning. The mountain valleys widen, the cañons deepen, and far above. these terrible barriers to man's approach, little unsuspected meadows appear, creeping near as they may to the stern barriers of rock and perpetual snow above them.

This is my last morning, and I shall never see her again! I read over my poor scribblings and feel like tearing them up. What are words, unless indeed you are of the magic few who can conjure with them? And not one of that small band of immortals has seen what I am looking on.

Kenia's beauty has been hidden long, wrapped in her mists, some of the earliest explorers unknowingly passing her by. Greek poets have made Olympus immortal. Many thousands who have never seen them, love Wordsworth's borderland hills. With Matthew Arnold you breathe again the spicy air of Alpine pasture lands. Kenia awaits her poet still. I can but hope that at some distant time a dark-skinned poet may arise from among those peoples who have gazed on her for ages, but who have never yet had their day, to sing the beauties of this most glorious of all the mountains of the plain. 


\section{CHAPTER XIII}

\section{A MORNING'S RIDE THROUGH RHINO COUNTRY}

WHEN the weather is fine I always breakfast in the open by the glowing embers of the watch-fire of the night before. Just as I had finished my meal this morning, the sun's rim rose on the plain - my back was to the sunrise - and quickly out of the gray dawning light a perfect rainbow shaped itself, so near, so clear, that one could surely mark the very spot where would at last be found by somebody the "golden key" which, as every well-educated child knows, or used to know, lies hidden in the ground at the place the rainbow starts from. There was not yet enough sunshine to make the edges of this sunrise rainbow very distinct, but the arch of it was very high and very perfect, and in the middle of its great bow all the morning vapours had taken on a soft rosy tinge wonderful to see.

"A rainbow at morning the shepherd's warning," says the old Scotch saw. At the Equator nature will not b bound by the rigid rules of the North, so my rainbow ushered in a delightful day.

I have said that there was but little colour among the trees and shrubs of this part of Africa. But its very-rarity makes its presence all the more welcome when you do light on it. Here to-day as I ride is colour indeed. It brushes against my mule, raises its sweetness to my face, hangs on all sides ready to be plucked and appreciated. Our way winds among scattered thickets of a straggling gray bush not particularly noticeable till its flowering time comes - which seems to last many weeks - but stop then and examine what 


\section{A RIDE THROUGH RHINO COUNTRY}

it offers you. In rows of from three to eight on the end of each bending stem hang the beautiful yellow blossoms, almost four inches long. At a few feet's distance they look like Marechal Niel roses half-blown, growing on a gray althea bush and if you imagine an althea flower four inches long and pendant, with five petals that overlap each other (I have no botany book with me and I am ashamed to say I have forgotten how many petals the althea has) and so thick and rich in colour that the flower is solid and heavy as it hangs, not spread out flat along the parent stem as the pretty althea, but bravely swinging free, then you would have some idea of my nameless yellow African beauty. The pistil is of a rich crimson, and so waxen that even in blotting paper all beauty is crushed and lost if you try to dry it. The calix is soft green. The petals are a brilliant scarlet at the base. Like many another beautiful and interesting thing in the land this flower is nameless; and when some one does give it a name I plead for something better than an inch or more of hyphenated Latin! There is, too, an orchid that hangs out now and then a flaming spot of crimson from its background and anchorage of cactus brush. The flowers are closely bunched together, about an inch and a half in length, little frills of yellow on their lips. This is a pretty orchid that shrivels and falls when you touch it, but if leftalone it seems somehow to get a good living by the side of even the warlike cactus.

The country around here for many miles is flat and when the veldt is flat and has been regularly pastured by herds or game after the rains, blue, yellow, white and mauve flowers grow in patches close to the ground. One, very like a single primrose in shape, colour and smell, is lovely. It raises its two inches of height from an inconspicuous little bunch of gray leaves, and lives only for a day or two.

And now, still following the river's course toward the blue wooded ridges that skirt the great mountains, the whole aspect of things changes. The tiresome euphorbia and its 
spiney following are all left behind and beneath me. The pretty cedar-like thorn trees still grow along the river bank, but mingling among them are others that tell of the mountain near by. The juniper, perhaps the best timber tree in East Africa, begins here to show itself, not yet grown into the stately tree with straight stem rising one hundred feet and more, free of knot or branch, which we left amid the dark woodland beyond Eldama Ravine. But stunted thought it way be, for the ravine land is too hot, sandy and dry for it to flourish in, it is good to see.

Here and there you notice a graceful rounded mass of rich lilac flowers, one of the most beautiful sights the forest has to show. I cannot find anyone who knows its name; it is commonly called the chestnut tree* but I can see no resemblance whatever to the chestnut about it, unless it be a prickly burr which protects the seed.

Seen at a few feet's distance the flowers look ragged, but from the ground the effect it presents of masses and bunches of fresh lilac colour is very striking indeed. It grows as high as sixty feet. The stem is smooth and graceful, the crown spreads wide and is one mass of bloom. I have not seen it growing anywhere at a height of less than seven hundred feet.

As I mount higher still, the wild olive crowns the river banks and in single trees and small groves is scattered over the steep stony slopes of bordering hills. The colour and height of the African wild olive (a common tree) is very much the same as its Italian cousin. And I could almost fancy I was riding beneath a neglected olive slope in those parts of Tuscany where the poor land scarcely repays the toil of the peasant and the terraces have been allowed to crumble away. Now I turn my mule's head for an hour or two away from the river and, scrambling up the stony slope that leads to the level country at my left, I come face to face with a totally different scene.

\footnotetext{
* Calidendron. I have since learned that it is well known in other parts of Africa.
} 


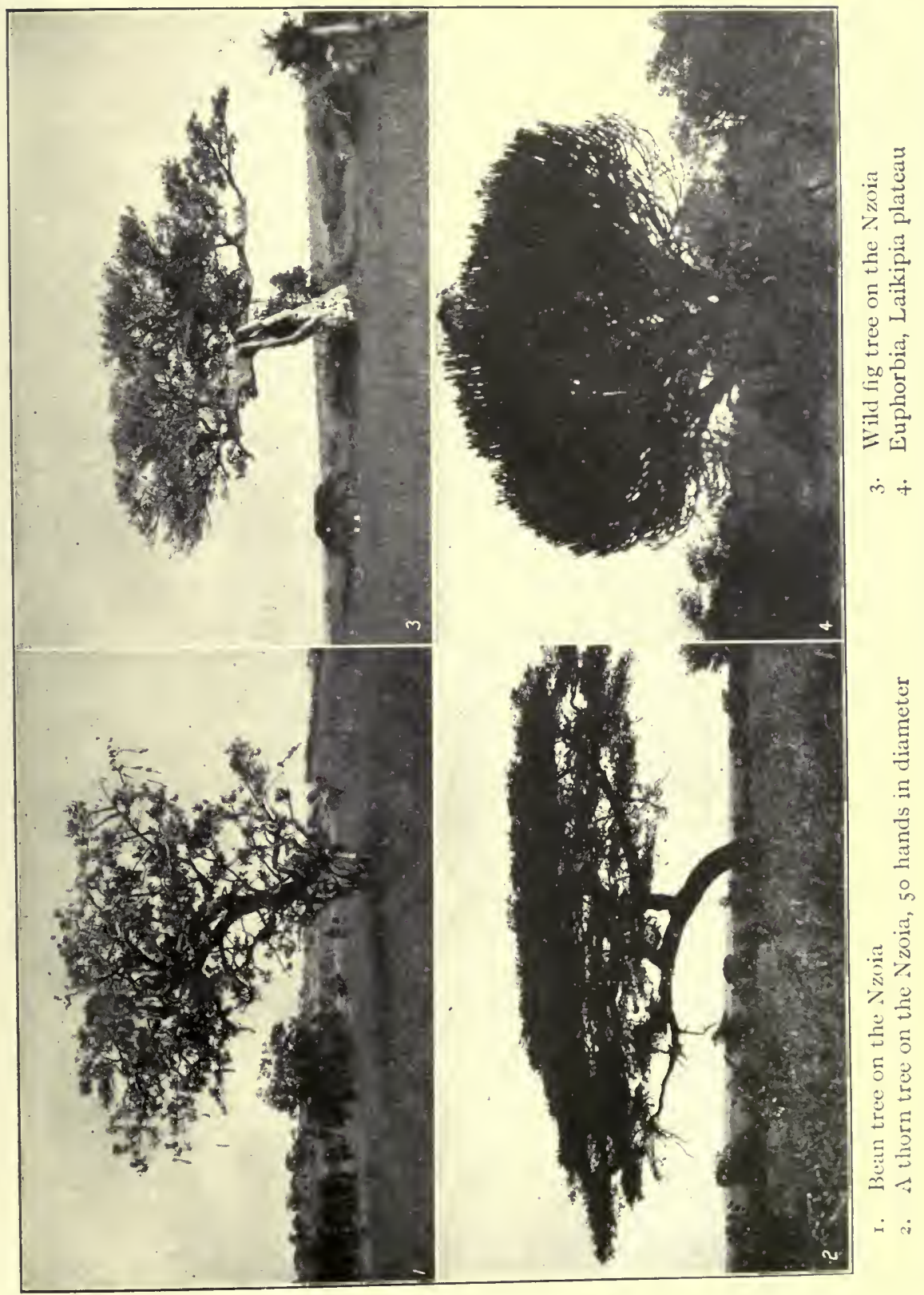





\section{A RIDE THROUGH RHINO COUNTRY}

The suddenness, the unexpectedness of this land, is one of its many charms. A ride of a few miles is full of surprises. You never can tell what you may meet or see.

The spaciousness of the splendid landscape, the mountains standing solitary, as though they would not be crowded on, makes it unlike any land I have ever seen.

I am on the northwest side of Kenia and about forty miles still from the mountain's base, though it is hard to believe it. And behind me and before me, as I face it, the level country is thickly sown for twenty-five miles with great masses of red granite, out-croppings of the same formation. A Celt would say that the Devil and the giants had been at war or play in the old days, and that these rocks were the mighty sling-stones they had hurled from the mountains at each other. Some of them are one hundred feet high, some nearer four hundred feet, and all are imposing.

Around their rocky bases the grass grows so smooth and fresh that it might be a carefully tended lawn - the disintegration of the great stones must have added richness to the soil, and the sward has buried their broad bases for some feet under its carpet. Then the prairie falls away from one, rises gently towards the next in curves and dips of green.

They are half a mile apart, or only fifty yards as it may be. Some rise sheer and steep with no crack or crevice for bush or vine. On some dwarfed wild fig trees climb and cling. All are of rich red granite, and the sides and crowns shine and glisten gloriously in the light of the rising and setting sun. In the highest and most inaccessible, great troups of little gray monkeys have found the safest of hiding places. There no climbing cerval cat or leopard can do them harm, and up and down the sheer sides of the cliffs they race and play, looking like flies walking on the ceiling, not like animals at all.

As I came between two of those great turreted rocky islands, there suddenly arose an outcry so dreadful that 
I took my rifle quickly from my gunboy. What could it be? Had a family of lions cornered a herd of zebra on the other side of the rocks? and was the hideous outcry the shrill death-cry of the zebra and the fierce growling of the lion echoed back by the rocky walls? It was simply the angry protest of a large band of baboons against our intrusion. I had often seen baboons before, in large troops too, but had never heard their war-cry. It was truly a dreadful cry. I can think of nothing to liken it to but a fire in a madhouse, when the flames might reach men, women and children at once. The simile is a horrid one, I admit, but the half human outcry was worse than anything I ever heard in my life.

As I get nearer still to the densely wooded country that lies before me, the masses of rock gradually soften the outline and merge themselves in higher and more regular hills and ridges, always covered with greenery that rise up and up till they meet the great flanks of Kenia. The sun was by now high in the heavens, yet the vapours still clung among these purple-blue foothills. In other lands you see the clouds rise up slowly, steadily from the woodland. Here sometimes they have a way of rising all their own; the breeze bids them be going; but they linger and cling to their home of the night that is over. I am not pressing too far a mere fancy; I am stating a literal fact. The clouds seem to drop cloudy anchor lines that from some miles' distance look as though they were twisted around the very tree-tops. The snowy feathery mass of them yields to the light air and floats away. But each separate cloud has its trailers behind it that bind it to the forest tops. The effect when the sun shines full on forest and mountain is very wonderful. It is as though a mighty army were camped on the great woodland, and that hidden among the trees ten thousand campfires were sending up columns of silver smoke. I have seen the same effect in early morning also on the slopes of Mt. Elgon. 
Here, as I said, it is the unexpected that happens. Suddenly we come on two rhinos feeding among the brush. As we climb a ridge we are close to them before either party is aware of the other. I have been scribbling notes as I ride, but the note-book is now hurriedly pocketed. Ugly brutes these rhinos surely are, and dangerous as they are ugly. Now a sporting license issued by the Government of the Protectorate only permits the holder to kill two rhinos. Personally I think this a mistake. All rhinos should be shot at sight. They are a common nuisance, too common hereabout; useless for food, and especially dangerous to unarmed people. The natives dread them. I have in another part of the country already taken half my allowance of rhinos, and as neither of these has the one redeeming feature allowed to a rhino, a good horn, they are safe so far as I am concerned; so there is nothing to be done but to go around them, which I do, my syce with the memory of the buffalo column still in his soul, crowding up close on the guns with the led mule. As we make a circle we draw off to one side and pass close to a winding water-course, dry in the hot weather, but holding running-water now, which gurgles among tall grass and thorn bushes, its sides rocky and steep. A little ridge runs from the hill we had to turn down, in order to go around the rhino, to the edge of the water course, and shuts off our view of a sharp bend in its stream. The gulley makes another bend to meet this ridge, so, as our heads rise above it, there lies a little tongueshaped promontory before us, and we stand on high ground at its centre. A few yards away is a whole family of ostriches, cock bird and hen and eight half-grown chicks (the chicks would stand over five feet high). For a moment dire confusion reigns, for the ostrich is exceedingly wary, and when the old birds have a brood they are the very most careful of all wild creatures; and if the Syrian ostriches, as the Good Book says, left their eggs to take their chances in the sand, 
their African cousins do nothing of the sort. The birds old and young run hither and thither. The water-course is not to be attempted; father and mother might get over, but the tender bodies of the chicks could not endure the thorn bushes or the sharp rocks. Presently the hen rushes off to our left, but the cock is not of her mind at all. He chooses a braver and, as it turns out, a wiser course. In some way or other he impresses his will on his eight frightened children. Led by the boldest chick, they form a "line ahead" and with their pretty brown fluffy wings half spread sail steadily by us, keeping distance as though they were a line of battleships, the cock in the rear. Then when the father realizes how close his brood must come to us in passing, he deliberately leaves the rear of the family column and splendidly sails along between the enemy and his children. He seemed to look right into my face as he went by, not thirty yards away. It was a rare and beautiful sight.

But the morning was not over yet, and I was to have another and a very near sight of an animal that always seems to me one of the most attractive in Africa.

I never care to shoot a giraffe. As a specimen he is unnatural unless mounted as he stands, and standing he would look uncouth unless one found him some such place to stand in as the Rotunda of the Capitol at Washington. (He would look better there, by the way, than some of the things now in it!)

The giraffe is too old to shoot; no one can tell how old he is, much older than the elephant. And no one would think of shooting an elephant were he not prodigiously destructive to the farmer and were his tusks not worth a great deal of money. But the giraffe is perfectly harmless, he was never known to hurt anyone, and he gets his living off the upper boughs of thorn trees, which no one can reach but himself, and nobody else would eat if he could reach them.

To see his beautifully mottled skin towering up among 


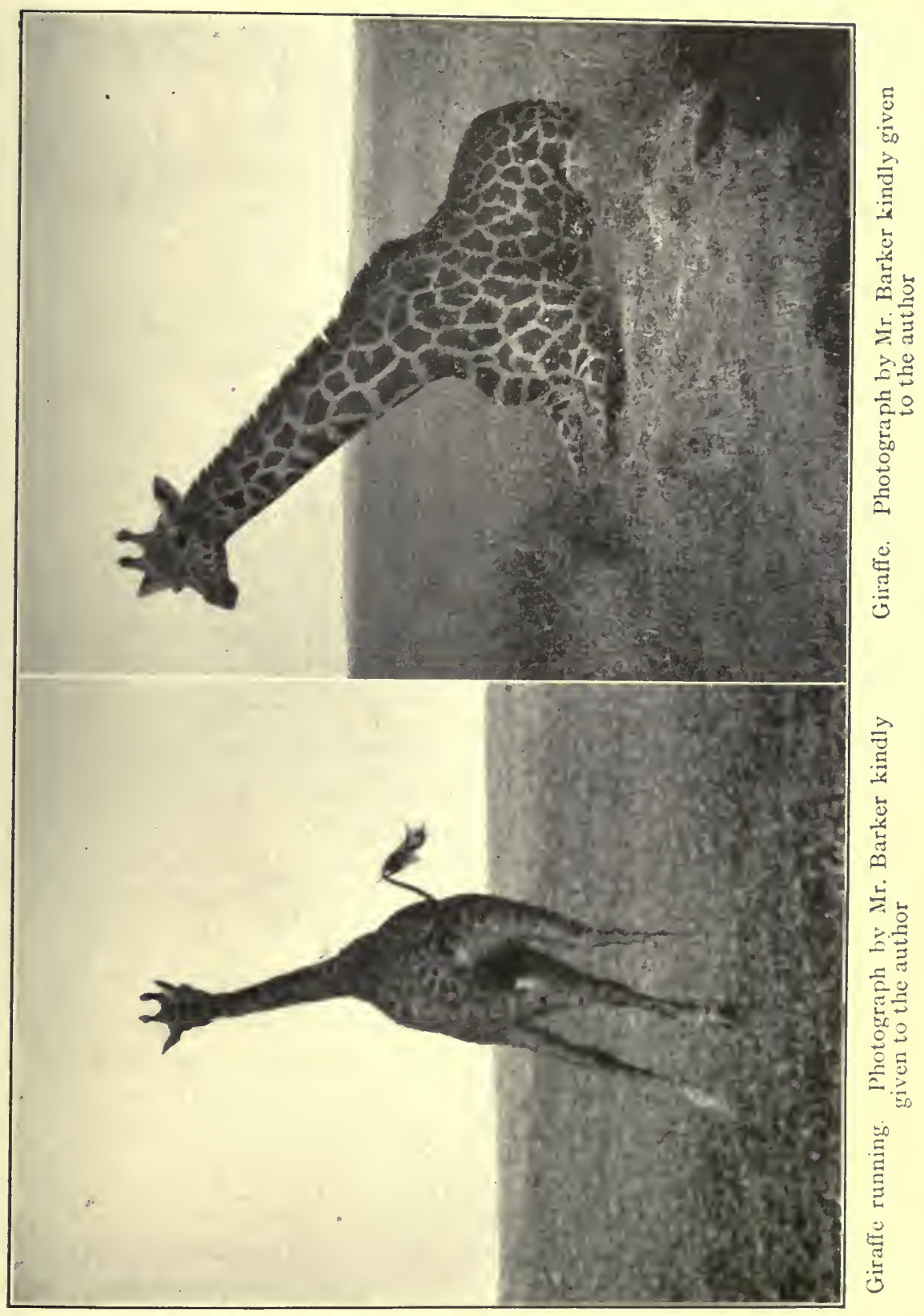



and over the flat green thorn trees, is surely one of the strangest and most beautiful sights the animal world offers to man. As he stands and dips and bends and twists his nine-foot long neck in and out among the armed branches of the tree, he is grace personified. I was able to watch seven of these creatures, the king, his harem and his children, all gathered around one green-topped tree. From seven points of vantage they dipped into it at once, stooping under an unusually keenly armed bough, bending over another, their necks seeming to twist two or three ways at once. I had the good fortune to come very near without alarming them, and with my Zeiss glass, could see them as though they were not more than ten yards away. But when at last the treacherous breeze betrayed us, and they plunged into flight! well, no one could call their movements graceful. The immensely long forelegs are thrown forward, as you see a very high-stepping horse sometimes throw his forelegs forward, till the hoof, for the faction of a second is pointed straight out in front. The giraffe makes this motion with a sort of jerk at the end of it, as though he intended in the first instance to fling his hoof as far as he could forward, and then as a sort of afterthought brings it to the ground, then when it reaches earth he flounders forward with his high shoulders, lifts both ungainly hindlegs and plants them almost together. There is a great antediluvian lizard known to us, who had two brains, one to move his body and another to move his abnormally long tail. It looks as though this giraffe, like the long lizard, also needed two brains, one to move his hind legs and another to move his forelegs, and as though the two brains wouldn't act perfectly together.

And now, coming back toward the river, camp is near. Is it possible that this upper country looking so fresh, so green, so shady, the streams running clear as in the hills of Ireland and Scotland, lies within twenty-five miles of the 
rhino cactus stronghold? This is the land of surprises indeed. A few hours ago you dismounted from your mule if you were wise, for rhinos seem to have a peculiar aversion to mules, and walked warily in the spiney jungle of Africa proper; footprints of lion and rhino crossed and re-crossed the way, and while from the river sandbank the cruel crocodile pushed noiselessly into the yellow stream. Here is another land, a land where soft green meadows in curving swells press up to the very edges of dense mountain forests as though they were English park lands browsed by the deer. And looking sheer down on you is the brow of as glorious a mountain as there is in the world.

Mount Kenia was ascended with immense difficulty five years ago. The ascent was made from the southern side shown in the extraordinary photograph by Mr. Binks, a copy of which he has kindly allowed me to publish. The northern side of the mountain as I drew near seemed to offer a much easier approach at least as far up as the great depression into which falls the main glacier. From that basin towers aloft the final peak, on this northern face of it surely unscalable. Here a calamity overtook our sefari, when we had almost reached the foot of these northern slopes. The man we had trusted to provision our men failed us completely. The buffalo herds which we had come to seek had been driven away by the Massai cattle. We were out of potio and in almost gameless land; nothing remained for us but to send most of our men back to Laikipia to get food, and while we awaited their return from the journey of seventy miles, we were chained to camp. I enjoyed the everchanging view of the mountain, but I greatly longed to push nearer and explore its northern side even for a little way. This was impossible; there were not enough men left in camp to move our tents, so I had to content myself by making excursions as far as my mule could carry me in a day.

I came to the conclusion that the forest belt here was not 


\section{A RIDE THROUGH RHINO COUNTRY}

nearly so dense as on the other sides and that a way through it might be found without any extraordinary difficulty.

On returning to Nairobi what was my chagrin on learning that a surveying party led by Mr. McGregor Ross was, at the very time we were restlessly waiting for our supplies at the foot of the mountain, making its way through the very forest belt that daily I searched with my glasses; and that having done so, they camped on the bare, heathy uplands that rose gradually to snow-level, and at a height of over ten thousand feet made a complete circuit of the peaks.

The scientific results of this remarkable expedition will soon be published, and with them I hope will appear, in some more popular form, Mr. Ross's beautiful series of telephotic photographs.

Mr. Ross tells me that a path through heavy woods and giant bamboo (the bamboo was often over sixty feet in height) was found. He passed these supposedly insuperable obstacles in two days' march, and that after this the upper mountain lands presented no difficulty whatever.

A trip to the snowy basin of Kenia will now be within the powers of any reasonably equipped sefari. Ten days from Naivasha should see camp pitched on the edge of its principal glacier. So much for the unexpected in East Africa!

Herds of elephant and buffalo were common amid these untrodden mountain solitudes. The explorers' time, however, was so taken up with scientific work that no hunting was done.

All round Kenia on the dry slopes of the Guasi Nyiro and farther to the northeast in the little known district of Meru, once dangerous but now pacified, is the chosen home of the rhino. It was in marching through the cactus lands of the Guasi Nyiro that Chanler's expedition, in the early nineties, was so tormented by their constant attentions. Lieutenant Von Höhnel was terribly wounded by one of these beasts, and had to be carried to the coast. The 
prolonged agony of such a journey cannot be imagined by any who have not been in the country. After Von Höhnel received what was almost a death-wound, on three occasions the porters carrying him were so fiercely charged that they let fall the unfortunate man's litter, and so almost extinguished the spark of life that nothing but his indomitable pluck kept alight.

Three of these porters were killed by rhino, so it was no heedless panic that made them drop their suffering charge.

I had in this same cactus jungle on this same river the only narrow escape from fatal injury I experienced in East Africa.

Two or three miles back from the river are to be found small bands of that rare and graceful little antelope, geranuk. Its neck is long and flexible like a small giraffe's, the horns somewhat like those of a reed buck, but turned inwards at the tip. It does not bound away as do other small antelopes, but throws its forefeet forward in a springing and exceedingly fast trot. I fancy this is the only place in the Protectorate where it is to be found. You are limited to two bucks and may count yourself lucky if you can get one. Given time and patience and fair shooting, you may expect that one, and should be content after that to leave the shy graceful creatures alone. Farther out on the veldt between the sparsely wooded hills and plains that stretch forty miles to the base of Kenia the oryx is found in abundant numbers. This is one of the finest of the African antelopes and carries one of the most beautiful of heads; the male and female both carry horns. The horns of the bull are thicker, those of the cow often the longer. I would advise you not to be in too great a hurry to shoot the first one you see. Learn to distinguish between bulls and cows. Look at them carefully with your glass. Patiently crawl near, for if these should escape you there will be other chances before long. You can shoot but two, and if you kill males you will not hurt the herd, 
for nature provides far more males than are necessary for reproduction. It is a pretty safe plan to select single bulls feeding by themselves. They nearly always carry a good horn. Oryx are sometimes rather difficult to approach, but with these antelopes, as with all the big game I know of in this country, perseverance is the sure road to success. When you have selected the animal carrying the trophy, wait; follow him, follow him as long as you can travel. If one stalk fail, wait a while, sit down and smoke a pipe, and follow him again. I have made four long and unsuccessful stalks in one day, on oryx, then sat down and waited until they began feeding at two miles off, then made my fifth attempt and secured my head. A good bull oryx often accompanies a large herd of zebra. It is therefore well to look the herds of zebra over carefully with your glass. If you can, separate your game from the zebra, as these often make an approach impossible. Never be discouraged, even in the morning you find the oryx almost unapproachable. Later in the day you will in all likelihood secure an easy stalk.

Six or eight miles up the Guasi Nyiro above its junction with the Guasi Narok, and some three or four miles out on the plain, among the giant kopjes that are here scattered over the country, seems the favourite haunt of this splendid antelope. Let me add the warning $I$ have repeated in another chapter. Go up to a wounded oryx carefully. And above all, when your gunbearer is ballaling him (cutting his throat), stand clear of the sweep of his long sharp horn. He can, even when dying, deliver a lightning-like sweeping thrust. In this way one of our gunbearers, an old and careful hand, was wounded in the leg. Lion have been found dead, impaled on a dead oryx's horns.

On these great game-browsed meadows, and around the red granite kopjes that dot them, many lions still roam. You will nightly hear their deep, coughing, grunting cry. 
They seem to go to bed very early in the morning, and unless you are lucky enough to find them loitering on their "kill" of the night before, they are hard to see. If you are well mounted or have a Somali or gunbearer mounted on a swift pony to round them up, Laikipia plain is an ideal place to get them.

Grant antelope are to be seen here, not in as large herds as are common south of the railroad and east of Naivasha plain, nor do these Grant carry as long a horn. These of Laikipia are the grantii notata, a different variety. The beautiful horn does not branch as widely and curves more decidedly forward. A twenty-four inch measurement is a good trophy.

I must not forget the giraffe but somehow I have never been able to think of these strange old world creatures as things to be shot. Here they can be seen and studied at leisure, for near the river, and north to within a few miles of the mountain, herds of from five to fifteen are common.

I shot a wild dog on the plateau which I am inclined to think is a distinct species. It is quite smooth-skinned, no hair anywhere on the body, only a few sparse white hairs on the tip of the tail. It is quite black and resembles closely a Mexican hound. And twice I heard it bark distinctly. Other wild dogs do not bark. Three or four times I had an opportunity of examining the dog carefully with my glasses, and also twice I had one thrust his head out of a bush and very distinctly bark at me. If this species is distinct it is as yet unknown to science. To give some idea of the game resources of this splendid country, I will enumerate what I saw during one morning's ride. Zebra, eland (several hundred), Grant, five rhino, one leopard, giraffe (twenty), klipspringer, impala (three large herds), ostrich, stein-buck, duiker-buck and geranuk.

There is another attraction that the Laikipia plateau 
to north of Mt. Kenia possesses. I name it last, though to my mind that is not by any means its place. The country is watered abundantly, for Africa, by streams, hill or mountain born, and though specially in Massai land with its great cattle herds, these soon lose their clear flow and become more or less turbid and yellow, still their waters are sweet and cool and are safe to drink without boiling. The one stream I now write about is unlike any I have found in Africa. It leaves the mountain by way of one of the many gorges that like great ribs seam its sides. There, somewhere among tangled forest as yet impenetrable, it has its spring sources. It has somehow chosen for itself a different course from that of all other brooks, which flow downward to form the Guasi Nyiro river, for these a few miles from the mountain are yellow, while this stream runs clear and cool as a trout brook in new or old England. Its flow is so rapid that it cuts for itself a gorge among the hills, and by the time it reaches the more level country that rises toward the base of the mountain, it has worn a veritable cañon deep in the grassy slopes.

I am sitting as I write, on a red granite kopje some half-mile from the edge. I can see the whole course of this mountain stream till it joins the large volume of the Guasi Nyiro five miles to the westward. In this very early morning light, while the vapours of night still hang tangled in the forest tops, faint silvery smoky columns of the lightest spray rise above the dark tree-tops which line the little cañon, marking each of them, the place where it rushes downward in a rapid or tumbles to a fall.

Clear streams are almost unknown here, so this one will repay a long ride. Indeed there is no better camping place in all the country. Its head waters are more frequented by buffalo than any other region, except it be the far lower and less healthy banks of the Tana River. And 
in its beautiful hidden woodlands you can always hear in the early morning the strange cry of the Colobus monkey sounding like a rapidly ground coffee mill.

I spent many a delightful hour exploring its banks and watching its delicious flow, so clear of all mud and swamp stain. The tree ferns love its cool shade. Many varieties unknown to me grew there. Little delicate fronded things like long branches of parsley. Clumps of maidenhair, and others with rich hanging, curling leaves. Some on the bank, some from great tree stems. You may ride within one hundred yards of that cañon's edge on smoothly cropped green grass land, and but for the broad tree-tops, just raising themselves above the level sward you could have no idea that a gorge fully a hundred feet deep lay at your feet.

Then as you walk for miles along its edge, you can study leisurely that new, strange world of the trees that you have so often longed to look into.

The heavy forests of Africa are usually dark, dank, unhealthy. The wild pig and an occasional bushbuck are the only animals that haunt them. But this upper world of the tree-tops is full of life. There, monkeys swing from bough to bough with extraordinary quickness. Parrots screech to their fellows, and the purple pigeons fly to and fro. All is above and beyond you as you walk in semi-darkness, or rather crawl, torn, scratched at every step. From the cañon's crest you have a clear view of what you never saw before, the world where the insects, the birds, the monkeys find a safe and sunny home, a region different as fancy can paint it from the sombre tangle below.

Besides, the little river in cutting its way so deeply has made a well-watered botanical garden all its own. There, great trees grow and sweet flowers bloom that are strangers to the country around. Here is the stateliest tree in East Africa, the juniper, whose great stem rises majestically 


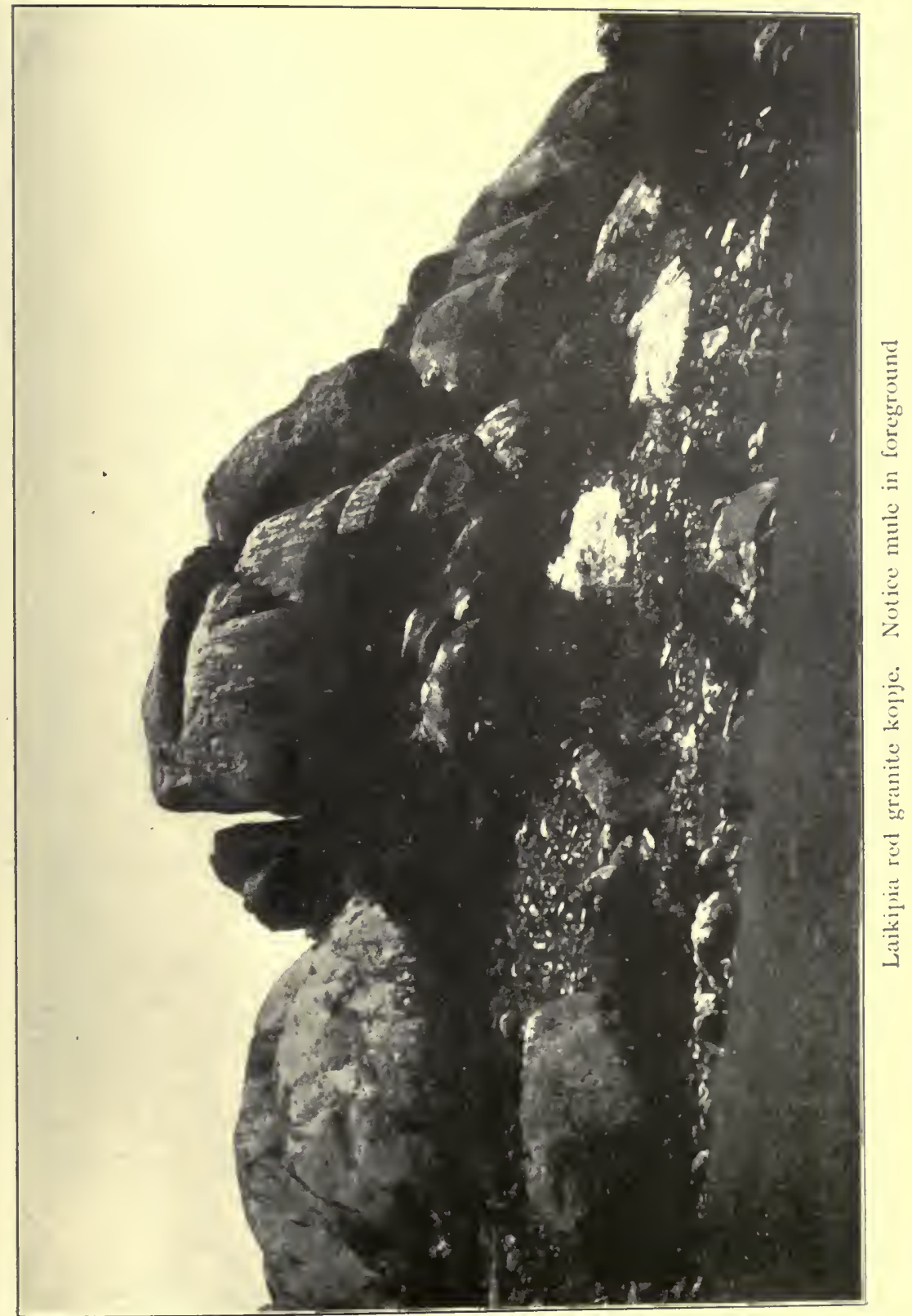



before you, as you painfully force your way amid the dark places of the great woods, but whose feathery boughs you never saw before, so densely packed and laced together are those forest tops. Here all open to the daylight, you can study the gnarled twistings of those splendid limbs, and they remind you of one of the trees Rousseau has so wonderfully painted, against a background of crimson sunsetting, a tree to dream of and but rarely seen. Here the wide-spreading chestnut finds all the space it needs for its great bouquet-like crown of rich lilac blossom, and groups of them take up the whole cañon from side to side. The precipitous sides of this cañon have saved them from the yearly devastating grass fire, and they sink their roots safely in the cool well watered soil. On the plain above grow juniper and olive trees. in scattered thousands, but all are ragged and scorched. The junipers for half their stunted growth are notched and unsightly. The olive trees bloom only at the crowns; when they live at all they live a life of protest; the hardy thorn tree alone shows scarcely any sign of these fierce recurrent purgatorial scorchings.

In the cañon fire never comes. Its rocky borders give the flames nothing to feed on, and thus it is that within it you find a secluded little woodland, naturally matured.

Darkness and dampness make the African forests unpleasant and uninteresting even when they are penetrable, while here are a hundred little green open glades where for part of the day the sun shines down. Silver gray moss hangs in long waving veils from upper branches. Rich orange-coloured mistletoe plants itself wherever it can see the sun. Long, delicate tree-ferns find rootage in the trees leaning close to the water, and between feathery juniper tops bunches of chestnut flowers twenty feet across make, with their gray moss wreathing, a colour scheme scarcely to be matched, and never to be forgotten. 
The shy and pretty Colobus monkey, has chosen the cañon for his special haunt and home. There he is to be seen in the early morning, sitting on some topmost branch of juniper, taking a sunbath, drying his silky coat of white and black and his long snowy tail, after the nightdew bath. Be merciful to him, take one specimen or at most two, and shoot him not till you have a sure chance, and are certain that he cannot escape wounded among the thick trees. His aquiline nose gives to his black face a rather unpleasant human look, and I felt guilty when I had shot mine.

The rhinoceros is one of the stupidest and perhaps from that very cause one of the most dangerous beasts in British East Africa. He cannot distinguish a man from a tree stump at forty yards. His hearing, however, is very good indeed, and he detects at once the lightest footfall. The earth seems to act as a conductor of sound to some animals more than to others. I have often noticed rhino show signs of uneasiness as I was trying to get near enough for a photograph, when it was quite impossible for them to have heard my tread. They would rise from their shaded resting-place, face in every direction, sniff the breeze and, as I stood quite still, lie down again. On resuming my approach the same restlessness would be shown.

They will often trot up toward the long sefari marching line, stamp and snort a little, and then walk off, generally taking a long circle, so as to get the wind of the moving human snake that slowly crawls by them. In this way they would cut across the head or tail of a column of porters, creating sudden consternation, and sometimes doing damage. When once they have confirmed their suspicions by a strong sniff of the tainted air, they will either rush away at a rapid trot, which they are apt to keep up for several miles, or, if viciously disposed, 
which is rare, will wheel sharply up wind and charge right down on the enemy they can but dimly see. Even then, nine times out of ten, a rifle ball at twenty yards hitting them anywhere about the head or the neck will make them swerve to one side in their charge, so they are not as dangerous as they look, which is fortunate, for there are few more disturbing sights than a two-ton rhino coming straight at you, his ugly head and threatening horns held well down, and at a pace so fast that no good runner could keep away from him. To the unarmed man and to the native he is specially dangerous, and a good many of these latter are killed by him. As such an accident seems of little consequence to the herdsman the news of it seldom reaches the local authorities. But they will drive their herds a long way round to avoid a bit of bush into which fresh tracks of rhino lead.

Some years ago, a noted professor of biology interested me greatly as he showed me the skull of a Myocene rhinoceros. In those far-away days the beast must have been well able to take care of himself, even in the dangerous company which he kept. The convolutions of the brain of the Myocene rhinoceros are fine, very much superior to those of his present-day descendant. The sawtooth tiger and cave bear took little chance out of him. $\mathrm{He}$ somehow so managed things, that while they disappeared he survived to see the end of his redoubtable antagonists. Then gradually life must have become too easy for him. He was big and burly and well armed; other animals kept out of his way. The inevitable consequences ensued. Competition keen and fierce had kept him up. The struggle for existence had made him the formidable, brainy beast that he was. When the struggle was over and his brain was no longer put to its best use, he began, like poor Dean Swift, "to die atop." The African fodder is as good as of yore. His hide is as thick, 
his horn as sharp, everything keeps out of his way, so he lives on, a surly, ill-natured, dangerous, and quite useless life; occupying ground that more useful and beautiful things need. Surely a striking illustration, in the animal world, of that universal truth we are so prone to forget: that easy times do not always make for real usefulness or greatness.

Only the other day my friend the missionary, Mr. Shauffaker, very nearly lost his life in an encounter with a rhino. He is preëminently a man of peace, and generally rides, more often walks, on his way unarmed. On this occasion he borrowed a mule from another missionary, for the road he must take was a long one. As he was passing through some thickish brush he was, with out warning, incontinently charged by a rhino. Such an onslaught is usually made with exceeding swiftness, and though his mule swerved for its life, the cruel horns pinned him. Mr. Shauffaker is a young and very active man. He threw himself off and darted behind a friendly bush, but all in vain. The furious beast crashed through the dense shrubbery, carrying everything before him, and when my friend came to himself, for he was partly stunned, he held in his hand a small remnant of his sun umbrella, while a cloud of dust and trailing brush and the rest of the umbrella decorating his horn showed where the rhino was still furiously charging away.

During the night rhino seldom troubled the camp. But Mr. Percivale, one of the game wardens appointed by the British East African Government, told me of an extraordinary escape that he had lately had. He had risen about two in the morning, leaving his tent and his companion who was sleeping in it, for a few moments. Rhino had not been common in the neighbourhood for some time. Suddenly in the pitchy blackness, for there was no moon, a dark animal rushed by him. There 
was a crash, down went the tent; then another crash, followed by loud cries from his men. He rushed back to find his friend crawling out unhurt from the wreckage, all bespattered with jam. He was scarcely awake, and quite at a loss to know what had happened. "Is it a tornado?" said he. Mr. Percivale's bed, from which he had risen but a moment before, was smashed to atoms. A tin of jam, crushed by the great beast's foot, had exploded like a bomb shell, spattering jam over everything. $\mathrm{He}$ called to his men and was answered by groans. One of them was badly trampled, and another bundled up in his little tent had been carried bodily off for twenty yards. The rhino's horn had cut a deep gash in the man's forehead, otherwise he was unhurt.

I have known of a rhino at night taking both sides of a Massai munyata in full charge, and scattering men, women, children and cattle right and left like a swarm of angry bees. But these are the only instances in which I have heard of a night attack by them. Were such things common, sefari life would be much less pleasant than it is, for neither their bomas nor campfires would prove any protection.

When I was near Fort Hall three years ago, a Government surveyor was run down by a rhino, and so badly trampled and horned that he died in two days. He had been warned not to go unarmed, but thought the chances of meeting a dangerous beast so slight that he could dispense with the bother of a rifle!

I may as well here tell my own experiences with the rhino. I shot the first two rhino I came across; they carried fairly good horns, and I shot them without any trouble. One bullet was enough for each, and each fell to a chest shot rather low down and full in front; a sure place to kill, I found it, though it is not usually counted so. Hit here by a solid $.45^{\circ}$ Cordite rifle, they wheeled at right 
angles, ran some twenty or thirty yards, and fell with a sharp squeaking cry, quite dead. After these two, I was far more anxious to get a photograph of rhino than to shoot them and spent much time and ran some risk, in unavailing efforts. The bush was too thick, the light too bad, or the rhino stamped and snorted so when I got nearly within photographing distance (you cannot do much with a kodak at more than fifteen yards) that I had to keep handing my camera to my nervous gunbearer and grasping my rifle.

In this way I find I have approached close to more than fifty and never had actual trouble with any of them till a few days ago.

Now, the danger of the rhino is twofold. In the first place, you are apt to stumble on him most unexpectedly. He makes very little noise when he feeds, and moves his unwieldy body with unaccountably little crackling of bush, even in places where you find it impossible to walk noiselessly. I have often stood silently and watched him feeding amid thorns that were dry and brittle, and over ground thickly covered with fallen twigs. He would go about his business with a silence that was almost uncannyListen as I would, scarcely a sound betrayed him, yet there he was before my eyes, not forty yards away.

In the second place, if you do surprise him at close quarters, it is impossible to say what he may do. He may snort and rush away, or he may rush away as though escape was his one aim and object, and as suddenly turn right around and charge over men and baggage, carrying ruin and consternation in his train; or he may charge head on without one instant's hesitation. The smell of many animals distinctly indicates their near presence. A herd of wapiti or kongoni can be smelt at several hundred yards distance in still warm weather. A band of lions are unmistakable when you get close to them in the long grass. 
buffalo, too, have a penetrating odour. But I have never been able to detect a rhino in this way, though I have often stood for several minutes within a few yards of them.

Bulky as he is, on a plain studded with ant hills, it is very hard to pick him out, since his brown bulk is just like an ant hill. If he is taking his siesta, it is under the deep shadow of a tree, and in the glow of sunlight you may pass quite near him and see nothing. Whereas if he is where he loves above all to be: in dense thorn or cactus scrub, he is absolutely invisible till you are within a few yards or even feet. It is surprising how often you find yourself unexpectedly quite close to rhino.

I had stalked up to so many during my previous ten months' hunting, and had so unvaryingly found them retreat that I began to think there was no such thing as a really vicious member of the family left. I was destined, however, to be abundantly convinced that on occasion they are extremely dangerous. I was trailing a buffalo bull on the Guasi Nyiro of the north quite near the little cañon I have tried to describe. It was an excellent game country. Oryx abounded, there were several small bands of buffalo and rhino were far too numerous to be pleasant. Cactus and thorn scrub covered densely the steep rocky hills rising sharply from the beautiful river and glades, green and partly open, ran between their bases. The fresh spoor we were following led us for a mile or more up and down this woody country, and then turned up one of the steepest hill sides, where the brush was quite impenetrable. I and my gunbearers had crawled silently as we could some two hundred yards into the tearing, cutting jungle and I was on the point of saying we had best go out, as in such a place nothing could be done, when through the black wall of herbage to our right came the sharp whistling snort of a rhino. We stood stock still, and I fortunately was able to stand upright just there, and clear very quietly 
the trailing creepers from my arms and rifle. Looking hard where the sound had come from, I was presently able to make out a small patch of brown skin, not longer than my hand, about ten yards away. I was naturally most anxious not to shoot. The noise would destroy my chances of coming on any buffalo thereabout, and besides, this was no place to shoot anything, much less a bush rhino, whose horn was almost certain to be a poor one. So we stood and waited, hoping that our most unwelcome neighbour would move away. He stood as silent as we did. Then very slowly I tried to retreat. All in vain, we were so near he must have seen us clearly. He wheeled with a crash, and snorting loudly rushed into us. I could see nothing to shoot at till his horn was within a few yards of the man next to me on my left. Now Dooda, my Somali, was a brave man enough, but in the presence of rhino or lion he became very much excited. He now fell back so violently against my left shoulder that as I threw him off, his rifle cut my hand and I almost fell. Had I done so nothing could have saved us all three from being gored and trampled on. As I straightened up I saw the broad shoulder and lowered horn almost on us. I fired the right barrel of my $.45^{\circ}$ into the spine, at a distance (afterward measured) of about ten feet. And the rhino fell, an inert mass, without a groan or a kick. I had just time behind the flash of my right barrel, to see a second great head and shoulder following the first. Indeed, so close was the second rush on the first that I could barely pull my left trigger quickly enough. Had I been using a black powder cartridge I could not have seen the second beast till he was upon me. Fortunately the almost unaimed shot took him in the same place as his fellow and he too collapsed. The charge of these two furious animals was so nearly simultaneous that my gunbearer, Dooda, had no idea that there were two, but fancied I had 


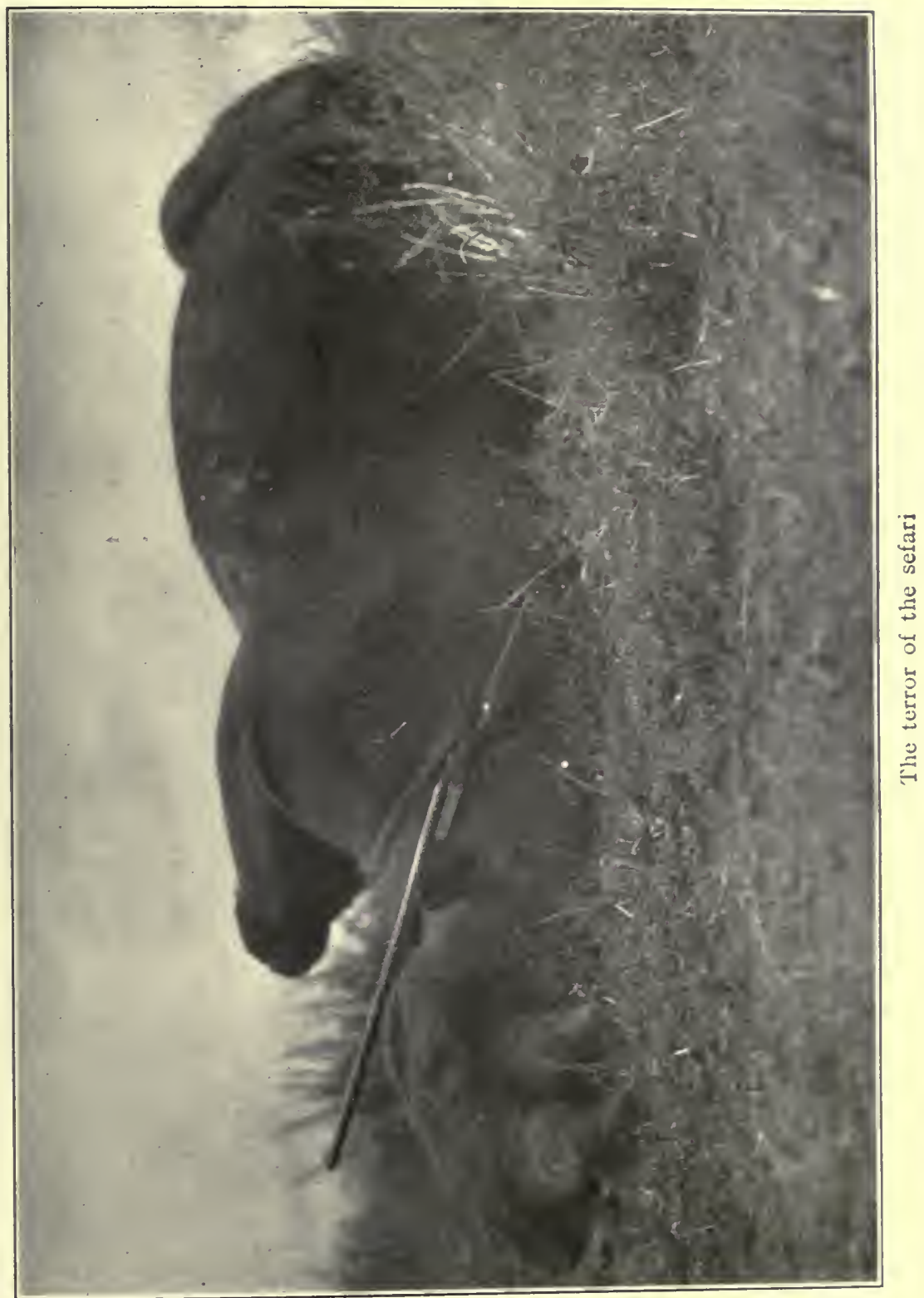





\section{A RIDE THROUGH RHINO COUNTRY}

shot twice into the one animal. When we stepped forward on top of two dead rhino, he leaped backward, thinking we had another untouched animal before us. My Brownie, cool as ever, had seen our second danger and had shot at the same moment as myself. He made a good shot for him, for he had actually scored in the fleshy part of the hind leg, a wound he took care to point out to me with pride, as I always chaffed him about not being able to hit anything.

Such is the rhino in East Africa. Nineteen times out of twenty, even in dense bush, he will rush away from you. But, as Bernard Shaw's play says, "you never can tell." And if as in this case there are two of them and they charge suddenly home, it is a very serious matter indeed. Two charging together have killed or maimed many a good man. When the bush is dense, when the little rhino birds fly up a few yards in front, it is best to go round or hunt somewhere else. I know that I shall next time.

Though the story I have just told proves conclusively enough that rhino in thick brush can at times be most dangerous, it by no means follows that all the yarns one constantly hears of charging rhino are true. The trouble is that most men when they shoot at a rhino, follow up their first shot with a stream of bullets. Indeed, after the first shot is fired, there is a good deal of excitement and confusion. It is the same story with elephant and with lion. I think this common plan is a bad one. If the first shot is, as it should be, carefully planted in a vital place, there is no need to fire any more. Indeed, a constant fire draws the animal's attention to where you are. If, on the other hand, you are sitting down quietly on the ground, the very great probability is that, confused and stunned by the impact of a modern bullet, your game has no idea where you are. He may rush toward you, though the chances are very many to one that he will not. 
If he should rush toward you he is almost sure to pass you by at very close range. And if it is necessary to fire again, you can do so without rising or moving, and with deadly effect. Whereas, a succession of bullets fired at the head and shoulders of a charging beast generally do little damage. If he is coming right on, let him come. And at a few yards the heavy bullet will stop, turn or kill him. This applies to elephant and rhino. Lion and buffalo when once they have made up their mind to charge keep coming on till killed. As they come toward you, animals often look as though they were coming right on when really they are not doing so. I repeat what I said before: When possible, receive dangerous game sitting down. Your doing so gives your men confidence and there will then be no wild rifle firing.

I cannot insist too constantly on the need of drilling the gunbearers; getting to know them; making them understand your wishes, your own peculiar way of handling your rifle and selecting your cartridges. I have looked most painstakingly into the details of those unfortunate incidents, when wounds or death have been inflicted by the wild beast. I can assert that in the great majority of cases lack of care of rifles, undisciplined gunbearers, or some such cause, has been uppermost in bringing about the calamity.

Lord - was charged, not far from Nairobi, by a lion he had ridden. Lady — was on horseback not a quarter of a mile away, and was a horror-stricken spectator of what came near being a tragedy. Lord was a poor shot. The lion came slowly at first, as they generally do, out of the grass. Lord - with a gunbearer on either side of him, sat down to kill him. He fired at about sixty yards' range and only scratched him. Then the excited Somali on either side fired and, of course, missed. This maddened the lion more and he rushed 


\section{A RIDE THROUGH RHINO COUNTRY}

in. Lord - turned first to one then to another of these much vaunted and useless men to find - empty guns!!! The lion was upon them. Lord - fell, for some reason or other, forward on his face. The lion seized one gunbearer and shook him. Then strode across the fallen body of Lord - and seized the second man. As he did so the bloody spume from his mouth was streaked all over Lord ___'s back. All three, to Lady __'s terror, lay prone, the lion standing over them. A man who was with Lady — told me it was the worst thing he ever saw. The great beast then walked quietly away, unmolested! That was a case where bad shooting and undisciplined gunbearers combined invited a tragedy.

The discipline of the gunbearer is a matter of life and death. I may be held guilty of giving brutal advice to sportsmen, but I feel sure that those who know what dangerous game shooting is, will acquit me of brutality. I advise you to have long talks and most clear explanations with the men who must accompany you into danger after wounded game. Having made your meaning perfectly plain, if your gunbearer disobeys you, there and then knock him down with such a blow as he is likely never to forget. It may save your life and his. And do not take Somali gunbearers with you unless you can help it. The Wakamba are in every way superior. Some Swahili that are first-class can be secured. A Somali, though brave, gets uncontrollably excited and is monstrously conceited, as a usual thing, to boot. He wants different food from the other men. Tea, ghee, halva rice, sugar. He seldom speaks the truth and he bullies the porters and makes much trouble in the sefari. And there is one thing more should be said. The outrageous prices that the Somali demand and receive are apt to have a most demoralizing effect on your other men. 


\section{CHAPTER XIV}

\section{THE COUNTRY}

TF I may borrow an illustration from old rowing days, 1 the Government of the Protectorate reminds me of a strong but ragged eight-oar crew. Individually they are a fair lot, but stroke does not know his own mind and looks a good deal out of the boat, so the men behind him cannot get together. Naturally the boat rolls and has not much pace on and the men growl at each other. Worst of all, the coach is too far away to see properly the crew's work, yet is constantly shouting contradictory orders to stroke, whose one aim seems not to be to win a race so much as to avoid an upset. The crew, too, has a pretty good German boat to race against.

The simple truth is this wonderfully promising land has been ruled and is still ruled after no settled policy. Philanthropists tried their hands, diplomats and soldiers all had their turn, but a consistent policy based on a study of the country, its native populations and its resources there never has been. One man tries one thing, he is recalled and his opponent given an innings. Commissioners and acting commissioners have been allowed to do what they wanted, whether it was or whether it was not consistent with the acts of their predecessors. No one, I think, has more wisely and temperately written a history of British rule in Uganda and East Africa than J. W. Gregory in his quite admirably lucid volume, "The Foundation of British East Africa" (page 243). I did not see Professor Gregory's book until I had written this chapter, but his summing up of the situa- 
tion seems so true that I quote his explanation of the present weakness of the Government, and the chief causes of native and immigrant discontent.

"British East Africa has had persistent ill luck. Pestilence, drought and famine are enemies that in a comparatively unknown land can neither be foreseen nor controlled, and they have devastated the country and engendered widespread misery and a spirit of unrest that has caused especial irritation against civilized restraint.

"But the blame for the confusion is not all extra human. The clumsiness of men, and the conservatism of government systems have been only too powerful for evil. The main cause of disaster in the rule of the Foreign Office (at present the Colonial Office has taken over the Protectorate) as in that of its predecessor, the British East African Co., has been the lack of a policy based on a scientific knowledge of the country and its people, framed in accordance with the views of the local authorities as to what is practically and economically possible, and consistently and continuously carried out, even despite the prejudices of philanthropists at home and the ambitions of military officials abroad.

"The primary need in equatorial Africa is of a special service of men appointed by open competition. According to the present system, the selection of men is necessarily somewhat haphazard. A man is sent for a few years' work to East Africa, thence he is promoted to act as consul at a Mediterranean watering-place or an American port. As soon as a man begins to understand the natives and to speak their language, he may be and often is transferred. Similarly a young official in British East Africa may at any time have placed over his head a man who knows nothing of Africa and African methods, and who may do serious mischief before he learns to take advice from his more experienced juniors." 
Trenchant and true as this criticism is, it at once calls forth a counter criticism. If this is so, if such obviously wise and necessary courses have been habitually neglected, how do you account for the equally obvious advance the Protectorate has made? How is it that in spite of stupid, and worse than stupid, muddling in Uganda, the bloody buccaneering policy that was allowed to continue there for a time, in spite of the folly and injustice that drove the best quality of East Coast natives to leave the country and settle after the Mazuri Rebellion (1895) in German territory - how is it that the country can even hold its own? There is just one answer to this and only one. It is not that the Colonial Office has, so far at least, greatly improved on the management of its predecessor, the Foreign Office; it is not that in the service of the Protectorate the worth and work of the officer is now always acknowledged and he no longer has appointed over his head "the man with the pull," it ought to be so, but as yet it is not so. But it is just this: that the ordinary young Englishman, employed by his country to do one of her difficult and thankless jobs in a distant land with but little to reward him and much to discourage him, is the most bonest, conscientious and successful civil servant in the world. In British East Africa he still comes out to a job too often unprepared, or but partially prepared, for it, having had scarcely a rudimentary education fitting him for it. He scarcely ever knows anything of the language when he lands. He is put often into positions where such knowledge should be a "sine qua non." $\mathrm{He}$, of course, makes many mistakes. I have often seen him on the magistrate's bench or in his working room at an outlying Government Boma, struggling with his Swahili dictionary, or perspiring and patient while some native evidence slowly trickles its way through the confused and twisted channels of two native interpreters, Kikuyu into Swahili, Swahili into English, and so back 


\section{THE COUNTRY}

again. He is moved about from one post to another, transferred from a tribe he is just beginning to understand, and which on its part is just beginning to understand and trust him from a great district, that at the cost of real privation and sometimes sickness he has travelled over, to a tribe totally different in usages and language which he knows nothing about and to a new district, as unknown to him as the Sahara. His hard-won knowledge is all thrown away, and a new man, knowing nothing of his people, takes his job, to continue or not, as the case may be, those plans and policies that he and he alone had thought out and begun to put into operation. Still, somehow he does well. He has poor and uncertain support from Nairobi, and is often obliged to live in a climate that saps his health. He is poorly paid, he is wretchedly pensioned. Yet in a great majority of cases he is and does what an English gentleman is expected to be and do, for he comes from that recruiting ground for men of worth, the middle classes of England.

The English civil servant in British East Africa, as everywhere else in the world, is a clean, honest, capable gentleman. $\mathrm{He}$ is the class of man that England above all the other nations has succeeded in rearing and binding to her service. A man, that under circumstances of loneliness, disheartenment and danger has done more than any other class, I don't even except the soldier, to hold unbroken, in spite of its vast extension, what Kipling in an immortal verse has called her "far-flung battle line."

He should be better paid, he should be better pensioned, he should be better supported at his outpost. "Ah, there is no money," "There are limits to the English taxpayers' capacity to pay up margins of expenditure for unprofitable colonies." Admitted! But one wrong is done him which might be quickly righted without the cost of an extra sovereign. He should be listened to, and he is not. His reports are pigeon-holed when he is abroad, and when he comes 
home at last, a man who has done things, a man who knows, whose dearly bought knowledge is invaluable, he and it go to the great waste-paper basket of the nation, $\mathrm{He}$ is not now, and never has been, called to the counsels of those who, without one fraction of his experience, direct the Colonial policy of the country.

There surely never was perpetrated by any sensible people such a purposeless, thankless, criminal waste. Oh, why not honour in the eyes of the whole nation they have served so well, some representatives at least, of this fine civil servant class? Why not give the ablest of them some unpaid advisory, but none the less honourable, place, in the Colonial administration of the Empire, so honouring in the eyes of the world men truly deserving of honour.

The English taxpayer has to-day a hard time of it. An immense fleet, an immense old-age pension bill, yet to be paid for; how can he be expected to put his hand deeply in his pocket at the behests of a little almost unknown African colony. Moreover, the very name "African" is just now very tiresome to his ears. He has scarcely met the monstrous expenses of the Boer war (nearly $\$ 300,000,000$ ). No, nor has he or his rulers as far as a sympathetic observer can see, learned its costly lesson, that war came, that treasure and blood were poured forth, just because England never took the trouble to have and to maintain one wise, righteous, settled policy for the country. Rather she preferred, or allowed her rulers to prefer, her traditional non-policy of "muddle through somehow," one Government doing and promising one thing, the next undoing and taking back the work and promises of its predecessors. The result was a war that need never have been. The further result lying in the future, is nothing less than the loss, to the English speaking race, of South Africa.

One can understand the policy that allowed the Boers to build up, unopposed, a Government that was intent on driv- 
ing from out the bounds of its control, Englishmen and things. English. One can understand a policy that poured forth blood and treasure like water, to save South Africa for the Empire, but in the days coming who will be able to explain or defend to intelligent Englishmen that policy of shillyshally that first let the Boers have their own way till war was inevitable, then called all her sons around her, and with their aid, beat her enemy to the dust; and then, before the hurts of battle were healed, handed back the land for which she and they had paid so new and heavy a price, to those very unconverted forces of ignorance, prejudice and race hatred, from which, all blood drenched, she had delivered it. Great surely is the policy of "muddling through"! and that is the one persistent policy pursued in the poor little Protectorate.

The Governor sits in council at regular seasons. The council's supposed value lies in its supposed capacity to represent the needs and wishes of the Protectorate. It. suggests local laws and regulations, which are, [after discussion, for warded to Downing Street. If approved there, they are printed in the Protectorate Gazette and become operative.

There are six provincial commissioners ruling the six dis-. tricts into which British East Africa is divided. These men know the country or are at least supposed to know it better than all others, for they are sent to govern it by aid of district commissioners who are under their orders. Not one of these six has a seat on the council. Nor on the council can any official retain office who votes contrary to the executive. So the council is neither legislative nor conciliar. It does not fairly represent anything, even officialdom. It is a sort of restricted debating society, denied even the privilege of recording by vote its convictions. It satisfies no one in the country and does not seemingly exercise much influence outside it.

It has no settled policy of administration. It is not so: 
constituted as to be able to formulate one. Laws are promulgated from time to time but those most deeply affected by them have not even had a consulting voice as to what they shall be, or how they are to be put in operation.

On a lesser scale the shilly-shally "policy of muddle," that has proved so costly and disastrous in South Africa, is being re-enacted all over again in the Protectorate, with, be it remembered, very similar elements to work on, the unsatisfied settler and the ignorant, tenacious Boer.

One thing seems evident and that is, the need of a settled policy for the country. The men who know its needs, who have studied and ruled its natives, who have scientifically examined its agricultural, mineral and forest resources should surely be called together to formulate such a policy; and this being done, British East Africa should be placed under the rule of a really efficient and experienced Colonial governor, who with the aid of trained civil officers should be permitted and encouraged to go ahead with the development of the country and the education of the native without being unduly hampered by the interference of either the Colonial office or ignorant, if well-wishing, agitators in the House of Commons or in the missionary societies. Shifting about and changing of men and politics works badly everywhere, but in Africa it works ruin pure and simple. England may not be able to do this, she may not even wish to do it; if she does not I am sure that all who know the country will agree with me when I say she is bound to lose it, as she is now in a fair way to lose South Africa.

The next question that naturally arises is this: Is the Protectorate worth maintaining at such a cost of trouble and treasure? It is a country with a big question mark after it. It is not a land of one problem but of a series of problems. Can the white man live and breed there in health and prosperity? Can the sudden and severe calamities that have overtaken the agriculturist and the herdsman be in the 
future, by science, diminished or controlled? Can fever and unknown diseases be overcome? Can native tribes that by long custom have entrenched themselves in habits of wandering and idleness be so educated, so firmly and wisely ruled, that these predispositions of theirs can be overcome and that they shall be taught to work with and under the white settler.

Only to name these, and they are but a few of the African problems, is enough to indicate the giavity of the situation.

On the other hand, much of East Africa is extraordinarily fertile if Uganda is included on our survey. It is impossible at present to state what immense products of food and raw material the soil can yield. Nowhere has it been more than scratched in isolated patches here and there. If the food-producing capacities of the East, of India and China has been pretty well reached already, then it is an asset that could greatly add to their store. Many millions might be fed by grains and fruit raised in that rich land lying between the Nile Valley and the Eastern sea. It would seem that from an agricultural point alone the country is worth holding. If it is to be held, it must be studied, developed, ruled. A beginning is being made in the first. Some excellent scientific men are now at work searching into the problems presented by its diseases in man and beast, its capacities for producing grain and fruit, cotton, fibre, etc., etc., but their present equipment is very inadequate.

As to its development, the real and pressing need of some real policy is apparent. There has as yet been no extensive survey made of lands opened to immigrants. Immigration has been invited, but when newcomers arrive nothing is ready for them. They have been told to go on to the country and look out locations for themselves. When at last these have been chosen, they find their intended homesteads lie within some native or government reserve, and all they have done has to be done over again. I have known men to be 
kept three years waiting for settlement, three years after they have entered their claim.

Then the terms on which land may be had have not only been altered more than once, but are subject to constant and irritating alteration. First, land is sold outright to bona fide settlers, then it is leased for ninety-nine years at a halfpenny an acre, then for thirty-three or twenty-three years at a penny. The list of changes is a long one and more and more to follow. It is confessedly difficult to attract real settlers to a land so full of problems and dangers, and at so great a distance from English homes and English markets, and it really would seem as though the purpose of those who make laws was to place hindrances in the path of actual settlement rather than to remove them.

As to the education of those in the country or coming to it, practically nothing whatever has been done. There are as yet very few true white settlers. As I have said in another place Englishmen who intend making their real home here are almost non-existent. Some are working with pluck and perseverance, some are beginning to make a little money, but just so soon as they have put their farms in order, found a crop that will pay them well, secured native labour to work it, and made reasonably sure of a market, they will pay some head man to carry on their work and, taking their savings with them, they will go home. I don't think it fair to call such men settlers, nor do I think it likely that such class of men, even when enterprising and industrious as they of ten are, will be able in the future to hold their own against the Boer, who, if less intelligent and less industrious, sits down on the land and raises a family. The Boer will need, and in the interest of the country itself should have, help given to him to educate his family. Many of them have spoken to me on the subject. There are in the Protectorate Boers and Boers. There are already some intelligent, progressive men who fully appreciate, as they believe them, the great possibilities 
of the country. They deplore the gross ignorance of some of their fellow countrymen, they say that to permit the children to grow up as Boer children often do is to entrench ignorance and disloyalty in the land. They also say that unless the more progressive elements among themselves are helped and encouraged to educate the children on the farms, the greater part of the young will grow up as the father, knowing no more, asking for nothing better.

Let the authorities offer educational help now and they can do so on their own terms. Let them neglect to do so and soon they will find the Boer, even in South Africa, asking to have the Taal (debased Dutch) and not English taught, and anyone can realize what that will mean.

It might be well worth while to make at least an experiment with a totally different sort of immigrant. The small farmer, the man who would himself till the ground he occupied up to the present time has not even been invited to the country. All farms allotted have been given on a scale which made native labour a necessity to those occupying them. At first these grants were of I0,000 acres and over. Now they are 4,000. The small farmer could not profitably make use of more than two or three hundred acres at most. Such an experiment should have good chance of success. Good land near the railroad can be found, and settlers grouped on it; as the Boers are now grouping themselves, this would soon be a self-supporting community.

The large part of the Protectorate so far as one can judge can never be anything but a planters' country. I mean by that a land in which the white man is the overseer of the black man's labour. Where cotton, fibre, rubber, and other tropical plants can be successfully raised by labour so cheap that it would enable the planter to compete in the world's market with other producers who were geographically more favourably situated than he, till such 
time as the development of the great water powers of the country enable East Africa to manufacture her own raw products, along the great water courses and by the coast line. There are millions of acres of such rich land lying at present under brush and swamp, superb plantations they would make, but the cost of reclamation is at present prohibitory.

As I have pointed out in these notes of a traveller, there are also many high plateaus where it seems as though the white farmer could work all day and where two crops a year could be raised. In Queensland, a far hotter country, such work is now being carried out very successfully by white men, and in the northern part of the South American continent, there are communities of pure-blooded Spaniards who in almost the same latitude and in an even higher altitude are thriving, and have thriven, for two hundred years.

If colonies of the unemployed could be directed here, helped and educated until they succeeded in taking root, they would do more to guarantee and perpetuate English influence and rule than could any military or governmental occupation (as at present thought of) possibly accomplish.

Lastly it is evident that the Protectorate needs as much as anything else, a firm hand at the helm. All within it, black and white alike, must obey the law if the Protectorate is to prosper. It is obvious if the white man may defy or evade law, the black man will be quick to observe it.

There is an evil tradition in East Africa, that as it is a black man's country, and the whites are but as one in a thousand, nothing to lower their prestige can be tolerated. A white man cannot do wrong, a white man should not be punished, even if he openly defies the law. (An exception, and a good one, was made to this rule lately by the Nairobi officials; I am glad to say a prominent white man, who had defied the law, was sent to prison.) This vicious 
fallacy should receive its death blow at the hands of the ruling executive, while unfortunately it has too often there been accepted and approved. The powers that be are used not so much to punish as to shield actual lawlessness; of incompetence I do not speak. Law-breaking officials must be shuffled out of the country, the aim being not to vindicate law in the keen eyes of the native, but to hush up scandal, to get bad men who have broken the law out of the country, to get them out as quickly as can be, but on no account to punish them. In German land a white man goes to prison promptly.

Englishmen may be slow to believe it, but this policy is in actual operation to-day and it is as foolish and as shortsighted as it is unmoral. No Government anywhere under the sun, in past times or in present, gained anything by following it, and it is, thank God, opposed to all Anglo-Saxon history and tradition.

The education of the native tribes is the immediate need of the land. When I speak of the education of the native I am far indeed from wishing to imply that the wild children of the land should be taught and put to school. I use the word in its widest sense. I mean the training, the helping, the compelling of the native to fit himself gradually to those new conditions that inevitably follow the white man's occupation of the country. Justice, common justice to him, demands as much at the white mans' hands.

The education he needs can only be given him when first a thorough and sympathetic study has been made of him and of his environment, of his past as well as of his present. And it is just here that the well-intentioned educators and missionaries of former days made their mistakes, and courted and won failure, failure for themselves and the wards they loved, but loved unwisely. Africa is a land of failures; we have as yet no knowledge 
which enables us to even guess the reason. If we except the Egyptians, no African people have written their name distinctly on any record of olden or modern time. No African race has risen to greatness. The splendours of Carthage were fed and sustained by the sea. Africa proper was in olden times, as in modern, a land ravaged by the gold seekers and slave hunter.

Mohammedanism has failed in Africa to give the tribes that embraced it anything approaching expansive civilization. Mohammedanism does much for the individual, let so much be admitted at once. Mohammedanism makes him at least, in sort, brother man with all those who follow the Prophet, tends to make him cleaner, braver and more self-respecting. But there always it seems, fatally, to stop. It leaves him with no regard for his fellow man as a man. The Mohammedan looks down, and as long as he is true to his creed, must ever look down, on all people not of his creed. So he remains forever a pledged opponent of all that is progressive and uplifting in modern knowledge or government. If there was any real and lasting benefit coming to the native African by way of Mohammedanism reason would demand that all good people should rejoice. Many of the tribes near the coast have in large part professedly accepted the Prophet. But their's seems to be a mere veneer of Mohammedanism. The slave-trading Arab and Somali was no doubt often a devoutly religious man after his kind, but he proved a poor sort of missionary, and so left behind him a trail of misery, blood, and death. I do not think, then, that those are prejudiced who say that there is likely to come to Africa from Mohammedanism no permanent uplift. It has had its great chance on that continent. It has worked its will with little let or hindrance for years and there is little to show for it. Africa is dark, very dark to-day, and very hopeless, except in those spots where 
Christian missionaries have broken the hard ground, and European (not Belgian) powers have, following in their steps, begun to lay the foundations of government.

Africa is like a chronic invalid, on whom almost every quack, as well as every physician of established reputation, has tried his nostrums in vain. She has furnished gold for a good part of the Eastern world in the past, and for the Northern in the present, and provided slaves for all the world from time out of mind, and still she breeds her dark myriads. Still they clash among themselves in unrecorded wars, and slaughter and enslave each other. They speak literally in hundreds of different tongues, and as Job said long ago they have no "Daysman" to stand between them, no interpreter to each other or to the outside world. Pestilence and famine, unchecked, unrelieved, have swept away whole nations at a time. The strong of the earth have enslaved and in vast regions still enslave and slaughter them at will, while of themselves no leader, no teacher, no governor arises to bring them order; such has been Africa's fate for unrecorded ages. It is in great part her fate to-day. Can any man with a heart in his bosom deny her and her many children pity and help?

The East African is not a man, he is a child, and a child's education and discipline is what he needs. England's coming has wrought already one profound change in his environment. It has put a stop to the constant blood-letting that drained the land of men. War, not between tribe and tribe only, but between petty chiefs and even insignificant villages, went on all over unoccupied Africa till England or German occupation stopped it.

Sir Charles Eliot in his admirable work on East Africa has stated with substantial truth what England has accomplished, although he makes no sufficient mention of what German rule has also achieved. He says, "England 
has reason to congratulate herself, without undue laudation, on the accomplishment of the greatest work of humanity that the world has ever seen. It is only ten or fifteen years since the whole country from the ocean to the Congo groaned beneath oppression and bloodshed; on the coast the Arab took two children out of three in every family as slaves. From Lake Victoria almost to Mombassa the Massai harried the land. The valleys were deserted, no one dared to keep cattle for fear of exciting the cupidity of the raiders. In Uganda, Mtessa put thousands and tens of thousands to death in apparently aimless fury. The caravans of the slave traders travelled the whole country seeking victims. Every tribe was at war with its neighbour. Nature augmented the terrible misery by causing terrible famines."

So much is only too true. Incidentally how strong a testimony is this borne by Sir Charles to the innate capacity and docility of the native. No rude children of the wild anywhere in the world are easier to lead or more faithful to those who lead them. They have welcomed the rule of England though that rule, so far as it has been extended to them, is as yet a rather shadowy rule. It has been just, it saves the oppressed from the oppressor and it most conscientiously strives to safeguard the rights of all. The well-to-do are not despoiled, nor are the feeble enslaved. "The Song of the Birds" that the young men of the Elgao sang to us as they danced by the signal rock overlooking the wide valley, is a true song to-day. The women need no longer fear for husband, son or daughter. The spears are no longer red, and the warrior may safely doze the day away as he squats in the sun on the table rock from which his forefathers so often cried to the tribe a dreadful note of warning.

The Elgao contentedly herds his little flock. The small brave communities of the forest N'dorobo come 
forth from their woodland shelters a little less cautiously than of yore. The Massai complacently watches the growth of his quite enormous herds; the Nandi, partly shorn of his, turns resolutely to the cultivation of a soil as rich as any in Africa. The Ketosch need no longer bury themselves and their cattle together in the stifling smoke of their cave fortresses on Elgao slopes, the little raid going on, and the small war parties occasionally hovering about, are not serious, and if the chiefs do not suppress such youthful exuberance the local police surely will. In short, at present, contentment reigns over all beautiful Nzoia land, and, indeed, in all British East Africa and Uganda. The question is, can it continue?

The difficulties and responsibilities of England's administration are only beginning. To these simple people who so readily trust and obey even a shadowy rule, something more than protection is owing. They can most easily be protected from each other, but can they as readily be protected from the consequences that must inevitably follow the coming to their country of the white man?

Alas! from much that is utterly evil England has already failed, quite failed, to protect them. She did a great work when she made a declaration that slavery should cease, and enforced that declaration with the crews and guns of her men-of-war. But in Africa to free the slave is not by any means the same thing as to rear and educate the man.

England surely has had laid on her shoulders the very greatest and most difficult of all possible tasks that civilization can allot to any people. All over the world, on continents and amid the islands of the sea, she has at least attempted to do what the judgments of posterity will assert has not been as persistently attempted by any conquering race. She has aimed high and her aim has been to be fair - to her conquered as well as her conquering 
children. But her policy presents so many contradictions that it is no wonder she has been and still is accused of an hypocrisy that on the one hand makes a pretension to high ideals and on the other shows subserviency to ordinary selfish nationalism. These contradictions she cannot explain to herself: how much less can she do so to her critics?

She forced opium on the Chinese at the muzzles of her cannon, and with the same civilizers she forces freedom on the East African slave. To attempt to explain the moral curiosities which attend the development of a great policy of trade or colonization requires time and study. In the United States so far as the same problems have arisen, our policy has often presented the same inconsistencies. Inevitable results and responsibilities will confront all who hold themselves to be keepers of their weaker brother, and in British East Africa these are about to press hard on England.

Can she continue to be fair to the mixed people coming to that land? Can the clashing needs and passions of men be so bridled and modified ? Can the selfishness of the human animal be so restrained? Can the heart of man be so enlarged that the white and black can live contentedly side by side to their mutual advantage? Many wise men already despair of such an Utopia, and in all honesty it must be admitted that till now there have been but few signs of any such issue to the struggle between the white man and the black, whether the field of competition be Africa or the United States.

One thing at any rate is quite admirable in England's attitude. That is its persistence. Blunderingly, defeatedly often, yet perseveringly, her mighty and but half-conscious democratic spirit struggles on, trying to right the.wrongs she has herself often been guilty of, trying always to be fair. Surely, in the day when nations must come forth to trial, this shall be counted to her for righteousness. 
So much every fair-minded man must admit that England has done, and is trying to do in the Protectorate. But aims and results are far from being the same. Actually the moral condition of many of the tribes has altered seriously for the worse since her arrival.

One of the fruitful causes of evil has arisen from the incapacity of the white man to understand quickly the black. The missionary, the soldier, the foreigner, generally insist on treating him as though he were a man; he is not a man, as I have before said, but a child, and a child whose childish development has in some mysterious way been retarded.

The philanthropists of the last century cried aloud, "Let us free him, and he will stand on his feet." Free him, yes, by all means, but from whom? From his taskmaster, you will say, of course. Yes, granted, but the very worst master he can have is bimself. Abstract freedom was a fetich to good men in London and Massachusetts, men who had not had an opportunity to study the halfdeveloped creature they would hurriedly and at all costs, make free. Ah! we are inevitably learning that manhood is a plant of slow and painful growth.

I have heard a story told of Lincoln, which, if I am not mistaken, does not appear in any life of the great President. Before Antietam he was waited on by an influential deputation of Boston Liberationists. They urged on Mr. Lincoln the immediate need of proclaiming a general emancipation. The President listened quietly to their arguments and when they had finished he said: "Gentlemen, do not be offended if I give you a simple question, and ask for a plain answer. How many legs has a calf?" The spokesman was indignant and he said so; said the President's question was lacking in respect to the Committee. "I intend no disrespect, sir," said he, "please answer my question." "Why, four, Mr. President." 
"Well, gentlemen, supposing we call the calf's tail a leg, how many legs has a calf then?" Again the Committee protested. "Please answer my question, gentlemen." "In that case, Mr. President, the calf has five legs." "No, gentlemen, for our calling the tail a leg does not make it one, the calf has still only four legs. Good morning!"

Every native between the Nile Valley and the sea may be declared free, his bonds may be broken, his master deprived of his services, and he of that master's protection and rule. But no declaration will make him free. He must have some master. No worse fate can befall him than to be deprived of one master and given no other. The very first step in his regeneration is taken when he is induced, forced, if necessary, to work. In part, he can be induced to work. I have pointed out again and again, that the East African does admirably the work he likes doing, if he is wisely and firmly forced to keep on doing it. The theorist who would insist on pulling down and opposing all plans for exerting pressure on the native, because such plans can be labelled "forced labour" is no friend of the African. It is the influence of such blind theorizing, self-satisfied and ignorant as it is, that thwarts often and brings to nothing the wise efforts of those who know the native, and are on the spot making sacrifices to aid and educate him-efforts that often the self-confident philanthropist in a far-away land might not be ready to make.

The native can be taught agriculture, the men can in time be taught to take part in it, as well as the women, but it is necessarily a slow work. The native can be trained into a fair mechanic. He naturally takes to iron work, pottery, brick-making, stone cutting, carpentry. But to teach him it is absolutely necessary to indenture him and make him stick to his job till he has gained a certain proficiency in it; otherwise in a few weeks or months he 
grows tired and, like the Arab, silently slips away; or after infinite pains have been expended on getting him and providing him with tools and teachers, his parents come demanding the youth to aid them to gather the harvest or to migrate with the flocks, and the disappointed teacher sees the last of a promising pupil.

$T$ he East African native is at heart a nomad still and no system of education or of government that does not take account of this deeply inbred tendency can do him much good. The influence of steady work is the one thing he wants in his present state, is indeed the only education he is at first fitted for. The influence of labour will make itself felt in every direction. It will tend to the material prosperity of the country and thus furnish funds which the white man can employ in keeping order and establishing a regular administration. "Best of all, the habit of labour will bring the native into contact with the white master, and supposing the native to be (as he is usually in British East Africa) justly and firmly treated, it will instill a confidence and respect, and hold up to the savage a superior standard of comfort which he may be in time impelled to obtain for himself." *

The African's nomadism is his toughest defence against all education, all real progress, no matter who he is or to what tribe he belongs, whether he be a mission boy, a heathen or a Mohammedan, nothing but force will make him stick to his job. Keep him to it, and he likes it. You will see him dancing from seven in the evening till midnight, two or three nights in the week, after he has done a long day's work with the hoe in a settler's shamba. You will see him engaging in impromptu races up and down Port Florence pier, after he has toiled from twelve to sixteen hours without a meal, unloading a steamer in the sun. This extraordinary spectacle I have seen myself,

* Lionel Dech. "Three years in Savage Africa," p. 526 . 
and the captain of the steamer who was with good reason proud of his "gang of boys," told me it was a common sight. But then he was a scrupulously fair and also a firm master and there was competition among the natives to get a place in that "gang." I might multiply such evidence of the East African's capacity for work, but any observant traveller will admit the truth of what I say.

The native shows every promise that a child can show of capacity for a sound industrial education, but as yet in German territory alone is any effort being made to provide him with it. In British East Africa the native tradesman were he competent, would be a godsend. The only artificers at present to be had there are Hindi, and very unșatisfactory workmen they prove. But the native must be controlled before he can be taught.

The Germans have already in this direction accomplished good results. The order and method obtained in their ports is in striking contrast to the wild confusion and inefficiency so painfully obvious among the natives of the English coast line. The German natives, too, are at least as well paid and both they and the travelling public gain by their discipline. At Tanga there are admirable industrial schools where native boys are indentured and kept at their work till they know it. But then Germany is quicker to understand the educational needs of a people than any other European nation.

From all this it follows that the programme of the well-intentioned, but very ignorant home-staying philanthropist, who insists on laying down the law for a people of whose actual condition he knows very little, is a mistaken and most hurtful policy. He hears of the gross evils attending forced labour in the Congo or in Portuguese Africa, and at once jumps to the conclusion that the cure for the evil is to abolish forced labour in any form.

There is very little labour yielded anywhere in the 
world except by compulsion of one sort or another; a blessed and universal compulsion drives us all to toil. Most of all does the child nature of the black man need its beneficent pressure. Least of all men does his environment supply it. He can sit in the sun and drink himself stupid on pomba, as alas! millions of natives do, while his wives and children easily accomplish the shallow tillage which is sufficient to provide him with food and drink; but where, in such an existence, are there any opportunities for advancement?

The misguided philanthropist again would insist on his being allowed to remain in the absolute possession of large portions of his land which should be interdicted to the white settler. There are places where it would seem to be advisable so to protect him, though the areas should not be too large, but a real knowledge of the local conditions is most necessary before any such arrangements are made. Generally speaking, the larger the native reservation, the harder it proves to reach, govern or educate the native, and the more strongly he intrenches himself in barbarism, adding to the ignorance and evils to which he is heir, those he too readily acquires from the white man.

The one thing that seems evident to every intelligent friend of the native to-day is that at all costs be must be made to work. Wants, new wants, must be created in him. Those of his would-be friends who ignore or forget this are doing what they can to make him in the end a dispossessed and perishing outcast.

Africa cannot be for ever left to savagery, or to savage men. The world needs Africa - needs what Africa can produce. Land-hunger among the peoples will not languish, it must increase. The death-rate of the East is falling. Famines and pestilence are being by science and philanthropy restrained. Vast rich tracts of earth's surface 
cannot be left to the careless savage, who does not know and will not learn how to use them. "From him that hath not shall be taken away that he hath" is not the cruel decree of an irresponsible tyrant, but the far-seeing declaration of one who loved men and knew what was in them.

So much for the need of making the native work for his own salvation's sake. But there is another side to the question of native labour which must not be forgotten.

Unless one is acquainted with the country one cannot at all realize the imperative importance of native labour to the African colonist. His fortune, his home, his all depends on a sufficient and staple supply of that labour, at the time that he wants it, and at such a fixed price that he can estimate his profit and loss.

Africa is as yet the land of dreadful uncertainties. Some new danger, some unexpected sickness, some worm or grub in the field, some murrain breaking out in the herd - these the settler must be prepraed to contend with. No other country compares with Africa in producing unheralded calamities.

In addition to these the agriculturalist has to prepare for an uncertain rainfall, in a country where even one season's shortage in the rains may mean dire famine.

To those who do not know Africa such language seems exaggeration but unfortunately it is the sober truth. Until lately it cost $\$ \mathrm{I}, 000$ per ton to bring goods from Uganda to the sea, a distance of only five hundred miles. Only a few months ago I had to pay $\$ 4$ for sixty pounds of food for my men, and poor grain too. That was a prohibitory price for natives. Many therefore died of actual hunger in a region that within a few weeks was so well supplied with native-grown grain that it could afford to export a good deal. In May you might see men dead by the roadside, where in August plenty reigned.

Try, then, to understand how great are the difficulties 
of the farmer living many days march from the railroad. When he does gain access to that road his difficulties are not over. There is only one little narrow-gauge line for all the country. The grades on it are very severe, ten small carriages or trucks are as much as an engine can draw. Freight rates are not as high as they were, but are still very high. Labour-saving farming machinery is out of question; no native could use it. If he works in the sun all day, he has only his two hands, and the sun kills. To break up his ground, to free it from a tropic luxuriance of weed, to sow and reap it, to carry his produce to the distant market, he is for all these dependent on native labour. His herds may have to be driven many miles to water, and if not watched at night and guarded by fires and thorn boma, they would soon disappear.

Without a regular supply, then, of native labour and at a fixed price the farmer cannot live. But the farmer has an inevitable competitor in the Government itself. Nothing can be accomplished in the Protectorate without native labour. The roads, the stations, the Government works, the supplying of military and civil forces at distant and inaccessible points - all these require immense numbers of partially trained and disciplined natives.

The East African is so important both to settler and official that there is often a scramble to get him, and he, while he is willing to work when starvation forces him to it, is apt, as soon as he has a rupee in the corner of his blanket, to try to avoid working for either Government or farmer. I am afraid it must be confessed that for him sefari life is not always a good thing. The wages he earns at it are much higher than the colonist can usually afford to give and it encourages his innate tendency to wander from place to place and from job to job.

I have given the merest outline of the difficulties incident to the employment of labour, but even that is enough 
to indicate how complex is the question. How is it being dealt with?

The civil officers of each district are, among their other multifarious duties, expected to provide native labour for colonists settled within that district, as well as to furnish the necessary gangs to carry on department contracts. Natives in gangs of several hundreds may be seen marching off to build roads, cut wood, mend railway embankments, carry supplies, etc. And as there is only a very small staff of Europeans in the country, all such works have to be let out on contract to Hindu or Swahili contractors. Here at once arises a need of protecting the native. No one in his senses would advocate handing over natives to the tender mercies of a Hindu contractor. He would be overworked, underfed and driven to desert before the time he had engaged for had expired.

By way of illustration, I will tell a story. Three years ago I was staying with $\mathrm{X}-$ charge of an important post. One afternoon three hundred miserable wretches crawled into the boma and seated themselves before the office. The officer came out and asked what was the matter. A little starved looking lad of certainly not more than twelve years separated himself from the dumb throng, came up alone, and said: "Bwana beat me and let me go home." The child then lay down on the ground, as the natives are made to do before being whipped; $X$ - took in the situation at a glance. "Here," said he, "is an instance of how these rascally Hindis go to work. I saw these people off to their Government job three months ago. They were in good enough shape then. Look at them now. Some down with fever, some with dysentery, and all of them starved. That devil has worked them harder and harder as their contract time drew to a close. He has harried them and beaten them and, having got almost three months work out of them, makes 
their lives so miserable that in the last fortnight of their time they desert. That is what he has been aiming at all along. The deserter forfeits all his wages, and can be punished by flogging as well. That is what that child's appeal means." Without delay the station doctor was called in and on examination declared that the men had been neglected and insufficiently fed. Potio was at once served from the stores. For a whole week these poor things were well fed and looked after and at the end of it you would scarcely have recognized them. Meanwhile the aggrieved contractor came to the Boma saying how impossible it was for him to complete his contract with such useless labour as had been supplied to him, and asking for another draft to finish up with. His dismay on finding his men feeding on full allowance of potio, at his own expense, was ludicrous. He met with a reception he is never likely to forget. He paid for three weeks' feeding in idleness, and he paid for their full three months' work. So rascality that time did not pay him. And alas for life's tragedy, poor X-got into some trouble soon after and shot himself. Everyone was down on him, though surely he had somewhere within him the makings of a man!

Now it is only fair to the local authorities to remember that they are keenly aware of the dangers attending the contracted employment of the native. They cannot at present rid themselves of the system, so they provided, so far as they can, laws that shall defend the native against just such outrages as this one to which I was a witness.

They had lately passed a new ordinance, for instance, which requires every employer of labour, whether contractor or farmer, to pay a certain part of the wages due to his servant in advance, and also provide him with blanket and cooking pot. Now, such an ordinance would work well in the case of hundreds of workmen engaged on 
regular Government work. The men on that sort of work are in gangs, keep regular hours, and are easily supervised. They cannot desert as soon as they get their advance and blanket, for there are armed guards to look after them and they would be caught and punished. They might desert in a body, but could not take that extreme step unless they had been badly treated indeed.

But now take the case of a settler needing a dozen or a hundred day labourers to herd his cattle or break his land. To obey this law for him means ruin. To pay the labourer beforehand, to give him blankets, etc., is to put temptation under his nose. He finds himself with wealth he has not worked for in his hands, and the muchcoveted blanket on his back. It is too much for native human nature. Next morning he is gone. The unfortunate employer is quite helpless. Now more than before it is impossible to leave his shamba. His crops, his stock, need every instant of his time. He is driven from morning to night. The last thing he can do is to chase natives in the wide country, or among native villages, where half a hundred of them might easily and successfully hide.

It was the issuing of this last order in council that caused such disturbance at Nairobi, during the spring of 1908. Popular feeling against the Government ran very high. The settlers had a strong case, but their mistake lay in their method of presenting it. There can be no prosperity, no steady progress made in the Protectorate till this question of native labour has been thrashed out, till the black man has been taught that whether he will or no he must work, or he will be taxed until he does.

Now let me turn for a little to this question of native taxation and diffidently offer a suggestion. Of course, a mere traveller through the country has not time fairly to estimate difficulties that might arise to prevent the 
success of what would seem at least a step in the right direction. Now, though no magicians' wand can be waved by any governor or government, that by its waving should suddenly transform age-long savage incapacity into the trained and educated ally of civilized progress, still the beginning of better things could be attempted here and now.

Some of the natives are willing to work; that number is increasing. A premium should be placed on such willingness, a prize which the native could understand and value offered to all who try, and as yet no attempt to do this has been made.

The system of taxation now in use in the Protectorate, presses most unfairly on some, and others, those often best able to endure it, it never reaches at all.

A friend of mine coming to meet me, in May last, saw three Kikuyu lying by the roadside, dead from actual starvation, while tied up in the corner of their poor, red, cotton blankets were the three rupees they were staggering along to pay as hut tax (the only tax the native now pays) to the district collector.

No native would touch the blankets or the rupees, the men lay in a shrunken little heap as they had died, with their blankets drawn over their faces.

Now by contrast see the case of the Massai, that petted and most useless of all the East African natives. The Massai will do no work; when he is a boy he herds the cows and sheep; after his initiation he lives for ten years in the warrior's kraal. As a warrior he must obey his chief's commands and be ready to defend his people against raids of wild men and beasts. Now, this military system of his once made him the dreaded master of all East Africa, but this time is past. There is now no further need for his militarism. He, as warrior, is nothing but a lazy licentious parasite, a burden on the country, if not a danger to it. Change he will not; why should he? He has the fattest 
of a fat land, counting his flocks by hundreds or thousands. These grow enormously, while he does nothing but sit in the sun. His wives keep his hut daubed with cow-dung and when his cattle have browsed down the neighbouring pastures, they pack for him all his belongings on their own or the donkeys' backs and move on to pastures new. He strolls ahead, chatting with the other "old men" while a new village arises, and its thorn Boma is put up. Now, how does a yearly tax of three rupees a hut affect this gentleman of means and leisure? It affects him not at all. His cows are worth one hundred rupees each, and he has several hundreds, sometimes several thousands of them. His bullocks are almost as numerous, and these he values not because he trains them to labour or intends selling them to the settler, for he scoffs at the idea of parting with any but the sick sheep or goats, or barren cows. He values them for their blood, which once in every few weeks he draws from them and drinks. He will sell nothing and he will till the ground nowhere.

In his case the fixed tax is an absurdity. There are Massai to-day whose herds in the open market would fetch $\$ 50,000$, and these enormous herds are in splendid condition and are increasing year by year.

The Massai should be taxed on his herds, every cow should pay a tax, and they should be forced to sell at least some portion of their cattle. Why should the very best grazing land of Africa be given over to nomads who cannot be induced to do anything for their living?

Why again should not every native in East Africa be told to present himself for Government registration? Such registration could be arranged at the various tribal posts by the civil authorities. If on presenting himself a native could show a certificate to prove he had worked either for the Government or for a settler, for two or three 
months his tax would be reduced or remitted altogether. If he had no such proof of work done, it might be increased. The strongest shoulders should be made to carry the heaviest loads. The Massai have everything done for them. Superb grazing lands are reserved for them, these including the best arable lands in the Protectorate; and, as things at present stand, they will not till them themselves and no one else is permitted to break up an acre of their reserve. So the end of this one-sided arrangement cannot be far distant.

Another cause of present friction in British East Africa is the anachronism presented by the law courts. The East African has his own ideas of right and wrong. These are embodied in tribal customs and, of course, vary considerably, but on the whole they form a system that does not work badly. The worst element is witchcraft, with its attendant cruelty and bloodshed, and gradually this must be suppressed.

In time a legal code should be given to East Africa by means of which the tribes could be educated and governed at the same time. The Indian criminal code, at present the established law, in obedience to which the high court at Mombasa is supposed to review the acts of the magistrates of the Protectorate, is a strange anachronism. Shall Kikuyu and Massai savages be educated to understand the Indian criminal code? How shall poor, harried, overworked local Magistrates govern their immense territories if they are on all occasions, as they are at present, subject to reversal of their findings by honourable gentlemen from England and India, who test such findings by the Indian penal code?

This extraordinary proceeding is today among black and white creating an irritation that is most harmful and may prove dangerous. He can understand his chief's findings and punishments. He can also submit himself 
to the orders and penalties of his white overlord, but how can he understand when the fines his white overlord has imposed on him are handed back to him at the bidding of some distant and quite unknown power? Moreover, almost surely in his own conscience he knew the fines to be just. It is a strange muddle!

An illustration of how badly this Indian code works arose quite lately; there was trouble among a certain tribe because witch doctors had poisoned, as they often do, some of their enemies. The natives thought matters had gone far enough, so they put two of the witch doctors through the ordeal. One was burned in his hut; the other pegged down under a cow skin in the sun. It was the rainy season. If the rain came, the moistened skin would not hurt the man, if the sun shone he would be suffocated. He was suffocated. Five natives implicated in the affair were tried for their lives. Three of them were sentenced to be hanged.

Now, imagine the confusion in the minds of these most unfortunate men. They had followed nothing but the tribal custom. Done nothing but what their fathers had done. That custom must, of course, be stopped, but it must be by a policy of fair play all around, not a policy that left the murdering witch doctor untouched while it visited with condign punishment those who, after the manner of their people, sought to limit and restrain its power. The Indian penal code knows nothing of the intricate matter of witch doctoring.

The Protectorate is indeed a land of problems and the native question is not the last of them; there remains still a difficult one to face

How about the Hindi? How far shall he come? Shall the land be ruled and financed in his favour? $\mathrm{He}$ is of the Empire. English fair-mindedness demands that he should have a chance in this new land to make 
a modest fortune and on this he contentedly retires to his own country, taking every rupee he has made with him.

Now the Hindi has been a necessity. He is a necessity still. His little trading shop exists everywhere under conditions which no white man's shop could face. It has often proved an immense convenience. The Hindi who comes here, however, is not, so I am told by those who know India, the best sort of an Indian. Certainly the natives do not respect him. He degrades them and cheats them. Economically he may be a convenience, but morally he is a curse.

His coming in the first instance was a necessity. The English policy of "muddle" had brought on the Uganda mutiny, and the home authorities, who could not be induced to spend a few thousand pounds to pay promptly the arrears due to an over-worked and underfed couple of battalions of expatriated Soudanese troops, came suddenly to the conviction that they would spend several million pounds to build a railroad, and so make sure of their hold on the rich Uganda land that had been so nearly lost to them. No preparations having been made, the work must be rushed through at all costs, though there was really no reason whatever to hurry. The little band in far-away Uganda had shed their blood freely, and Uganda and Englishmen, civilian, soldier and missionary, had beaten that mutiny and had won out. But it is England's way first to refuse to do anything and then to make up for lost time by trying to do everything at once; so the Uganda railroad was ordered to be rushed through. The ignorant and terrified tribes of the interior who had been harried for ages by slave hunters and who only managed to live in the country through which the railroad had to pass after leaving the coast by hiding their huts and villages in densest forest and thorn scrub, could not be induced to bring their labour. Their refusal forced 
on the administration the importation of the Indian coolie, and in the wake of the coolie, who was ready to depart when his work was finished, came the Hindi trader who elected to remain.

The Indian debauches the native wherever he gains influence over him and leaves his dreadful mark wherever he remains. $\mathrm{He}$ is a past master in all departments of deceit and fraud. $\mathrm{He}$ is the worst element in the labour market. He cheats the native workman and knows enough of Indian law to avoid, when avoidance is possible, the just punishment of his rascality. He has no permanent interest in the country. It is to him merely an orange to suck as dry as may be.

As far as one can see the Indian is likely to remain. He makes himself useful in many ways. He supplies a relatively cheap and fairly good railroad servant. None but he work in stone, iron or wood; and no effort has yet been made to educate the natural mechanical gift of the native, to compete with him, in this all-important field.

There are no savings banks of the natives and he therefore secures the savings of the black wage earners, and sometimes absconds with them. To keep them safely he charges the poor porter eight per cent., and then, of course, lends the cash to someone else, at ten or more per cent. The transaction is not an unprofitable one. Of course, in speaking thus harshly of Indian influences in East Africa, I do not forget that there are some honest and upright men of that race. I speak of the Indian influence as it is generally felt in the country, and I have met no single man, civil officer, or resident missionary, who does not assent to the truth of what I have tried temperately to state.

Now there arrives on the scene another incongruous element, one, too, that must be reckoned with, namely, the Boer. He, with a better eye for country than the English immigrant, has already fastened on the very best as 
good enough for him. He comes here as he has come before to other parts of the continent. He comes sometimes to make a home, and as a home-maker he should be and is welcome. Sometimes to make but a short stay and then move on, selling his holding which he has done little or nothing to improve, and again seeking some wilder land where he can live the rough and uncontrolled life he loves. Why these immigrant Boers who now are crowding into the Protectorate by the ship-load have left the Transvaal which is now theirs beyond controversy, none of them seems to be able to say; unless the excuse that times are hard there counts as valid.

The wandering Boer is an unmixed nuisance; he openly boasts of his hatred of England and all things English, yet he very shrewdly avails himself of every loophole that the extraordinarily generous provisions of the Protectorate allow him. I will quote one concrete illustration of this temper of his and of his attitude to the powers that be.

A sportmans's licence to kill game in British East Africa costs 250 dollars. A settler's licence 50 dollars. In addition to these purchased commissions to kill game the law permits a bona fide settler to shoot all game except elephant, eland and giraffe, on his own land, and as the grants of land are as extensive as ten thousand acres and often more, a small farm will sometimes extend to four thousand acres; this privilege is worth a great deal to the newly arrived and struggling immigrant.

Many bona fide English settlers were for long refused permission to take out even a $5^{0}$-dollar or settlers' licence, but were told by the authorities they must take a 250 -dollar licence if they wished to kill game. It is but the truth to say that 50-dollar licences were only granted after considerable delay, and when positive proof was forthcoming that land was taken up and occupied.

Now just as soon as the Boers began to arrive in any 
considerable number, a new order from the local government is issued. Under it an immigrant may take out a 5-dollar licence good for three months, which will permit him to kill game while he is travelling over the country looking for the location on which he wishes to settle.

It must be admitted that such an arrangement, if it is naturally nettling to the older British settlers, is at least generous to the Boer. How does the Dutchman take it ? I have heard married men among the Boers, not young, irresponsible hot heads, standing among their friends and with their wives and children by them, openly defy the game wardens and police and boast when these officers question them politely, that they had taken out one such licence, and that its date would expire in a few days; that they would not be bothered to take out another, and that they would go when they pleased, and shoot all the game they chose, and no one should stop them! These men were convinced that everyone was afraid of them, and that the privileges granted them by the Government were only granted because those in authority did not dare to do otherwise. Such men are an undesirable element in the country.

I have dwelt at length on this case, because their presence complicates seriously the native question. No one knowing the history of Boer immigration can welcome such settlers as likely to aid in establishing and maintaining honourable relations with the natives. Here another and grave difficulty awaits the Government. To put it as mildly as possible, the Dutch treatment of the aborigine, if in his own view it is just, could not be called sympathetic. Some of the native tribes cannot at present live without the game. Their clothing and much of their food depends on their hunting. The Boer utterly wipes all game out, and having done so in one country goes elsewhere to do the same thing over again. He despises the native, scorns 
any idea of educating or improving him, and is naturally dreaded by the helpless being he so ruthlessly tramples on.

Can a weak local government, such as this grudgingly supported by Downing Street, successfully mediate between two elements so opposed in tradition and interest?

The policy that would seem to offer, "for the present distress," the best prospects of success is one of closed districts. This plan has been adopted in the case of the Massai and there is some hope that it may be extended so as to shield the far more helpless, and fully as interesting peoples of Mount Elgao and Nzoia plateau.

The lands reserved for the Massai are closed to everyone, sportsman or traveller, unless he has procured from the lieutenant-governor a permit to enter them; any others found within such boundaries, are subject to arrest.

If Elgao, Maraquette, Cherangang, N'dorobo, Kamasea, Suk and Karamojo countries were declared closed, these people would be saved from the Boer intrusion that now threatens them, and the Boers themselves would lose nothing by the limitation, for the land they are crowding into, the finest perhaps in B. E. A., is a "no man's land," and has been for years merely the battle ground of the tribes.

The country occupied by the tribes I name borders the rich plateau of the Nzoia; just now the plateau is covered with herds of game, more numerous, probably, than anywhere else in Africa. As soon as the land is settled, these herds will disappear, the remnants of them will seek grazing farther from Boer settlements, in the drier, less valuable regions bordering the plateau. If the Boer is allowed, he will surely follow them into such retreats and then most certainly we shall hear of native disturbances.

Tribes like the Karamojo, Kamasea, and Suk, are still so far away and occupy so rough a country, that just 
now there is no great danger of their being harassed, but the kindly Elgao and N'dorobo are close neighbours and need immediate protection. "Closing" their little country would be no hardship on the incomers, and would save the simple and brave people from untold misery.

Nairobi as it is at present is a fruitful cause of evil to the whole country. Thousands of porters and labourers from many different tribes come there to get work. They are engaged for Government contracts or on hunting sefaris, and return there to be paid off. There are some five hundred white men and women in and near the town, and how many Somali and Hindi it is not easy to say. Probably at least two thousand. The black population, of course, varies a good deal, but there cannot be fewer than from ten to fifteen thousand natives, and very few comparatively of these are married. When the labourers and porters come back, having worked on Government contract or on sefari for months, much of their cash goes in a wild spree. Men and women in plenty are there to grab from them what they are but too ready to part with. The results can better be imagined than described.

British East Africa needs to-day the service of the ablest young men the homeland can send her. There amid her tribes, among her mountains, work that cannot fail to influence the great future awaits the doer.

She needs, first, a settled policy that shall free her from the unsettling result of whirligig politics and shifting parties in England.

Second, she needs the trained civil servant fitted for his work among settlers and natives, reasonably paid for doing it, reasonably pensioned when it is done.

Third, she needs a first-rate staff of young men; veterinary, agricultural, medical, educational, and police, to study the country, overcome its peculiar dangers, solve its problems and aid those in authority by placing at their 


\section{THE COUNTRY}

disposal the accurate information by the help of which the Protectorate may be guided toward a lasting prosperity.

Fourthly, she needs a wise man and a resolute, with some experience in ruling men, who shall be supported and encouraged in undertaking one of the most complex and difficult tasks that England has ever offered to. the ability and patriotism of her sons. 


\section{CHAPTER XV}

\section{A PLEA FOR THE NATIVE EAST AFRICAN AND HIS MISSIONARY}

THE native in East Africa is untold thousands of I years younger than Abraham, untold thousands nearer the monkey, than were Abraham's Phœnician kinsfolk. Yet Christian missions have too often in the Negroes' case, as in that of other far more enlightened peoples, set themselves the hopeless and impossible task of offering this neglected laggard of our race the complex and contradictory theological conclusions that matured mankind has only accepted after years of discussion and conflict, and which reverent and thoughtful men to-day are everywhere modifying or casting aside.

If Christian missions are not succeeding in East Africa it is not because the missionaries themselves are lacking in ability or self-sacrifice. No braver or more consecrated men and women ever went forth to the doing of a thankless task than they. These men and women who have left home and friends in order to bring life and hope and freedom to the oppressed and exploited people of the earth, have especially here, in this continent of death and loneliness, "not counted their lives dear unto themselves."

None ever faced a more dangerous task than they. Few ever faced any task more bravely. But they have not succeeded as they should, and they will not succeed as they might, because to take what they bring, to do what they demand, to believe what they exact, is beyond the present power of the undeveloped East African's intelligence. He can love and follow his missionary bwana and he does. 
He has followed him even to the death. See the splendid bravery of the Waganda spearman at Lubwas' boma. But he can no more understand his mental processes than he can change his soft, brownish black skin to the tint of his. Abraham was not sufficiently civilized to be a monogamist. I do not think the East African always is. Christian missions, by insisting on a strictly monogamous state for all natives, as a prerequisite to membership in the Christian brotherhood, as well as by enforcing systematic doctrinal teaching, have often blocked their own path of access to the native, and have left, and are leaving, to Mohammedanism, millions of these people for whom a simple form of the Christian religion could accomplish what, of course, Mohammedanism never can.

To the rapid advance of Mohammedanism I shall refer later. Here, as I said above, I only wish to state clearly at the outset what I believe to be the one cause above all others why Christianity advances slowly and Mohammedanism by leaps and bounds. Africa needs a very simple, very rudimentary Christianity. The African is incapable of understanding any other. (I have had no personal opportunity of judging of any missions other than those of East Africa and Uganda. To these, and these only, I refer, but generally speaking, what is true of East African missions is true of all missions on that continent.) Any religion for him is an immense advance. He is, in his native state, an atheist pure and simple. Christian missions have been unable to offer him such a Christianity. Partly because our missionaries have not been trained to do this. Partly because they are bound too constantly by the laws of "Medes and Persians" obtaining in missionary societies and directing committees at home.

The Mohammedan missionary, on the other hand, has done what the European failed to do, and hence his phenomenal success. He has given the native as much as he 
can at present take. He has offered him membership in a great, free (no Mohammedan can be a slave) brotherhood. And the East African crowds to him, and proudly steps forward into the better, higher life offered.

Africa is the land of failures. We have as yet no knowledge which enables us to do more than guess at the cause of such universal failure. But the sad fact remains. Religious and political influences that have succeeded elsewhere have failed in Africa. If we except the Egyptians, no African race has risen to greatness, no African people have written their name distinctly on any record of olden or modern time. Africa proper has never had a chance. In oldest times as in most modern, its fate has been to be ravaged by the gold-seeker and the slave-hunter. No nation seems to have cared or thought it worth while so much as to try to bring to its dark millions the blessings of order and settled rule. Religious movements that transformed the rest of the world and gave or preserved to mankind art, literature, civilization and hope, in dark tempestuous times, if they ever seriously tried to help Africa, failed. They seem indeed, never to have deeply penetrated the continent, and soon lost foothold even on the coast.

We know that in the fifth century there were no less than four-hundred African bishoprics. For a time the African branch of the Christian Church was strong both in members and influence; but even in those days of her glory she seems to have stood helplessly before the stupendous missionary problem which the dark, unknown southern continent presented to her, and was contented to maintain herself among the civilized and luxurious peoples of the coast lands, while she left unhelped and untaught the dark millions beyond the mountains. Perhaps if she had better discharged her duty to them, they might have in turn succoured her, in her long and bloody decline. 


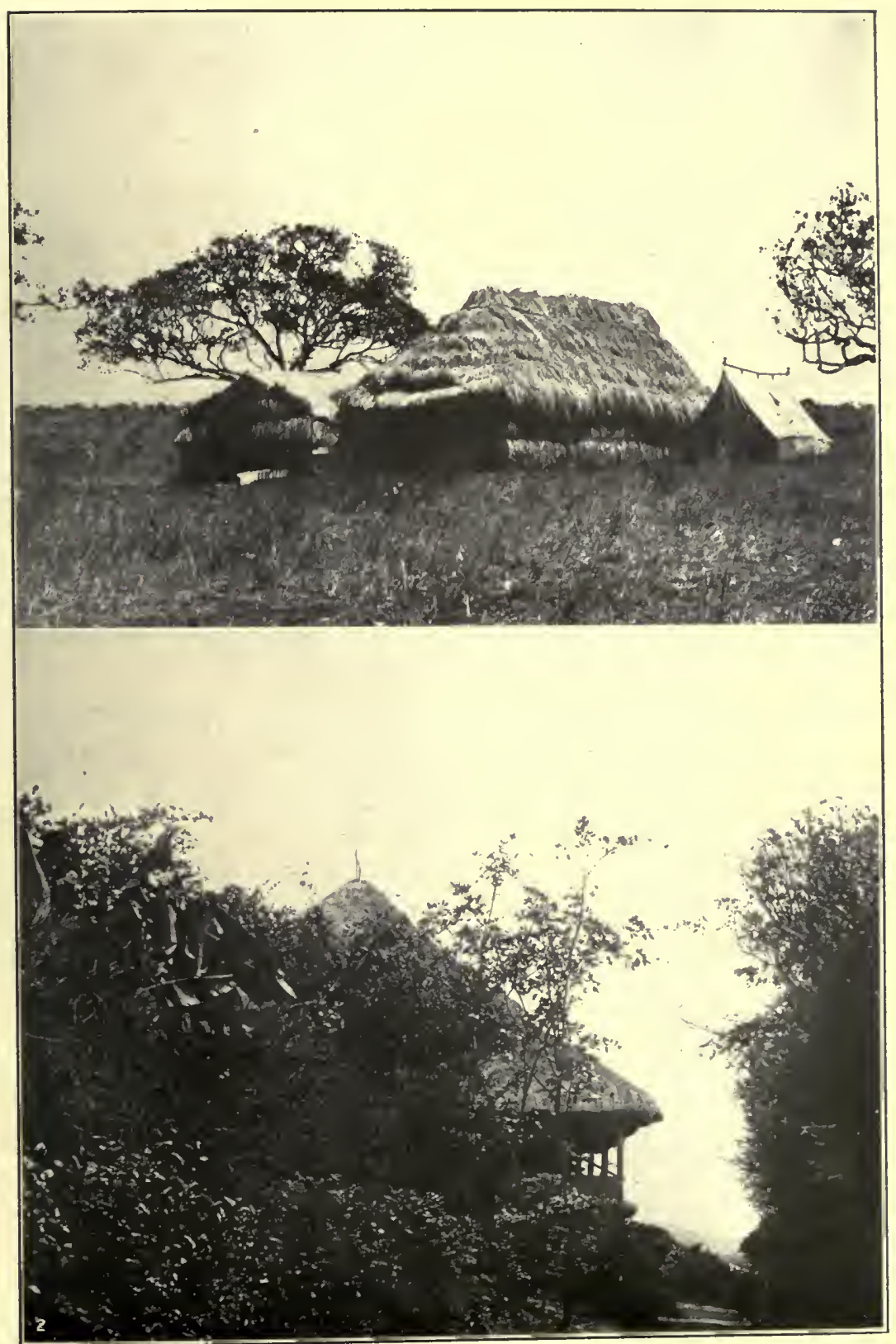

r. A settler's beginning

2. Missionary house on Mengo hill near Cathedral 

So far, at least, as Africa was concerned, she was not a missionary church. And even before the Mohammedan invasion swept her down, she was, as all non-missionary churches must sooner or later become, a church decaying and ready to perish.

North African Christianity of long ago is represented to-day by the Coptic Church of Egypt, and the Christianity, such as it is, of the mountaineers of Abyssinia. Favoured by their mountain fastnesses, the Abyssinians have heroically, for more than twelve hundred years held their own, a nominally Christian country islanded in a dark sea of Mohammedanism. But that the religion the Abyssinians profess is much in advance of that of his Mohammedan neighbour he so cordially hates, few who know him well will be prepared to admit. Nor does the Copt represent a high moral standard. In Africa, Christianity may be said to have failed. Its tribes have had no saviour, governor, or guide. For ages, so far as we can tell, its teeming millions have stood still.

How was it in those far-away days, when the man was. slowly rising from the clod, when first there came to the half-beast savage a dawning sense of law and beauty, that these unguided feet halted or went astray? Did some far forefather throw life's once-offered chance for himself and his offspring away? Why for all other peoples has existence been on the whole an advance, while for these gentle, lovable, dark men, who are so easily made happy, who up to their lights perform man's duty so well, there has been no progress, no marching forward but merely an age-long period of "marking time"?

The hopes and longings that in other branches of our race ripened to fruitage, have never, so far as we can tell, blossomed for them. Or if they blossomed, the fruit withered in the green.

Why has no influence from within or without drawn 
them or spurred them upward? What is it that has ever held the black man back? Probably many causes combined to produce this tragedy of arrested development, causes that science is not likely ever fully to know, for the African, as far as we know, has no history and no tradition.

But one cause, and one most important to the student of humanity, we may understand and be guided by. It is the particularly favourable (sic) nature of the African environment. In his case, that richness and favourableness are in themselves his greatest hindrance. The opulence of his sunny native land is his undoing. He scratches the ground with wooden hoe and twice in the year it answers him with abundant harvest. For months in the springtime he can wander where he will. So long as he keeps out of enemies' country he has no need for thought of the morrow. The bees alone can and do feed him, and the honey bird daily guides him to the luxury he craves. This is on the high tablelands where the thorny mimosas grow on hundreds of square miles of luxuriant green uplands. In the lower country, near the coastline, life is easier still. The sea is swarming with delicious fish. Bananas grow with little cultivation all the year round. Beans, sugarcane, cocoa-nut and a great variety of vegetables ripen easily. The only shelter he needs is quickly constructed from the sedges of a neighbouring river bank, or the long tough elephant grass. So long as he is left in peace and is safe from the slave-hunter, his is a life of careless ease, of sunshine and of plenty. If he is a herdsman, as are many of the more inland tribes, existence may be more precarious, but under usual circumstances his life could not be accounted a hard one. His goats, sheep, donkeys, camels and cattle, multiply exceedingly, and he pays nothing for their pasturing. The little boys and growing youths tend the herds in the daytime, during the night the more fully grown men 
supply a stouter guard. Time was when even the possession of a few goats might be fraught with danger and his half-starved cattle had to be secretly fed by day and carefully hidden in impenetrable thickets by night, if they were to be saved from the all too frequent raids of the ubiquitous Massai. These ever-dreaded warriors are now under control, having their own pasturages assigned them. They may, and do still, proudly maintain that all cattle were given, by the Creator God, to the Massai and that none but they have a right to them. But in practice the fear of losing their own immense and beautiful herds renders them the most conservative and law-abiding of the tribes. Of the East African native then, it may indeed truly be said, that "His lines have fallen unto him in pleasant places and that he has a goodly heritage." Yet perhaps that it has been too goodly, too easy, and too luxuriant, has been his undoing. It has supplied him with an environment in some respects so favourable that from the very beginning there never have been called forth in him (by the hard insistence of mother nature) those sterner qualities that alone have enabled the conquering races to remain masters of the field, in life's long welter of battle. The struggle for existence that has turned half-beasts into whole man has been tempered fatally for him and in consequence some quality of character, some soul-bone or soul-muscle that the fully upstanding man cannot live without, he has never developed.

The explorers of Africa found themselves confronted by well-nigh insuperable difficulties and dangers. To get on, to force a desperate way forward, to reach some hitherto unknown lake, river, or mountain, these were their goals. In the attainment of them lay the hope of reward and recognition. They were only human, and the swarming black life that opposed or aided their progress, had to be beaten back or forced to do their will, for the white man can 
do nothing in Africa if he be not aided by the black. The native knowing nothing whatever of the differences of race among Europeans, naturally found it impossible to distinguish between his would-be friend and his would-be enslaver Age-long experience had impressed one thing on him, to hide from the stranger, if he be stronger than you, or to fight him if he be weaker. In any case, to see he does not cheat you, for he is sure to be your enemy. And so it came about that exploration was usually accompanied by bloodshedding, and explorers beginning their journeys with the best intentions possible toward the natives, were only able to prosecute or end them by overcoming native resistance, and taking by force native supplies of food or transport.

Some of the greatest explorers - and the greatest of the great, Livingstone - never fired a shot in anger, and never took a load of food. But, then, such men made the dark continent their home, and for the love of its dark children they were content to accept it as a grave - living among the people not to exploit, but only to save. Were they opposed and misunderstood, they waited till opposition changed to friendship, or if the evil doings of others had closed the path they had chosen, they turned aside by some other way. But the explorer wanted to get on, the ivory-hunter must kill ivory to live. He often was not a bad man or a cruel, but circumstances were too much for him. If the native would not sell he found himself forced to take. If the naked warriors lay in ambush in the grass, it was his life or theirs, so he tramped forward and his footsteps left a bloody trace.

Inevitable, perhaps, but none the less very sad. And what I want to impress on my readers as I briefly outline the events that have so lately taken place in Africa is this that we cannot look to such men for a reliable estimate of the native character or capacity. 
If the explorer was obliged to be ruthless in Africa, if his impressions were of necessity those of a man met by hostile forces, and so not of highest value, what shall be said of the value of the impressions poured forth by game hunters, or those who were but pleasure seekers, during a brief stay of weeks?

These are, of course, of still less value, yet they have not been without their effect in influencing the reading world.

The gulf between the white man and the black is wide enough and profound enough, God knows, it needs not to be exaggerated, it must somehow be bridged. For Africa is preeminently the black man's country, he is necessary to it, it cannot possibly prosper without him. All its possible advancement depends on his advancement. There he was found, and there he will remain though every white man perish from the continent. Continental conditions are being made plain, rivers traced to their sources, mountains robbed of their mystery, impenetrable forest regions opened to the light, animals, a few years ago unknown to science, stand stiffly in our museums, and of all these we know something. Now it is time that human pity and Christian compassion should turn with a fuller, deeper purpose to the study of real Africa, to the study of the man.

I was often amazed at the amount of half-cooked food my people could consume at a sitting, or series of sittings. In the sefari were a few Kavorondo and these were champions in this respect. Once I remember we were camped in a good game country, and the camp remained stationary for some days. Potio for three days was given out, that is, each man received four and a half pounds of good, wellground Indian corn meal. There was at the time a large supply of zebra meat in camp, and each man had at the very least a ten-pound chunk of this venison, of which they are inordinately fond, for his own eating. Next morning David Rebman (the headman) brought round the 
Kavorondo to my tent door. They said they wanted "dowa." David explained that since eleven o'clock of the day before they had eaten all their three days' potio, and the zebra meat into the bargain, a truly appalling amount. This accounted for their call on the medicine chest. I asked them why they had been such gluttons. Quite seriously they answered, "Bwana, we had our potio, there are many lions about here and some of the men are sick. You never can tell when death will come. We would hate to die before we had eaten our potio." I told them they might fast for the next three days. They did not seem at all disquieted at this prospect, but as they went away one of them said quietly that bwana koubwa (the big master) did not know evidently much about eating. If he would but come to Kavorondo land they would gladly show him how two reasonably competent Kavorondo could eat up a whole sheep at one sitting!

The incident illustrates what all who would help him must recognize, the crude savage has but one aim and end in life, and his existence centres around that aim. It is to have enough to eat. Even his wives are chiefly valuable to him because, since they till his shamba, they assure him his food and sometimes his beer.

Sometimes he seems to have no affection for his offspring, or care for them other than that attaching to a more or less valuable chattel.

The Kikuyu seem specially lacking in this regard. A very unusually intelligent Kikuyu, a man of considerable influence in his own section of that tribe, came with us on a long hunting trip. He was badly mauled by a lion, and his return home to his four wives was delayed. When asked what they would do in his absence, he replied that he did not care what they did; they must keep his shamba in order, and for the rest, if an unexpected child or two should come, it did not matter, for they would be his property. The 
Kavorondo living by the great lake and the Kikuyu, holding the very rich, arable, forest-protected regions, to the south of Mount Kenia, both seemed to me to be singularly backward tribes. These latter specially had a low standard of morals and are generally spoken of as liars and thieves. They seem to have adopted the vices of their enemies, the Massai, without being able to emulate them in military organization. The Wakamba, another large tribe living east of Kikuyu country, and subsisting partly on their herds, as well as by agriculture, have developed a tribal life superior in some ways to that of their neighbours. In appearance they differ, are taller, slenderer, and distinctly lighter in colour, they have frequently the slanting eye of the Mongolian type. They are a very brave and independent race, are excellent hunters, and, so far as I could learn, and I had many of them with me for months on sefari, are more careful of their women and children. I have known a Wakamba to take a long journey, and to undergo great inconvenience in order to be with his little wife during the time of her confinement.

A superficial, if sympathetic, study of the interesting group of tribes living on and near the beautiful uplands of North East Africa was, of course, all that was possible in my case. I moved among them, camped by their firesides and chatted night after night to them, for more than a year, during my two journeys through that country. I tested their courage and tried their endurance, and as a result I bade them good-bye with a sincere regret. I have met among the crowd of sportsmen and emigrants whom one comes across in Africa, some few men only who, not wholly occupied with the pursuit of their own pleasure or gain, have taken time to study the native. Such men, without one exception, have a warm heart for the East African and a more or less firm belief in his capacity for betterment. Still these men seldom write books, for they cannot 
gain the public ear. The utter nonsense, the untruthful rubbish, that appears in the English and American papers and magazines on things East African in general, and on its natives and game in particular, disgust and dishearten them. They talk little and write less. But they love the native. It is easy, very easy to see what this native lacks. As I have said, his main idea is to get food; he has no thought for the morrow and this is the inevitable consequence of his lack of memory. He learns quickly and as quickly forgets, and human memory is a slow-growing plant. He has no traditions reaching far back into the past. What traces of tradition he has puzzle him, as completely as they puzzle you. The reasons for the things he does he cannot give you; he is incapable of measuring time; he never knows his own age; he is an atheist pure and simple, having no idea of God, or the faintest conception whatever of any future life. Even when he has become a declared Mohammedan, his new religion has not in the least awakened in him, as yet, any desire for a life beyond. He believes in witches, and dreads, while he consults, the witch doctor. He has no sacred places (if we except the metalliferous cliffs of Elgon near which the Massai, with probable truth, say that a man cannot stand and live during a storm). He seldom buries his dead, and the hyena is his only undertaker. In the case of a great chief's death, or where a man or woman leave behind them many children, the body may sometimes be buried in a shallow grave and possibly a goat or sheep is killed above it. Missionaries I know have fancied that in this rare ceremony they have discovered some signs of a rudimentary sacrificial idea. But I must confess that the reason which the natives insisted on giving, when I questioned them particularly and repeatedly on this subject, seems to me to be the more likely one. They always said it was to prevent the hyenas from digging for the body underneath. 
In their regard for truth there is the widest difference among the tribes of East Africa. The remoter, the wilder, the tribe, the more truthful you will find the tribesman. The Waganda by the lake, who are comparatively well known, and among whom missionaries, both English and French, have laboured with great success for many years, have attained to a degree of culture quite unexampled in East or Central Africa. These are sadly acknowledged to be, even by their missionary guides and teachers, both dishonest and untruthful. The Kikuyu are noted liars and thieves. The Massai and the Nandi will deliberately lie to you, though I have noticed that if you know the man to whom you are appealing, and ask him directly to tell you the real truth or be silent, he will pluck a blade of grass and hold it for a moment between his fingers; if, after having done so, he repeats his previous statement, it will be the truth. I have in another place written at some length of what impressed me as the quite extraordinary regard for truth that you find among some of the smaller and unknown tribes. I cannot fancy any man more scrupulously accurate than the N'dorobo, a tribe popularly (and I feel sure mistakenly) supposed to be people of a low order of intelligence. The Elgao would proudly declare that no liar could remain in the tribe. They asserted as much of their neighbours, the Maraquette, with whom they were not always on the best of terms. No scientific man could possibly desire more careful, more accurate, more painstaking witnesses to facts that come within their observation, than were these wild men, who had never conversed with any white man but myself and my guide, Mr. A. C. Hoey. Their power of observation was excellent, their statements of the incidents of a quite bloody battle in which they had engaged three years before was, as I happened to be able to prove, wonderfully free of all exaggeration.

How then can we account for this remarkable difference 
in regard for the truth between tribes that have lived near each other for ages? Environment in part accounts for it. These truth speakers have been independent, they are men of the mountain or of the impenetrable forest, no one has lorded it over them, while the Waganda have been crushed under the ruthless tyranny of their kings; and the Kikuyu have been, till lately, a timid, ill-nourished people cowering before the onslaughts of the irresistible Massai.

In the case of the Massai and of their cousins the Nandi, though they do not seem to place any value on truth for truth's sake, as do these other peoples, still, in matters that affect tribal possessions, they are truthfulness itself.

You can leave a bunch of cows, sheep or goats for years in a Massai or Nandi munyata (village) and be quite certain that an accurate tally will be kept and delivered to you of every calf, lamb or kid born in your absence; the beasts that died or were killed by wild animals, and every particular regarding your property will be accurately remembered and accounted for.

I have known of a man of mixed native blood, who was driven forth from the Nandi tribe before the Nandi war in I 906 for (as he himself confessed to me) making love to girls he had no right to make love to. He had to escape by night in order to save his life. Since his enforced flight the war had taken place, and the Nandi had lost by capture one-third of their immense herds. He had not ventured to visit the village for five years, yet he had no slightest doubt that on his return, a completely accurate accounting would be made with him, and he would be told just how many cattle he stood possessed of.

Such a standard of truthfulness is remarkable. Few western American cattle owners, a few years back, would dream of exacting it or would themselves have adhered to it. My object in dwelling at such length on the moral differences I found among the East African tribes, is to supply 


\section{A PLEA FOR THE NATIVE}

some ground for the protest I desire to make against the common statements you read everywhere, of the utter immorality and untruthfulness of the native population between the sea and the great lakes. Those who bunch them all together and speak of them as beasts, liars, and thieves, prove simply that, though they may have rushed through the country, they know little of the inhabitants.

No man who has written on the problem of East Africa knows his subject better than does Sir Harry Johnston. I remember that he somewhere says: "It may have required one million years for the evolution of the brute into the man, and half a million more to raise him to the level of the Australian savage. On the other hand, a few hundred years were probably enough for the development of the savage Hamitic races into the civilized Egyptians."

The best informed can only venture a guess on these subjects, and when it comes to guessing on what has been, or what may yet be, in Africa, there are everywhere so many unknown factors that they who know most will venture fewest guesses. But so much is certain, the East African is so far behind his white instructor that the latter's processes of thought are quite beyond his understanding. As I said before, he is an atheist, he has no idea of causation, death itself he makes no effort to explain, unless it be to attribute it to a witch doctor. Witchcraft is not a religion with him, but perhaps it is the nearest thing he knows to religion. The spirits help the witch doctors, the witch doctors set the spirits at their evil work; but back of it all is no idea of Creator or of Supreme Cause producing good or evil. He is content with things as they are. Only when some calamity strikes him does he look about for its cause, and if it continues he will probably burn some witch doctor alive. If he believes in nothing else he believes in witchcraft, and this, his one belief, offers to the missionary a most difficult obstacle. Only as this is eradicated can the native 
be helped and saved. His belief in witchcraft creates the very thing that he dreads There are witch doctors whose influence for evil is appalling. Taking advantage of the power that ignorance is too ready to give them, they are often wholesale poisoners. They will force their enemies, or the men whose herds or possessions they covet, to submit to some tribal ordeal and since all ordeal arrangements are in their hands, those whom they wish to destroy die by poison or by the infliction of a tribal penalty. Thus their powers increase, as do their possessions, until the day arrives when native patience reaches its limit, and the witch doctor has to have a dose of his own medicine forced upon him; his thatch hut is set on fire at night while spears guard the door, or he or she is pegged down, under a raw cow-hide, early one morning, on the hard-trodden earth, in front of the native village. If the rain, promised by his witchcraft, comes, the hide will not tighten and he can escape with life, but if no rain comes, the equatorial sun soon does its work, and the miserable being - male or female - underneath, is baked and suffocated to death.*

Among some of the tribes, notably the Kikuyu, there can be no doubt that witch doctors are often wholesale poisoners. Among others, the verdict delivered by those best informed will be at least one of "non-proven." But the whole subject of witchcraft and its evils is one with which the white man finds it most difficult to acquaint himself. His intrusion, however well intended and even necessary, is resented. He has but inadequate means of reaching the facts, and when, as has occurred lately, the cumbrous and most ill-adapted legal machinery of British East Africa is put in motion against those natives who rise in protest against the intolerable evil of the witch doctor, I cannot but believe that more harm than good is done.

The criminal code of India is the legal instrument of

\footnotetext{
* Two w tches were thus executed by the natives when I was in Kikuyu country, in the winter of 1908 .
} 
the British East African government, and it is hard to conceive of any code less fitted to the needs of these backward people. A wise and firm-handed local administrator can accomplish what no high court official at Mombassa can possibly achieve. The local civil servant knows, or should know, his people; the missionary, if there be one, certainly does, and these can, and should, be allowed to deal with the problems that witch belief constantly gives rise to.

The Mohammedans (Somali or Hindi) very cleverly taking advantage of the natives' belief in witchcraft, have sometimes gained an influence on even the most intelligent of them, which they have no scruple in turning to their own advantage. I have told elsewhere of an instance of this unscrupulous deviltry of theirs. They succeeded in gaining almost complete mastery on one of the best known headmen in Nairobi, a man who had been an officer in the Sultan of Zanzibar's army, who had commanded native soldiers in the desperate fight at Lubwas, and who had been brought up from infancy as a Christian, a good and faithful man, who knows Africa from the sea to the hills as few know it. In an evil hour for himself —- consulted a Mohammedan doctor at Nairobi for an affection that had attacked his eye. They threw him into an hypnotic state, and while under this influence, robbed him of a large part of his hard-earned money. More than that, they persuaded him that no European could do for his eyesight what they could do. This I found out with much difficulty, after I had proposed to take him to see my doctor in Nairobi. Nothing I could do or say at the time could persuade — to accompany me. He insisted on "going to his own man," as he said. I had my suspicions aroused by this, but as yet had no idea how far they had gone with him or how completely he was under their spell. Arriving at Nairobi, - disappeared and failed next day to do his work; this failure seemed to me extraordinary, as I had 
well proved his faithfulness and competency. I found him with some difficulty, and then the extent of the plot was evident. Surrounded by Mohammedans he lay in a deep hypnotic trance, and 250 rupees, three months' wages, had already disappeared. For several days he was in a dreamy and irresponsible state. When his mind cleared up I think I made him see the extent of his folly, at any rate he placed himself under my doctor's care, and gave me his word he would have nothing more to do with native "dowa" (medicine). These men, as he said, had "put dowa on him" for years, and thereby had probably robbed him of quite half what he had earned.

I have only space to touch thus briefly on some of the most evident of moral and social shortcomings of the East African native. I do not believe, nor do I think that many who know the native believe, them to be capable of any sudden social, moral, or religious conversion. They must be helped slowly, they are Nature's retarded children, and to hurry them, is in the end but to push them backward and downward.

But to deny, on the other hand, their capability for steady progress and development toward better things, is to deny the evidence of palpable facts. Men who have travelled far in Africa are sometimes found saying that the native is without natural affection, that he neglects his children, that he casts out unburied his dead, that he makes no provision for the future, but squanders all he wins. In many cases this is true, but in many more it is untrue. I have seen evidence often of a tender care for children, and a willingness to provide for parents who were old and past all work. If we but knew better and were in a position to enter into their tribal life, we could judge as now we cannot. Those whose testimony on such subjects is of real value, are the missionaries. They know the native as no traveller, no official, ever can (Lieutenant 
Governor Jackson, who knows the country as few do, said once to me, that one of the chief values of the missionary to the administration is this priceless one that he learns to think in Kikuyu, Waganda, etc), and the misionaries are far from admitting that the native is hopelessly callous. Even such unsatisfactory opportunities as were afforded me, were quite sufficient to convince me that on the score of heedless wastefulness the East African native does not deserve the universal censure poured on him.

I struggled with my men and I must admit, struggled in vain, to induce them to save their earnings, which seemed to melt away as soon as we reached Nairobi. I did not expect to be able to accomplish much in the case of the casual porter who was without home or family, but it did disappoint me when I found that often the hard-earned savings of the men I had been intimately associated with as well as the liberal bakshisch I gave them, seemed to go almost as quickly as did the ten rupees a month of the mere burden bearers of our band. It took me many months of quiet searching and hours of talk and expostulation, before I got any light in the matter; but finally I did. The nomad, of course, is not naturally given to economy. In his long past there has been too small a possibility of guarding his little savings to encourage thrift in him. The theory put in practice by my Kavorondo in the matter of their three days' potio, was a philosophic attitude enough. In days gone by "lions were plentiful, sickness prevalent, potio rare, so let us make sure of a good meal while nature allows us a good appetite." African environment in their case had done its work thoroughly, so they gladly and gluttonously set themselves to eat three days' food in one. Evidently such people have much to learn before they become a thrifty race, and we cannot hurry them. But they, even they, have a social economy of their own, for which much can be said. In the old book a parable is told of a certain 
man who, though unjust in his stewardship, was not lacking in worldly wisdom. He distributed his gifts in such a way that, when he failed, his friends were in honour bound to give him a helping hand. Such is to-day the settled habit among the most enlightened East African natives.

I myself traced, again and again, the money I had given to the best of my men. It took much cautious perseverance on my part to draw out the information I needed, but when I had done so, I found that the money had not really disappeared. It had gone into the impoverished hands (not pockets, no native has a pocket, and no one has thought of opening a savings bank for him) of his multitudinous relatives - old, middle-aged, and young. A poor porter, earning his ten rupees a month, was often quite ready to feed, clothe, and lodge several relations poorer than himself, while the relatives of a man like my Brownie or John or David seemed to me numerous enough to require a Nairobi "Social Register" to record them, and that register, be it understood, would include a suburban region of several hundred miles! My men were "in funds," the friends and relatives were not! That was enough. When their own time of need should come, those they had helped could be counted on to do for them what they without hesitation were now doing for others. Better far, they argued, give the rupees to those they knew, than trust them to some Hindi trader who might run off to India suddenly; or to bury them in the floor of the hut from whence often they were stolen.

The East African is, when once given a chance, far from being what the unobservant traveller might take him for. $\mathrm{He}$ is no mere savage spendthrift, his methods are his own, his way of arriving at them, also his own. Superficially he may seem simplicity itself, but he is a keen observer, and if you succeed in winning his confidence you will find that often he has good reason for what he does.

I must touch next on another supposed evidence of the 
native's hopelessness, his incapacity or unwillingness to undertake and carry through any hard work. On every hand this is the common accusation brought against all natives alike, brought by those who have had little opportunity to study their present condition or have taken any thought of their past unfavourable environment. The charge in many instances is entirely and in many more partially untrue.

Give the East African the work that he is fitted for, be patient with him, be just and at the same time be firm, and he can do and often has done, extraordinarily good work. On the other hand, put him to a work that his ancestry has for ages unfitted him for, put the Massai cattleherder (if you can catch him!) to hoeing the veldt, or the corn-raising Kikuyu to heavy lumbering or raising railroad embankments, and the result will be unsatisfactory in the extreme. Put him under the control of men who cannot speak his language, who take no trouble to understand him, who have little patience, and he will most likely cause no end of trouble and annoyance. East Africa is, from the white man's point of view, a land of hurry. He rushes out to it, he entertains all sorts of unreasonable expectations regarding it. It is a "get rich quick" land for him. Laws, regulations, natives, beasts - all, exist only for his pleasure and profit. He would gladly, were he allowed to do so, exploit them all for his own purpose, and go home as soon as he was assured of a competence. In this spirit he is prepared to deal with the native and, after his own ideas, be fair and just to him. But still, to hold him as nothing more than a necessary pawn in the winning of his adventurous game, as something to serve his needs, to supply him with the labour he must have, the unfortunate native must cease to be a nomad and must be at his beck and call, to do the work he requires for such wages as he can afford to pay. 
Only yesterday this native was a nomad or a slave. If he had luck and his tribe had maintained its independence, in that case his own little shamba cultivated by his wives, gave him all he needed. In any case, he worked only because he had to allay the pangs of hunger. To store up goods, to lay plans for a large increase of cattle, meant additional risk in a life already too full of it. English and German occupancy have modified, for him, these conditions during the last fifteen years at most. Is it reasonable, then, to expect that people who have only emerged from such a social chaos for so little a space, should suddenly change the ingrained habits and tastes of untold centuries at the half-understood command of some strange white man? Yet this is what the settler expects.

Give the native time and some little chance, and he soon shows aptitudes which are full of promise for his own future and that of the country. See him work when he is accustomed to the work exacted of him. As a burden-bearer he is not the child of yesterday. He has, or some of his people have, carried burdens for generations. In the line of steady, patient, successful burden-bearing under circumstances of extreme difficulty, he is probably without a rival on the globe. He will travel farther and faster, he will endure greater hardships, and more successfully resist disease, eat more frugally and cost less than any other human burden-bearer on earth. Carrying sixty to ninety pounds a man, from fifteen to twenty-five miles a day, through poisonous, thorny thickets, or malarial swamps, over lavastrewn stretches, under tropical sun, from early morning till late evening for several thousand miles, I have seen him march; a cupful of coarse meal or gritty rice and beans his daily ration. And he does it all right cheerfully, too, starting with a song in the morning, and tramping into camp to the wild notes of his reed or horn whistle in the evening. Six shillings a month and finding his own rations is his pay 
in Uganda and British Central Africa. In British Central Africa things are dearer, so he gets his potio and ten rupees a month.

So much for the African porter. The longer I knew him, the more I liked and honoured him. He is far indeed from being a hopelessly "lazy savage." I learned to respect him as a man who sets himself to earn the money he is paid, who gives what he promises to give and gives it, on the whole, ungrudgingly. But I grew to wonder increasingly at the pent-up stores of energy within him. My porters recuperated quickly, even when they were very severely exhausted at the close of a long and possibly waterless march. No white man's head or shoulders could possibly have endured the strain laid on theirs. They would lie down for a few moments - and a few moments seemed enough - then, without orders, in the vast majority of cases, the remaining work was undertaken, and that work was considerable. Much tent pitching, a hard and difficult task, large piles of wood to be cut, with worse than indifferent axes and pangas (native knives), a platform of logs and scrub to be laid for the loads so as to keep them above the damp ground, and be it remembered there is no such thing as soft wood in Africa, for the softest wood there is much tougher than our oak. When cut, too, the wood had of ten to be carried for a distance of more than a mile; then there are bomas of thorn scrub for the mules and donkeys, and lastly the work to be done for themselves, tent-pitching, wood-gathering, and cooking. The day had begun at $4.30 \mathrm{~A}$. M., the big meal of the day would not be over till seven at night, and surely the sefari has done enough to use up its energy. But no, far from it: in the centre of the camp burns the bwana's fire, where the askari stand on guard in a wide horse-shoe curve around it, the porters' fires are lit, and little yellow spires of flame rise with scarcely a waver heavenward in the windless, 
blue-black African night. All now is jollity, chatter, and song. Someone starts a dance, and soon, tribe not to be outdone by tribe, they all join in. In swaying line or bending circles, scores of naked black figures dance to their own chanting with immense energy and untiring enthusiasm.

That these simple, lovable folk have been left behind, in the great world race, is true; but, if so, it is no less true that the divine sources of energy, so needful to all progress, are still most surely ebullient within them. They can toil without exhaustion and after the severest toil have plenty of surplus energy left, for play. In thirteen months' daily marching, among a band that generally numbers over one hundred men, I only knew of one serious quarrel. Who shall say that of such material good men cannot be made? Who shall deny to such a race a future?

By the shores of the great lake dwell the naked tribe of the Kavorondo. They are supposed to be the laziest and least enterprising of people. Yet the supercargo of the smart lake steamer told me that his trained and organized band of Kavorondo longshoremen, could, if he called on them, work for sixteen hours at a stretch, without food, handling heavy steam freight on a sun-smitten wharf, in an atmosphere as enervating as can be found in East Africa, and that after this long stint of work was once done, they would race up and down the wooden pier at Kasumo for the mere fun of the thing! Then, be it remembered, these men were well-fed, kindly and justly treated, and taught to take a pride in their work. Vacancies in the band could always be filled at once.

The Kikuyus first met the white man only a few years ago. They had held their own against the Massai with exceeding difficulty, and owing chiefly to the fact that a thick belt of primeval forest defended their rich agricultural country. During their past but small opportunity was afforded them to accumulate anything. The richer their 
shambas or the larger their goat or sheep herds, the greater became their danger. English occupation meant the immediate curbing of Massai aggressiveness; the Kikuyu won a breathing spell. What has been the result? Within fifteen years the tribe has changed. They are to-day raising great quantities of grain, and their men and women are fast becoming the porters and field-workers of East Africa. Only four years ago a Kikuyu could not be persuaded to take any work, however well paid, outside the narrow limits of his own country. He would throw down his burden and slip into the bush if he found the sefari's route pointed away from his home. He might be convoyed or guarded to some point on the railroad where he had work given him, but the terror of the unknown would finally prove too much for him. Leaving his job, sacrificing his pay, the timid savage would slink away, perhaps to die by the roadside, as he staggered toward the distant slope of Kenia, his forest home. He is now another man; he is his own man, and the small cash of the country is finding its way into his pocket; he is richer than any other native, with the exception of the Massai. He is, of course, still deeply marked with the moral scars of his long misery; he is a liar and a thief, and parts quite readily with his women folk, but he is undoubtedly on "the march upward."

I stood, one muggy morning watching a band of Waganda carrying earth for the foundation of a new wing to the miserably dirty little hotel at Eutebbi (lately the official capital of Uganda). Each man had an empty kerosene can, a box of some kind or a basket, on his head into which he scooped the dirt he was removing with a small hoe. The earth had to be excavated from one place and dumped at another. The journey was forty yards; the men strolled along in line; if one of them wanted to converse with a passing friend he did so leisurely and all the line waited till the 
conversation ended before proceeding. Each of them balanced his load with one hand while he held a long pipe of tobacco to his mouth with the other. One by one they tilted their loads on to the heap of earth. I examined the loads carefully, they did not average five pounds. I could scarcely believe my eyes, but so it was. Some one of their number had settled for all the gang what the load should be; there was scarcely an ounce of difference in the weight, and the Waganda were intelligent enough to know what not to do. Their wage was twopence a day, it was not worth a penny. A few hours afterward I found myself in a 'rickshaw bound for Mengo, the native capital, twentyfour miles away - one Waganda in the shafts, three behind. The road for this country was good but very hilly, and in places very soft. The 'rickshaw was a clumsy native-made affair, the wheels heavy enough for a pony-cart, and far heavier than those of a well-made American buggy. I weighed two hundred pounds, my friend one hundred and forty; and we had cameras and two good-sized bags, a heavy load for men to draw in a truly awful machine from a traction point of view. Our few Waganda, however, made nothing of it, and went off in the sweltering heat, chanting one of their endless, grunting songs. When the road was good we made at least eight miles the hour. We did the twenty-four miles with one change of men, without one moment's stop in four hours. Considering the circumstances, this was surely extraordinarily good going. The men at first sweated profusely, but before covering twelve miles they had run themselves dry. Only one of the eight men employed, so far as I could see, drank a drop of water during the whole run. The willingness and heartiness with which the whole thing was done, and their evident content with the modest tip given them, of three shillings for the whole eight, was impressive. The men came from the same tribe and had about the same physique as my 
friends of the earlier morning, but one group had found an employer who organized and directed them, the other had not and therein lay the difference.

These Waganda are everywhere spoken of as being the most advanced and the most readily civilized of all the Central African tribes. And, after seeing the houses they have builded for their kings, and the fine brick cathedral (it seats four thousand people, if I remember rightly) they have put up for their Protestant worship, it is easy to understand the optimism of those missionaries, who cheered all Christians the world over, by declaring that a great Christian people would soon arise to power on the shores of these great lakes. But the best of us are at times apt to forget that neither in Africa nor yet in Europe does tyranny make for true civilization. We stand aghast to-day at the longdrawn-out blood-letting that is bleeding Russia. White men lose their heads there; they have been themselves crushed for so long that they seem to have lost all belief in any other methods than those of "crushing." They have been the victims of barbarism, cruelty, and ignorance for so long, that cruelty and injustice have become, in their eyes at least, subordinate and inconsiderable evils. Tyranny has eaten away, as an awful natural law decrees that it shall, something of their moral consciousness.

So, in the Wagandas' case, the tyranny of their kings has left the people lacking in sturdy uprightness. (I speak here with hesitation, my knowledge of the Waganda being, of necessity, a second-hand knowledge: I did not live among them as I did among the tribes farther east, though I had plenty of opportunity of consulting those who had intimately known them for years.) The Waganda are untruthful and dishonest; they have a cringing way with them which does not appeal to the stranger. For upright, self-respecting manliness, they did not seem to me to compare at all with the wilder and far poorer people of the higher 
plateaus between Victoria Nyanza and the sea. But who shall blame the Waganda for cringing? He has learned to cringe to save his life. Unlike his neighbours to eastward, he has acquired traditions; he can name for you his kings (running backward for at least five hundred years), and many of these have been bloody monsters. Mtessa, when the humour took him, would have a long trench dug in the porous earth, and above it he would have men's throats cut, till the flowing blood filled the trench to the brim; and that was only a few years ago. Can a people be expected to emerge quickly from a rule such as that into an honourable, self-controlled manner of living? To expect such a thing is to expect the impossible.

I have said nothing about the native as a craftsman, but undoubtedly he has in him the makings of a very good craftsman, and no one has made, as yet, much of an effort to help him along this most evident line of advance.* On any sefari it is easy to pick out a number of handy men. I have written elsewhere of the variety of their accomplishments. The Wakamba make quite beautiful iron and brass work. I have seen some chains made by them, that, considering the coarseness of their tools, were wonderfully fine. Several tribes smelted their own iron and sometimes their copper. In parts of East Africa they understand irrigation, and streams of water are carried across wide chasms, and along steep mountain sides with no small engineering skill.

The point that I wish, then, to insist on, even at the risk of wearying my readers, is this: these people must have time given them. They are full of promise; those who know them always love them. I think I am safe in saying so much. I do not mean the missionaries only,

* Good industrial schools are now established by the German authorities at Tango. A very small attempt at such teaching may be seen here and there in the Protestant or Catholic Mission schocls, but this, the one all-important method of education for the African, has received little attention. 
but almost all the men I have met, in Africa and out of it, who have lived among the natives and studied them, love them and are hopeful of their future.

Four things the native must have accorded to him: patience, sympathy, leadership, and a settled policy of government. He has sometimes, though only very recently and partially, had the two first. He has never yet had the two last, and till he has had all four for generations, he surely has had no fair chance. His past has been uneventful and gloomy. Foreign adventurers, caring nothing for him, have ravaged his coasts. Tribal tyranny has drenched with blood the interior. Deserts, marshes, jungles have cut him off and hemmed him in.

From the outside world, and until quite recently, no beneficent influences have ever reached the East African. $\mathrm{He}$ is but a mere child; he has his long life before him. Give him, then, time and give him a chance.

Of all the faults his critics ascribe to the East African, of none is he more commonly accused than of ingratitude, and in my judgment that charge is not deserved. He is a savage, with the savage's power of memory, undeveloped. $\mathrm{He}$ readily forgets both evil things and good. He acquires knowledge quickly and his untrained mental faculty as quickly forgets it. But he is far indeed from being ungrateful or unfaithful to any trust he has accepted. I do not speak for myself alone, I speak for all the men I have met who know the country and have tested the native, when I say that no more faithful attendant in danger exists than the East African gunboy. He takes his life in his hand daily, he follows, often if allowed to, precedes, his bivana as they together creep along, foot by foot, yard by yard, in the treacherous grass that may hide, at but a few feet's distance, the deadliest antagonist that the scientifically equipped hunter can face - the wounded lion or the waiting buffalo. $\mathrm{He}$ pays heavily, too, for his daring; again and again he is 
cruelly mauled. A man I had on my first trip was mauled by a wounded lion twice in six months and, though his master was a cowardly fellow, who could not shoot straight, and ran away and left him, the first time, Malin stayed faithfully by him since he had engaged himself for the trip; so he was deserted in danger a second time, and almost lost his life. Long weeks of pain, sometimes of permanent disablement, and hence poverty, await these poor fellows, and sometimes they are killed then and there. They are not allowed to shoot, for their business is to have the gun they carry, ready at an instant's notice, to be handed, loaded, to their master. If they could shoot in self-defence it would not mend matters, as, for some strange reason which I am quite unable to account for, even the bravest of them can hit nothing with a rifle. Their life is thus absolutely dependent on the skill and courage of the stranger they so resolutely follow. The time was, when almost all sportsmen took, as gunboys, the Somali. The Somali is courageous enough. In those days when he was known to the white man, he agreed with his master in despising the natives of whom he knew nothing. Neither Somali nor white man trusted the native; he was fit for porterage and nothing more, though occasionally he might act as guide; but to stand fast in a tight place - this no one expected of him. Then why under such circumstances, should he stand? He had certainly nothing to gain by it, so he ran away. But the Somali's faults are serious ones. Though no coward in danger, he is so easily excited that it takes much trouble to keep him from firing off the rifle he carries. He is generally a poor shot, with the further drawback of having a profound belief in his own capacity for shooting! He does not compare to the native East African, as a woodsman, a stalker, or a friend. He is insolent, most untruthful, and exceedingly careless in handling his (or your) gun. 


\section{A PLEA FOR THE NATIVE}

So it came about by degrees that the despised Wakamba, Massai or N'dorobo had a chance given him to prove what he could do, and to-day the men who know, the men who understand the pursuit of dangerous game, invariably place confidence in the native rather than in the much-vaunted Somali.

I cannot conceive of men more brave, of men more absolutely devoid of all nervousness, men more utterly faithful and self-sacrificing than those good fellows who came with me. My one difficulty with them was to prevent them from thrusting their own bodies, in front of mine, into the dangerous cover where death lurked. I found myself one morning in long grass, with lions all round me, all of them unseen, two of them wounded, deep nerve-shaking grunts coming from all sides but a few yards away. My Somali danced hither and thither like a nut on a hot fryingpan; my Wakamba "Brownie" never moved a muscle.

One thief, and one only, I had in my sefaris, in thirteen months' travelling. He stole my precious letter bag, photos, hunting knife, and seventy-five rupees. When I got back to Nairobi I talked the matter over with Brownie. The man was a Wakamba, one I had taken on at Nairobi for a short sefari only. I asked Brownie what he could do to catch the thief and save the honour of his people; he undertook to do his best. He took up the man's trail, followed him for several hundred miles, first to one outlying village then to another, and finally at Kilinduni, the port of Mombassa, ran him to ground. The job cost both of us much trouble and me not a little expense. I may mention incidentally that the affair was undertaken at the government's request, and though $I$ did thereby a real service to the authorities by bringing to justice a most cunning criminal, I could not even procure for Brownie so much as a pass on the railroad from Mombassa back to Nairobi, but had to pay this expense myself. They muddle things strangely 
between the different departments and the Uganda Railroad in British East Africa.

No, backward the East African may be, mysteriously retarded he has been, but unfaithful or ungrateful he surely is not. Let the story of the fight at Lubwas Boma in the days of the Uganda mutiny bear witness.

The story of that mutiny is not yet known as it should be. It is a story of mismanagement and muddle, not so much by the men on the spot, as by the authorities at Downing Street, who did not grasp the situation themselves, and would not listen to those who did. It is the story, so often repeated in the history of England's Colonial enterprises, of a little band of neglected and unsupported white folk, making good at last for the Homeland's sake, against overwhelming odds. It is also the story of how the black man that had learned to trust the leadership of the missionary, gladly threw his life away to support a cause he knew nothing of, save that it was the missionary's cause.

The Soudanese battalions, whose mutiny cost England so dear, would never have mutinied if they had been accorded, not sympathy, but scantest justice. England broke faith with them, orders from home forced their officers to break faith, and the men, under new and unknown leaders cannot be much blamed for what they did. That, however, is a long and a sad story, and as usual, the heavy bills had in time to be paid in precious blood and outpoured treasure.

But it was the heroic aid given to England by the Waganda, for whom England's missionaries had done so much, that broke the heart of the mutiny almost at the very beginning, and saved for England the immensely important strategic position she held on the great lakes and at the sources of the Nile.

The story of the fight at Lubwas Boma, in 1897 , has been told, yet few have heard it. It is a great story and 
needs a Kipling's pen to do it justice. It is the story of a long, hot, bloody, morning's fighting, from sunrise till eleven o'clock. It is the story of how the Waganda rallied to the help of the white man, because the white man had first come to them in the blessed guise of their missionaries. His enemies were their enemies, his friends, their friends. It is the story of how, ill-armed as they were, without discipline, led by one of these same missionaries Mr. Pilkington - they charged and charged again, on hilltop crowned by deepcut trench and heavy thorn boma. Their opponents were trained and disciplined soldiers, inured for years to war; a race of men accustomed to conquer, and these fought from behind a stockade strong and high and from whose trenched corners a new and deathly engine of war, the Maxim, cut them down in swaths and heaps. Yet, on that morning, these men, in a quarrel, not their own, threw away their lives gladly, tore at the boma with their hands, and retreated only when their war chief and Mr. Pilkington were shot dead, and nine hundred of their bravest lay beside them.

"Little use to missionize the nigger, he has no gratitude," says the ignorant. The story of Lubwas Boma is no uncertain answer to such slander.

So much for the native's capacity for better things. But were that capacity even far less than it is, were he a far more embrutalized man, were he lacking, as he is not, in those qualities which enable him to advance when he is wisely helped and ruled and educated; there remains one factor in the problem of his future, which is often forgotten and yet may not be evaded. He is in Africa to stay. He will increase. The country cannot be a country without him.

In other lands colonized by the Circassian, the native has not been necessary, absolutely necessary, to the development of the land seized on. In Australia no one needs poor "Jackie." In the United States and Canada, the native 
was ever a rover, a mere huntsman or the most indifferent of farmers. The incomer was gladly rid of him. The red man perished or was driven back. No one dreamed of employing him to develop the country that strong hands had wrested from him. In Africa all this is reversed.

Africa is the black man's country. Nothing has been done, it seems unlikely that anything of consequence can be done, in its vast tropic regions, without him. Here and there isolated spots may be found where the white man can make a home and rear his children. Too often his most abiding memorial in it has been the graves of his dead. In other countries, too, settlement and occupation have proceeded gradually. By slow degrees the conquered country has come under the influence of the conquering colonizer. In Africa's case it may be said, that a vast continent, neglected for thousands of years, has, in a sudden access of international jealousy, been hurriedly cut up and partitioned among the great nations of the earth, each of them solely bent on outdoing his competitors, and grabbing for himself all that might be grasped. The native has, of course, been utterly forgotten, and ignored - but he remains.

The national pirates have laid violent hands on possessions they had no moral or other claim to, but their booty is valueless to them without the aid of the forgotten and despised native. This is the state of things to-day, and so far as the future can be forecast, this must ever remain the truth of Africa. The one atonement that it is in the power of civilization to make to the native, is to improve him, lead him forward, help him to develop his magnificent country, and see that he benefits by that development.

Personally, I am not at all doubtful that this will be done, for, apart from all emotional or moral considerations, Africa cannot advance without him, and, as a mere matter of business, his safeguarding and fair treatment will therefore be assured. 
The economic waste of such government or non-government as obtains in the rich Congo country, to leave out of account its monstrous wickedness, must soon be evident to intelligent men.

The folly of submitting much of richest Africa to the Portuguese, who seem to have learned nothing and forgotten nothing in three hundred years, will also in time be apparent. The Congo regions and those parts of the country held still by the Portuguese, are in a worse than backward condition. The tribes within them have at present no chance, they are almost as ignorant and terror-stricken as they were hundreds of years ago. They have gained, so far as I could learn, nothing by passing under the control of selfish and brutal European powers. Nothing has been done to help the native either in the Congo or in Portuguese East Africa. To all intents and purposes he is a mere slave, the slave of a government; that is to say, a slave in far worse plight than is the slave of a master. It is in the master's interest, however cruel he may be, to protect his chattel, while government or corporation slavery is only interested in forcing from him his stint of ivory, rubber, or toil.

The missionary represents the attempt of civilization to make good to the East African a tithe of its responsibility. Undoubtedly the present state of things there is bad. It would be far worse if it were not for the missionary.

$\mathrm{He}$ is, indeed, a light in a dark land. And these lights are very far apart, and only feebly fed with the oil of reasonable and necessary support. Still they shine, and there is hope for the darkest places and problems in their shining.

The missionary comes to Africa profoundly ignorant of the real conditions awaiting him. He has had no training that fits him for the tremendous task he must take up.

Mr. S., one of the ablest and most fully consecrated missionaries I ever met in my life, said to me: "They send 
me good fellows, trained at - who could conduct a Massai prayer meeting admirably, I am sure, but they have no idea how to plough a bit of land, build a house, or take care of themselves, much less teach the ignorant and obstinate savage how to do these things." It reminded me of what Mackay of Uganda, perhaps the greatest missionary that ever laboured there, wrote long before to England, when I was a young man. "Send us," he said, "not, university men who know Latin and Greek, but healthy, Christian ploughmen and blacksmiths - these are what we need in Uganda."

I greatly dislike to criticise the methods of these selfsacrificing men and women, who willingly give their all to save and uplift the black man, but I am forced to confess, that to me. the missionary plan of campaign seems mistaken in some important particulars. The native is not capable of benefiting by what is offered him; the offerer is not able, and sometimes not permitted, to offer anything else. Three things I would insist on:

First: The native is only capable of understanding the very simplest of religious ideas. Protestant and Roman Catholic missionaries have not simplified the message enough for him.

Second: He needs industrial education. As it is, the effort is everywhere being made, where there is any effort made at all, to give him a poor sort of English school training.

Third: To advance at all he must be firmly, lovingly forced to work, kept at his job, for his one strongest defence against all civilization and religion is the fact that at heart he is a nomad still.

I say he is necessary to Africa; his well-being spells Africa's progress. Therefore, for that very reason, he must not be, cannot be, left to his own devices, any more than an ignorant and sometimes vicious child can be safely 


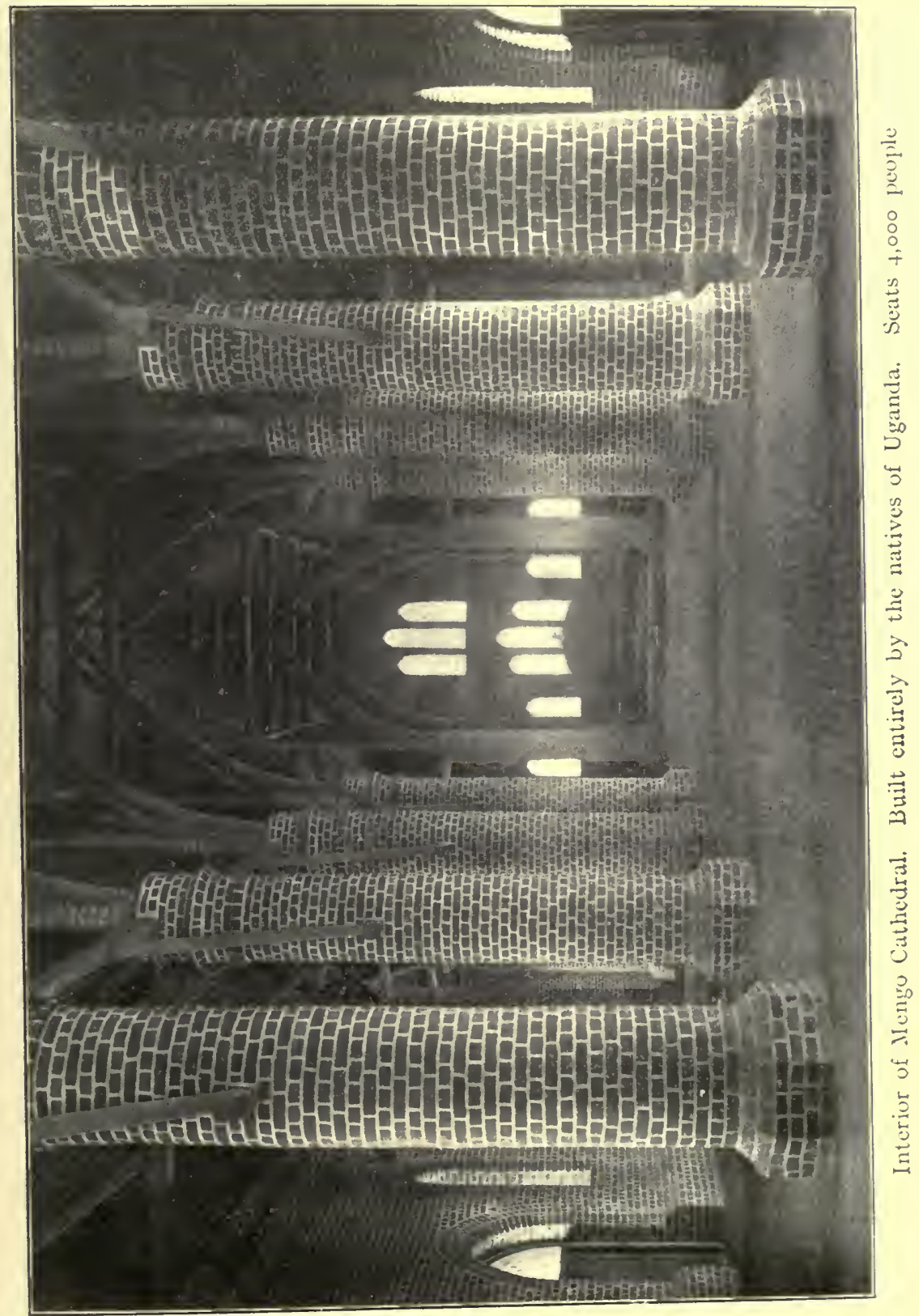





\section{A PLEA FOR THE NATIVE}

left to his. He must be trained, controlled, made to work, if necessary, for if this is not done he will surely perish from the earth.

His land cannot remain forever dark and unknown. The growing world needs it; the multiplying hungry mouths of the race must call on Africa, sooner or later, to do its share in feeding them. Uncounted millions can draw their subsistence from its rich soil and an abundance be left over for the African cultivator.

These three considerations, then, should control and direct all civil and missionary enterprises in British East Africa. Having stated them, let me deal with them briefly one by one.

I. Mr. Stanley's expeditions in Africa had, speaking charitably, little of the missionary element about them. The natives called him "Breaker of stones." His methods were often ruthless and bloody in the extreme. But when he outlined for Christian missions the course they should adopt, in order to benefit the Waganda, his summing up of the situation and of what it required, was admirable. $\mathrm{He}$ writes: "The practical Christian man who can teach the people how to become Christians; cure their diseases; construct dwellings; understand agriculture; turn his hand to anything; this is the man wanted. Tied to no church or sect; professing God and His Son; living a blameless life; inspired by liberal principles; with charity to all men and a devout faith in heaven. He must belong to no nation in particular, but to the entire white race." As a sketch of an ideal missionary for East Africa this could not, I think, be improved upon. It reveals in Mr. Stanley a prescience quite extraordinary, and the dreadful calamities that for so long overwhelmed the Uganda mission, were just the inevitable results of the failure of modern missions to act on the common sense rules he so clearly laid down.

The bloody turmoil that for years afflicted the unhappy 
Waganda, was largely owing to the introduction into that country of the age-long feud between Roman Catholic and Protestant. One Christianity the Waganda and their king could understand. It was the religion of the allpowerful white man, and might be expected to do for them what it had accomplished for these. But white man attacking white man, Christian denouncing Christian, was something astounding and inconceivable. A simple, understandable Christianity they were ready to heed and accept; but how could they, their chiefs, or their king, decide between two religions, both claiming to be the real religion of Christ, the advocates of which were at each other's throats. They naturally rejected both, and the whole land came near falling into anarchy.

It must be apparent to anyone that such divisions are a prime cause of our failure as missionaries. But the full extent of this evil of division can be evident to no one who has not seen its results in heathen lands. The Christianity of Western Europe cannot succeed as a missionary religion till it is truly catholic. If it is to be a true world-religion, it must go to the world as a world-religion, and not as an "ism." Not as Roman Catholic, Protestant, or Greek, but as Christian. The present situation in the mission field the whole world over is ridiculous, deplorable, and pathetic. Instead of an organized army fighting against evil and ignorance, regiment supporting regiment, corps aiding and acting with corps, all obeying a plan of campaign, we have thousands of unrelated, undisciplined squads and companies, guerrillas and volunteers, acknowledging no leader, with no plan of action, powerless against the enemy, and often bitterly hostile (as in the case of Uganda) to each other.

The Uganda missionaries are not to be specially blamed. They proved themselves a noble band of men. They were but the victims of our system. The wave of a national 


\section{A PLEA FOR THE NATIVE}

struggle between England and France for the mastery in Africa, swept them along to deeds they could not avoid doing, to the attainment of ends they could not have foreseen. They held Uganda nobly for England, but that is a very different matter from winning the Waganda for Christ. Religious politics and political religion come near ruining the country.

Apart from political considerations, from which missionary effort in East Africa may perhaps now be hoped to be free, there remains the matter to be taught to the natives. In this there is, I am persuaded, a permanent hindrance to missionary success. An effort is put forth to make the native what he cannot be, a black man with a white man's mind. I am far from pessimistic as to the native's capacity for development, but he is too far behind, his whole habit of mind is too foreign to that of the white man, to make it possible for him to benefit by the usual doctrinal teaching which missionary customs, rules, and standards impose. He has been for ages without any religion at all. He cannot suddenly accept, understandingly, those forms of religious thought and belief which have only been formulated even in his teacher's mind as the result of ages of conflict, elimination and absorption. What can the doctrine of the Trinity mean to him? Miracles of a certain kind he will readily accept, his profound belief in the witch doctors' power makes such acceptance both natural and of no value. On the other hand, when such a miracle as "the virgin birth" is insisted on, as it is unfortunately almost universally insisted on by missionary England and America, a very real difficulty at once arises. Faith, in its true sense, he knows nothing of. $\mathrm{He}$ is of necessity a materialist, and to ask him to believe something beyond his reason, is to ask him to do what the very best impulses within him rebel against his doing. Again and again, in conversation with the most intelligent men of my sefari, who were Mohammedans, 
they have confronted me with this difficulty: "How can we believe that a child was born without a father ?"

The natives have no idea of God, and this fact, instead of making their conversion easy, makes it far more difficult. There is nothing to build on; the whole idea is outside the range of their minds, they must be raised, helped, educated for a long time before it can have any real hold on them. So with regard to a future life, they have no wish for it. It in no way appeals to them. I have not found that the Mohammedan conception of the future affects the Mohammedan native in the slightest degree. His lot may seem to us to be utterly miserable, it does not seem so to him. Theoretically, like other natives who recognize only nature's powers, he should be a terror-stricken coward. In his own judgment he is neither poor nor unhappy. What need has he of a supremely good Creator, a Redeemer or a heaven to come? As a matter of fact, he is measurably satisfied with what he has and is.

The real hold that the missionary has on him is the fact that he is a white man, a being of another and a high order. Gladly, proudly, he follows him; painstakingly he imitates him. The missionary's hymns, the missionary's Bible, everything pertaining to his "bwana," are, for that "bwana's" sake, dear. He is proud, indeed, to show to all who will see it the evidence of his devotion. I have heard him called a hypocrite for pulling from a corner of his scant clothing a testament he could not read, as was too evident by the fact that he held it upside down! But the poor child of nature was only trying to show that he was a mission boy.

Let me repeat what I have said. The personality of the missionary is the one great link holding the native to better things during these difficult days of rearrangement and disorder, still awaiting him.

In this respect no words can exaggerate the good the Christian missionary has accomplished and is to-day 


\section{A PLEA FOR THE NATIVE}

accomplishing. The civil servant does his best, and in East Africa, as I have again and again said, it is a very noble best. But the civil officer changes often. Scarcely has he learned to know, even slightly, the needs of the tribes he governs, when unknown high powers call him away to some other post. The missionary remains; he learns his language, at last he learns to think his thoughts. Lieutenant-Governor Jackson once said to me: "Quite apart from the great good they do as interpreters of native needs and aims, the missionaries are absolutely invaluable to the government." And he added, speaking of one we both honoured: "He thinks Kikuyu."

But if our missionaries had brought or could bring to-morrow, to these dark races who are prepared to so love and follow them, a very much less complex, a quite simple religion, I cannot but believe Christianity would have had a success in East Africa that it has certainly failed to obtain.

Frankly, I think a great opportunity was thrown away. I am afraid I am right in saying "was," for I am not sure that it can now be recalled, even were Christians willing or able to recall it.

Africa is becoming not Christian but Mohammedan, and it is becoming Mohammedan in spite of the immense advantage Christianity naturally has over the latter religion, owing to the fact that the rulers of the land are Christian. Mohammedanism wins one hundred, where Christianity wins one, because Mohammedanism gives the native what he can understand, what he wants, while it leaves him in possession of much that he is not willing to part with; much that I think he should not be asked to part with. To make little of the influence of Mohammedanism is not wise. To deny its influence on the native for good, is not just. It means a real step forward for the East African when he becomes a follower, even in the name of the Prophet.

His new religion lifts him out of mere tribalism into a 
family of free men. No man can enslave him, he is a member of a great brotherhood. Further than that, in the vast majority of cases, I do not think the matter goes, but this simple religion or beginnings of a religion, is not without evident effect in his life. He is at least as truthful, as clean in his manner of living, and certainly more sober, than the Christianized native.

Of the doctrine of Mohammedanism he knows nothing except that he must stand by his brother religionists, and must not eat meat that has not been "hallalled."* $\mathrm{He}$ remains, of course, a polygamist. There will doubtless be many who maintain that such a religion is no religion at all, and that it measures no practical advance whatever. I can but say that this is not so, and that for the native it measures perhaps as great an advance as at present he is capable of. Lift him too high, force him too fast, and reaction certainly ensues.

Mohammedanism is born of the East and understands the East better than we of the West do. We foolishly flatter ourselves that we have, in our Western Christianity, evolved the pure, the final, the universal religion. Some of us are profoundly doubtful that as yet we have attained so great a goal. At any rate, we have not sent forth our missionaries empowered to teach a religion so simple, so universal, so fundamental that it can meet the needs of these newest, least developed, and most pathetically needy children, of the dark land.

A brotherhood as simple, as universal as that Mohammedanism has offered him, we might have offered. He might have been invited to membership in the white man's religious family, given a real, even if the lowest, place in it. What has been done, what is being done, is that he is set to learn, told to believe, things that though they are simple enough to us, are quite beyond his powers of understanding.

*Throat cut before animal is actually dead. 


\section{A PLEA FOR THE NATIVE}

He must change all his methods of living, think as the white man thinks, believe what the white man believes. He is generally ready to try, but he soon tires of the impossible task set him, and, demoralized by failure, discouraged to find that he cannot retain the approval of his masters and teachers, he falls back among his own people, and is distinctly a worse man for his relapse.

If we will not give Africa a much simpler religion than any of our missionaries are now empowered and encouraged to teach, Africa will become Mohammedan. One of the chief difficulties in the way of Christian missions in East and Central Africa is that missionary organizations are controlled and directed from a distance by committees composed of men who, however excellent and well intentioned, are actually ignorant of the people they set themselves to help and convert.

People at home do not know Africa, do not understand the native. The most difficult thing in the world is to bring the facts of native life before them. In illustration of this extraordinary state of things, I take my own case. Whatever value these notes of mine may have, lies in the fact that they state facts for the truth of which I vouch, and which are well known to be true by all men who know the country. In my chapter on the life of the tribes I visited I wrote of their social customs, the relation of the sexes simply stating things as they were. To ignore them, to refuse to recognize them, can serve no good end. They should be known, they must be reckoned with, if these people are to be helped. But I was told, "No library will take your work if these facts are stated baldly, as you state them." There in a nutshell is the main cause, as I see it, of the weakness of the Christian missionary position to-day. If missions would but take the public - the great interested public - that really wants to do right, and longs to help the downtrodden, if it only knew how to do it, into its 
confidence; tell the truth about the field it seeks to occupy, the methods it wishes to pursue, and the difficulties it is confronted with; if this were only done, would not missionary reports soon receive another greeting than that now accorded to them? Who now reads them? Who quotes them? Who is influenced by them? A comparatively small knot of excellent, middle-aged or elderly philanthropists.

They should be the most fascinating current literature of the age. They should be read with the same absorbing interest as that with which we study the reports from a seat of war, where husbands and sons are fighting for the fatherland. As it is, their destination is too of ten the wastepaper basket!

How can it harm the sheltered home-keeping sensibilities of good people to know something of how the dark people they want to help, live? How can they really help them if they do not know? As it is, reports are doctored, facts are suppressed, the religious public is given what it is supposed to want to know, and what it is supposed not to want to know is carefully kept from it. A policy of catechism and rose water, I call it. Its result is bad enough to-day, and will be worse to-morrow. This has been for long the politician's plan, in reporting on Africa. God knows, it has cost enough in blood and treasure. Is it to be the Christian's plan, too?

II. The African above all things needs industrial education. This and this alone can fit him to fill the rôle providence has destined, that for ages to come he must surely fill. The Germans, always pioneers in such matters, have grasped this fact, and have already laid the foundation for such education to be given to the native of German East Africa. Though English missions and French held the strategically important positions in East Africa long before German occupancy was more than a nominal affair, 


\section{A PLEA FOR THE NATIVE}

they have not yet done as much. No words can exaggerate the good work accomplished by the C. M. S. medical missions in Uganda. No hospital anywhere in the European protectorates controlled by England, France, Italy, Germany, or Portugal, compares with that established by the two brothers, Doctors Cook and Mengo, so far as help to the native is concerned. Doctors and nurses, belonging to our own African Inland Mission, are pushing their way among quite unreached, unmissionized tribes, and are, wherever they go, a light in a dark place.

But, putting on one side medical missionary work, the importance of industrial teaching has not yet been recognized. To teach large numbers of the East and Central Africans to read and write seems to me, to-day, to be of far less immediate value than to so educate them that they shall take a greater interest in the land they till, and the cattle they tend. I have spoken of native capacity for mechanical and industrial work elsewhere and need not now enlarge on it, but surely these industrial qualities must be roused up and educated if he is to hold his own. The yoke of his kings was a cruel yoke, but under it the Waganda had to toil. The coast Arabs drew their supply of slaves from the lands between the sea level country and the great lakes. Their discipline was at times cruel, but it gave the East African a master, for whom he had to work.

There is danger to-day of his becoming a masterless man, for no mastership could be so hurtful to him as his own. To save him he must be taught, not to read or write, such knowledge usually only makes him conceited and worthless. He must be taught to work.

Uganda is everywhere spoken of as the garden spot of missions. There the missionaries have immense influency as they well deserve to have. There is an important school in the hands of the C. M. S. at Mengo, the capital of Uganda. In it more than one hundred of the sons of the leading men 
of the Waganda and allied tribes are receiving education at the missionaries' hands. These lads, aged from ten to eighteen, will shortly be men of commanding influence in the country. A fine new building lately opened by $\mathrm{Mr}$. W. Churchill, is the schoolroom; the appearance of the boys is excellent; the atmosphere and discipline of the school evidently sound and good. But the education is the three R's.

"You tell me," I said, "that these lads will have the control of an immense part of Uganda. Why don't you teach them interesting things about their own lands -its crops, its possibilities? Teach them to be mechanics, carpenters, good agriculturists. Their method of farming is rudimentary." "Oh, Dr. Rainsford, we are fitting them for Government appointments. Their lands and their cattle do not interest them as they used to do." I fully admit the need of finding among the Waganda young men fitted to be clerks and government officials in a small way. As the railroad enters, as English government machinery becomes more complex, such a class of young men will be of great value. He will keep the Goanese and Hindi officials out of the country, a matter of great importance.

But Uganda is to-day and always will be a food producing country, capable of feeding untold millions of people. It is only cultivated in spots. Its rich surface has only been scratched. If its owners lose interest in the land, it is in their own fortune, in their own future, they are losing interest. It is a glorious land, not a white man's country, to be sure, but among the very richest of all the lands of the earth; and in the world-scramble that is ours to-day, such a land can only be left to a people that recognizes its value and is prepared to develop it by patient toil and intelligent resourcefulness.

As I looked round those fine schoolroom walls, I recognized many an old acquaintance of days long gone by: 
the familiar rolls of canvas hung down before me covered with the natural-history illustrations of my youth. The flowers, fishes, vegetables and animals of England were all there, after their well-known and somewhat inaccurately depicted sort of English! I wanted to see Uganda. There was one concession only to the tropics, that I could see an American alligator was made to do service for an African crocodile, a very different sort of saurian, indeed.

I criticized these schoolroom posters then and there, but was told it would cost too much to reproduce the flowers, vegetables, or animals of the country. But the whole thing saddened me, for it showed to my mind a total lack of appreciation of the real education that these people need. A slight knowledge of drawing, a little clever use of the camera, might have made these fine schoolroom walls tell another and a far more interesting story to the boys who were one day to rule Uganda.

III. Industrial education cannot be given to the nomad. Most true, and it is for that reason and in his own interests, that the East African must, therefore, for a long time to come, be firmly and wisely made to do what he ought to do.

I know well that such a statement is at once greeted by indignant outcries. The philanthropists, the theorists, the public interested in East Africa but actually uninformed about it, will have none of it. The opponents of forced labour in any form and under any circumstances wax ignorantly eloquent. But outcries do not alter facts. The man who is not fit to be his own master must be put under the mastership of someone else, or he will perish from the earth.

Some sort of forced labour is absolutely necessary. No savage ever did (or ever will) in any age or in any land, work systematically unless he was obliged to. The African is no exception to the universal rule, and he must be made to work there not only to develop the country, but to save 
himself. Such work as is at present accomplished is practically accomplished only by forcing the native.* The district commissioner applies to the chief for so many men, to mend a road, cut firewood for the railway, build an embankment, or break up so much land. The chief sees that these labourers are forthcoming. When such labour is honestly paid and justly treated, very soon the native himself falls into line. He sings at his work, when the sun goes down he (as I have often seen him) dances far on into the night, and will in numberless instances volunteer to continue his contract or take another job under the white master he has learned to trust. The fact remains, however, that had he not been forced in the first instance to leave his lazy life and his half-tilled shamba, he never would have been found carrying the burden or wielding the hoe. This is true of him even when cash down is paid for labour done. How much truer is it then, when, for his own salvation he must be made to work without remuneration, in an industrial school for months or years, while he learns a trade.

To make any real progress in the matter of industrial education, then, the pupil, the capable but ignorant and unwilling pupil, must be held to his job. And partly because the missionaries have had no such authority vested in them so to indenture the natives, little in this way has been accomplished.

A promising beginning is made; the young men learn quickly, but just as real progress is in sight, the nomad nature reasserts itself, and under some specious pretext the scholar disappears. All is to do over again, and if the

\footnotetext{
* Forced labour can be, and has often been, a cruel wrong in his case, but even forced labour is far better for him than encouraged idleness. The native on the native reserve will be, must ever be, the idle, backward, unprogressive native. No well-informed student of East African conditions would adrocate a great development of the system of native reserves. It would mean shutting the native in, leaving him the victim of his own evil influences.. Not even resident missionaries could accomplish for him under such circumstances what the steady education of work done, and new needs and wants acquired in contact with more progressive people, could accomplish.
} 


\section{A PLEA FOR THE NATIVE}

inexhaustible patience of the teacher is not quite worn out, the modest financial resources at his command certainly are. Forced labour in Congo land means the bloodiest sort of slavery. Under its régime the native population has decreased. Forced labour in Portuguese East Africa is worked on a system but little in advance of that obtaining three hundred years ago. Progress for the native, there, is quite impossible. No account whatever is taken of him. He exists for the benefit of the white colonist only. But the declared aim and policy of the English and German governments is manifestly different. True, they are no mere philanthropists. The country they have acquired must pay its way, or ruin awaits both white and black, but theoretically both have realized that Africa can only be prosperous as the White and Black succeed, together.

The Germans seem to have sat down and thought out the problem confronting them. They act on a plan; they govern on a system. Englishmen are apt to criticize German methods. as being hampered by too much system, too much red tape. This may be so, but if there is too much system in German territory, there is surely too little across the border. The fertile source of evil and inefficiency there, has been the evident lack of one settled policy. Governors, laws, regulations, policies - all change continually. Native tribes are moved from one location to another. Farmers are invited to come and till a new land of promise. But the tribes are uncertain of the tenure of their grazing lands, and the maddened farmer cannot get a title to his farm.

One year sees one policy declared, the next sees this overthrown, and something new promised. Is the country to be a game reserve? Is it to be a native reserve? Is it to be an East Indian reserve? Are the Boers to have it, or is it reserved for Englishmen? No land can present a longer list of problems to the statesman or the missionary, and it is hard to believe that as yet there has been formulated. 
at the Colonial Office any settled policy regarding it, which its governors and executive officers are ordered to pursue.

Fairness, firmness, sympathetic knowledge, and a fixed policy - these are manifestly necessary to its well-being, to the prosperity of its native population, or the success of its white colonists. And these as yet East Africa has not had.

But great and immediate as the need is to help the native East African to acquire habits of industry, habits by which alone he can climb out of savagery, by which alone he can be made co-worker with the colonist, I should indeed belittle Christian missions - what they have accomplished and what they aim to do - were I to speak of them as only busy in the endeavour to materially advance the black man's status. He who "made of one blood all nations of men for to dwell on all the face of the earth," has ordained that though man may not live or advance without toiling, yet by toil alone he cannot grow to manhood's stature. Bread is easily come by in most parts of Africa, and by bread and bread alone, the native has, in his poor, downtrodden, slavery-haunted state, been forced to live. But he is a man, and as man has had need for, and right to, a higher life, which cannot be lived by bread alone. For the seeds of future manhood within him, for the signs and promises of a better and higher life, who cares to-day?

Dwarfed and stunted as he is, few see promise or hope of these things within him. The missionary does; in them he believes; for them he waits. In their first faint springing he seeks and finds his exceeding great reward.

African darkness in the past and in the present is the darkness of a continent without ideals, a continent given over to the vainest of all vain efforts, the effort to live without ideals. In the face of such materialism, an abiding protest against it, lives, teaches and dies the missionary. Some smile on him as a visionary, a very few still slander him as a self-seeker, but the men who see and know, the men 
on whose hearts the charm and terror of Africa have laid their spell, even if sometimes they have sadly lost faith in the creeds of their childhood, hold him for what he is - the real saviour of the Africa of the future.

He has been her true discoverer. He opened the dark places to the day. No man has so good a right as he to a voice in her government. Our present day materialism has small understanding of the missionary, but surely his own will come to him. He is the idealist of Africa. A man's work is, as it were, the perishable body of him; after a few years the body wears out, only the ideas he gave forth, the living, detachable seeds of him, as it were, remain. Where would the world be to-day but for ideas? Jewish ideas, Greek ideas, Italian ideas, English ideas? Who cares or knows anything of the mere fortune-builders of old time, or even of those who led hosts to slaughter in those ten thousand battles of long ago? Yet in our so-called materialistic century, men pour out treasure or eagerly cross sea and land if only they may learn a little of those great ones who gave ideas to men. Their memory is revered, their words written, their pictures painted, the statues they hewed, the cathedrals or towers they builded, are our priceless possessions to-day.

Adventure and traffic in Africa has too often brutalized those who pursued them. Colonists cannot be trusted to safeguard the rights of those whom, at least in part, they have come to dispossess. Between the colonial adventurer and the native, stands the disinterested, self-sacrificing missionary. He should, in the best interests of the country he knows, have a far more influential voice than he now has, in formulating its laws and outlining its policy.

If "blood is the price of admiralty," as Kipling says, who has better earned his right to a voice in the council of the land of his adoption than he? Pensions and honour may await the successful soldier. Some recognition, however 
inadequate, is assured the capable civil official. These come for a time, stay but a few years, and then go home. The missionary's home is among his black folk. He lives among them and dies among them. The splendid assurance that upheld the great missionary Krapf in those early desperate days, when East Africa was quite unknown, is still his. "Though many missionaries may fall in the fight, yet the survivors will pass over the slain in the trenches, and take the great African fortress for the Lord." 


\section{CHAPTER XVI}

\section{THE LAST SEFARI}

SPORTSMEN arriving in British East Africa are natu$D$ rally in a hurry to leave the railroad and civilization behind, and plunge into the wilder country as soon as possible. Unless the newcomer has secured very unusually extensive and reliable information, or unless he has placed himself in the hands of a hunter whose experience and character are well known, this is a mistaken course.

There are several professional hunters hanging round Nairobi always looking out for a job, whose services are as useless as they are expensive. And so many inexperienced sportsmen, and others with no conscience, have for one cause or another supplied these gentlemen with testimonials so wholly out of keeping with facts that written recommendations are of little use. If you have time, as I have said more than once in these notes, much the best way is to go out alone or with a friend on your own sefari, and learn the ways of the country, its natives, and its game. Afterward when you begin to know what you want, engage. a professional hunter if you need him.

If you have the good fortune to be in no great hurry, do not too quickly rush away from Nairobi. It is a beautiful and most interesting place, and in no way can you learn so quickly what you want to learn, or gain so much information that will prove valuable, as you can by making a few short expeditions in the neighbourhood of the town. Here one at least of the game rangers is to be found. These officers know more about the location of game, which, by the way, is constantly changing, than any one else. 
Lieutenant-Governor Jackson is always ready to give to strangers the advantage of his unique experience. Those who are hoping to secure some uncommon species will find in him an invaluable ally. If you immediately rush away on sefari, then you must be content to take what you can get in the way of headmen, tentboy, gunbearers and porters. If you delay a little, and wait to gain knowledge and some experience, you are sure to come in contact with many who are both willing and able to aid you. The walks and rides round the town will introduce you to some of the most beautiful scenery in Africa. The curving ridge that looks over the lovely blue plain was often my early morning walk. From its farthermost end I have seen soon after sunrise, or just before the sunsetting, the snowy truncated cone of Kilimanjaro, I75 miles away on the right; in front Donya Sabuk (thirty miles) and Kenia and Kinan Kop on the left, all at the same time. There can be but few views in the world to compare with this. Then turning backward and homeward along the ridge, fragrant hedges of pomegranate and yellow roses thrust their boughs over inadequate fencing, as they fill the fresh morning air with odour.

Snowy mountains, wide sweeping plains, waving banana and a great abundance of sweetest English flowers. This is Nairobi ridge, surely the strangest, and one of the most lovely unions of tropical and temperate beauty and life. Stand on this southern end of the ridge, and turn your glasses on the level plain before you. Here, not three miles away, are the game herds of East Africa. Thousands of little dots, kongoni, zebra, Tommy, Grant, and probably a few gnu are in sight. The popping of rifle shots at the range beneath you affects them not at all. Take your rifle, however, saunter out on that level veldt, and you will not find them so easy of approach.

Tempted by the game herds, lions still at times come 
up close to the town; one big fellow, while I was there, must have somehow lost his bearings, for he walked over the race course and almost into the large native market near the quarantine line, at two o'clock in the afternoon, and only leisurely departed when the buyers and sellers raised a clamorous outcry. Any one near by with a rifle then had got a lion on easy terms.

The forest at the back of the town still holds a good deal of game, and the officers of the King's African Rifles can generally get a buck, even when they may not be able to lead the regimental lines for four o'clock in the afternoon.

Now and then on the outskirts of the town a maneater makes an appearance. Two Kikuyu were eaten by one not very long ago, and so far as could be learned, a Goanese, looking for guinea fowl, came on the beast in some thick scrub and killed it with a charge of duck shot in the ribs.

Two mornings before I left Nairobi a Mr. T., who has a garden on which he prides himself, was awakened before daylight by a most unusual noise in front of the house.

On looking out, he beheld three buffalo dancing a war dance among his flower beds. Yes, there is a good deal going on at Nairobi.

On my first sefari, three years before, I had pushed from Nairobi into the country between the Theka and Tana rivers, a very easy locality to reach, and at that time full of game.

Before packing up my rifles and selling my tent and camp belongings, I determined to make one more visit to it, and in the most rugged and hilly part of it try for a buffalo.

I found an accumulation of letters awaiting me, eight months' arrears in fact, and what with these and the settlement of large sefari matters, I had no time to bother about 
my little expedition, but let my outfitters give me any men they chose. I had, of course, my own tentboy and gunbearer. I mention this, not because it is of any importance, but because it illustrates how necessary in every case it is to look after the choice of your men, if you expect to do any good work with them. We were only going to Punda Melia, forty-five miles away, by the best road in the Protectorate. I had light loads and seventeen men. Well, the sefari made just ten miles and then stuck fast. I camped by the roadside, tried to possess my soul in patience, and wrote up my notes for two days, till I could send back, get better men and proceed on my way.

The country on the Fort Hall road I found greatly changed. When I had passed that way before, the road was only a track, there were no bridges, and we had to ford with difficulty several of the streams. The considerable stream of the Theka then detained us. Now I found an almost continuous line of farms, and solidly built bridges everywhere.

The game herds had vanished, and I made no attempt to get meat for my men till I reached Punda Melia.

At P. I found two old friends, who had already put more than four years of desperately hard work behind them, and in consequence were beginning to see their way to a modest measure of success. Here I was on the outer edge of the native shamba country once more.

From Punda Melia the land slopes rapidly down to the Tana valley on the northeast. On this side rough, hilly country, broken into innumerable valleys, forms a sort of steep promontory, that thrusts in between the two rivers - Theka and Tana.

To the north, a very broken district, dry and rocky, stretches far away towards Kenia.

To the northwest lies the best tilled, and best watered land in the Protectorate, the very richest of the Kikuyu 
country, a dimpled country in whose slight folds and hollows a quite dense native population dwells. This is the present granary of the land, yet you cannot make out a village, you can scarcely see a hut, and out of it Kikuyu carriers, men and women, stream Nairobiwards, a thousand at a time.

It was the beginning of December. The lesser rains had been very abundant and the country was looking fresh and lovely.

Where there is broken and hilly land in this part of East Africa, the soil is good in the hollows and on the hillsides. Hence the grass grows to such a length that hunting is impossible. Hence again, the need of choosing the right time in which to visit the right country.

I have said before that in my judgment the best time of all to visit East Africa is in the rainy season, which generally begins with the first week in March. The old grass is then burned. The new will be sprouting. Game travels and can be tracked. Sefaris depart and can well be spared.

It rarely does much raining in the morning except in the Naivasha district. If you are strenuous you can march through it, and in spite of it you will dry off before the afternoon. If you are not hurried you can wait for the morning shower to pass and then march.

In far the greater number of localities the rain only begins in the afternoon, not before two, sometimes not till four. In that case you will do well to have your hunting and marching all over and your camp well pitched; the rain will then incommode you but little. The lesser rains generally come in November and December; every one anxiously awaits them, for if they are abundant that means a second crop for the farmer.

The hilly country to east of Punda Melia had been well burned over. The upper slopes were a fresh and vivid 
green. But there were many places, down in the precipitous hollows, where the searching grass fires always seemed to be beaten back, and the long yellow tangle still made an impenetrable hiding place for rhino and buffalo.

Among these hills I had made my first bow to African game in 1906 , and here I now came for my last sefari and sad good-bye.

I advise any one wanting a short trip near Nairobi to take his sefari here rather than on to the baked, sticky Athe plains, where most go. Here game is much more various. The stalking ground is better. There are far fewer ticks. And last but not least the scenery is far finer.

In one morning's tramp I saw rhone (preserved), waterbuck, fine, very fine impala, kongoni (Cokes), zebra, duiker-buck, oraby (Kenia oraby, a distinct species), stein-buck, reed-buck, Chanler's reed-buck, bush-buck, and warthog. I also saw rhino, buffalo, and gnu. Think of so great a variety within fifty miles of Nairobi in December, I908, and each and all of them I could, with time, have shot.

The hilly country I write of rises several hundred feet above the plateau of Punda Melia, and then growing more rocky and broken, tumbles down to the wide Tana valley, whose floor is more than two thousand feet lower than the Nairobi plain.

It was from Punda Melia I had first gazed enchanted at the grand curve of Kenia with its crown of purest snow. I was glad indeed again to look on it from the southern side, and compare this view with that from the northern. Kenia is a beautiful mountain, looked at from anywhere. But impressive as it is when seen from these hills above the Tana, the view gives but a poor idea of the lofty grandeur of the peaks that face the north.

Krapf, the heroic German missionary, was the first 
white man to see Kenia, December 3, I 849. The great explorer, Joseph Thompson, whose statue Sir Harry Johnson well says should stand at the gateway of the land he toiled and suffered so much to explore, saw Kenia next. He came across the Aberdare and saw it from the west, and had the same view that I had of the upper battlements of the mountain, gleaming forth above the dense cloud bank that blots out all sign of the massive sweeping base.

In the evening, just before sunset, Kenia is often so seen. In the hot weather the heavy forest land round the mountain base breeds a perpetual fog bank. The colour of the cloudy mass mingles with and merges in the plain. None would fancy that behind it a great Alp lay hidden. The upper cloud strata thin out and part about five-thirty o'clock, especially if the evening is still; suddenly you lift your eyes from the ground, as you trudge homeward, and the glorious vision is vouchsafed to you. Ice, snow, rock, all glorified by the setting sun; marvelous, spirit-like, divine, cut off, as it were, by immeasurable distance, from all contact with the gross earth. Thompson says: "Kenia was to me what the sacred stone of Mecca is to the faithful who have wandered from distant lands, surmounted perils and hardships that they might kiss or see the beloved object, and then if it were God's will, die."

I had not yet bagged a buffalo. I had, as I have tried to tell elsewhere, worked hard and often for one, but in vain. I had camped on the borderland of a forest country where they were most abundant; but the bad management of my friend's professional hunter, who asserted that he knew the country thoroughly, when he did not know it at all, had resulted in our sefari being tied fast for ten days, while all the men had to make a journey of more than seventy miles to get food. Such contretemps will happen. You will pass close to a place where the very beasts you are most anxious to secure are easily found, and if you do 
not stumble on them, or if you have no native scouts who know the habitat of the game, you may not be aware of the opportunities you have thrown away till you are a hundred miles distant.

One more determined effort I would make to get my buffalo, and I so laid my plans that if these green hilly ridges would not give me one, I would go farther down stream and try the swampy and less healthy country towards Embo.

As we made our way slowly over the crests of the hills and descended rapidly towards the Tana Valley, the heat was oppressive; the hills shut us in, and shut off the cool Kenia breezes that are so refreshing in the evening as you sit at your tent door and face the lovely mountain; and the men were fagged and thirsty when we pitched camp, beneath a precipitous slope that rose 2,500 feet above our heads.

My friends at Punda Melia had provided me with a local hunter, a Kikuyu, whose soubriquet was "Plumes," a good man on lions, and a fair tracker. He knew the country well, and was confident we should at least find fresh sign of buffalo before making camp. But it was not to be. Buffalo there had been, but it was several weeks since they had visited the ravines we were crossing.

The country is so broken up hereabouts, there are so many gorges and dongas and corners in it and buffalo go to bed so early in the morning, feeding only at night, hiding themselves almost as soon as the sun is up, that unless you have the good fortune to come on a large herd you may hunt for days, and not get a shot.

Here, too, the ground is extraordinarily hard. The ponderous rhino. scarcely leaves a sign, and were it not that the heavy night dews lie on the grass where cliffs and trees shade it for more than two hours after sunrise, success would be largely a matter of mere luck. 
As soon as the men had eaten I sent two or three parties out to look for sign. By evening all returned with unfavourable reports. They had seen nothing.

Next morning John roused me before five o'clock, and half an hour before full daylight we were working our way along the bases of the hills. There was plenty of game, and a few fresh rhino signs, but we tramped for two hours and a half before we saw any fresh buffalo spoor.'

One of my Wakamba was the first to make out a very faint print on the flinty red soil. It turned upward into a mountain gorge, and as the earth on a bench we were crossing softened a little, showed up more plainly. The spoor was that of a single old bull, and was quite fresh. Our hopes rose accordingly.

After almost two hours' patient tracking I found myself on a green slope, not more than two hundred yards wide, that steeply fell away on my right hand and soon rose to a precipice on my left. A sort of bench, it was cut by deep dongas every half mile or so, and these were most of them dry and filled up with dense brush.

Crossing them took time and care. Here the rank grass of last season had somehow escaped the grass fire, and stood tough and high - impossible stuff to track in, almost impossible to shoot in. Things began to look hopeless. The dew was gone, and we lost the trail utterly. As we topped a little ridge, I saw a rhino strolling along in the perfectly aimless way they have, on the other side of a deep donga that opened up a few yards beyond us. I looked him over, for the country owed me one more. The horn was not very large but it was not badly shaped, and was as long as any I was likely to see. I told Brownie I would have him, as our chance of a buffalo seemed now so slim.

Just then the rhino decided to take a dry rub down, as there were no water holes near by, and tumbled 
into a red hollow among some thorn trees, battered his head, and rubbed his tick-bitten sides against the rough, scrapy earth.

Three tough thorn trees stood close together within a few feet of his wallow, and I saw at once that here might be an admirable chance to photograph him before shooting, as the stems of the tough thorn supplied me both with a screen and a defence till I should have time to lay down my camera and take my rifle. Off we set, therefore, to make our stalk, Brownie and I. The donga had first to be crossed, and so densely dark and deep was it that I had to give up my rifle, scramble down without it, and be helped up on the other side. Just as we were getting close to the rhino, he suddenly decided he would do something else, and out of his wallow he scrambled and came along, aimlessly pushing first to one side then to another right across our front. Just here there was no grass and bad as a rhino's sight is, in such a place if we stirred, he couldn't fail to see our dark bodies moving over the sunbaked yellow earth. He saved us all trouble by ambling along in one direction. About seventy yards away he must have smelt us. There was but little wind, but what there was blew from us to him; and he came to a dead stop, stamping and snorting as rhinos do. I hit him low down and well forward in the shoulder. He spun round once or twice, and then made a straight line for where I was sitting, coming fast. I didn't fire my left barrel, as I wanted to see what he would do, for plainly he was mortally wounded.

Here, now, was another pretty illustration of what is so often described, and described inaccurately, as a charging rhino.

Had I kept on firing, as is usually the custom, any one looking on would have said that that rhino was bent on getting his enemy, and that his charge was only stopped or turned aside by repeated rifle fire. Nothing "of the sort 
would have been true. The poor beast did not even see where he was going, and rushed aimlessly forward in his death struggle. He came very fast to within about twenty yards of the knoll where I sat. Whether he saw me then or no, I cannot say; anyway, he turned a little to one side, as scores of other rhino that I stalked close up to have done, and passing quite near, collapsed, squeaking loudly, on the very edge of the donga I had just scrambled through.

Now in all this there is nothing in the least unusual and I have only entered into these details on account of what follows, for here begins the really interesting part of my story.

As I turned back to look at my rhino and measure him, I saw my Wakamba tracker, who had that morning proved himself an unusually good man at his work, standing but a few yards away from me, on the other side of the donga I had crossed, and making silent, frantic signs for me to come to him. After the Wakamba method, his arms were stretched forward and downward while he opened and closed rapidly his hands.

Brownie and I at once saw something serious was up, though what it was neither of us could imagine. We ran down the donga's edge to a place where we could cross, as the sides sloped and the passage was easy, and came up alongside Gallinero, the Wakamba. His eyes were popping out of his head as he pointed into the black depths of the donga, on whose very edge we now stood, and whispered M'Bogo (buffalo). It seemed absurdly impossible. Here the narrow gulf was quite thirty feet deep, and not only densely packed with tangle but quite filled up and overshadowed by thickly growing thorn trees and trailing plants that roofed it over, shutting out all light. It didn't seem possible that a buffalo should be down there. Brownie and I had lowered ourselves down into it, a few yards from this very spot. I had shot off my heavy rifle 
a few yards beyond it. The rhino had dashed squeaking along its very edge and had noisily died there. How was it possible that a bull under such circumstances could have lain all the time hidden, and make no sign?

I thought the man was certainly mistaken, and owing to the complete blackness of the place, had taken a rock for a buffalo bull.

Brownie thought so, too, for I saw him smile incredulously as he noiselessly drew alongside the Wakamba, and looked close into the chasm where the other was pointing. Presently he too saw the hiding beast and tried to make me see it. I looked and looked, but all was dark. Then as my eyes grew accustomed to the gloom, I did see a big shadow of an animal standing against a rock right under my feet, but which was head and which was rump I could not see.

I never fire a first shot at any dangerous beast till I know where I am shooting. It is a good rule to remember and has saved both my men and me trouble many a time, and I observed it now, though the temptation to break it on this my last chance at a buffalo was, I confess, very strong. As I waited, the shadow vanished without a sound, and presently, higher up the donga, I heard the heavy body crashing through the scrub. Through the tremendously high and matted grass, I made the best running I could, and in a couple of hundred yards reached a place where the donga widened and shallowed, as its course ascended sharply to the mountain above us. I was just in time to see above the long grass the heavy points of his horns and the line of his black back, no more, as he reached the level I stood on. He was going fast, his butt almost towards me. In another few yards the grass tangle would completely hide him. I was puffing from my run, my eyes all dimmed by sweat-covered glasses, but I pulled myself together, for well I knew it was now or 
never, and if I did not cripple him, that supremely cunning old bull was lost to me.

I tried very hard for a raking shot, that should avoid his fleshy rump where an expanding bullet could not kill him, but should take him high up in the ribs and range forward. As I fired I felt I was at least near the mark; and sure enough, with a fierce, loud whistling snort, he spun right around to the shot, facing me. Now he was head on, and I had no mark to shoot at, for nothing was visible above the tangle but the heavy black impenetrable bosses of horn. He stood stamping and snorting for a moment, made but a half-hearted attempt to charge, and swung back into the dense bush fringing the edge of the donga. As he did so, I shot through the grass where I fancied his shoulder should be. We now had to go slowly and carefully, for our bull was an old solitary one, about the most dangerous beast, when wounded, that there is in Africa or any other land. I crept forward a foot at a time, parting the long grass in front of me with my rifle barrel, and tried to keep Brownie from pushing himself ahead of me, as he ever was inclined to do when he knew danger lay in the next bit of grass. It was impossible to see any sign of the wounded bull; but plentiful blood spattered the cover. The tangle was eight or ten feet high hereabout, but the precipitous donga was behind, and he could never get out of it again should he retreat into it, if, as I believed, he was severely wounded. This was no time to hurry, for danger lay in the terribly thick tangled grass.

Foot by foot, for fully forty or fifty yards, we followed on. At last I made him out right in front of me only a few feet away, his head held low and looking very ugly indeed. The moment I made him out I shot and he sank down in his tracks, stone dead. We all breathed more freely, for it had been anxious work. Then we shook hands all round, and I bakshished the men, not forgetting the fine bit 
of tracking that Gallinero had done. He had kept on looking for the spoor, when we went after the rhino, and had picked it up on the very border of the black and seemingly impossible place where that cunning old warrior had cached himself so effectually.

He proved to be a very old solitary bull, with unusually massive bosses to his horns. Their spread was not unusual. Still, if not quite what the men called him, Koubwa Sana (very big one), he was a fine trophy and in very good condition. His horns spread just 40 inches. Along the curves, which were fine and regular, he measured $61 \frac{1}{2}$, and the bosses were $\mathrm{I}_{4} \frac{3}{4}$, and very massive. It was a most unusual piece of luck seeing him at all, and that I owed to the very fine tracking of my Wakamba. Who could have believed that with all that racket round him he would still lie so closely, so cunningly hidden? Had he charged me when I was struggling through the donga, right under his nose, I should have been in a bad plight. I could not even have fired off my rifle. I had had extraordinary bad luck with buffalo up to this very last little hunt, but on it, equally good fortune attended me. I had at least "kept my fly in the water." Such, sometimes, is hunting in British East Africa.

Little more remains to be said. I had longed, from the time when I was little boy, to visit Africa. Two lands above all others I hoped to see, two things to do. I wanted to ride buffalo on our own wide beautiful prairies, and I hoped against hope some day to see for myself the splendid wild life of Africa at her best. There are not many men alive who have ridden among the countless herds of our perished bison side by side with the Red Indian in the days of his glory. I suppose there is no man who has seen what I saw in 1868 and who has also seen what is most savage and most splendid in the African 


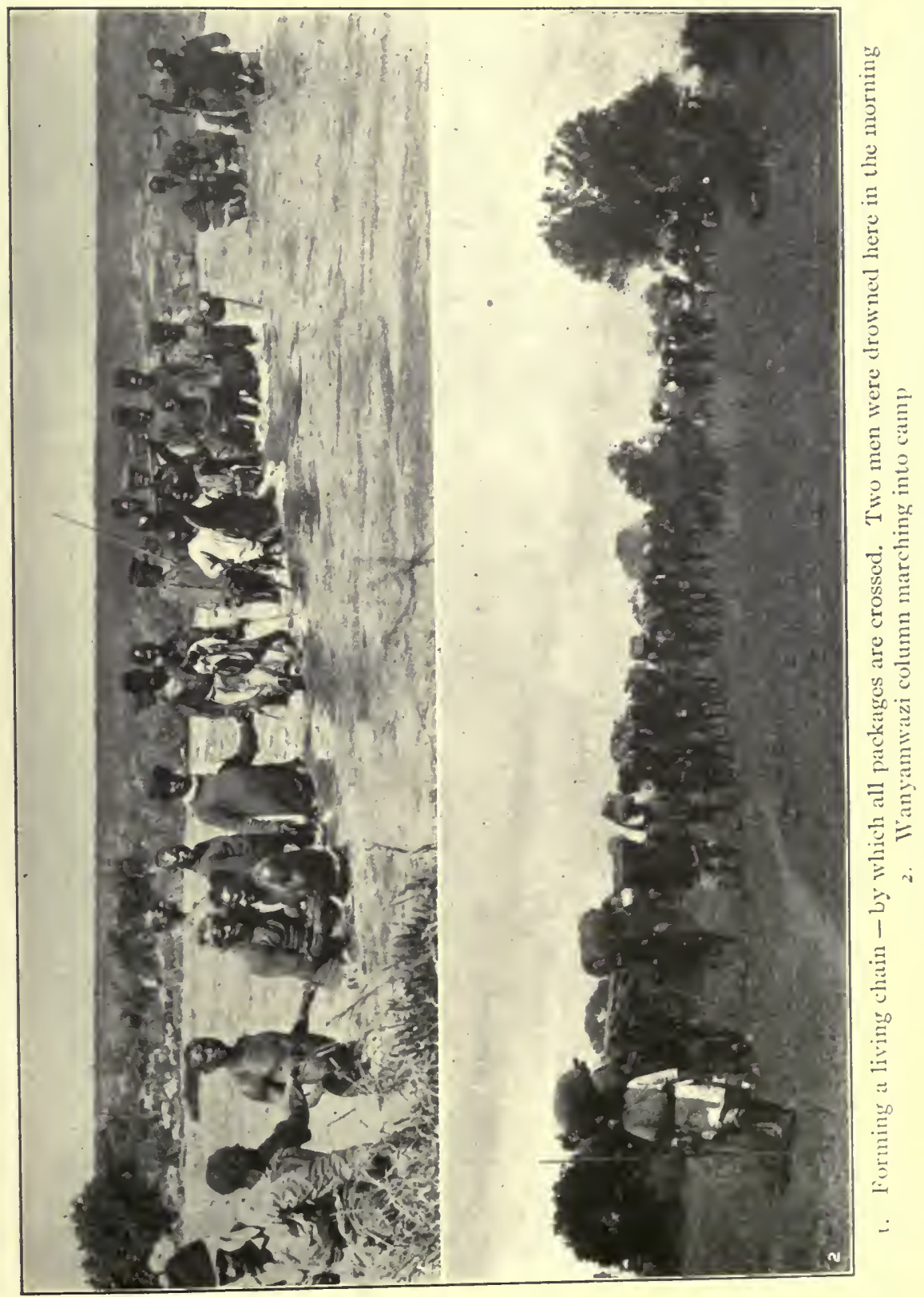



wilderness. There is something in what John Burroughs says, who, when he does allow himself a rare excursion into poetry, writes well.

\section{"The moon comes nightly to the sky, \\ The tidal wave unto the sea; \\ Nor time nor space nor deep nor high \\ Can keep my own away from me."*}

This old world is not a bad, but a good and a beautiful world; and a man is better, or should be, for seeing it. And even its neglected and forgotten sons, called sometimes too contemptuously, heathen, men with no history, no great tradition to help them along the stony paths of life, are still full worthy to be held as brothers by the best of us.

"He hath made of one blood all men to dwell on the face of the earth." So the old book has it, and the man who moves among his kind with eyes open and heart in his bosom, knows it to be true.

Tried by our standards they are ignorant, and certainly they have no hope of any other life beyond the grave. But they have a good working morality of their own, and I have well proved many of them to be brave, honest, faithful, courteous, heathen gentlemen. They gave me, a stranger, of their best, and what more can any of us give to his friend. Ah! How few give that?

To know Africa once, they say, is never to forget her; and I surely take away memories with me, that have become part of myself. Waking and sleeping, they will revisit me again and again.

The delight of early morning riding, through the new and wonderful world of the dew. The freshness and peace everywhere, when at last the long watch and ward of the night were over, and even the most timid beasts cast fear

* I am obliged to make any quotations I indulge in from memozy, and mine is very poor. 
away. The purple forest ridges sending up their morning oblation of silvery cloud incense to their lord the sun.

The measured tramp and tap, tap of the porters' sticks, as the Wanyamwazi column marches steadily into camp.

The tender wonder of evening light - you see it in Africa as nowhere else - flushing not the sky only, but rolling in a flood of gold and crimson over the wideflung veldt.

The delicious cool of the evening, when all work is over and the fragrant smoke of thorn wood fires rises in to the still air.

The long talks and gradually won confidences, as wild men told quietly of deeds done and wrongs suffered, spoke, at first hesitatingly, of strange rites observed by them, they knew not why. They did as their fathers had done before them.

I shall see the haunting beauty of Kenia's silvery crown, as far up in heaven it rose before me in the twilight, serene, virginal, unearthly. And again long black lines of mighty elephants will come slowly down from the purple slopes of Elgon, and stream across the wide yellow plain.

My first lion comes forth at last from the shelter of the thorn bushes. The morning sun shining full upon him, as he turns his massive head toward me.

It is hard to bid Africa good-bye. But harder far to look in the dark faces of the men I have learned to trust my companions and friends - for the last time. These true friends and companions of more than a year's wandering! How often I shall see them rise before me, as again we trudge along in the white glare of the noonday, or as their faces are lit up by the leaping flame of the camp fire, on glorious African nights!

There is little Peter, the cook, merry as a grig, tramping with his two kettles, one in each hand, all day, cooking all the evening, and dancing vigorously in every dance 
going on with Wanyamwazi, Massai, N'dorobo, Karamojo, till la te into the night.

Then, leading the column, steadily stalks Juma, the Wanyamwazi head porter, who, though he carried ninetysix pounds, told me on the last day of the sefari I had never given him a heavy enough load.

Along comes David Rebman, following the last lazy or tired porter into camp. The best headman in East Africa when he keeps away from "pomba," which (it is but fair to say) he usually does. Brave, competent and loved by his men David, who has tramped up and down all East Africa since the 'eighties, a very Ulysses in his many wanderings, though unlike Homer's boastful hero, modest and ever faithful to his black Penelope!

David who bore his part bravely in the desperate fight at Lubwas when first in the open, at but a few yards' distance, brave men shot each other down and then in grass and cover, desperately engaged in a life and death struggle for hours on the issue of which it is no exaggeration to say hung the fate of Uganda. Poor, forgotten, unrewarded, unthanked David, who like many another who served England well in her hour of extreme need, has not even a bit of riband or medal to show for it.

David, an intrepid leader of men, a devout communicant in the Anglican church, and at the same time a profound believer in, and sufferer from, Mohammedan dowa* (medicine of witchcraft).* .

Poor David, already past his prime, and like all his kith and kin, with not one penny saved.

I shall see oftener than any of the rest, and closer than the others, my brave Wakamba "Brownie" and my little faithful John, the two friends who always looked after my well-being with an untiring, unselfish care in the field and in the camp. I had from them always a faithful service

* I tell in another place my experience with David R. and the witch doctors. 
which may have been my due. But the friendship they gave with it, was a thing beyond purchase.

To have known two such men, one a heathen, the other a Christian, both natives of East Africa, would make it impossible for me to be pessimistic as to the natives' future.

The shore recedes. I shall see those kindly dark faces no more. Some have a Christian hope; to more of them that hope means nothing at all. But surely if an Almighty Fatherhood looks down on all the children of men, black and white, then those who have striven here, with most unequal chances accorded them, to do what their hands found to do, following such light as was given them, shall have some not unworthy place and task assigned in "the company of just men being made perfect."

\footnotetext{
"For, like a child, sent with a flickering light,

To find his way across a gusty night,

Man walks the world.

Again and yet again

The lamp may be

By fits of passion slain,

But shall not $\mathrm{He}$

Who sent him from the door,

Relight that lamp once more

And yet once more?"
} 


\section{APPENDIX I \\ NOTES ON PERSONAL OUTFIT}

7 HOSE who visit the country usually encumber themI will now put down certain things essential to health and comfort, and others advisable but not essential.

First as to clothes. Warm Jaeger underclothes are necessary; they can indeed scarcely be too warm. These must come from home and should be many sizes too large, as most tentboys who always do your washing, shrink them in the process. During long sefaris, ticks and small gray invisible fleas will, spite of all you can do, make their home in these garments. Ordinary washing, these pests seem to enjoy. Have your underclothes boiled from time to time, putting a little ammonia in the water. Avoid tick country, after and during the rains. Have your boy pick you off immediately you come in from march or hunting. Wear tight puttees and a tight belt. Use ammonia in a very hot bath. Tick bites neglected cause trouble to some people.

Never go round your tent, much less outside it, in bare feet. Always wear slippers, or better, boots. If you feel irritation in your feet, have your boy at once examine them. A neglected jigger may spoil your trip. Jiggers are more common south of Nairobi, and round Nakuru and Naivasha, than in less frequented places.

Protect your feet by the thickest stockings you can buy. Better have some one knit half a dozen pair of long, heavy woollen stockings. They will outlast a year's marching, keeping your feet warm when they are wet, and cool and unblistered when the marching is over broken rock, and 
lava stone. Many suffer from sore feet, and sores once established are often slow to heal in Africa. They are, moreover, generally caused by wearing thin socks.

Get your boots in England or the United States, and get the very best. Three pair for a year's sefari. Let them lace well up, have broad soles, not too heavy, nails screwed in, and carry extra nails. Bring one light pair of mosquito boots to draw easily on your feet in the evening, if you are in mosquito country. Puttees are generally better than leggings; they keep out crawling things.

Unless you want to waste money do not buy your shooting clothes till you reach Nairobi. There you can get an admirable choice of khaki stuffs and have them very well made for about a third of what you must pay your London tailor, one fifth of what your New York man will demand. Three good suits are sufficient for a year's work. They will not weigh three pounds a suit, and will cost about one pound each.

Study the question of pockets. Have plenty and have them large. Each little contraption that you must carry with you daily should have its own pocket. Thus you can always find it quickly and, always keeping it there, you will not leave camp without it.

Have four wide, deep pockets in your khaki hunting jacket, good flaps buttoning over them, to keep out rain.

The best place by far to carry your field glasses, is in the left breast pocket of this jacket; the narrow leather strap of the glass passed round your neck. They can then be used instantaneously, which is most important. Carried in a leather case slung round the shoulder, they are practically useless for quick work, and in stalking the case is very much in the way. The right hand lower pocket of the shooting jacket is the best place for handy cartridges. The leather holders, London gun makers insist on pressing on you and charging you very highly for, are 
useless things. Unless your gun boy constantly takes out the cartridges in them, the dampness of your body produces verdigris on the cases, and they stick. If the leather cover over them is not buttoned, every drop of rain falls full on the one exposed part of the cartridge, the butt, and dampness once in there, a misfire is certain. You cannot afford misfires in Africa. In thirteen months constant shooting I had just one. Then I never carry my cartridges on a leather belt, and if the rain has got into my pocket, I promptly throw away the cartridges that had been in it. I think the right pocket of the jacket, and if you want to carry two sorts of cartridges, as sometimes you will, the right trousers pocket, are the best places in which to stow them. A big cotton handkerchief can be thrust into the left breast pocket over the glasses. There will then be little chance of their becoming thoroughly wetted. Save your Zeiss glasses from wet. Once the dampness gets in they must be cleaned or they may take weeks to dry off. Always take an extra pair; you can get your money back for them. Tobacco, pipe, matches, notebook, will fill the other two jacket pockets. Compass, measuring tape, pocket knife, and a bit of string, always useful, will fill your capacious trousers pockets. If you a re obliged, as I am, to wear glasses, then have an extra big pocket made down the front of your left leg. There carry your cases, and an extra pair of spectacles. It is the safest side. Wear a strong leather belt, with a short, light, tested, hunting knife on it: wide in the blade; thin in the back.

Always carry a whistle, and teach your men to come immediately to its call. Never use it unless you want instant obedience. Punish severely any and every one in the sefari, from the headman down, if on giving the signal you employ, you are not immediately obeyed. Firmness in such trifles means kindness in the end to the sefari, and it may be safety, too. Never forget that on sefari you 
have very great responsibility. You are Leader, Master, Magistrate, Doctor, Executioner, Guardian and Friend.

I have a whistle pocket in all my jackets, high up on the left side.

Now, one thing more. Fill your pockets over night. Always fill them, and keep them filled. You cannot rush off without your clothes, you can rush off leaving many necessary things behind you. There is nothing more annoying than to have to wait on a man in the early raw morning, while he rushes round in the mirk looking for the essentials which should have been carefully stowed in his pockets the night before. It is a bad way to begin the day.

It as is well to have your trousers faced with soft leather.

Bring one coat from England, a good short Berberry cape. It will protect your shoulders from heavy rain. Long skirts to the coat are heavy and useless, you cannot walk in them; and in Africa it is useless to try to keep your legs dry. Ten minutes after you leave your tent door, in the early morning, the dewy grass will have soaked your lower half and filled your boots with water.

I have found a stout regulation sun helmet, khaki coloured, the best head-gear. Bring a couple of shooting caps for evening wear, and a double terai hat, in case you lose or smash your helmet.

Flannel shirts I found too hot. Jaeger underwear and a khaki coat, thickly quilted down the spine, I found comfortable to march in in all weathers. I always carried a warm knitted waistcoat wrapped up in my Berberry cape, strapped across the front of my saddle.

If I had no mule my gunbearer carried both these indispensables in a small leather wrap slung over his shoulder. The waistcoat I found most necessary when I had to stop and wait some time in the shade, when a long stalk was finished, or while I waited for my lagging porters. Drenched with perspiration, a tired man flings himself 
under a grateful shade tree, to rise in a quarter of an hour chilled right through. It is such small carelessnesses as these, that bring trouble in Africa. I forgot one thing, never leave camp without matches, in a waterproof box.

If you ride, stow in your saddle bag a few necessary things, and never take these out without at once renewing them. Some biscuits or bit of chocolate, a hank of strong twine, and, wrapped carefully in a thick cotton handkerchief, a syringe, small bottle of permanganate crystals, roll of strong bandage and a bit of lint. Let your syce always carry your water bottle kept clean, inside and out, and ever filled with water that has been boiled, and kept boiling five minutes. Punish promptly any carelessness resulting in a half-full bottle, or water not boiled. Stand over the fire, show cook, cook boys, and your tentboy, what you call boiling water. Promise them a reward if this is always given you, and let them understand that unboiled water means "koboko." This may sound brutal, but it is not. Buy two water bottles in England, strong aluminum are best, covered with felt. Don't be persuaded to invest in any fancy article.

Saddlery. Bring a good second-hand saddle from England. Mounted infantry pattern is the best, straps in front, saddle bags behind, good double bridle and strong headstall. Girths you will find at Nairobi. English girths are apt to scald and rub your animals. A leather girth with two buckles at each end, folded double, linseed oil now and then poured into the fold of the leather to keep it soft, cuts no beast, never wears out, and saves much trouble. Attention to little things such as these saves much bother in the long run. The man who will rush off on sefari, a day or two after his arrival in the country, cannot possibly attend to things himself, and will find out when too late that no outfitter in the world can be expected to look after them for him. 
Have a night blanket fitted to your mules or ponies. Green waterproof canvas on the outside, a warm blanket on the in; with one of these coverings carefully put on, your mount will not suffer, even in heavy rain, and you will be saved the trouble of carrying a special tent for them. Horses, and more especially mules, have a maddening way of getting outside a tent, when they should be inside.

The first zebra or kongoni you shoot, see that your men make a good rawhide rope for your mule with it. If you do not insist on this, skin after skin will disappear, and your mount will never have a secure picket rope. Ordinary ropes are heavy to carry, and soon wear out. When you are in country you are not certain of, never let your syce lead the pony or mule down to the water. $\mathrm{He}$ has nothing else to do in camp but look after his animals, see that he brings up water to the mule. Many a valuable animal is lost by such carelessness. Tsetse flies are often near water.

Medicines. A Burrough's and Welcome's soldier's medicine chest, weighing about six pounds, is the best thing of its kind to be had, but the stock it contains is too dainty to meet the needs of a large sefari. Take it, of course, but take besides:

Epsom salts for the men, bandages in plenty, a bottle of calomel tablets, bottle of castor oil, iodoform, mustard leaves, Dover's powders, rolls of sticking plaster, some surgeon's needles, a strong syringe, plenty of carbolized cotton, two or three pound cans of vaseline, bottle of permanganate crystals, and if you are ambitious, a forceps. Bring plenty of quinine in tablets (hydroclor is best).

You should know how to wash out a wound, fix a bandage, or set a bone.

Have a fixed time (as soon as luncheon is over I found the most convenient) at which you expect the men to come to you with their ailments. Encourage them to come, 
and be patient with them. They will make much of a trifle, and make a trifle of a serious symptom.

The common troubles are the result of over-eating of half-cooked food, and of cold nights and penetrating rains. If you are travelling far, and if you are to be out in the rainy season, see that you have an old tent for every seven men, as well as a new one. The old can be stretched over the new, and both together when pitched admirably, as the men can pitch them, if you insist that they do so, will turn almost any rain. New tents cost seven rupees each (\$2.50), old ones you can buy for two rupees, so that the extra cost is not great. This matter of tent-pitching is allimportant. Let the men see at once that you will not tolerate slovenly put-up tents, and they will act accordingly. Leave them alone, and some of your tents will be in rags in a month. When we marched across bamboo country, I made the men, much against their will, cut and carry bamboo ridge poles for each porter's tent. Though we encountered unusual rains, there was very little sickness in the sefari. Jiggers, the men see to themselves. Thorn wounds are often troublesome, these you will need to cleanse out thoroughly with disinfectant and keep the dirt out. Old cracks and wounds in the feet are the hardest things to care for. Fever is very common among them. Give a cathartic before giving quinine.

See a good doctor, if possible a man who has some scientific knowledge of the tropics, and get him to write down for you the treatment necessary for simple cases of cold, fever, dysentery, etc. Many of the doctors in Africa seemed to me, to put it charitably, singularly unenlightened; and so long as the home authorities keep on sending out, as they do sometimes still, young men who have not even had a single course of instruction in any tropical medicine school, how can the civilian or the soldier have the help and skilled attention they need and surely deserve. 
There are many admirably equipped medical men in the country, but the utter lack of system, the purposeless muddling, as it seems to the onlooker, of the Home Authorities, results in needless loss of precious life. I must give one instance of what I mean.

Mombassa, and Kilindine, its port, are hotbeds of fever. One energetic medical man, reasonably supported, could destroy malaria there in one season. But no, nothing is done. The people drink from old Portuguese and Arab wells. And even in so small a community of white people hundreds of severe cases of fever occur yearly.

The German authorities would not tolerate for a week such a state of things. But in English territory "what is everybody's business is nobody's business," as the Irish tenant said to his landlord when he asked him why no one shot at him.

Tent. Your tent is your home; take pains with it. Get it from Edgington, 2 Duke Street, London Bridge No tents that I have seen compare with his tropical green tent, certainly none made in America. Get it big enough. One tent for each man. Mine is $9 \times 8 \times 7 \frac{1}{2}$. Bath room extends four feet farther; a veranda about as far in front. Net pockets around side of tent inside, a leather strap studded with brass hooks to fasten around tent poles, and a ground sheet to book up inside. This is important, as it makes it harder for ants, rats, and snakes to get in during the night. Have your bed (made by Edgington) extra strong. Have also a light canvas-covered table, an easy canvas chair, a smaller one for tent use, and a dining table, the legs folding under.

Procure the brown Jaeger blankets, sown into a sack, and a thin hair mattress, with a couple of good pillows. These, with a heavy coat added for the chilly evenings and nights, can all be rolled tightly into a canvas hold-all. Mosquito nets are made by the same firm to fit the tent, and two of these can be carried in the same bedding roll. 
When you are ordering your tent get two or three ground sheets. These are always useful, and can be more cheaply bought in London than in Africa. No sefari ever has enough of them. Have at least one large ground sheet, $18 \times \mathrm{I} 2$. Half a dozen canvas buckets, and a canvas bath and washbasin; these complete your tent outfit. I must not forget the one or two officers' tin boxes, water-tight (they make excellent floats for a raft on occasion, since African wood will not float) wooden bottoms, marked and numbered; these for your clothes, tobacco, books and odds and ends. They must not weigh over fifty-five pounds when packed.

Food Supplies. I have found the Army and Navy Coöperative Company, Victoria Street, London, very satisfactory as caterers. They have had a large experience in fitting out expeditions with provisions, etc., to all parts of the world. The things supplied are of first class quality. Their packing leaves nothing to be desired. There are subordinate clerks in each department who know what you require, and are most efficient and capable in helping you to select what is necessary.

Some men are content to order good, simple food, only insisting that there shall be variety enough to insure health. Others supply themselves with large assortments of various canned stuffs, and carry wines, spirits, etc.

I give below my own list. I am sure one needs in the tropics to live well, but by living well, I don't mean supplying oneself either with much artificial food or stimulating drinks. Better never touch whisky or any alcohol, on sefari. But such advice, I fear, will be regarded as a counsel of perfection. In my account I leave all stimulants out.

All provisions must be packed by the company in chop boxes. These when full ought not to weigh more than fifty-five pounds at most, better fifty. Each box is numbered and padlocked, and a little book given you, containing a list of what each box contains. Hand this book 
(better have it made out in duplicate) with the keys, to your tentboy, and let him serve out the things to the cook.

After some considerable experience in more lands than one, I have found that the accompanying quantities of food will well suffice two men of ordinary appetite for a week. Bacon is best packed in salt, in a box by itself; otherwise it soon grows rusty. It is well to carry all flour, oatmeal, sugar, coffee, rice, salt in carefully sealed tins. This the Army and Navy Company do. Mouldy flour makes wretched bread, and when there are no vegetables, bread is all important.

I put no baking powder in my list, for I insist on good yeast-raised bread, and will take no cook along who cannot make such bread.. Test your cook on his baking before you engage him. See he does not pass off someone else's loaf as his own.

I believe good powdered eggs can now be had. If that is so, they should be included. Large quantities of dried fruit, carefully stewed are, I think, a necessity.

Indeed, food on sefari can be and should be far more appetizing than the food you are supplied with at club or hotel. One of the hardest things I know is to keep in good health when you leave your camping life for the frontier town or the still more trying steamer.

\section{RATIONS FOR TWO MEN FOR A WEEK}

10 lbs. Flour. One third fine corn meal mixed

$\begin{array}{lll}5 & \text { " } & \text { Sugar } \\ 5 & \text { " } & \text { Dried fruit } \\ 4 & \text { " } & \text { Butter } \\ 7 & \text { " Tea } \\ 1 & \text { “ } & \text { Coffee } \\ \frac{1}{2} & \text { " } & \text { Cocoa } \\ 2 & \text { " } & \text { Lard } \\ 4 & \text { " } & \text { Bacon } \\ 7 & \text { " } & \text { Rice } \\ 2 & \text { " Oatmeal }\end{array}$

$$
\begin{aligned}
& \text { Io lbs. Potatoes } \\
& 4 \text { " Onions } \\
& \text { I "Soap } \\
& \text { I "Salt } \\
& 1 \text { “ Worcester Sauce } \\
& \frac{1}{2} \text { " Currie powder } \\
& \frac{1}{2} \text { “. Dubbing for boots } \\
& \text { I “ Cooper's Marmalade } \\
& \text { I " Jam } \\
& \text { I “ Lentels } \\
& 14 \text { cans (small) Ideal Milk } \\
& \frac{1}{2} \text { lb. Box of biscuits }
\end{aligned}
$$


Some corn beef, canned soups, fruit, currants, chocolate may be taken.

If these provisions are properly cooked, and there is no pilfering among the men, they should provide appetizing. and abundant meals for two.

Keep your stock pot on the fire when in fixed camp. Add a few onions and potatoes, and good soup is always ready. When you come in, fagged, a cupful of it is much better for you than a whisky and soda.

Examine from time to time your cook's kettles and see they are kept clean. See that a clean rack for drying all the cooking utensils is always put up by the headman's orders near the cooking fire; any boughs or scrub can readily be built into a rack. Dirt in and near your food is not only undesirable, but often dangerous. Insist on cleanliness and good cooking and you will certainly get them. And do not grudge the time to go round yourself, and tell your little cook, and not your cook only but his hard-worked and much abused aids, the two cook boys, that you are pleased with them, when they have given you a clean, hot meal. In short, don't forget sometimes to "purr," as well as to "growl."

As to cups, plates, dishes, I think it is as well to get them on the spot. You are always liberally allowed for such things at the sefari's end. 


\section{APPENDIX II}

\section{NOTES ON ANIMALS AND WHERE TO FIND THEM}

\section{Elephant:}

Elephant carrying tusk of reasonable size can be secured by the persevering hunter within the borders of the Protectorate.

A trip to Uganda will, if proper arrangements have been made beforehand, yield you larger tusks. But it must be remembered that the climate of Uganda is not so healthy, and that at present the spiritum tick adds very considerable danger to the expedition. In order to reach the best elephant countries in Uganda, Toro, or Bunyoro, a fortnight's trek along roads infested with this dangerous tick is necessary. One bite from an infected insect is enough to bring on the fever, and tick fever means a series of threeday attacks, that may completely disable the toughest for months. Sometimes, as in the case of a missionary who was down with the disease while I was there, the very first fever ends fatally.

If a special licence is procured (and influence at home will secure such a licence) money may be made, over and above all expenses, by shooting Congo elephants. But no tyro should attempt the trip. Better be contented to kill one or two fair-sized bulls within the limits of a healthier and more accessible country.

German East Africa, east of Tanganeka Lake, is a good elephant country. The licence paid by sportsmen is low, $£ \mathrm{I}$, and a hunter, if he wishes to give up time to the sport, can kill almost any number of elephants. There are men 
who make a good living and lay by money, who hunt professionally in these lands. Within British East Africa the herds have been much harried. Till three years ago many elephants were killed by so-called sportsmen, whose licence limited them to two bulls. There was no prohibition against trading ivory from the natives, so two of the largest bulls killed were taken on licence, and declaration was untruthfully made that all the rest were traded from natives. In this way men would collect, often with little trouble, $£ \mathrm{I}, 000$ worth or more of ivory, and so pay all sefari expenses and have a margin of profit left over.

The law is now strictly enforced, and makes such a proceeding impossible. No trading with natives is permitted, and unless the hunter is unscrupulous enough to smuggle illicit ivory over the German border, he must content himself with his two bulls.

The natives harry the herds perpetually and on the long and unwatched frontiers of the Protectorate, ivory running is easy. Unscrupulous Somali and Swahili come round from time to time. The natives bury the ivory they kill and wait for the coming of the trader.

I am convinced that the present policy of the Protectorate authorities is a great mistake. If they would but authorize certain men of well-known good character, men who should pay a heavy licence fee, binding them to handle no small tusks or cow ivory, to trade with the natives for ivory, a considerable revenue would accrue to the government, and the elephants would be more really protected.

Owing to constant pursuit, the British elephant has learned to take good care of himself. He is also much more likely to turn on his persecutors than his cousin of the Congo. Accidents from elephants are very common. The very thick cover he loves, such as bamboo, or the quite open 
plains, are both rather undesirable places in which to tackle him. But the elephant hunter must take on elephant wherever he is fortunate enough to come on them.

There is scarcely any part of the protectorate in which you may not happen on elephant. They turn up unexpectedly in most unlikely places. In the Kinan Kop woods near Naivasha, all round Kenia, in the Aberdare range, on all sides of the Nzoia plateau, on the slopes of Mt. Elgon and in the Elgao forests, they are still abundant. But you may have to go up as I have to many herds, before you find bulls carrying ivory heavy enough to shoot.

Shoot: (I) between the eye and ear, nearer the ear and lower than the eye. (2) Right in the shoulder. (3) A foot above the tail, if he is going straight away, reaches the spine, and stops him. One shot in any of these places is enough.

\section{Buffalo:}

Buffalo have increased greatly in later years. One bull is now the limit permitted. There must be a change made soon, for buffalo are becoming destructive.

There are several herds near Nairobi and permission can often be obtained to take a head from these. Donyea Sabuk has many buffalo. There are more in the Kedong, thirty miles from the town.

Five miles from Punda Melia near Fort Hall there are several herds. All down the Tana near Embo they are very numerous. Laikipia along the Quasi Nyiro of the North they are common, but the cactus cover makes hunting very dangerous.

The valley of the Kerio and the slopes of Cherangang are full of them, but the horns do not seem to be quite as large as in other parts. Shoot them well forward and low down in the shoulder.

Rbino:

Everywhere. Few big horns anywhere. Across the 
Quasi Nyiro of the South, along German borders they run larger. North of Kenia there are some large ones. There are very many on the Tana and Theka, three days from Nairobi. And also on Laikipia plateau.

Shoot them for a side shot well forward, rather low down; for a front shot, full in the chest and only a few inches above the brisket. They are easy to kill.

Greater Koodo:

Not common anywhere in British East Africa. Permits are given to some to shoot a single bull in the game reserve north of Lake Baringo. I saw a good one shot at Solai Swamp (the hills near by) three days from Nakuru north. The game rangers can be depended upon to know the latest news as to their whereabouts.

Lesser Koodo:

At the junction of Quasi Narok and Quasi Nyiro I saw them. They can be had with a little trouble. The railroad people are most courteous in giving information about lesser koodo. This antelope is very local, choosing a place and staying there for months, not moving to any distance so long as he can get water. He seems to feed on the nightshade fruit, the yellow tomato, so common everywhere. I am not aware of any other animal that eats it. The natives declare it is most poisonous and certainly it looks it.

\section{Roan:}

Common near Punda, where at present it is protected. Common at Muhroni, three stations from Port Florence on the Lake. Before visiting Muhroni find out if the grass has been burned. In long unburned grass, hunting them is a trying experience. There is much fever too. The buck is a splendid beast, weighing as much as 500 pounds, but in British East Africa the horns seldom attain a great length. Twenty-seven inches is a good head. 


\section{Water-buck:}

The finest are to be had on the Nzoia. There, horns of over thirty inches are not uncommon. This antelope is one of the finest in East Africa, weighs about 600 pounds, has a habit of concealing himself when wounded, and should be approached with caution. A friend of mine was almost killed by a buck he had wounded and which he approached carelessly. The only hurt I received during thirteen months' hunting was from a wounded waterbuck. All African antelope fall quickly to a shot well forward in the shoulder.

\section{Kongoni:}

Coke's hartebeest and Jackson's hartebeest are the two common kinds. Jackson's hartebeest is much the finer of the two, weighing, I should say, almost one hundred pounds more than Coke's. Jackson's is common on the Nzoia and less frequently met with on the Aberdare and the Mau Escarpment.

There is an established belief that kongoni are unusually hard to kill. I have not found this to be true. They will fall as promptly to a well-placed bullet, even if it be not bigger than the little .256 Mannlicher, as any other antelope. Most men shoot all game much too far back. I have been at times obliged to feed my sefari for many days together on kongoni meat. There was famine in the country and "potio" was unattainable. I have more than once killed ten with ten consecutive shots (in about a week).

I once shot three with three shots. The nearest lay when I shot him 275 yards off, the farthest was 290 yards; a circle with a diameter of thirty yards contained all three. I always sat down for such long-range shooting, and invariably used a small telescope sight.

\section{Eland:}

Eland are now very much more plentiful than they were three years ago. Between the Athi and Theka rivers, north 
of Nakuru, all over Laikipia country, everywhere on Nzoia plateau, they are to be found.

One bull is now allowed on a licence, a second can be shot on payment of seventy-five rupees.

They are a magnificent animal. The largest bulls must, I think, weigh 2,000 pounds. A twenty-five inch horn is a fair specimen. They are sometimes hard to approach, sometimes very easy. You can always ride them down if you are well mounted. They have a strange habit of kicking up behind (a very high kick) when they receive the ball. The bulls are easily distinguished from the cows (which are protected) by their darker blue colour, and by their much heavier build.

Wildesbeest or Gnu:

A strange antelope. Far more like a small buffalo (American) than an antelope. They travel in lines, and whisk their tails, just as our buffalo used to do. Plentiful on the Athi plains, and in all the country south of the railroad. Sometimes rather hard to stalk. If shot too far back they will take a lot of following. Shot forward, they drop at once. Two are allowed.

\section{Oryx:}

Very plentiful on Laikipia plateau. You are allowed two. If you want good heads take some time and examine the heads well before shooting. I found the horns particularly hard to judge. Thirty-three inches are not uncommon. But if care is not taken you will shoot much shorter specimens. Keep your legs free from the sweep of the very sharp and dangerous horns. They weigh up to $45^{\circ}$ pounds.

The fringed-ear oryx is a distinct species. Can be shot near Simba, east of Nairobi.

Impala:

One of the most beautiful of all African antelopes. Widely distributed, easy of approach. I have found it 
harder to judge the impala horn than the horn of any other. Twenty-six is a fair measurement. Twenty-eight inches can be got. They sometimes go off when frightened with a series of extraordinary high bounds. I am quite sure that I have seen impala, so bounding, rise at least ten feet into the air. A good buck will go one hundred and eighty pounds. I have known a leopard carry a full-sized buck impala, horns and all, high up into a well-grown tree, and so hide it from the vultures.

\section{Topi:}

An ugly antelope, darker and smaller than a kongoni. In most places rather shy of approach. Common in Nzoia and at Muhroni near the lake. If shot too far back will give you a lot of trouble.

Grant Gazelle:

A beautiful antelope with a beautiful head. Ten are allowed on a licence, but it seems a shame to shoot anything like so many. Shoot the useless and fat zebra instead, when you want meat for sefari. Grant are widely distributed. There are some very large heads to be got. Southeast of Naivasha near Shuswa (the extinct crater) I have shot a $29 \frac{1}{2}$-inch head. A distinct species of Grant (annotata) is found on Laikipia plateau. These have not so heavy heads; 24 inches is a good measurement.

Robert's Eye, another Grant, is quite plentiful south of the railroad toward the German line. The horns are quite extraordinarily widely spread at the tips. A good Grant buck will weigh about 150 pounds.

Thompson Gazelle:

Tommy are everywhere except on the Nzoia. There you never see one. They have been so cruelly shot down that the numbers are greatly reduced. Grant and Tommy often run in herds together. Tommy are much smaller, weighing (the buck) about ninety pounds. A thirteen-inch 
horn is a fair specimen. Be merciful to the pretty fellow, don't shoo: him for your men. And when you shoot (he is a small mark) shoot to miss or kill by shooting well forward.

Reed-buck:

Very widely distributed, wherever there are reeds or damp ground. A good buck will weigh almost one hundred and fifty pounds. Short horns, curving forward. An easy antelope to stalk and kill. Rather poor eating.

Bush-buck:

One of the prettiest trophies in Africa. Dark red colour, horn straight, very sharp and very strong. The cry is strange, almost a dog's bark. The flesh good food. $\mathrm{He}$ keeps close during daytime. Early morning and late evening finds him feeding round the outside of the thick coverts he loves. The steep slopes falling toward Embellossett Swamp are one of his most favourite resorts. On the borders of many swampy rivers of the Nzoia plateau he is common, and large heads can be shot. High up in bamboo and elephant country you find him. Bush-buck take some looking for, but are well worth it. An eighteeninch horn measured along the curving rib is a good specimen. Why Ward so measures bush-buck horns I don't know. I should have thought that straight measurement from base to tip was the simplest and fairest.

Oraby:

A beautiful little antelope. A more constant jumper than any other. Weighs not more than fifty pounds. Short, sharp horns, six inches a fair head, hinged at the base. Perhaps the best venison in East Africa. In the hills to the east of Punda Melia, nowhere else so far as I know near Nairobi. Very common on the Nzoia plateau. Rather rare at Laikipia. Here and there south of the railroad and very abundant as you approach the great lake. Kobus Kob:

A fine antelope. Only found in one place within the 
Protectorate, viz., the banks of the Nzoia River. Here it is very numerous indeed. Herds of a hundred or more are quite common. Twenty-two-inch horns is a good head. A big buck must weigh almost two hundred pounds. The horns curve first backward and then forward.

Stein-buck:

Like an oraby but smaller, does not show as much white, and when running does not rush away with the same beautiful swinging jumps. Horn smooth and straight.

Klipspringer:

A rock antelope found on stony kopjes. Widely distributed. Dark brown, weighing about twenty pounds. Horns rimmed at base, four inches a good specimen.

Gerenuk:

Only found on the Laikipia plateau and in the lower country east of Nairobi. A slim antelope, shy and hard to approach. Light red in colour. Unlike all other African antelopes, moves at a very fast trot, throwing forward its unusually long legs. Horns curve inward at tips. Weighs less than one hundred pounds.

Duiker-buck:

Always springs up suddenly from long grass. A dark gray antelope. In cover it resembles an immense rabbit in motion. Hard to shoot with rifle as it never seems to stand still. Straight, sharp horns, six inches a good head.

\section{Dick-Dick:}

The smallest of the antelopes, found plentifully in lower bushy country, does not weigh more than a hare.

Hippopotamus:

Hippo are not usually worth shooting in the Protectorate. Occasionally a good tusk can be got on Naivasha Lake.

If I were again shooting in East Africa I should try 
to get dogs for following up wounded lion in thick cover. I think that one or two plucky terriers would greatly lessen the risk run in doing so.

Places to Go:

Short trips of from a fortnight to a month's duration can very pleasantly be made from Nairobi. Twenty porters are ample for such trips, since potio supplies can be obtained in every direction. Careful hunting will result in a good variety of specimens, many of the rarer antelopes can be shot, and if you are a stranger in the country, one or two such trips are the best preparation possible for a long sefari.

Messrs. Newland, Tarlton \& Co., can always advise as to the best places to visit.

Beside these short expeditions, there are three directions in which for some years to come long journeys, which would entail a more elaborate preparation, can be made.

I: Across the Rift Valley toward the German border, and westward to the lake. A wagon can be used on this trip and this mode of travelling greatly lessens expenses.

Elephant, buffalo, rhino, most of the antelopes, and plentiful lion may be expected by this route.

II: Guash Gnisu Plateau across the Nzoia, and as far north as the Turquell River, exploring Mt. Elgon and returning southward by Cherangang mountains and the Elgao Escarpment, of this I have written at length.

III: From Gilgil or Naivasha, along or over the Aberdare to Laikipia Boma. Thence to Guasi Nyiro of the North. Round Kenia, and back by Ft. Hall. Of this trip I have also written. Each of these should require four months' sefari at least. Nothing is gained by hurrying. The scenery is lovely. The climate very fine. And in my judgment the very best time to start on such expeditions is April or even a month earlier. The rain is no obstacle to a good sefari, and there are many hours of warm sunshine in each day. 
If you want good porters, good servants, good headman, and a good white hunter, be sure to make your arrangements at least six months beforehand. I strongly advise those who do not know East Africa to engage, either Mr. Cunningham, or Mr. Hoey, both can be communicated with through Messrs. Newland, Tarlton \& Co., Nairobi.

\section{Head Skins:}

The treatment and preservation of head skins, and skins generally is rather beyond the scope of these notes of mine. It needs a whole chapter to itself. Mr. Ward has published an admirable small book which gives all requisite information. Any good gunbearer, however, who knows his business, is sure to be able to give your specimens all the care they need. On your sefari also see that you engage one or two skinners to help him. Some of your men are sure to know how to skin heads. Do not load yourself up with patent preparations for curing skins. These are not necessary. Sun, alum and care, are about all that you need, especially care. 


\section{APPENDIX III \\ LION TELEGRAMS}

I copy out four telegrams sent by Hindi stationmaster, on the Uganda railroad, and procured for me by the courtesy of the manager of the line.

\section{Simba (I)}

$$
\text { I7-8-05, I hr. } 45 \text { mins. }
$$

The Traffic Manager

Lion is on the platform. Please instruct guard and driver to proceed carefully and without signal in yard. Guard to advise passengers not to get out here and be careful when coming in office.

Simba (2)

$$
\text { I 7-8-05, } 7 \text { hr. } 45 \text { mins. }
$$

The Traffic Manager.

One African injured at 6 o'clock again by lion and hence sent to Makindu Hospital by trolley. Traffic manager please send cartridges by 4 down train certain.

Simba (3)

$$
\text { I 7-8-05, i } 6 \text { hrs. }
$$

The Traffic Manager,

Pointsman is surrounded by two lions while returning from distant signal and hence pointsman went on top of telegraph post near water tanks. Train to stop there and take him on train and then proceed. Traffic manager to please arrange steps.

\section{Tsavo (4)}

$$
\text { 20-4-08, } 23 \text { hrs. } 35 \text { mins. }
$$

The Traffic Manager,

2 down driver to enter my yard very cautiously points locked up. No one can go out. Myself Shedman Porters all in office. Lion sitting before office door. 


\section{APPENDIX IV}

\section{VOCABULARY OF AFRICAN WORDS}

Load up, Bandika.

Take hold, Kamata, shika.

Come back, Rudi, rudi nyuma.

Left, Shoto.

Right, Kurme.

Day, Siku.

Hold your tongue, Nyamaza, kelele.

Liar, Mwongo.

Plenty, Nyingi.

Bad, Mbaya.

How many? Ngapi?

Much, Nyingi.

Far, Mbali.

Near, Karibu.

Big, Kubwa.

Little, Ndogo.

Too far away, Mbali sana.

Knife, $K$ isu.

Gun, Bunduki.

Cartridge, Kiasi (pl. Viasi).

Sharpen knife, Noa kisu.

Clean gun, Safisha bunduki.

Give me, Nipe mimi.

Put in tent, Weka hemani, tia katika bema.

Bring, Lete.

Skin this, Cbuna bii.

Mule, Nyumbu.

Sheep, Kondoo.

Horse, Farasi.

Cow, $N g^{\prime}$ ombe (mke).

Donkey, Punda.

Get down, Shuka chini.

Sit down, Kaa chini.

Go ahead, Nenda mbele, tangulia.

Pay attention, Sikiliza, sikia.
Tie, Funga.

Untie, Fungua.

Stop, Bass, wacha.

Look round, Tazama sana, tazama buku na buku.

Look for (game), Tafuta (nyama).

You are wanted, Unatakiwa.

You are called, Unakwitwa.

Take care, Angalia.

Where is? Wapi?

What is?, Nini?

Wait, Ngoja.

Let it down, Wacha.

Are you ready? (pl.), M'ko tayari (sgl., uko tayari)?

Do you understand? Unasikia, wasikia?

What do you want? Unataka nini, watakani?

What is your name? Fina lako nani?

Thank you, $A b$, santa, $A b$, sante.

Good morning, Fambo, Hujambo.

Good evening, Kua beri.

How are you? Ubali gani?

Not yet, Bado.

One, Moja.

Two, Mbili.

Three, Tatu.

Four, Nine.

Five, Tano.

Six, Sita.

Seven, Saba.

Eight, Nane.

Nine, Kenda, tissia.

Ten, Kumi.

Evening, Fioni. 


\section{VOCABULARY OF AFRICAN WORDS}

Morning, Assubui.

To-day, Leo.

Yesterday, Fana.

Day before yesterday, $\mathcal{F}_{u z i}$.

To-morrow, $K$ esho.

Be quick, Upesi, Hima.

Come on, $N$ joo.

Wait here, Ngoja bapa.

Stay behind, Simama nyuma.

Cold, Barid $t$.

Cold water, Maji ya baridi.

Hot (water) Moto (maji ya moto).

White, $N$ yeupe.

Black, $N$ yeusi.

Fish, Samaki.

To fish, $K$ uvua samaki.

Meat (game), Nyama (mwitu).

Meat dried, Nyama kavu.

Many, $N$ yingi.

None, Hapana.

Few, Haba.

Big, Kubwa.
Small, $N$ dogo.

Wood, Mwitu.

Fire wood, Kuni.

Get wood, Lete kuni.

Water, Maji.

Fire, Moto.

Make fire, Koka moto.

Load, Mzigo (pl. Mizigo).

Put down your loads, Tueni mizigo yenu (Tuani mizigo).

Take up your loads, Fitwekeni mizigo, inuani mizigo.

Good man, Mtu mzuri.

Elephant, $\mathcal{T}_{\text {embo. }}$

Rhino, Faru, Fao.

Leopard, Chui.

Eland, $P$ ofu.

Waterbuck, Kuro.

Giraffe, Twiga.

Zebra, Punda milia.

Bush-buck, Pongo (Swala mkubwa).

Hartebeeste, Kongoni. 

THE LIBRARY

UNIVERSITY OF CALIFORNIA

Santa Barbara

THIS BOOK IS DUE ON THE LAST DATE STAMPED BELOW.

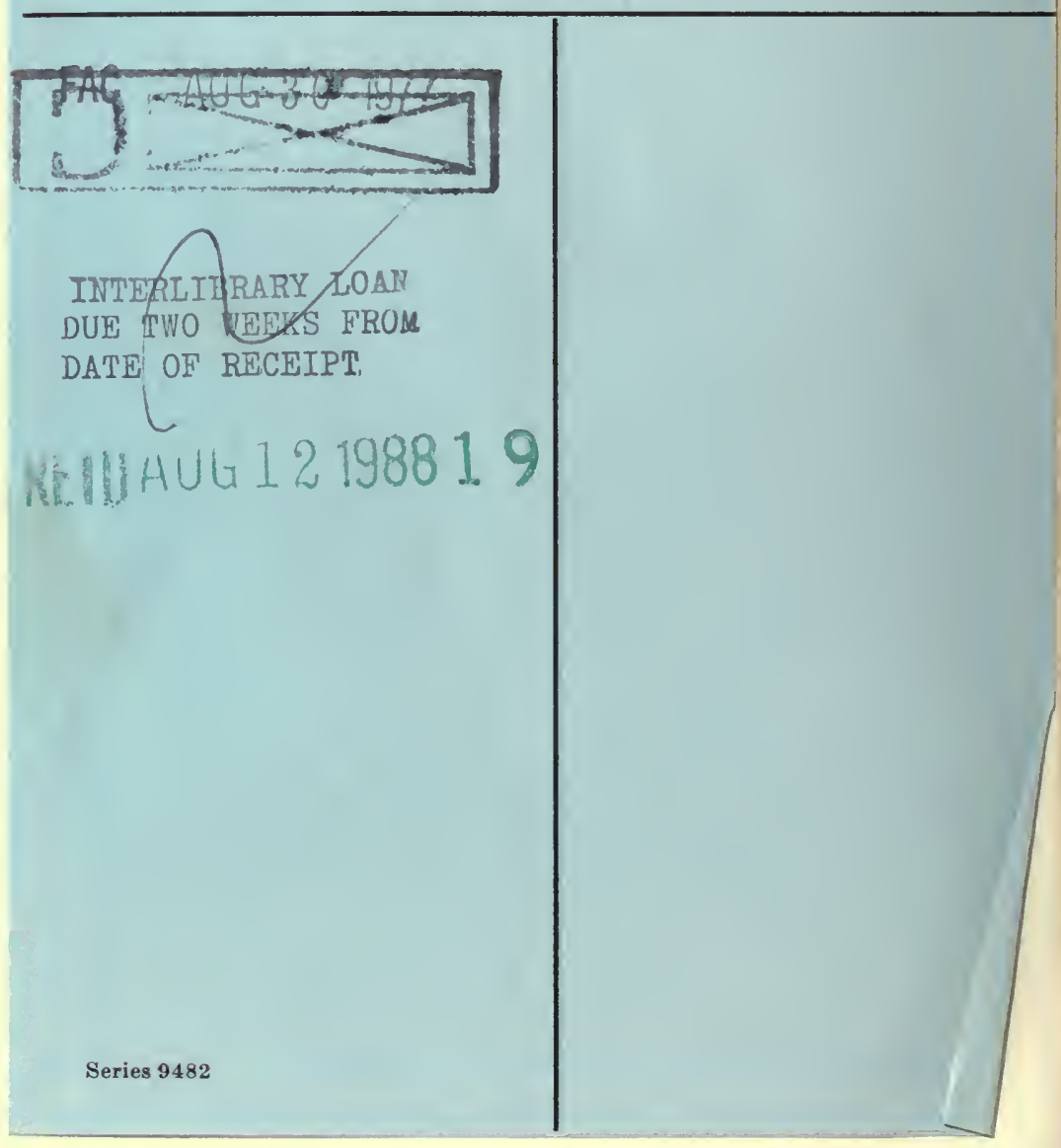



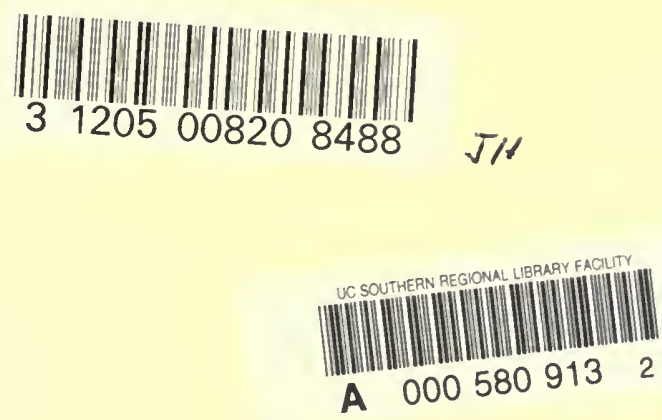


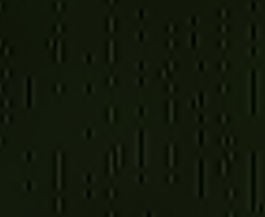

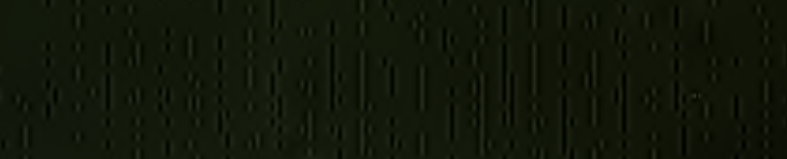

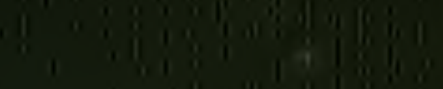

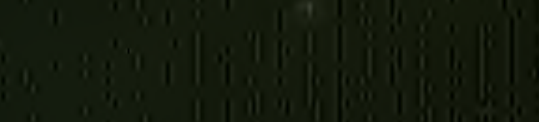

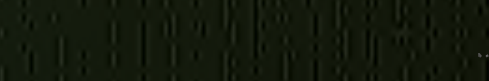

I.

| 11 i

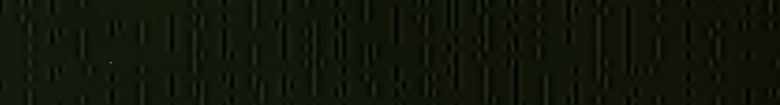

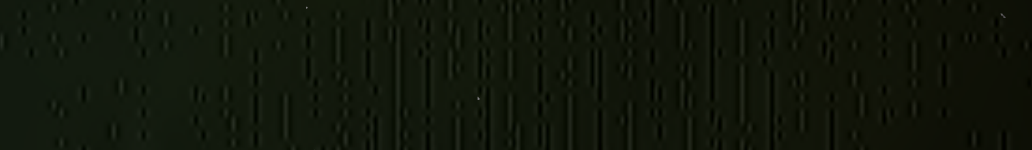

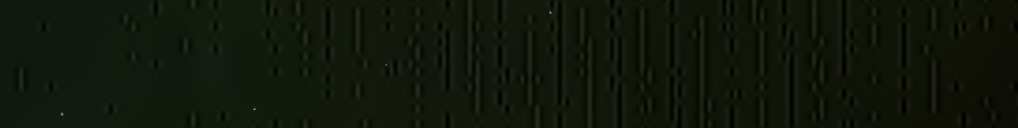

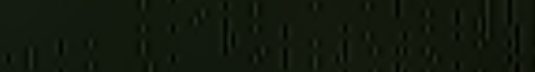

(1) 